S A T O R 22

\title{
CURRENT STUDIES Udmurt Mythology and Folklore
}


S A T OR 22 
Estonian Literary Museum

\title{
Udmurt \\ Mythology and Folklore
}

\author{
Edited by Nikolai Anisimov, \\ Mare Kõiva, Eva Toulouze
}

Tartu 2021

ELM Scholarly Press 
Main editor: Mare Kõiva

Co-editor: Mare Kalda

Editors for this issue: Nikolai Anisimov, Mare Kõiva, Eva Toulouze

Language editor: Daniel Edward Allen

Translations: Tatiana Panina, Eva Toulouze, Translation Office LUISA

Layout: Diana Kahre

WEB: Andrus Tins, the Centre of Excellence in Estonian Studies

Cover: Udmurt Design-Studio MONAMI

Maps: Vincent Dautancourt

International board: Ekaterina Anastasova (Institute of Folklore and Ethnology with Ethnographic Museum, BAS Bulgaria), Madis Arukask (Tartu University), Reet Hiiemäe (Estonian Literary Museum), Tiiu Jaago (Tartu University), Andres Kuperjanov (Estonian Literary Museum), Tünde Komaromi (Károli Gáspár University, Budapest), Nikolay Kuznetsov (Estonian Literary Museum; Tartu University), Marju Kõivupuu (Tallinn University), Emily Lyle (School of Scottish Studies in Edinburgh), Mirjam Mencej (Ljubljana University), Skaidre Urboniene (Lithuanian Culture Research Institute), Tatsiana Valodzina (Belorusian Institute), Irina Vinokurova (Institute of Karelian History, Language and Literature in Petroskoi), Tatiana Vladykina (Udmurt Institute for Research in History, Language and Literature,Udmurt Federal Research Centre, Ural Branch of the Russian Academy of Sciences, Izhevsk)

This volume is supported by the Kindred Peoples' programme, the Centre of Excellence in Estonian Studies (CEES, European Regional Development Fund), and is related to the research project ELM 8-2-20-3. This issue has been prepared within the international cooperation between the Estonian Literary Museum and the Research Associate Udmurt Institute for Research in History, Language and Literature, Udmurt Federal Research Centre of the Ural Branch of the Russian Academy of Sciences.

The issue is proposed to Scopus, WoS, DOAJ, EBSCO, Internationale Volkskundliche Bibliographie.

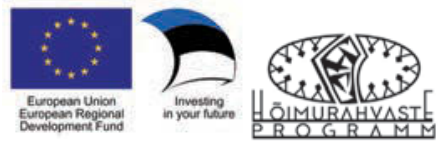

ISSN 1406-2011 (print)

ISSN 1736-0323 (e-version)

DOI: 10.7592/Sator.2021.22

https://folklore.ee/sator/

Address: ELM Scholarly Press,

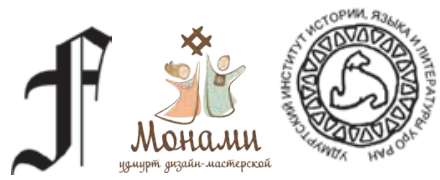

Vanemuise 42, Tartu 51003, ESTONIA

Phone: +372 7377740

E-mail: kirjastus@folklore.ee

| | | || | || || |||| Estonian Literary Museum

(C) Estonian Literary Museum

(C) Udmurt Federal Research Centre of the Ural Branch of the Russian

Academy of Sciences

(C) Authors

(C) Udmurt design-studio MONAMI 
To Tatiana Vladykina.

Gratefully 



\section{Contents}

Preface: Ninety Years - Something Old and Something New

Mare Kõiva, Eva Toulouze, Nikolai Anisimov

\section{Studies in Udmurt Folkloristics}

Rituals and Socialisation in the Udmurt Folk Calendar

Tatiana Vladykina, Galina Glukhova, Tatiana Panina

Transition Periods in the Udmurt Folk Calendar and Their Spirits Galina Glukhova

About vozho, the Spirit of Transition Time and Formation of Holiness among Udmurt and Komi Aado Lintrop

Water Bodies in Besserman Mythology and Rituals Elena Popova

The Udmurt Pantheon and the Udmurt Worldview Tatiana Vladykina

Inmar, the Udmurt God, in Modern Udmurt Literature Aleksey Arzamazov

Forest Spirits in the Udmurt Worldview Tatiana Panina, Tatiana Vladykina

Home Spirits in the Udmurt Mythology

Tatiana Vladykina, Galina Glukhova

A Systematic Investigation of Sacred Space in the

Kama-Vyatka Region: Udmurt Materials

Nadezhda Shutova

Tradition and Diversity among Udmurt Sacrificial Priests Eva Toulouze, Liivo Niglas

"Seeing off a Recruit": The Ritual and Its Songs in the

Udmurt Traditional Culture

Valeriia Fedorova

The Ritual Importance of the Chuk, a Symbolic Bundle of Thread

Tatiana Vladykina, Galina Glukhova, Tatiana Panina 
A Contemporary Commemoration of the Dead:

Yyr-pyd s'oton in Southern Udmurtia

Denis Kornilov

Sound in Udmurt Rituals

Irina Nurieva

An Udmurt Flute

Irina Pchelovodova

An Udmurt Exceptional Performer, Dzhakapay

Irina Pchelovodova, Nikolai Anisimov

Presence of Witchcraft in the Contemporary Udmurt Village

469

Nikolai Anisimov

\section{Book Reviews}

The Udmurt Ritual Year and Its Roots

503 Mare Kõiva

How the Udmurt Understand the World, and Man in It Eva Toulouze, Nikolai Anisimov

\section{About Tatiana Vladykina}

Tatiana Vladykina's Contribution to Udmurt Folkloristics Aleksey Arzamazov, Galina Glukhova, Tatiana Panina

Grateful Remembrances Aleksey Arzamazov

My Teacher, My Master and My Friend for Life:

Or the Person, the Scholar Who Determined My Fate Galina Glukhova

She Taught Me to See the World (Dedicated to Tatiana

Grigoryevna Vladykina)

Tatiana Korobova (Okuneva)

About Tatiana Vladykina

Anna Mutina

To Tatiana

Mare Kõiva

A Mind That Understands Words...

Eva Toulouze

Direct and Indirect Sources of the Articles 


\section{Preface: Ninety Years - Something Old and Something New}

Mare Kõiva, Eva Toulouze, Nikolai Anisimov

The book you have in your hands is not an ordinary book. It is the first wider approach to Udmurt folklore in English. Udmurt folkloristics has a relatively long history: taking into account the general pattern of cultural development it is more than one and a half centuries. Unhappily for international communication, it is overwhelmingly in Russian. This is the first systematic attempt to open up this rich material to the international scholarly community.

To understand Udmurt folklore, it is relevant to start with general information. The Udmurt are one of the numerous indigenous peoples living in Russia, and the Udmurt Republic is part of the Russian Federation. Geographically, Udmurtia is in Central Russia, near the Ural Mountains and between the Rivers Kama and Vyatka, in the so-called Volga region. An important characteristic, that is highly relevant to Udmurt identity is that the Udmurt belong to the Finno-Ugric language family, which means that they feel incorporated with other communities into a wider ensemble, speaking languages from the same origin and thus feeling a kin connection. Today the Udmurt form only $28 \%$ of the population, 
within an industrial republic of 1.5 million inhabitants. The percentage of indigenous inhabitants has decreased continuously over the last decades (in 2010 there were 552,299 Udmurt in Russia, circa 100,000 less than in 2002). It is possible that one of the reasons is that the region's, but mainly the capital Izhevsk's, standard of living is one of the best among Russian cities (Census 2010) and so is undoubtedly attractive to others. We must add that the Udmurt do not live only in the eponym Republic: there are also significant groups of Udmurt living in the Republics of Tatarstan and Bashkortostan as well as in other nearby regions (Kirov and Perm' oblast', the Republic of Mari El, etc.). Apart from these core territories there are Udmurt in other regions as a result of migration: in Siberia, for example, but also abroad. At the same time, northern Udmurtia is home to an ethnic group whose culture deserves particular attention, i.e. the Besserman who live alongside the northern Udmurt. They share some aspects of their culture, while others are distinct. Their language is thoroughly connected to Udmurt, but has its peculiar features which have been deeply investigated in recent years. Ethnographer Elena Popova, herself from this group, has dedicated many works to Besserman culture, and here she proposes a study on their ritual culture and mythological world.

The authors of these current studies propose an insight about different domains of folk culture, such as mythical narratives (about heaven, the forest and water, the homestead), calendar as well as birth rites and the fading of relevant rituals, ethnomusicologic fields, the role of the individual Kulturträger, etc. Both in subject and methods contemporary approaches and new, interdisciplinary, results are emphasised. Indeed, in social sciences, the methods of different disciplines and their theoretical equipment differ, but they complete each other and their combination allows for richer outputs. 
The first Udmurt academic scientific institution, the Institute of Complex Scientific Research, was founded in 1931 in the Udmurt Autonomous Republic, which had been created roughly one decade before. It was a very important step for the scientific community, for it gave Udmurt the framework to investigate their own culture. The Institute was active not only in researching Udmurt history, language and folklore, but also in regional and kolkhoz economics, and in following the use of natural resources. In the organisation chart of the Institute, we do not explicitly find a folklore department, which is also lacking today: in Russia, folkloristics is traditionally encompassed within what is called philology, and therefore famous folklorists work in the philology department. Working in a common structure postulates cooperation with archaeologists, ethnographers, ethnomusicologists and linguists, and institutional continuity allows scholars to widen their approaches, in other words to integrate through historic and comparative discourse previously collected material in contemporary observation, not forgetting that research always takes place within the given political and social boundaries.

\section{Empire, religion, and revival}

These socio-political aspects are not to be ignored. The Udmurt are among those communities whose language bearers are not numerous and thus find themselves, as an ethnic minority, in a critical situation, as they were since the Russian Empire as well as in the following years within the Soviet Union. They have been integrated throughout history into an Empire, which has significantly influenced their culture and their ways. The Udmurt share the fate of other Finno-Ugric and other-language-speaking communities in that in the $16^{\text {th }}$ century their lands were included in what was becoming the Russian empire (in 1552, the capital 
of the Turkic khanate of Kazan was taken by Ivan the Terrible's army). In the $18^{\text {th }}$ century Udmurts and others in the region fled Evangelisation and poverty in whole groups to neighbouring areas (Toulouze, Anisimov 2021).

Thus, Udmurt religious history encompasses long contact with Christianity and Islam as well as a long period of religious conversion. From the point of view of our topic, we must take into account that until the end of the $19^{\text {th }}$ century some Udmurts, those who had not merged into the Russian language and culture, and had not totally accepted Christianity as their own, had maintained their syncretic and animist beliefs, sometimes even alongside Orthodox practice. Some went over to "the Tatar faith" (Sadikov 2019). The permanence of the previous religious practice disturbed the state authorities, for it showed that the Udmurt had not yet given their full allegiance to the tsarist regime. In the $19^{\text {th }}$ century, some religious movements attempted vainly to bring the Udmurt together (a movement called Vyle Pyris' 'those who enter above', or the 'lime tree worshippers', see Sergei Filatov and Aleksandr Shchipkov 1997: 177 ff.). But their protests never reached the level of the attempts by the Mari to have their right to their own worship restored (Lallukka, Popov 2009). Religious strife reached liberal-minded Europe with the Multan affair (1892-1896), in which Udmurt pagans were framed for performing human sacrifices in three widely publicised court cases. It was a time of religious intolerance all over Europe. In a tradition set by the murder of William of Norwich (the first accusation of ritual murder by Jews in 1144 (G. Bennett 2005)), several similar cases were known all over Europe by the end of the $19^{\text {th }}$ century, the best-known being the Dreyfus affair (1894-1906). This kind of case in Russia has been described by for example A. Panchenko (2000). A similar case of blood libel triggered anti-Jewish movements in Hungary (1882-1883). In all these cases, justice cleared the accused, as ultimately happened in the Multan case. The aim of this incident was to show that the 
Udmurt were still a savage pagan people and that enlightenment had to be forced into them.

In the following period, the religious question ceased to be as tense, for understandable reasons. With the revolution, Christianity was no longer a required standard. For some time, family and village rituals continued to take place in agrarian regions and the role of sacred places and sacred buildings (kuala for example) as sites of meeting and performing community rites remained unchanged. But the Udmurt, at that time as well as today, did not chose to institutionalise their religion. In this period, more elements of Christianity started to be integrated into their worldview: icons were put in sacred places and some Orthodox saints were merged with figures of Udmurt mythology (see Vladykin 1994: 213-216). The Udmurt were characterised by a powerful syncretism. Then came the time of collectivisation (1928-), which disrupted the Udmurt's agrarian community.

No people in the Soviet Union, big or small, could remain untouched by the economic changes and the repressions of the 1930s. The Udmurt intelligentsia was almost eliminated, ceremonial practice was discouraged, cult places in villages and families were destroyed or left to decay. The Udmurt were treated as if their own cultural expression was a threat to Soviet rule (Toulouze 2017). But the Udmurt were a small community, theirs was not an institutionalised religion, thus they were much more fragile than other well-known cultures and institutionalised religions. Nevertheless, these attempts to break the Udmurt and others' resistance did not succeed, their passive resistance turned out to be resilient enough.

This appeared clearly in the 1980s and the 1990s, another period that requires thorough observation. It was a time in which social, political and cultural movements emerged, aimed at highlighting Udmurt culture and at re-establishing the dignity of Udmurt history. Spiritual quest and continuation of old customs were and still are a relevant element of Udmurt identity and self-determination. 
Mare Kõiva, Eva Toulouze, Nikolai Anisimov

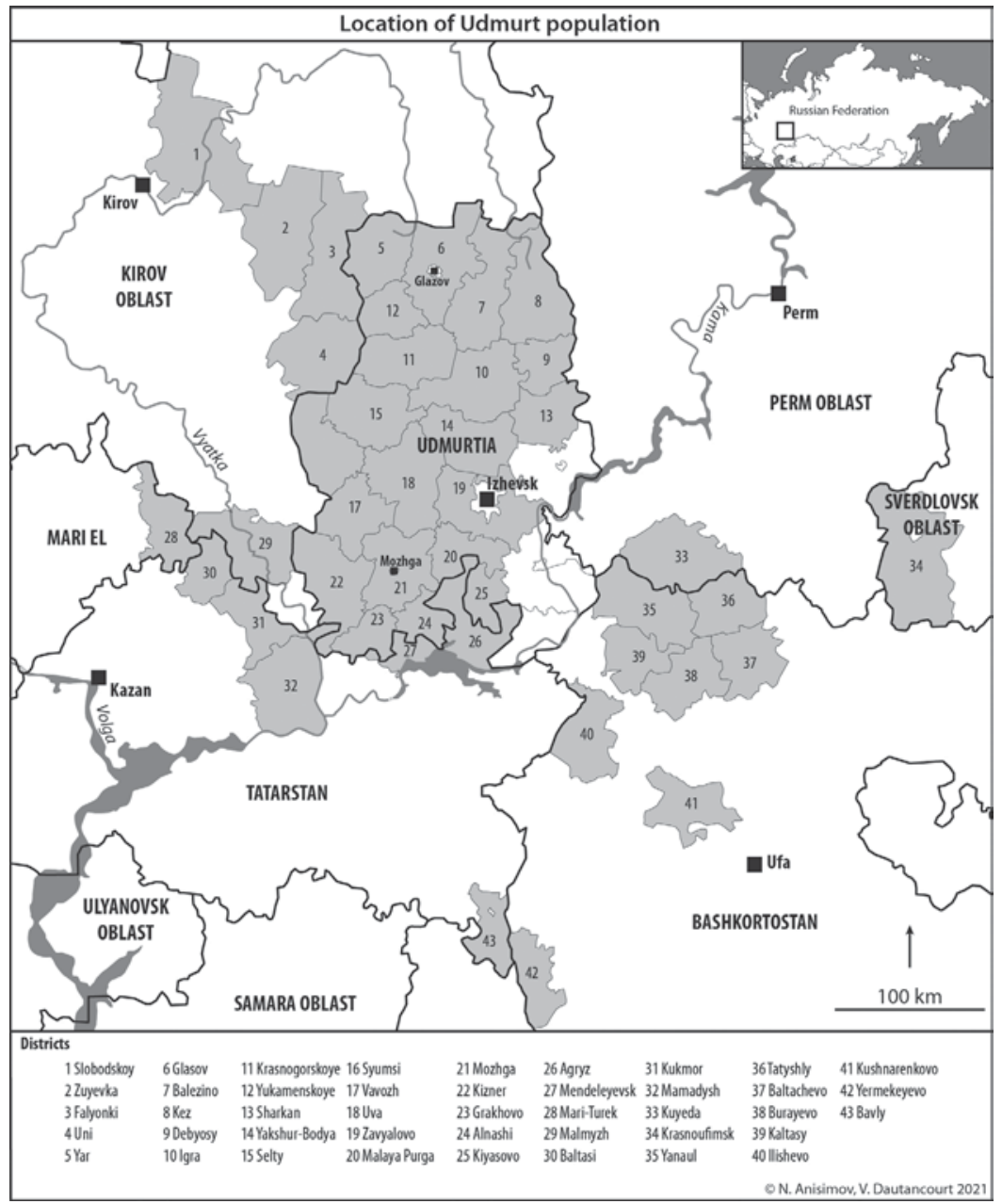

Map 1. Location of Udmurt population. 
The reflection on folk religion and religious narratives has been influenced in the last decades by the results of cognitive and neurosciences. In our context, it is important to take into account the fact that experiments and observations have rejected the idea that belief in the supernatural relies on intuitive thinking and that it is possible to reduce it by developing knowledge and analytic reflexion. Today, we would insist on social and cultural upbringing. This is the foundation on which religious thinking can emerge and resist, which means that its role is more significant than other factors (Farias et al. 2017).

Some important articles in our collection focus on religious practice and its context. Thus, Nadezhda Shutova, commenting on sacred ritual space, draws our attention to the reconstruction of "traditional sacral space (which) is being updated by the eastern Udmurt in Bashkortostan, in a dozen villages in Udmurtia and Tatarstan. Another ongoing project in several administrative regions is the formation of an Udmurt ethnic sacred landscape, with the annual republic celebrations, called Gerber in Udmurtia" (see p. 240). Eva Toulouze and Liivo Niglas reflect on the contemporary practice of Udmurt religion in Bashkortostan, one of the regions where this form of worship is the natural way for people to be themselves.

This process of revival is not an unknown phenomenon. While it is reminiscent of some aspects of European movements from the beginning of the $20^{\text {th }}$ century (Hann 2002; Chari, Verdery 2009), in which old customs were revived in the quest to find people's roots and traditions, the highlighting and revival of one's culture and religion found a new impetus in the 1990s. In the post-socialist space there have been similar movements in Mongolia and in Yakutia (Republic of Sakha). Is this a universal trend? The goal was not a pure return to the past, but a confirmation of one's identity, one's roots, through tradition, however inserted into the modern world. The peculiarity for the Udmurt and other northern Finno-Ugrians was that their communities 
had direct access to knowledge from people who had personal experience of the older world and, even more important, worldview.

\section{Centre and periphery, local culture}

It is complicated to live in a peripheral culture, for several reasons. The foundation of research institutions at the beginning of the $20^{\text {th }}$ century and the national awakening gave young Udmurt scholarship the basis for development in compliance with modern requirements and entrusted this scholarship with a huge working field. For decades, Udmurt scholars have efficiently taken over the challenge and covered the tasks they had to achieve, while endeavouring to be present in scientific dialogue within Russia's scientific debate, as well as in international forums and working groups. They were compelled by reality to do so not in their mother tongue, which is not accepted in their country as a scientific language, but in Russian, which requires a deep awareness of cultural translation. This awareness must be even higher when achieving translation of their reflections in another language, for example English. Some cultural features are deemed to remain underexpressed, for translation does not allow these features to be transmitted properly. As Tatiana Vladykina, Galina Glukhova and Tatiana Panina observe: "Terminological vocabulary is locally differentiated: the northern Udmurt had the influence of Russian folk and Orthodox calendars, while the southern Udmurt and the Udmurt of the enclaves in Tatarstan and Bashkortostan had the influence of Turkic cultural traditions. These local variations in the calendar give the opportunity to consider the peculiarities of its formation and development, and its importance in the general system of ethnic culture" (see p. 30).

These and other questions emerge in the contents of this collection. Some of the articles are centred on Udmurt mythology and 
the characters in it, others on rituals and ritual life and others on topical issues, such as soundscape and individuals in culture, the importance of witchcraft in Udmurt rural life.

\section{Mythology}

The roots of mythology go back to time immemorial, and regretfully no complete written source has been found. Mythology has been reconstructed relying on different sources from manuscripts and publication of modern times, using archaeological data and folklore recordings of legends, myths and beliefs. The Udmurt mythological pantheon is rich and has been subject to scientific discourse since the $19^{\text {th }}$ century, but its key texts and connected rituals were deeply analysed during the $20^{\text {th }}$ century. The Udmurt mythological worldview has been commented upon in numerous writings by Udmurt scholars Vladimir Vladykin and Tatiana Vladykina, and by Vladimir Napolskikh, just to mention the most relevant, but by no means only, scholars.

The deities connected to different spheres of the world-model, their activities, as well as the rituals dedicated to them, are here commented upon in eight articles. Some of the articles encompass both mythological characters and rituals, as this is the case with the periods around the solstices. The celebration of the winter solstice from January $7^{\text {th }}$ to $19^{\text {th }}$, about which Galina Glukhova writes in detail, is accompanied by mumming and masking, as well as by new year's communication with the spirits of the transition time who come to inhabit the human space from their underwater dwellings. The summer solstice is connected with the image of the Mother/Foremother Invozho, who descends at this time of year from heaven to earth and is received with significant festivals. Both Galina Glukhova and Aado Lintrop comment, from different points of view, on the same phenomenon: Glukhova describes the 
actions that take place in this period, while Lintrop, with a keen philological sensitivity, draws parallels with Komi tradition and sets the whole religious complex against a wider background.

The Heavenly area, its construction, constellations and its Gods are central in one of the articles by Tatiana Vladykina. The research concentrates on the supreme deities, including the creator God and female foremothers. Extending the scope of the heavenly God to literature, Aleksey Arzamazov investigates the figure of Inmar, the Udmurt God, in modern Udmurt literature at the turn of the $21^{\text {st }}$ century. His study analyses predominantly ethnic and futuristic poems by Petr Zakharov, Viktor Shibanov and Anastasiya Shumilova.

Elena Popova introduces the role of springs and rivers as mythology (with the master spirits of water), looking at the ritual practice connected with them as a metaphor for the traditional world model and as a connector to different parts of space, including sky and earth. Popova concentrates on Besserman material, although in this case Besserman material dialogues efficiently with northern Udmurt material, which, although in detail may differ, in essence answers to the same logic.

Another joint article by Tatiana Panina and Tatiana Vladykina provides a detailed description of the appearance of forest spirits, with their distinctive features and functions, and presents how beliefs about those mythological beings have evolved over the last centuries (and are still partly alive today). The paper investigates the best-known mythological beings living in the woods: n'ulesmurt ('forest man'), palesmurt (lit: 'half man'), and obyda ('forest woman').

Finally, an article by Tatiana Vladykina and Galina Glukhova investigates the familiar spirits of domesticated space the master of the house, the master of the bathhouse and the master of the cowshed. 


\section{Place, ritual and materiality}

Ritual is never disconnected from location. Nadezhda Shutova, who has dedicated long years to sacred landscapes in the VyatkaKama region, dedicates her article to sacred places. Research on landscape has emphasised the social and symbolic 'creation' of the space through everyday practice, for landscapes reflect history, which has meanings, values and strengths. (See for example Tilley 2006, which is close to the results of Shutova's investigations.) Shutova defines sacred space as a complicated natural, historical and cultural, religious and mythological set, and divides the places into family, patronymic, conditional clan, village, regional, tribal and territorial units. Her reconstruction emphasises that in the surroundings of each village community, there was a complete system of cult places and sites with different levels of significance.

Two other contemporary rituals are described in this collection. One of them in detail: the Seeing off a Recruit ritual for boys is the object of Valeriia Fedorova's article. This is a ritual that is still alive in Udmurtia, with some changes for although the period a boy spends in the army today is very short compared to historical experience, it is the first time he leaves his home for a long period in order to delve into the unknown. The interest of Fedorova's treatment is its musical dimension, for she neatly presents the songs sung within the ritual, with the tune and the lyrics, and comments on them, reminding us that songs are an integral part of ritual activity.

Yyr-pyd s'oton (the 'giving of head and legs' of a sacrificial animal) is a family ritual still performed in some places in Udmurtia some years after the death of one's parents. It is the last commemorative rite dedicated to real people, who henceforth become ancestors. Denis Kornilov describes a peculiar yyr-pyd s'oton held in 2020 in a southern Udmurt village in honour of the inhabitants of the neighbouring villages Bagrash-Bigra and Orlovo, who died during the Second World War. This ceremony took place in spite of COVID-19 restrictions and was an original combination 
of a commemorative, and at the same time another, ceremony. It was a unique performance 'invented' by local activists in a village where the tradition has been lost, in order to answer the population's spiritual needs.

If the first article about rituals concentrated on the different spaces dedicated to them, the starting point for the last, by Vladykina, Glukhova and Panina, is an object, a bundle of coloured thread called a chuk, which has in everyday and in ritual contexts polysemic contents, starting from apotropaic magic and folk medicine to passage, calendar or recruiting rites. This article echoes Fedorova's article, for chuk is of material importance in the seeing off of a young man to the army.

\section{Personal folklore and the role of the individual in folklore}

The dialogue between the collector and the tradition bearer, the consistency between his/her worldview and repertoire, is an old research issue developed in folkloristics since Mark Azadowski's famous investigation "Eine sibirische Märchenerzählerin” (1926). This direction was subsequently pursued in different countries, for example in Estonia by Richard Viidalepp (1938, 2004), who alongside his long monograph on great storytellers, analysed remarkable storytellers, their performances and styles (2004). Juha Pentikäinen's research of individual anthropology about Marina Takalo's religion (1971) and the series of publications in different languages about Finno-Ugric and Nordic wise men, witches, singers (Paulaharju 1929; Siikala 1990; Saarinen 2018; Kõiva 1990; etc.) have given the opportunity, through research focused on performers, to elaborate new theoretical positions. In these articles we find analyses of the remarkable intellectual contributions and cultural strategies of contemporary informants and traditional experts. Irina Pchelovodova and Nikolai Anisimov concentrate 
on the phenomenon represented by Ol'ga Solov'yova (1932-2018), called Dzhakapay. They analyse her repertoire, her improvisation ability and her personal songs, which represent a kind of personal, and at the same time collective, memoire in musical form, as well as her spontaneous translations, her partnership with folklorists and her manifold roles of go-between.

The next papers allows us to get acquainted with other types of sacral specialist such as the witches and priests who, through their performance, influence for good or for evil, the life of their village. Eva Toulouze and Liivo Niglas' text on Udmurt sacrificial priests focuses on the key figure in Udmurt ritual, the sacrificial priest, called vös'as'/kuris'kis'. The paper attempts to sketch a pattern of contemporary function-performance and transmission, following and analysing changes introduced in recent decades. On another topic, still focused on personalities, Nikolai Anisimov's research on contemporary witchcraft in the Udmurt village examines how wizards and witches are seen in today's Udmurt society, including the evolution in the village of their reception. Of course, for understandable ethical reasons, Anisimov is less focused on real personalities, but on narratives and stories, which show the great relevance of this topic for Udmurt life today.

\section{Soundscapes in ethnomusicology}

As we have already seen, music has popped in through ritual analysis (pp. 215 etc). Music, especially song, is an unavoidable dimension in Udmurt folk culture, which encompasses much more than entertainment or an accessory role in ritual, rather it covers the entire field of communication, as researchers have emphasised (Gerd 1926; Nurieva 2014). The description of soundscapes and of sound ecology is also, independently of its relevance for Udmurt folk culture, one of the rising trends in anthropology and opens new opportunities for research. Irina Nurieva starts her article 
by reflecting on the sounds of the Udmurt village and of its environment, such as the forest. Alongside the acoustic milieu and natural sounds (such as animal noises), the mechanical sounds that accompany work come with traditional music and singing and form the unique soundscape of the region. Nurieva explores the norms of behaviour regarding sound in the acoustic community in villages. Irina Pchelovodova turns to instrumental traditions and gives a complete description of the uz'ygumy, the Udmurt traditional flute: the process of manufacture of the instrument, the way of playing it and the repertoire. As previously mentioned, Dzhakapay's art also brings us deeply into the musical world, with all of its communicational dimensions.

\section{About this book}

In the Philology Department of the Udmurt Institute there are fourteen scholars who have taken on responsibility for investigating the very wide domain of Udmurt traditions and folklore from different points of view. They work on folk narratives, folk songs, and musical culture, which includes games and dances, beliefs and ethnically central rituals, proverbs, riddles and sayings. But not only these: they also work on folk medicine, omens and predictions, incantations and prayers. Although this list seems incredibly long, it is indeed covered by publications and defended theses. It is the soil from which this collection of articles has emerged. This issue of the journal SATOR has been prepared through cooperation between the Department of Folkloristics at the Estonian Literary Museum, and the Udmurt History, Language and Literature Institute at the Federal Research Centre of the Ural Branch of the Russian Academy of Sciences. It started with Tatiana Vladykina's idea of presenting Udmurt mythology in English; under the encouragement of editors Nikolai Anisimov, Eva Toulouze and Mare Kõiva 
it grew as an insight into Udmurt folklore with a wider scope, including new and exciting topics.

The list of the authors reflects our wish to show that contemporary folk culture research can be an open field, a domain of dialogue between cultural insiders and outsiders. While in some regions the question of who is authorised to investigate culture is ongoing, we are convinced that the richness of research results depends on it reflecting a multiplicity of points of view. Of course, most of the authors are renowned Udmurt researchers. We find among them beacons of the Udmurt humanities such as Tatiana Vladykina, a classic author in folkloristics and ethnology, to whom we are happy to gratefully dedicate this book. Our homage to Tatiana Vladykina is enriched by recensions of two crucial books she has published in recent years. Moreover, we have collected some texts from students and colleagues that allow the reader to understand why Vladykina is scientifically, as well as personally, the object of both respect and affection.

Other authors are famous researchers, such as Irina Nurieva, Nadezhda Shutova, Galina Glukhova, Elena Popova, Tatiana Panina, as well as representatives of a new generation such as Irina Pchelovodova, Valeriia Fedorova, Denis Kornilov and Nikolai Anisimov, the latter representing both Udmurt and Estonian scholarship. Their articles cannot but reflect the results of the work of the previous generations. Contemporary scholars can often reach further, and are able to generalise knowledge, when relying on material collected a century ago and enriching it with contemporary data. At the moment, Udmurt scholars have not adopted a unified rule about the orthography of folklore terminology (ritual, sacred places names, deities etc). They are still discussing it among themselves. In these conditions we have decided to accept the way each scholar chooses to write these terms.

Among the outsiders to Udmurt culture there are texts by researchers, fans and lovers of Udmurt culture, who all are dedicated 
to it. Here we have chosen Aado Lintrop's, as well as Liivo Niglas' and Eva Toulouze's articles (relying on tradition, we consider the latter in this collection as an Estonian scholar, although she also represents French Finno-Ugristics).

We have said that this is the first overview in English of Udmurt mythology and folk culture. Hopefully it will not be the last. We are living a time of restrictions: there are political, geographical, and cultural boundaries; COVID-19 added to the obstacles to free communication. Nevertheless, this book is proof that goodwill and the desire to share in mutual cooperation can overcome these obstacles, and we are ready to go further.

We are grateful to Daniel Edward Allen, who polished the English text, and to Diana Kahre, who was of great support at every step of the achievement of this book.

\section{References}

Azadowski, M. 1926. Eine sibirische Märchenerzählerin. FF Communications 68. Helsinki: Suomalainen Tiedeakatemia, Academia Scientiarum Fennica.

Bennett, G. 2005. Towards a Revaluation of the Legend of "Saint" William of Norwich and its Place in the Blood Libel Legend. Folklore, 116 (2), pp. 119-139.

Census 2010. Vserossiiskaya perepis naseleniya. http://www.gks.ru/ free_doc/new_site/perepis2010/croc/perepis_itogi1612.htm.

Chari, S., Verdery, K. 2009. Thinking between the Posts: Postcolonialism, Postsocialism, and Ethnography after the Cold War. In: Comparative Studies in Society and History 51(1), pp. 6-34. 0010-4175/09 \$15.00 \#2009 Society for the Comparative Study of Society and History. DOI: 10.1017/S0010417509000024.

Farias, M., van Mulukom, V., Kahane, G., Kreplin, U., Joyce, A., Soares, P., Oviedo, L., Hernu, M., Rokita, K., Savulescu, J., Möttönen, R. 2017. Supernatural Belief Is Not Modulated by Intuitive Thinking Style or Cognitive Inhibition. Nature. Scientific Report. www.nature.com/ scientificreports. 
Filatov, S., Shchipkov, A. 1997. Udmurtia: Orthodoxy, Paganism, Authority. In: Religion, State \& Society 25 (2), pp. 177-183.

Gerd, K. 1926. Votyak v suoikh pesnyakh. Glava 1. Pesni o pesnyakh [The Votyak in His Songs. Chapter 1. Song about Songs]. Votyaki [The Votyak]. Moscow, pp. 17-41.

Hann, C. 2002. Postsocialism: ideals, ideologies and practices in Eurasia. London: Routledge.

Kõiva, M. 1995. From Incantations to Rites. In: Kai Vassiljeva, Mare Kõiva (eds). Folk Belief Today. Tartu: Institute of Estonian Language and Estonian Literary Museum, pp. 215-236.

Lallukka, S., Popov, N. 2009. Testing the limits of the permissible. Mari ethno-religious ferment and Russian authority, 1820s-1840s. In: Michael Branch (ed.) Defining Self. Essays on emergent identities in Russia Seventeenth to Nineteenth Centuries, Studia Fennica, Ethnologica 10, pp. 316-333.

Nurieva, I. 2014. Udmurtskaya muzykal'no-pesennaya traditsiya; spetsifika zhanroobrazovaniya i funktsionirovaniya [The Udmurt Musical and Singing Tradition: Peculiarities of Genre Formation and Functioning]. $\mathrm{PhD}$ Dissertation. Izhevsk.

Panchenko, A. 2000. "Strange faith" and the blood libel. In: Fol'klor i postfol'klor: struktura, tipologiya, semiotika. Staraya Ladoga Collection. Vol. III. Saint-Petersburg: Staraya Ladoga.

Paulaharju, S. 1929. Vienan Karjalan tietäjistä. In: Kalevalaseuran vuosikirja 9. Helsinki: Suomalainen Kirjallisuudern Seura, pp. 177-184.

Pentikäinen, J. 1971. Marina Takalon uskonto: Uskontoantropologinen tutkimus. Suomalaisen Kirjallisuuden Seuran toimituksia 29. Helsinki: Finnish Literary Society.

Saarinen, J. 2018. Runolaulun poetiikka: Säe, syntaksi ja parallelismi Arhippa Perttusen runoissa [Poetics of Runic Songs: Song, Syntax and Parallelism in Arhippa Perttunen's Songs]. PhD Dissertation. Helsinki: University of Helsinki.

Sadikov, R. 2019. "Prezhde zhe khotya i byli yaztchniki, no nyne magometanskogo veroispovedeniya": $\mathrm{k}$ voprosu o prinyatie islama zakamskimi udmurtami [Formerly, We Were Pagans, but Now We Follow the Faith of Islam]. In: Voprosy vostokovedeniya [Questions of Oriental Studies] 2 (84), pp. 32-37. 
Siikala, A.-L. 1990. Singing of Incantations in Nordic Tradition. In: Tore Ahlbäck (ed.) Old Norse and Finnish religions and cultic place-names. Helsinki: Almqvist \& Wiksell International, pp. 191-205.

Tilley, C. 2006. Introduction: Identity, Place, Landscape and Heritage In: Journal of Material Culture, Vol. 1 (1-2), pp. 7-32. DOI: 10.1177/1359183506062990.

Toulouze, E. 2017. A long terror in the Volga region: a war before the war. In: A. Kotljarchuk, O. Sundström (eds.) Ethnic and Religious Minorities in Stalin's Soviet Union: New Dimensions of Research. Södertörn Academic Studies 72. Huddinge: Södertörn University, pp. 153-172.

Toulouze, E., Anisimov, N. 2020. An ethno-cultural portrait of a diaspora in central Russia: the formation and culture of the eastern Udmurt. Folklore: Electronic Journal of Folklore 79, pp. 31-58. DOI: 10.7592/ FEJF2020.79.toulouze_anisimov.

Viidalepp, R. Ühest suurjutustajast ja tema toodangust [About a Great Narrator and His Production]. In: Õpetatud Eesti Seltsi toimetused XXX. Tartu: K. Mattiesen, pp. 830-845.

Viidalepp, R. 2004. Eesti rahvajuttude laadist, funktsioonist ja jutustajatest [About the Nature, Function and Narrators of Estonian Folk Tales]. Reet Hiiemäe (ed) SATOR: Artikleid usundi-ja kombeloost Tartu : Eesti Kirjandusmuuseum.

Vladykin, V. 1994 Religiozno-mifologicheskaya kartina mira udmurtov [Religious and mythologic worldview by the Udmurt]. Izhevsk: Udmurtia.

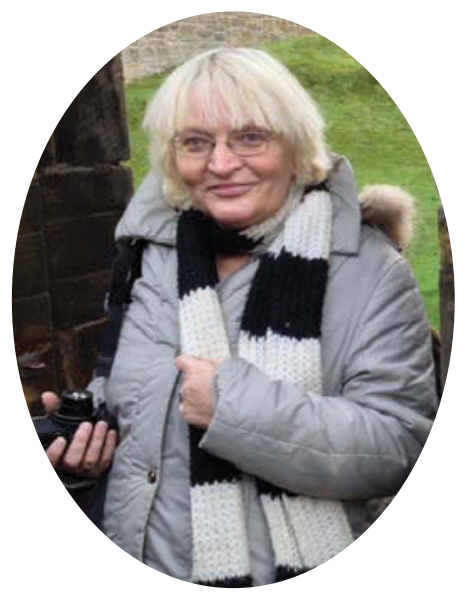

Mare Kõiva $(\mathrm{PhD})$ is Head of the Centre of Excellence in Estonian Studies, and Leading Research Fellow, Head of the Department of Folkloristics at the Estonian Literary Museum, Estonia. Her main research areas are charms and charmers, belief narratives, mythology, and human/non-human relationships. e-mail: mare.koiva@folklore.ee 


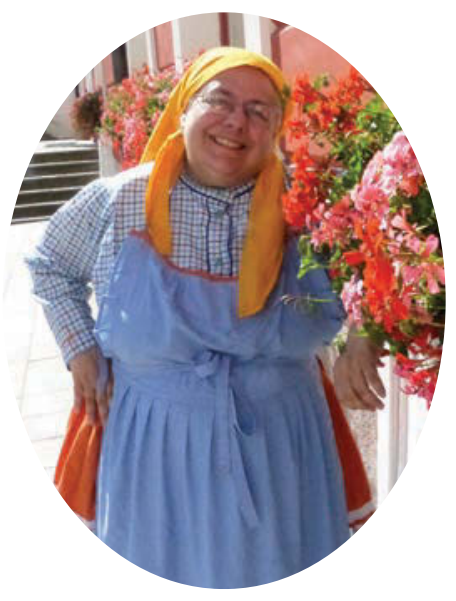

Eva Toulouze ( $\mathrm{PhD}$ hab) is a professor of Finno-Ugric languages at the Institute of Eastern Languages and Cultures (INALCO, Paris), and a researcher at the Department of Ethnology, University of Tartu, Estonia. Her main fields of interest are the cultures of Russia's FinnoUgric peoples, the emergence of a written culture in Finno-Ugric areas, Forest Nenets culture and Udmurt religious practice.

e-mail: evatoulouze@gmail.com

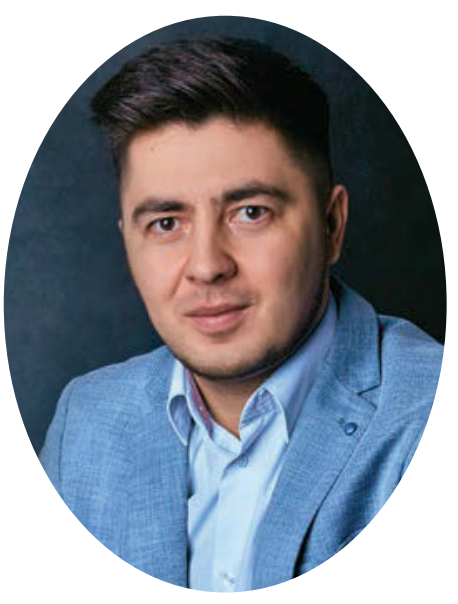

Nikolai Anisimov ( $\mathrm{PhD}$ ) is a researcher at the Department of Folkloristics at the Estonian Literary Museum, Estonia, and at the Department of Philological Studies at the Udmurt Institute for Research in History, Language and Literature (Udmurt Federal Research Centre of the Ural Branch of the Russian Academy of Sciences). His main field of interest is Udmurt traditional and contemporary culture, and more precisely, the Udmurt living ancestors' cult, and their singing tradition.

e-mail: nikolai.anisimov@folklore.ee 



\section{Studies in Udmurt Folkloristics}





\title{
Rituals and Socialisation in the Udmurt Folk Calendar ${ }^{1}$
}

\author{
Tatiana Vladykina \\ e-mail: tgvladykina@mail.ru
}

\section{Galina Glukhova}

e-mail: galant@udm.ru

\section{Tatiana Panina}

e-mail: tipanina@mail.ru

\begin{abstract}
The article describes Udmurt folk calendar rites from the perspective of age and gender socialisation as one form of regulation of the ritual act. It shows, using particular examples, the interdependence of gender and age differences. Men played an important role in the process of prayer. However, the 'female theme' has become the quintessence of spring ceremonies, the main functions of which were fertility and production. A special role was given to older women who were not only the supervisors of ritual actions, but also the initiators of occasional rituals. They also established contact with the other world. Youth held an active position at the beginning of half-year as equivalent periods (palar) of calendar cycle - spring and autumn. Boys and girls were the main participants in the spring and summer merrymaking dances and at the autumn and winter gatherings. The main task of these rituals was the formation of pairs with the prospect of marriage. The eve of the holiday could be correlated with puberty. Children participated in appropriate games in which the basic images and characters of
\end{abstract}


the rituals are revealed. Attention is focused on the functions of the participants and the peculiarities of their behaviour.

Keywords: Udmurt folk calendar, rites and holidays, spring and summer merrymaking, winter gatherings, age and gender socialisation, men in the rite, child-bearing age of women, elderly people, youth, the characters of ritual actions, behavioural stereotypes.

\section{The Udmurt folk calendar}

The Udmurt folk calendar is a vivid example of an interaction of cultures. It preserved the old views of ordinary and sacred time as a particular manifestation of the recurring natural cycle, it preserved the evolution of these views and their influence on interethnic contact and the world religions. Milestones in the annual cycle, its structural components and the nomination of ceremonies are directly related to ethno-genetic processes in the Ural-Volga region. At the same time terminological vocabulary is locally differentiated: the northern Udmurt had the influence of Russian folk and Orthodox calendars, while the southern Udmurt and the Udmurt of the enclaves in Tatarstan and Bashkortostan had the influence of Turkic cultural traditions (Vladykina, Glukhova 2013: 115). These local variations in the calendar give the opportunity to consider the peculiarities of its formation and development, and its importance in the general system of ethnic culture.

The schedule ran according to the seasons: winter ( $t o l)$, spring (tulys), summer (guzhem), autumn (siz'yl), taken from the annual cycle (ar), which was divided into two semesters, autumn-winter and spring-summer and were considered equal and equivalent, existing in a pairs (palar six months; unpaired year).

The borders of the semesters were the days of the winter (vozhodyr/uyvozho) and summer solstices (invozhodyr/invozho), perceived as dangerous and requiring special reverence. The majority of the calendar festivals (vozho-yuon/tolsur/roshvo; 
Kuarsur/Gerber/Guzhem-yuon/Petrol) are related to these periods or are associated with the beginning and end of agricultural work (Akashka/gery potton; pörtmas'kon/siz'yl-yuon).

Great value of the autumn-winter period is seen in the coincidence of the concepts 'autumn' and 'year' (ar) (Alatyrev 1988: 98-99), although views about the new year beginning in autumn are preserved only in fragments and associated with a more archaic counting of the time, when an important calendar milestone was the beginning of the hunting season, connected to the time of the autumn sowing (Vladykina, Glukhova 2011b: 14).

The ancient tradition of considering spring as the beginning of the new year was preserved in the rites of the first thawed patch of ground (guzhdor) and the seeing-off of ice (yö-kel'an). In agricultural tradition these were united with the beginning of planting (Akashka/Akayashka), and in the Christian calendar with Easter (Byddzh'ynnal/Paska/Vel'iktem).

The division of the year into specific months is a rather recent phenomenon, nevertheless it is usual to make a division of twelve months. Their names are a synthesis of different types of time measurement according to the cycle of the sun and periods of the moon, duration of hunting, care of cattle and the rhythm of agricultural work. For a long time the main milestones of the annual ritual cycle were not correlated with the modern calendar: their confinement to specific dates is rather recent and is often linked to Christianisation. Therefore one and the same month had several names, especially in local tradition, for example March was yuzhtolez'/oshtolez'/kuakatolez'(lit: 'month of thin crust of ice over snow' / 'month of water' / 'month of [the arrival of] rooks'); April was oshtolez'/kyz'putolez'(lit: 'the month of water' / 'month of birch sap'); June was invozho /vozhtolez'/l'ektolez'(lit: 'month of invozho' / 'angry month' / 'transition month'); August was gudyrikoshkon / siz'yl/dzh'egkiz'on/vil'dzh'uktolez' (lit: 'month of passing thunder' I 
'autumn month' / 'month of planting rye' / 'month of new cereal'), etc. (Vasil'yev 1906: 346-349; Vladykina, Glukhova 2011b: 128-129).

The modern weekly cycle of the Udmurt, as in other cultures, consists of seven days. Their names reflect traces of ancient time reckoning and the influence of Christian (Russian) and Tatar cultures. Initially a quinary system built on an opposition between working days and sacred days was used. Three of weekdays were nameless, i.e. they were simply called arn'a 'day of year', '[the shortest] short period of the year', 'the nameless day', while the sacred days were connected with sacrifice: in one case the slaughter of an animal (virnunal - lit: 'blood [of thanks offering] day'), in other there was no sacrifice (kösnunal lit: 'dry day' / 'fast day'). In the modern nomination of weekdays the first name is associated with Wednesday, the second with Saturday (Vladykina, Glukhova 2011a: 39-40). (Compare in this regard a typology of the nomination of the Baltic-Finnish peoples in Vinokurova 1994: 18-19).

The perception of particular 'transition' calendar days - more often periods - from the point of view of the ordinary/profane and the sacred, every day and festive time gave rise to the common term yuondyr (lit: 'time to drink [a ritual drink]') as well as the sporadically used shyd-s'iyon [dyr] (north, lit: '[time of] eating a soup'). Therefore the Udmurt language and ritual traditions have preserved the notions of a magical connection of festive culture and ritual drinks/ritual food. Intoxicants made on the basis of bread (grain, flour, malt) such as kvas (s'ukas'), beer (sur) and home-made wine (kumyshka) became not only an attributive symbols of the holiday, but also became the basis of their local names: tolsur (lit: 'winter beer') meaning 'winter festival' ( $\approx$ Christmas); Kuarsur (lit: 'leafy beer') meaning 'summer holiday' ( $\approx$ the Trinity).

For example, northern Udmurt had common terms for the autumn youth gatherings nyl-braga (lit: 'maiden mead') meaning 'girls' holiday', and the end of the autumn field work the kolkhozbraga (lit: kolkhoz braga) meaning 'collective farm holiday'. It is 
obvious that the term braga was used instead of the previous term (apparently not without the influence of the old believers' culture): nyl sur/nylsur 'maiden beer', nyl braga 'maiden mead' both of which equate to 'autumn festival' (autumn youth gathering).

\section{Village community gender and age stratification in the system of calendar holidays}

The content of a rite gives information about features of behavioural stereotypes. Here are two examples.

The Northern Udmurt called the winter solstice vozhodyr (lit: 'transitional period', 'crossroad' / 'transition of time'; 'time of evil spirits' / 'time [of outrage] of vozho'). With the introduction of the Christian chronology and the transition to the official calendar this period was timed to Christmastide, i.e. from the $7^{\text {th }}$ to $19^{\text {th }}$ January. The name reflects how this period was identified as sacred (in direct opposition to ordinary time, as also with the Komi 'vezha 'holy'/'consecrated'/'sacred' (Lytkin 1999: 50)).

According to the archaic beliefs of the Udmurt, in the days of transitional time the spirits vozho 'come out' from the water, personified as little black and white creatures in zoomorphic and anthropomorphic shapes. Anything abnormal that happens to people at night during this period is ascribed to their tricks. To combat this, people used an elaborate system of prohibitions and amulets. They tried not to walk outside, were afraid to pass across bridges, didn't walk near abandoned houses or bathhouses at dusk and at night, especially around midnight. It was believed that vozho live in these places. People protected themselves by invoking God's name: “Oste, Inmare!”('My God!') or by using invective language. Children were told: "En pota ber uyin: vozhoos vetlo/kutozy" ('Don't go outside at night: vozho walk' / 'they will catch you'). Crying children 
were also threatened with vozho: "En börd, vozhoos s'örazy nuozy" ('Don't cry, vozho will carry you off [under the water]').

At Christmas there was a ban on certain activities: washing floors, doing laundry, going to the bathhouse, taking ash out of the furnace, rumpling linen and making malt. If doing the laundry was unavoidable, people were guided by prescriptions not to leave the washed clothes outside before going to bed, otherwise vozho will "behave outrageously", cutting the clothes and throwing dirt on them. After washing the water was poured away only in the evening and the spot covered with snow.

During these days people had to do needlework, although even so it was limited. Spinning and knitting were only permitted in the afternoon and late in the evening, doing this work in the twilight was strictly forbidden.

According to the materials of the 19th century, in the tradition of the northern Udmurt the first day of Christmas was called 'the treat [lit: soup] of vozho' (vozho-shyd). The highlight of the day was sharing a meal in the village community hall (shyd-s'iyon), under the leadership of the chief priest (zek pop). Appealing to the original mother vozho (Vozho-mumy) he requested that she not harm the people during two 'terrible'/'transitional' weeks so that the spirit 'would go without anger into the water on January 6 [Church calendar], and the next year would contribute to the good crops" (Pervukhin 1888 (2): 130).

On the night of Epiphany younger people 'conjured' the spirits (vozho-kel'an) from their terrestrial habitat going from bathhouse to bathhouse with songs, drew a circle with burnt wood inside and 'listened to destiny', appealing to the invisible beings with the demand that they get out, "Pote tatys?" ('Get out from here!').

One peculiarity of the winter transition period among the northern Udmurt was a woman's holiday, the day after Epiphany. Women chose an old man as the master of the rite and under his leadership went from house to house with songs and dances. This feast ended the winter cycle, initiating the spring period. 
'Meeting' and 'seeing-off' of vozho included the following components: gatherings, divination, disguise.

Gatherings were the main form of entertainment and took place in the bathhouse or in a house specially purchased for the occasion (pukon korka). For boys and girls, gatherings were an opportunity to get acquainted, to find a groom or a bride. Participants competed in wit, intelligence, storytelling ability, life stories, making puzzles, singing. Everything that was told or sung at these gatherings was called vozho-mad' 'stories/tales/songs of [the time of] vozho'. There were special games played only during this period. The main idea was projected onto the producing power of man and nature ('to shoot grouse', 'bundles') and communication with the ancestors ('hide and seek', 'butterfly').

This time was also considered favourable for divination (tunatskon): the girls wanted to know the future in order 'to see' their betrothed. The whole Christmas period was considered favourable for the predictions, but especially attractive and popular was the night from $13^{\text {th }}$ to $14^{\text {th }}$ January, vozholen l'ek dyryz (lit: 'the most evil/powerful time for the vozho'). Old people also conjectured on this night. They wanted to know about the coming year, the harvest and whether or not the livestock would produce good offspring.

All members of the village community from young to old were involved in winter disguise (vozhoyas'kon, from vozhoyas'kyny 'to dress up, to camouflage', lit: 'to be like vozho / to turn into vozho'; vozhoyas'kysa vetlyny, lit: 'to walk [in the shape] of vozho'). Children dressed in the afternoon, and adults and youth in the late evening. People gathered in one house, usually at the end of the village, and there changed their dress. It was believed that the mummers should be an odd number. A person was permitted to participate in disguise not more than three times. There were masks made from birch (tuy bam) and leather (suron bam); a mask of 'laughing death' with teeth cut from a raw potato; a face smeared with soot (suam bam) or covered with white canvas (later tulle, 
gauze or a white handkerchief) is considered an archaic Christmas mask. It is obligatory to have zoomorphic (bear, horse, cow) and ornithomorphic masks (magpie, goose). The anthropomorphic masks are 'the old man' and the 'old woman', 'the Mari', 'soldier', 'beggar', 'hunchback', 'pregnant'. One of the most common types of disguise was the travesty, in which a man wore homespun female dress (shortderem) or linen skirt (dera yubka); he then tied a cloth on his head and put a cradle made of homespun linen (nyp"yet) or bast (muchko) on his back. In return women wore men's outerwear (now a jacket), trousers and hat, and were girded with an embroidered towel. They could make some sounds or sing songs with disguised voices only on the street. They dragged the people they met into the snow. At the entrance to the house they signalled their arrival with noise and a loud thud, but the house was entered silently. They banged with sticks on the floor in the shed, danced in a circle to the accompaniment of the oven dampers, rollers for ironing, washing boards. The hosts tried to recognise the mummers by attempting to remove their masks, and by pinching and tickling them to make them speak. Those who were not recognised took of their masks at the last moment, after which they were treated to beer, specially prepared for this holiday, as well as cakes, bread and even flour. After returning home they fed the cattle with this food, believing that the disguise contributed to the animals producing offspring and that it brought good luck in other affairs, for example promoting harvests of hemp, flax and cabbage. Therefore, despite the fact that the mummers came deep in the night, gates and doors were open and they were welcomed in every house.

Many ritual components of the Christmas period (prohibitions, charms, divinations, disguise, and gatherings with the obligatory needlework) were preserved during the years of the Soviet Union, despite antireligious propaganda. Even in the 1960s and 1970s, elderly people believed in the magical function of the rituals. This is evidenced by reports of informants, who stated that in some villages older women, believing in the magical power of disguise, believed 
also that it was necessary to visit the neighbours at least once in the guise of a mummer over the Christmas period. In addition, the archaic traditional masks disappeared and ethnic costume or its details became attributes of the disguise. The younger people took a minor part in the events, but the primordial function of the ritual was lost: disguise became just fun. This was caused by widespread tradition of New Year's masquerades in kindergartens, schools, clubs, and urban culture houses. Attempts to revive the

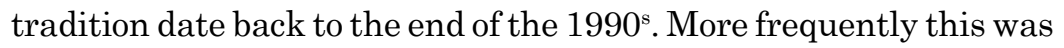
initiated by young people, moreover in the city, and this led to the inclusion of elements that were uncharacteristic of Udmurt ritual, for example loud singing, dancing, and dialogue with the hosts.

The Christmas cycle of the northern Udmurt included the obligatory ritual component of seeing off the spirits that came from the underworld during this period. The ceremony was timed to the Epiphany (yö vylyn sylon lit: 'standing on ice'; kres'en'n'al kreshen'n'a). People gathered in a special hut that was bought for a small fee by the youngsters after the New Year. The evening before the festival the young people went from house to house, inviting guests with the words: "Come to the feast of vozho", lit: "Come to drink vozho home-brewed beer' ("Vozho-braga yuyny lykte"). Everything was done beforehand: the products were collected, drinks were prepared, meals were cooked. The visiting continued until late into the night. Then gatherings young people began in the bathhouses. First having outlined themselves with a charred piece of wood they 'listened to destiny', and then conjured 'spirits'/"water sprites'. Compusory matchmaking was the order of this day.

In the early morning the girls stoked the bathhouse and the men having taken axes, sticks or twigs, went to the river under the leadership of the priest and pounded on the ice and screamed, conjuring vozho. Then they washed in the bathhouse and went to Church to attend the ceremony of consecration of water. After returning home they cooked porridge with poultry (goose or duck), and the priest's assistants (pokchi pop) went around the houses 
praying using the established rules, completing the Christmas cycle vozhodyr/vozhovyl.

A striking example of gender and age stratification of society in the ritual is presented by Shrovetide, which held a special position in the system of calendar holidays because it marked the transition from winter to spring. It was celebrated in late February or early March, necessarily taking into account the transition of the moon from the last quarter to the new moon. This is reflected in the proverb "Washing dishes should be seen by both the old and young moons" (Tus'ty-pun'y mis'kemez tolez'vuzhez no, vyl'ez no med addzh'oz), and in naming March 'the month of washing/cleansing dishes' (tus'typun'y mis'kon tolez) in one of the local variants, a meaning that stems from the tradition of cleansing before Lent. Obviously, these symbolic expressions are evidence of the influence of folk Christianity, which absorbed archaic ideas about the changing seasons and corresponding behavioural stereotypes as they relate to the etiquette norms of Orthodoxy. The ritual in this context is manifested differently in different local variants and gives the opportunity to speak about inter-ethnic relations in the Ural and Volga region.

Unlike the Russian tradition, Shrovetide in the Udmurt tradition began on Thursday, 'Udmurt Sunday', and ended on Sunday in the southern part of Udmurtia and Monday, marked as a 'day of horseradish' (kren/kirennunal) in northern districts. The height of fun was on 'Russian Sunday' (dzh'ucharn'a). Horses were dressed up for this day with bells, the head towels of married women (chalma), ribbons (chuk), etc. Tassels of coloured wool were plaited into their manes and they were covered with homespun blankets and sheepskin coats; sometimes the horses were even dressed in trousers. People rode on pillows in carts, went into the yards and drove around in circles. Sometimes a lit iron stove was put in a sled harnessed to people who danced and dragged the sled through the village. The northern Udmurt had a tradition of burning ordinary straw or cow dung on the street or in front of their gates over which 
people rode horses or pulled sledged. Torches were lit as another kind of fire on this day.

An important component of Shrovetide, as in other calendar holidays, was ritual visits to relatives and neighbours' houses (is'kavyn-böl'ak), where the status of older members of the community was especially emphasised. Festivals/entertainments were the prerogative of the young people. Southern Udmurts had the culmination of Shrovetide merriment on Sunday, which was perceived as a day of seeing off. The whole village participated in this action. The northern Udmurt did this from noon until midnight with only older women leading the ceremony and unmarried young people necessarily presented in their 'suits'. The old woman wore long six-wedged (sometimes more) red dresses (shortderem) and went from house to house, feasting and singing a melody of guesting (yuon-golos). The fun was accompanied with dance songs (purultem mad'), the texts of which were quite frivolous and were perceived as unsavoury outside of the ritual.

The seeing off continued the next day after noon, although here the main role was played only by women of childbearing age.

Anthropomorphising the holiday led to the production of a special dummy for the mumming of participants. The attributive symbols of Shrovetide for the northern Udmurt are straw and the horseradish root. There is evidence of making Shrovetide ritual dummies in the shape of an old man or old woman in the southern part of Udmurtia. But because in the Udmurt language there is no grammatical indicator of gender, descriptions of the fact in different local traditions do not always identify the female or male appearance of the dummy.

Most often the details indicate a female image, for example a woman's dress, apron or shawl are mentioned. Sometimes the doll gets a female name (Kabysta-apay 'auntie Cabbage', i.e. aunt Vulva). The Udmurt of Bashkiria had 'male' dummy that wore a shirt (the Udmurt word derem is translated as 'woman's dress' 
or 'shirt') and trousers stuffed with straw. But taking into account the details of the Udmurt women's costume, with its compulsory trousers, and the leading of the dummy through the village (two men 'hug' it from either side, its legs are tied to their legs, or they put dummy's trouser leg in the tops of theirs boots, then they 'lay with' the dummy in the snow beyond the village), the perception of the dummy as a woman is justified.

Northern Udmurt youth participated in the ceremony on Monday morning (kren/kiren-nunal lit: 'day of horseradish'). They harnessed the horse to the sleigh and rode through the streets. Used brooms were hung on the ends of a shaft and a big bell was attached to the collar instead of small bells. They rode through the streets in silence, without singing, laughter or music. Having passed through the village several times, they went out of the village, threw away their brooms and returned home. In the afternoon the holiday was continued by women of childbearing age who chose an old man to go with them from house to house gathering all the women to celebrate. He wore a cylindrical birch bark cap with sewn multi-coloured patches on his head. Another attribute was a long staff brought especially from the forest and prepared for the event. His wife tied the patches of cloth (deremsep) to the stick and a pouch (tamakpuyy) or headkerchief (kyshet).

The same gifts were tied around every house. In multiple villages there was the custom for women to choose two young men who, allegedly, had to protect them from attacks armed with bundles of sticks. The women took a drink and a few roots of horseradish with them when visiting the houses. They treated the men to mead or beer and gave a horseradish root as a titbit, saying: "This is all that remained of Shrovetide" (Glukhova 1997: 45-47; Vladykina, Glukhova 2009: 223-226). The prevalence of erotic symbolism (the abundance of phallic symbols as indication of productive capacity) in folklore texts and the playing space of calendar festivals (especially at Shrovetide) is also emphasised by researchers of the Slavic tradition (Agapkina 2002: 169-202). 
According to the examples, the originators of cults were mainly men (vorgoron, piosmurt), the priests (vös'as') who conducted the prayers were also men. Their role was especially significant in the spring and summer rituals that marked the completion of spring field work or on the occasion of the new harvest (yu-vös) or village prayers (meren-vös', el'en-vös'). Only men prayed in the holy groves (Lud/Keremet), the reason for which researchers see in the Muslim influence (Vladykin 1994: 202; Minniyakhmetova 2009: 16-20).

Men took responsibility for the prayer procedures as a main component of the calendar festival; nevertheless, other stages of the ceremonial complex are associated with the special status of women (kyshnomurt/kyshno/ nylkyshnokalyk lit: 'woman'/'wife' / 'female people'). And not only as a hostess who has guests during the ceremonies, but also as a special character in ritual scenarios aiming at the magic of the production: the woman's childbearing potential was used in the calendar rituals in order to enhance the growing abilities of the earth. Women also assumed a key function in childbirth and the health of family (Shutova 2009: 10), in funeral sacrifices for parents after marriage (atas-viro, the southern Udmurt custom of slaughtering a rooster if there was trouble in the new family (Vladykina, Glukhova 2011b: 19). (On the social roles and behavioural stereotypes of women in Russian traditional culture see Adon'yeva 1998: 26-28; on women's participation in ritual actions throughout the year in Slavic and Russian cultures see Kabakova 1999: 205-208; Madlevskaya 2005: 25-26; and on parallels in Vyatka see Trushkova 2009).

The participation of young people in the rituals was of great importance and age was always emphasised in the calendar cycle. For example, boys and young married men participated in spring rites of conjuring (uray-vös'lit: 'a noisy prayer', shaytan-ul'l'an lit: 'conjuring of devil/satan'), combined with the rituals of Holy Thursday in modern traditions. The young people played a major role in conjuring spirits at Christmas, as described above. At Easter, girls of marriageable age participated in the ritual of collecting food for 
prayers, making a round of the whole village. They were the main participants in the ritual round dances among the ripening grains or in the meadow during haymaking. Only young adults could attend games (shudon/shudon'n'i) and gatherings (dzhyt-pukon/ pukon'n'i) (see below). Generally, the game was perceived as one of the components of the calendar cycle and was strictly regulated by age in all cultures. Indoor games prevailed at gatherings of young people in the autumn and winter period, and round dances and other games in the spring and summer (from Easter to Trinity).

The main theme of both was matrimonial and was realised at different levels: imaginative, efficient, subject. The actional and verbal components of many games and round dances were aimed at forming couples and showing feelings in the presence of spectators. The main motive of the games was the idea of young people at a transitional age and status and their readiness for marriage (Bernstein 1988; Dolganova and others 1995; Morozov 1998).

Children at ceremonies participate primarily as observers. Some periods of the calendar emphasise the pubertal period for girls, for example the southern Udmurt collection of patches (chuk/ chacha-kuran) on Holy Thursday to sew into talismanic dolls (see on this matter the customs of the Besserman living locally with the northern Udmurt, Popova 2004: 80-81) or clothes for doll 'wedding' dances in the field (shyr-s'uan lit: 'mouse wedding' / 'wedding of mouse', where the image of the mouse is a metaphorical substitute for the penis or vulva).

\section{Women's rites in the calendar}

Highlighting the feminine theme in the calendar, it is necessary to keep in mind, first of all, the function of rituals which were aimed at the magical stimulation of the productive forces of nature. The use of women's fertility was one possible way to accomplish the task. Analysis of rituals and their content gives an opportunity to 
see that there are not separate 'female' rituals, they come generally within the festivities of the holidays. A female theme runs through all the rites of the spring summer cycle, in the period of flowering and fruiting. Moreover, the presence of women of childbearing age is prescribed both in direct participation and in attributive symbols. First of all one of the symbols is the married woman's head towel (chalma), in addition to which are a headband (yyrkerttet) and a shawl (s'ulyk). The woman's hair braided in two braids and wrapped around the head was hidden under the chalma. In wedding songs the woman's headdress is the antithesis of the small cap worn by maidens (tak"ya), symbolising girlhood. Therefore the chalma was perceived as the main symbol of parting with girlhood and gaining the status of married woman. Usually women took these towels as gifts to the family shrine (baddzh'ym / buddzh'ym kuala), or to the places of prayer in order to hang them on tree branches as a symbolic fence for the sacred space. In calendar situations, head towels were used as gifts, for example they were given to the winners of races organised at Trinity (Gershyd/Troycha/Trochin').

In northern and central districts of Udmurtia the summer holiday (Gerber lit: 'after the plough'; Gerbernunal/Gerberprazdn'ik) ended the spring-summer half of the year. It was celebrated in the last days of the summer solstice, although in the modern calendar it has become strictly linked to the 12 July. It is believed that this is the 'last feast of earth'. To this day all the spring work on the soil in which a plough was used finished on this day.

The names Guzhem-yuon ('summer feast'), Petrol (Rus. Petrov/ Petrov day), Kuarsur (lit: 'leafy beer' / 'holiday of leaves/greenery') are also known. The sun "was turning" towards autumn already and one 'unpaired' year was finishing. People finished their festive meal before noon. After dinner everyone went haymaking and, according to custom, performed the ritual of young women's bathing (s'altym). This period was also considered auspicious for weddings: "Get married this day - you will be happy" ("Ta nunale, pe, byz'id ke, shudo luod"). 
In the north of Udmurtia festively dressed singing women walked through a rye field, providing it with protection and fertility (Gerber lud orchyny lit: 'to walk through [the holiday of] Gerber'). This was one of the substitute rituals that are famous among other nations (Agapkina 2009: 361).

The symbolism of the female presence in the calendar is also formed by spinning - a purely feminine occupation that is closely related to ideas about fate. Attributes related to spinning (the spinning wheel, yarn, etc.) not only become individual symbols of calendar celebrations, but also form the basis of naming calendar rites and its components. For example during Shrovetide the Transvyatka Udmurt (who live in the territory of today's Republic of Tatarstan) had the custom of collecting village gifts on the removable top of a distaff belonging to a young woman who had married in the current year (kubochuk-kuran, from kubochuk kurany lit: 'to ask for spinning victim').

During visiting from house to house, the hostess donated patches, ribbons, towels, while young women donated head towel chalma. The distaff as a symbolic attribute of the holiday was apparently ambivalent semantically, as was the personification of the holiday, the Shrovetide dummy, with its male and female attributes. If the distaff as a whole, especially its lower part, was associated with the feminine, the removable top of it was thought of as male. In this regard, the leading role played by boys and young men in the ritual becomes clear.

The northern Udmurt added to the ritual the process of washing reels of yarn that had been spun during the winter (short-mis'kon) (Pervukhin 1888 (2): 110-111). The yarn was washed in turn at all the farms. A hole was cut in the river and neighbours were invited to help. On the appointed day, the women gathered early in the morning, harnessed the horse in a good harness with bells, rode in the sleigh on the hanks and went to the river with laughter and jokes. Here the elder woman poured the wine, prayed and threw a piece of bread into the hole. After that everyone began merrily to 
wash the reels of yarn. Young married women were jokingly forced to untangle knots as it was said that the house spirit (korkamurt) had tangled them as punishment for defiling the marriage bed. During this time people tried to splash them (equivalent to the southern Udmurt bathing of the young married women, s'altym, on the first day of haymaking). Young women had to treat guests with wine. After work they returned home with songs, dressed in festive clothes, and arranged a feast.

Upon completion of the washing, a common village holiday (short-tuy lit: 'yarn holiday') was arranged that included all farms. Food was prepared in the morning and Lenten porridge was cooked because the holiday fell on the days of Lent. Village priests went from house to house, sanctifying the food. Then the women went with a distaff from house to house, showing a desire to spin and a ritual meal was held in each house. Women's aid during the days of Lent marked the end of spinning.

'Spinning aid' (cherson-veme) is a commemorative rite inscribed in the calendar cycle of the Udmurt living in Kizner district, one of central districts of Udmurtia. A year after the death of an elderly woman, before the Festival of the Holy Name of the Virgin Mary, old women from the whole village come to her relatives' house and span for the whole evening. The essence of the rite was not so much to help the family, as evidenced by the name of the rite, but in the symbolism of spinning, indicating in this situation, the end of human life: death cut the thread of fate (Vladykina 2013: 37).

The ritual situations in which women of childbearing age were replaced by elder women should be considered separately. The latter were mainly involved in situations of alleged contact with the spirit world, i.e. seeing off the holiday outside the living space, 'seeing off' of funeral food into the boundary places. Only the elder women were allowed to use foul language: speaking or singing obscene expressions and songs was usually their prerogative.

The southern Udmurts celebrated the holiday of the spring meeting, which was joined with the Christian Easter, over three 
days including the Great Day (Buddzh'ymnunal/Byddzh'ynnal/ Paskha), 'holiday'/'day of going into the ploughed field'/'holiday of the plough' (Akashka), the seeing off [holiday] of Akashka (Akashka - kel'an / ul'l'an). On the last day, older community members, mainly women, went from house to house, following the river, singing a ritual chant at every house. Mandatory attributes were willow twigs that substituted 'horses' for the participants of the ceremony. 'Having saddled up' their 'horses' the women saw off the festival to the lower edge of the village.

During the week before Easter the eastern Udmurt (in the territory of the modern Republic of Bashkortostan) had a ritual in which older women conjured spirits away (verva-kis'ton lit: 'willow commemoration'). The old women went from house to house, visiting only the oldest people. They went down the street to the lower edge of the village, hitting the gates with pussy willow whips and bust baskets saying "pussy willow has come!" Near the river people jumped over the bust baskets and threw them across the river.

Until recently the rite of oshorok had also been preserved in the eastern Udmurt tradition. On the second day after the spring commemoration, or the fourth day of Easter, old women dressed in rags, wore inside-out coats and smeared their faces with soot. They took a stick in hand and tied a carrot or turnip to their belt, symbolising male genitalia. Sometimes these phalluses were carved from wood. Shouting "Neigh neigh" and jumping, they chased young guys, drag them along the floor, poking them with sticks or carrots. The same thing was done with young married women.

The old women tried to strip the men they met naked, imitating violence. They "neighed like horses", sang obscene songs and explained the purpose of their actions ("Kidys viyatis'kom, kidys!" 'We scatter seeds' (lit: 'forced to flow, seeds'). According to belief, the ritual helped keep the village free of disease and favoured the reproduction of livestock and the growth of plants. Today it is definitely perceived as shameful entertainment (viz'tem 
shuldyr"yas"kon) because the semantics of the ritual position it as a way of stimulating the production forces of man, meaning that nature has already been lost (Minniyakhmetova 2000: 31-32; Vladykina, Glukhova 2011b: 103-104).

The old women secretly regulated the structure of the rites as the original guarantors of the correctness of events, transmitting knowledge to the younger people (n'erge-utis' lit: 'custom keeper'). Most often they were the initiators of rites, especially occasional rites such as the ritual of summoning rain during drought (zorkuron) (Khristolyubova 1995: 153-156; Minniyakhmetova 2000: 47-49; Vladykina, Glukhova 2011a: 76). Occasional rain rituals had compulsory parallels in the calendar cycle, the functional orientation of which was hidden under the temporal and cultural layers. These included the rites of seeing-off, funeral rites and the 'wedding' of insects (caterpillars, bugs) (kiby-ul'l'an; numyr /urbokel'an; urbo-s'uan), all of which were characterised by elements of disguise and were confined mainly to rites of expulsion in the period between Holy Thursday and the summer solstice. The initiators of these rites were also older women (Vladykina, Glukhova 2011b: $96,136)$.

The role of these older women increased in situations when the ritual purity of women was emphasised (see Kabakova 1999: 208). For example, a somersault or rolling on the ground was perceived as sexual contact with the earth during its revival at the time of the first thunder or during the spring and summer ceremonies. The old woman rolled down hills in the ritual of the appearance of the first thawed patch of ground (guzhdor), and some old women rolled down a hill in rites associated with the production of crops. The mythological background of these actions is often disguised as more normal actions, for example rolling on the ground because of backache caused by the harvest. The logic of such actions is conditioned by the perception of summersaulting as a sexual act during which a man can give life-giving power to the land, and receive it in return. 


\section{Maiden holidays}

In traditional Udmurt culture maiden holidays are mainly associated with the autumn cycle, particularly with the initial stage of young people's gathering period. For these events, young people specifically bought a house or, with the consent of the owners, held them in a new but uninhabited house.

Upon completion of harvest, the northern Udmurt celebrated the nyl braga (lit: 'maiden mead') holiday. The ceremony lasted a day, although the planning started long before. The preparation included discussion of the day and place, the collection of food (flour, malt) for the preparation of ritual beverages (beer, mead), informing young people in the neighbouring villages (verbal or written), deciding the number of attendees as well as choosing clothing (which was supposed to be similar).

On the scheduled day, the girls gathered in one house to meet people. The newcomers were seated at the table and brought only tea. At this time, a specially selected 'newly married couple' went from house to house singing, a musical instrument in hand. They summoned boys to the feast, whom they greeted with questions about how they had arrived and whether they had lost anyone on the way. They sang the song "Where Did You Come from..." ("Kytys'en ti lyktidy...") as a greeting. People sat at the table in the same clothes, with girls in white embroidered blouses and black skirts. After a ritual meal, everyone got up from the table, except the 'couple'.

The girls cleared away the meal, folded the tablecloth and put it over the heads of the young couple. Only afterwards could the boy and the girl get up from the table. The merrymaking began, during which boys and girls continued to get acquainted. At midnight, the girls dressed in colourful dresses that were the mandatory for the situation. Then the fun resumed and continued until dawn. Toward morning, the girls once again dressed, but so that the boy could not find his chosen girl they wore someone else's clothes, covered 
their faces with headkerchiefs. The girls lined up in a row, and the boys were supposed to find their favourite girl. Those who tried to leave the party secretly (single girls or couples), had water thrown on them or were smeared with soot. In the afternoon the guests started to go home.

One of the highlights of the ritual was dressing up. The meaning of this lies, apparently, in views about the transition of girls to a different status (byde vuem, marriageable girl / fiancée). The time of changing clothes (midnight, i.e. the end/beginning of the day) also reinforces the symbolism of the action (compare: the bride changes clothes on the second day of the wedding). The disguising of the girls (wearing someone else's clothes, obscuring the face) goes beyond just being a game. It is one of the ways of depersonalising the girls as future brides, as people of liminal status related to beliefs about the supernatural world of the afterlife (compare: the substitution of the bride with her friend or an old lady in the Udmurt wedding ceremony).

More complicated in terms of semantics are these actions of throwing water over the girls and smearing their faces with soot. Since the ceremony is reconstructed from later records, the explanation of not allowing the girls to run away from celebration is definitely not enough. Apparently, all the girls should have received both treatments by the end of the ceremony. Its main point was to play out a situation of temporary death and rebirth, marked by soot and water (compare: the ritual of pouring water over the bride at a wedding (ken-pylaton) and the bathing of young woman on the first day of haymaking; also the rite of washing hanks of yarn).

A local variant of the kushman-s'uan autumn maiden feast (lit: 'radish wedding' / 'the feast of the radish'), timed to the Festival of the Holy Name of the Virgin Mary, is recorded in central Udmurtia. Girls 10-15 years old participated. The most important attribute of the participants was a hat (often the same one for all participants). It had a wire frame with a piece of swede in the middle, decorated with branches, with paper flowers and trimmed at the edges with fringe 
and ribbons. In appearance and construction it was very similar to the dev'ya krasota (lit: 'maiden beauty') of northern Russians and Slavic kvitka (Vladykina 2006: 53).

The hat was put on over a shawl and fastened under the chin. The dress was complemented with beads and a necklace. In this attire the girls went from house to house accompanied by the boys. Moreover the boys entered the house first, asking permission of the owners to come in. The hostess greeted the girls by teasing them, inviting them to dance. Girls danced and sang songs to a wedding tune. Reproaching songs were also sung, making fun of the boys from neighbouring villages. After that, the feast began. As well as baked goods, pickled beets were put on the table. Visiting houses, the girls showed themselves as future brides (Dolganova, Morozov, Minasenko 1995: 39-40).

The western districts of the Udmurt Republic celebrate a young persons' rite called siz'yl pörtmas'kon ('autumn disguise'). When it was celebrated is not clear, although modern versions are most often associated with dates related to the Christian calendar: the Festival of the Holy Name of the Virgin Mary, i.e. October 14 (1 October by the old calendar), the day of Our Lady of Kazan, i.e. November 4 (22 October by the church calendar).

On the eve of the festival, the girls made special hats of straw, decorated them with goose or rooster feathers, pieces of cloth, coloured paper. The hats were not made by all participants, one hat was made for each group of three or four people. There were about five or six groups, depending on the number of young people in the village. But everyone participated in the procession without dividing into groups. The celebration lasted only one night: the ceremony began late in the afternoon and lasted until morning. The hats were given to 'supervisors' chosen from among the boys, who kept them until the next season. The owners of each house set the table when the guests arrived. Traditionally, the route began at the end of the village. Visiting of each house consisted of several stages that have their own songs. The participants announced their 
arrival by singing and asked permission to enter the house, called the host matchmaker. A request to serve wine was allegorically expressed in the song formula 'to let the blood of a six-year-old/ forty-year-old bull' (Vladykina 2012). The obligatory motifs of the songs were arrival from far away by river (the Kama, the Kil'mez'), and the assimilation of girls and boys by migratory birds (geese and cranes). During the feast the songs performed generally contained erotic content. Their images were allegorical, and sometimes undisguised and demonstrative. This manifested itself particularly clearly in the dance songs. Leaving, the participants sang about their desire to visit another house, thanked the hosts and said goodbye to them until next year.

'Marriage' symbols correspond to the magic function of the ritual action - the rebirth of productive forces of the earth. It is necessary to consider the peculiarity of the perception of autumn as the beginning of the year, when understanding the annual cycle as two halves of equal length. Singing frivolous songs was a kind of test for understanding metaphors, demonstrative use of language about the relations between the sexes was explained by the removal of the taboo on verbal limitations in everyday life. An appeal to the wedding symbolism is natural for premarital youngster's games.

Typological correspondences of wedding and calendar rituals, caused by their transitivity, are found in other rituals performed by young people. For example, the central Udmurt had a ritual called pukis' kuno (lit: 'the sitting guest [for a long time]') (Vereshchagin 1996: 109). With the beginning of the autumn gatherings, girls of marriageable age were invited to relatives in neighbouring or distant villages, where they lived for about $2-3$ weeks, helping with the housework, mainly spinning. Both the guests and the hosts had certain expenses: the host ordered a spinning wheel (kubo) and gave money to the girl, and the girl gave wine and towels. This residency was a kind of bride-show because girls participated in the young people's gatherings. 
In the western districts of Udmurtia a separate kind of autumn girls' gatherings (siz'yl [kualan] pukyny lit: 'to sit [in kuala] in autumn') had been recorded. Adult girls gathered in someone's family kuala (family sanctuary, optionally used as a summer kitchen) sewing late at night. According to custom, before this they stole roots and baskets of sunflowers from gardens. They kindled a fire in the kuala and cooked and ate vegetables. Boys were not allowed to attend the ceremony (Churakova 1999: 15).

Girl's gatherings called pukon-taban' (lit: 'sitting flatbread') (Vereshchagin 1996: 109-110) and pukon-korka (lit: 'house for gatherings') were held in a new unoccupied house in autumn and lasted for a whole week. Young married men and women could participate. Women span and knitted, men braided sandals and played cards. At the end of the week, on Saturday, the participants brought flour and made dough. Closer to the night people went home, formed couples remained in the house. The girls made pancakes (taban') for the boys. The pairs that spent the night together were considered married.

In the morning, the girls' mothers came and made pancakes with holes and gave them to the couples. The erotic symbolism can be clearly seen in these pancakes, which symbolised deflowering as the physiological act of turning a girl into a woman. The fact that the mothers baked cakes tells about their admission of the new status of their daughters. (On the presence of attributes with a hole and metaphoric assimilation to women's genitals in a wedding ceremony of other peoples see: Tolstaya 1996: 192-206). During the feast, comic songs were sung, a characteristic of the second day of the wedding. In general, the situation imitated the wedding feast.

Eastern Udmurts had young people's autumn gatherings, called aulak/aullak/allak korka (lit: 'secret/silent house'). The participants gathered in the house of those whose parents went away. Sometimes a house for the rite was bought from lonely people. The girls brought handcraft with them. The peculiarity of the rite is a ritual meal with chicken meat. There is no information on special 
manipulations with the cooked chicken but the circumstances of the situation are explained: the chicken was brought by boys, moreover it was a stolen chicken; windows were closed, so that "nobody could see". The nomination of the ceremony is mediate, apparently, not so much by the situation of communication separate from adults, but the fact of ritual theft.

Poultry as a ritual dish in Udmurt traditional culture is associated mostly only with funeral rites. Cooking of chicken in a young people's rite can be explained by the symbolic views on girls as a birds (compare the images of female grouse, hens, pigeons, ducks in the Udmurt wedding songs). Images of migratory birds are replaced by domesticated, where the hen represents the bird in general (Vladykina 2006: 56-57). (On the analogy of the metaphorical substitutions of the image of the bride in wedding laments of the Karelian, see: Stepanova 1985: 76-77; compare also the ambiguity of the semantics of the chicken in autumn agricultural rites and marriage and erotic symbolism in the Russian tradition (Bushkevich 2004: 62-63)). The joint meal was obviously a symbolic action that binds the love of the couple and their communication. A proverb of the Bashkiria Udmurts "Aulak korkan nyl muso" ("The girls are nice in the house of aulak/during the ceremony of aulak") indirectly confirms this opinion.

In the eastern Udmurt tradition, there were the autumnwinter gatherings nardugan in a new, not yet inhabited house. Thiq name is common among all the peoples of the Volga region, The Tatar and Bashkir have nardugan, the Chuvash nartugan, nartavan, the Mordva-Erzya nartava, the Mordva-Moksha nardvan. The components of the rite, as in other traditions, were disguise, divination, dance and games (Munkácsi 1952: 31-33). One of the characteristic features of the nardugan was a game that involved boys 'rolling' girls on the sleeping benches. In the course of time, the permissiveness of the ritual situation, usual for archaic consciousness, following the logic of mythological thinking, conflicted with the ethical and religious norms of society. The 
merry and riotous pastimes of young people began to be perceived negatively, which explains the revaluation of the ceremony and adjustments not only in the semantics of the term (the Tatars called the rite of nardugan, shaytan tuyy, 'the devil's wedding' and the Chuvash shuyttan vayi, 'devil's game'), but also to the structure of the rite. Nardugan was 'played' not in a new, but in an abandoned house. Subsequently the rite was rejected by the tradition. Perhaps one of the reasons was the attitude to the festival as though it was simply revelry. In the tradition of the eastern Udmurt, the expression nardugan karyny 'to do nardugan' and nardugan karysa 'as during nardugan' mean noisy, ugly, indecent behaviour (Nuriyeva 1999: 107).

According to examples, maiden festivals had a multi-functional orientation. Their main idea was to show off the majority of the girls and to form future married couples. These festivals were timed to the beginning of the gatherings, i.e. to the beginning of autumn because this was considered the beginning of the new calendar and mating cycles.

The participation of girls in these ceremonies was a kind of initiation, only then were they allowed to go to gatherings (pukny vetlon/munchoyn-pukon / dzhyt pukynny lit: 'go to gatherings' / 'sit in bathhouses' / 'evening meetings') that were a sustainable form of young people's meetings.

\section{Women's rites and maiden holidays in the Udmurt understanding of time}

Women's rites and maiden holidays, structured by calendar, draw attention to the transitional states of the human body and nature. Traditional society associates women with giving birth, a connecting link in an unending stream of reproducing energy. In the religious views of many ethnic groups, including the Udmurt, 
at the archaic stage of development divine natural essence in female shape played an important role, for example in the form of the mother sun (Shundy-mumy), the mother moon (Tolez'mumy), mother earth (Muz"yem-mumy), etc. In this regard, the philosophical depth of a folk song with what appears at first glance to be very simple words is revealed:

Shundy no dzh'uzha no, Shundy no puks'e no.

Nosh ik so intyye

Tolez' no dzh'uzha.

Pios / nyl"yos no budo no,

Pios / nyl"yos no koshko no,

Nosh ik so intyye

Pios / nyl'yos budylo.

S'as'ka no dzh'uzha no,

S'as'ka no töldzh'e no.

Nosh ik so intyye

Yemysh bygyl'ske...
The sun and rises and,

The sun and sets and.

Instead of it

The moon rises.

Daughters/sons grow up and,

Daughters/sons go away and.

Instead of them

Daughters/sons grow up...

Flowers and bloom and,

Flowers and fall and.

Instead of them

Fruit appears...

(Authors' interlinear translation)

Overall maiden and women's festivals reflect a specific aspect of gender and age stratification of the village community as it relates to the calendar. In the rites and celebrations of the annual cycle, all members of the village community were always involved and each age and gender group was involved in the actional structure of the rites at different levels. The ratio of participants depended on the functions of each ritual and notions about the interdependence of cyclic (natural-space) and linear (personal) time (spring is youth, summer is maturity, autumn is old age, winter is death), as well as on mythological ideas about magic stimulation and the possibilities that both nature and man have for production. 


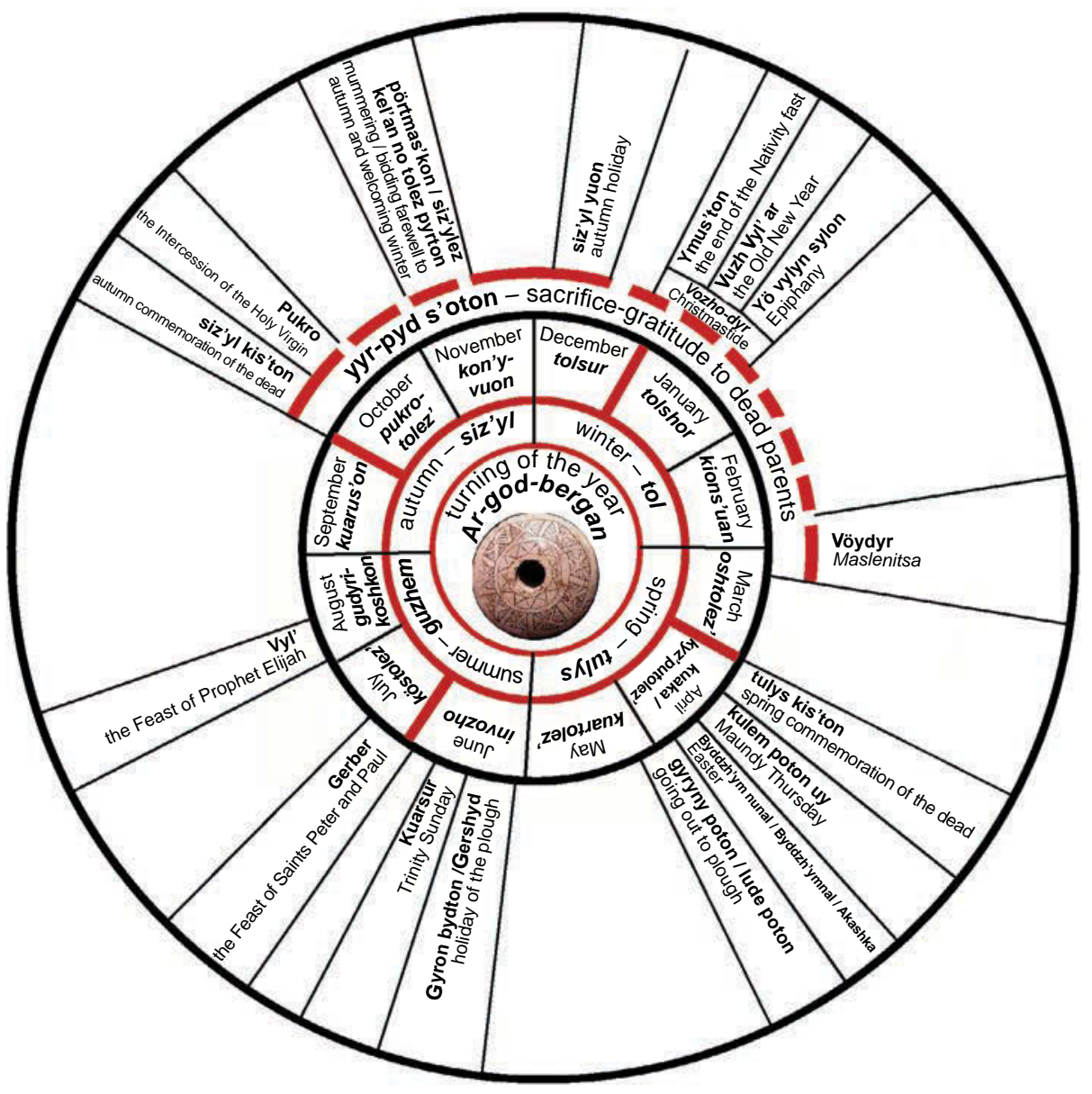

Diagram 1. Diagram of the Udmurt's ritual calendar, elaborated by Vladimir Vladykin and Tatiana Vladykina, 1990. 
Ar-god-bergan - "turning of the year" = "wheel of the year" = calendar Ar-godbergan

winter - tol

spring - tulys

summer - guzhem

autumn - siz'yl

January - tolshor / tolshor tolez' = "middle of winter"/ midwinter month

February-kions'uan/kions'uan tolez" ="wolf's wedding"/month of wolf's weddings March - oshtolez' / vutolez' / vuoshtolez' = "month of the bull" / "month of water" / "month of the waterbull"

April - kyz'putolez' $=$ month of the birch / month of the birch sap / kuakatolez' $=$ month of the rook

May - kuartolez' $=$ month of [the green] foliage

June - invozho / invozho tolez' $=$ month of invozho / month of flowers invozho / month of flowers of wild carnations / "angry" month / transition month July - köstolez' = dry month

August - gudyrikoshkon / gudyrikoshkon tolez' = leaving of the thunder / month of the leaving of the thunder

September - kuarus'on / kuarus'on tolez' = leaf fall / month of leaf fall

October - pukrotolez' $=$ month of [snow] cover $/$ month of the Intercession of the Holy Virgin

November-kon'yvuon/kon'yvuon tolez'= month when squirrels reach maturity December - tolsur $=$ month of winter beer $/$ month of winter holiday

yyr-pyd s'oton - lit: "head-legs sacrifice/offering" = sacrifice-gratitude to dead parents

Vozho-dyr - Christmastide

Ymus'ton - lit: "opening of the mouth" = the end of the Nativity fast

Vuzh Vyl' ar - the Old New Year (New Year according to Julian Calendar on 14 January)

Yö vylyn sylon - lit: "stand in gonice" = Epiphany (celebrated on 19 January) Vöydyr - lit: "butter time" = Maslenitsa (a spring holiday celebrated a week before the Great Lent)

tulys kis'ton - lit:"spring libation" = spring commemoration of the dead kulem poton uy - lit: "night when the dead come" = Maundy Thursday Byddzh'ym nunal / Byddzh'ymnal / Akashka - Great Day - Easter gyryny poton / lude poton - lit: "going out to plough"

Gyron bydton / Gershyd - the end of sowing; lit: "soup / treat in honour of the plough" = holiday of the plough

Kuarsur - lit: "beer of leaves / greenery" = holiday of [green] foliage = Trinity Sunday

Gerber - lit: "after the plough" = the Feast of Saints Peter and Paul

Vyl' - lit: "new" = New Year = the Feast of Prophet Elijah

siz'yl kis'ton - lit: 'autumn libation' = autumn commemoration of the dead

Pukro - the Intercession of the Holy Virgin

pörtmas'kon / siz'ylez kel'an no tolez pyrton - mummering/ bidding farewell to autumn and welcoming winter

siz'yl yuon - autumn holiday 


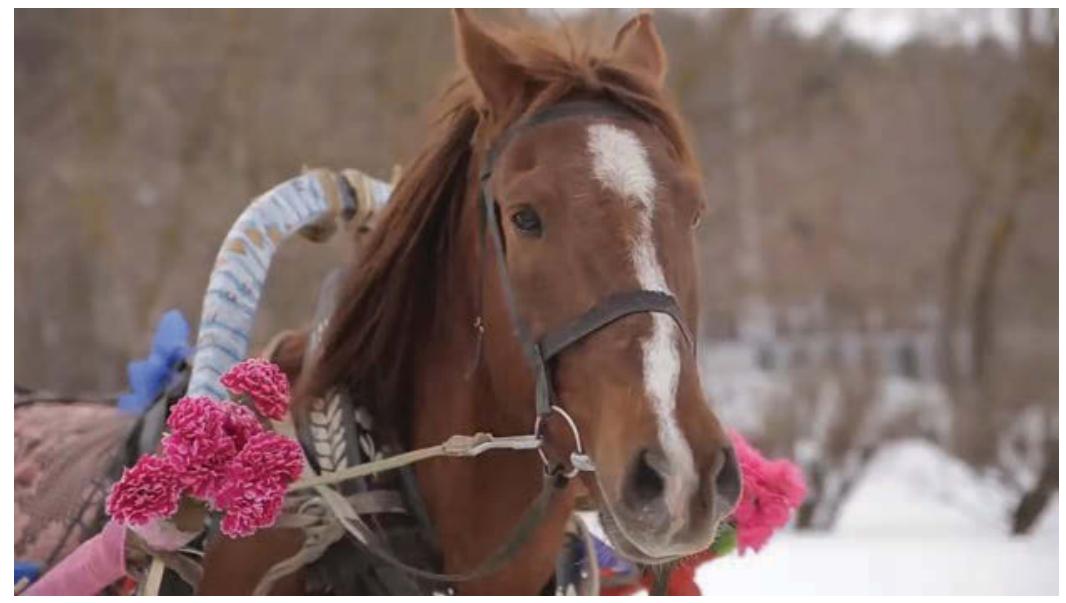

Photo 1. A horse at the ritual Seeing off of Shrovetide. Bob'ya-Ucha, Malaya Purga district, Udmurt Republic, 2016. Source: https://youtube.com/ playlist?list=PLGROZcMSNIi_BTODN, last accessed 10.6.2021.

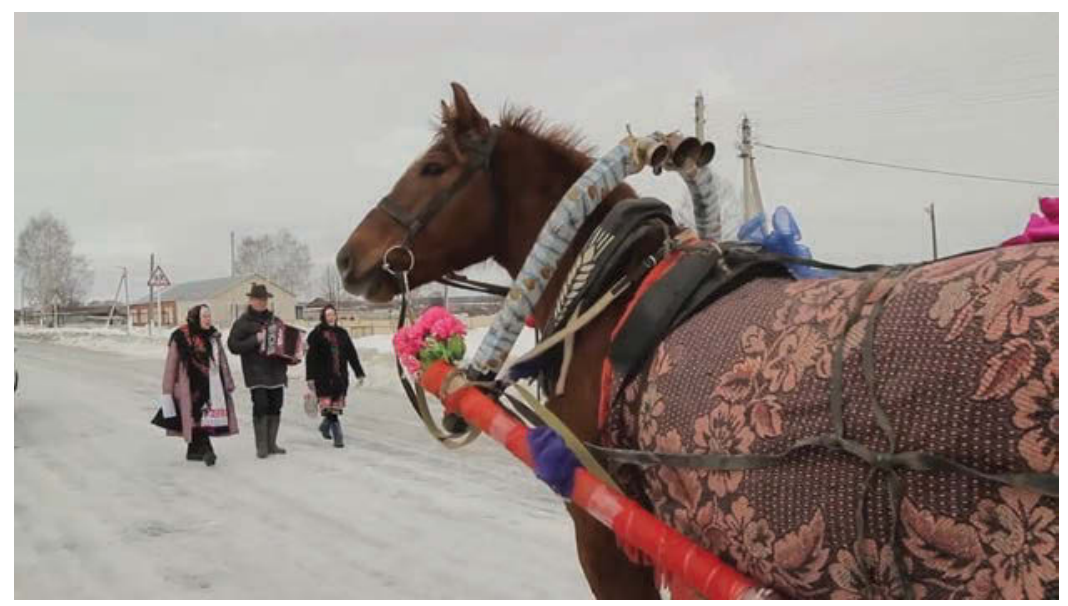

Photo 2. A horse at the ritual Seeing off of Shrovetide. Bob'ya-Ucha, Malaya Purga district, Udmurt Republic, 2016. Source: https://youtube.com/ playlist?list=PLGROZcMSNIi_BTODN, last accessed 10.6.2021. 


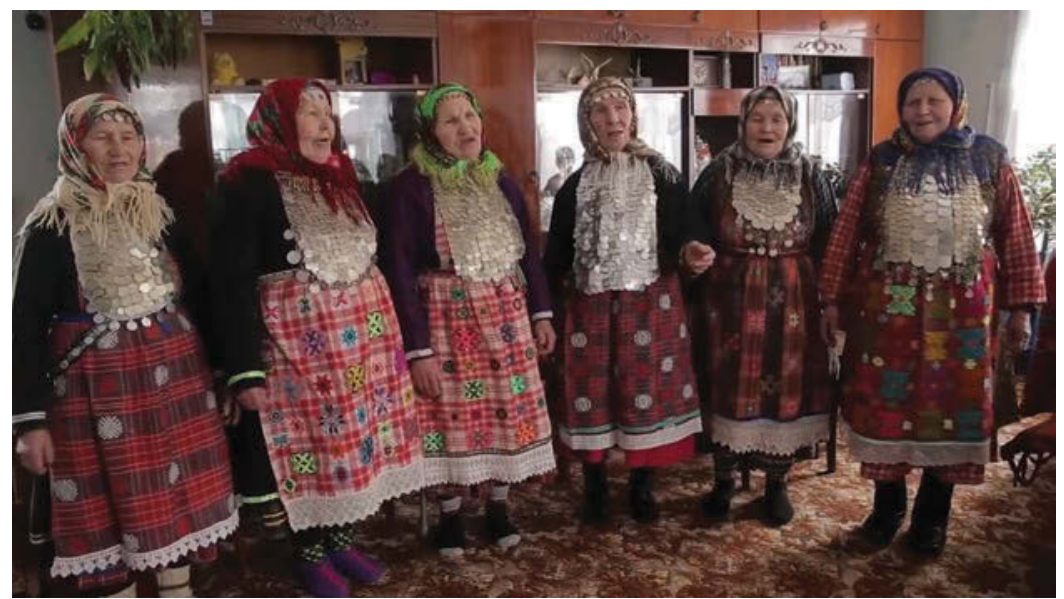

Photo 3. Singing a ritual tune. Shrovetide in Bob'ya-Ucha, Malaya Purga district, Udmurt Republic, 2016. Source: https:/youtube.com/ playlist?list=PLGROZcMSNIi_BTODN, last accessed 10.6.2021.

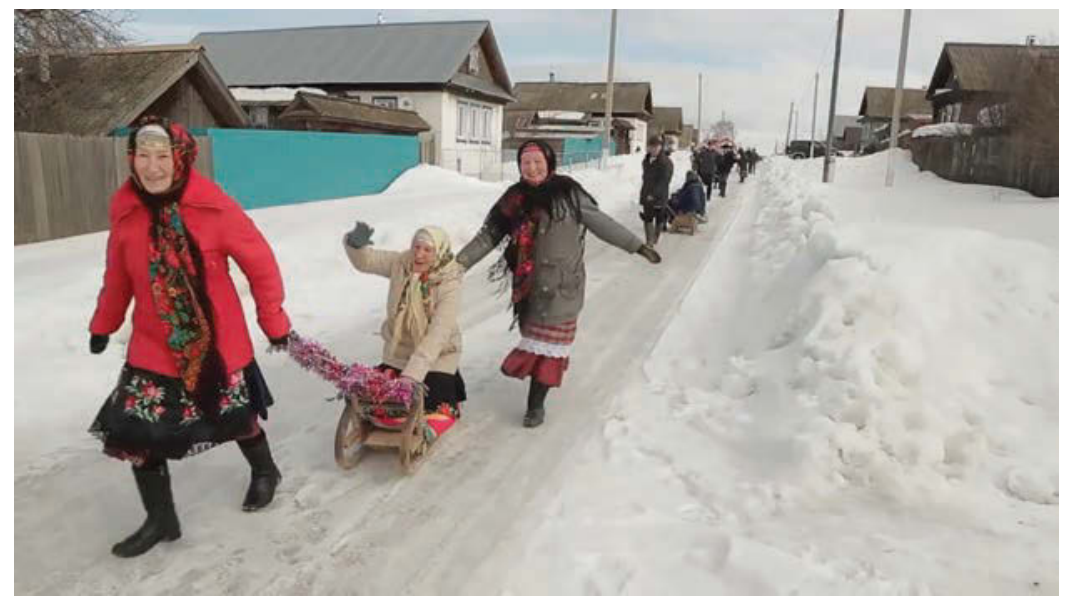

Photo 4. Women riding sledges, as incarnations of Shrovetide. Bob'ya-Ucha, Malaya Purga district, Udmurt Republic, 2016. Source: https://youtube.com/ playlist?list=PLGROZcMSNIi_BTODN, last accessed 10.6.2021. 


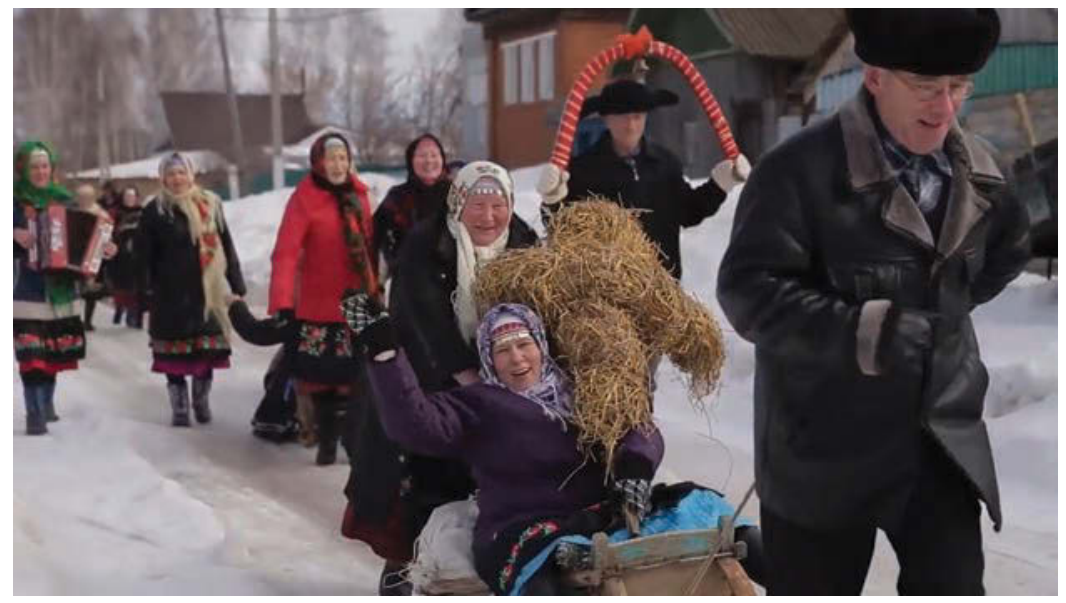

Photo 5. A dummy representing Shrovetide is led to the edge of the village to be burned. Bob'ya-Ucha, Malaya Purga district, Udmurt Republic, 2016. Source: https://youtube.com/playlist?list=PLGROZcMSNIi_BTODN, last accessed 10.6.2021.

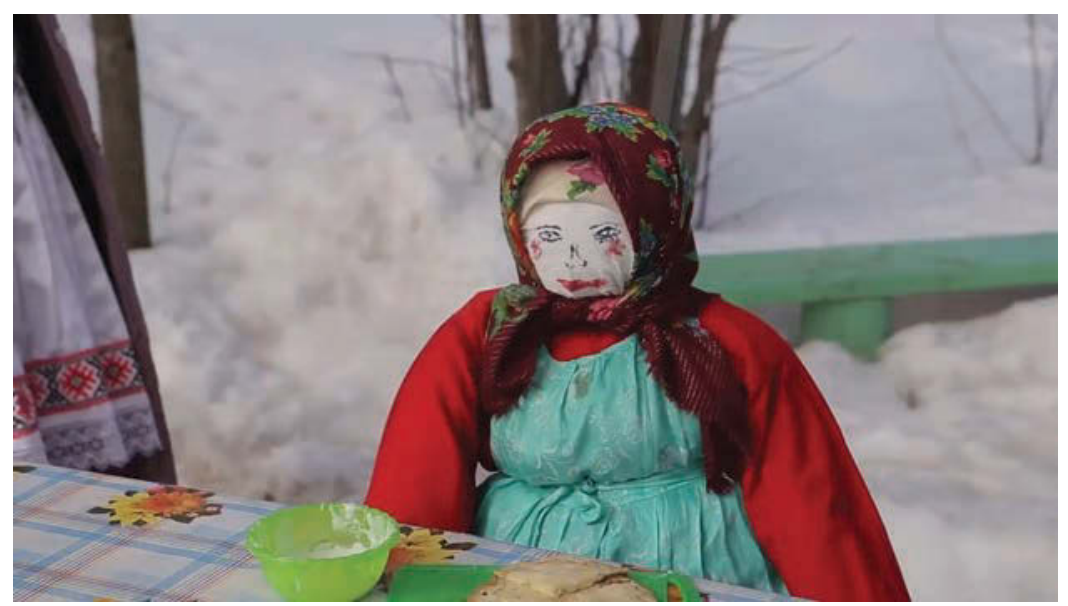

Photo 6. Food for the doll-Shrovetide. Bob'ya-Ucha, Malaya Purga district, Udmurt Republic, 2016. Source: https://youtube.com/ playlist?list=PLGROZcMSNIi_BTODN, last accessed 10.6.2021. 


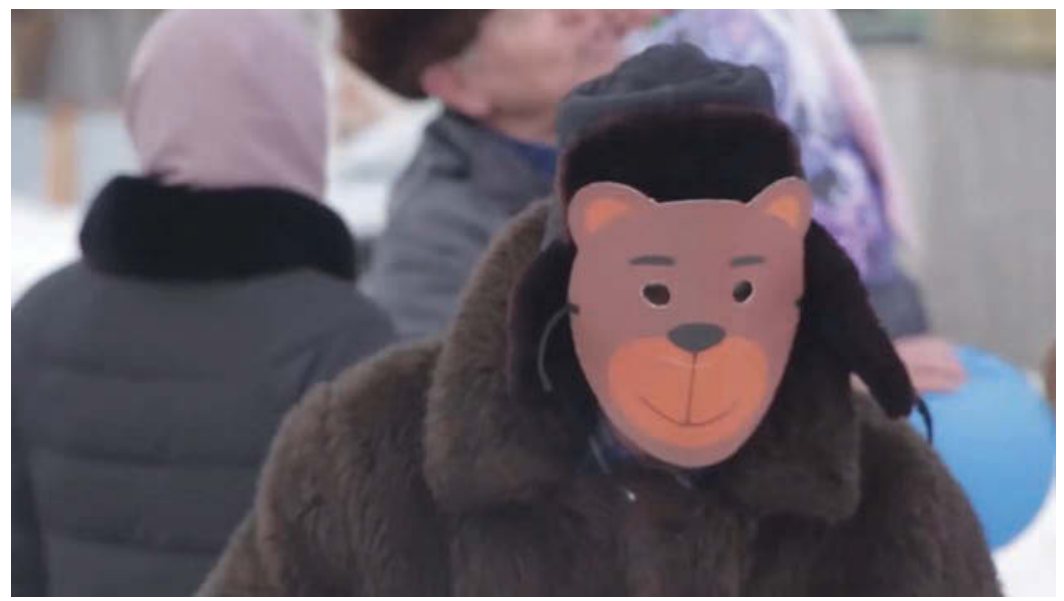

Photo 7. The "bear" at Shrovetide. Bob'ya-Ucha, Malaya Purga district, Udmurt Republic, 2016. Source: https://youtube.com/playlist?list=PLGROZcMSNIi BTODN, last accessed 10.6.2021.

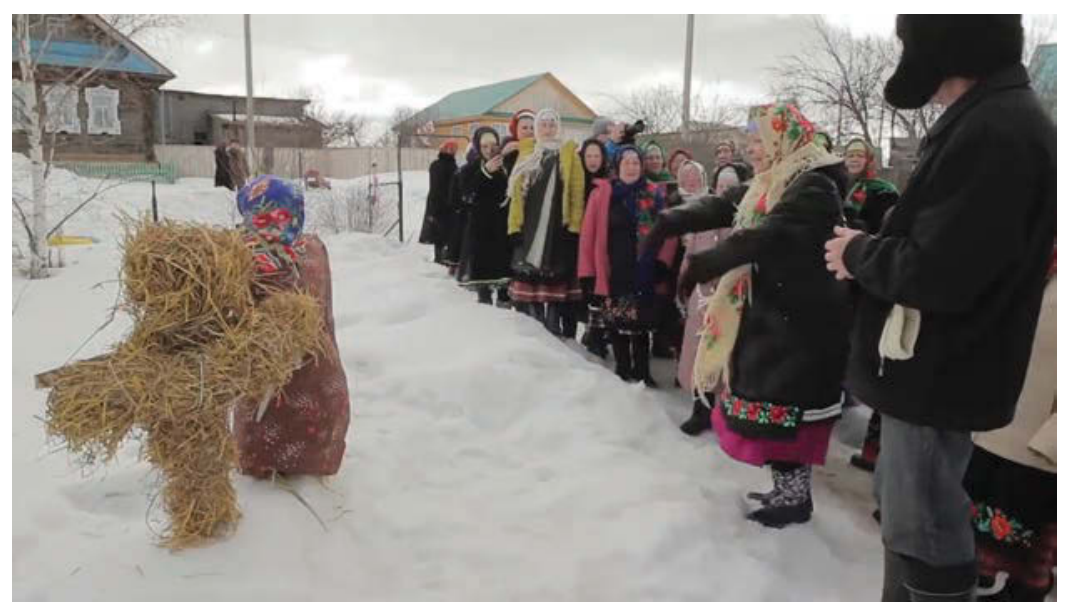

Photo 8. The dummy representing Shrovetide before the ritual burning. Bob'ya-Ucha, Malaya Purga district, Udmurt Republic, 2016. Source: https:// youtube.com/playlist?list=PLGROZcMSNIi_BTODN, last accessed 10.6.2021. 
Tatiana Vladykina, Galina Glukhova, Tatiana Panina

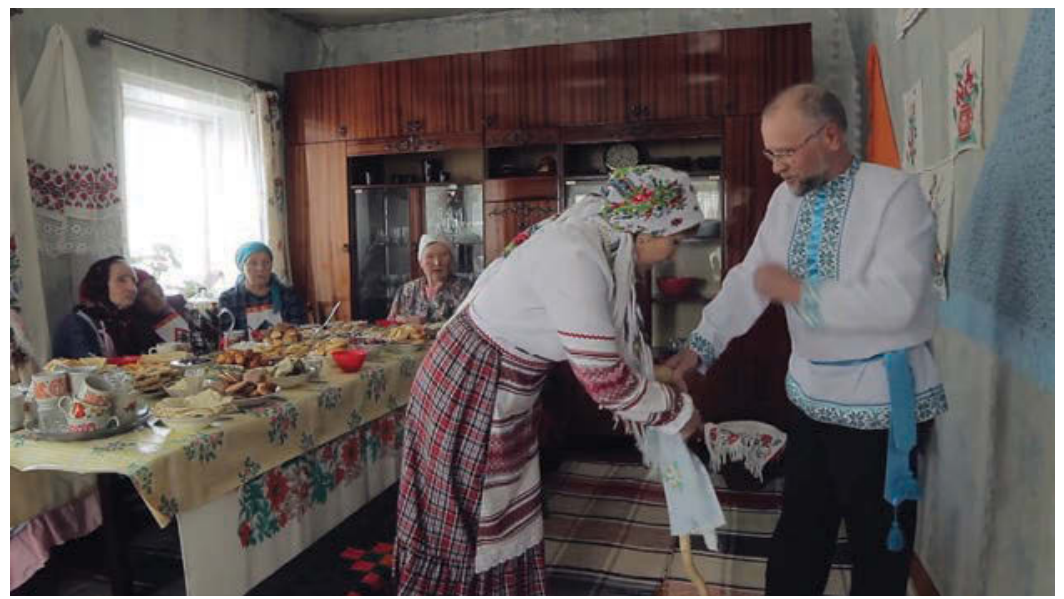

Photo 9. The wife of the man responsible for the ritual ties chuk in the form of a towel to the staff. Kel'dysh, Sharkan district, Udmurt Republic, 2016. Source: https://youtube.com/playlist?list=PLGROZcMSNIi_BTODN, last accessed 10.6.2021.

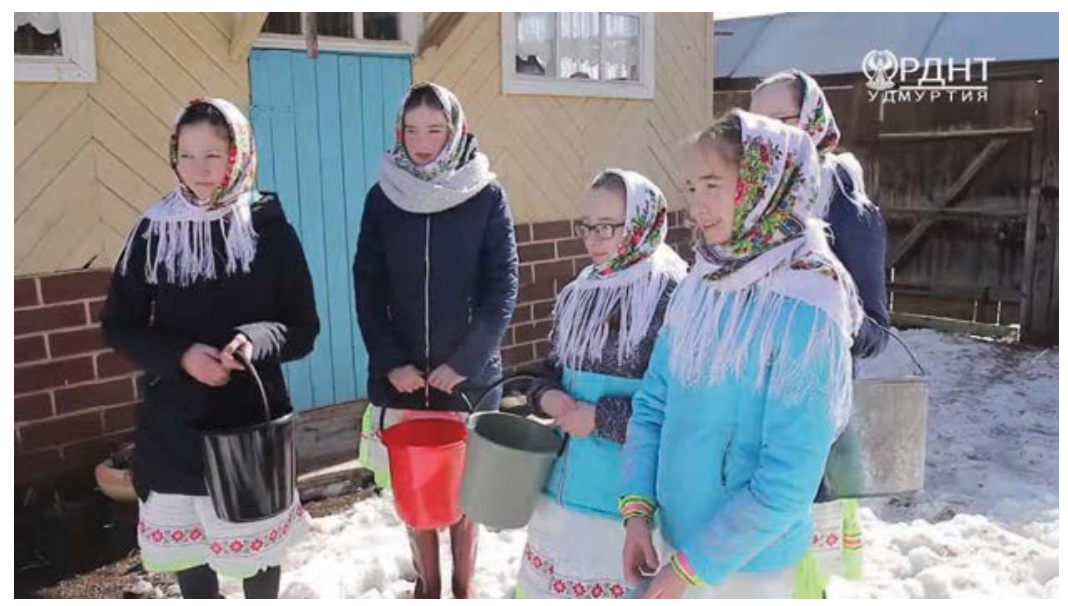

Photo 10. Collecting food for the ritual porridge. Karamas-Pel'ga, Kiyasovo district, Udmurt Republic. Source: https://youtube.com/ playlist?list=PLGROZcMSNIi_BTODN, last accessed 10.6.2021. 


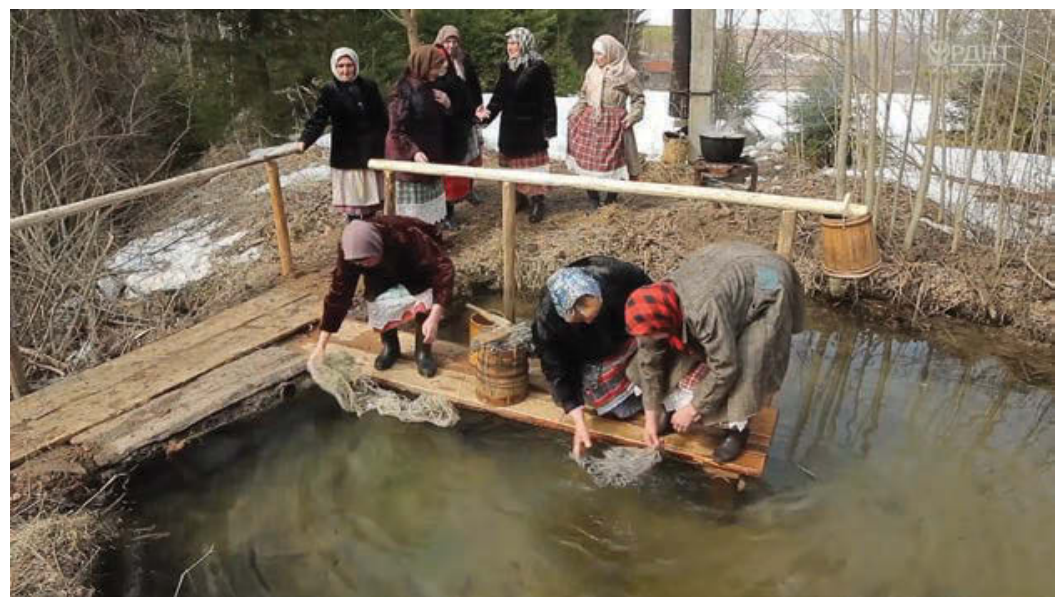

Photo 11. The washing of threads. Reconstruction of ritual. Srednyeye Shadbegovo, Igra district, Udmurt Republic, 2019. Source: https://youtube. com/playlist?list=PLGROZcMSNIi_BTODN, last accessed 10.6.2021.

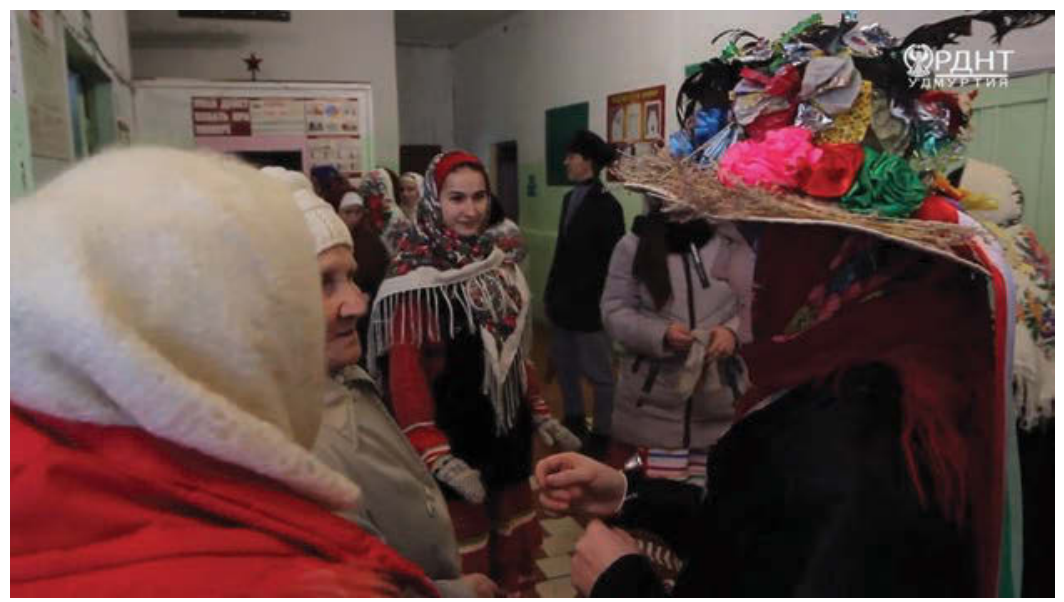

Photo 12. The ritual hat at the siz'yl pörtmas'kon autumn mumming ritual. Novaya Mon'ya, Selty district, Udmurt Republic, 2019. Source: https://youtube. com/playlist?list=PLGROZcMSNIi_BTODN, last accessed 10.6.2021. 
Tatiana Vladykina, Galina Glukhova, Tatiana Panina

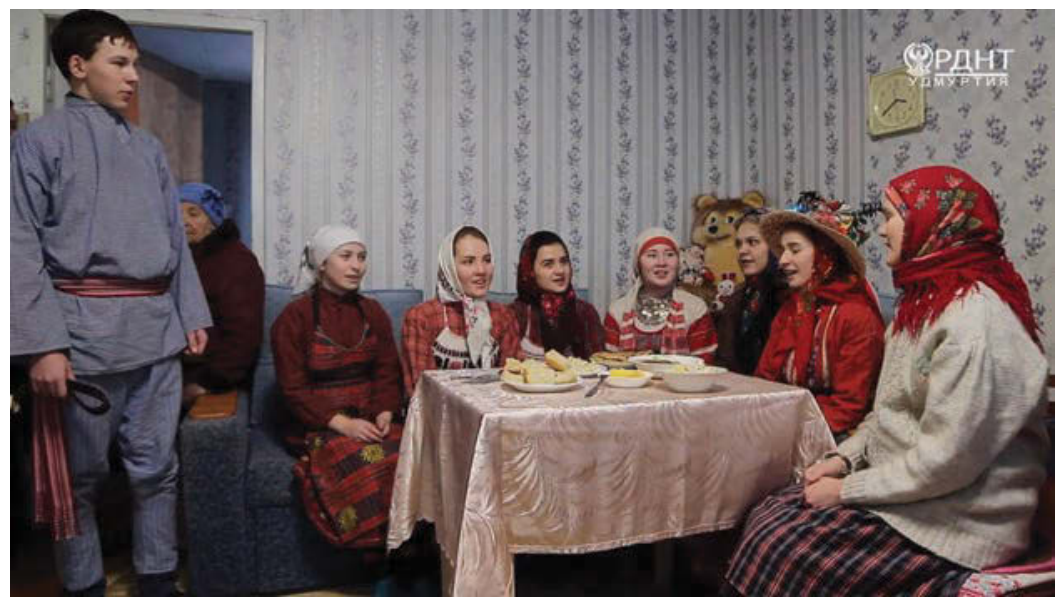

Photo 13. Traditional celebration. Novaya Mon'ya, Selty district, Udmurt Republic, 2019. Source: https://youtube.com/playlist?list=PLGROZcMSNIi BTODN, last accessed 10.6.2021.

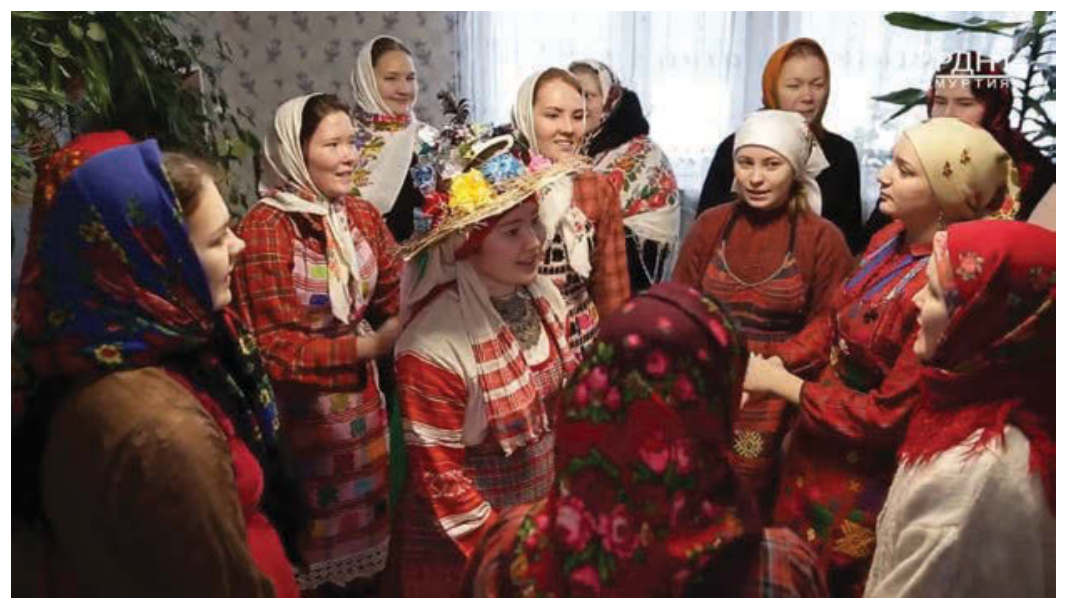

Photo 14. The ritual participants after the celebration. Novaya Mon'ya, Selty district, Udmurt Republic, 2019. Source: https://youtube.com/ playlist?list=PLGROZcMSNIi_BTODN, last accessed 10.6.2021. 


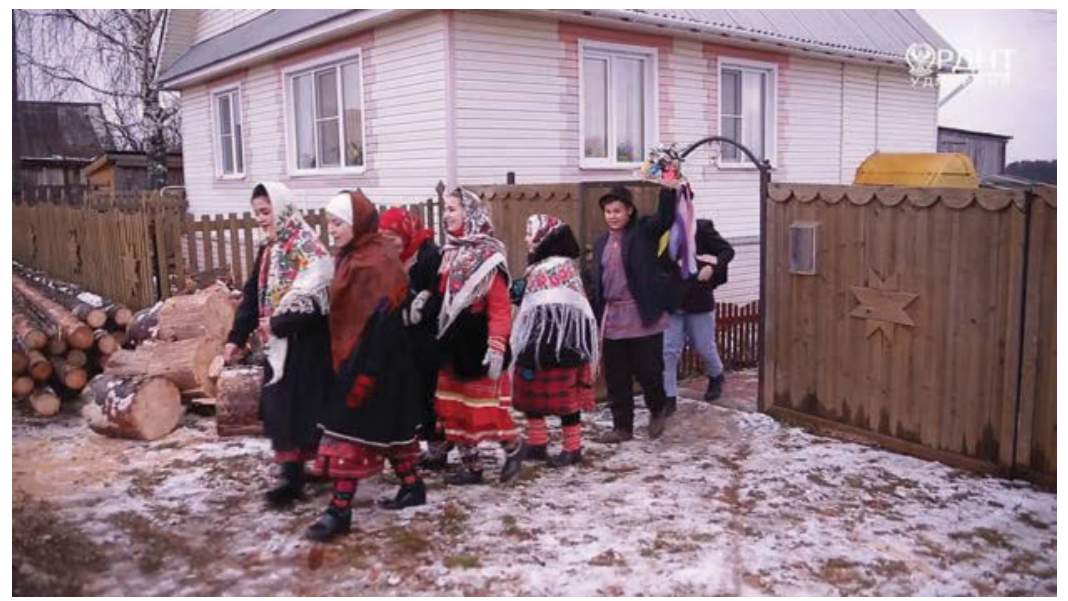

Photo 15. The ceremony of going from house to house performed by the participants in the ritual. Novaya Mon'ya, Selty district, Udmurt Republic, 2019. Source: https://youtube.com/playlist?list=PLGROZcMSNIi_BTODN, last accessed 10.6.2021.

\section{Note}

1 The article is written within the Program of Fundamental Researches of the Ural Branch of the Russian Academy of Sciences in 2015-2017 on "Udmurt Mythology in Historical and Cultural Heritage" No. 15-13-6-8.

\section{References}

Agapkina, T. 2009. Put' obryadovyy [Ritual path]. In: N. Tolstoy (ed.-inchief). Slavyanskie drevnosti: Etnolinguisticheskiy slovar v 5-ti tomakh: $P-S$. [Slavic Heritage: Ethnolinguistic Dictionary in 5 Volumes. 1: P-S.] Moscow: Mezhdunarodnye otnosheniya.

Alatyrev, V. 1988. Etimologicheskiy slovar' udmurtskogo yazyka: Bukvy $A$, B. [Etymological Dictionary of the Udmurt Language: Letters A, B.]. Izhevsk: Nauchno-issledovatel'skiy institut pri Sovete Ministrov UASSR. 
Bernshtam, T.1988. Molodezh v obryadovoy zhizni russkoy derevni XIX-nachala XX v.: Polovozrastnoy aspect traditsionnoy kultury [Young People in the Ceremonial Life of the Russian Village of the $19^{\text {th }}-$ Beginning 20 ${ }^{\text {th }}$ Century: Age and Gender Aspect of Traditional Culture]. Leningrad: Nauka.

Bushkevich, S. 2009. Kuritsa [Hen]. In: N. Tolstoy (ed.-in-chief). Slavyanskiye drevnosti: Etnolinguisticheskiy slovar'v 5-ti tomakh: $K-P$. [Slavic Heritage: Ethnolinguistic Dictionary in 5 Volumes. 1: K-P.]. Moscow: Mezhdunarodnye otnosheniya.

Churakova, R. 1999. Pesni yuzhnyh udmurtov [Songs of Southern Udmurts]. Izhevsk: Udmurtskiy institut istorii, yazyka i literatury Ural'skogo otdeleniya Rossiyskoy akademii nauk.

Dolganova, L. \& Morozov, I. 1995. Igry i razvlecheniya udmurtov: istoriya $i$ sovremennost' [Games and Entertainment of the Udmurts: History and Present Time]. Moscow: Udmurtskiy institut istorii, yazyka i literatury Ural'skogo otdeleniya Rossiyskoy akademii nauk.

Kabakova, G. 1999. Zhenshchina [Woman]. In: N. Tolstoy (ed.-in-chief). Slavyanskiye drevnosti: Etnolingvisticheskiy slovar v 5-ti tomakh: $D-K$. [Slavic Heritage: Ethnolinguistic Dictionary in 5 Volumes. 2: D-K.] Moscow: Institut slavyanovedeniya RAN.

Khristolyubova, L. 1995. Kalyk s'am"yosty chaklasa [Following Folk Traditions]. Izhevsk: Udmurtia.

Lytkin, V., Gulyaev, E. 1970. Kratkiy etimologicheskiy slovar komi yazyka [Short Etymological Dictionary of the Komi Language]. Syktyvkar: Nauka.

Minniyakhmetova, T. 2000. Kalendarnyye obryady zakamskikh udmurtov [Calendar Rites of the Eastern Udmurts]. Izhevsk: Udmurtskiy institut istorii, yazyka i literatury Ural'skogo otdeleniya Rossiiskoy akademii nauk.

Morozov, I. 1998. Zhenit'ba dobra molodtsa: Proiskhozhdeniye $i$ tipologiya traditsionnyh molodezhnykh razvlecheniy s simvolikoy 'svad'by'/'zhenit'by' [Marrying of a Fine Young Man: Origin and Typology of Traditional Youth Holidays with 'Wedding' Symbolic]. Moscow: Gosudarstvennyy respublikanskiy tsentr russkogo fol'klora; Izdatel'stvo "Labirint". 
Munkácsi, B. 1952. Volksbräuche und Volksdichtung der Wotjaken [Folk Customs and Folk Poetry of the Votyak]. Aus dem Nachlasse von Bernhard Munkácsi. Herausgegeben von D. R. Fuchs. MSFOu, 102. Helsinki SUS.

Nuriyeva, I. 1999. Muzyka v obryadovoy kul'ture zavyatskih udmurtov: Problemy kul'turnogo konteksta i traditsionnogo myshleniya [Music in Ceremonial Culture of the Trans-Vyatka Udmurts: Problems of Cultural Context and Traditional Way of Thinking]. Izhevsk: Udmurtskiy institut istorii, yazyka i literatury Ural'skogo otdeleniya Rossiyskoy akademii nauk.

Pervukhin, N. 1888 (2). Eskizy predaniy $i$ byta inorodtsev Glazovskogo uyezda [Essays about the Legends and the Everyday Life of Non-Russians of the Glazov District]. Eskiz 2: Idolozhertvennyy ritual drevnikh votyakov po ego sledam $\mathrm{v}$ rasskazakh starikov i v sovremennykh obryadakh [Essay 2: The Idol-Sacrificial Ritual of the Ancient Votyak in Its Traces in the Stories of Elder People and in Modern Rituals]. Vyatka: Gubernskaya tipografiya.

Stepanova, A. 1985. Metaforicheskiy mir karel'skikh prichitaniy [The Metaphorical World of the Karelian Lamentations]. Leningrad: Nauka.

Tolstaya, S. 1996. Simvolika devstvennosti v Polesskom svadebnom obryade [Symbolic of Virginity in Polessky Wedding Ritual]. In: Seks $i$ erotica $v$ traditsionnoy russkoy kul'ture [Sex and Erotic in the Traditional Russian Culture]. Moscow: Ladomir, pp. 192-206.

Vasil'yev, I. 1906. Obozreniye yazycheskikh obryadov i verovaniy votyakov Kazanskoy, Vyatskoy guberniy [An Overview of Pagan Rituals and Beliefs of the Votyaks in the Kazan and Vyatka Governorates]. Izvestiya Obshchestva arkheologii, istorii i etnografii pri Imperatorskom Kazanskom universitete 5. [Journal of the Society of Archaeology, History and Ethnography at the Imperial Kazan University]. Kazan: Kazanskaya tipo-litografiya Imperatorskogo universiteta, pp. 321-349.

Vereshchagin, G. 1996. Votyaki Sarapul'skogo uyezda Vyatskoy gubernii. Sobranie sochineniy v $6 t$. [The Votyaks of Sarapul District, Vyatka Governorate. Collected Works in 6 Volumes]. II. Izhevsk: Udmurtskiy institut istorii, yazyka i literatury Uralskogo otdeleniya Rossiyskoy akademii nauk. 
Vinokurova, I. 1994. Kalendarnyye obychai, obryady i prazdniki vepsov (konets XIX-nachalo XX v.) [Calendar Customs, Rituals and Celebrations of the Vepsians (End 19 ${ }^{\text {th }}-$ Beginning 20 ${ }^{\text {th }}$ Century)]. SanktPetersburg: Nauka.

Vladykina, T. 2006. Atributivnye i verbal'nye paralleli v udmurtskom i russkom svadebnom ritualakh [Attributive and Verbal Parallels in Udmurt and Russian Wedding Rituals]. In: V. Gatsak \& T. Vladykina (eds.) Russkiy Sever i vostochnye finno-ugry: problemy prostranstvennovremennogo fol'klornogo dialoga. Materialy I Mezhregional'noy konferentsii $i$ VII Mezhdunarodnoy shkoly molodogo fol'klorista. Izhevsk, 23-26 oktyabrya 2005 g. [Northern Russia and Eastern FinnoUgrians: Problems Concerning Time and Space in Folk Dialogue. Materials of the $1^{\text {st }}$ Inter-regional Conference and $7^{\text {th }}$ International School for Young Folklorists. Izhevsk, 23-26 October 2005]. Izhevsk: ANK, pp. 50-57.

Vladykina, T. 2012. Vsego ob odnoy pesennoy formule osennego ryazhenya udmurtov-kalmezov [Just about One Song Formula of Autumn Disguise of the Udmurt-Kalmez]. In: Problemy kul'turno-yazykovoy regionalistiki [Problems of Cultural-Linguistic Regional Studies]. Perm', pp. 190-194.

Vladykina, T. 2013. Pominal'nyye obryady udmurtov: yavnoye i neochevidnoye [Funeral Rituals of the Udmurts: The Obvious and the NonObvious]. In: Narodnaya kul'tura $v$ slove i tekste: sb. issl-y i materialov pamyati Valentiny Viktorovny Filippovoy [Folk Culture in Word and Text: Collection of Research Works and Materials in Memory of Valentina Viktorovna Filippova]. Syktyvkar: Izd-vo SyktGU, pp. 32-37.

Vladykina, T., Glukhova, G. 2011a. Dni nedeli v systeme predstavleniy udmurtov o vremeni [Days of week in the system of views on time of the Udmurts]. Yezhegodnik finno-ugorskikh issledovaniy. Issue 3, pp. $38-54$.

Vladykina, T., Glukhova, G. 2011b. Ar-god-bergan: Obryady i prazdniki udmurtskogo kalendarya [Year-Circle: Rituals and Celebrations of the Udmurt Calendar]. Izhevsk: Udmurtskiy universitet.

Vladykina, T., Glukhova, G. 2013. Etnokulturnyy kontekt predstavleniy udmurtov o vremeni [Ethno-Cultural Context of Views on Time of the Udmurts]. Traditsionnaya kul'tura, Vol. 1, pp. 111-117. 


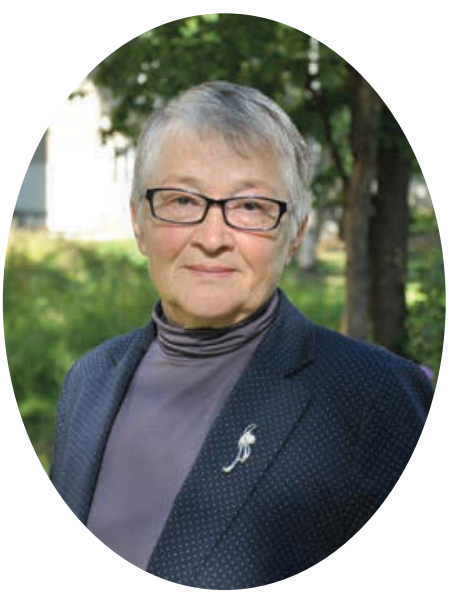

Tatiana Vladykina is ( $\mathrm{PhD}$ hab) a professor and leading researcher at the Udmurt Institute for Research in History, Language and Literature (Udmurt Federal Research Centre of the Ural Branch of the Russian Academy of Sciences). She has covered the range of topics in Udmurt folkloristics, especially mythology, specialising both in genre and in the treatment of the most important topics across genres.

e-mail: tgvladykina@mail.ru

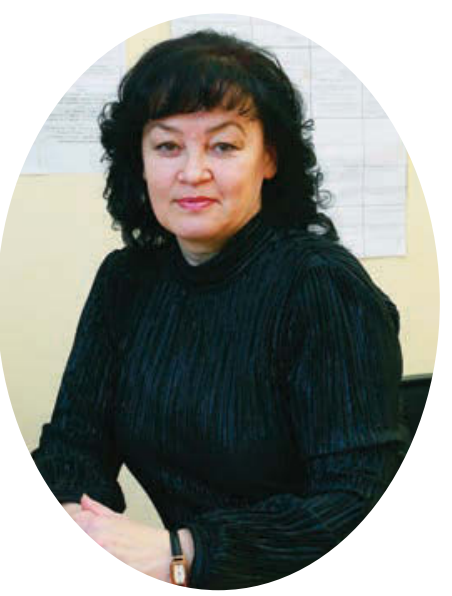

Galina Glukhova ( $\mathrm{PhD}$ ) is an associate professor and director of the Institute of Udmurt Philology, Finno-Ugric Studies and Journalism of Udmurt State University and teaches Udmurt literature and folklore. Her main field of interest is related to research on Udmurt and FinnoUgric folklore, Udmurt traditional culture, and the interaction of Udmurt folklore and literature. e-mail: galant@udm.ru 


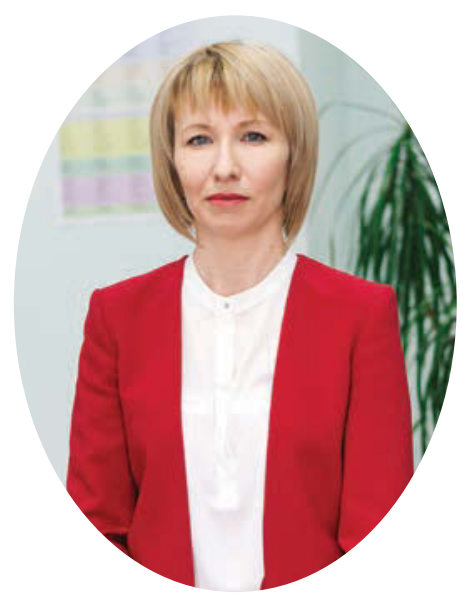

Tatiana Panina (PhD) is a researcher at the Department of Philological Studies, at the Udmurt Institute for Research in History, Language and Literature (Udmurt Federal Research Centre of the Ural Branch of the Russian Academy of Sciences). She is interested in traditional Udmurt culture, more precisely in folk medicine, incantation tradition and more recently dreams. Panina teaches English at the Izhevsk State Medical Academy. e-mail: tipanina@mail.ru 


\title{
Transition Periods in the Udmurt Folk Calendar and Their Spirits
}

\section{Galina Glukhova}

e-mail: galant@udm.ru

\begin{abstract}
The article investigates the perceptions of time based on lunar and solar cycles, seasonal changes in nature, and the rhythm of agricultural work. The key events of the annual cycle in the Udmurt calendar are winter (vozhodyr/uyvozho) and summer (invozhodyr) solstices. The winter solstice period (vozhodyr, lit: transition time, crossroads / crossroads of time, the time of vozho, the time of evil spirits) and the time of the summer solstice are described. The winter period is dedicated to the winter Christmas period from January $7^{\text {th }}$ to January $19^{\text {th }}$, and includes the following components: gatherings with songs and games, divination, dressing up, and mumming. The article characterises the most important events, such as mumming and masking, as well as beliefs, rituals and prohibitions connected with the spirits of the transition time. The summer solstice is connected with the image of the Mother/ Foremother Invozho (In(')vozho-mumy), that descends from heaven to earth at that time of year. During summer solstice period the Udmurt particularly venerated heavenly powers and held calendar festivals (Gershyd, Gerber, Gyron-Bydton) in order to glorify blooming nature and peasant farmer's labour.
\end{abstract}

Keywords: masking, masks, rituals, spirits of transition times, summer solstice period, time, winter solstice period 


\section{Galina Glukhova}

Time is one of the basic features of any culture, not only in the performance of its pragmatic utilitarian functions, but also because of its symbolic functions, associated with descriptions of the world and worldview. In archaic cultures, time played a significant role in the life of the people. Unlike modern man, ancient man had a different perspective on the flow of time, as evidenced by the structure of mythological temporal representations and their different perceptions of time. Ancient man almost lived in two dimensions simultaneously, the normal chronological time and an eternally repeating sacred time.

The Udmurt folk calendar is no exception. It incorporated everything it was supposed to: perceptions of time based on lunar and solar cycles, seasonal changes in nature, the rhythm of agricultural work. The Udmurts perceived time in seasons: winter ( $t o l)$, spring (tulys), summer (guzhem), autumn (siz'yl). These seasons comprised a segment of a cycle, the year (ar), which was divided into two halfyear periods (palar), autumn-winter and spring-summer, whose boundaries were the days of the winter and summer solstices, or the beginning and the end of agricultural activities.

Various multi-genre folklore and ethnographic materials on the Udmurt traditional calendar contain information about mythological spirits of the transition periods in the year (Invozho-mumy, the spirit of the summer solstice; vozho, the spirit of winter solstice; shaytan, the spirits of Maundy (Great) Thursday; chokmor, the spirit of autumn) and in the day (dzh'ardon, sunrise; uyshor, midnight; akshan, dusk).

This article contains an analysis of vozho and Invozho-mumy, spirits of the transitional period, which is included both in rare sources from the $19^{\text {th }}$ century and the works of modern researchers on Udmurt calendar rituals (Vereshchagin 1995; Pervukhin 1884; Vladykin 1994; Pletneva 1999; Glukhova 2002, 2009; Vladykina, Glukhova 2001, etc). 
The key events of the annual cycle of the Udmurt calendar are the winter (vozhodyr/uyvozho) and summer (invozhodyr) solstices. Since the introduction of the Christian calendar and the switch to an official calendar, the winter solstice period (vozhodyr, lit: transition time; crossroads / crossroads of time; the time of vozho (mischief), the time of evil spirits) has been dedicated to the winter Christmas period from January $7^{\text {th }}$ to January $19^{\text {th }}$, and includes gatherings with songs and games, divination, dressing up, and mumming.

According to $19^{\text {th }}$ century researchers, the Udmurt had rituals of welcoming vozho as well as seeing them off. The northern Udmurt called the first day of Christmas "vozho treat" (vozhoshyd, lit: 'soup in honour of vozho'). The main event of this day was a joint meal for all of the village community (shyd-s'iyon) with the presence of the head priest (zök pop). Praying to foremother vozho (Vozhomumy), he asked her to not hurt the people during the two terrifying transitional weeks of this period and to leave when it was time; finally the priest asked vozho to grant the people a great harvest of cereals (Pervukhin 1888: 34, Essay 3).

The night before Epiphany young people chased away the spirits of the transitional period (vozho-kel'an) from this world. After New Year young villagers began to look for a house to rent for a small sum of money. They cooked food and prepared beverages in advance. The night before the celebration they went from house to house, inviting guests with the following phrase: "Come to the celebration of vozho", lit: "Come to drink the beverage of vozho" ("Vozho-braga yuyny lyktele"). The celebration lasted late into the night. Afterwards the young people of the village had gatherings in the steam bath house, where participants used a stick touched with fire to draw a circle around themselves and "listened to their fortune", i.e. took part in fortune telling. They then chased away the spirits/master of water (vozho/vumurt). Choosing a sweetheart was an indispensable element of this day. 
Early in the morning girls heated the bath houses; under the guidance of the pagan priest, men armed with axes, sticks and clubs went to the river, shouting and banging on the ice to chase vozho away. Then they washed themselves in the bath houses and went to church, where the ritual of water sanctifying was performed. On returning home, they cooked a meal of cereals with poultry (goose or duck), then the pagan priest's assistants (pokchi pop) went door to door offering prayers (Pervukhin 1888: 105-106; Vladykina, Glukhova 2011: 36-37).

Up to the mid-1950 the northern Udmurt had a tradition of meeting vozho. On the night of January $6^{\text {th }}$ young people went to crossroads "to listen to vozho go" ("vozho kylskyny"): a circle was drawn at the crossroads either with an oven fork or a frying pan holder (taba pud) as it was believed that in a circle drawn with a stick it was impossible to hear vozho: ("prostoy bodyyen nenomyre no ug kylis'ky"). There was a custom of listening at a river. The following story was recorded during an expedition to Northern Udmurt: "The night from January, $6^{\text {th }}$ to January, $7^{\text {th }}$, a few young men and girls took a fur-coat and a frying-pan holder and went to the river to listen to vozho. Having drawn a circle on the ice, they were sitting quietly. Suddenly the ice cracked and a big dog came out from beneath it. Everyone was frightened, but then they calmed down and said a prayer - and the dog disappeared" (Glukhova 1997: 83).

During this period, young people, especially girls, were very interested in divination (tunatskon). Everyone wanted to know their fate and to 'see' their soulmate. The entire Christmas period was considered favourable for divination, but the night of January $13^{\text {th }}$ was the most popular: "vozholen l'ek dyryz" (lit: the most evil/powerful time of vozho's (influence)). The elderly also looked into the future that night, to find out what the coming year would be like, whether the harvest would be good or livestock would breed. 
According to the archaic Udmurt beliefs, during the transition time, the spirits of the transition (vozho) 'leave' the waters they inhabit and come to our land. The Udmurt believed that the personification of vozho was a multitude of small creatures, white and black, zoo- and anthropomorphic. Vozho are often invisible; they only appear in certain situations looking like small, shaggy, black creatures. They are perceived mainly in the plural. They live in steam bath houses and abandoned houses, under the floor. They act like demons (shaytan). All paranormal phenomena occurring to people at night during the transition period are attributed to their tricks. Because of this, the people created a carefully thought-out system of charms and restrictions. At dusk, and at night, especially around midnight, people tried to avoid being outside, walking across a bridge or being close to abandoned houses and bathhouses, as it was believed that these places were inhabited by vozho. As a charm, they only had to call out to God: "Oste, Inmare?" ("Oh, Lord! Oh, God!”) or use profane language. Kids were prohibited from being outside at night: "En pota ber uin: vozhoos vetlo/kutozy" ("Don't walk around at night, vozho are out there / will catch you”). Crying children were also threatened with vozho: "En börd, vozhoos s'örazy nuozy" ("Don't cry or vozho will drag you (underwater) with them").

During the winter holidays, vozho are personified by mummers, who combine in their appearance both supernatural creatures and the dead ancestors. In this way, they are very similar to the shulikuns of the Vyatka and Siberian Russians. Unlike other supernatural creatures of the transition, shulikuns, like vozho, come out of the water and disappear back there.

Researchers of the $19^{\text {th }}$ century believed that vozho were in the service of witches and wizards. If the latter decide to destroy someone, they soak a shred of their clothing in water and the vozho put a curse on the owner of these things. If an ear of corn, piece of bread or wool is thrown into the water, then cattle will die and the crops won't be harvested. Sometimes vozho come out of their 
watery dwellings to fly across the sky, looking like fiery arrows. Several villages located on the banks of the same river had their own, individual, vozho. Offerings were brought to them on behalf of newlyweds; otherwise vozho would curse them with illness.

In terms of appearance, the description of these mythical creatures is rather vague. They are very small, about 14 inches or less, of different colours (mainly white, but often black) and have little horns and tails. Sometimes they may come looking like a dog, but more often they take an anthropomorphic appearance.

Vozho came in contact with people when certain taboos were violated. Their job then was to take the person with them and turn him or her into a creature like themselves. The plots of the stories are structured around vozho meeting travellers in a field or by a river after midnight. Only a particular spell (vozhokyl) can set them free. In fairy tales, the hero usually frees him- or herself from vozho by using a safe space (stove) or by using his/her skill in playing musical instruments, allowing vozho to do what they love (gambol and dance) before the first roosters crow. The hero can also restore his or her appearance with a cross. In socially-oriented fairy tales, vozho appear as either benevolent or malevolent spirits, depending on the actions of the main characters. For example, in the tale about a stepmother who hated her stepdaughter and sent her to an abandoned house after midnight to die, vozho give the stepdaughter a beautiful necklace (kamal'i), and when the stepmother sends her favourite daughter there, because of her greed, they kill her.

During the Christmas period, certain activities were prohibited, such as cleaning the floor, washing clothes, going to the bath house, removing ash from the stove, processing flax, and making malt. Washing clothes was prohibited, but if it could not be avoided, different rules applied, such as not leaving the washed clothing outside overnight otherwise vozho "will make mischief" by cutting, staining or scattering it. The water left after the washing was 
poured away only in the evening, and the spot then covered with snow. During this period, handicraft was not only permitted but also encouraged, even though it still had time limits. Spinning and knitting were allowed only during the day and late evening, at dusk (akshan).

The period of the winter solstice is contrasted and simultaneously reflected in the summer solstice, in(')vozhodyr (lit: heavenly transition, heavenly (summer/green) festivity), a time associated with ideas of the dominance of higher or heavenly forces as represented by the image of the Mother / Foremother-Invozho (In(')vozho-mumy). This deity is one of the heavenly foremothers who, during the summer/ solstice period, descends from the 'heavenly world' to earth and lives on wild clove flowers (invozhos'as'ka, gudyri-s'as'ka), hence picking them is forbidden (otherwise "lightning will strike you"). It is believed that at this time, prayer (vös') 'leaves' the sanctuary (vös' kualas' kyre pote) and so the Udmurt pray outdoors surrounded by nature during this period. The veneration of the heavenly forces during the summer/green festivity was preserved in a number of beliefs, for example at noon it was forbidden to work in the field, to swim, to make noise, to shout close to water or to wash clothes at the springs. Otherwise, the wrath of gods would fall on the people: In(')vozho-mumy would send terrible thunderstorms with hail and destroy crops. These beliefs explain the origin of the Udmurt names for the month of June: month of invozho (invozho tolez), terrible month (l'ek tolez). During this period, the Udmurt celebrate holidays dedicated to blooming nature and the labour of the peasant farmer, who grows crops (Gershyd, Gerber, Gyron-Bydton). During this time, a special sacred chant was performed (in(')vu; invu-utchan gur), which was a version of the ceremonial visit chant (vös'gur). During the ritual tour of the village, the prayer melody was played on a stringed musical instrument (krez) and sung in each of the houses visited. 
The beliefs about vozho's connection with water have also manifested themselves in the observance of certain customs during the summer festivity, for example no one performs the khorovod, round dance at the river, no one washes clothing next to water bodies, no one goes swimming at noon, and no one leads their cattle into the river to drink. People also never yell loudly at the river, make noise, or sing songs when crossing the river. Thus, modern Udmurt traditions have preserved mythological beliefs of the past, both about the mythological creatures of the transition time and about the period itself.

\section{References}

Gavrilov, B. 1880. Proizvedeniya narodnoy slovesnosti, obryady i pover'ya votyakov Kazanskoy $i$ Vyatskoy guberniy [Pieces of Folklore, Rites and Beliefs of the Votyak of Kazan and Vyatka Governorates]. Kazan: Pravoslavnoye missionerskoye obshchestvo.

Gavrilov, B. 1891. Pover'ya, obryady i obychai votyakov Mamadyshskogo uyezda, Urias'-Uchinskogo prikhoda [Beliefs, Rites and Traditions of the Votyak of Mamadysh District, Urias'-Ucha Parish]. Trudy chetvertogo arkheologicheskogo s"yezda $v$ Rossii [Works of the $4^{\text {th }}$ Congress of Archaeologists of Russia]. Kazan, pp. 80-156.

Glukhova, G. 1997. Traditsionnaya svyatochnaya obryadnost' severnykh udmurtov [Traditional Christmas Rituals of the Northern Udmurt]. In: Istoriya i kul'tura finno-ugorskikh narodov: Materialy mezhdunarodnoy studencheskoy nauchno-prakticheskoy konferencii. 1. Arheologiya. Etnologiya. Istoriya. Kraevedenie [History and Culture of the FinnoUgric Peoples: Materials of Students' International Conference. Part 1. Archeology. Ethnology. History. Regional Studies]. Glazov, pp. 82-85.

Glukhova, G. 2009. Terminologiya udmurtskogo ryazhen'ya [Terminology of Udmurt Mumming]. Traditsionnaya kul'tura v izmenyayushchemsya mire: Materialy VIII Mezhdunar. shkoly molodogo fol'klorista "Traditsionnaya kul'tura $v$ izmenyayushchemsya mire" $i$ seminara "Permistika: yazyk i stil'fol'klora" [Traditional Culture in the Changing 
World: Proc. $8^{\text {th }}$ Int. School of Young Folklorist, Traditional Culture in the Changing world, and Seminar Permistika: The Language and Style of Folklore]. Izhevsk: Udmurtskiy institut istorii, yazyka i literatury Uralskogo otdeleniya Rossiyskoy akademii nauk, pp. 45-48.

Pervukhin, N. 1888. Eskizy predaniy i byta inorodtsev Glazovskogo uyezda [Essays about the Legends and the Everyday Life of Non-Russians of the Glazov District]. Eskiz 3: Sledy yazycheskoy drevnosti v obraztsakh proizvedeniy ustnoy narodnoy poezii votyakov (liricheskikh i didakticheskikh) [Essay 3: Traces of Pagan Antiquity in Images of the (Lyrical and Didactical) Oral Folk Poetry of the Votyak]. Vyatka: Gubernskaya tipografiya.

Vereshchagin, G. 1995. Sobraniye sochineniy: $V 6 t$. [Collected Works in 6 Vols]. Vol. 1: Votyaki Sosnovskogo kraya [The Votyak of the Sosnovka Region]. Izhevsk: Udmurtskiy institut istorii, yazyka i literatury Uralskogo otdeleniya Rossiyskoy akademii nauk.

Vereshchagin, G. 1996. Sobraniye sochineniy: $V 6 t$. [Collected Works in 6 Vols]. Vol. 2: Votyaki Sarapul'skogo uyezda Vyatskoy gubernii [The Votyaks of Sarapul District of Vyatka Province]. Izhevsk: Udmurtskiy institut istorii, yazyka i literatury Uralskogo otdeleniya Rossiyskoy akademii nauk.

Vladykin, V. 1994. Religiozno-mifologicheskaya kartina mira udmurtov [The Udmurt Religious and Mythological Worldview]. Izhevsk: Udmurtia.

Vladykina, T., Glukhova G. 2011. Ar-god-bergan: Obryady i prazdniki udmurtskogo kalendarya [Year Circulation: Rituals and Celebrations of the Udmurt Calendar]. Izhevsk: Udmurtskiy universitet.

Vladykina T., Glukhova G. 2011a. Dni nedeli v sisteme predstavleniy udmurtov o vremeni [The Days of the Week within the Conception of Time in the Udmurt's Worldview]. Ezhegodnik finno-ugorskikh issledovaniy [Yearbook of Finno-Ugric Studies] 3. Izhevsk, pp. 38-54.

Vladykina T., Glukhova G. 2011b. Invu-mumy-povelitel'nitsa nebesnoy vlagi $\mathrm{v}$ traditsionnoy sisteme mirovideniya udmurtov [Invu-Mother the Goddess of Celestial Moisture in the Udmurt's Traditional Worldview]. Vestnik Udmurtskogo universiteta. Istoriya i filologiya [Bulletin of Udmurt University. History and Philology] 4. Izhevsk: Udmurtskiy institut istorii, yazyka i literatury Uralskogo otdeleniya Rossiyskoy akademii nauk, pp. 114-119. 


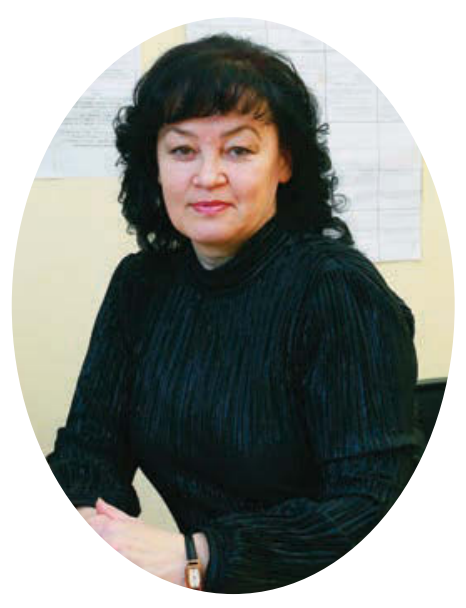

Galina Glukhova ( $\mathrm{PhD})$ is an associate professor and director of the Institute of Udmurt Philology, Finno-Ugric Studies and Journalism of Udmurt State University and teaches Udmurt literature and folklore. Her main field of interest is related to research on Udmurt and FinnoUgric folklore, Udmurt traditional culture, and the interaction of Udmurt folklore and literature.

e-mail: galant@udm.ru 


\title{
About vozho, the Spirit of Transition Time and Formation of Holiness among Udmurt and Komi
}

\author{
Aado Lintrop \\ e-mail: aado@folklore.ee
}

\begin{abstract}
This article concentrates on one very central character in Udmurt mythology. It is a character typical of the transitional time around the solstices, an ambiguous and liminal time, which requires particular caution from the humans to protect themselves from dangerous interference from the world beyond. This character, whose name, vozho, appears in the Udmurt name of these periods, vozhodyr, the time of vozho for the winter solstice and invozho, heaven-vozho for the summer solstice, is also a water spirit. I reflect also on other water spirits and on their peculiarities. This analysis leads me to reflect on the origin and the ramifications of the concept behind vozho with its linguistic correlations, the way it is articulated and how it sheds light on the concept of holy in the Permic languages and for the Permians, Udmurt and Komi. This leads me to reflect on the correlations between liminality and holiness, the liminal places and spaces and their value, and the particular characters in the mummery festivities that characterise this transitional winter time and which are connected both to the spirits of the other world and to the dead ancestors, who are among the main providers of well-being in the Udmurt world.
\end{abstract}

Keywords: liminal period, liminal places, Permian mythology, solstices, transitional time, vozho, water spirit 


\section{Introduction}

Having set out to study the Udmurt mythology I was amazed by how little attention has been given in modern folklore studies to a supernatural creature that I consider extremely intriguing. This creature is vozho, a water-related being who is widely discussed in the studies of Udmurt folk belief made by the late $19^{\text {th }}$ century and early $20^{\text {th }}$ century authors. ${ }^{1}$ Vladimir Vladykin's fundamental treatment of Udmurt mythology discusses vozho in connection with the popular calendar, mentioning that the winter solstice period ends with a ritual called Yö vyle sulton. ${ }^{2}$ The common belief associated with this ritual was that "this day all the filth or impurity - vozhoos ${ }^{3}$ - goes under water" (Vladykin 1994: 229). Tatiana Vladykina touches upon vozho in her monograph on genre issues in connection with genre names and mumming (Vladykina 1998: $11,14,53-55,84)$. The only author who has written singularly on vozho is Irina Pletneva, who has briefly summarised everything written on the subject (Pletneva 1999). In his article on supernatural creatures connected to Udmurt buildings, Ranus Sadikov writes: "Several peoples have believed that at a certain period of time the saunas will be inhabited by spirits closely associated with water. The Komi-Permyak, for example, believed that kul'piyannez ${ }^{4}$, or water spirits, come to the sauna to warm themselves" (Sadikov 2000: 116). For some reason he makes no reference to vozho, which was known mainly in the traditions of the northern Udmurts. In December 2002 Galina Glukhova defended her doctor's thesis (supervisor Tatiana Vladykina) on the tradition of mumming, where the author also touches upon beliefs associated with vozho (Glukhova 2002: 7-10).

Becoming further involved in the subject, it began to appear to me that vozho is something of a key figure in the evolution of religious thought among the Permian peoples. By 'evolution' I do not mean progress from a lower level, or a simpler form, to a higher 
level or to a more complex form, but a process of continuous, though very common, change of meaning to which all human concepts are subject. Now I have come to the concept of 'holy', the development of which in the Permian tradition would be incomplete without the concept of vozho. The notion 'holy', which will be discussed below, is not holy in its modern, Christian sense. Vozho enables us to take a look into the worldview of people centuries ago, when the divine and the infernal were not separated by an unsurpassable gap. And since we cannot discuss vozho separately from other water-related mythological creatures, I will first observe the Udmurt beliefs associated with water spirits.

\section{Udmurt water spirits}

For me, water spirit is a conditional common name for several water-related supernatural creatures, which are difficult, if not impossible, to distinguish. In the following I will briefly present narrative motifs associated with three mythological characters in Udmurt mythology ${ }^{5}$. In order to fully comprehend their idiosyncrasies and scope, I will compare these characters with several North European mythologies by drawing parallels with motifs from the works of Stith Thompson and Antti Aarne.

\section{Vumurt or vukuz'o (water + man; water + master)}

This mythological character is anthropomorphic and dwells in rivers (MI F212. Fairyland under water; G303.8.8. Devil lives in the water). Vumurt has a large family (MI F420.3.1. Water-spirits have family life under water). It is wealthy, heads a prosperous household and a large herd (MI F241.2.3. Faires' cattle under a lake; F420.4.8. Water-spirits have treasures under water), and 
sometimes appears either as a beautiful woman (MI F420.1.2.1. Water-maidens are of unusual beauty) or is dirty, ugly and hairy (MI F451.2.0.1. Dwarfs are ugly). Vumurt usually appears as a naked human, most often a woman (MI F420.1.6.7. Water-spirits are nude), who sits on the wheel of a water mill or on the river bank and combs her long hair (MI F420.5.3.1. Water-spirits sit on beach combing their long hair). Vumurt often visits marketplaces and fairs (MI F420.3.2.2. Water-women come to market and store), has the appearance of a regular farmer in the crowd (MI F420.1.6.1. Water spirits are dressed like people around them), but can be recognised by the coat, whose left skirt/corner is always wet (MI F420.1.7.1. Corner of water-spirits' dress is always wet).

In narratives water spirits become visible to the hero when he spreads a special ointment or liquid on his eyelids. In some variants a midwife smears her eyelids with the faeces of a water spirit's newborn child (MI F235.4.1. Fairies made visible through use of ointment; F235.4.4. Fairies made visible through use of magic water).

Some reports suggest that it was believed that vumurt had a single eye at the back of its head (ogre, the Devil), and that its fingers dropped off and could be found at river banks (oblong fingershaped stones have been called 'vumurt's fingers' - Pervukhin 1888 (1): 73; Vereshchagin 1996: 90).

Seeing a vumurt was sometimes considered an omen of illness or calamity. Vumurt may have married a human (MI F420.6.1.1. Water-man woos mortal girl). It may have drowned people (MI F420.5.2.1. Water-spirits lure mortal into water) and posed a threat to those who choose to swim at the wrong time, were not wearing crosses, etc. In a commonly known motif, a water spirit summons a midwife to his wife in labour (MI F372.1. Fairies take human midwife to attend fairy woman; F420.5.3.2. Water-spirit calls human midwife, F451.5.5. Dwarfs have human woman as midwife). The water spirit generously rewards the midwife, but the money/gold turns into coals or leaves (MI G303.21.1. Devil's money becomes ashes). 
About vozho, the Spirit of Transition Time and Formation of Holiness

Sometimes vumurt acts as a treasure bringer. This attribute relates it to the treasure-bringing goblins (kratt, puuk, para), known in the Estonian and Finnish tradition. In folk tales it is often attributed the role of an ignorant Old Heathen (MI K171.1. Deceptive crop division: above the ground, below the ground: AT 1030 Sharing crops, MI K72 Deceptive contest in carrying a horse; AT 1082 Carrying horse; MI K18. Throwing contest won by deception; AT 1063 Slinging contest).

From the viewpoint of this article the most intriguing belief was that during Yuletide vumurt came out of the water and dwelled in saunas.

\section{Vozho (meaning and etymology will be discussed below)}

Vozho dwell in water, rivers and ponds (MI G303.8.8. Devil lives in the water), but also in mills, saunas and empty houses. In some texts vozho is mentioned as the helper of a witch who lives in a river or a spring (Bogaevskiy 1890: 90-91). In this case it is sometimes seen flying through the air (MI F451.3.3.6. Dwarfs fly through air; MI G242. Witch flies through air). Bogaevskiy notes that vozho is a fire snake who flies over the sky and brings family luck (Bogaevskiy 1890: 98 treasure-bringer, cf. the Estonian treasure-bringing goblins puuk, kratt, and the Finnish para). The general belief was that vozho looked like a small hairy devil with a tail, horns and hoofs (MI F420.1.4.6. Water-spirits with horse feet; F451.2.1.1. Dwarfs are small; G303.4.1.6. Devil has horns; G303.4.5.3. Devil has horse's foot; G303.4.6. The devil's tail).

Vozhos often appear in great numbers. They come out of the water at night and dance and sing in abandoned houses and water mills (dancing fairies, witches, devils). They fear the cock's crow (MI F383.4. Fairy must leave at cock-crow; F420.3.4.2. Water-spirits must be in water before dawn; G303.16.19.4. Devil (Satan) flees when cock is made to crow). They may drag a human not wearing a cross into the 
water (MI F451.5.9.1. Dwarfs fear the cross; G303.16.3 Devil's power avoided by the cross). During yuletide they came to the villages, dwelled in saunas and played evil tricks at humans (MI F451.5.2.7. Dwarfs play pranks; F451.5.2.10. Dwarfs frighten mortals).

\section{Munchokuz'o (sauna + master), munchomurt (sauna + man), töd'y murt (white + man)}

A sauna fairy naturally dwells in the sauna. It usually appears as an old man clad in white (MI F236.1.3. Fairies in white clothes; F451.2.7.4. Dwarfs clad in white). In some regions it was believed to have long hair and one eye. The southern Udmurt imagined munchokuz'o as a small hairy creature. Trans-Kama Udmurts called the spirit inhabiting saunas kuz'yyrs' $i$ (the one with long hair; Sadikov 2000: 116). In some regions it was believed that saunas were inhabited by a multitude of spirits who dance and sing at night (ibid.: 115). Sauna spirits/fairies also play tricks on humans, and may even exchange a child (MI F321.1. Changeling; F420.5.2.4. Water-spirits steal children and leave changeling; G303.9.9.4. Devil takes an unbaptised child out of the cradle and lays a wooden log in its place).

We can distinguish between three main types of motif associated with water spirits:

(i) Motifs associated with water spirit, fairy and dwarf lore;

(ii) Motifs associated with the Devil and ignorant Old Heathen;

(iii) Motifs related to helpers/henchmen of the Devil (witches, vampires, treasure-bringers). 
About vozho, the Spirit of Transition Time and Formation of Holiness

\section{The semantic meaning and associations of the word vozho}

The semantic field of the Old Permian word vezha enabled its use as an equivalent for the Christian concept 'holy'/'sacred': yyen vezha lov, holy spirit; vezha kuima, Holy Trinity; vezha lun, holy day (Sunday) (Lytkin 1952: 156). In Modern Komi vezh also means 'holy'/'sacred', but also 'cross': vezha va, holy water; vezhay, godfather (holy / cross father); vezhan, godmother. Vezhadyr means Yuletide (Russian svyatki), but the Komi-Zyryan vezha also means 'filthy'/'impure' and 'the Devil' (Gribova 1975: 110). The verb vezhny means 'exchange', vezhöm was the child exchanged by the Devil or an evil spirit in Komi mythology. In the Udmurt language vozho does not directly mean 'holy', this particular meaning becomes evident in connection with Yuletide, called vozhodyr among the Udmurt, as well as the Komi. The Udmurt have a different name for its summer counterpart, invozho $d y r$ (sky + vozho + time/tide). The vozhos are the previously-described demonic spirits. The word vozh, closely related to vozho, means 'green', 'verdure', 'unripe' in the Udmurt language. In the expression 'vozhde en vay' (don't be angry / don't bear a grudge!) it means 'anger'. The words vozhomyny (vozho + to go) 'get excited/heated' and vozhpoton (vozh + will/wish/ feeling) 'anger' appear to derive from the same root. Interestingly, the Finnish words viha, vihainen 'anger', 'angry' and vihannuus, vihannoida 'green', 'to turn green' seem to share a common root. Michael Agricola and Jacobus Finno have used the words wihleinen, wihileijnen, wihileitzet, wiheliaidzexi in the sense 'bad', 'vile', 'weak', 'impure/filthy', 'deceitful/dishonourable', 'faulty/spiteful' (SKES VI 1735). Such words from the Estonian mythology like maaviha, küüneviha, perhaps also humalaviha may derive from the negative force emanating from these objects (earth, nail, hops). 
On the one hand the semantic field of the word vozho seems to approach the concept 'holy/sacred' and on the other hand it can be associated with notions 'anger', 'green', 'evil' and 'impure'.

It is likely that such an extended form of the semantic field may have originated from two different roots. The first could be associated with liminality, or existing somewhere in-between: *vayesh > Early Permian vezh-> Udm. vozh 'crossroad', 'river mouth', 'either of two warps', 'the crossing of warps and woofs', cf. vozhen-vozhen 'alternatively', vozhmin 'in turns', perhaps also invozh (sky + vozh) 'horizon'; Komi vezh, vizh - tuy-vezh 'crossroad', vezhny 'change'; Finnish vaihe, Estonian vahe 'difference', 'interval', 'gap' (SKES V: 1592-1593).

Finnish linguists have speculated on the relation of the Finnish vaihe and the Permyak vezh-, but had they been acquainted with Udmurt or Komi mythology this would not have been mere speculation. In the Komi compound and its Udmurt equivalent the first component signified liminality, the solstitial period, or the extraordinary transition period between two ordinary periods.

The second root was associated with the colour green, bitter taste and strong emotions (like anger and lust): *visha $>$ East Mordvin ozho 'yellow'; Cheremis (zhar, zhar, Eastern Mari uzhar 'green', 'young', 'unripe'; Udm. vozh 'green', 'unripe', 'small', 'anger', 'fury'; Komi vezh 'green', 'yellow', 'envy', 'lust'. Cf. Finnish viha, vihainen, vihannuus, Old Hindi visám 'poison', Avestan visha - vish zairitəm 'greenish poisonous liquid', Pahlavi wish 'poison', 'bile', 'spiteful', etc. (SKES VI: 1734). In time the two roots approached each other and their meanings may have overlapped. An attempt to interpret the word vozhodyr as 'becoming angry or furious' occurs in earlier studies on Udmurt mythology. 
About vozho, the Spirit of Transition Time and Formation of Holiness

\section{Liminality of crossroads and river mouth}

Crossroads and river mouths, places between two water bodies or roads, are certainly liminal places. In his short monograph The Crossroad in Folklore and Myth Martin Puhvel studies beliefs associated with crossroads in many traditions throughout history (Puhvel 1989). Interestingly enough, he does not mention liminality as the main characteristic of crossroads, although he presents numerous examples of how it was believed that homeless/restless/ placeless spirits gather in these particular places. In the mythologies of several Siberian peoples, a specific water body (river, lake) was associated with a specific supernatural creature, which functioned as a master/fairy of the body of water. Among the Ob-Ugrians these spiritual beings were related according to a complex system, such as in the narrative about the Old Man of the Ob and the Fairy of the Salym River, recorded by Anzori Barkalaja:

As-iki is the master of fish. He makes fish and sends them into the nets of the fishermen. He also decides how many fish must go into each river. Once it so happened that the god of Salym [a tributary of Ob. The god of Salym is master of thunder and notorious for his bellicose disposition - A. Barkalaja] thought he was getting too few fish from As-iki. So up he goes to As-iki and demands: "Listen, why do you give me so few fish, give me more." But As-iki was in a defiant mood, did not give him fish. So the god of Salym went away and began to prepare for war. He picked up an arrow-shaft and began to whittle away on it. Whittled one chip off it - the chip turned into a stickle-back. Whittled another chip - that, too, turned into a stickle-back. Thus the stickle-backs became many. They swam downstream into the river Ob. As-iki looks - a stickle-back. Looks again - nu, holera, (emotional interjection in Russian, translates as "Oh, cholera!") another 
stickle-back! So he went upstream along the Ob until he could see - the Old Man of Salym is whittling away at arrow-shafts, chips are falling down and turning into stickle-backs. As-iki got a terrible fright, began to call from afar: "What are you doing there, planning to wage war? Against whom?" Salymiki called back: "Against you, of course, why don't you give me fish?!" So As-iki reckoned the matter was grave and sent lots of fish into the Salym, many large pikes. Hmh. (Barkalaja 1999: 69 > Semyon Pesikov, Lyamin, 1993).

The estuaries of rivers can then be regarded as territories between the domains of two similar supernatural creatures. Analogous beliefs are known about crossroads. Puhvel's examples on the inability of supernatural creatures to cross crossroads (Puhvel 1989: 97-98) seem to indicate as much. The liminality of crossroads is also emphasised by the association of various initiation rites and solstitial traditions connected with crossroads. The Awemba tribe in northern Zambia, for example, conducted ritual purification of young girls at puberty at crossroads (ibid.: 73), in some parts of Europe (for example France, northern Sweden) the midsummer fires were lit at crossroads (ibid.: 75). Among many peoples, including the Estonians and the Udmurts, it was customary to perform various magical actions, especially foretelling, at crossroads.

\section{Holy periods}

Human lives and calendar years contain interim periods, characterised by indefiniteness due to a lack of boundary. These periods are exposed to good and evil and are close to praeternatural. The boundaries are a part of our system of orientation. With no limits the space would be homogeneous: there would be no difference between familiar and unfamiliar, good and bad, sacred and profane places. The same applies to time. Expressions like good times, bad 
times, difficult times, mad times, fast times, holidays, common days, childhood, youth, manhood, etc., clearly express evaluation and definition of limits. Transitions from one period, one stage of life, or one condition to another are like crossroads or partings of ways in time. When liminality renders the ordinary orientation dysfunctional, ordinary behaviour will become ineffective or inappropriate. Different times need different behaviour. This is why people have carried out various practices related to liminal conditions and periods and analytically called them rites of passage throughout history.

\section{Holy time in the Udmurt popular calendar}

Several restrictions were established for the summer and winter vozho period:

The Votyaks of Glazov county still hold the belief that during the vozho period it is forbidden to make noise, especially near a body of water: this is why people do not swim, or play singing games, or do the laundry in or near bodies of water in summer. In winter people do not do laundry in the river and avoid singing when crossing a bridge. During this winter period it is also forbidden to put out embers, like those falling from burning chips, by stomping... In the Gyya, Lyp and Polom parishes the period of vozho was associated with the blooming of rye. ${ }^{6}$ Soiling water during this period was considered a grave sin - therefore it was forbidden to swim, wash the laundry or the dishes (even near a well), and even drive the herd into the river. These restrictions had to be followed especially around noon, when people tried to make no loud noises (Pervukhin 1888 (1): 59-60).

Harva notes that violating the restriction caused suffering for the whole community, either in the form of storm or hail storm (Harva 
1914: 174). Women in the village of Kuz'ebayevo have told the author of this paper that during the summer invozho period it was forbidden to work with wool or hemp and to mow and pick flowers. In Kuz'ebayevo this period ended on St. Peter's Day (July 12 $\left.{ }^{\text {th }}\right)$. The invozho period was often associated with the blooming of catchfly or maiden pink (invozho s'as'ka). In June 2003 some people from Varkled-Bod'ya village said: "vös', pe, voz'vyle pote invozho dyr"ya”, there is saying that during the invozho period religion/belief walks in the meadows.

The winter vozho period was the main storytelling and riddling time for the Udmurt (Shklyayev 1989: 36). Even as late as in June 2002 three informants, living in Udmurtskiy-Karaul and Deby villages in the Krasnogorskoye region, claimed that the words for 'riddle' in local dialect were vozho kyl (vozho 'language/word/story') or vozho mad' (vozho 'speech/word/story') ${ }^{7}$. Even though Pervukhin assumed that the word vozho mad'could be interpreted as "the story of the winter vozho period" (Pervukhin 1888 (3): 70), and Tatiana Vladykina seems to agree (Vladykina 1988: 11), this interpretation does not seem justified. On the one hand the word vozho mad' referred to the traditional, ancestral nature of the text (cf. vyzhy kyl, 'myth', 'root/gender/tribe/generation' + 'language/word/story'), on the other hand the word might have indicated the existence of a special style for communicating with visitors at solstices, the artistic style of folk tales and riddles.

In Russian folklore the water fairy sleeps in the winter and is at the peak of its action at midsummer, from Midsummer Day $^{8}$ to St Peter's Day or to St Eliyah's Day (at the beginning of August) (Krinichnaya 1994: 19-21), i.e. during the period that the Udmurt call invozho dyr. In Russian accounts the most dangerous time for bathing and swimming was noon and midnight, but also early in the morning and late at night (ibid.: 21-22). The Votian water spirit is also active in summer (especially around the Midsummer Day). A ram was reportedly sacrificed to it at the River Lauga on St Eliyah's Day while saying: "Nahh, sü̈̈ boranaa päit, elä süü 
About vozho, the Spirit of Transition Time and Formation of Holiness

inemisii!' (There, eat ram heads, not people!) (Västrik 1999: 24, 25). We can only speculate on whether the sacrifice was supposed to symbolise the end of the water spirit's period of activity.

\section{Visitors of the liminal period}

The Udmurts of the Glazov County believed that water spirits came into the villages and inhabited the saunas before Christmas. In the twilight they could be encountered on the street:

During the summer vozho $d y r$ it sleeps, but on the winter solstice (before Christmas) it leaves the water and spends most of its time in saunas, though it could be met on the street. This is why no Votyak dares to walk alone on the streets without a burnt wood chip during Christmas. (Pervukhin 1888 (1): 75).

The water spirits of the Christmas period were mainly called the vozhos. Pervukhin continues:

From December $25^{\text {th }}$ to January $6^{\text {th }}$ small (no longer than a few archines tall), colourful, though relatively similarlooking devils (with tails and horns) walk on the streets of villages, settlements, even the town of Glazov. The Russians call them kulish, the Votyaks vozho. Like water spirits, the vozho fear even the smallest piece of burnt wood.... Those who walk around without a chip, will be tripped up by the vozho.... for the same purpose they turn into a post, or the corner of a house... They might take a man to his neighbour's house instead of his own, or might make a woman drive other people's cattle to her own yard... (Pervukhin 1888 (1): 99-100). 
For the Udmurt, vozhodyr is the period for mumming. The most common name for mumming is pörtmas'kon, cf. pörtmany - 'to change', 'to transform', 'to slander'. Other words for mumming are pen'dzh'as'kon (cf. pen' 'soot', 'ashes', pen'dzh'any incinerate', 'to burn to ashes', referring to the most common way of masking by smearing the face with soot or ashes), vozhoyas'kon vozhoas'kon ('vozho-ing'; in several regions the mummers called themselves the vozho) and chokmorskon. The latter derives from the word chokmor, wooden club (cf. Russian chekmar' 'wooden club', 'beater' < cheka 'wedge', 'pole') and refers to the banging of house corners and floors with sticks and clubs, a characteristic activity of the mummers, which helped to repel evil spirits and diseases from the house and the village (Vladykin 1994: 227). The Udmurt Christmas mummers almost seem to have split personalities: the fact that they wore clothes inside out, had faces smeared with soot, men were wearing women's clothes and women were wearing men's clothes, indicates that they were visitors from the otherworld (where, according to universal belief, things are the reverse of this world). The fact that they were believed to bring luck in herding relates them to the souls of ancestors, who were universally considered the primary bringers of herding luck in many cultures. And, last but not least, the mummers were addressed as the vozho, which was undoubtedly related to the dead ancestors.

The Udmurt Christmas mummers also functioned as repellers of evil forces. Vladykin mentions an account that described how mummers ran along village streets, screaming loudly, banging against the corners of houses, and on the floors inside the houses, frightening the sauna spirits away (munchokuz'oos Vladykin 1994: 226-22), although according to a fairly commonly held belief the vozhos inhabited the saunas. As I have indicated before, no clear distinction was made between the sauna fairies and the vozhos. The exorcistic function of the Udmurt Christmas mummers very likely originates in the traditions associated with the end of the solstitial period. 
About vozho, the Spirit of Transition Time and Formation of Holiness

The winter vozho period ends on January $19^{9}$ (or the Epiphany of Jesus according to the Orthodox calendar) with a feast day called vozho kel'an 'the sending off', or 'the departure of vozho' or yö vylyn sylon 'standing on ice'. On the night before January 6 the young people of the village walked from sauna to sauna singing songs, "listened to their fate" and told the vozho: "pot tatys' mil'emesty les'?' ('leave us!'). The next morning all the men went to the river and banged on the ice with their axes and clubs, shouting "koshky tatys'?' ('leave this place!') (Pervukhin 1888 (2): 105-106).

\section{The formation of the concept 'holy' among the Permian peoples}

Considering that the word vozhodyr denoted the liminal period of the winter and summer solstices and was not a recent loan from the Russian svyatki, and considering that the vozhos were the praeternatural visitors of this period, probably related to departed ancestors, we can now reflect on the formation of the concept 'holy' among the Permians.

The solstice was a special and dangerous period, and the supernatural visitors of this period, although expected, were considered dangerous and required special treatment. The concept 'holy' was closely related to the strange, the special, the liminal, the dangerous and the desirable. Before the introduction of Christian terminology, the Permian word for such phenomena was vezh. Words derived from this root were probably used to signify places, periods, objects and creatures that required special treatment, including transitional or interim periods in calendar and geographical and territorial border areas. As the concept also comprised the sacred places for worship and cult objects, the word vezh seemed most appropriate for the Permian equivalent for the Christian concept 'holy', and Stephan of Perm soon adopted the word in Komi. Even though the Second Commandment declares "for I the Lord thy God 
am a jealous God" (Ex 20:5) and the Second Book of Moses says "for the LORD, whose name is Jealous" (Ex 34:14), the Christian concept of 'holy wrath' is less inclined to the unknown, liminal and dangerous. The supernatural visitors of the solstitial period were no longer included in the semantic field of the concept (vezh), and came to be called the Chudes.

Common conceptions about the Chudes can be divided into three major groups: (i) the Chudes were a people living on the upper course of the River Kama and the Vychegda River long before the Komi; (ii) the Chudes were the Komi before their conversion to Christianity; (iii) the Chudes were the Komi heroes (Gribova 1975: 93). The Chudes objected to the arrival of tall people. They hid themselves in saunas and holes, and threw stones and coal at the newcomers. The holes of the Chudes are still there: they probably fell down through them (ibid.: 95). They were the Komi, only unbaptised like the Chudes. When they were Christianised, they believed it was something bad and hurt themselves: they built dugouts, descended to these dugouts and severed the beams supporting the ceilings... (ibid.: 96).

The Komi also attributed the name Chudes to vozho-like creatures:

According to Komi-Permyak belief the Chudes are...small anthropomorphic black creatures who live in dark places: abandoned houses, saunas, drying barns, cellars, inside the house behind the oven and under the floor, in the woods and in water. They are, in fact, called sauna-Chudes, barn-Chudes, etc. They cause troubles for humans: they frighten them (especially at Christmas), drag them into eddies, smother them in the sauna. Sometimes they steal children and replace them with wooden logs. These children are called 'woodlogs', or vezhöm 'exchanged'. The exchange is particularly successful when the child is unbaptised or does not wear a cross around its neck. The exchanged child can eat and drink as much as it likes, but it will neither grow nor develop (Gribova 1975: 107). 
About vozho, the Spirit of Transition Time and Formation of Holiness

Regardless of the several presented etymologies tracing the origin of the word Chude to more distant languages, I tend to support the Slavic origin of the word (chudo, chudyy, ethnonym chud', which the Christianised Slavic tribes appeared to have used for heathen Finno-Ugrians). Similarly to the visitors of the liminal period, who were associated with deceased ancestors, the Christian Komi attributed the Chudes a new identity as heathen forefathers or heroes and demonised them. Several Komi folklore texts describe the demonisation of the heathen ancestors of the Christianised Komi:

The Kars ${ }^{10}$, these were the towns: Kudym Kar, Kureg Kar. People lived underground, built log houses and lived on meat and fish.... But later, when the conversion to Christianity began, they began to destroy themselves, buried themselves alive. Whoever refused to be baptised was not allowed in the house. Walked around as a Chude - small, pitiful, was afraid of everyone. These were the years of spirits - you pass the sauna, pass the river, it haunts everywhere. ${ }^{11}$ Even when doing needlework. But they would not surrender, they slept in the sauna or in the threshing barn. Even now they are called the 'sauna-Chudes' (Limerov 1998: 39).

Stephan of Perm's influence did not affect the Udmurt area, and the later coiners of Christian terminology in the Udmurt language were probably unable to see the relationship between the Udmurt vozh-/vozho and the Christian concept of 'holy/sacred'. For this reason the Udmurt do not have their own word for this and use Russian loans svyatoy and svyashchennyy (for example a recently collected modern prayer: sv'atoy Inmar, sv'atoy kulontem, mil'emly dzh'ech kar - Holy God, Holy Strong, Holy Immortal, have mercy on us (lit: do us good ${ }^{12}$ ). At the same time there was no need for the new name of visitors during the solstitial period, who continued to be known as the vozhos, and were demonised. The demonisation of analogous mythological characters, such as 'various fairies, spirits 
and dwarfs, in the mythologies of different countries is suggested by the motifs presented at the beginning of the article.

In the Permian languages the Christian concept of 'holy/sacred' was derived either from the word originally denoting the liminal, the unusual, perhaps even the impure (the Komi example), or was a loan word (the Udmurt example). The study of toponyms should reveal whether vezha and vozho were used in a religious sense. A good example from the Komi language is perhaps the KhantyMansi sacred place at the River Ob, Yem vosh / Yalp uus, the residence of the mythological Old Man of the Holy Town, which after the Komi expansion came to be called by its literal equivalent Vezhakary, or the Holy Town. Toponyms, however, will not be very useful because in the Udmurt language it is difficult to distinguish between the notions vozh ('green', 'anger') and vozho (originally 'holy'). We may speculate that the village name Vozheshur and the river name Vozhoy shur originate in the concept 'holy' rather than 'green', therefore meaning 'the Holy River', and also the village name Vozhoyka, but we cannot be absolutely certain, especially because it is clear that the village name Vozhkyr originates in the notion 'green' and has the meaning 'green woodpecker'. The Permian example enables us to explain Veikko Anttonen's argument that the concept of 'holy' is associated with impureness - his assumption was strongly misunderstood by Anzori Barkalaja in his master's thesis (Barkalaja 1996: 23). Having accused several other authors of being too "progressive", Barkalaja seems to have fallen into his own trap, as he refused to admit the possibility of the change of religious concepts in time. Like the concept of 'holy', the concept of 'filthy/impure' has definitely changed as well. In several traditional cultures objects associated with birth and death often require special treatment, for example these objects are taken into particular wood groves or other places, sanctuaries, distinct from ordinary places. A woman, who is considered impure during menstruation and in the postnatal period, requires special treatment often being isolated, either symbolically or physically, 
from the rest of the community. In Mansi villages there are specific houses called man' kol (the small house) for this purpose, where other villagers would not go. Harriet Lutzky has argued that the Latin sacer derives from the Indo-European root *sak- or *sek-, both meaning 'to cut', 'to set apart', therefore sacralised through separation (Lutzky 1993: 285-287). Emile Benveniste has argued that the Latin adjective sacer had two contradictory meanings: (a) he who belongs to the gods and (b) he who is cast out, afraid, damned. A person marked with the word sacer was considered impure and therefore a social outcast. The one given to gods (sacer) as well as the impure (sacer) signified whoever or whatever was cast/cut out of human society (Benveniste 1973: 453). This cut-off or separated object served as a bridge, doorway, threshold or path (whichever metaphor you choose) connecting the everyday world and the supernatural sphere. Even Jesus, the Son of Mary was cast out of human society in birth and in death. Particularly for this reason he was authorised to say "I am the way, the truth, and the life: no man cometh unto the Father, but by me" (Jh 14:6). According to Veikko Anttonen the two main features of the 'holy' category are anomality and liminality (Anttonen 1992: 2526). The formation of the concept 'holy' among the Permian peoples illustrates and supports Anttonen's statement. Liminality was undoubtedly an important distinguishing feature between the holy and the profane. Another example of the threshold between the two spheres are the inscriptions above church doors or gates Hic est domus Dei et porta caeli.

\section{Conclusion}

I hope the article helped to clarify why supernatural visitors related to deceased ancestors come from water and how and why are they related to water spirits in the Udmurt mythology. The answer is quite simple - according to a commonly held belief the realm of the dead is situated on the other side of water (often on an island in the 
northern sea), or it was believed that the pathway to the otherworld ran downstream beside the river. It is quite logical to believe that if the dead (or their souls) descend to the realm of the dead downstream, they will return to visit their living relatives upstream.

I am aware that the Udmurt vozhos and the Komi vezhas or Chudes have counterparts in other North Eurasian mythologies. For example, the Russian kulish $\sim$ kulyash and shulikun. The etymologies of these words are quite intriguing. Kulish and kulyash originate in the Ugrian and/or Permian languages (cf. the Mansi kul' or kul'otor 'Lord of the underworld, the Devil', Komi kul' 'water spirit, the Devil'. Shulikun or shilikun appears to be linguistically, as well as mythologically, related to the character sülüükün süllükün in Yakut mythology (speculated origin in the Old Turkic word suvluY 'water-', 'water-related'). Parallels could also be drawn with the demonic Christmas visitors of the Russians, Yakuts and Udmurts. Here I am not saying that the Russians have borrowed their solstitial visitors from the Turkic or Finno-Ugric peoples. It is highly likely that the Russians had their own word for such supernatural creatures, and the name was either abandoned or was attributed a new meaning. As to the names of St Martinmas' and St Catherine's Day's mummers (mardisandid, kadrisandid) in the Estonian tradition, the word sant ('beggar' or 'cripple' in Modern Estonian) seems to be either a similar loan for the same purposes, or was borrowed from the official language used in the contemporary liturgy with the purpose of rehabilitating the spiritual visitors in the eyes of the Church.

\section{Notes}

1 Especially by N. Pervukhin, but also by I. Vasilyev, P. Bogaevskiy.

${ }^{2}$ Literally 'standing on ice'. On the previous night the village youngsters performed a ritual called vozho kel'an 'the sending off or the departure of vozho', walking from sauna to sauna, shouting loudly, in order to repel the Vozho who had gone to live there over Christmas. 
About vozho, the Spirit of Transition Time and Formation of Holiness

3 The plural form of vozho, i.e. vozhos.

${ }^{4}$ In the Komi mythology Kul' is both the Devil and an evil water spirit. Kul'piyannez could be the diminutive form - sons/cubs of the Devil.

5 On references to the origin of the Udmurt motifs, see Lintrop 2000.

6 The motif of water sprites walking in the fields while rye was blooming is also known in Russian folklore (Krinichnaya 1994: 23).

7 The ethnic genre name for riddles, vozho mad', is mentioned in Gavrilov 1880: 54, Pervukhin 1888 (3): 70; Wichmann (1901: 6-7). Pervukhin has used the same word for folk tale. The more common modern term for riddle is mad'is'kon kyl or mad'kyl.

8 In the Yaroslavl Governorate Midsummer Day was considered the water spirit's name day (Krinichnaya 1994: 19).

9 January 6 according to the old calendar.

${ }^{10} \mathrm{Kar}$, 'town', 'township' in the Permyak language.

${ }^{11}$ Originally: 'chudlivyye ved' gody byl'i - mimo ban'i id'osh', mimo reki, tak vs'udu chud'its'a".

12 The prayer derives from the Orthodox liturgy Trisagion Svyatyy Bozhe, Suyatyy Krepkiy, suyatyy Bessmertnyy, pomiluy nas (Holy God, holy Strong, holy Immortal, have mercy on us), which in the Udmurt language is sv'atoy inmar, sv'atoy kulontem, mil'emly dzh'ech kar.

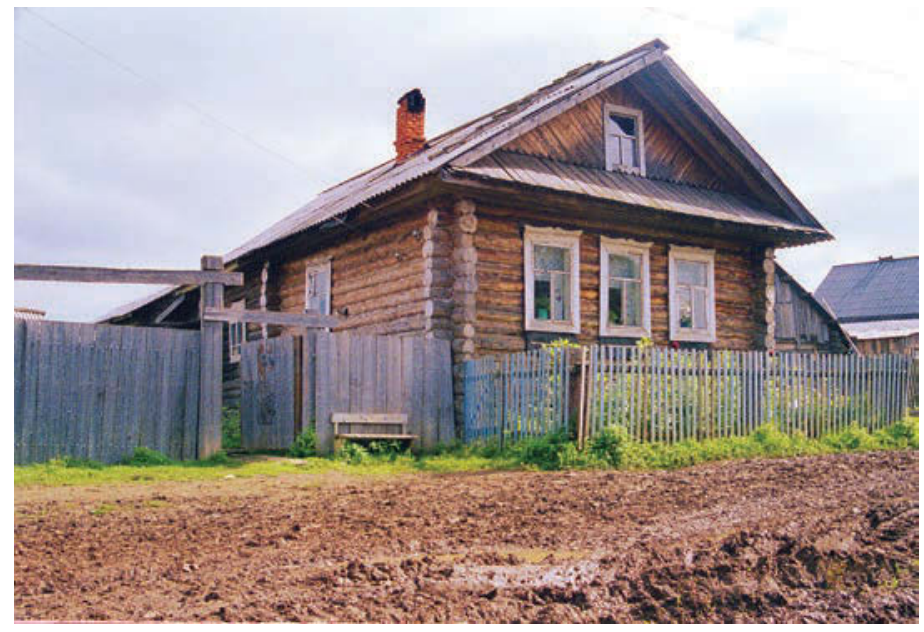

Photo 1. A Besserman village in Udmurtia. Photo by A. Kuperjanov 2000. 


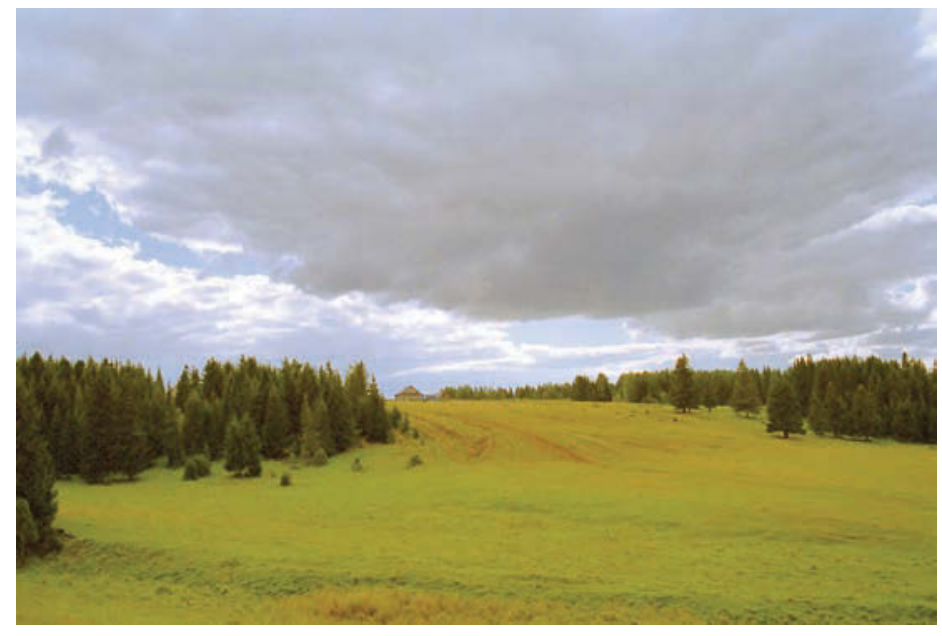

Photo 2. Northern Udmurtia landscape.

Photo by A. Kuperjanov 2000.

\section{References}

AT $=$ Aarne, A. \& Thompson, S. 1961. The Types of the Folktale. FF Communications 184. Helsinki. Academia Scientiarum fennica.

Anttonen, V. 1992. "Püha" mõiste rahvausundi uurimises [The Concept of "Holy" in Folkloristic Research]. Akadeemia 12, pp. 2514-2535.

Barkalaja, A. 1996. Handi rahvausundist, selle seostest vene oigeusu ja teadusliku mõtlemisega [About Khanty Folk Beliefs, Their Connections with Russian Orthodoxy and Scientific Thinking]. Väitekiri magistrikraadi taotlemiseks eesti rahvaluule alal. Tartu Ülikool, eesti ja võrdleva rahvaluule õppetool.

Barkalaja, A. 1999. On the Sacrificial Rituals of the Pim River Khanties: Part Two. Pro Ethnologia 8, Arctic Studies 3. Tartu, pp. 57-71.

Benveniste, E. 1973. Indo-European Language and Society. Miami Linguistics Series No. 12. University of Miami Press.

Bogaevskiy, P. 1890. Ocherki religioznykh predstavleniy udmurtov [Essay about the Religious Representations of the Udmurt]. Etnograficheskoye obozreniye, Nos. 1, 2, 4. Moskva. 
About vozho, the Spirit of Transition Time and Formation of Holiness

Gavrilov, B. 1880. Proizvedeniya narodnoy slovesnosti, obryady i pover'ya votyakov Kazanskoy i Vyatskoy guberniy [Works of folk Orality, Rituals and Beliefs of the Votyaks from the Kazan and Vyatka Governorates]. Kazan: Pravoslavnoye missionerskoye obshchestvo.

Glukhova, G. 2002. Simvolika ryazhen'ya v traditsionnoy kul'ture udmurtov [The Symbolic of Mumming in the Udmurt's Traditional Culture]. Avtoreferat dissertatsii soiskanie uchenoy stepeni kandidata filologicheskikh nauk. Izhevsk.

Gribova, L. 1975. Permskiy zverinyy stil' [The Perm' Animal Style]. Moskva: Nauka.

Holmberg, U. 1914. Permalaisten uskonto. Suomen suvun uskonnot IV. [The Permians' Religion. The Beliefs of the Finn's Kin]. Porvoo. SKS.

Krinichnaya, N. 1994. Na sinem kamne. Mifologicheskiye rasskazy i pover'ya o dukhe-"khozyaine" vody [On the Blue Stone. Mythological Tales and Beliefs about the "Master" Spirit of the Water]. Petrozavodsk: Karel'skiy nauchnyy tsentr RAN.

Limerov, P. 1998. Komi neskazochnaya proza [The Komi Non-Narrative Prose]. Syktyvkar: Izd-vo SGU.

Lintrop, A. 2000. Udmurdi usundi peamised tunnusjooned XIX ja $X X$ sajandil [The Main Features of the Udmurt Beliefs in the $19^{\text {th }}$ and $20^{\text {th }}$ Centuries]. Doktoriväitekiri. CD. Tartu.

Lutzky, H. 1993. On a Concept Underlying Indo-European Terms for the Sacred. The Journal of Indo-European Studies 21, pp. 283-301.

Lytkin, V. 1952. Drevnepermskiy yazyk [The Old Permian Language]. Moskva: Izdatel'stvo Akademii Nauk SSSR.

MI = Thompson, S. 1932-1936. Motif-Index of Folk-Literature. FF Communications 106-109, 116, 117. Helsinki.

Pervukhin, N. 1888. Eskizy predaniy i byta inorodtsev Glazovskogo uyezda [Essays about the Legends and the Everyday Life of Non-Russians of the Glazov District]. Eskiz 1, Eskiz 2, Eskiz 3 [Essay 1, Essay 2, Essay 3]. Vyatka: Gubernskaya tipografiya.

Pletneva, I. 1999. K semantike udmurtskogo vozho. Problemy udmurtskoy i finno-ugorskoy filologii: Mezhvuzovskiy sbornik nauchnykh trudov [About the Semantics of Vozho. Problems of Udmurt and Finno-Ugric Philology. University Collection of Scientific Works]. Izhevsk: Udmurtskiy universitet, kafedra obshchego i finno-ugorskogo yazykoznaniya.

Puhvel, M. 1989. The Crossroads in Folklore and Myth. American University Studies. Series IV, English Language and Literature. Vol. 88. New York. 
Sadikov, R. 2000. Kaama-taguste udmurtide ettekujutused elamu kaitsevaimudest [The Trans-Kama Udmurt's Representations of the Home Protective Spirits]. Mäetagused 13, pp. 112-118.

SKES 1975, 1978. Suomen kielen etymologinen sanakirja [The Etymology dictionary of Finnish]. V, VI, Helsinki. SUS.

Shklyayev, G. 1989. Obryady i pover'ya udmurtov, svyazannyye s zhilishchem [Rituals and Beliefs of the Udmurt about Dwellings]. Fol'klor i etnografiya udmurtov: obryady, obychai, pover'ya [Udmurt Folklore and Ethnography: Rituals, Customs, Beliefs]. Izhevsk: Udmurtskiy institut istorii, yazyka i literatury Uralskogo otdeleniya Rossiyskoy akademii nauk, pp. 28-43.

Vereshchagin, G. 1996. Votyaki Sarapul'skogo uyezda Vyatskoy gubernii. [The Votyaks of the Sarapul District of the Vyatka Governorate]. Sobraniye sochineniy, t. 2. Izhevsk: Udmurtskiy institut istorii, yazyka i literatury Uralskogo otdeleniya Rossiyskoy akademii nauk.

Vladykin, V. 1994. Religiozno-mifologicheskaya kartina mira udmurtov The Udmurt's Religious and Mythological Worldview]. Izhevsk: Udmurtia.

Vladykina, T. 1998. Udmurtskiy fol'klor. Problemy zhanrovoy evolyutsii $i$ sistematiki [The Udmurt Folklore. Problems of Genre Evolution and Systematisation]. Izhevsk: Udmurtskiy institut istorii, yazyka i literatury Uralskogo otdeleniya Rossiyskoy akademii nauk.

Västrik, E.-H. 1999. The Waters and Water Spirits in Votian Folk Belief. Folklore, Vol. 12, pp. 16-37.

Wichmann, Y. 1901. Wotjakische Chrestomatie mit Glossar. Helsingfors. Finnische-Ugrische Gesellschaft.

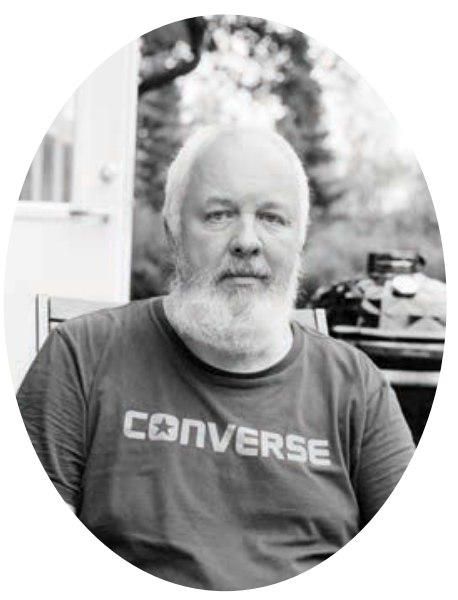

Aado Lintrop ( $\mathrm{PhD}$ ) is a senior researcher at the Estonian Folklore Archives of the Estonian Literary Museum, Estonia. He is interested in Ob-Ugrian mythology and folklore as well as in Udmurt mythology and traditional religion.

e-mail: aado@folklore.ee 


\title{
Water Bodies in Besserman Mythology and Rituals
}

\author{
Elena Popova \\ e-mail: elvpopova@yandex.ru
}

\begin{abstract}
Springs and rivers determine the formation of the sacral landscape of settlements and play a part in the rituals, mythology, traditional world model and space of the Besserman. They serve as essential resources of subsistence, are used domestically and are taken into account when zoning settlements. Besserman villages are located on hills near rivers and large freshwater springs. In the traditional world model, rivers connect different parts of the space, i.e. the upper and lower worlds, upper and lower reaches, sky and earth. Rivers simultaneously serve as natural and mythological borders, functioning as roads both metaphorically and literally. According to popular belief, water from rivers and springs travels to the sky via rainbows, and then falls to earth and into rivers by way of rain and snow. Historically prayers were said and rituals held near rivers from the start of the floating of the ice to the autumn. In summer, they were held only in emergency cases (drought or wet summers). Water from springs had healing properties and was used in folk medicine. Alongside traditional perceptions, the Besserman also have local rituals related to the veneration of springs that are connected with Orthodox and Muslim beliefs and revered saints.
\end{abstract}

Keywords: Besserman, folk calendar, mythology, rituals, river, sacral landscape, spring 
The veneration of rivers and springs in one's locality is a constituent part of traditional and modern Besserman rituals: it is ingrained in the structure of the folk calendar and in rituals of seasonal field work. Rituals near rivers or springs are held in emergency situations, in certain seasons (i.e. when rivers were frozen) or during the floating of the ice. A large number of prayer sites are located near rivers and village springs. This special attitude to springs and rivers can be attributed to their domestic significance and the role they play in rural landscape and mythological concepts.

The materials presented in this article were collected during field studies in Besserman villages in north-west Udmurtia. Some comparative examples are also provided from expeditions to neighbouring peoples and, in particular, to the northern Udmurt and Cheptsa Tatar, who, like the Besserman, inhabit the basin of the Cheptsa River and its tributaries. Special attention has been paid to springs and rivers in modern rituals.

\section{The significance of springs and rivers to households and in settlement zoning}

Rivers and sources of drinking water are essential resources for subsistence. When selecting a location to build a village, the proximity of a river and springs was of key importance, alongside other natural resources, such as forests, good soil and availability of game. Springs play an important part in Besserman legends, while a river is mentioned as the road by which the first inhabitants arrived:

The first to arrive here was a Besserman called Kat'arin [who was descended from] Vorcha. He built a house on the hillside near the river. It is right where Vasily [who is descended from] Ol'oksana's house stands now. I guess he chose this place because of its proximity to water. Then other people 
started coming here with their families. This is how the settlement formed. It was named Vorcha (Vortsa) after Kat'arin who was descended from Vorcha (Fedotov 1982: 127).

Our ancestors travelled up the Lekma River. The people of Zhuvam sailed up right where the bridge crosses the river today. And that's where they remained. This place is still called Vuzh Gurt, i.e. 'the old village'. Sometimes during the ploughing season the old logs still come to the surface over there (FWM, 1990'1).

Besserman villages are located on hills near rivers and large springs with drinking water. This determined the zoning of the villages, i.e. the location of houses and streets with regard to cardinal directions and the river. Household structures (such as smithies, mills, livestock shelters, wood chopping blocks and walkway boards for washing clothes) were also built near springs and rivers. River meadows were good pastures and provided abundant hay. Fish from the rivers was an essential part of the local diet. The inhabitants of villages located near rivers abundant in fish sold some of their catch to villages that were situated further from rivers (Satrapinskiy 1854: L. 27). Winter and summer fishing is an essential activity for country folk, as well as a pastime and a means to diversify food supplies, giving rise to traditional meals made from local fish.

Village springs would have a log structure at the water's exit point, and sometimes also a fence around the entire spring area. One or more wooden planks would run from the spring, with one large plank meant for watering cattle and washing clothes. Village springs, along with wells and modern standpipes, are still used as sources of drinking water. Rituals are held near village springs and folk mythology is linked to them, as well as spatial taboos and preferences, in spite of a number of modern means for delivering water to houses. Water for ritual purposes is drawn directly from the springs rather than from tap, well or standpipe. 
The notions 'spring', 'well' and 'spring-well' can be expressed in Besserman as oshmes and vudor. The main village spring is referred to as z'eg vudor or 'large spring', while other springs, usually located outside the village, are oshmes. Springs often have special names, such as pichi oshmes 'small spring'; they also may be named after the people who found them, for example Pedod vudor 'Fedot's spring' (Gordino village), Savapi oshmes 'Savva's ancestors' spring' (Zhuvam village), and Kuz'ma oshmes 'Kuz'ma's spring' (Mitroshata village). Or they are named after the owner of the house that is closest to the spring. Springs near sacred groves were called 'springs near the place where people pray' (for example Zhuvam village). It was forbidden to desecrate springs or to muddy the waters in them. The points from which the spring flows are called oshmes sin' or the 'eye of the spring' and are regarded as sacral spring centres. When a spring is addressed in prayer the 'eye of the spring' is referred to.

According to popular belief, special rituals can help to increase the amount and height of water:

It is a small spring. A bull-calf should be killed next to it so that the spring is larger and comes in useful for eating and drinking. People would eat and drink [cook] from it (FWM, 2001²).

Springs were referred to in human terms, for example if a spring ran dry 'the spring dies' oshmes kuliz, while the emergence of a new spring was described as 'the spring that was born' oshmes vorz'ekiz. Desecration of a spring could lead to it drying out, especially if done on purpose, for example if the eye of the spring had ashes poured into it. There is a story about this in the legends of a village that was set up near a spring and later abandoned because it had run dry:

There are plenty of springs here. There used to be a spring in Kuki, which is a field near the village. The Pal'l'anpi (Pal'l'anpios) clan moved there at some point. They settled 
down there. That spring was little, and they say that somebody wanted to harm them and poured ashes into the spring, which closed the eye of the spring. Yes, such things would happen from time to time. They ran out of water. And you can't survive without water. The only way out is to dig a well. But there are few wells here, because the water runs very deep in the ground (FWM, 2009 ${ }^{3}$ ).

Bridges were built across rivers and there were boat crossings, and in shallow places people would wade or walk on logs or felled trees. Local rivers often served as natural borders between settlements or the territories of other villages and communities, in addition to which they were also regarded as mythological boundaries. Villagers would not buy livestock or poultry "from across the river" or transport animals across since it was believed that such livestock would not breed or survive in the new village. Before heading off on a long journey, or when the young men were sent to the army, or during wedding ceremonies, river crossings and bridges on routes out of the village were used for rituals of veneration for the rivers and the spirit-masters of the water. For example, wedding guests would dance and sing on a bridge and when crossing the river threw coins into the water, marking the border and buying the right to cross it (Yunda village, Balezino district). As part of the ritual marking conscription into the army, a recruit would throw a coin into the water over his shoulder when crossing the bridge, asking the River Master for a good journey. When a person crossed the river for the first time after the spring flood, he made offerings to the river and the River Master in the form of coins or bread. Such ways of marking the river and its crossing as a natural and mythological boundary existed within different rituals, cultures and road mythologies.

The locations for prayers and setting up ceremonial objects were selected with due consideration for where the river was located and whether drinking water was available for sacral meals. Springs and rivers often served as essential constituents of a sacred site. 


\section{Beliefs about the Spirit/Master of the water vukuz'o}

The veneration of springs and rivers, and relevant rituals, were related to both the household and mythological functions of rivers and springs, and to beliefs about the spirit (deity) of water and rivers, i.e. vukuz'o/vumurt (lit: Master of the Water). The Besserman believed that his habitat was springs, rivers, wells and artificial water bodies (ponds). The first prayer gathering in the calendar year was held when the floating of the ice started and the river was 'waking up'. This period was regarded as the activity cycle of the River Master. Prayers stopped when the river froze up and "the River Master fell asleep".

According to popular belief, the Master of the Water could be seen or encountered near a spring on the banks of the river, especially at 'dangerous' times of the day and year (midday, midsummer) when he was "sitting", "taking a rest" or "combing his hair". He was different from people because he had "wet edges to his clothes". It was forbidden to go swimming at midday in summer: he "stepped out of the river", "was travelling to the market to do some shopping" or "could drag careless swimmers underwater". Today these rules are still observed, meaning that swimming, walking into the river or washing clothes in it, at midday in summer was banned.

In popular perception the Master of the Water is an old man with a beard and long hair. He usually wears white clothes (a shirt and a kaftan) and sometimes appears in the shape of a woman. Meeting him was seen as a foretoken, and people tried to avoid it:

I don't know what kind of clothes he wears. They say longhaired vumurt sits near the water. If someone sees him, then let them. Inmar [the supreme deity] will protect us (FWM, 19994); 
Vukuz'o, the Master of the Water... Sometimes he can be seen. The woman who told me this story has passed away already. ... Once, in the evening, after milking the cows, everyone went back to the village, but she headed to the river to wash [her clothes]. ... And she said that she saw something. ... There was a woman with knee-length hair on the opposite bank of the river. She had long, beautiful, pure white hair. She was sitting there and combing it. The woman didn't even start washing her clothes, and without saying a word or making any noise she returned to the village (FWM, 20005).

People never touched anything found by the river, for example combs or soap, because they believed that they belonged to the Master of the Water, and if you took them you might get sick, scared or injured, or you might drown.

Perceptions of the Master of the Water are related to the mythological perception of rivers and springs, which are polysemantic objects included in the structure of numerous rituals. Every village had a place where prayers to the water springs and the Master of the Water were said near a river or village spring. Either a goose or a duck was sacrificed: "A bird that swims is offered up as a sacrifice". This phenomenon is represented in the name of a prayer and in the sacral space: "a sacrifice to the Master of the Water", "offer up a sacrifice to the water", "kill for the water", "a place for saying a prayer with a goose" or "a place where a goose is killed". The ritual of worshipping the Master of the Water is the veneration of water springs in the area: "[The offering] is made near the river for the sake of veneration of all rivers" (FWM, 20096).

A special ritual devoted to the local spring and the Master of the Water was held in special cases, with an attempt to involve a newcomer to the village or their family. For example, after moving to the house of her groom, the bride demonstrated her veneration by offering bread and coins to the spring and the Master of the Water: 
On the third day after the wedding, a member of a wedding procession would come to the house of the newlyweds, with musicians, and then together they headed to the river or an ice hole, if it was winter. The bride would throw a piece of bread, some butter, and a copper coin into the water, saying in Besserman: "Lest the water should scare me, but wash me. And lest vumurt [the Master of the Water] should grab me" (Steinfeld 1894: 247).

Prayers were said for the Master of the Water to accept the bride as one of his own kind and not scare her away (Popova 1998: 142). The bride would give the water from the spring to the people waiting for her at the gates, then make tea and invite the guests to dinner. The tradition of fetching water and the bride worshipping the spring and water guardian deities also existed among other peoples inhabiting the area (Udmurts, Russians and Tatars) (Il'yin 1926: 59; Zorin 1981: 122-123; Belitser 1958: 308).

\section{Springs and rivers in rituals}

The veneration of rivers and the Master of the Water vukuz'o stands side by side with the veneration of the deities and spirits of wild nature. This veneration emphasises the ritual and household meaning of rivers and springs and their special status in different fields of family and village life. Exposure to the local spring and the veneration of the Master of the Water are constituents of rituals included in the agricultural calendar, prayers relating to the weather and rituals associated with folk healing practices.

In the mythology and in the traditional world model rivers and springs are linked to the sky, since they replenish the sky's moisture. It was believed that the ends (or end) of a rainbow were in a river or spring: "One of its ends was in the river, and the other was up in the sky" (FWM, 20007); "It really flows from one river 
into another" (FWM, 20008); "The rainbow stems from the very middle of the spring. And then it flows into the sky" (FWM, 20019). According to popular belief, water travels to the sky via the rainbow and then falls to earth and into rivers by way of rain and snow.

They call the rainbow vuyuis' (lit: 'water drinker'). It appears after rain. They said that one of its ends dropped into the river to drink water. They called it a beautiful bow in our village. Look, there is a beautiful bow. It can be seen quite often when the rain passes. They used to say, "Look, it is drawing water from a river again" (FWM, 2000 $\left.{ }^{10}\right)$.

It is drawing water from the river for rain. Here comes the rainbow. They say it comes out to draw the water for the rain (FWM, 2000 ${ }^{11}$ ).

It was believed that with the help of prayers and by worshipping springs and rivers in dry weather or in the rainy months it was possible to ask for rain or fair weather. Balance in nature as well as precipitation were dependent on complying with spatial and temporal prohibitions that related to rivers and springs, especially in the period of the summer solstice, when it was forbidden to draw water using kitchenware, to swim or to wash clothes (especially of vibrant colours) near a spring or in the river. During the harvest and haymaking period putting a rake into the water was forbidden as it could cause bad weather, storms or even hurricanes:

This is what they used to do. When you go to wash clothes in the spring, no red or other brightly coloured clothes should be washed. Otherwise the weather could get windy. They used to have special watchmen in the village. They said that if it was windy, someone was washing clothes in the spring (FWM, 2001'2). 
At Gerber [during the summer solstice] washing clothes at lunchtime was not allowed, it had to be done between 3 and $4 \mathrm{pm}$. If this rule was broken, hail would beat down on the crops in the field (AFD, 2000 ${ }^{13}$ ).

When rye is ripening, washing clothes in the river is not allowed. The weather turns bad. There is thunder and lightning (FWM, 2000 ${ }^{14}$ ).

During the summer solstice drawing water from springs and rivers was allowed using birchbark or wooden kitchenware, but iron or dirty kitchenware, and making noise, were forbidden. Such prohibitions were common also among the Udmurt (Vladykina 1998: 84).

In the traditional Besserman world model, rivers connect different parts of a space, i.e. the upper and lower worlds, upper and lower reaches, sky and earth, and the elements of sacral space. The upper reaches of the river are endowed with positive features relating to wealth and prosperity, while the lower reaches are associated with the 'other' world and disease, while spring waters "take away misfortune and difficulties in life". Different rituals, prohibitions and rules of everyday life are related to these perceptions. For example, babies' clothes could not be washed in flowing water, in a spring, in the river or in an ice hole. This prohibition was related to the idea that one of the child's souls (urt) might slip into 'other' worlds along the river causing him or her to become ill (FWM, $1995^{15} ; 1993^{16}$ ). For the same reason washing a sick person's clothes in flowing water (either a spring or river) was forbidden.

The concepts of a river as a pathway between the worlds and of the upper reaches being part of some 'other' space often appear in rituals of purification as well as funeral and commemorative traditions. For example, in some villages, commemorative meals for a dead person and his or her ancestors were left outside the estate in the direction of the upper reaches of the river (Shamardan village). Diseases and insects (cockroaches and bedbugs) were sent off downriver: 
Sometimes we had bedbugs and fleas... We would send them off when the ice was floating. Before the ice started floating, we would put them into a box and take it to the river. We would ask them to drift away with the ice. But would they? They should be eradicated (FWM, 200177).

Just before the spring sowing, a special purification ritual was held on the riverbank. Villagers would walk around the village and knock on the door of every single house with wooden sticks, driving away diseases and evil spirits, and then walk down to the river. A tree trunk would be set up on the bank, and people would knock their sticks on it. They would also sing a tune called the arafa krez'(the arafa tune). Then they would throw the log and the wooden sticks into the river and send them away, singing a ritual tune (Popova 2004: 89). This is how diseases and the old year were sent away downriver, then the next day people would go into the field and start sowing, and the new agricultural year began.

The opposition of the upper and lower reaches of the river as different spaces also exists in the rituals of the Christmas cycle. According to folk belief, with the beginning of the Christmas period, from 6 January (Christmas Eve) the vozho spirits come from the upper reaches of the river, while at Epiphany they would head to its lower reaches. In this period, washing clothes in springs and rivers is forbidden, as is crossing the river, or even being near it, at night or during twilight. On the eve of the Epiphany, the farewell ceremony for Christmas spirits is held. The villagers see the Christmas spirits off along rivers with an accordion, porridge, bread and drinks, and say goodbye to them until the next year. Today, this ritual also incorporates a feast in the house and a procession heading beside the river, where porridge, bread and drinks are left on the bank or in an ice hole that has been dug in advance (Popova 2014: 105-110).

The folk calendar used to include separate rituals for the veneration of the river, the spring and the Master of the Water. When the floating of the ice started and the river was waking up, 
the ye kel'an/vu kel'an 'saying goodbye to ice/water' ritual was held. This marked a significant period in the agricultural calendar, i.e. the waking up not just of the river but of nature as a whole:

In spring, when the ice was breaking up, a householder, together with his family, and beer or home-made vodka, would come to the bank of the river, or a bridge, and pour a glass of beer or home-made vodka into the river, as if plying it with alcohol. While they were doing so, they kept asking the river for a safe floating of the ice, without doing any damage or taking anything away from anyone, i.e. without anyone in the family drowning during the summer. After that the villagers offered one another food and drinks, and young men and maids started dancing and singing (Satrapinskiy 1854: L. 30 ob.).

Villagers prayed and sang songs to the river and the Master of the Water, poured drinks into the water and threw bread and coins into it. A feast was held on the bank and people had fun, singing ritual 'ice farewell' songs, asking for prosperity, rain and good weather in summer from the river and the Master of the Water:

We had an ice farewell ceremony. We would go down to the river to say goodbye to the ice. We were standing near the river, making fires on the bank, singing different songs. We were throwing different things into the water for the Master of the Water vukuz'o; coins, for example. And nowadays as well, when we cross the river for the first time after the floating of the ice, we throw coins into the water. Otherwise he [the Master of the Water] might drag you down into the water (FWM, 1999 ${ }^{18}$ ).

We would come down to the river and sing the 'ice farewell' song on the river bank. We made fires.... We poured wine or home brew into the river. Just like before the start of sowing, 
we would put a cloth on the ground, sit around it and eat and drink. Then we would dance to the accordion. It was great fun. People would pour moonshine into the river downstream. Then we would bow to the river and ask it to take all of the bad things downstream and keep all of the good things. This was in spring, in April or maybe in May, after the snow had melted. No such feasts were held any later. People thought it was too late and that there was no use.... We would gather together near the water and sing songs. Yeah, we would sing songs, saying goodbye to the ice. We would sing songs and weep, all of us. This is how we said goodbye (FWM, 1999 ${ }^{19}$ ).

Words and actions had purifying properties: "Let the water take away all diseases" and "let us be healthy". People sought to determine the weather in the forthcoming summer using the condition of the ice: "If the ice was moving smoothly and concertedly", "we were saying goodbye to the ice, so that the weather in summer would be nice and the rain would fall in due time". Guns were fired in the direction of the upper reaches of the river so that there would be no severe thunderstorms or downpours in summer. The ice farewell ceremony was still being held as late as the second half of the $20^{\text {th }}$ century. It was quite common among the Udmurt, especially in villages near large rivers (Pervukhin 1888: 41; Vereshchagin 1998: 221-223; Minniyakhmetova 2000: 38-39). This ritual still survives in some settlements of the northern Udmurt and the Besserman that are near large rivers, such as the Cheptsa River and its tributaries. The tradition of coming to the river and observing the floating ice has significant emotional and aesthetic value.

Another important ritual in the peasant calendar of villagers is 'sacrificing a bull-calf with a prayer' also known as 'eating a bull-calf near the river', which took place in August and in which only men participated. The ritual, involving the slaughtering of a red bullcalf, was held near the river or near a village spring on 3 August, i.e. the day after Saint Eliyah's Day. 
On the day after Eliyah's Day, an offering was made to the Master of the Water. They would buy a red bull-calf and kill it on the bank of the river. Blood would be spilled on the ground. Women were not allowed to be there (Mashtakova 1970: L. 29-30).

Elijah's Day is a feast for the dead. They would once again kill a red bull-calf here, this time for vumurt [the Master of the Water]. They would kill a bull-calf near the river and pour its blood into the river (Biyanova 1946: L. 7).

Special prayers near the river in order to 'get the weather straight' were held in emergency situations, in summer droughts and in steady rain during the haymaking or harvest periods (FWM, 200120). In some villages, every householder held them annually, in turn, near the spring if there was nasty weather (Shutova 2004: 159).

The last ritual was held near the river in late October / early November, but before prayers were held in the sacred grove, which was the 'closing of the year', i.e. before 14 November (Cosma's and Damian's Day). People used to believe that when the river froze over, the Master of the Water took a well-deserved rest and fell asleep, and so no rituals were held after that. The last ritual was a family prayer session, with a bird (a goose or duck) being offered as a sacrifice to the river and the local spring and to the Master of the Water with gratitude for good weather and help in summer. People would also ask him for assistance in the future:

An offering was made by killing [an animal] near the river, for all of the rivers, and after that the ice 'closed down' (FWM, 2009²1);

Animals were killed as offerings to the water. People would [pray] near rivers. ... Almost all sacrifices were made in autumn. A goose was killed near the water so that there would be no problems when grazing cattle, for example they wouldn't drown. So that it would be sent off [to pasture] after 
a year, too, drink from the river and walk across it. This is what villagers would say, addressing the Master of the Water and the river: "Let there be a lot of bread. Let the cattle live long. Let us be happy and prosperous" (FWM, 199122);

Before Cosmas' Day, people tried to hold prayers with a goose. They killed a goose near the river, asking for an abundant goose flock. They boiled the goose near the spring. When collective farms were established, people started sacrificing geese [at home]. They would boil [and eat a goose] with their family members only, without any outsiders (FWM, 2000²3).

Every family would say prayers and hold a feast separately. The ritual was usually led by the head of the family or the oldest man in the family. Several adult men headed with him to the river, and sometimes boys, too. The autumn ritual included a bird offering, cooking ritual porridge and venerating of the river (or the spring):

Geese were killed near the river, so that goslings would not drown in the river. People would gather together and eat goose meat with their family members only. In more recent times they would cook meat at home, but bring feathers, bones, porridge and a hunk of bread to the river. They would leave them on the bank, near the river (FWM, 1995 ${ }^{24}$ );

If a goose was killed for vukuz'o ... they would take a goose to the river in the evening, kill it near the water and pour the bloodinto the water. Then they would boil the goose at home and throw the bones and everything else into the water (FWM, 198725).

A bird was gutted and butchered on the bank of the river, and porridge was cooked in the broth at that spot. In the second half of the $20^{\text {th }}$ century, this ritual was held secretly: a bird was killed near the river, but butchered and boiled at home, since it was 
forbidden to say prayers in public places. Ritual feasts were held in the house, but the feathers, bones, porridge and bread were taken to the river later. Outsiders were not allowed to take part in the feast, and parts of the sacrificial bird were not put into meals cooked on other days or given to outsiders.

The rituals for the Master of the Water and water springs stopped in winter. People would only come to the river to say farewell to the Christmas spirits vozho on the eve of Epiphany and when consecrating the Epiphany baptismal font in the local river.

\section{Water from springs and rivers in folk healing practices}

Water from springs, especially from the most important village spring, was imbued with healing properties. It was used to treat diseases and the evil eye, and was drunk to "be healthy" and "derive strength from the spring". People sought to transfer the qualitative attributes of a spring, such as power, energy and purity, onto human beings. The water drawn from several springs (in odd numbers as a rule, i.e. three, five or seven) was imbued with healing properties, thus intensifying them even more. Water drawn downstream, on any Thursday, or from three springs in the morning or during twilight was imbued with healing properties. An iron object was placed in the dish with the water, which was closed with a lid or a towel in an attempt to protect it from evil spirits. Slack water was regarded as being dead, in addition to which, water drawn upstream could cause disease, since disease was sent away downriver. 'Living' water could be drawn from flowing water running from the spring downstream. The quality of water could change in different parts of the day and the calendar. Villagers would try to draw water early in the morning or during twilight, i.e. during akshan, which was a sacral liminal period: 
Water is drawn from Thursday to Friday from three locations: a spring, a river and some other spring. This is akshan vu. They would wash children's faces with this water. Akshan means twilight, the sun at sunset. Elderly people would fetch water at akshan, too. Akshan vu is drawn in the evening, not in the morning. When things get really bad, healer women are invited. If a sick person was getting better, it was believed that the right word [magic spell] had been said (FWM, 1999²6).

People would go to fetch water in important temporal and calendar periods, on Holy Thursday and on the Epiphany. For example, Epiphany water was stored for healing for the whole year. 'New vil'vu water' fetched in the early morning on Holy Thursday was believed to have special properties:

The 'new vil' vu water' was fetched from the spring early in the morning on Holy Thursday. It was sprinkled on cattle and children and washed the faces of crying babies' (FWM, 1992 ${ }^{27}$ );

People still fetch water from the spring on Holy Thursday and at Epiphany. When they are fetching the water, they do not talk to anyone they meet on the way home. Then they sprinkle this water on cattle and wash their faces with it. Or drink it (FWM, 2000²8);

On Holy Thursday, they would put a silver coin in a bucket and go to the spring to fetch some water (FWM, 1993 ${ }^{29}$ ).

"People would wash their faces with fresh water from the river so as to be healthy for the whole year", - as the local priest described the ritual of the Bessermans and the Udmurts in the mid- $19^{\text {th }}$ century (Satrapinskiy 1845: $23 \mathrm{ob}$.). The 'new water' was stored for the whole year, away from doors and windows, under a bench in the kitchen cupboard, behind icons. 
Several rules were connected with springs: drinking from the spring or leaning into it was forbidden, rather the water was scooped up using a dish or the palm of one's hand. First of all, the spring had to be treated or fed by dropping a piece of bread, a coin, some grass or a leaf into it. "If you are drinking from the spring, drop some bread crumbs into it. Otherwise it will 'catch' you. Or, as they say today, diseases come from it" (FWM, 200030). As a rule, they would say: "Don't grab me!"

Some village springs were regarded as 'dangerous', i.e. l'ek os$h m e s$ 'an evil/dangerous spring'. They could 'catch' people, especially during liminal periods (midday and twilight). In such cases, people would bring food (grain or flour) or certain objects (wool, fabric or coins) to the spring:

We have a log padeyshur. A dangerous spring. We try not to draw water from there or go there. Disease 'catches' people. We made [offerings] to the master of that spring. ... Some people would still never set foot there. They say some people did and became sick. They got abscesses on their feet which 'watered' like the eye of the spring.. ... They say it was all because of the evil spring. ... The disease 'caught' them, their feet were 'watering', vesicating, or their arms were vesicating. And it was all because of 'setting foot' near that spring. They say it was all because of the spring. ... They said the disease was clinging to them. They say it's because of the spring. They turned to my mother, too. Made offerings to the master of the spring. But the disease 'caught' them. We made some [offerings], some food and drink [were offered]. We brought bread and butter to the spring. [We brought] grain (FWM, 2000 ${ }^{31}$ ).

Folk healing methods took due consideration of the different semantic specifications of the upper and lower reaches of the river, and slack and flowing water. Slack water was regarded as dangerous and 'dead'. For healing purposes, people were only 
allowed to take water downstream, not upstream, because they believed that if water was taken against the current, they might "scoop up a disease". Different objects were sent downriver (threads, sauna whisks, branches) as well as diseases. New whisks were thrown into the river after being used in the bathhouse on the eve of Kupala Night (7 July), because people believed that if you sent the whisk down the river it would take away all of your diseases (FWM, 1991 ${ }^{32}$ ). For the same purposes, threads collected on the morning of Holy Thursday were thrown into a river or spring:

Threads were tied up on the morning of Holy Thursday. Children would collect the threads. Then the threads were sent away down the river. Some people still do that. Different silk threads are tied together: yellow, green, blue and black (FWM, 2000 ${ }^{33}$ ).

If people believed that the the Master of the Water had caused a fright or a disease, they would bring bread or porridge to the river and hold a healing ritual on the bank. For example, if a child got scared near the river, or after falling into the river started stammering, they would turn to the Master of the Water near the river with a request not to scare the child anymore. Then they would feed the sick child with porridge oatmeal from a magpie's nest, trying to bring back his fluent speech (Turchino, Filimonovo, Istoshur villages).

\section{Veneration of springs in the context of Orthodox and Muslim traditions}

Within the context of the veneration of springs, in addition to traditional concepts there are also local rituals that take us back to the traditions of Islam or Orthodoxy. The emergence of such springs is usually related to a miraculous event or saint. Such springs turned into places of worship for people residing in other 
villages and pilgrims from faraway places, as well as being visited by representatives of other religions.

While researching the territory inhabited by the Besserman, two springs the veneration of which is related to Orthodox traditions were found. These are tumpal oshmes 'Tumpal spring' (Tumpal village, Yar District) and the Holy Spring (Kamennoye Zadel'ye village, Balezino District).

As recalled by locals, Tumpal spring is a "popular spring", "regarded as a praying and healing spring"; they also recall that "priests used to visit it". According to some legends, a number of miraculous healings took place here, and it helps "to get rid of different diseases". People visited this spring during wedding ceremonies and on memorial days, but mainly after the Trinity on Whit Monday, drawing water for healing, washing themselves and leaving coins in the spring (FWM, 2009 ${ }^{34}$ ). The locals believed that this spring acquired its special status when the parish church operated nearby. "The priest came to this spring and consecrated it with an icon of the Mother of God". Since then, it has been regarded as having healing properties and has been revered. People visited it on Whit Monday, which was a very important event in the parish. After the church was closed no prayer services were held, but the tradition of visiting the spring did not end, and people continued having feasts and making porridge near the spring. In the $1960^{\mathrm{s}}$ and $1970^{\mathrm{s}}$, the area around the spring was made more comfortable, and a table and bench were installed. People drew water from the spring, washed their faces and left coins. "People throw coins into it to be healthy" (FWM, 2009 ${ }^{35}$ ).

Another revered spring is the Holy Spring, which is a famous Orthodox sanctuary in Kamennoye Zadel'ye village. According to legend, its appearance was marked by a miracle, named after the reverend Tryphon of Vyatka (a miracle worker), a locally venerated saint of Kirov Oblast and Perm Oblast, the archimandrite, founder and senior priest of Vyatka Uspensky Trifonov Monastery in Khlynov (present-day Kirov) (Osokin 1912; Vyatka Eparchy 1912: 
527-528; Works of Vyatka Academic Archival Committee 1912: 24; Tryphon of Vyatka 1996: 447). Legends about Tryphon of Vyatka and the emergence of the spring were recorded in the late $19^{\text {th }}$ century, saying that the spring started flowing from the place where he took a stone:

They say that the reverend Tryphon was working at Kamennoye Zadel'ye (on the route between Polom and Balezino), where he was moving millstones. ... Once, on the banks of the Cheptsa River, Tryphon, after being laughed at by other workers, rolled the millstone down into the river, and this is when a miracle happened: the millstone did not sink, but was lying on the surface of the water, just like on solid ground. Tryphon sat on top of the millstone and travelled down the river (Vereshchagin 1886: 202).

Some peculiar features were attributed to this spring after the healing of a surveyor who strayed into the area by chance. The first cases described in the legend date back to the mid- and late $19^{\text {th }}$ century:

The veneration of this spring started recently, and this is what happened: a surveyor was passing by our village, and his eyes hurt. Due to some secret inclination, he approached the spring, leaned over it, washed his face with its water and a miracle happened: his illness left his eyes like dirt from his hands. People from neighbouring villages heard about this miracle, and sick people started visiting the spring with a strong belief in the miraculous power of the water; many of them were healed completely (Vereshchagin 1889: 5-6).

The spring was visited by people on Whit Monday, on important Orthodox and patronal days, when people were sick (especially by people with eye diseases) and by those who just came to pay respect to the sacred place (Osokin 1912: 51; AFD, 2004). The chapel of the 
Holy Spirit and the Dormition of the Mother of God were built near the Holy Spring. In 1913, a wooden church was built on the site of the chapel (Pravoslavnye khramy Udmurtii 2000: 137).

The traditional beliefs of the Bessermans and the Tatars were associated with the veneration of the spring zek oshmes, "a large spring" in the village of Gordino, inhabited by Orthodox Bessermans and Muslim Tatars. The spring is well-known far beyond the village, and it is believed that its water has healing properties.

There are a number of reasons for the veneration of the spring and its healing properties. According to one of the legends, it flows from beneath "a holy grave". There is a grave on the hill several hundred metres above the spring. According to legend, a Muslim saint was buried here. The site is especially revered by the Bessermans and Tatars inhabiting the village and Tatars from neighbouring villages and other locations throughout the Volga Region (Popova 2004; 2011: 244). A stone with an inscription in the Bulgar language was found on the site of the grave, which dated back to 1323 (Yusupov 1960: 20). The locals refer to this grave as auliya keber 'the holy grave', auliya 'the saint' and auliya Damrikhan 'Saint Damrihan'. The villagers believe that this burial site belongs to a 'holy' or 'respected' man, or to the first settlers. This is why the spring is also revered, since it is located right next to this holy place.

According to another legend, the spring emerged after the first settlers made a sacrifice, since there was no water in their new settlement:

When they came here, there was no water here at all. They were living here with no water. The first settler made an offering. They made kârban [sacrifice] ... and this is when the spring emerged. ... (FWM, 1999 $\left.{ }^{36}\right)$.

This spring is a source of drinking water which flows into the village through pipes. The revered burial site, the spring and the place for saying summer prayers form a single complex. There is a special sacral ground near the spring where Muslim Tatars and 
Orthodox Bessermans used to hold a summer ritual and pray for good weather. They slaughtered a sheep (bull) there. As before, village prayers are led by a mullah and the Tatar men who know the prayers and the ritual itself:

We eat a bull behind the village. This is our long-term tradition. We eat the bull praying for good weather. It is like a feast. We say prayers, too. We do it all together, Bessermans and Tatars (FWM, 1999 ${ }^{37}$ ).

We would hold this ritual whenever the weather turned bad, it was raining too much or not raining at all. If there was too much rain or hail or storms, then we would hold the ritual. And by Saturday everything would calm down (AFD, 2004 ${ }^{38}$ ).

The people from this village and from neighbouring villages came to the spring to draw healing water. When trying to figure out the reasons for a disease the healer women would pour tin into the water from the spring:

There is a large spring nearby, in a small ravine. It is a holy spring. People would come to the spring from different places. They would even bring dishes to draw the water from the spring. They would wash children's faces with it and pour it over them. It can cure you, like some sort of medication (FWM, 1999 ${ }^{39}$ ).

They would make offerings near the spring. Right nearby. It is the most important place. They don't even walk in its waters. It is a large spring. We drink water from it. So you can't spoil it. It will 'catch' you there (FWM, 2004 ${ }^{40}$ ).

If the reason for the disease was associated with the spring, offerings were left nearby, such as flour, grain and salt. At the summer solstice and until the end of summer, the Tatars and Bessermans tried not to 
bother the spring, neither drawing water from it nor washing clothes there. This requirement is still quite strict today. People who come to the village still draw water from the spring and take it home with them.

\section{Conclusion}

Rituals and mythological perceptions of rivers and springs are built on the basis of their essential domestic purpose and the place they occupy in the system of subsistence and the historical and cultural landscape. Within the framework of the cosmogonic model of the world, a river is at the same time a passage from one world into another and a spatial borderline. The road to the upper and lower reaches of the river and crossing the river are represented in the mythology of the road and in the relocation in space of both the souls of the dead and spirits, diseases, ritual participants, ordinary people and travellers. The concepts of upper/lower reaches of the river lie in the semantic field of such oppositions as up/down and determine the structure of rituals as well as the location of sacral objects.

Prayers and addresses to a river or spring are also held today, whenever the need arises. This tradition has been retained for a long time by the people working near the rivers (millers and shepherds) and was associated with bodies of water. The veneration of local rivers is obvious in everyday and festive culture, in rituals aimed at improving the weather and when addressing the springs in folk healing practices. The rituals still include perceptions of the purifying and healing properties of the water.

The veneration of rivers and of the spirit deity, the Master of the Water, and of cult practices as a whole, are linked to the traditional perceptions of nature, waters and precipitation included in the annual calendar cycle, and were part of cosmogonic perceptions. Information about the rituals held in the past is still preserved and handed down in the form of oral tradition and place names and is still alive in folk healing practices and ecological and landscape knowledge. 
Photo 1. Village spring and a block for washing clothes. Bessermans, Mitroshata village, Yukamenskiy District, Udmurtia. Photo: Elena Popova. 2009.

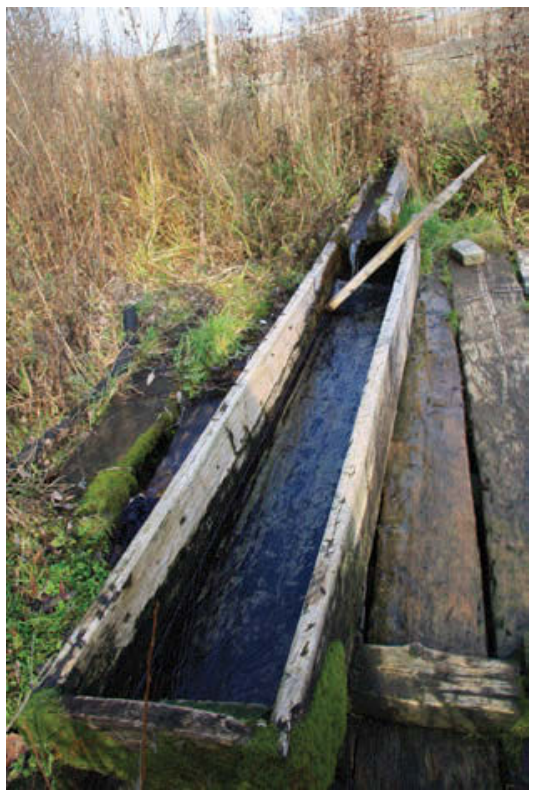

Photo 2. Village spring of drinking water. Blocks for drainage and washing clothes. Bessermans, Zhuvam village, Yukamenskiy District, Udmurtia. Photo: Elena Popova. 2009.

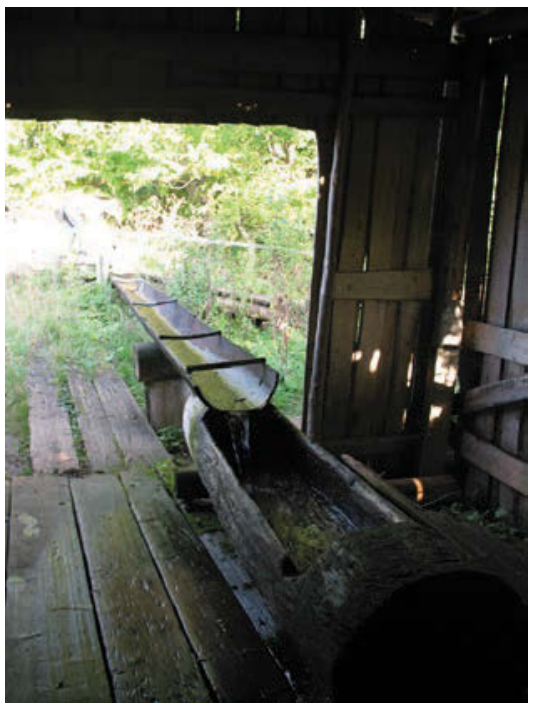




\section{Elena Popova}

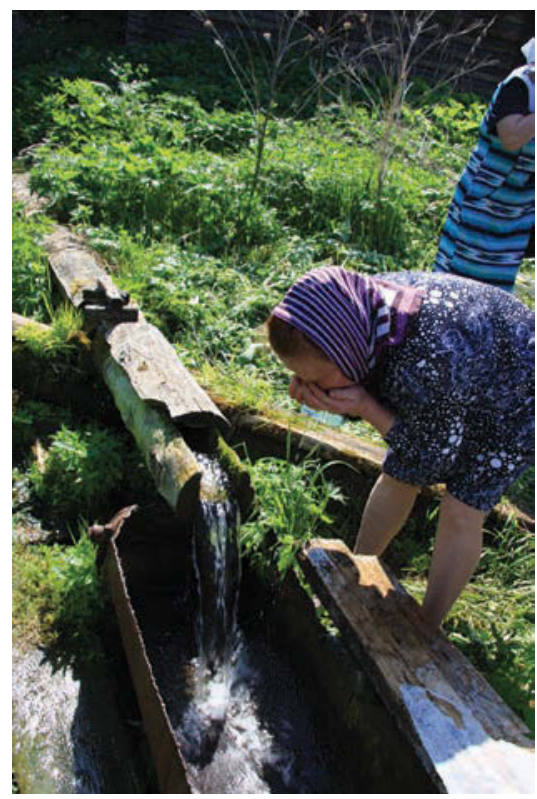

Photo 3. Revered village spring. Bessermans and Cheptsa Tatars. Gordino village, Balezino District, Udmurtia. Photo: Elena Popova. 2015.

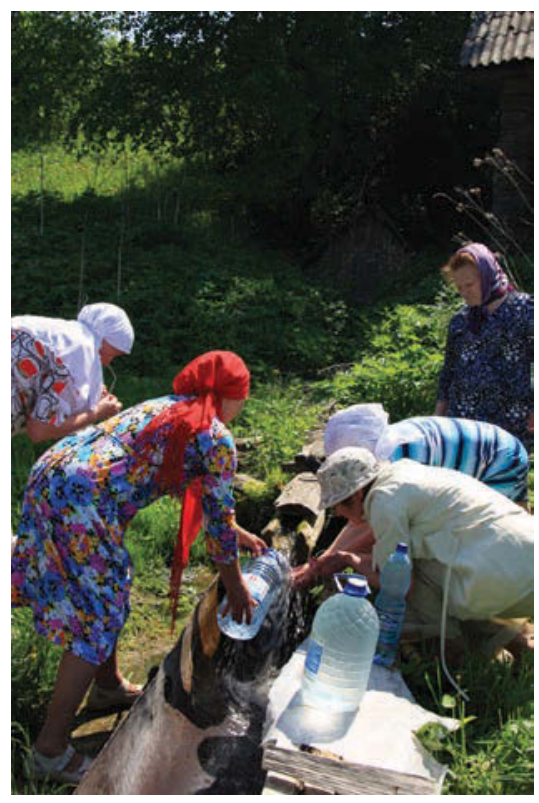

Photo 4. Participants in a village celebration and prayers, drawing water from the revered spring. Bessermans and Tatars, Gordino village, Balezino District, Udmurtia. Photo: Elena Popova. 2015. 


\section{Water Bodies in Besserman Mythology and Rituals}

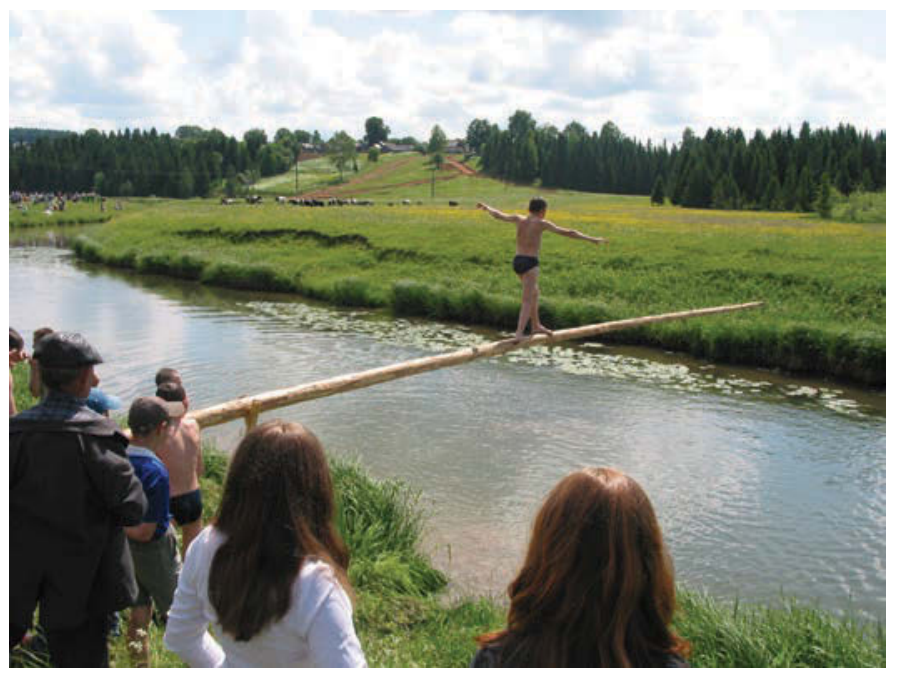

Photo 5. A contest in walking across a pole above the river. The feast day of the Besserman. Abashevo village, Yukamenskiy District, Udmurtia. Photo: Elena Popova. 2006.

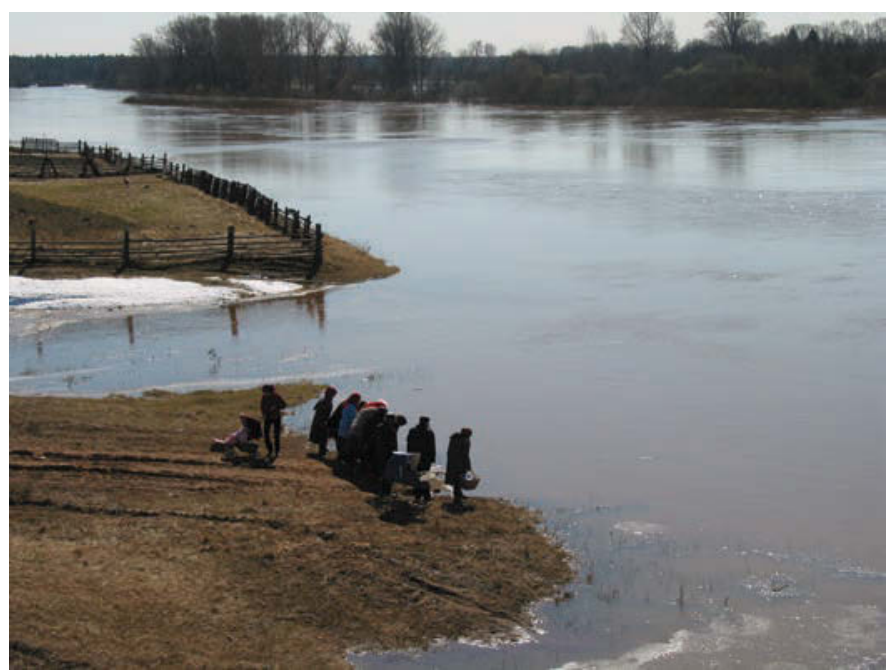

Photo 6. "Saying farewell to the ice" and prayers of the northern Udmurts on the Cheptsa River. Ozon village, Kez District, Udmurtia. Photo: Elena Popova. 2006. 


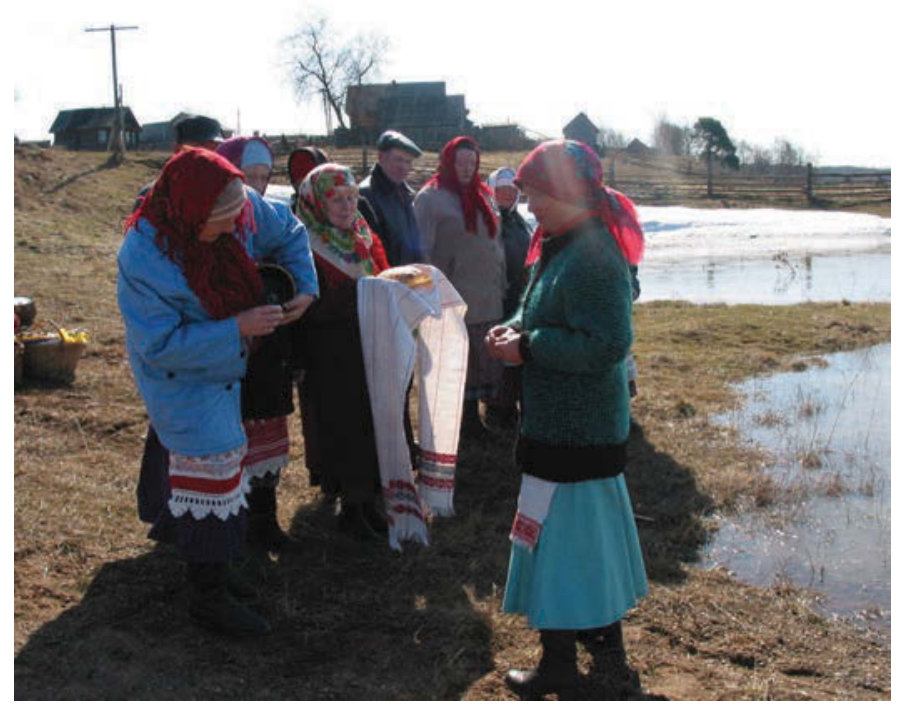

Photo 7. "Saying farewell to the ice" and visiting the river during spring prayers on the Cheptsa River. Northern Udmurts. Ozon village, Kez District, Udmurtia. Photo: Elena Popova. 2006.

\section{Notes}

1 Recorded from M. A. Nevostruyev, in Mitroshata village, Yukamenskiy District, Udmurtia, by Elena Popova.

${ }^{2}$ Recorded from I. K. Malykh, in Zhuvam village, Yukamenskiy District, Udmurtia.

${ }^{3}$ Recorded from N. A. Bekmement'yev, in Yozhevo village, Yukamenskiy District, Udmurtia.

${ }^{4}$ Recorded from M. A. Ponomareva, in Korotay village, Glazov District, Udmurtia, by Elena Popova.

5 Recorded from E. G. Zyambakhtina, in Turchno village, Yukamenskiy District, Udmurtia, by Elena Popova.

6 Recorded from K. A. Gavrilova, in Vortsa village, Yar District, Udmurtia, by Elena Popova. 
7 Recorded from E. G. Zyambakhtina, in Turchno village, Yukamenskiy District, Udmurtia, by Elena Popova.

${ }^{8}$ Recorded from M. V. Sabrekova, in Shamardan village, Yukamenskiy District, Udmurtia, by Elena Popova.

9 Recorded from I. K. Malykh, in Zhuvam village, Yukamenskiy District, Udmurtia, by Elena Popova.

${ }^{10}$ Recorded from V. N. Borisov, in Shamardan village, Yukamenskiy District, Udmurtia, by Elena Popova.

${ }^{11}$ Recorded from R. M. Karavayeva, in Shamardan village, Yukamenskiy District, Udmurtia, by Elena Popova.

${ }^{12}$ Recorded from I. K. Malykh, in Zhuvam village, Yukamenskiy District, Udmurtia, by Elena Popova.

${ }^{13}$ Recorded from D. A. Malykh, in Zhuvam village, Yukamenskiy District, Udmurtia, by Elena Popova.

${ }^{14}$ Recorded from M. V. Sabrekova, in Shamardan village, Yukamenskiy District, Udmurtia, by Elena Popova.

${ }^{15}$ Recorded from A. N. Baltacheva, Baltacheva Z. I., in Tylys village, Yukamenskiy District, Udmurtia, by Elena Popova.

${ }^{16}$ Recorded from I. K. Malykh, in Zhuvam village, Yukamenskiy District, Udmurtia, by Elena Popova.

${ }^{17}$ Recorded from L. A. Vershinina, in Zhuvam village, Yukamenskiy District, Udmurtia, by Elena Popova.

${ }^{18}$ Recorded in Gordino village, Balezino District, Udmurtia, by Elena Popova.

${ }^{19}$ Recorded from M. A Ponomareva., in Korotay village, Glazov District, Udmurtia, by Elena Popova.

${ }^{20}$ Recorded in Zhuvam village, Yukamenskoe District, Udmurtia, by Elena Popova.

${ }^{21}$ Recorded from K. A. Gavrilova, in Vortsa village, Yar District, Udmurtia, by Elena Popova.

${ }^{22}$ Recorded from E. G. Zyambakhtina, in Turchno village, Yukamenskiy District, Udmurtia, by Elena Popova.

${ }^{23}$ Recorded from T. S. Baltacheva, in Tylys village, Yukamenskiy District, Udmurtia, by Elena Popova. 


\section{Elena Popova}

${ }^{24}$ Recorded from E. G. Zyambakhtina, in Turchno village, Yukamenskiy District, Udmurtia, by Elena Popova.

${ }^{25}$ Recorded from M. C. Nevostruyeva, Zhuvam village, Yukamenskiy District, Udmurtia, by Elena Popova.

${ }^{26}$ Recorded from A. D. Sabrekova, Glazov District, Udmurtia, by Elena Popova.

${ }^{27}$ Recorded in Shamardan village, Yukamenskiy District, Udmurtia, by Elena Popova.

${ }^{28}$ Recorded from T. S. Baltacheva, in Tylys village, Yukamenskiy District, Udmurtia, by Elena Popova.

${ }^{29}$ Recorded from D. I. Kalinina, in Gordino village, Balezino District, Udmurtia, by Elena Popova.

${ }^{30}$ Recorded from M. S. Yashkina (Baltacheva), in Tylys village, Yukamenskiy District, Udmurtia, by Elena Popova.

${ }^{31}$ Recorded from V. N. Borisov, in Shamardan village, Yukamenskiy District, Udmurtia, by Elena Popova.

${ }^{32}$ Recorded from M. P. Zyambakhtina, in Turchno village, Yukamenskiy District, Udmurtia, by Elena Popova.

${ }^{33}$ Recorded from N. A. Zyankin, in Filimonovo village, Yukamenskiy District, Udmurtia, by Elena Popova.

${ }^{34}$ Recorded in Ukan village, Yar District, Udmurtia, by Elena Popova.

${ }^{35}$ Recorded in Ukan village, Yar District, Udmurtia, by Elena Popova.

${ }^{36}$ Recorded from A. Tyutina, in Gordino village, Balezino District, Udmurtia, by Elena Popova.

${ }^{37}$ Recorded from N. L. Tyutina, in Gordino village, Balezino District, Udmurtia, by Elena Popova.

${ }^{38}$ Recorded from Z. I. Zhuravl'ova, in Gordino village, Balezino District, Udmurtia, by Elena Popova.

${ }^{39}$ Recorded from A. Tyutina, in Gordino village, Balezino District, Udmurtia, by Elena Popova.

${ }^{40}$ Recorded from Z. I. Zhuravl'ova, in Gordino village, Balezino District, Udmurtia, by Elena Popova. 
Water Bodies in Besserman Mythology and Rituals

\section{References}

Belitser, V. 1958. Ocherki po etnografii komi [Essays on the Ethnography of the Komi]. In: Trudy instituta etnografii. Novaya seriya [Proceedings of the Institute of Ethnography. New Series]. Vol. 14. Moscow: [n.a.].

Biyanova, M. 1946. Istoriya naroda besermyan [History of the Besserman People]. In: Nauchno otraslevoy arkhiv UIIYaL UrO RAN. Rukopisnyy fond. Op. 2N. 1946 g. D. 391 [Scientific Branch Archive of UIIYAL UB RAS. Handwritten Fund. Op. 2H. 1946 D. 391].

Fedotov, M. 1982. Vortsynskiy govor besermyanskogo narechiya [Vortsynsk Dialect of the Besserman Dialect]. In: Obraztsy rechi udmurtskogo yazyka [Specimens of Speech of the Udmurt Language]. Izhevsk: [n.a.], pp. 116-130.

Il'yin, M. 1926. Svadebnyye obychai i obryady u votyakov [Wedding Customs and Ceremonies among the Votyaks]. In: Trudy nauchnogo obshchestva po izucheniyu Votskogo kraya [Proceedings of the Scientific Society for the Study of the Votyak Territory]. Issue 2. Izhevsk, pp. 25-69.

Mashtakova, M. 1970. Polevaya tetrad' etnograficheskoy ekspeditsii v Debesskiy, Balezinskiy, Yarskiy rayony UASSR. 1970 g. [Field Notebook of an Ethnographic Expedition to Debes, Balezino, Yar Districts of the Udmurt ASSR]. In: Nauchno otraslevoy arkhiv UIIYAL UrO RAN. Rukopisnyy fond. Op. 2N. D. 433. Sovmestnaya etnograficheskaya ekspeditsiya UdGU i UdNII [Scientific Branch Archive of UIIYAL UrO RAN. Handwritten Fund. Op. 2H. D. 433. Joint Ethnographic Expedition of UdGU and UdNII].

Minniyakhmetova, T. 2000. Kalendarnyye obryady zakamskikh udmurtov [Calendar Rites of the Eastern (Trans-Kama) Udmurts]. Izhevsk: Udmurtskiy institut istorii, yazyka i literatury Uralskogo otdeleniya Rossiyskoy akademii nauk.

Osokin, I. 1912. Istoricheskiy ocherk pochitaniya prepodobnogo Trifona, Vyatskogo Chudotvortsa ( $† 1612$ goda 8 oktyabrya) [Historical Sketch of the Veneration of the Monk Tryphon, the Vyatka Wonderworker (†1612, October 8)]. In: Trudy Vyatskoy Uchenoy Arkhivnoy Komissii. 1912 god. Vypusk I-II. Posvyashchaetsya pamyati prep. Trifona, Vyatskogo Chudotvortsa, po sluchayu 300-letiya yubileya so dnya ego blazhennoy konchiny [Proceedings of the Vyatka Scientific Archival Commission. 1912 Year. Issue I-II. Dedicated to the Memory of 


\section{Elena Popova}

St Tryphon, the Wonderworker of Vyatka, on the Occasion of the $300^{\text {th }}$ Anniversary of His Blessed Death]. Vyatka, pp. 1-70.

Pervukhin, N. 1888. Eskizy predaniy i byta inorodtsev Glazovskogo uyezda

[Essays about the Legends and the Everyday Life of Non-Russians of the Glazov District]. Eskiz 2: Idolozhertvennyy ritual drevnikh votyakov po ego sledam v rasskazakh starikov i v sovremennykh obryadakh [Essay 2: The Idol-Sacrificial Ritual of the Ancient Votyak in Its Traces in the Stories of Elder People and in Modern Rituals]. Vyatka: Gubernskaya tipografiya.

Popova, E. 2004. Gordinskiy nadgrobnyy kamen' "svyataya mogila" pamyatnik chepetskikh tatar i besermyan [Gordinsky Tombstone "Holy Grave" - a Monument of the Cheptsa Tatars and Bessermans]. In: Kul'tovye pamyatniki Kamsko-Vyatskogo regiona: Materialy $i$ issledovaniya [Cult Monuments of the Kama-Vyatka Region: Materials and Research]. Izhevsk: Udmurtskiy institut istorii, yazyka i literatury Uralskogo otdeleniya Rossiyskoy akademii nauk, pp. 167-177.

Popova, E. 2011. Kul'tovyye pamyatniki i sakral'nyye ob"yekty besermyan [Cult monuments and sacral objects of the Besserman]. Izhevsk: Udmurtskiy institut istorii, yazyka i literatury Uralskogo otdeleniya Rossiyskoy akademii nauk.

Popova, E. 2012. Reki i rodniki v obryadakh i kul'tovoy praktike besermyan [Rivers and Springs in Rituals and Cult Practice of Besserman]. In: Traditsionnaya kul'tura [Traditional Culture] 4, pp. 15-22.

Popova, E. 2014. Talsipühade sanditamised ja maskid bessermanide tänapäevases kalendrikombestikus [Mummery during the Winter Holidays and the Masks in the Contemporary Calendar Tradition]. Mäetagused 57, pp. 91-114.

Pravoslavnyye khramy Udmurtii 2000. Spravochnik-ukazatel' [Orthodox Churches of Udmurtia: Reference Book]. Izhevsk: Izhevsk.

Satrapinskiy, K. 1854. Votyaki i besermyane, prozhivayushchiye v prikhode i sele Ukan Glazovskogo uyezda [The Votyaks and the Bessermans Living in the Parish and Village of Ukan of the Glazov District]. In: Arkhiv Russkogo geograficheskogo obshchestva [Archive of the Russian Geographical Society]. R. 10. Op. 1. D. 48.

Shutova, N. 2004. Svyatilishcha v okrestnostyakh derevni Malyy Dasos: $\mathrm{K}$ voprosu o tipologii i semantike besermyanskikh kul'tovykh mest [Sanctuaries in the Vicinity of the Village of Maly Dasos: On the 
Typology and Semantics of the Besserman Cult Places]. In: Kul'tovyye pamyatniki Kamsko-Vyatskogo regiona: Materialy i issledovaniya [Cult Monuments of the Kama-Vyatka Region: Materials and Research]. Izhevsk: Udmurtskiy institut istorii, yazyka i literatury Uralskogo otdeleniya Rossiyskoy akademii nauk, pp. 154-166.

Steinfeldt, N. 1894. Besermyane. Opyt etnograficheskogo issledovaniya [The Besserman. Experience of Ethnographic Research]. In: Kalendar' i Pamyatnaya knizhka Vyatskoy gubernii na 1895 god [Calendar and memorial book of the Vyatka Governorate for 1895]. Vyatka: Gubernskaya tipografiya, pp. 220-259.

Trifon Vyatskiy 1996. In: Entsiklopediya zemli Vyatskoy [Encyclopedia of the Vyatka Land]. Vol. 6. Znatnyye lyudi [Famous People]. Kirov, pp. 447-448.

Vereshchagin G. 1886. Votyaki Sosnovskogo kraya [The Votyak of the Sosnovka Region]. In: Zapiski Russkogo geograficheskogo obshchestva [Notes of the Russian Geographical Society]. Vol. 14, issue 2. SanktPetersburg.

Vereshchagin G. 1889. Votyaki Sarapul'skogo uyezda Vyatskoy gubernii [The Votyaks of the Sarapul District of the Vyatka Province]. In: Zapiski Russkogo geograficheskogo obshchestva [Notes of the Russian Geographical Society]. Vol. 14, issue 3. Sankt-Petersburg.

Vereshchagin, G. 1998. Staryye obychai i verovaniya votyakov Glazovskogo uyezda [Old Customs and Beliefs of the Votyaks of the Glazov District]. In: Sobraniye sochineniy: Etnograficheskiye ocherki 1 [Collected Essays: Ethnographic Essays 1]. Vol. 6, issue 3, b. 1. Izhevsk: Udmurtskiy institut istorii, yazyka i literatury Uralskogo otdeleniya Rossiyskoy akademii nauk, pp. 206-239.

Vyatskaya eparkhiya 1912. Istoriko-geograficheskoye i statisticheskoye opisaniye (S kartoy Vyatskoy gubernii) [Vyatka Diocese. Historical, Geographical and Statistical Description (With a Map of the Vyatka Governorate)]. Redaktsii Vyatskikh eparkhial'nykh Vedomostey [The Vyatka Diocesan Gazette]. Vyatka: Gubernskaya tipografiya.

Vladykina, T. 1998. Udmurtskiy fol'klor: problemy zhanrovoy evolyutsii $i$ sistematiki [Udmurt Folklore: Problems of Genre Evolution and Systematisation]. Izhevsk: Udmurtskiy institut istorii, yazyka i literatury Uralskogo otdeleniya Rossiyskoy akademii nauk. 


\section{Elena Popova}

Yusupov, G. 1960. Vvedeniye v bulgaro-tatarskuyu epigrafiku [Introduction to the Bulgaro-Tatar Epigraphy]. Moscow-Leningrad: Nauka.

Zorin, N. 1981. Russkaya svad'ba v Srednem Povolzh"ye [Russian Wedding in the Middle Volga Region]. Kazan: Kazansk. Universitet.

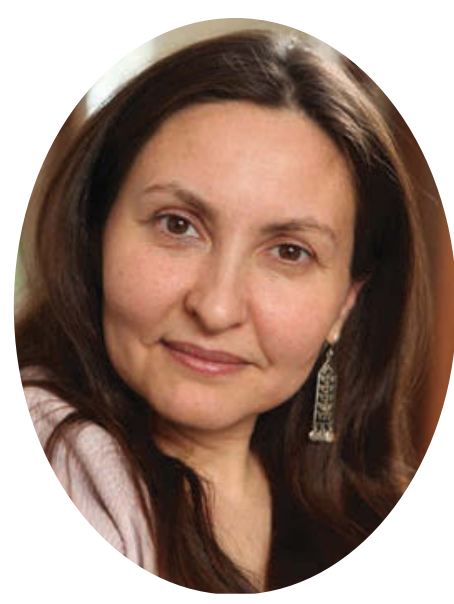

Elena Popova $(\mathrm{PhD})$, is a Senior Research Associate, Udmurt Institute for Research in History, Language and Literature (Udmurt Federal Research Centre of the Ural Branch of the Russian Academy of Sciences), Besserman ethnographer and anthropologist. She has a huge bibliography of research among the Besserman, the Udmurt and other peoples of the Volga-Kama region. Her interests are wide, from spiritual to material culture, from traditional rituals to the most contemporary phenomena of modern world.

e-mail: elvpopova@yandex.ru 


\title{
The Udmurt Pantheon and the Udmurt Worldview
}

\author{
Tatiana Vladykina \\ e-mail: tgvladykina@mail.ru
}

\begin{abstract}
The research gives an overview of the Heavenly (in/inma/ immu/inmu, lit: 'heaven/heavenly earth') area, its construction, and its gods. Udmurt narratives about the creation of the world are related to biblical subjects and images. In their folklore we find the image of a heavenly stove and heavenly table, i.e. the constellation of Ursa Major. The supreme deities include the creator God (Inmar, Kuaz', Kyldys'in/ Kylchin) and the female deities (Kaldyk-mumy/Kaltak, Shundy-mumy, "Mother-Sun / Mother of the Sun", Invu-mumy "Mother of Heavenly Water / Heavenly Grace", Invozho-mumy "Mother-Invozho, Goddess of Summer Feast Time, i.e. Transitional Time", Gudyri-mumy, ThunderMother, Muz"yem-mumy, Mother-Earth).
\end{abstract}

Keywords: heaven, heavenly gods, Inmar, Invozho, Udmurt mythology

The Udmurt conception of the world (dun'n'e) is not always formed into detailed and complete stories. One of the possible ways to reconstruct mythological concepts is to use language in all its forms of expression from the everyday to the ritual. The richest source can be the language of folklore, from the point of view of sustainable images, which in their entirety are revealed only in the context of the rite. Restoration of contextual connections of the rite itself, 
in turn, allows the reconstruction of the spatio-temporal parameters of the world model, filling it with meaning and highlighting its individual components, the aggregate-holistic meaning of which is often hidden even from the bearers of traditions. Sources of research, therefore, are texts of completely different levels: speech units in the form of separate words, expressions, motifs and other genres with complete plots; attributive ritual texts, everyday behavioural stereotypes. To a great extent, the tradition of spells 'preserved' archaic conceptions because of the sacredness of the language and the possibility of maintaining different time layers. A whole layer of information about the Udmurt conception of the world can also be obtained from beliefs, the system of the most important requirements covering the entire lifecycle and regulating the information about the social and natural environment of a person at his or her most important spatio-temporal levels.

Implicit information about the relict, diatomaceous, vertical two-part earth can be found in the nominations of heaven and earth. Heavenly (in/inma/immu/inmu, lit: 'heaven/heavenly earth') and earthly areas are perceived as similar. Both areas have a bottom: mu pydes / the bottom of the earth, and in pydes / the bottom of heaven. There are also conceptions of a multi-layered earth in kuin'/siz'ym mu pydes, the third/seventh bottom of earth. The concept of pydes/bottom corresponds with the bottom of the water (vu pydes) and river bottom (shur pydes), which creates the idea of water $(v a / v u)$ as a cosmic, universal body that surrounds earth and heaven.

The commonly used word inbam/skyline (lit: 'heavenly cheek') replaced the word ingur/firmament, also meaning skyline. The pronunciation of this last word served as the basis for the mythological perception of the sky as a heavenly stove. Riddles have generally preserved this image, for example in Ingur ulyn tshuzh chipy Shundy (Under the heavenly stove there is a yellow chicken (the Sun)); Chil'tyrtis'koz, voshtis'koz - in gur ule suz'tis'koz - Vuyuis' (Well-dressed and beautiful, sitting under the heavenly stove (the 
Rainbow)). The perception of the sky as a stove is also preserved in riddles about the moon and stars, although here the word heavenly is missing: Gur tyros perepech, shoraz odig n'an' koldy / shanga (The stove is full of cheesecakes and in the middle there is a loaf of bread), Gur ulyn tshuzh chipi vetle (Under a stove there is a chick) (Perevozchikova 1982: 214-216). Along with the image of a heavenly stove, there is an image of a heavenly table as a heavenly altar, which is hidden in the word that means Ursa Major ([In] dzhökkuk kiz'ili, lit: Stars are the legs of the [heavenly] table). The images of a heavenly and an earthly stove, a heavenly table and an earthly table are continued by dichotomous parallels of spells containing images of the heavenly sun and the earthly sun, as well as the heavenly and the earthly stars.

The well-known rite entitled 'travelling to heavenly earth' (immala-vetlon) takes place during the summer solstice when pilgrims travel to places of worship, marked with birch trees and a spring (Vladykina 2004: 10). The word inma has served as the basis for the conception of Inmar, the God who rules heaven. This can be seen in the expression inmare tubyny / climb up to Inmar, meaning climb up to heaven; inmar zore / it is raining, lit: 'heaven is raining'. Under the influence of Christianity, Inmar began to be perceived as Jesus Christ or God the Father.

As with Inmar, the formation of another deity image has occurred. The concept of atmosphere, weather/kuaz' has grown into the deity named Kuaz'. The expression zore ('it is raining', lit: 'rains') is similar to kuaz' zore ('the sky is raining', lit: 'the God named Kuaz' has sent the rain'). According to belief, Kuaz' is awake during the day, but sleeps at night, therefore, you cannot mention him in the evening: Kuaz'ez dzhytaz'e verany ug yara: Kuaz' iz'e $n ' i$ ('You cannot talk about Kuaz' in the evening, because he is already sleeping'). Kuaz' rules the bee swarms, he is worshipped when hives are carried. People say about him mush ishtys'-kosys' 'sending and leading bees'. His evolution is connected with the wood spirit (n'ulesmurt) and St Nicholas. 
Inmar and Kuaz'together with the creator God (Kyldys'in / Kylchin; from Udmurt kyldytis', creating, creator) have formed a triad of supreme deities. Kyldys'in helps livestock births, patronises human births, children (Nuny-Kylchin); later he became the god of fertility ( $M u-K y l d y s$ 'in). According to legend, in ancient times he lived among people, walking through fields as an old man in white clothes, looking after the crops. But he was offended by the disobedience of people and left them. People have begged him to return, he acceded to their appeals and has appeared on the holy birch in the form of a squirrel. People wanted to keep him forever and shot the squirrel, but it turned into a hazel grouse, the hazel grouse turned into a black grouse, and that grouse into a perch that hid in the river. Since then, according to legend, the Udmurt keep images of Kyldys in (wood chips, squirrel skin, hazel grouse wing, black grouse wing, dried fish) as relics. These items made up the content of the vorshud box in the clan sanctuary, the kua.

The female hypostasis of Kyldys'in is Kaldyk Mumy / Kaltak, one of the great mothers along with Shundy-mumy (Mother-Sun / Mother of the Sun), Invu-mumy (Mother of Heavenly Water / Heavenly Grace), Invozho-mumy (Mother-Invozho, Goddess of Summer Feast Time, i.e. Transitional Time), Gudyri-mumy (ThunderMother), Muz"yem-mumy (Mother-Earth).

It might seem that the list of deities is chaotic, as it resulted from various multi-temporal layers. However, it highlights an important detail: the deification of natural phenomena (sky, weather, sun, thunder, earth, rain) is replaced with deification of the creation process, as exemplified by the appearance of Inmar-Kylchin, whose ancestor is Grand Mother Kaltak, a name that shows typological parallels with the Mari and Ob-Ugric people. Today Inmar-Kylchin is one of the images of Jesus Christ, in linguistic expression a synonym, often a guardian angel (Vladykin 1994: 181-183).

Attention to the image is already found in the first written sources, i.e. travellers' notes from the end of the $18^{\text {th }}$ century (Georgi, Pallas, Messerschmidt), as well as a lot of evidence 
The Udmurt Pantheon and the Udmurt Worldview

Invu-mumy. Computer generated image. Made by Ulyana

Konstantinova (2021).

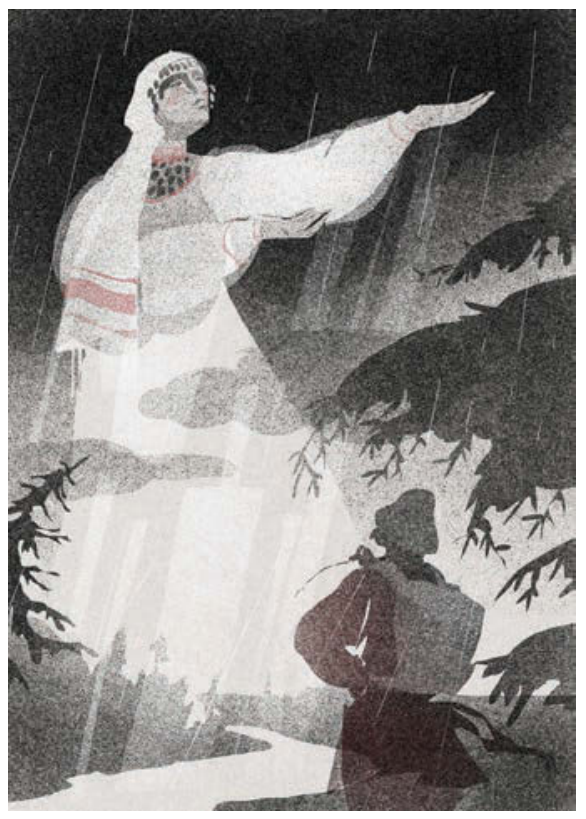

Kyldys'in. Computer generated image. Made by Ulyana

Konstantinova (2021).

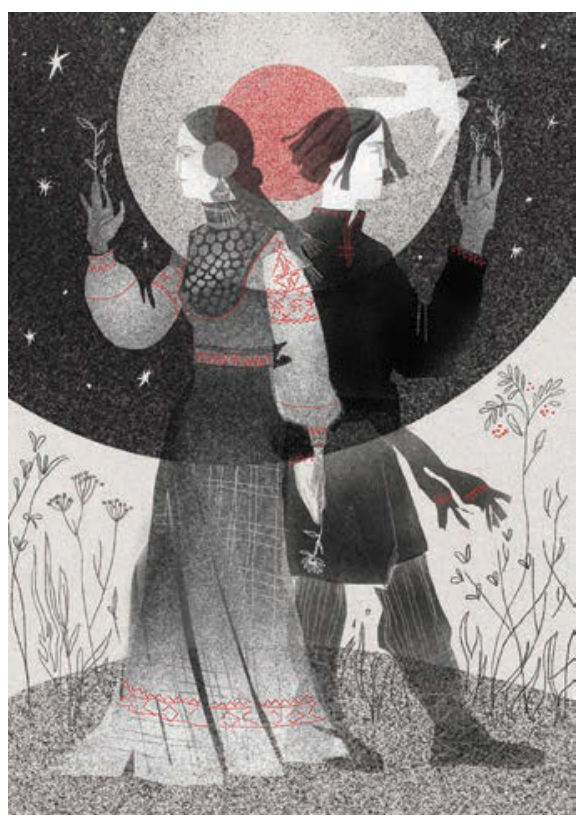



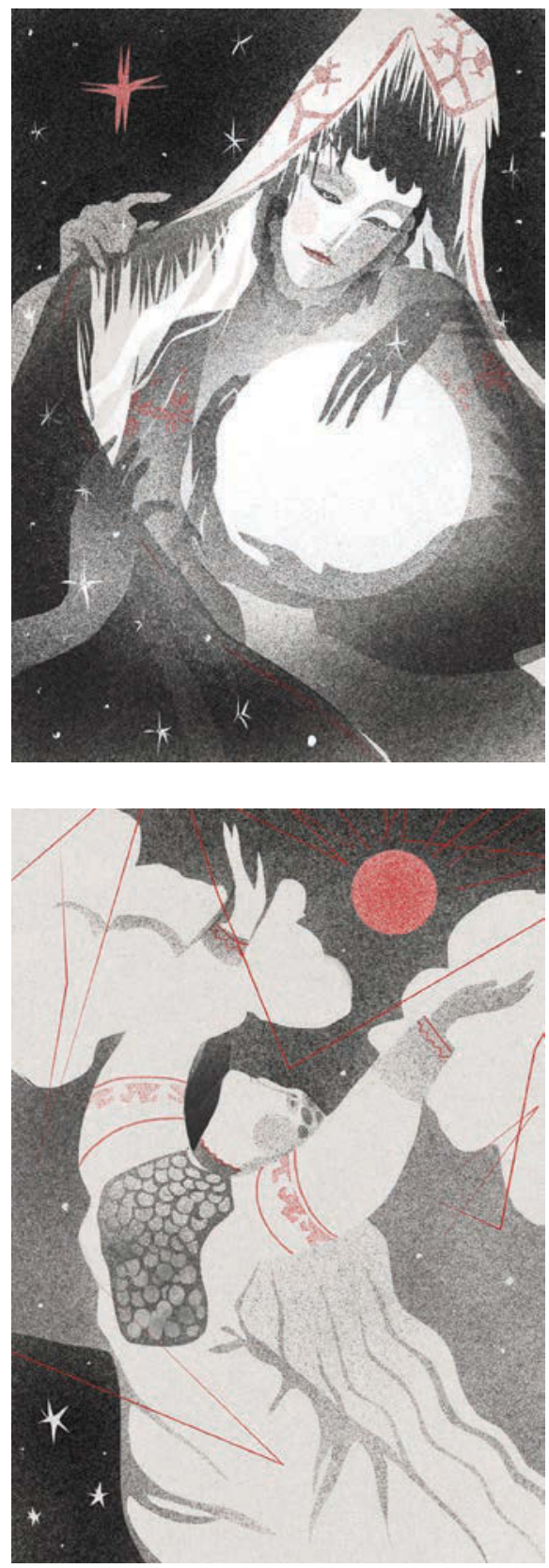

Tolez'-mumy. Computer generated image. Made by Ulyana Konstantinova (2021).
Shundy-mumy. Computer generated image. Made by Ulyana Konstantinova (2021). 
recorded in the $19^{\text {th }}$ century, generalised studies of which are presented by Vladimir Vladykin (Vladykin 1994).

The distinctive feature of Kildys'in, emphasised by modern researchers (Shutova 2014), is the number of different forms the deity has: creator of water, creator of the earth, keeper of the harvest, keeper of women. This plurality and multifunctionality of Kildys'in has become possible because of various multi-temporal layers.

Separate traits of this deity can be found in linguistic and folklore materials, representing additional argumentation in favour of one or other of its properties (Vladykina 2017). Today the expression "Kaltak! E, kaltak!", showing extreme annoyance at someone else's behaviour, has practically disappeared from everyday life. It is similar to the Russian expression “O Bozhe! O Gospodi?'. The only difference is that the Udmurt appeal to the mother ancestor Kaltak / Kaldyk Mumy, who has direct analogies with Koltesh among the Ugric people and their wish that someone be healthy as a result of 'rebirth'.

Kaltak seems to be the more ancient female hypostasis of Kyldys'in, who transferred to him her patronage of women in labour.

The concept of the merging of Kyldys'in with Vorshud, the ancestral deity, or mother-ancestor of a clan, has the same quality in our opinion. According to legend, during the summer this combined deity 'flies out' from the family sanctuary, the kuala, to the countryside and lives on the flowers. The Udmurts explain the reason for prayers in the summer in the countryside, rather than indoors, precisely because of this: vös' kyre pote, 'prayers go out / to freedom / to nature'. As an additional argument there is a set phrase, s'as'ka vylys' shed'tyny, 'found on flowers', meaning an illegitimate child. And if in Russian culture such a child is called 'wren, Udmurt mothers who have consciously had illegitimate children treated the children as gifts from above, from the mother-ancestor using the expression '[the child] was found on the flowers', which should be understood as 'the child was given by the mother-ancestor Kaltak / Kaldyk Mumy'.

Implicit semantic relationships such as mother-ancestorflowers-children can also be found, in our opinion, in separate 
local traditions among the Uva and Vavozh Udmurts, where the Trinity day commemorations were perceived as 'children's commemorations'. This means that dead children were remembered during the flowering season in spring.

In modern translations of the scripture, Kylchin-Inmar is a guardian angel. The complexity of the Kaldyk/Kaltak/Kyldys'in image, which combines feminine and masculine features, is connected, in our opinion, with the ancient androgynous essence of the deity. His qualitative characteristics are evolutionarily replenished with spatial parameters: Kyldys’in is localised in the sky, underground, and in water (Vladykina, Glukhova 2011).

The above images were, at a certain stage, able to perform the function of cosmological models, and were later replaced with detailed stories about mythological traditions and legends about the creation of the earth, man, and the establishment of customs. In etiological traditions, the motifs of the creation and the emergence of reality were revised in line with later traditions that had a predominance of moral and ethical attitudes, creating a peculiar synthesis of archaic narratives. One vivid example is the story about spots on the Moon (Vladykina 1998: 56-57). According to the belief, on the moon one can see an orphan girl with buckets and a shoulder yoke. She was sent for water by her evil stepmother at a freezing Christmas midnight. The girl decided to drown herself and jumped into the water. But, as the story says, "the water did not take her" (vu soye bas'tymte). Then the girl turned to the full moon begging for pity. And the moon took her to itself (ibidem). The narratives about the creation of the world that exist in the Udmurt tradition are related to biblical subjects and images, retold and modified in line with the national tradition through Russian / Old Believer (apocrypha) and Turkic mediation. Therefore, the legends about the creation of the world, man, and the reasons for the removal of heaven from the earth, have a lot in common with different cultures and create their own versions of the source material. 
We can say with a certain degree of probability that myths can reconstruct an imaginative system of spells and mantras and make use of a complex of artistic representations. But archaic mythologies, due to the perception of the world order/space, the Sun / tyr shundy, the Moon / tyr tolez', stars/kiz'il'i, the sky / in'yubo, the hub of the universe / muz"yemgogy, the beam that supports the earth / muz"yem közono were the guarantors of stability and eternal values. Spells have frozen the ideas about parallel - upper and lower/ underground - worlds, in which zoomorphic celestials live (the heavenly horse, the sun serpent, the golden-winged hawk), along with chthonic creatures, i.e. prototypes of water and underground elements (the water bull, the water horse,the gold-headed snake, the gold-headed toad with silver feet) (Vladykina 1998: 75-82).

Synthesizing examples of ritual practice, linguistic function and terminology provides an opportunity to expand Udmurt imagemythology and find the place in the religious and mythological picture of the world where mythological consciousness turns the world of the purely real into a system of absolute symbols.

\section{References}

Perevozchikova, T. 1982. Udmurtskiy fol'klor. Zagadki [Udmurt Folklore. Riddles]. Izhevsk: Udmurtia.

Shutova, N. 2014. Traditsionnoye udmurtskoye zhenskoye bozhestvo Kyldysin: Mnozhestvennost' obraza i napravleniya evolyutsii [Traditional Udmurt Female deity Kyldys'in: The Plurality of the Image and the Courses of Evolution]. Religiya $v$ istorii narodov Rossii i Tsentral'noy Azii: materialy II Mezhdunarodnoy konferentsii [Religion in History of the Peoples of Russia and Central Asia: Works of II International Conference]. Barnaul: Izd. Barnaul'skogo universiteta, pp. 366-370.

Vladykin, V. 1994. Religiozno-mifologicheskaya kartina mira udmurtov [The Udmurt's Religious and Mythological Worldview]. Izhevsk: Udmurtia. 
Vladykina, T. 1998. Udmurtskiy fol'klor: problemy zhanrovoy evolyutsii $i$ sistematiki [Udmurt Folklore: Problems of Genre Evolution and Systematisation]. Izhevsk: Udmurtskiy institut istorii, yazyka i literatury Uralskogo otdeleniya Rossiyskoy akademii nauk.

Vladykina, T. 2017. Lingvo-fol'klornyye metamorfozy Boga-Tvortsa $\mathrm{v}$ religiozno-mifologicheskoy kartine mira udmurtov [Linguistic and Folklore Metamorphoses of God the Creator in the Udmurt's ReligiousMythological Worldview]. XII Kongress antropologov i etnologov Rossii: Missiya antropologii $i$ etnologii: nauchnye traditsii $i$ sovremennyye vyzovy (3-6 iyulya 2017 g., Izhevsk) [XII Congress of Anthropologists and Ethnologists of Russia: The Mission of Anthropology and Ethnology: Scientific Traditions and Modern Challenges]. Izhevsk: Udmurtskiy universitet, p. 116.

Vladykina, T., Glukhova, G. 2011. Invu-mumy - povelitel'nitsa nebesnoy vlagi $\mathrm{v}$ traditsionnoy sisteme mirovideniya udmurtov [Invu-Mother the Goddess of Celestial Moisture in the Udmurt's Traditional Worldview]. Vestnik Udmurtskogo universiteta, Istoriya i filologiya [Bulletin of Udmurt University. History and Philology] 4, pp. 114-119.

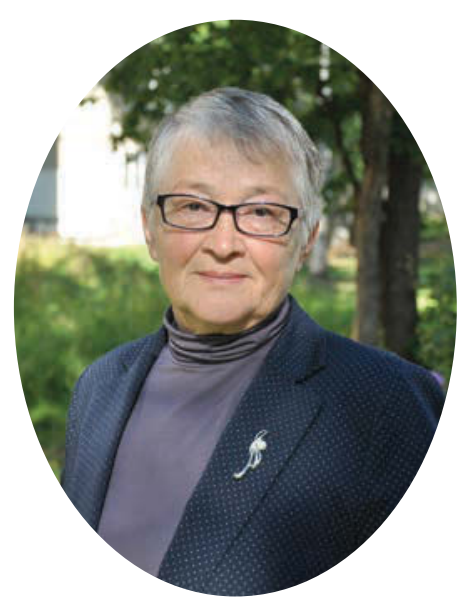

Tatiana Vladykina is ( $\mathrm{PhD}$ hab) a professor and leading researcher at the Udmurt Institute for Research in History, Language and Literature (Udmurt Federal Research Centre of the Ural Branch of the Russian Academy of Sciences). She has covered the range of topics in Udmurt folkloristics, especially mythology, specialising both in genre and in the treatment of the most important topics across genres.

e-mail: tgvladykina@mail.ru 


\title{
Inmar, the Udmurt God, in Modern Udmurt Literature
}

\author{
Aleksey Arzamazov \\ e-mail: arzami@rambler.ru
}

\begin{abstract}
One of the productive directions of research into Udmurt literature (and more broadly other Finno-Ugric 'small' literary traditions) is the identification and interpretation of multidimensional mythological clusters, textual representativeness and semantic ambivalence. In this work I have focused on only one aspect, the functional and semantic field of a particular character in Udmurt mythology and national poetry at the turn of the $21^{\text {st }}$ century. The chosen mythological character is Inmarl God. The study has predominantly focused on ethnic and futuristic poems by Petr Zakharov, Viktor Shibanov, and Anastasiya Shumilova, characterised by a high concentration of mythological symbols. The presented research demonstrates how complex the image of Inmar is for direct artistic understanding.
\end{abstract}

Keywords: Udmurt mythology, Inmar/God, use of Inmar in literature

One of the productive directions of research into Udmurt literature (and more broadly other Finno-Ugric 'small' literary traditions) is the identification and interpretation of multidimensional mythological clusters, textual representativeness and semantic 
ambivalence. These are primarily caused by the stadial-typological nature of the national literature and its internal and external markers of genetic conjugation with the figurative-symbolic universe of traditional culture. The scientific problem of the search for and analysis of mythological roots, i.e. the layers of literature found in the complex consideration of the development of a minority literary system, is already highly relevant, and moreover it should be mandatory, a programmed analytical strategy, the inevitable choice of the scientist. Mythological representations and folklore imagery are a kind of ethno-cultural fundamental principle on the basis of which the author's artistic identity is formed. It is noteworthy that modern Udmurt literary critics, working with written pieces from different historical periods, trends and genres, usually avoid updating scientific issues related to the folklore and mythological beginning of the artistic whole. To date, study of mythological plots, and mythological and folklore paradigms of Udmurt literature have been limited to individual articles, usually the work of one author (Arzamazov 2010; Vanyushev 2004; Vasil'yev, Shibanov 1997; Zaytseva 2006; Il'yina 2006; Shklyayev 2004). The undeveloped nature of this topic is explained, among other things, by its theoretical complexity. Some blurring of the conceptual and categorical apparatus has developed (or is developing) that hinders interpretation and description of the myth in the systems of Udmurt worldview and culture. The appeal of the mythological strata is of great importance in the context of justifying a systematic development of Udmurt literature, as well as in determining the quality and originality of Udmurt writers' interpretation of their ethnic mythology.

In a global sense, we can talk about identifying the features of an author's 'experience' of mythological matrices in typologically related and unrelated literatures, and about building scientifically reasoned comparative collations.

The mythological expressiveness of Udmurt literature and poetry (depending on the rhetoric of the era), which determines the artistic priorities and semantic centres, had a different qual- 
ity of presentation in the written work. Great attention was given to traditional culture by the poet and educator Kuzebay Gerd, for example in his poems. Here we see many mythological contexts and subtexts, and when the characters of Udmurt mythology appear they receive the sufficiently broad dissemination of folk images. Within socialist realism, which for many decades set the themes and determined the artistic and plot pragmatics of national literature, the open mythological hypertexts that go back to the traditional worldview of the Udmurt, were unacceptable. They would have been perceived as an alternative to the Soviet model of the world, as a mentally dangerous symbolic reality. In the conditions of significant ideological and communicative limitations that the Soviet era presented there was a replacement of one system of values and ideas with another. The original Udmurt figurative and symbolic codes were subject to displacement by the socialist emblematic. We can also talk about the emergence of the author's ideologised 'double bottom' texts that have references to ethnos or language and which, despite the strict and artificial external regulations, somehow manifest themselves and translate their semantics.

In the years of perestroika there was a rapid renewal of artistic interests with an inevitable revision of the themes, objectives and concepts of national culture. The undeveloped mythological heritage of the people, the symbolic potency of folklore became a more and more creative attraction. In the early 1990s, the cultural life of Udmurtia saw the rise of ethno-futurism, a complex modernisation phenomenon that played a key role in the history of Udmurt literature and art. In ethno-futuristically oriented works, a significant place is given to mythology, which is perceived not so much as a heterogeneous worldview but more as a source of new imagery, symbolic depiction. The semiotic reality of many written pieces from the post-Soviet period suggests that the national writers' understanding of the subtle matters of the religious and mythological picture of the Udmurt world is incomplete and fragmentary. Decades of ideological press cut off the ethno-forum from 
the cultural resources of its people. However, the artistic need for this own yet foreign, not yet acquired language of writing, is notorious. The natural tendency of Udmurt artists to work with mythology and folklore material, including mechanisms of cultural memory, seems to be natural. In the framework of ethnic futurism a specific multi-level mythological discourse developed within art that saw worlds opposed to each other form a sort of single whole, a world of nature and the urban daily routine, paganism, atheism and Orthodox Christianity. It was psychologically interactive, with a sense of ethnic liberation and socio-political awareness of bitterness and a deep sense of being creatively unrealised. Multifaceted mental-social transformations, experienced by the Udmurt people, could not be better reflected in these mythological re-glued mirrors of ethnic futurism, where each shard of glass shows its own picture, its own event.

Realising the scale of the analytical problem of considering the mythological plan of Udmurt literature, in this work we have focused on only one aspect, the functional and semantic field of a particular character from Udmurt mythology in the Udmurt poetry at the turn of the $21^{\text {st }}$ century. Our choice, among other things, was dictated by the relative simplicity of the object of study, the outline of the artistic search area. In the structure of poetic texts the chosen mythological character - Inmar/God - is almost always in sight. It was assumed that his in-text position is usually complicated by the author's point of view. Our study has predominantly focused on ethnic and futuristic poems by Petr Zakharov, Viktor Shibanov and Anastasiya Shumilova, characterised by a high concentration of mythological symbols.

Considering the mythological personages of Udmurt poetic works, it is necessary to produce a list of characters that authors would use, and at the same time could be found in the spiritual and ideological foundations of the Udmurt ethnic group. These criteria produce a number of images, subjects, 'beings' that show varying degrees of meaningful and functional complexity and relatedness 
to the realities of world religions (Inmar, Kyldys'in, Shaytan, Keremet, N'ulesmurt, Vukuz'o/Vumurt, Vunyl, Palesmurt, Ishan, Albasty, Vozho). Accordingly, the list of 'heroes' in the study can be continued, and the very formulation of the problem and scale of its scientific solution, suggest comprehensive multilateral analytical work, the results of which go far beyond a single scientific article.

The first in the hierarchical system and one of the most ambiguous from the point of view of artistic conceptualisation of symbols is Inmar/God (see Vladykina, Glukhova 2011: 69).

The mythological character Inmar as an image in the poetry of Pyotr Zakharov has high indices of use, i.e. it is in high demand. However, the symbol under consideration does not always fit well into a lyrical story, and does not necessarily have an independent artistic function. The analysis of a large corpus of texts showed that the semantic load of Inmar in the structure of Zakharov's poems is rarely motivated by mythological representations of the Udmurt ethnic group. In his debut, and most voluminous collection of poems, Vozh vyzh ('The Green Bridge', 2001) the symbol of Inmar appears more than 30 times, which shows the great potential 'operationality' of this concept in this specific style. Nevertheless, the prevailing scenario emphasises the real poetic role of Inmar in the author's text, the facets of its existence and the minimum, peripheral connectedness with the semantic centre of the work. Mention of Inmar in a number of Zakharov's texts is often part of a statement about a lyrical subject, a component of speech that expresses a certain set of socially conditioned feelings, a lexical echo of a complex psychological state, a pensive and dreamy immersion in oneself:

"Inmar ponna ud s'oty-a mynym? ('For God's sake, will you give me?');

"Okh, Inmare, - kure Isay, - / tynyd mon van'ze s'otysal, / Puzhyosse soles' ke tshupasal...” ('Oh, my God, says Isai, I 
I would give you everything, / If I'd have kissed her freckles...');

“Okh, Inmare, kytshe mözmyt...” ('Oh, my God, how sad...’);

“Peymyt mynym, ton us'ty val öste, / Kot'yugdy val ton, oste Inmare..." ('I'm in the dark, open the door / At least, give the light, my God').

The fixed frequency of use of the name Inmar, in all probability, is due to subconscious compensatory factors relating to God, with especially obvious pagan mythological outlines which during the Soviet period were impossible to mention let alone give a creatively conscious response. After perestroika, in the 1990s, this important word in Udmurt intellectual culture became not just regular in literary, journalistic national discourses but also one of the dominants of everyday communication and colloquial speech, often unburdened by any significant spiritual or mental pragmatics.

The word Inmar in Zakharov's work can be semantically integrated into a meaningful artistic context in which the author prescribes its truths and defends his existential position, opposing the position of another. In a poem entitled "Kabakyn todmatskon" ('Meeting in a Pub'), a lyrical 'me' declares that poetry for him is Inmar, God, thus pointing out his distinguished status to his collocutor. The belittling of the lyric 'you' follows:

Mon ponna poeziya Inmar, For me, poetry is Inmar (God), Ton ponna ug todis'ky For you, I don't know what mon mar I am

(Zakharov 2001: 124)

This poem reflects Zakharov's favourite aphorism: that poetry is the quintessence of culture, art, literature, etc., and that the poet 
has a special relationship with God. The poet him- or herself is allowed to be a demiurge, creating his or her own universe in the literary word. The lyrical subject compares himself with Inmar in the poem “Töd'y kagaz” ('White Paper'). Here he talks again about the divine beginning of creation, creativity.

Mynam az'am töd'y-töd' kagaz,

Ogpol no kutymte no isamte no na so.

Inmar kad' pukis'ko solen $a z^{\prime} a z$,

Nosh no utshke. Vit'e.

Dun'n'e tuso...

(Zakharov 2001: 48)
Before me there is white white paper,

Never held, never touched.

Like Inmar, I'm sitting in front of it.

And it is watching...

Waiting...

It features the guise of the world...

The name Inmar in Zakharov's book Vozh vyzh can be contextually associated with artistically playing with social issues. The main body of poems included in this collection was written in the $1990^{\mathrm{s}}$ and was permeated with the drama of experiencing the new time and the new rules of the social games. In Nunal pörat ('Every Day') (Zakharov 2001: 75) the post-Soviet era is associated with the inevitability of atonement for socialist deceptions and illusions. In the nineties people sacrifice themselves to Inmar and human blood flowed (the motif of blood shed by the people is also found in the poetry of Mikhail Fedotov, whose lyrical hero perceives the new era in a passive way).

One of the most common subjects in Zakharov's poems is a dispute with himself about the existence of God. Doubts are often marked with a 'hob-and-nob' intonation of appealing to the Almighty: 
Van'-a ton, övöl-a ton,

Inmar?

Van'ke, bas'ty, tan'i so

luly...

(Zakharov 2001: 45)

Van'-a ton, Inmare? - mon

shuo.

Van'-a ton? - mon shuo,

Inmare.

Van'ton, van'ton! - achim

ik shuo.

Van' ton, van'ton! - shuo

Inmare.

(Zakharov 2001: 94)
Do you exist, do you not, Inmar?

If you exist, here is this soul, take it...
Do you exist, my Inmar? - shall I say.

Do you exist? - I shall say, my Inmar.

You exist, you exist! - I shall say myself.

You exist, you exist! - I shall say, my Inmar.

Such rhetorical combinations and cognitive reactions are, apparently, the projection of the 'open' consciousness of the post-Soviet Udmurt ethno-forum, existing in the mode of a multi-directional perception of the world, standing at the crossroads of atheism, Orthodox Christianity and traditional belief. Udmurt culture's understanding of its unreadiness for the new realities of the turn of the century is superimposed on this complex internal state of self-determination.

In the poem Uysyos ('Owls') Inmar is called to witness the lovingly erotic mutual learning of a village boy and girl, whose unity is shown in the lyrical 'me' as an important life event, and as another, new, face of sin: Ekh, kytshe busas'ko ta uyyos! / / Med addzh'oz n’i, addzh'oz ke Inmar... / Med luozn’i, luoz ke koshmar... / Mi gine shat sytshe s'ölykoyes'... (“Oh, how foggy were those nights!/Let him see already, if Inmar sees,/Let it be already, if there is a nightmare./Are only we such sinners?" (Zakharov 2001: 24). On the compositional level, the poem Adzh'yli val, s'in "yosyd tynad ('I Saw Your Eyes...'), is a lyrical monologue by a man who persuades a girl in love with 
him to forget him. He asks her to erase him from her memory and her heart, and not to ask Inmar about him:

Ogshory mon ul'chays'

shpana-

Vamyshly byde vuzas'kis'ko

Inmarez en kure mon

ponna,

Ton soku achid s'ölykas'kod
I'm an ordinary street rabble

For sale at every step

Do not ask Inmar for me

Then you yourself will become a sinner

(Zakharov 2001: 79).

Again, Inmar is narratively manifested in the possibility of sin.

In the lovingly playful poem Dzh'ol'gyri so dzh'ol'gyri ('The Sparrow is a Sparrow') the mood of the beloved is expressed using floral, ornithomorphic characters. Within the framework of this association the pine is a cold Inmar. Apparently, this parallel emphasises inaccessibility, the cold detachment of the favoured one.

Notably, among the many poems in the collection the Udmurt Inmar (inmaryos, inmars, gods) is mentioned only once. This mythological character is generally characterised by a weak correlation with the semantic core of the poem. His appearance is in parallel to the development of the love story and brings a semantic shade, the divine symbolism or fatal predetermination of the feeling of love:

As'meos kyldytemyn parly: We're made to be a couple:

Kyknamy uk yug-yug chukdores'. We're both fair-haired, white-

Vashkala udmurt maned.

inmar"yosly

Par val"yos luo val The ancient Udmurt gods

yarys'es'...

Needed a couple of decent

(Zakharov 2001: 132) 
In Vozh vyzh, the phrase Inmar yurtte! ('Inmar helps') is used once. At the same time, God's help is presented as a phenomenon from the lives of others: Yaram in'i, Inmar, shuo, yurtte" ('Well, at least Inmar, they say, helps').

Inmar is one of the hypostases of the corporeality of the lyrical 'me':

Nosh mugory, ben, mugory, Napchem omyr so ogshory...

Achiz inmar, achiz ishan Achiz kötdzhozh, achiz veshan -

Pöyas'konen suro zemlyk

Kudiz ug s'oty buyganlyk... (Zakharov 2001: 176)
And my body, yes, my body, The thickened air is just it...

It is Inmar, it is Ishan, It is the very grief, it is affection, The truth mixed with deception That does not give rest...

In the second poetic collection, Karas (Honeycombs), by Petr Zakharov, the word image Inmar, despite the general mythological orientation of most poems, is presented fragmentarily, weakly associated with the traditional culture of the Udmurt people. It should be noted that Karas is a curious linguistic and artistic experiment in which Udmurt poems are accompanied by Russianlanguage substrings, often not very accurately made. Individual texts in the collection in terms of their meaning look dark, difficult to easily apprehend or interpret. This category of poem includes Kytyn övöl kuara ('Where There Is No Voice') (Zakharov 2010: 18-19). The attraction to the image of Inmar here is poorly motivated, reflecting the general artistic ambiguity of the author's idea. Inmar is probably actualised in connection with the metatheme of the imperfections of human life, receiving development in Karas, 
through which the main message of losses and disappointments is delivered.

The poem Kuke siz'o dzhökkyshetles' s'ures ('When They Wish You Good Riddance!') is interesting for its artistic reconstruction of the semantics of the image of Inmar (Zakharov 2010: 24-25). The text is also notable for the errors in Russian translation: "Kogda nas shlyut po skaterchnoy dorozhke, pripomnyu, chto nash zad krasivshe pereda". It seems that there was a language failure when preparing the Russian version: the poet seems to forget about the basic rules of word usage, violates the laws of Russian grammar, and significantly distorts the lexemes.

Such sudden powerlessness before the Russian language is apparently connected with the author's actualisation in the first lines of the poem in its Udmurt phraseological construction. Initially, the original meaning of the phraseology used (the requirement to leave, to get away) is semantically complicated by deep ideological confrontations. The artistic and meaningful 'struggle' between the Udmurt and the Russian languages correlates in the plot with the juxtaposition of the Christian Orthodox God and Pagan Udmurt Inmar. The 'darkened' poem, abundant in changes in the author's thoughts, continues the topic of the interaction/mutual repulsion of Udmurt and Russian cultures, which is important and productive for Zakharov because it accentuates the complexity of events in the mind of a priori ethno-forum mythological units and the Christian worldview. In 'When They Wish You Good Riddance!' the multiplicative reality of the worldview of the Udmurt individual can be felt as the phraseology of traditional beliefs merges with the desire of the author's 'me' to use Christian philosophical generalisations and conclusions such as the designation of human sinfulness and the inevitability of punishment.

Another option for the mixing of poetry and mythology is present in the sixth poem of Zakharov's Udmurt tunolen kyrdzhan"yosyz ('Songs of the Udmurt Shaman') cycle (Zakharov 2010: 42-43). 
The Udmurt gods Inmar and Kuaz', who give the lyrical hero secret knowledge, are narratively and contextually associated with the Sumerian/Akkadian Marduk. In his literary work, Zakharov often reduces heterogeneous mythological characters to subjects of culture, thereby intuitively emphasising antiquity and Nostratic nature as well as the civilisational 'competitiveness' of the traditional Udmurt worldview and folklore, and the artistic openness of its literature.

Inmar appears in the Utopian urban poem "Uzy-bory kis'ma val gorodyn..." ('Strawberries Ripe in the City...'). The space of the city is occupied by insects and worms, busy with affairs that are absurd and useless from the human point of view. Apparently by using such a comparison the poet parodies the life of the modern citizens of Izhevsk. In the poem, Inmar becomes a passenger on the tram, the route of which is the sky, the night, light, symbolically named Uruguay:

Kuar"yos ulys' taka-baka s'örys'

Potiz zor-papaly ukshas' tramvay

Inbam ulti gyldzh’iz so

kyrdzh'asa

So yardure, kytyn val

Urugvay.

Nosh tramvayyn pishtis'

kylbur"yosyn

Myniz Inmar, udmurt

kad', kunoye.

Kiz'il'ios mynda ik

tyl'yosyn

Salam nuiz so kyd'okys'

uye...

(Zakharov 2010: 124-125)
From under the leaves, from behind the shell

Out came a ladybird-like tram,

And it slipped with a song through the sky,

Onto the shores where Uruguay was.

And in the tram in the shape of bright poems

Inmar went on a visit like an Udmurt.

In innumerable lights, as

stars

He was carrying presents into those distant nights... 
It is no coincidence that Inmar is associated with poetry in this poem. For Zakharov, poetry is equivalent to God, life, love; its nature is magical, conjuring, sacred.

In Zakharov's third collection of poems, Kyrmush ('Wild bee') (Zakharov 2015), Inmar neither appears often, nor is he artistically significant. The content of this book suggests that Zakharov's poetry has changed direction towards a deeper discussion of social issues and coverage of recent Udmurt history. The mythological symbolism at this poetic turn remains unclaimed.

Inmar - a symbol of borderline semantics that combines pagan and Christian ideas about God - is very rare in the poems of Viktor Shibanov, one of the main ideologists of the ethno-futurist trend. Shibanov regularly refers to mythological characters of a "second row" that does not usually correspond to Christian or Orthodox contexts. In his debut book Vyl' uzh"osy öt'o ('From Case to Case') (Shibanov 1982), the mythological characters do not exist due to the internal and external constraints of social realism. In his Bertis'ko uyshore ('I am going back to Midnight') (Shibanov 1991) a whole gallery of mythological subjects is presented, among which there is no place for Inmar. Inmar does, however, appear in several texts in Shibanov's Ös ('Door') (Shibanov 2003), although his artistic functioning is minimised as a whole. In the sixth and seventh poems of the Yöl kis'tis'kem ('The Milk Spilled') cycle Inmar acts in a unified semantic context with Keremet, which embodies the evil principle of the universe. At the same time, the author's attention is more focused on the negative character with whom the lyrical 'me' enters into dialogue. The author perceives the opposition of Inmar and Keremet as an irrefutable existential reality, an axiological inevitability. The reciprocity of Inmar and Keremet is iconic - a person rejected by Inmar may not be protected by Keremet: 
Soin ik kot'ku Inmaren arte

Med keremet syloz.

Mynam soin

Kuddyr s'ulmys'

veras'keme pote.

So vaz'ysal: "Vordskid

bere uin,

Uyyn ik ul no buygat

esh"yoste".

"Soos van'zy in'i uzyr".

Nosh kin

Dan"ya tshukez addzh'ylytek,

So ush"yamon ke no, urod poet.

So vatsasal: "Kushtiz bere inmar

Mynam no yurtteme tynyd ug lu.

Gerdzh'as'kemyn mimur vyzhy no kuar

Nish ogaz'yn

kyldytis'kom: pispu.

Modos nachar bere, soku nachar

S’öd dun'n'eys' vyzhyosyd.
So always next to Inmar

Let Keremet stand.

I sincerely

Sometimes want to talk to him.

He'd say: "Just as you were born in the night, Live at night and calm your friends."

"They're all rich already."

"And who

Glorifies the morning, morning not seeing,

Although it is commendable, is a bad poet."

He would add: "If Inmar left you,

And I can't help you.

Connected, we're a deep root and a leaf,

And together we form a tree.

Once the trunk is weak, so weak

Your roots are in this black world."

(Shibanov 2003: 34-35)

Inmar in the poems of Anastasiya Shumilova, who represents the younger generation of Udmurt poets, occupies a very modest place. The new generation of national writers is far from both the 
religious and mythological foundations of the Udmurt world, and from any religion in general. Something of which the artistic existence of Udmurt mythological characters in Shumilova's creative discourse is indicative. Thus, Inmar ceases to be the centre of the universe and loses his sacred significance; as he comes to obey the desires and actions of the lyrical 'me', he is mortal and debased.

The presented study shows how complex the image of Inmar is to those who wish through art to understand its usage. Despite using Inmar frequently, Udmurt poets failed to create meaningful semantic contexts for the poetic use of Inmar; for example, mythological resources were not used and the system of Christian Orthodox representations was not fully activated.

\section{References}

Arzamazov, A. 2010. Fenomen vizual'nogo v sovremennoy udmurtskoy poezii (opyt analiza tvorchestva P. M. Zakharova) [The Phenomenon of the Visual in Modern Udmurt Poetry (Analysis of P. M. Zakharov's Poetry)]. Izhevsk: Udmurtskiy institut istorii, yazyka i literatury Uralskogo otdeleniya Rossiyskoy akademii nauk; Udmurtskiy universitet.

Il'yina, N. 2006. Khudozhestvennyy mifologizm besermyanskogo poeta M. Fedotova $v$ kontekste udmurtskoy literatury 1980-1990 gg.: Kand. Diss. [Poetic Mythology of the Beserman Poet M. Fedotov in the Context of Udmurt Literature of the $1980^{\mathrm{s}}-1990^{\mathrm{s}}$ : PhD Thesis]. Cheboksary: Cheboksary Universtitet.

Shibanov, V. 2003. Ös: kylbur"yos [The Door: Poems]. Izhevsk: Invozho.

Shibanov V., Vasil'yev, S. 1997. Pod ten'yu zerpala: diskursivnost', samosoznaniye $i$ logika istorii udmurtov [In the Shadow of Zerpal: Discursivity, Identity and the Logic of History of Udmurts]. Izhevsk: Udmurtia. Vol. 1.

Shklyayev, A. 2004. Literatura mifa i mify o literature: o nekotorykh formakh vzaimootnosheniy literatury i mifa [Literature of Myth and Myths about Literature: About Some Models of Relations between Literature and Myth]. In: Udmurtskaya mifologiya [Udmurt Mythology]. Izhevsk: Udmurtskiy institut istorii, yazyka i literatury Uralskogo otdeleniya Rossiyskoy akademii nauk, pp. 171-177. 
Vanyushev, V. 2004. Mifologicheskiye syuzhety i obrazy v udmurtskoy poezii. [Mythological Plots and Images in Udmurt Poetry]. In: Udmurtskaya mifologiya [Udmurt Mythology]. Izhevsk: Udmurtskiy institut istorii, yazyka i literatury Uralskogo otdeleniya Rossiyskoy akademii nauk, pp. 159-170.

Vladykina, T., Glukhova, G. 2011. Ar-god-bergan: Obryady i prazdniki udmurtskogo kalendarya [Year Circulation: Rituals and Celebrations of the Udmurt Calendar]. Izhevsk: Udmurtskiy institut istorii, yazyka i literatury Uralskogo otdeleniya Rossiyskoy akademii nauk.

Zaytseva, T. 2006. Proza Nikvlada Samsonova: mifopoeticheskaya obraznost' [The Prose by Nikvlad Samsonov: The Mythopoetic Imagery]. In: Sovremennaya udmurtskaya proza (1980-2000-e gody) [Modern Udmurt Prose $\left(1980^{s}-2000^{\mathrm{s}}\right]$. Izhevsk: Udmurtskiy universitet, pp. 25-56.

Zakharov, P. 2001. Vozh vyzh = Zelenyy most: stikhi, poemy, perevody [The Green Bridge: Poems, Long Poems, Translations]. Izhevsk: Invozho.

Zakharov, P. 2010. Karas = Soty: pesni udmurtskogo shamana [Honeycombs: Songs of the Udmurt Shaman]. Izhevsk: Invozho.

Zueva-Izmaylova, A. 1997. Udmurtskaya literatura $v$ kontekste yazycheskikh $i$ khristianskikh traditsiy [Udmurt Literature within the Context of Pagan and Christian Traditions: A Monograph]. Izhevsk: Udmurtskiy universitet.

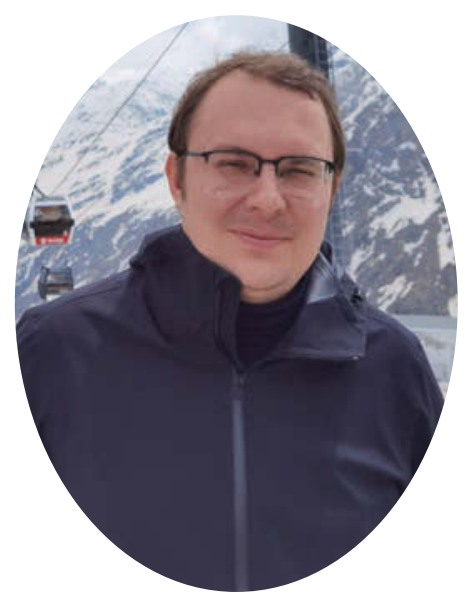

Aleksey Arzamazov ( $\mathrm{PhD}$ hab) is a professor, leader of the laboratory of multifactorial analysis and cognitive philology at the FRC Kazan Scientific Center, Russian Academy of Sciences. He is a specialist in literature in general and Udmurt modern literature in particular.

e-mail: arzami@rambler.ru 


\title{
Forest Spirits in the Udmurt Worldview
}

Tatiana Panina

e-mail: tipanina@mail.ru

\section{Tatiana Vladykina}

e-mail: tgvladykina@mail.ru

\begin{abstract}
Forest spirits are widely represented in the Udmurt traditional belief system. The present study is aimed at systematising traditional folk beliefs about the best-known mythological beings living in the woods, namely n'ulesmurt ('forest man'), palesmurt (lit: 'half-man'), and obyda ('forest woman'). The article provides a detailed description of the appearance of forest spirits, analyses their distinctive features and functions, and presents how beliefs about those mythological beings have evolved over the last centuries.
\end{abstract}

Keywords: forest spirits, n'ulesmurt, obyda, palesmurt, Udmurt mythology

\section{Introduction}

Forest spirits are widely represented in the Udmurt traditional belief system. The process of populating the forests with all kinds of supernatural agents is indubitably related to natural geographical features in the place the Udmurt inhabit and the activities they 
have been engaged in, for example hunting, an important means of livelihood for many centuries. The present study is aimed at systematising traditional folk beliefs about the best-known mythological beings living in the woods, namely n'ulesmurt (lit: 'forest man'), palesmurt (lit: 'half-man'), and obyda ('forest woman'). The study is based firstly on archive materials from the Udmurt Institute of History, Language and Literature, and the Institute for Udmurt Philology, Finno-Ugric Studies and Journalism at the Udmurt State University; secondly, on field data collected by the authors in different parts of the Udmurt Republic in the late $20^{\text {th }}$ and early $21^{\text {st }}$ centuries; and, finally, on various pieces of published research about Udmurt traditional culture. Comprehensive data including descriptive details of the forest spirits and unique folklore texts were collected by Russian and foreign researchers of the late $19^{\text {th }}$ and early $20^{\text {th }}$ centuries (for example, Yrjö Wichmann, Bernát Munkácsi, Nikolay Pervukhin, Grigoriy Vereshchagin, Uno Holmberg). As for contemporary studies by ethnographers and folklorists, not only do they provide some generalising characteristics of mythological beings and forms of worship, they also introduce new field records into scientific discourse (Vladykin 1994: 97; Shutova 2001: 95-96, 237-238; Vladykina 2009; Vladykina, Panina 2015; Panina 2017). Unique folklore and ethnographic data can also be found in dialectal collections of transcribed Udmurt texts published by linguists (Kel'makov 1981; Karpova 2005).

When conducting this research we adopted both synchronous and diachronic approaches. The article provides a detailed description of the forest spirits' appearance, analyses their distinctive features and functions, and presents how the beliefs about these mythological beings have evolved over the last centuries. 


\section{N'ulesmurt, 'forest man'}

Today n'ulesmurt, 'forest man', is unambiguously considered the main mythological being, who acts as a keeper and warden of the woodland. Depending on local traditions, this creature is also known by other names, such as tshatshtshamurt ('forest man'), n'ulesn'un'a ('forest father/uncle'), bydzh'ym n'un'a ('great father/ uncle'), n'uleskuz'o / tshatshtshakoz'ain ('forest master'), l'eshak (a Russian borrowing, one of the name variations of leshiy).

The forest spirit analysed here is believed to be invisible to the human eye in most cases, although it invariably appears before those who break any taboo. In folk tales, a person first hears a sudden loud noise and only then sees the spirit itself. In physical appearance it resembles a human being, generally an elderly man. However, it is able to change shape depending on the circumstances: in a forest it is as tall as the trees, in a meadow as short as the grass, and in a crowd a bit taller than people. If n'ulesmurt likes a person it looks like an ordinary man, otherwise it tends to take on a scary appearance (Vereshchagin 1995: 153). It can be either black and fearsome or as grey as a badger. It has a long beard and wears a white hat with a hole on its top so one can see the hairless crown of its head (Vereshchagin 1996: 89). It is also believed to have long equine ears, wear a long traditional coat called $a z^{\prime} a m$ or sukman and, unlike the leshiy of Russian belief (Levkiyevskaya 2004: 105), it is always girded with a black or multicolour woven belt (FE-1980:

Illustration 1. Picture by Valentin Belykh. N’ulesmurt (Forest man).

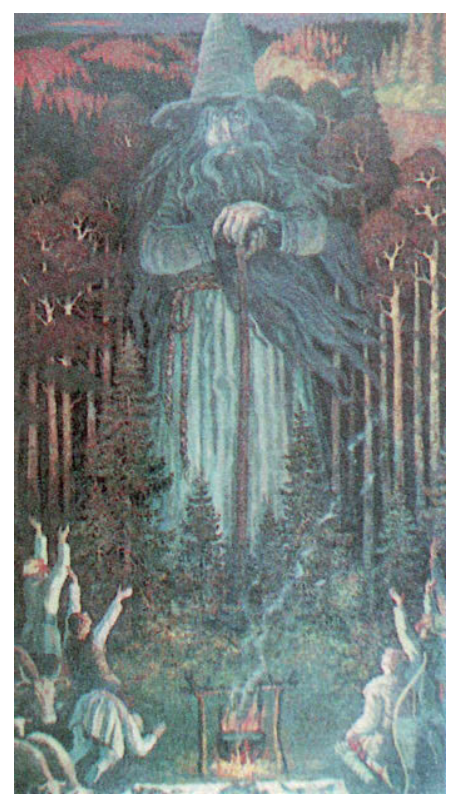


Selty district of Udmurtia. NB. 3. Pp. 94-96), which obviously serves as evidence of its greater proximity to the domesticated space, which is not typical of other spirits. It is believed to hold sway over other forest inhabitants, for example animals and birds can move anywhere it orders them to go. Sometimes n'ulesmurt gambles forest animals away and relocates their herds to other n'ulesmurts that inhabit neighbouring forests. It becomes extremely angry with hunters who laugh at a dead bear; in order to punish blasphemers it breathes life into the bear (Vereshchagin 1995: 94). Its whistle and shout can easily animate animals and birds killed by hunters (Vereshchagin 2001: 47, 48-49).

One of its distinguishing features, and a constant motif in Udmurt folk tales, is its ability to move rapidly: it can walk and run like the wind and fly in a whirlwind (Vereshchagin 1996: 175). A man raised by n'ulesmurt high in the sky exclaims that his hat has fallen down, and the forest spirit immediately replies to him that his hat is already seven or forty versts away.

The initially syncretic notion of n'ulesmurt as forest and wind deity emphasises that it is equivalent and identical to the spirit tölperi (derived from words töl 'wind' and peri 'spirit'). The last component of its name is of eastern origin, and apparently implies that the spirit of the wind is of more recent origin. Its distinctive characteristics overlap with those of n'ulesmurt, for example, they both hoot with laughter, and their appearances are generally accompanied by loud noise so that trees start to sway with the wind. While in the past they were split, today the images of these mythological beings have tended to merge (Volkova 1997: 56-57).

According to folk tales, God presented people with the wind to prevent the sunlight from being blocked by cobwebs, but the wind submitted to n'ulesmurt and began to blow too strongly, thus causing a whirlwind (Vereshchagin 1996: 130). The Udmurts living in the Glazov uyezd, Vyatka governorate (today's northern districts of the Udmurt Republic) believed that debris in the woods caused by terrible storms are the road followed by a n'ulesmurt wedding 
procession (n'ulesmurt koshkiz s'uane[n]) (Pervukhin 1888 (1): 77). The belief that wood debris occur in places where nyulesmurt moves around has persisted to the present day. The Udmurt try to keep away from these sites in order to avoid trouble or bad luck, such as becoming suddenly paralysed.

The whirlwind can stop if a person utters the magic formula Tirepurte bordam! ((I have) my axe and knife by me!) or throws a knife or axe at it. In Udmurt mythological narratives tölperi itself or its father can unexpectedly appear in front of people in the guise of an elderly man. It demonstrates the weapon thrown into the whirlwind and rebukes them for attempting to kill it. In another story, a hunter throws a knife into a whirlwind, but then suffers the consequences when tölperi unroofs his house and household buildings. Later tölperi explains that the hunter stabbed it with a knife when it was driving hares into the hunter's trap (Bogaevskiy 1890: 6364). During a raging storm the northern Udmurt would go outside and shout, "Grandfather [the forest man], do not harm me!", and the family would expect the house buildings to be safe from the storm.

Like other mythological beings, n'ulesmurt is an ambivalent spirit, it can both do considerable harm and also bring substantial benefit. It is always hostile towards people who misbehave and break accepted norms, in which case it takes them over the forest or tickles them to death. It greatly dislikes being mentioned as l'eshak (derived from the Russian word leshiy), which demonstrates a lack of respect. N'ulesmurt is scared stiff of dogs or even a small piece of dog fur. There is a belief that it is more frightened of a dog than of a cross (Pervukhin 1888 (1): 84), so, before going hunting or forest harvesting, the Udmurt sew a piece of dog fur into their outerwear or wind it into their onuchi (cloth wrapped around the feet inside the boots) to protect themselves, and sew it round their gunpowder pouches. In folk tales the forest spirits cannot harm people until they take off their dog fur mittens (Pervukhin 1888 (1): 81-82). 
N'ulesmurt is merciful to people if they offer it a propitiatory sacrifice (a black duck, goose, black cock, or hazel hen) (Pervukhin 1888 (1): 77). In these cases, it assists in hunting wild animals, treasure hunting and finding lost cattle. If a pack of wolves came down to a village, the locals vowed to offer two foals and ducks as sacrifices to n'ulesmurt. The sacrifice was invariably performed only by men in the forest.

According to folk belief, n'ulesmurt often acts as a conveyor of supernatural knowledge: a trainee is carried over the forest by someone invisible (FWM: Yakshur-Bod'ya district of Udmurtia, 1996) and as a result gains supernatural knowledge and the ability to use magic and witchcraft. As a token of the acquired supernatural power, they are awarded a white scarf and an antique silver coin (Pervukhin 1888 (1): 85). Those who are not capable of mastering the supernatural knowledge are believed to become insane.

N'ulesmurt is an ardent devotee of Udmurt "pagan" religious beliefs. It takes a trainee over the forest and indicates the improprieties the Udmurt are committing (for example, disregard for the customs of ancestors, wearing coloured clothes instead of white garments, violating taboos, etc.). However, this does not prevent it from attending church services, which it leaves before the cherubic hymn (Vereshchagin 1997: 209-210). According to contemporary data, only people with magical powers (tuno, pel'l'as'kis') are capable of seeing it in the church. It generally appears in the guise of a man wearing black clothes and turns a somersault before leaving the church (FWM: Yakshur-Bod'ya district of Udmurtia, 2006). With the spread of Christianity, n'ulesmurt merges with the image of Saint Nicholas.

In the past, the northern Udmurts sought n'ulesmurt's protection practically every week. On Tuesdays, Thursdays or Sundays, they enacted the rite s'iyon potton, 'taking food out' (Vereshchagin 1998: 212-213). A housemistress baked saltless pancakes of unleavened bread and wrapped them into a piece of white canvas, which the housemaster took away to a field fence where n'ulesmurt 
was believed to walk. While performing the rite, certain rules are compulsory, for example, it was prohibited to talk to passers-by or to meet people crossing a road. The pancakes were placed on a tree stump or on a narrow shelf specially made of small branches as well as being placed between fence sticks. Afterwards, the man made three deep bows but without crossing himself. Birds flocking to the sacrifice were a token of n'ulesmurt's favour.

The custom of offering a sacrifice to n'ulesmurt prior to the gardening season has survived to this day. In order to get a rich harvest the housemistress bakes pancakes out of egg yolks and puts the pancakes and a piece of bread on a fence post or a tree fork. Some Udmurt still believe that people who maintain contact with the n'ulesmurt produce good yields (FWM: Yakshur-Bod'ya district of Udmurtia, 2006).

During calendar holidays the Udmurt worshipped not only their supreme gods (Inmar, Kyldys'in, Kuaz), but also n'ulesmurt. In addition, there were special days to worship and offer sacrifices to the forest spirit, for example, n'ulesmurt n'iman'n'ik ('n'ulesmurt's day'), in which a red bull was slaughtered on the third or fourth day after Trinity Sunday in honour of n'ulesmurt (Pervukhin 1888 (2): $26,68)$. In Udmurt prayers n'ulesmurt is mentioned along with the triad of supreme gods and the guardian spirit Vorshud (Pervukhin 1888 (3): 23). The Udmurt asked it to calm storms, to divert whirlwinds and prevent crops being damaged by storms. N'ulesmurt was also supposed to protect the livestock allowed to graze in the forest (Pervukhin 1888 (3): 23). If the cattle went astray, an extremely large bast shoe was hung on a spruce as a propitiatory sacrifice to n'ulesmurt (Bogaevskiy 1890: 67). The symbolism of the bast and the custom performed are similar to those in Russian indigenous culture (Vinogradova, Tolstaya 2004: 81).

According to folk narratives and mythological texts recorded recently in different local traditions, beliefs about n'ulesmurt are still widely held, although they are definitely undergoing transformation. Thus, in the late $19^{\text {th }}$ century n'ulesmurt was followed by 
a wolf (Vereshchagin 2001: 44) and was believed to be extremely scared of dogs. Currently it is accompanied by a pack of dogs, the colours of which emphasise their otherworld nature (grey, black and spotted): “...a grey, a black and a white-necked dog suddenly appeared. Someone like a human followed them, he had black hair and a black beard, he was wearing sukman and was girded with a belt with red, blue, and green stripes fringed with tassels. A rifle was strapped to his back" (FE - 1991: Sharkan district of Udmurtia. NB. 4. Pp. 15-16). When describing the forest man's appearance, respondents provide specific details that correspond to folk beliefs about mythological beings: "We, two girls, were going on a cart pulled by a bull. I feel that the forest man was walking along. He had a white stick, a beard, a pointed hat, and a black belt" (FE - 1980: Selty district of Udmurtia. NB. 3. Pp. 94-96.). Contemporary folk narratives also emphasise the idea that people who are known to have supernatural knowledge can easily establish communication with the forest spirit: "In my childhood we went cranberry picking with an elderly man. We knew he could talk to the forest spirit. We sat down to have a rest and the old man said: "You guys, do not be afraid if I invite someone”. He and an elderly man sat down some distance from us and spoke some strange language. It lasted about one hour. Then the forest man stood up and left, and a fierce wind blew up. Trees bent to the ground" (FE - 1991: Sharkan district of Udmurtia. NB. 4. Pp. 15-16).

N'ulesmurt performs didactic functions as before, but today it is considered to be more responsible for the environment: "My father used to tell me [this story]. He said he was harrowing near the forest. He found a crow's nest and took it. He only went two or three steps into the forest and got lost. He said he was walking around the forest and coming to the same place. Then he saw a grey-bearded elder sitting on a tree stump and counting money. "Why are you walking around?" the old man asked. "I went astray and cannot get out of the forest", he said. "And why have you taken the crow's nest?" the old man asked. "I don't know", my father said. "Never 
do it again". And then suddenly, he said, both the tree stump and the elder disappeared. And my father found himself at a fence. He had met the forest man then" (FE - 1988: Igra district of Udmurtia. NB. 1. Pp. 118-119).

Contemporary beliefs about n'ulesmurt are dependent on multiple traditional elements (the interrelationship between pre-Christian and Christian beliefs, interethnic relations, the influence of modern mass media and new information technologies), but despite the fact that current ideas about this mythological character are fragmentary and incomplete, the spirit's dominant traits have been preserved in complete agreement with the traditional belief system. The following example amply illustrates the proposition. A woman, who falls asleep in the forest at noon, is awoken by a creature that an informant refers to as töd'y kylchin (white, i.e. holy, tutelar deity) only because of its key attribute, i.e. its white clothes, and emphasises that white clothes are a good omen, whereas black is an evil one. Moreover, it is perfectly obvious that the supernatural agent mentioned is n'ulesmurt as it retains distinctive features (it is tall, it wears a soldier's coat, dances, and wakes a person who goes to sleep in the forest) (Shutova et al. 2009: 207).

\section{Palesmurt ('half man')}

Another forest spirit in the Udmurt mythology is palesmurt ('half man') / palkuas ('one ski'). Folklore and ethnographic materials demonstrate that it ranks second among all the other mythological beings inhabiting woodlands considering the prevalence of beliefs about it and the frequency of mentions in Udmurt fairy tale and non-fairy tale prose.

Folk beliefs about palesmurt vary in different regions of the Udmurt Republic. Most of the information was collected from the Udmurt living in the northern and central districts, which are covered by forest. According to the data recorded there palesmurt has 
a highly specific appearance, its main distinguishing feature is halfness, i.e. it is represented as an anthropomorphic being, dissected along the spine. Folklore data provide a more detailed description: palesmurt is believed to move by jumping on one foot; it is supposed to have only one arm, one eye and one ear as its head is half-split, but its nose and mouth are complete (Pervukhin 1888 (1): 88); and one can see all its internal organs (Vereshchagin 2000: 215), in particular its lungs and liver (FE - 1982: Yakshur-Bod'ya district of Udmurtia. NB. 5, p. 68) which fall out of its body (RA UIHLL: F. 762. NB. 11, p. 5). Implicit information about its unusual physical appearance is given by describing its ski tracks: "They say, when it travels across the snow, it leaves one ski track" (FDE - 1988: Igra district of Udmurtia. NB. 2, Pp. 39-40). The Udmurt living in the central part of Udmurtia believe that palesmurt has a whole body, with one transparent half (Kel'makov 1981: 118). As a rule, its gender identity is not established, although the evidence collected in Yakshur-Bod'ya district demonstrates that palesmurt is a male being (FE-1982: Yakshur-Bod'ya district of Udmurtia. NB. 5, P. 68).

According to our current studies, the Udmurt inhabiting the southern regions with low forest cover either have never heard of palesmurt, or believe it to be a giant monster: "They say that once palesmurt bumped into the gates. They say it is extremely big - as tall as a haystack" (FE - 1984: Alnashi district of Udmurtia. NB. 3, P. 48); "My maternal grandmother used to tell me that once she was returning from haymaking at twilight, it was almost dark, and she was walking around the place where people could see or hear weird things. She said she was running along the road, and it [palesmurt] was following her behind the woodline. It followed her to the bridge but it could not cross the river. She said, it was extremely tall" (FWM: Alnashi district of Udmurtia, 2015). In the southern Udmurt folk tales about ancient settlers, palesmurt is associated with the mythical giant alangasar. "In the old days our land was covered by dark, impenetrable forests. Those forests were inhabited by palesmurts called alangasar. They were as tall as fir trees, they 
could almost reach the sky, they were half-bodied, and their insides fell out of their body" (Atamanov 1981: 55). This plotline develops alongside another storyline about giants who turn into legendary warrior heroes and clan leaders (Vladykina 1998: 169-239).

Folk beliefs about half-beings are worldwide spread: they are typical of the traditional cultures of other indigenous peoples inhabiting Eurasia, Africa, Australia, Oceania, and North and South America (Berezkin 2011: 155-156). However there is a significant difference between those beliefs about half-creatures. In the Central part of the Old World (Europe, North Africa and Asia, with the axis passing through the Mediterranean and across Indonesia) they are presented as positive characters in fairy tales. They are ultimately able to restore their physical integrity in the final part of narratives. Whereas in the southern (south of the Sahara) and northern parts of the Old World (a large part of Eurasia from the Baltic Sea to the Pacific Ocean, and South-East Asia) mythic halfbeings are generally presented as dangerous, and hostile creatures of the underworld (Berezkin 2011: 155-156). In the Evenki epos, for example, malevolent spirits of the Lower world - avakhi, ogengaare described as huge creatures whose appearance can easily make people scared of them: they have one huge iron leg, one arm in the middle of their chest, one eye in the middle of the forehead, and one ear at the back of the head (Martazova 2009: 143).

Udmurt beliefs and folklore texts confirm the above observations, made by Yuriy Berezkin: unlike n'ulesmurt, palesmurt is always considered hostile towards people, it can frighten or tickle them to death, and contacts with it are believed to foreshadow misfortune. A vast number of memorates (bylichka) concerning experiences of encountering palesmurt finish by breaking tragic news. "We were harrowing near small ravine called Izishurn'uk, I was about 12 . We heard somebody crying 'oh-oh-ay'. The cry was heard closer and closer. [My friend called] Zoya said to me, 'Fira, let's go back home'. So we came back home around lunchtime. We met a woman called Afinia. She said, 'You should have answered 
with "last year's aspen leaves [go] down the river". She made us return to that place. If you don't answer, the palesmurt, it will reach you and tickle you to death. So we went to that place again, with Afinia. She went into the forest and either said something or did not, but immediately it became quiet there. We finished harrowing and went back home, trying to predict who was going to have trouble. Zoya came into the yard - her mother had died in the yard. An abscess turned out to have developed on her chest and it burst. The palesmurt yelled terribly. We both heard it yelling" (Tronina 2007: 138).

A palesmurt possesses characteristic features typical of demonic beings: people encounter it only in the forest, which is supposed to be a territory belonging to the otherworld, and this unexpected meeting generally comes at twilight or at noon. Moreover, not only does it emerge suddenly, it also disappears instantaneously (Pervukhin 1888 (1): 88-89). Before it becomes visible, one can hear some strange sounds, noise, screams, crying, or a person can even be called by name. According to folklore texts, its speech is inarticulate and poorly developed and mainly consists of interjections and exclamations.

People are supposed to follow a set of rules in order to protect themselves in the forest. For example, it is generally accepted that you should not shout for any reason, make noise or respond to any kind of cries, exclamations or calls, otherwise you may encounter demonic beings, including palesmurt. If one meets a palesmurt anyway, one has to strip naked (FE - 1982: Yakshur-Bod'ya district of Udmurtia. NB. 2, Pp. 50-51) or wear shoes on the wrong feet (FE - 1985: Alnashi district of Udmurtia. NB. 1, P. 57). These actions are aimed at removing the evidence of belonging to the human world and obtaining the characteristic features of the other world. One can also escape death by climbing over a village fence (FWM: Igra district of Udmurtia, 2005), which is interpreted as the boundary between civilised, domesticated space, built by men and their activities, and wild and hostile space where malevolent 
spirits live. Palesmurt cannot see and harm people hiding behind a mountain ash or rowan tree, which are believed to have apotropaic power and can protect people from malicious agents (RA - UIHLL: F. 519. P. 312). If a palesmurt asks a traveller where it should go, or asks the traveller where he or she is going, they are expected to answer briefly 'downriver', or just point towards the mouth of a river. If a palesmurt is sent to the source of a river, it can return and tickle the person to death (Atamanov 1981: 55). However, the contemporary data collected from young Udmurt demonstrate that folk beliefs are being transformed: "They say if you happen to meet a palesmurt, you should direct it upriver!" (Tronina 2007: 82). Other possible responses to avoid the negative effects of contact with this supernatural being are: "Last year's aspen leaves go down the river!" or an extremely brief reply, a truncated version of this, "Last year's" (Tronina 2007: 138). Sending malevolent spirits downriver is a well-known motif in Udmurt mythology. The river is regarded as a specific route to the underworld in most indigenous cultures (Vinogradova 2009: 416). According to the Udmurt, the river connects the human world with the upper and lower worlds (Vladykin 1994: 75; Napol'skikh 1992). These beliefs are reflected in, for example, Udmurt calendar rites (Vladykina, Glukhova 2011: 144) and healing rituals (Panina 2014: 74-76).

As far back as the late $19^{\text {th }}$ century Nikolai Pervukhin mentioned that folk beliefs about palesmurt were consigned to oblivion as they had been gradually disappearing among the Udmurt inhabiting the Glazov Uyezd in Vyatka Governorate (today the northern districts of Udmurtia) due to the considerable influence of local Russian folk culture (Pervukhin 1888 (1): 89). Contemporary field studies confirm this situation in the north-western districts (for instance, Krasnogorskoye and Yukamenskiy districts) where interviewees reported that today it is almost impossible to encounter palesmurt because of the radical change that has occurred recently. Forests have become scarce while the number of motor vehicles, such as tractors, conversely, has dramatically increased. Neverthe- 
less, the archival materials of the Institute of Udmurt Philology, Finno-Ugric Studies and Journalism of the Udmurt State University (Izhevsk, Russia), and contemporary field studies amply demonstrate that folk beliefs about palesmurt have successfully persisted down the centuries in some parts of the Udmurt Republic (for example, Igra, Yakshur-Bod'ya, and Debessy districts). People still tell stories about unexpected and undesirable meetings with this forest demon. Field studies clearly demonstrate that beliefs about mythological beings are gradually changing, a transformation process that generally occurs among the young.

\section{Obyda ('forest woman')}

Although obyda is much less famous than the forest beings analysed above, it is of great scientific interest for several reasons. First, despite diverse and valuable research into Udmurt mythology and folk belief, obyda has not thus far been a subject of intensive study, either by folklorists or by ethnographers. Researchers either mention it without going into detail or provide extremely fragmentary information. The only exception is a recent article by Tatiana Vladykina titled "The Bee in Udmurt Mythoritual Practice and Folklore", wherein the obyda is considered a protector of bees and a helper in wild-hive beekeeping (Vladykina 2016: 149-150). Secondly, there is a marked trend towards promoting the image of obyda in contemporary pop culture. For example, in Tol Babay's residence, in Sharkan, one of the most popular winter tourist destinations in the Udmurt Republic, visitors are entertained not only by the famous New Year characters Tol Babay ("Winter grandfather", similar to Father Christmas) and Lymynyl ("Snow maiden'), but also by an obyda that resembles the baba yaga from Russian fairy tales. The Centre of Udmurt Culture, located in the village of Lyuk in Balezino district, organises visits to a local spring, and there, the participants meet an obyda introduced as 
the spring keeper. Another example, a museum guide in the guise of obyda conducts excursions for children in Glazov Museum of Local Lore (Nelidova 2008); in kindergartens during art classes, obyda is presented as a beautiful and gracious lady wearing a traditional Udmurt dress (Alekseeva 2016). These examples clearly demonstrate that contemporary ideas of obyda vary radically. On the one hand, this forest spirit is believed to be similar to Russian baba yaga or kikimora, i.e. an ugly tousle-haired woman wearing ragged clothes, while on the other hand it is presented as a pretty woman. In view of the current situation, the following questions arise: who is obyda according to traditional Udmurt folk beliefs, and what factors underlie the modern interpretations of its image? When conducting the research we rely both on textual and on linguistic data to answer these questions.

The earliest mention of obyda is due to Russian ethnographer of German origin Johann G. Georgi in the $18^{\text {th }}$ century. He wrote briefly about forest beings called Palas murt (half-man), and about Alida (leshiy), which had only one leg, turned backward, one big eye and one breast, which was so large that it could suffocate people when it was pressed into their mouths (Georgi 2007: 96). This information requires some clarification: firstly, as the researcher did not speak Udmurt, he was not quite accurate in writing the names of the mythological characters - palesmurt and obyda respectively. Secondly, their brief description is a sort of summary of features that characterise both beings, which makes the information rather ambiguous; in fact, the human-like half-creature with one leg, arm and eye is palesmurt, while obyda, according to folk belief, is a forest female creature with feet turned backward and huge saggy breasts, which it threw over its shoulders. It is noteworthy that mammary hypertrophy is one of the characteristic features of female demonic characters. Mythological beliefs about shaggy female creatures with overly large saggy breasts are widespread in traditional cultures of Eurasian peoples. They are to be found in the mythology of the Turkic peoples (Dyrenkova 2012: 231), for example, of the Bashkir 


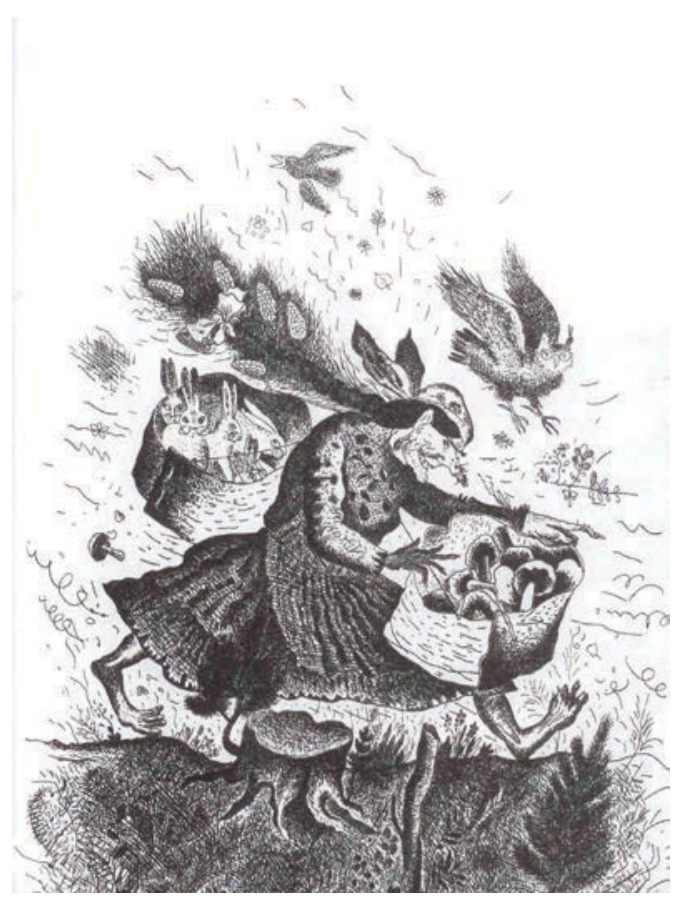

Illustration 2. Picture by Mensadyk Garipov. Obyda (Forest woman).

(albasty, shurale) (Rudenko 2006: 271; Khisamitdinova 2016 : 108, 218), the Altaians and Teleuts (almis) (Dyrenkova 2012: 235); in the folklore of peoples inhabiting the Caucasus (Shemshedinov 1910: 152), as well as in Slavic (boginka, rusalka, lisunka) and FinnoUgric traditions (ovda, vir'-ava) (Afanas"yev 1868: 343; Holmberg 1927: 438-439; Zelenin 1995: 213; Petrukhin 2005: 321; Toydybekova 2007: 176-178). Feet turned backward as an abnormal characteristic is also considered a distinctive attribute of otherworldly beings, for instance this feature is typical of demonic characters in the mythology of the indigenous peoples of the Volga-Ural region, such as the Mari ovda (Holmberg 1927: 183) and Bashkir yarymtyk (Khisamitdinova 2010: 382). These features are particular manifestations of basic semantic binary oppositions which are characteristic of an archaic worldview (human - nonhuman, us - them). There have been suggestions that Mari beliefs about ovda are based on historical facts about an ancient indigenous people inhabiting the territory between the Volga and the Vyatka Rivers in approximately the $10^{\text {th }}-11^{\text {th }}$ centuries (Aktsorin 1967; Toydybekova 2007: 178), but this theory seems unlikely. 
Illustration 3. Picture by Vladimir Nagovitsyn, Obyda (The forest woman).

During the first stage of the research process we selected a number of texts about this mythological character and discovered that there is a quite scant collection of Udmurt folk beliefs and narratives about obyda. we found data only in the Folklore Archive of the Udmurt Institute of

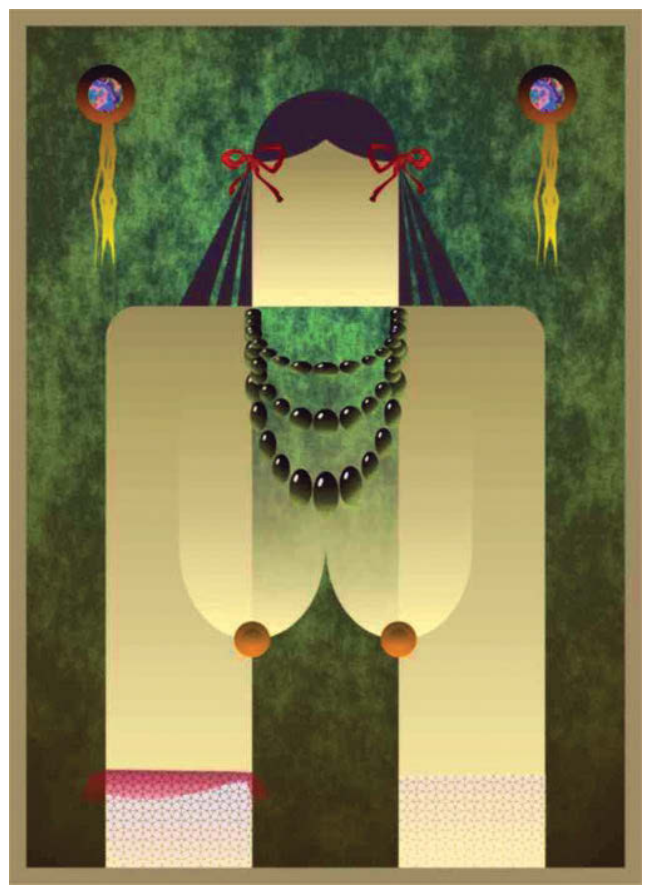
History, Language and Literature (Izhevsk) and in some published collections of Udmurt folklore texts (Gavrilov 1880; Wichmann 1901 (1), 1901 (2); Udmurtskiye narodnyye skazki 1948; Udmurt kalyk vyzhykyl"yos 1954; Sto skazok udmurtskogo naroda 1960; Udmurtskiye narodnyye skazki 1976). However, further analysis showed that the actual number of folklore texts about obyda is far less than the total number found, because one and the same folk story 'migrated' from one collection to another, often with no reference to the original source. Moreover, even in those books where compilers provide a commentary on the texts, the original is sometimes given incorrectly. For example, two out of three texts about obyda from the collection of Udmurt fairy tales (Sto skazok udmurtskogo naroda 1960) published in Russian contain false information about their origin. In fact, the fairy tales "The man and obyda" and "The soldier and obyda" are translated 
versions of folklore texts from one of Yrjö Wichmann's works (Wichmann 1901 (1): 56-57, 60-61), and not from Vyacheslav Gorbushin's collections, as the compiler Nadezhda Kralina states (Sto skazok udmurtskogo naroda 1960: 296). The Udmurt tale "Obyda the Crone" was also republished with some revisions providing no information on its source (Udmurt kalyk vyzhykyl"yos 1954: 62-63), that is "Folklore Texts, Rituals and Beliefs of the Votyaks from Kazan and Vyatka governorates", which was originally published in 1880 (Gavrilov 1880: 58-59).

The found originals have allowed us to clarify crucially important information, specifically when and where those texts were collected. All of them turned out to be recorded outside the Udmurt Republic in the late $19^{\text {th }}$ century: Yrjö Wichmann conducted field research in Bol'shoy Karlygan, village located in the Mari-Turek district of the Mari El Republic, while Boris Gavrilov recorded his fairy tale in the village of Tsip"ya, in the Baltasi district of Tatarstan, which borders Mari-Turek district. Thus, the researchers interviewed a group of local Udmurt who had direct contact with representatives of other ethnic groups, i.e. the Mari and Tatars. Moreover, in Mari folklore, ovda is one of the best-known mythological characters. Depending on local variations, ovda is believed to be an evil spirit (male or female). It can also be a forest female with saggy breasts that it throws crosswise over its shoulders, or a little owl that once used to be a man whom God turned into a bird as a penalty for some faults (Moisio, Saarinen 2008: 438-439), or a female creature with huge breasts, long hair and a shaggy coat (Bushkov 2014: 102). Researchers of Mari traditional culture note that folk stories about ovda are still widespread in rural communities (Toydybekova 2007: 176-178).

Linguists unanimously agree that the word obyda is not of Udmurt origin. Rifkat Akhmet'yanov suggests that the Mari words ovda/ovyda/abda, 'mischievious spirit', the Tatar atapa, 'unspecified spirit, devil', the Chuvash upăte, 'leshy, forest spirit', and the Udmurt obyda, 'forest female being' emerged in these 
languages as ancient Turkic borrowings from Buddhist literature deriving from the Sanskrit word amithaba, 'spirit of nature' (Akhmet'yanov 1981: 19). Adopting a phonetic criterion, the Finnish researcher Yrjö Wichmann suggested that the Udmurt word obyda came from the Chuvash language, and, moreover, the Mari words ovda and abda could also originate from Chuvash (Wichmann 1903, 89). This opinion is shared by Mikhail Fedotov, the author of the etymological dictionary of the Chuvash language (Fedotov 1996: 282). However, Fedor Gordeev puts forward a diametrically opposite hypothesis: he compared the Mari word ovda with the Ossetian lexemes ävdiiw and ävdew, 'demon, sorcerer', and suggested that ovda could originate from a ProtoOssetian (Sarmatian) source, and that the Chuvash word upăte/ opăte could come from Mari (Gordeev 1967: 201). However, other linguists refuted Gordeev's idea as it ignored a phonetic law: in the Mari language the Chuvash occlusive -p-/-b- transforms into the labiodental -v (Fedotov 1996: 282). Taking into account Yrjö Wichmann's conclusions, the Udmurt lexicologist Ivan Tarakanov considers that the word obyda is a Turkic-Bulgarian borrowing (Tarakanov 1982: 37). Nevertheless, this hypothesis raises some serious doubts. If it was a Bulgar loan word, it would be spoken in most Udmurt dialects. It presumably appeared in the Udmurt language as a result of interethnic contact with the Mari. According to the history of the vocalism of the first syllable in Udmurt dialects, to avoid an abundance of the vowel $o$ in the Udmurt vowel system the primary ${ }^{*} o$ had transformed to $u$ by the $15^{\text {th }}$ century (Kel'makov 1993: 17). This indicates that the word obyda could be borrowed long after this period, otherwise it would have changed into ubyda. Moreover, this lexeme occurs only in peripheral southern Udmurt dialects that are geographically distant from each other, namely in Shoshma dialect (spoken in Baltasi district of Tatarstan, Ivanovo district of the Republic of Mari El, and Malmyzh district of the Kirov Oblast) and in Krasnoufimsk dialect (Krasnoufimsk district of Sverdlovsk Oblast). In the former dialect it refers to 'monkey' or 
a 'forest mythological being', while in the latter it is used to describe a female mythological creature with huge saggy breasts (Nasibullin 1978: 130). This can be explained by the fact that the Shoshma and Krasnoufimsk local groups of Udmurt were considerably influenced by the Mari as they have been residing together for a prolonged time. It also provides indirect confirmation for the hypothesis that the Udmurt moved to the territory of modern Sverdlovsk Oblast with the Mari after the fall of Kazan in 1552 (Nasibullin 1978: 86). Having analysed the use of the particle ben (Udmurt ben 'yes', 'indeed') in the Udmurt dialects, Sergey Maksimov argues that the Krasnoufa Udmurt moved away from either the region where the Arsk (Trans-Vyatka) Udmurt currently reside, or from other southern Udmurt territories (Maksimov 2009: 73).

In Udmurt folklore texts obyda is presented as a forest creature who gives a human being assistance, and as a supernatural being similar to Russian baba yaga. The narratives provide neither general nor detailed description of the mythological being's appearance, but indirectly indicate that obyda comes from a large family. According to one folktale, obyda asks a man to make a wedding feast in the forest, specifically to bring the necessary tableware, to cook special dishes and to brew honey beer. The arrival of the wedding procession is accompanied by typical signs that indicate the presence of beings belonging to the demonic world: a fierce storm breaks out and blows trees down, so that the land starts to thrill. In Udmurt traditional culture the deafening noise and sudden changes in the weather are generally interpreted as evidence confirming the unexpected emergence of the forest master, n'ulesmurt.

Moreover, both n'ulesmurt and obyda are believed to bring good luck in wild-hive beekeeping. The Udmurt used to petition n'ulesmurt for good luck in beekeeping and hunting, alongside asking it to preserve grazing cattle and sheep in summer. In Udmurt folklore texts obyda shows a unique tree to a man, which he is to hollow out as a wild-hive. According to one story he makes three hives, each three arshins long (approximately 2 meters long) 
(Wichmann 1901 (1): 56), and according to another story nine wild hives (Wichmann 1901 (1): 59). The man follows obyda's advice and achieves phenomenal success: bees occupy all the hives because the tree that obyda found turns out to be a tree king (pispulen kunez). Udmurt texts about obyda's protection were also recorded, as mentioned above, in Mari-Turek district of the Mari El Republic, where there is widespread belief among the rural Mari that ovda can help people with the housework and on the farm, assist in keeping livestock, look after children and teach the Mari how to get money and hunt (Toydybekova 2007: 177).

Obyda's assistance is a dominant motif in the Udmurt folklore texts considered here. For example, one narrative starts with a man who wakes a sleeping obyda and thus saves it from a bear. As a token of gratitude it later helps him avoid long military service, presents him with a valid passport and returns him home (Wichmann 1901 (1): 60-61). In another story, obyda thanks a man for preparing a wedding feast and foretells that he will become fairly wealthy. Indeed, he largely succeeds in beekeeping and becomes a prosperous merchant (Wichmann 1901 (1): 56-57). This motif is also found in Mari traditional culture. For example, the Mari who lived in the village of Sernur in the Urzhum uyezd of Vyatka governorate believed that ovda often got its shaggy hair caught in a fence and generously rewarded people for setting it free (Bushkov 2014: 102). Mythological tales about ovda riding horses, often to death, all night long are widely spread among the Mari. In order to catch a mysterious rider the horse's back is smeared with tar. Ovda expresses gratitude to everyone who let her get off a horse, and curses those who decide to take its life (Toydybekova 2007: 177). Udmurt folk prose also comprises stories about mysterious night riders, but they generally refer to other mythological beings such as palesmurt and gidmurt (Udmurt: gidmurt, 'cattle barn spirit'). Folk tales about horse theft committed by demonic beings are widely distributed in the mythology of Turkic peoples as well, for example, in Tatar and Bashkir belief systems shurale and 
yarymtyk (Rudenko 2006: 269; Khisamitdinova 2016: 219) ride horses at night completely exhausting them.

In the Udmurt fairy tale "Obyda the Crone", obyda is presented as a devourer of people. In this regard it is functionally similar to other mythological characters such as kalmyk kyshno (literally: 'a Kalmyk woman'), kukri-baba (lit: 'a crooked old woman'), kuz'pin'omurt (lit: 'a being with long teeth') and iskalpydomurt (lit: 'a being with cow's legs'). According to the folk tale, a childless old man carves a son named Vanka (a diminutive of the Slavic name Ivan) from a log and sends him to plough. At that moment he is abducted by obyda who asks her daughter to roast the boy in a stove, but he cunningly deceives them and burns both of them. The narrative motifs of this tale partially correspond with East Slavic tale variants \#327A and 327C included in the Comparative Index of Plots: East Slavic Tales and international motifs G512.3.2 (Ogre burned in his own oven), and G512.3.2.1 (Ogre's wife (daughter) burned in his own oven) from Stith Thompson's Motif-Index of Folk-Literature (Thompson 1955-1958).

It is the Udmurt text's close similarity to East Slavic fairy tales that explains why obyda is almost identical to the Russian baba yaga in contemporary popular culture. The lack of detail on what obyda looks like and undeveloped ideas about this mythological character in the territory of Udmurtia contributed to the fact that it is now described as the Russian baba yaga. As regards the descriptions of obyda as a graceful girl wearing Udmurt traditional costume, they were probably influenced by folk tales in which obyda behaves in a kind and friendly way towards a human providing him with generous help.

The study shows that the motifs found in Udmurt folk tales about obyda are basically similar to those of Mari texts about ovda. However, unlike Mari folklore, in which ideas about ovda are well developed, Udmurt beliefs about obyda are not widespread. There are sparse text data recorded only in the late $19^{\text {th }}$ century from local groups of Udmurt living outside of Udmurtia and having 
direct contact with the Mari population. Since the middle of the 20th century, information about obyda has become available to the wider public due to the collections of Udmurt fairy tales published both in Udmurt and Russian.

\section{Abbreviations}

FWM - (Authors') fieldwork materials

F - file

$\mathrm{NB}$ - notebook

$\mathrm{P}$ - page

FE - Folklore expedition (Folklore Archive of the Institute of Udmurt Philology, Finno-Ugric Studies and Journalism of the Udmurt State University, Izhevsk, Russia)

RA UIHLL - Research Archive of the Udmurt Institute of History, Language and Literature, Udmurt Federal Research Centre of the Ural Branch of the Russian Academy of Sciences (Izhevsk, Russia)

FDE - Folklore and Dialect. Expedition (Folklore and Dialectal Archive of the Institute of Udmurt Philology, Finno-Ugric Studies and Journalism of the Udmurt State University, Izhevsk, Russia)

\section{References}

Afanas'yev, A. 1981. Poeticheskiye vozzreniya slavyan na prirodu. Opyt sravnitel'nogo izucheniya slavyanskikh predaniy $i$ verovaniy, $v$ svyazi s mificheskimi skazanyami drugikh rodstvennykh narodov [The Poetic Views of the Slavic People on Nature. Experience of Comparative Study of Slavic Legends, Belief, and Sayings in the Frame of Mythical Tales of Other Related Peoples]. II. Moscow: Gracheva i Komp.

Akhmet'yanov, R. 1981. Obshchaya leksika dukhovnoy kul'tury narodov Srednego Povolzh'ya [The General Vocabulary of the Spiritual Culture of the Peoples of the Middle Volga Region]. Moscow: Nauka.

Aktsorin, V. 1967. Etnogenez mariyskogo naroda po dannym fol'klora. Proizkhozhdeniye mariyskogo naroda [The Ethnogenesis of the Mari People According to Folklore. The Origin of the Mari People]. YoshkarOla: Mariyskoye knizhnoye izdatel'stvo, pp. 159-164.

Alekseeva, T. 2016. Obyda. Otkrytyy urok [Open Lesson]. https://openlesson.net/2561/ (accessed 26.09.2020). 
Atamanov, M. 1981. Grakhovskiye govory yuzhnoudmurtskogo narechiya. Materialy po udmurtskoy dialektologii:Obraztsy rechi [Grakhov Subdialect of the Southern Udmurt Dialect. Materials on Udmurt Dialectology: Speech Samples]. Izhevsk: Nauchno-issledovatel'skiy institut, pp. 45-96.

Barag, L., Berezovskiy, I., Kabashnikov, K., Novikov, N. 1979. Sravnitel'nyy ukazatel' syuzhetov: Vostochnoslavyanskaya skazka [Comparative Index of Plots: East Slavic Tales]. Leningrad: Nauka.

Berezkin, Y. 2011. Chetyre fol'klornykh motiva iz trekh epokh v istorii Filippin i Indonezii. Pilipinas muna! Filippiny prezhde vsego: K 80-letiyu Gennadiya Evgen'evicha Rachkova [Pilipinas Muna! Philippines First of All: On the $80^{\text {th }}$ Birthday of Gennady Rachkov]. Sankt-Petersburg: MAE RAN. Maklayevskiy sbornik 4, pp. 136-172.

Bogaevskiy, P. 1890. Ocherki religioznykh predstavleniy votyakov [Essays about the Religious Representations of the Votyak] VI. Etnograficheskoye obozreniye [Ethnographic Review]. Book VII. No. 4, pp. 42-70.

Bushkov, R. 2014. Zhernovoy kamen' [A Millstone]. Vestnik mariyskogo gosudarstvennogo universiteta [Mari State University Bulletin] 1, pp. 102-106.

Dyrenkova, N. 2012. Tyurki Sayano-Altaya. Stat'i i etnograficheskiye materialy [The Turks of Sayan-Altai. Articles and Ethnographic Materials]. Saint-Petersburg: Nauka.

Emel'yanov, A. 1921. Kurs po etnografii votyakov [A Course on Ethnography of the Votyaks]. Issue 3: Ostatki starinnykh verovaniy i obryadov $\mathrm{u}$ votyakov [Traces of Ancient Beliefs and Rites among the Votyak]. Kazan: Kazanskiy votskiy izdatel'skiy podotdel.

Fedotov, M. 1996. Etimologicheskiy slovar' chuvashskogo yazyka [Etymological Dictionary of the Chuvash Language]. Vol. 2. Cheboksary: Chuvashskiy gosudarstvennyy institut gumanitarnykh nauk.

Gavrilov, B. 1880. Proizvedeniya narodnoy slovesnosti, obryady i pover'ya votyakov Kazanskoy i Vyatskoy guberniy [Works on Folk Literature, Rituals and Beliefs of the Votyak of Kazan and Vyatka Governorates]. Kazan: Tipografiya A. A. Kokovinoy.

Georgi, J. G. 2007. Opisaniye vsekh obitayushchikh v Rossiyskom gosudarstve narodov: ikh zhiteyskikh obryadov, obyknoveniy, odezhd, zhilishch, uprazhneniy, zabav, veroispovedaniy $i$ drugikh dostopamyatnostey [Description of all the Peoples Living in the Russian State: Their Rituals, Habits, Costumes, Dwellings, Practices, Pastimes, Beliefs and Other Peculiarities]. Sankt-Petersburg: Russkaya simfoniya.

Gordeev, F. 1967. Baltiyskiye i iranskiye zaimstvovaniya $v$ mariyskom yazyke. Proiskhozhdeniye mariyskogo naroda [Baltic and Iranian Loanwords in Mari. The Origin of the Mari People]. Yoshkar-Ola: Mariyskoe knizhnoe izdatel'stvo, pp. 180-203. 
Holmberg, U. 1927. Finno-Ugric, Siberian. The Mythology of All Races. IV. Boston: Cooper Square Publishers.

Karpova, L. 2005. Srednechepetskiy dialekt udmurtskogo yazyka: Obraztsy rechi [The Middle Cheptsa Dialect of the Udmurt Language: Speech Samples] 9. Izhevsk: Udmurtskiy institut istorii, yazyka i literatury Uralskogo otdeleniya Rossiyskoy akademii nauk.

Kel'makov, V. 1981. Obraztsy udmurtskoy rechi: Severnoye narechiye $i$ sredinnyye govory [Samples of the Udmurt Speech. Northern Dialects and Central Subdialects]. Izhevsk: Udmurtia.

Kel'makov, V. 1993. Formirovaniye i razvitiye fonetiki udmurtskikh dialektov [Formation and Development of Phonetics of the Udmurt Dialects]. Izhevsk: Udmurtskiy universitet.

Khisamitdinova, F. 2010. Mifologicheskiy slovar' bashkirskogo yazyka [Mythological Dictionary of the Bashkir Language]. Moscow: Nauka.

Khisamitdinova, F. 2016. Mifologicheskaya leksika bashkirskogo yazyka (vetnolingvisticheskom osveshchenii) [Mythological Vocabulary of the Bashkir Language (in Ethnolinguistic Coverage]. Ufa: Udmurtskiy institut istorii, yazyka i literatury Uralskogo otdeleniya Rossiyskoy akademii nauk.

Kralina, N. 1960. Sto skazok udmurtskogo naroda [One Hundred Fairy Tales of the Udmurt People]. Izhevsk: Udmurtskoye knizhnoye izdatel'stvo.

Levkiyevskaya, E. 2004. Leshiy [The Forest Spirit]. In: Slavyanskiye dreunosti: Etnolinguisticheskiy slovar' [Slavic Antiquities: Ethnolinguistic Dictionary]. Vol. 3. Moscow: Mezhdunar. otnosheniya, pp. 104-109.

Maksimov, S. 2009. Kommentarii k karte. Chastitsa 'da' [Comments about a Map. The Particle "da"]. In: R. Nasibullin, S. Maksimov, V. Semenov et al. Dialektologicheskiy atlas udmurtskogo yazyka. Karty $i$ kommentarii [Dialectological Atlas of the Udmurt Language. Maps and Comments]. Izhevsk: NITS, pp. 69-73.

Martazova, O. 2009. Obrazy dukhov trekh mirov v evenkiyskom epose [The Characters of the Spirits of Three Worlds in the Evenki Epic]. In: T. Vladykina (ed.) Traditsionnaya kul'tura v izmenyayushchemsya mire [Traditional Culture in the Changing World]. Izhevsk: Udmurtskiy institut istorii, yazyka i literatury Uralskogo otdeleniya Rossiyskoy akademii nauk, pp. 137-145.

Moisio, A., Saarinen, S. 2008. Tscheremissisches Wörterbuch [Mari Dictionary]. Helsinki: Suomalais-Ugrilainen Seura.

Munkácsi, B. 1952. Volksbräuche und Volksdichtung der Wotjaken [Folk Customs and Folk Poetry of the Votyak]. Helsinki: Suomalais Ugrilainen Seura.

Napol'skikh, V. 1992. Proto-Uralic World Picture: A Reconstruction. In: Northern Religions and Shamanism. Ethnologica Uralica, 3. Budapest \& Helsinki: Akadémiai Kiadó; Suomalainen Kirjallisuuden Seura, pp. 3-20. 
Nasibullin, R. 1978. Nablyudeniya nad yazykom krasnoufimskikh udmurtov [Observations about the Languages of the Krasnoufa Udmurt]. In: $O$ dialektakh $i$ govorakh yuzhnoudmurtskogo narechiya [About Dialects and subdialects of the South Udmurt Language]. Izhevsk: Udmurtskiy institut istorii, yazyka i literatury Uralskogo otdeleniya Rossiyskoy akademii nauk, pp. 86-151.

Nelidova, N. 2008. Nechistaya sila k Svyatkam gotova [The Impure Force is Ready for Christmas]. In: Udmurtskaya Pravda [Udmurt Truth] No. 2. http://archive.udmpravda.ru/default/article?article=11992632 $30 \&$ issue $=24241 \&$ tape $=($ accessed 30.10 .2020$)$.

Panina, T.2014. Slovoiritualvnarodnoy meditsine udmurtov [Word and Ritual in the Udmurt's Folk Medicine]. Izhevsk: Udmurtskiy institut istorii, yazyka i literatury Uralskogo otdeleniya Rossiyskoy akademii nauk.

Panina, T. 2013. Ritual'noye zadabrivaniye dukha bolezni v kontekste udmurtskoy etnomeditsiny [Ritual Propitiation if the Illness Spirit in the Context of Udmurt Ethnomedicine]. Traditsionnaya kul'tura [Traditional Culture] 1, pp. 42-50.

Panina, T. 2017. Obrazy lesnykh dukhov v udmurtskoy mifologii i fol'klore. III: Obyda (lesnaya zhenshchina) [The Characters of the Forest Spirits in the Udmurt Mythology and Folklore. III: Obyda (Forest Female)]. In: Ezhegodnik finno-ugorskikh issledovaniy [Yearbook of Finno-Ugric Studies] 11 (2), pp. 53-66.

Pervukhin, N. 1888 (1). Eskizy predaniy $i$ byta inorodtsev Glazovskogo uyezda [Essays about the Legends and the Everyday Life of NonRussians of the Glazov District]. Eskiz 1: Drevnyaya religiya votyakov po ego sledam v sovremennykh predaniyakh [Essay 1: The Ancient Religion of the Votyak in Its Traces in Modern Traditions.]. Vyatka: Gubernskaya tipografiya.

Pervukhin, N. 1888 (2). Eskizy predaniy $i$ byta inorodtsev Glazovskogo uyezda [Essays about the Legends and the Everyday Life of Non-Russians of the Glazov District]. Eskiz 2: Idolozhertvennyy ritual drevnikh votyakov po ego sledam v rasskazakh starikov i v sovremennykh obryadakh [Essay 2: The Idol-Sacrificial Ritual of the Ancient Votyak in Its Traces in the Stories of Elder People and in Modern Rituals]. Vyatka: Gubernskaya tipografiya.

Pervukhin, N. 1888 (3). Eskizy predaniy i byta inorodtsev Glazovskogo uyezda [Essays about the Legends and the Everyday Life of NonRussians of the Glazov District]. Eskiz 3: Sledy yazycheskoy drevnosti v obraztsakh proizvedeniy ustnoy narodnoy poezii votyakov (liricheskikh i didakticheskikh) [Essay 3: Traces of Pagan Antiquity in Images of the (Lyrical and Didactical) Oral Folk Poetry of the Votyak]. Vyatka: Gubernskaya tipografiya.

Pervukhin, N. 1889. Eskizy predaniy i byta inorodtsev Glazovskogo uyezda [Essays about the Legends and the Everyday Life of Non-Russians of the 
Glazov District]. Eskiz 4: Sledy yazycheskoy drevnosti vobraztsakh ustnoy narodnoy poezii votyakov [Essay 4: Traces of Pagan Antiquity in Images of the Oral Folk Poetry of the Votyak]. Vyatka: Gubernskaya tipografiya.

Petrukhin, V. 2005. Mify finno-ugrov [Finno-Ugric Myths]. Moscow: Astrel'.

Rudenko, S. 2006. Bashkiry: Istoriko-etnograficheskiye ocherki [Bashkirs: Historical and Ethnographic Essays]. Ufa: Kitap.

Sadikov, R. 2008. Traditsionnyye religioznyye verovaniya i obryadnost' zakamskikh udmurtov (istoriya i sovremennyye tendentsii razvitiya). [Traditional Religious Beliefs and Rituals of the Eastern Udmurts (History and Modern Development Trends]. Ufa: Centr etnologicheskikh issledovaniy UNTs RAN.

Sadikov, R., Khafiz, K. 2010. Religioznyye verovaniya i obryady udmurtov Permskoy $i$ Ufimskoy gubernii $v$ nachale $X X$ veka: ekspeditsionnyye materialy Uno Holmberga [Religious Beliefs and Rituals of the Udmurts of the Perm and Ufa Governorates at the Beginning of the $20^{\text {th }}$ Century: Expedition Data by Uno Holmberg]. Ufa: Institut Etnologicheskikh issledovaniy UrO RAN.

Shemshedinov, A. 1910. Legendy $i$ skazaniya kumykov [Legends and Tales of the Kumyks]. In: Etnograficheskoye obozreniye [Ethnographic Review], 1-2, pp. 137-155.

Shutova, N. 2001. Dokhristianskiye kul'tovye pamyatniki v udmurtskoy religioznoy traditsii: Opyt kompleksnogo issledovaniya [Pre-Christian Cult Monuments in the Udmurt Religious Tradition: An Experience of Comprehensive Research]. Izhevsk: Udmurtskiy institut istorii, yazyka i literatury Uralskogo otdeleniya Rossiyskoy akademii nauk.

Shutova, N., Kapitonov, V., Kirillova, L., Ostanina, T. 2009. Istoriko-kul'turnyy landshaft Kamsko-Vyatskogo regiona [Historical and Cultural landscape of the Kama-Vyatka Region]. Izhevsk: Udmurtskiy institut istorii, yazyka i literatury Uralskogo otdeleniya Rossiyskoy akademii nauk.

Smirnov, I. 1890. Votyaki: Istoriko-etnograficheskiy ocherk [The Votyak: Historical and Ethnographic Essay]. Kazan: Tipografiya Imperatorskago universiteta.

Tarakanov, I. 1982. Zaimstvovannaya leksika v udmurtskom yazyke (Udmurtsko-tyurkskiye yazykouye kontakty) [Borrowed Vocabulary in the Udmurt Language: (Udmurt-Turkic Language Contacts)]. Izhevsk: Udmurtia.

Thompson, S. 1955-1958. Motif-Index of Folk-Literature: A Classification of Narrative Elements in Folk Tales, Ballads, Myths, Fables, Medieval Romances, Exempla, Fabliaux, Jest Books and Local Legends. In 6 Vols. Bloomington: Indiana University Press. http://www.ruthenia. ru/folklore/thompson/g.htm (accessed 15.10.2020).

Toydybekova, L. 2007. Mariyskaya mifologiya [Mari Mythology]. YoshkarOla: MPIK. 
Tronina, I. 2007. Zhanry i obrazy udmurtskoy mifologicheskoy prozy [Genres and Images of the Udmurt Mythological Prose]. BA dissertation, scientific supervisor T. Vladykina. Izhevsk: Udmurtskiy gosudarstvennyy universitet.

Udmurtskiye narodnyye skazki [Udmurt Fairy Tales] 1948. Klabukov, A. (compiler). Izhevsk: Udmurtgosizdat.

Udmurt kalyk vyzhykyl"yos [Udmurt Fairy Tales] 1954. Klabukov, A. and Kralina, N. (compilers). Izhevsk: Udmurtskoye knizhnoye izdatel'stvo.

Udmurtskiye narodnyye skazki [Udmurt Fairy Tales] 1976. Kralina, N. (compiler). Izhevsk: Udmurtia.

Vereshchagin, G. 1995. Sobraniye sochineniy. Votyaki Sosnovskogo kraya [Collected Works: The Votyak of the Sosnovka Region]. Vol. I. Izhevsk: Udmurtskiy institut istorii, yazyka i literatury Uralskogo otdeleniya Rossiyskoy akademii nauk.

Vereshchagin, G. 1996. Sobraniye sochineniy: Votyaki Sarapul'skogo uyezda Vyatskoy gubernii [Collected Works: The Votyak from the Sarapul of the Vyatka Governorate]. Vol. 2. Izhevsk: Udmurtskiy institut istorii, yazyka i literatury Uralskogo otdeleniya Rossiyskoy akademii nauk.

Vereshchagin, G. 1998. Sobraniye sochineniy: Etnograficheskiye ocherki 1 [Collected Works: Ethnographic Essays 1]. Vol. 3. Izhevsk: Udmurtskiy institut istorii, yazyka i literatury Uralskogo otdeleniya Rossiyskoy akademii nauk.

Vereshchagin, G. 2000. Sobraniye sochineniy: Etnograficheskiye ocherki 2 [CollectedWorks: EthnographicEssays2]. Vol.4.Izhevsk:Udmurtskiyinstitut istorii, yazyka i literatury Uralskogo otdeleniya Rossiyskoy akademii nauk.

Vereshchagin, G. 2001. Sobranie sochineniy: Udmurtskiy fol'klor 1. Predaniya. Legendy. Pobyval'shchiny. Skazki. Basni. Poslovitsy. Pogovorki. Zagadki [Collected Works: Udmurt Folklore 1. Traditions. Legends. Prose. Fairy Tales. Proverbs. Sayings. Riddles]. Izhevsk: Udmurtskiy institut istorii, yazyka i literatury Uralskogo otdeleniya Rossiyskoy akademii nauk.

Vinogradova, L. 2009. Reka [The River]. Slavyanskiye drevnosti: Etnolingvisticheskiy slovar' [Slavic Antiquities: Ethnolinguistic Dictionary] 4. Moscow: Mezhdunar. Otnosheniya, pp. 416-419.

Vinogradova, L., Tolstaya, S. 2004. Lapti [The Bast-Shoes]. Slavyanskie drevnosti: Etnolingvisticheskiy slovar' [Slavic Antiquities: Ethnolinguistic Dictionary] Vol. 3, pp. 79-82.

Vladykin, V. 1994. Religiozno-mifologicheskaya kartina mira udmurtov [Udmurts' Religious and Mythological Worldview]. Izhevsk: Udmurtia.

Vladykina, T. 1998. Udmurtskiy fol'klor: problemy zhanrovoy evolyutsii $i$ sistematiki [Udmurt Folklore: Problems of Genre Evolution and Systematisation]. Izhevsk: Udmurtskiy institut istorii, yazyka i literatury Uralskogo otdeleniya Rossiyskoy akademii nauk. 
Vladykina, T. 2009. Obrazy lesnykh dukhov v udmurtskoy mifologii i fol'klore: I. N'ulesmurt (lesnoy chelovek/leshiy). [Images of Forest Spirits in Udmurt Mythology and Folklore I. N'ulesmurt (Forest Human / Forest Spirit)]. Traditsionnaya kul'tura v izmenyayushchemsya mire [Traditional Culture in the Changing World]. Izhevsk: Udmurtskiy institut istorii, yazyka i literatury Uralskogo otdeleniya Rossiyskoy akademii nauk, pp. 24-30.

Vladykina T., Glukhova G. 2011. Ar-god-bergan: Obryady i prazdniki udmurtskogo kalendarya [Year Circle: Rituals and Celebrations of the Udmurt Calendar]. Izhevsk: Udmurtskiy institut istorii, yazyka i literatury Uralskogo otdeleniya Rossiyskoy akademii nauk.

Vladykina, T., Panina, T. 2015. Obrazy lesnykh dukhov v udmurtskoy mifologii i fol'klore: II. Palesmurt (polovinchatyy chelovek) [Images of Forest Spirits in Udmurt Mythology and Folklore II. Palesmurt (HalfHuman Being)]. Ezhegodnik finno-ugorskikh issledovaniy [Yearbook of Finno-Ugric Studies] 4, pp. 59-67.

Vladykina, T. 2016. Pchela v fol'klore i miforitual'noy praktike udmurtov [The Bee in Folklore and Mythoritual Practice of the Udmurt]. Traditsionnaya kul'tura [Traditional Culture] 4, pp. 147-158.

Volkova, L. 1997. Veter kak mifologicheskiy personazh v mirovozzrenii udmurtov [Wind as a Mythological Character in the Worldview of the Udmurts]. Dukhovnaya kul'tura finno-ugorskikh narodov: istoriya i problemy razvitiya [The Spiritual Culture of the Finno-Ugric Peoples: History and Development Problems]. II. Glazov: GGPI, pp. 56-57.

Wichmann, Y. 1901 (1). Wotjakische Sprachproben II: Sprichwörter, Rätsel, Märchen, Sagen undErzählungen [Samples of VotyakLanguageII:Proverbs, Riddles, Tales, and Narratives]. Helsingfors: Finnish Literature Society.

Wichmann, Y. 1901 (2).Wotjakische Chrestomathie mit Glossar [A Votyak Chrestomathy with a Glossar]. Helsingfors: Finnish Literature Society.

Wichmann, Y. 1903. Die tschuwassischen Lehnwörter in den permischen Sprachen [The Chuvash Loanwords in the Permian Languages]. Helsingfors: Finnish Literature Society.

Yashin, D. 1974. Obshchiye motivy v skazkakh permskikh i tyurkoyazychnykh narodov [Common Motives in the Fairy Tales of the Permian and Turkic Peoples]. Fol'klor narodov RSFSR [Folklore of the Peoples of the RSFSR]. I. Ufa: Bashkirskiy Gosudarstvennyy universitet, pp. 63-68.

Zelenin, D. 1995. Izbrannyye trudy. Ocherki russkoy mifologii. Umershiye neestestvennoy smert'yu i rusalki [Selected Works. Essays on Russian Mythology. Dead by an Unnatural Death and Mermaids]. Moscow: Indrik. 


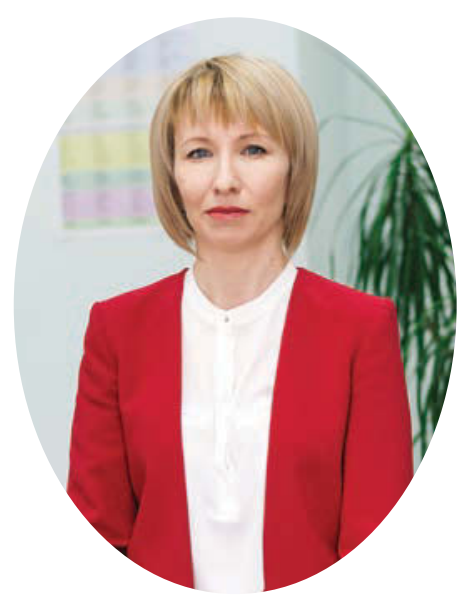

Tatiana Panina (PhD) is a researcher at the Department of Philological Studies, at the Udmurt Institute for Research in History, Language and Literature (Udmurt Federal Research Centre of the Ural Branch of the Russian Academy of Sciences). She is interested in traditional Udmurt culture, more precisely in folk medicine, incantation tradition and more recently dreams. Panina teaches English at the Izhevsk State Medical Academy. e-mail: tipanina@mail.ru

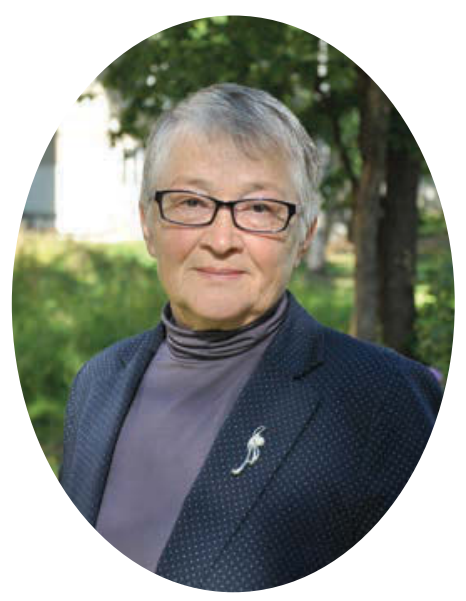

Tatiana Vladykina is ( $\mathrm{PhD}$ hab) a professor and leading researcher at the Udmurt Institute for Research in History, Language and Literature (Udmurt Federal Research Centre of the Ural Branch of the Russian Academy of Sciences). She has covered the range of topics in Udmurt folkloristics, especially mythology, specialising both in genre and in the treatment of the most important topics across genres.

e-mail: tgvladykina@mail.ru 


\title{
Home Spirits in the Udmurt Mythology
}

\author{
Tatiana Vladykina \\ e-mail: tgvladykina@mail.ru \\ Galina Glukhova \\ e-mail: galant@udm.ru
}

\begin{abstract}
Udmurt spirits had a clear hierarchy, with each one of them functioning in their own specific field. The article investigates the spirits of domesticated space, including korkamurt, korkakuz'o, s'us'etka (lit: 'man from/of the house, the master of the house, sus'etka'), bannik ('bathhouse spirit') / munchomurt, munchokuz'o (lit: 'man from/of the bathhouse, master of the bathhouse') and the master of the cowshed / gidmurt, gidkuz'o (lit: 'man from/of the cowshed').
\end{abstract}

Keywords: bathhouse spirit, house spirits, master of the cowshed, Udmurt mythology

Mythological plots still prevail in modern Udmurt folklore, contributing to the genre of bailichkas and narrations ishan-mad', literally: 'a story [about] a ghost') (Kel'makov 1981, 1990; Pletneva 1999; Slesareva 2004, 2005; Glukhova 2004; Vladykina 2009; Vladykina, Glukhova 2011; Vladykina, Panina 2015; Panina 2017, and others). The images of mythological characters in these stories are not as 
diverse as they used to be, but they bear witness to the preservation of ancient beliefs and the evolution of a number of deities and spirits. There is information in $19^{\text {th }}$-century sources about the fact that the number of Udmurt gods, deities and spirits reached 40 (see: Vladykin 1994: 96-97). There was a clear hierarchy with each one of the spirits functioning in their own specific field. Just like other peoples living in the forest belt, the Udmurt had two circles of mythological characters: deities/spirits of wild nature and spirits of domesticated space. Both have evolved to some degree, mainly in their appearance. The spirits of domesticated, or domestic, space include korkamurt, korkakuz'o, s'us'etka (lit: 'man from/of the house, master of the house, sus'etka'), bannik (bathhouse spirit) / munchomurt, munchokuz'o (lit: 'man from/of the bathhouse', 'master of the bathhouse' $)^{1}$ and the master of the cowshed/gidmurt, gidkuz'o (lit: 'man from/of the cowshed').

In the Udmurt traditional homestead, an izba (korka) occupied the central position among other buildings in the yard (which were the family sanctuary/kuala, barn, granary/kenos, cowshed/gid and bathhouse/muncho). A high fence with large gates surrounded the buildings, marking the enclosed space, i.e. the yard/azbar, and representing the independent, integral household (Orlov 1999: 38). In the $1930^{\text {s }}$, researchers compared the Udmurt yard to a castle (Belitser and others, 1931: 21) because every large patriarchal family ${ }^{2}$ would produce everything they needed for domestic consumption within their own household (Vladykin 1994: 264). It is for good reason that the Udmurt associated the image of the perfect life in their prayers/kuris'kon, with the peasant homestead, thinking of it as a "perfect world" (Vladykin 1994: 312). Peasant homesteads were opposed to the outside world, which was strange, unfamiliar and unknown; the homestead was perceived as the centre of the world/microcosm.

The house protected its inhabitants not only against bad weather, but also against hostile forces. So that family life would be happy, abundant and peaceful, every home owner was very careful 
when selecting the place for construction. For example, building a house at a crossroads was not allowed, as was building on the site of another house that had burned down, in small ravines, diagonally opposite an old house, etc. It was believed that life in such a house would not be happy or abundant. When building a house, people would also adhere to certain beliefs, and hold rituals in order to ensure certain outcomes (see: Shklyayev 1989; Orlov 1999).

The prosperity of a dwelling was also dependent on each resident themselves. In accordance with religious and mythological perceptions, every family member was supposed to follow a number of set rules and taboos. If these were violated, another member of the household, i.e. korkakuz'o, made his presence felt.

Korkamurt, or man [from] the house, is the most widespread and neutral semantical notion. Its synonyms are the dialectic notions of korkakuz'o, yurtkuz'o master of the house and domut'is'/ korkaut'is' guardian of the house. Negative changes in status are obvious in such terms as korkaperi, i.e. an evil spirit of the house, busturgan and s'us'etka, from the Russian susedka/susedko, i.e. neighbour, and vyzhulkuz'o, i.e. master of the cellar.

Korkakuz'o is very rarely depicted as a human being in folklore, but is mainly referred to as an invisible creature. This is why his appearance can only be reconstructed from details. According to some archaic beliefs, he is a hairy creature "like a monkey", and you must not say his name at night so that he "does not grow extremely large, like a haystack" (Vereshchagin 1996: 91). The hairiness is emphasised in particular in the tradition of the northern Udmurts: "Gondyr is the name that the closest relative of Korkamurt is known by to the Votyaks in Glazov Uyezd, i.e. the house spirit who is in charge of supplies, living in the cellar if the house has one, and in barns. His main place of living is the underlying structure of the house. The appearance of Gondyr correlates with his name; the punishment he inflicts on people who have made him angry consists of a rapid reduction in the volume of supplies" (Pervukhin 1888: 91-92). In the author's opinion, this type of house spirit is 
the most ancient and the least Russified, compared to the names listed above (Perkvuhin 1888: 92).

In the course of its evolution, the house spirit has gradually acquired the features of a human being, and correspondingly the components of $\mathrm{murt} / \mathrm{human}$ being and $k u z$ 'o/master in his name. According to some descriptions, he is "an elderly man who always wears a sheepskin coat with the fur inside out" (Pervukhin 1888: 90), "a manlike creature ... who sometimes takes the form of the master of the house himself" (Emel'yanov 1921: 116). On the whole, according to the beliefs of the Udmurts, korkakuz'o was not distinguished by gender and was in charge of both men's and women's work (Pervukhin 1888: 90). At night he would help family members do some housework, for example, spinning and weaving, or splitting firewood (Pervukhin 1888: 91; Emel'yanov 1921: 116). Sometimes korkakuz'o could even be touched or caught

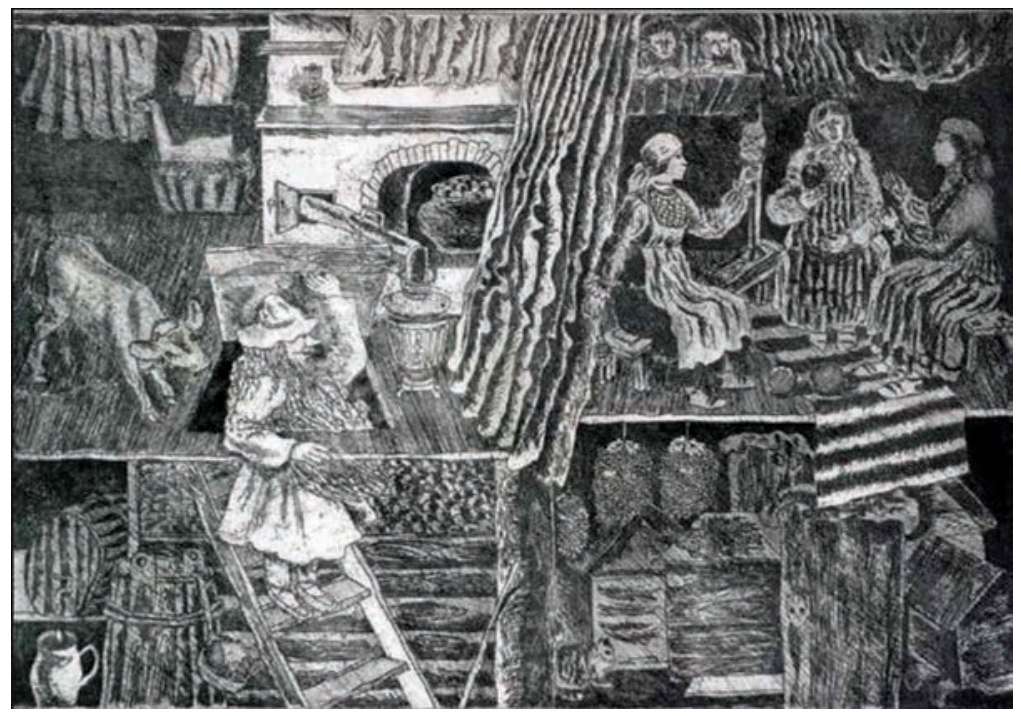

Illustration 1. Picture by Mensadyk Garipov. Korkakuz'o dzhyt pukonyn (The house spirit at an evening gathering). 
in the dark. If someone managed to do so, they would ask it to light a candle. It was believed that "if you saw the house spirit in the light, later on he would have to obey the orders" of the person who caught him (Pervukhin 1888: 90). On the whole, korkamurt was regarded as a kind and useful creature, since he protected the family from other korkakuz'o and guarded the house. The whole house $(i z b a)$ was under his influence.

He could get angry if family members violated standard rules of behaviour: in everyday life one was not allowed to have fun without good reason, or laugh or talk loudly or have rows ${ }^{4}$, otherwise he would remind family members of his existence by torturing them in their sleep, messing up their hair or beard, or doing harm while they worked. Korkakuz'o could replace a child, which is why one was never allowed to leave a new-born baby alone in the house. If a child was not developing normally (was sick all the time, crying or refusing to eat or sleep), people would say "s'us'etka voshtem" ('replaced by s'us'etka'). To guard the child people would put scissors, a knife or a piece of bread at the head of the cradle.

In some individual local traditions, when moving to a new house people would invite the house spirit from the old house to join them. As a rule, they made a small doll, put it in shoes made from bast and took it to the new house, singing wedding songs. In the new house, they would put a bast shoe beneath the stove or in the cellar. After settling in the new house, the house owners would hold a party known variously as korka pyron 'housewarming party', korka s'uan 'wedding/ party in izba' or korka s'ektan 'house treat'. The range of notions for this kind of party also includes korkamurt s'ektan, i.e. 'the feast/treat for korkamurt'. In ethnographic sources from the $19^{\text {th }}$ century there is information that tells us that before the celebration, or directly afterwards, and sometimes even instead of it, a sacrament ritual was held called gulbeche siz'kon. The husband and wife went down into the cellar, taking one pancake, house wine and a young spruce as tall as one $\operatorname{arshin}^{5}$ with them. In the cellar, the owner of the house would stick the spruce in the 
floor in the front corner of the house, break off one small branch and drop to his knees in front of the spruce. The wife would put a tablecloth in front of him and put the pancake on it. Then she would pour house wine into a glass and hand it to her husband. The husband, holding the glass in his right hand and the branch in his left hand, would pray to the supreme god Inmar, asking for a happy life in the new house until old age. Then he made a promise to offer up a black sheep or other four-footed animal as a sacrifice (Vereshchagin 1995: 70; Emel'yanov 1921: 117) so that busturgan "would not haunt the people living in the house" (Vereshchagin 1995: 70). The sacrifice was made some time later in the house or in the cellar. While the sacrificed animal was being cooked, the house owner would pray on his knees, asking for happiness, wealth and all earthly blessings to enter his house; the bones of the sacrificed animals were buried in the ground in the cellar. Such a sacrifice was referred to as gulbeche taka vös'an, 'sacrificing a sheep in the cellar' (ibid.). Contemporary researchers believe that this type of ritual, interpreted as a sacrifice to the house spirit, was not like this, in fact. Most probably it was "a sacrifice to the earth aiming to pass productive/fertile forces on to the people living in the house. As a rule, no such sacrifice was made to the house spirit. Besides, gifts to him were never buried in the ground" (Shklyayev, manuscript).

In modern recordings, there are abundant texts about korkakuz'o and his appearance is more specific. He is also described as a creature with fur or feathers, in the shape of either a hen or a rooster with only one eye. He can also be a small man with a long white beard. However, much more widespread is the anthropomorphic image of a man with beard, wearing white clothes:

Yashkaos doryn kölykum, olokytys' tusho ad'ami potem.

When I was sleeping at Yashka's house, a bearded man appeared from nowhere') (FE 1984'): 
Korkakuz'o - so töd'y dis'en, badzh'ym tusho marke.

The house spirit is someone wearing white clothes, with a long white beard (FE 19947).

Sometimes it is a creature of a dual nature with abnormal features:

Odig kyshnomurt uzhany koshkem no Van'ush n'imo pize ognaz kel'tem. Piyez iz'e vylem. Shödem no, az'az sytshe kuz' yyrs’iyo kyshnomurt, pe, syle. S’in”yosyz no ogkad'es'övöl, pe, ad'amilen, suy-pyd"yosyz ikyr-kukyres', pe.

One woman went to work and left her son Vanyushka alone. He was sleeping. But when he woke up, he saw a woman with long hair standing right in front of him. And she had different eyes, that woman, and her arms and legs were crooked (FE 1982 ${ }^{8}$ );

Mil'am brat shue: “Gulbechys'tuzh badzh'ym, pas'kyt s'inmo ad'ami potiz".

Our brother told us: "A man with very big rolling eyes stepped out of the cellar" (FE 1982).

In Udmurt mythological prose recorded in the late $20^{\text {th }}$ century, korkakuz'o is most often represented as a white man-like creature that is small, of regular height or very tall:

Pichi dyr"ya, tshapak raskulachit' karonles' az'lo, tatshe ishan adzh'i. Soku suzere chachayen vis'e val. Odig uye sendrays'tym vas'kono lui, gulbeche myni (az'lo gulbech gur berez shuo val). Gulbeche lyktysa gine vui no, az'am mon bydzh'a ik töd'y ad'ami potiz. Kurdasa kes'as'kis'ko, beryktis'ki no - so s'öram lykte. 
During my childhood, right before we were dekulakised, I saw a ghost. My sister was sick with smallpox at the time. One night I had to get off my bunk on top of the stove and go to a place behind the stove. And when I went around behind the stove, a white man much taller than me appeared right in front of me. I cried out in fear; and when I turned around, he was following me $\left(\mathrm{FE} 2003^{10}\right)$.

Korkakuz'o is most often invisible and intangible in his physicality. However, from time to time he can reveal himself by making a noise or by knocking:

Tan'i, shuo, gur vyle, pe, ishan"yos tubyny ug bygato. Nosh mon gur vylyn kölis'ko. Kin ke tshash-pash kare.

They say ghosts can't climb on the stove. I sleep on the stove. And I can hear someone rustling about right next to me all the time (FE $\left.1991^{11}\right)$ :

Odigaz guzhem dzhyte kerttis'kysa pukis'ko val. Kin ke no korka pyriz-pyd kuaraos kylis'kizy. Lyktiz so guraz'e. Dzhök vylyn marke no shaltyrtem kuara kylis'ke.

One summer evening I was sitting doing some knitting when I heard someone enter the house. I heard footsteps. He went into the kitchen. I heard dishes rattling on the table (FE 1989 ${ }^{12}$ ).

Concepts of the localisation of the house spirit are often related to the stove, i.e. the family hearth, and the surrounding space (you can see him on, behind or under the stove):

Uin kölykumy, anayelen umme us'emez luymte, soin ik so adzh'em, kyz'y gulbech s'örys' kin ke no potiz tuzh kuz' gono, punyly kel'shis'. 
While everyone else was sleeping one night my mother could not get to sleep, and she saw someone walking from behind the stove, with long hair; he looked like a dog (FE 1991 $\left.{ }^{13}\right)$.

But most often korkamurt emerges from the cellar or stands next to it, and 'disappears' into the cellar as well:

Kuchyranys' Maykova Irina adzh'em: murdzholys' potem, kak budto kytshe ke ad'ami.

Irina Maikova from Kuchyran village witnessed the following: it seemed like some kind of man stepped out from the cellar (FE 1984 UIHII of USU - 1984 ${ }^{14}$ ).

His favourite place seems also to be an attic, where his footsteps can often be heard:

Ogpol, 8 chase, pe, korka s’igti olokin kuazh-kuazh vetle, völdetys' lampayez ule-vyle dzhutka no lez'ya.

Once, at about 8 o'clock, we heard footsteps in the attic, and the light bulb right beneath the ceiling was pulled up and down (FE 1975 $\left.{ }^{15}\right)$.

Modern beliefs about the house spirit are mainly related to negative phenomena. It is believed that korkamurt appears before people before something bad happens, informing them about the impending death or illness of relatives. Quite often he appears in the shape of the master of the house:

Kartelen kulon mataz in'i, nosh nonok nontysa kyl'l'is'ko taz'y no, vyzhulys' nosh potiz ad'ami. So kad'ik, karte kad' $i k$, dis'as'kemyn: voyennoy, kyk kruzhka vu yuiz no, doram lyktysa, taz' syle divan pumam. Ug no koshky, ug no mara. 
Mon Vit'i ik shuko, karte ik. Taz'y beram kime lez'i no, so dumbyl'ak beram kyl'l'e, so ves' syle al'i. "Kozma! Ta ved' korkamurt", - shui no, otchy ik bytmiz srazu.

Shortly before my husband's death I was in bed, breastfeeding my child, when a man stepped out of the cellar. He looked just like my husband and was wearing military dress. He drank two cups of water and came closer to me, standing near the sofa. And he clearly wasn't going to leave. I thought it was Vitya, my husband. But then I put my hand behind me, and he (her husband) was lying there as usual, while this man was still standing right in front of me. "Oh my God! It's korkamurt!" I said, and he disappeared (FE 2003 ${ }^{16}$ );

Tatshe deymon ad'amiyez adzh'ysa, piyash kyshkatskem tuzh zol. N'eznay, olokyz'y todiz na so (Van'ush) verany: gulbechys' potem so. Soin todis'kom, so korkakuz'o vylem shuysa. Soye adzh'em beraz, so pi vis'yny kutskiz no tuzh kuradzh'ysa kuliz.

When he saw the man, who was very frightening, the boy became incredibly scared. He (Vanyusha) could hardly speak, but he said: he stepped out of the cellar. This is why we know that it was korkamurt. After what he had seen the boy got sick and died in pain (FE 1982 ${ }^{17}$ );

Potamez ishanly luem. Anayez no atayez tshosh kulil'l'am.

[His] emergence became an omen of death. The mother and father died together (FE UIHII of USU 1984 ${ }^{18}$ ).

One of the surest remedies for healing sick people among peasants was pleasing the house spirit by 'feeding' him. A treat for him was seen as a simplified form of sacrifice, which is why he was also treated with caution: 
Vyl' korkas' gurez nyrys'se estyku, odno ik taban' pyzho.

In a new house, when the stove is stoked for the first time, sour flat pancakes taban' are always made (FE $\left.1983^{19}\right)$.

Thus, in today's perception, the house spirit takes the shape of a human being with certain abnormal features. His zoomorphic features can also be perceived as abnormalities. The image of the house spirit is often exaggerated. In the modern tradition, korkamurt often appears as a prophet or a harbinger praying and showing himself before something bad happens or a person falls seriously ill or dies. He appears on the threshold: at midnight or midday, and sometimes during twilight.

Another demonological character of the Udmurt household is "bathhouse spirit", munchokuz'o "master of the bathhouse", munchomurt "bathhouse man", muncho-Mar"ya "bathhouse Mar"ya", mynchokukn'ik "bathhouse man kukn'ik", mynchopochetka "bathhouse man pochetka", or töd'y-murt "white man". In folklore and ethnographic sources from the $19^{\text {th }}$ century, the bathhouse man is many-faced, and his nudity, hairiness, long hair and huge eye are also often mentioned. One feature common to all descriptions of munchokuz'o is that he does not have an invariable appearance, but can look completely different in different visions. Sometimes his short stature is emphasised. "The bathhouse man was a oneeyed creature with long hair, but sometimes he was perceived as a small, hairy dwarf" (Emel'yanov 1921: 120); "the bathhouse man has the appearance of a small, hairy dwarf" (Pervukhin 1888: 120). Sometimes he is described as a tall, middle-aged man wearing a white shirt and trousers (Pervukhin 1889: 95). His appearance can be exaggerated: "He [the guy] had barely run 10 sazhen ${ }^{20}$ when he looked around and saw Munchomurt (the bathhouse spirit) running after him in the shape of a huge haystack" (Vereshchagin 2001: 41). The bathhouse spirit can also look amorphous: "this creature seems to be... an animal without bones, like jelly, with long 
hair and one huge eye like a moon..." (Vereshchagin 1996: 89). He could appear in the shape of a man or a woman: "the naked, hairy, long-haired, big-eyed Munchomurt is dancing in the bathhouse, and his wife is sitting on the stove and breastfeeding their two children..." (Vereshchagin 2001: 42). A female munchomurt looks unkempt: "a black, ugly, long-haired woman is sitting on the stove whisking her child, holding him on her knees...” (Ibid.: 38).

The bathhouse spirit appeared to young people in the shape of youngsters: "we heard a nice (cheerful) song from one of the bathhouses. He (Vitya) entered and saw beautiful ladies dancing. And there was one man. He was playing the accordion..." (Emel'yanov 1921: 242).

In the recordings of the $19^{\text {th }}$ century, the image of a munchokuz'o is generally anthropomorphic. Some individual cases of witnessing a bathhouse man with zoomorphic features were recorded: "they put

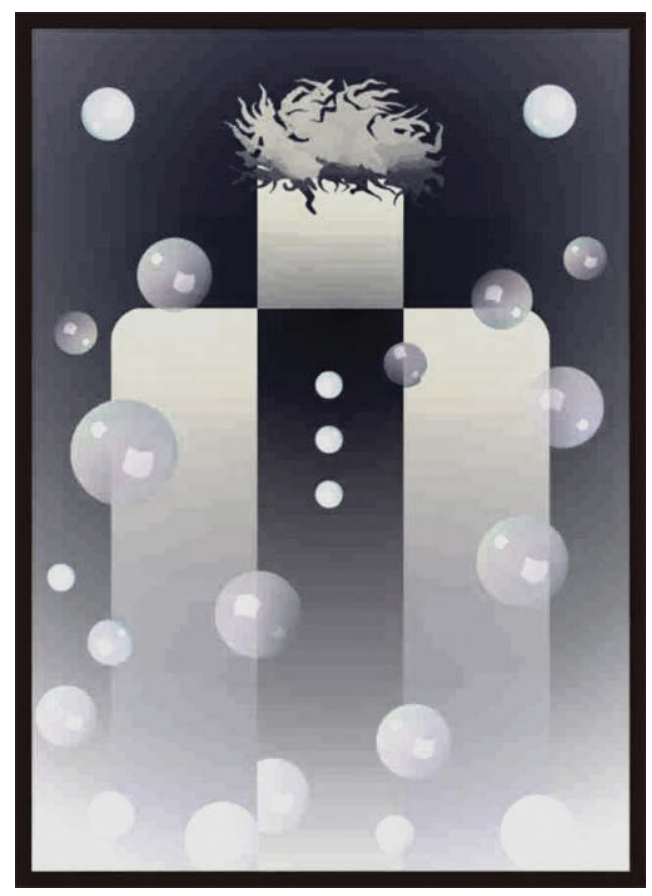

Illustration 2. Picture by Vladimir Nagovitsyn. Töd'y murt (The white man). 
straw around the bathhouse and burned it. When the bathhouse was on fire, mynchokukn'iks (bathhouse spirits) started flying to another bathhouse in the shape of roosters..." (Vereshchagin 2001: 142). At times, the bathhouse man appeared before people in several guises at the same time: "They (munchomurt girls) were dancing and dancing, and then their feet turned into calves' feet. Then the girls disappeared, and that man remained near him (Vitya). And we saw that he had hairy arms and hooves (...) Then he said, "kick me when you are leaving!" And he sat down right in the middle. And I stood up immediately and I kicked him hard on the back when I was leaving ... And when I turned around to look at the man one more time, I saw a stone in his place..." (Emel'yanov 1921: 243).

In modern mythological texts munchokuz'o also has a polymorphic image, but most often takes the shape of a human being:

Us'tem gine no muncho össe - polat'yn kuz', s’öd yyrs’iyo kyshnomurt. So yyrs'ize synasa, pe, puke, s’in”yosyz vozh dzhualo, pe.

I had barely managed to open the door of the bathhouse when I saw a woman with long black hair. She was combing it, and her eyes were green (FE 1982 ${ }^{21}$ );

S’öd yyrs’iyo, yyrs’iyez s’öd-s’öd.

With black hair; her hair was blacker-than-black (FE 1984²2);

Munchoye myni, pylas'kysa öy vuy - tuzh badzh'ym s'inmo, yyro piosmurt pyriz.

I went to the bathhouse but barely had I managed to wash myself when a man with big eyes and a big head entered (FE 199123). 
In modern recordings, munchomurt can also emerge as a kind of amorphous mythological creature white in colour: "Uyin vina pöz'tis'ko val no, korka pyray. Tare korkas' potko no - myncho az'yn töd'y ad'ami syle" ('I was making moonshine at night and I went into the house. When I came out, I saw a white man standing in the dressing room') (FE 20044), or having unclear zoomorphic features: "Mugoraz, pe, s'öd-s'öd gon budemyn" ('there was blackerthan-black fur on his body') (DE 199025).

Most often the bathhouse man is invisible, although he reveals himself with the help of different noises (rustling, knocking, stamping, with his voice or playing a musical instrument):

Pel' s'öraz kylis'kem argan kuara. Kylzis'kem no, valam: so kuara munchoys' kylis'ke vylem. Ösez us'tem no, nokine adzh'ymte, argan kuara no chusomem.

He heard someone playing the accordion. He listened to the music for a while, then realised that it was coming from the bathhouse. He opened the door but didn't see anyone, and the music stopped (FE 1982 26 ).

In many contemporary bailichkas the bathhouse spirit is envisaged on a sauna bench where he is taking some steam and whisking himself:

Polat'yn kuz's'öd yyrs’iyo kyshnomurt.

There was a woman with long black hair on the sauna bench (FE $1982^{27}$ ).

The sauna bench is the favourite place of the master of the bathhouse, which is why he doesn't like it when it is occupied:

Pydyz kynmem no shunskyny pyrem, polat'vylaz umme us'em, sapegze kyl'sa. Shop! karsa, badzh'ym pydchin'yze kurtchem. 
His feet were cold, so he went to the bathhouse to warm up. He took off by boots and fell asleep on the sauna bench. Chop! Someone bit him on his big toe (FE 200128).

The master of the bathhouse always lives and shows himself in an enclosed space, limited with walls. However, from time to time, he can also appear outside.

In Udmurt mythological stories one of the most popular motifs is the kidnapping or replacing of a child by the bathhouse spirit. According to beliefs, munchomurt kidnaps or replaces a child in the bathhouse while his or her parents are washing and the child is waiting for them in the dressing room. A number of precautionary measures should be taken in order to avoid this. For example, put scissors or some other metal object underneath the blanket the child is lying on. It was believed that if the child is christened, the bathhouse man will not be able to touch it. A child who had been 'replaced' by the bathhouse man was physically underdeveloped, crying all the time, not growing, not standing on his or her feet or trying to walk, but at the same time extremely gluttonous:

Pinalzy yalan zubkayn kyl'l'e. Tare so ug n’i bördy. Tshukaz'e 18 ares tyrmoz n'i, nosh so ug no veras'ky, ug no vetly.

The child is still in the cradle. He doesn't cry anymore. He turns 18 tomorrow, but he still neither walks nor talks (Kel'makov 1981: 139-140).

The bathhouse spirit can also steal a child (most often a girl) and raise her until she comes of age and, finally, gets married. Her miraculous saviour is usually a young man whom the girl lures in when he comes to the bathhouse at night or just passes by. The girl offers herself to him as a wife, albeit with a threat: 
18 ar ulysa, kyk yegit pios so munchoys'iz vayyny echeshil'l'am; polat' ulys' soles' kize kutil'l'am, nosh as'seos ug adsko, kyshno bas'tidy ke, lez'om, pe, shuo. Kyshkamenyzy piyash”yos soglash luil'l'am.

Two 18-year-old boys made a bet that at night they would take stones from the bathhouse; then someone grabbed at the arm of one of them from under the sauna bench, but they couldn't see anyone. They heard a voice that said that if that boy would take her as his wife, she would let him go. The boys were so scared that they agreed (FE $1984^{29}$ ).

If the boy agrees to take the changeling as a wife, the girl goes back to her house, where the deception is exposed: the parents see their real daughter, who regains her human shape:

Tan’i berto in’i nylen piyen nyllen korkayaz. Nyl pyrem no zubkays' nylez bas'tem. Pol vyle kushtem no-pil'is'kem, pushkys'tyz s'is'mem köshna paz'gis'kem.

Then the girl and the boy went to the girl's house. She entered the house and took the girl from the cradle in her arms. Then she threw her on the floor, and rot and dust poured out (Kel'makov 1981: 139-140).

According to mythological perceptions, when the bathhouse spirit kidnapped or replaced a child, he left a charred log or chock of wood in the child's place:

Shaytan ${ }^{30}$ lyktem no nylzes voshtem, so intyye muket pinal ponem: vylyz pinally tupa, nosh pushkyz pu köshnays'.

Shaytan came and replaced their girl with another child. She looked like a real child, but inside it was all rot and dust... (Ibid.). 
Quite often this kind of fate is cast on children by their own parents, who unwittingly shout "Shaytan bas'ton!' ('may you be taken by shaytan!') when they get angry with their children. These words, said in a rage, can sometimes be fatal. "The daughter wanted to put her shoes on, but she couldn't find her bast shoes. She had them in the bathhouse. She told her mother about this, who called her shaytan. The daughter stepped out of the house in silence and went to the bathhouse. In the bathhouse, shaytans adopted her, and in her place they sent back a girl from their own family... with bast shoes on..." (Vereshchagin 2001: 132).

According to beliefs and mythological stories, munchomurt is multifunctional. He punishes those who break certain taboos, for example if someone goes to the sauna at midnight, 'intruding' on the space of the bathhouse spirit. He can tickle or choke a person to death. In the past, the Udmurt protected themselves from the bathhouse spirit's tricks with "a piece of iron or metal used as an amulet" (Emel'yanov 1921: 120), and after the adoption of Christianity they did this with the help of a cross worn next to the skin, and Christian prayers mentioning God.

Overall, the following can be said about munchokuz'o: he lives in the bathhouse; does not have a fixed appearance; only reveals himself at night when people violate rules relating to time; and can manifest with the help of noises. He is perceived as an expressly evil creature with regard to humans ${ }^{31}$. People believed that he was only afraid of a four-eyed $\operatorname{dog}^{32}$ :

Pörtmas'kon nunal"yosy pörtmas'kyny potimy. Ogaz'yn sylo vylem kuin' muncho. Tolez' yugyt pishte. S'öramy n'yl' s'inmo puny kutimy val... Vot sytshe n'yl' s'inmo puny, pe, munchokuz'oyez syskyny bygate. So munchoosys', shapka kad' kuren', pitrasa munchokuz'o potiz. Punymy uyiz no öz bygaty kutyny, munchokuz'o doskaos ule vuiz pyryny. 
At Christmas we decided to go to a fancy dress party. There were three bathhouses in a line. The moon was shining so bright. We took a dog with four eyes with us... Because such a dog can gnaw and bite munchokuz'o. Munchokuz'o rolled out of those bathhouses like a brown hat. Our dog started chasing him, but couldn't catch him, that munchokuz'o slipped under the planking (FE $1985^{33}$ ).

People tried to hold the bathhouse spirit in esteem. When they entered the bathhouse, they asked for permission to wash themselves and thanked the spirit before leaving. They left a scoop or a basin with warm water as well as a whisk so that munchomurt could wash and whisk himself. In modern mythological texts, munchomurt is not perceived as an expressly evil spirit, but the Udmurt believe that if you see a bathhouse spirit, such as a korkamurt, it means bad luck, perhaps the death of someone close to you, a serious illness or some other trouble or disaster.

Another 'master' spirit of farmhouse buildings in Udmurt mythology is gidmurt/ gidkuz'o, gidut'is' or s'us'etka (the man/ master of the cowshed, the guardian of the cowshed). Unlike the mythological characters described above, the amount of information about gidmurt is quite limited in both $19^{\text {th }}$ century sources and modern recordings.

Analysis of folklore and ethnographic material enables us to say that gidkuz'o virtually never reveals himself to people, although it is possible to prove that he exists by the way he treats animals because in the cowshed where he lives the animals are well cared for and nourished. People even used to say that there is such a creature as nullis'kis', literally: someone who carries, which brings feed for cattle from other cowsheds. Most of all, gidkuz'o liked or disliked horses. It was believed that if gidkuz'o liked the horses of the master, he could steal hay and oats for them from neighbours. He would comb the manes and tails of his favourite horses and braid them. If he didn't like a horse, he would torture 
it at night riding it the whole night without rest and exhausting it with heavy loads (Pervukhin 1888: 92; Emel'yanov 1921: 119). In such cases people believed that the horse was 'unsuitable'/ug tupa, and it was recommended that they buy another horse, preferably a piebald one.

People also thought that the master of the cowshed could be seen after they performed certain actions. According to Nikolai Pervukhin, gidmurt could appear in front of people both as a human, "a little old man not taller than half an arshin... was riding a black horse" (Pervukhin 1888: 93); and in zoomorphic shape, "there was a bear on his hind legs standing right behind the water tub on the water carrying sledge" (Pervukhin 1888: 94). Sometimes gidmurt would leave "bear paw tracks behind him" (Emel'yanov 1921: 119).

In individual modern mythological texts gidmurt appears as an amorphous white creature:

Ogpol skal kyskis' kyshnomurt dory töd'y murt vuem. Skal kyskyny maza, pe, ug s'ot. Kalyk"yos, as gurtoossy, lyktil'l'am. Od'ekolon piyalayen yake kachyyen, pe, lez'yalo-ug koshky. Tyl dzhuatis'kod ke - yshe, peymytyn nosh, pe, pote. S'ör gurtys'pel'l'as'kis'ez vail'l'am. Achiz main ke s'urem lez'yany kutskem pörtmas'kysez, pel'l'am-maram no-so töd'y ad'ami byrem, potamys' no dugde.

Once a white man appeared in front of a woman milking a cow. He wouldn't let her milk the cow properly. The villagers came to help her. They were throwing perfume bottles (with perfume) and scissors at him, but he just wouldn't leave. When the lights were turned on he disappeared, but in the darkness he would appear again. They brought a healer woman from the neighbouring village. She also threw things at him and whispered something, and then the man disappeared and never came back again (FE 1985 $5^{34}$ ). 
In the old days, sacrifices were made to the master of the cowshed, just as to house spirit, in spring and in autumn. In spring, before putting cattle out to pasture, they made a sacrificial vow with bread and porridge, and the offering itself was made in autumn, when the young animals were mature enough. If a cow was sick, a wood grouse was sacrificed; if a horse was sick, a couple of pikes were offered to the spirit. Sometimes pikes were sacrificed because people believed that if they did so, the skin of their horses would be as shiny as a pike's scales. In this case, the pike was not boiled, but buried whole in the ground in the cowshed. Only family members took part in the offering ritual, and the procedure was similar to the one of making a sacrifice to korkakuz'o in the cellar (gulbech taka vös'an). Addressing gidkuz'o in his prayers, the master of the house asked him to fill his stockyard with strong healthy horses and dairy cows (Emel'yanov 1021: 119).

Expedition records from the second half of the $20^{\text {th }}$ century also contain information about offerings to the master of the cowshed:

Gidkuz'oly ke viro s'oto, dzh'az'egez gidyn vando. Achid gine s'em'yayenyd s'iis'kod. Kyl'e ke no, nokinly no ug s'oto. Ortche oz'y ik, kyz'y korkakuz'oly s'oto. Gidut'is'ly vaz'is'ko, “tynyd viro s'otis'ko" shusa.

If offerings are made to the spirit of a cowshed, a goose is killed there. Only family members can eat the goose. If any meat is left over, it is not given to anyone outside the family. The ritual is held in the same way as the ritual for the spirit of the house. Family members address the spirit of the cowshed saying "Here is a sacrifice for you" (FE 1989 ${ }^{35}$ );

“...Pudo-zhivotez ut', yu-n'an'med luoz, mushez ut', s'em'yame ut', nylpime ut'." Soye veras'ko no kiros ponis'ko. 
“...Protect my cattle, give me good bread crops, keep my bees, protect my family, protect my children." This is what I say and cross myself (FE 2012 $2^{36}$.

Analysis of the material we have enables us to draw a number of conclusions. Such spirits of domesticated space as korkakuz'o and the master of the cowshed/gidmurt are well-meaning creatures. Compared to the bathhouse spirit, they are described in a negative way to a lesser degree. A comment made by a researcher of the traditions of the northern Udmurt based on material he had collected in the $19^{\text {th }}$ century about the fact that the most ancient concept of house spirits is a bear, i.e. "...a figurative demigod of farmhouse buildings", is correct (Pervukhin 1889: 94). The totemic ancestor, whose benevolence in the past was essential to ensure the life and well-being of the entire family line, takes the shape of a spirit/master of the house. Later, when the period of the overriding of totemistic worldviews started, the totemic bear was replaced by a small old man with a beard, or just an old man, as "an ancestor/ progenitor, the head of a clan, consisting of numerous generations of kinsmen, dead or alive" (Krinichnaya 2004: 9).

In records made in recent years the images of mythological creatures under consideration as well as their functions transformed, with each of them more and more starting to look like an ordinary man, perhaps taking after a relative, neighbour or acquaintance, either dead or away from the home. The images mainly appear in dreams, bailichkas and narrations. Their main functions are predicting future events (death, disease and misfortune) or punishing people for violations of rules (human behaviour in nature and the community).

Different guises of mythological domestic spirits as well as of farmhouse buildings (the masters of the house, of the bathhouse and the master of the cowshed) evolved from zoo- and phyto- to anthropomorphic shapes. The last stage of evolution of these images is marked by the phantom of töd'y murt / 'the white man' and 
an amorphous visual shadow figure. Even with all the common features of these vague portrait specifications, their appearance can be differentiated depending on the location where the human being encounters the spirit master. A peculiar feature of modern mythological images is their predominantly acoustic nature: they reveal themselves by means of a number of audible signals (laughing, cackling, screaming, rustling or weeping, impact sounds, the sound of someone playing a musical instrument, dancing, etc.) and are also capable of reproducing human speech. To this extent, it can be said that their mythos returns to its archaic nature, i.e. syncretic and indivisible.

In the modern tradition, all of these images virtually lose their ambivalence with regard to people. They are regarded only as hostile creatures and lose their conspicuity in the hierarchical system.

\section{Abbreviations}

$\mathrm{NB}$ - notebook

$\mathrm{P} / \mathrm{Pp}$ - page/pages

FE - Folklore Expedition of the Institute of Udmurt Philology, Finno-Ugric Studies and Journalism at the Udmurt State University (Izhevsk, Russia)

FE UIHLL and USU - Folklore Expedition of the Udmurt Institute of History, Language and Literature, Udmurt Federal Research Centre at the Ural Branch of the Russian Academy of Sciences, and Udmurt State University (Izhevsk, Russia)

FDE - Folklore and Dialect Expedition of the Institute of Udmurt Philology, Finno-Ugric Studies and Journalism at the Udmurt State University (Izhevsk, Russia)

DE - Dialect Expedition of the Institute of Udmurt Philology, Finno-Ugric Studies and Journalism at the Udmurt State University (Izhevsk, Russia) 


\section{Notes}

1 In the past, the Udmurt built bathhouses on river banks or close to other bodies of water, or in their yards. In the national consciousness, the bathhouse was perceived as a dangerous place because it used to stand on the border of one's own and somebody else's space. Gradually people started building bathhouses in their yards, which is why we regard the mythological perceptions related to it within the context of domesticated space.

2 Researchers who study Udmurt families say that, for a number of reasons, the Udmurt had large extended families for a very long time (see Grishkina 1989: 210; Vladykin 1994: 202), which united three or four generations and consisted of $30-40$, sometimes even 60 people (Orlov 1999: 37).

${ }^{3}$ Udm. Gondyr "bear".

${ }^{4}$ It used to be very quiet in Udmurt houses, perhaps also to please korkakuz'o. This is how G. Vereshchagin described the traditional way of life: "If you want to learn about family life, enter the dwelling of a Votyak in winter and take a closer look at life among his family members ... It is all peace and quiet in the room; you will only hear a spindle spinning, the crackle of a burning log, the bast rustling, which resembles the rustle of the grass in the wind; occasionally you will also hear short, insignificant words about everyday things; if there are children in the house, you might also hear one of them crying because he was offended by another, but this weeping will not last long: as soon as the mother or father says something gentle, like "En bördy, gydyke!' '(Stop crying, darling!'), the child stops weeping and it is silent in the room once again. You will not hear any kind of row or quarrel" (Vereshchagin 1995: 21-22).

5 An old Russian length unit equal to about 71 centimeters or 28 inches.

6 Alnashi District, Udmurtia. NB. 4. P. 27.

7 Krasnogorskoye District, Udmurtia. NB. 5. P. 13.

8 Yakshur-Bod'ya District, Udmurtia. NB. 4. P. 45.

9 Yakshur-Bod'ya District, Udmurtia. NB. 2. P. 33.

${ }^{10}$ Grakhovo District, Udmurtia. NB. 3. P. 47.

${ }^{11}$ Sharkan District, Udmurtia. NB. 2. P. 20.

${ }^{12}$ Vavozh District, Udmurtia. NB. 4. Pp. 46-47.

${ }^{13}$ Sharkan District, Udmurtia. NB. 1. P. 6. 
${ }^{14}$ Alnashi District, Udmurtia. NB. 4. P. 5.

${ }^{15}$ Mozhga District, Udmurtia. NB. 6. Pp. 20-22.

${ }^{16}$ Grakhovo District, Udmurtia. NB. 3. P. 38.

${ }^{17}$ Yakshur-Bod'ya District, Kekoran village. Volume No. 4. P. 45.

${ }^{18}$ Alnashi District, Udmurtia. NB. 4. P. 20.

${ }^{19}$ Yakshur-Bod'ya District, Udmurtia. NB. 5. P. 5.

${ }^{20}$ An old Russian length unit equal to about 2 meters.

${ }^{21}$ Yakshur-Bod'ya District, Udmurtia. NB. 4. Pp. 47-48.

${ }^{22}$ Sharkan District of Udmurtia. NB. 1. P. 11.

${ }^{23}$ Sharkan District, Udmurtia. NB. 4. P. 2.

${ }^{24}$ Kez District, Udmurtia. NB. 2. P. 7.

${ }^{25}$ Sharkan District, Udmurtia. NB. 2. P. 40.

${ }^{26}$ Yakshur-Bod'ya District, Udmurtia. NB. 4. P. 38.

${ }^{27}$ Yakshur-Bod'ya District, Udmurtia. NB. 4. Pp. 47-48.

${ }^{28}$ Selty District, Udmurtia. NB. 5. P. 23.

${ }^{29}$ Sharkan District, Udmurtia. NB. 5. Pp. 10-13.

${ }^{30}$ Under the influence of Christian tradition, differentiated 'master' spirits become unified in a generalised image of an evil spirit (shaytan)/devil).

${ }^{31}$ Perhaps the main reason munchokuz'o was attributed with expressly negative features was because bathhouses used to stand furthest from all other buildings in the yard.

${ }^{32} \mathrm{~A}$ four-eyed dog is a dog whose fur around the eyes is much lighter or darker than its main colour. According to beliefs, such dogs can see evil spirits.

${ }^{33}$ Malaya Purga District, Udmurtia. NB. 2. P. 50.

${ }^{34}$ Malaya Purga District, Udmurtia. NB. 2. P. 50.

${ }^{35}$ Vavozh District, Udmurtia. NB. 4. P. 31.

${ }^{36}$ Kizner District, Udmurtia. NB. 3. P. 35. 


\section{References}

Belitser, V., Markelov, M., Sidorov, G. 1931. Udmurty [The Udmurt]. Izhevsk: Udmurtkniga.

Emel'yanov, A. 1921. Kurs po etnografii votyakov [A Course on Ethnography of the Votyaks]. Issue 3: Ostatki starinnykh verovaniy i obryadov $\mathrm{u}$ votyakov [Traces of Ancient Beliefs and Rites among the Votyak]. Kazan: Kazanskiy votskiy izdatel'skiy podotdel.

Glukhova, G. 1990. Obraz bannika v udmurtskoy neskazochnoy proze [The Image of the Spirit Living in Sauna in Udmurt Non-Fairytale Prose]. 6-aya ross. Univ. Akadem. Nauchno-prakticheskaya konferentsiya $\left[6^{\text {th }}\right.$ Russian Univ. Academ. Theoretical and Practical Conference. Part I]. Izhevsk: Udmurtskiy universitet, pp. 51-53.

Grishkina, M. 1989. Tipologiya udmurtskoy krest'yanskoy sem'i kon. XVII - per. pol. XIX vv. [Typology of the Udmurt Peasant Family at the End of XVII c. - First Half of XIX c.]. Materialy VI Mezhdunarodnogo kongressa finno-ugrovedov [Works of VI International Congress of Finno-Ugric Scholars]. Vol. 1. Moscow: Nauka, pp. 104-125.

Holmberg, U. 1927. Finno-Ugric, Siberian. The Mythology of All Races IV. Boston: Archaeological Institute of America.

Kel'makov, V. 1981. Obraztsy udmurtskoy rechi: Severnoye narechiye $i$ sredinnyye govory [Samples of Udmurt Dialects: the Northern Dialect and the Central Subdialects]. Izhevsk: Udmurtia.

Kel'makov, V. 1990. Obraztsy udmurtskoy rechi 2: Sredinnyye govory [Samples of Udmurt Dialects 2: the Central Subdialects]. Izhevsk: Udmurtia.

Krinichnaya, N. 2004. Russkaya mifologiya. Mir obrazov fol'klora [Russian Mythology. The World of Folklore Characters]. Moscow: Akademicheskiy proekt Gaudeamus.

Levkiyevskaya, E. 2006. Pragmatika mifologicheskogo teksta [Pragmatics of Mythological Texts]. Slavyanskiy i balkanskiy fol'klor. Semantika $i$ pragmatika teksta [Slavic and Balkan Folklore. Semantics and Pragmatics of the Text]. Issue 10. Moscow: Indrik, pp. 150-211.

Orlov, P. 1999. Veshchnyy mir udmurtov: K semantike material'noy kul'tury: Dissert. na soisk. uch. step. kand. nauk. [Udmurts' World of Things: On the Semantics of Material Culture. Cand. sci. diss.]. Izhevsk: Udmurtskiy universitet. 
Panina, T. 2017. Obrazy lesnykh dukhov v udmurtskoy mifologiy i fol'klore: III. Obyda (lesnaya zhenshchina) [Images of Forest Spirits in Udmurt Mythology and Folklore: III. Obyda (Forest Woman)]. Ezhegodnik finno-ugorskikh issledovaniy [Yearbook of Finno-Ugric Studies] 11 (2), pp. 53-67.

Pervukhin, N. 1888. Eskizy predaniy byta inorodtsev Glazovskogo uyezda [Essays about the Legends and the Everyday Life of Non-Russians of the Glazov District]. Eskiz 1: Drevnyaya religiya votyakov po ego sledam v sovremennykh predaniyakh [Essay 1: The Ancient Religion of the Votyak according to its Traces in Modern Legends]. Vyatka: Gubernskiy statisticheskiy komitet.

Pervukhin, N. 1889. Eskizy predaniy byta inorodtsev Glazovskogo uyezda [Essays about the Legends and the Everyday Life of Non-Russians of the Glazov District]. Eskiz 4: Sledy yazycheskoy drevnosti v obraztsakh ustnoy narodnoy poezii votyakov [Essay 4: Traces of Pagan Antiquites in Samples of Oral Folk Poetry of Votyak]. Vyatka: Gubernskiy statisticheskii komitet.

Pletneva, I. 1999. K semantike udmurtskogo vozho [On the Semantics of the Udmurt Vozho]. Problemy udmurtskoy i finno-ugorskoy filologii [Questions of Udmurt and Finno-Ugric Philology]. Izhevsk: Udmurtskiy universitet, pp. 245-250.

Shklyayev, G. 1989. Obryady i pover'ya udmurtov, svyazannyye s zhilishchem [The Udmurt's Rituals and Beliefs Related to the House]. Fol'klor i etnografiya udmurtov: obryady, obychai, pover'ya [Folklore and Ethnography of the Udmurt: Rituals, Customs, Beliefs]. Izhevsk: Udmurtskiy institut istorii, yazyka i literatury Uralskogo otdeleniya Rossiyskoy akademii nauk, pp. 28-43.

Shklyayev, G. [n.y.]. Korkamurt (domovoy) [Korkamurt (House Spirit)]. Mifologiya udmurtov: entsiklopedicheskiy slovar'. Rukopis' [Mythology of the Udmurt: Encyclopaedia] [Manuscript].

Slesareva, M. 2004. Zhanr bylichki v publikatsiyakh G. Vereshchagina [The Genre of 'Bylichka' (a short story/fable) in the Publications of G. Vereshchagin] G. E. Vereshchagin i etnokul'turnoye razvitiye narodov Uralo-Povolzh'ya: Sb. st. [G. Vereshchagin and the Ethnocultural Development of Peoples of Ural and Volga Regions. Collected Articles]. Izhevsk: Udmurtskiy institut istorii, yazyka i literatury Uralskogo otdeleniya Rossiyskoy akademii nauk, pp. 115-117. 
Slesareva, M. 2005. Mifologicheskiye obrazy: izmeneniye traditsii vo vremeni [Mythological Characters: Changing Tradition in Time]. Material'naya $i$ dukhovnaya kul'tura narodov Urala i Povolzh'ya: istoriya i sovremennost'. Materialy Mezhregional'noy nauchno-prakticheskoy konferentsii. [Material and Spiritual Culture of the Peoples of Ural and Volga Regions. Works from International Theoretical and Practical Conference]. Glazov: Glazovskiy gosudarstvennyy pedagogicheskiy institut.

Tronina, I. 2007. Zhanry i obrazy udmurtskoy mifologicheskoy prozy: Vypusk. kvalif. rabota / Ruk. T. G. Vladykina [Genres and Metaphores in Udmurt Mythological Prose. Graduation Thesis, Sci. Supervisor T. G. Vladykina]. Izhevsk: Udmurtskiy universitet.

Vereshchagin, G. 1995. Sobraniye sochineniy: V 6 t. [Collected Works: In 6 Vols.]. Vol. 1: Votyaki Sosnovskogo kraya [The Votyak of Sosnovka Region]. Izhevsk: Udmurtskiy institut istorii, yazyka i literatury Uralskogo otdeleniya Rossiyskoy akademii nauk.

Vereshchagin, G. 1996. Sobraniye sochineniy: V $6 t$. [Collected Works: In 6 Vols.]. Vol. 2: Votyaki Sarapul'skogo uyezda Vyatskoy gubernii [The Votyak of Sarapul District of the Vyatka Governorate]. Izhevsk: Udmurtskiy institut istorii, yazyka i literatury Uralskogo otdeleniya Rossiyskoy akademii nauk.

Vereshchagin, G. 2001. Sobraniye sochineniy: V 6 t. [Collected Works: In 6 Vols.]. Vol. 4: Fol'klor. Book 1: Udmurtskiy fol'klor: Predaniya. Legendy. Pobyval'shchiny. Skazki. Basni. Poslovitsy. Pogovorki. Zagadki [Folklore. Book 1: Udmurt Folklore: Traditions. Legends. Stories. Fairy Tales. Fables. Proverbs. Riddles]. Izhevsk: Udmurtskiy institut istorii, yazyka i literatury Uralskogo otdeleniya Rossiyskoy akademii nauk.

Vladykin, V. 1994. Religiozno-mifologicheskaya kartina mira udmurtov [The Udmurt's Religious and Mythological Worldview]. Izhevsk: Udmurtia.

Vladykina, T. 2009. Obrazy lesnykh dukhov v udmurtskoy mifologiy i fol'klore: I. N'ulesmurt (lesnoi chelovek/leshii) [Forest Beings in Udmurt Mythology and Folklore: 1. N'ulesmurt (Wood Spirit)]. Traditsionnaya kul'tura $v$ izmenyayushchemsya mire: Materialy VIII Mezhdunar. shkoly molodogo fol'klorista "Traditsionnaya kul'tura $v$ izmenyayushchemsya mire" $i$ seminara "Permistika: yazyk $i$ stil" fol'klora" [Traditional Culture in the Changing World: Proc. $8^{\text {th }}$ Int. School of Young Folklorist "Traditional Culture in the Changing world" and Seminar "Permistika: the Language and Style of Folklore"]. Izhevsk: Udmurtskiy institut istorii, yazyka i literatury Uralskogo otdeleniya Rossiyskoy akademii nauk, pp. 24-30. 
Vladykina, T., Glukhova, G. 2011. Ar-god-bergan: Obryady i prazdniki udmurtskogo kalendar'ya [Year Circle: Rituals and Celebrations of the Udmurt Calendar]. Izhevsk: Udmurtskiy universitet.

Vladykina, T., Panina, T. 2015. Obrazy lesnykh dukhov v udmurtskoy mifologiy i fol'klore: II. Palesmurt (polovinchatyy chelovek) [Forest Beings in the Udmurt Mythology and Folklore: 2. Palesmurt (HalfHuman Creature)]. Ezhegodnik finno-ugorskikh issledovaniy [Yearbook of Finno-Ugric Studies] 4, pp. 59-67.

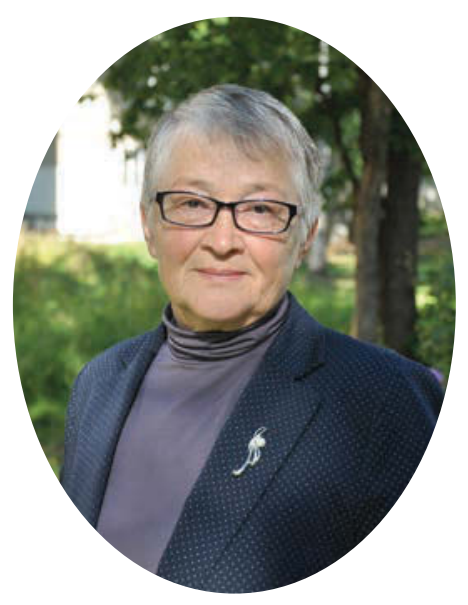

Tatiana Vladykina is ( $\mathrm{PhD}$ hab) a professor and leading researcher at the Udmurt Institute for Research in History, Language and Literature (Udmurt Federal Research Centre of the Ural Branch of the Russian Academy of Sciences). She has covered the range of topics in Udmurt folkloristics, especially mythology, specialising both in genre and in the treatment of the most important topics across genres.

e-mail: tgvladykina@mail.ru

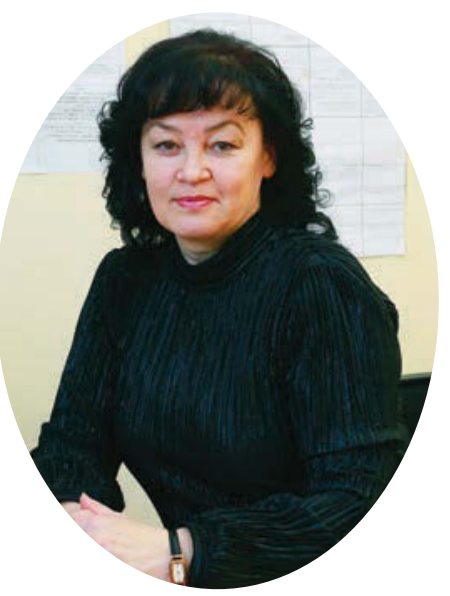

Galina Glukhova ( $\mathrm{PhD})$ is an associate professor and director of the Institute of Udmurt Philology, Finno-Ugric Studies and Journalism of Udmurt State University and teaches Udmurt literature and folklore. Her main field of interest is related to research on Udmurt and FinnoUgric folklore, Udmurt traditional culture, and the interaction of Udmurt folklore and literature. e-mail: galant@udm.ru 


\title{
A Systematic Investigation of Sacred Space in the Kama-Vyatka Region: Udmurt Materials
}

\author{
Nadezhda Shutova \\ e-mail: nad_shutova@mail.ru
}

\begin{abstract}
This article summarises the results of long-term studies of cult places and reconstructions of sacred space at the turn of the $20^{\text {th }}$ century. The studies were carried out by the Udmurt Institute of History Language and Literature, Urals Department of the Russian Academy of Science.

The article starts by reflecting on the meaning of the word 'sacred' in Russian and Udmurt. It then explains the main approaches and research methods used when looking at spaces that have become sacred as a result of a particular activity, for example through symbolical domestication and transformation of the environment; or because of the natural, social, cultural and spiritual milieu; or as a particular creative transformation of the hierotopy, including hierophany as the presence of a divine (or mystical) component. In reconstructing the traditional sacred space of the Udmurt, we used systematic, and structural/semiotic methods. The first sees sacred space as a complicated natural, historical and cultural, religious and mythological set, while the second reveals the semantics of these cultural places, objects and rituals. We pay particular attention to the study of structure, of the main indicators and the semantics of the Udmurt traditional space at the turn of the $20^{\text {th }}$ century. We have followed the means of organising sacred landscapes, which assumed the existence of networks of shrines and cult objects, a systematic
\end{abstract}


organisation of ceremonies and rituals at each of them, and the holding of family and calendar rituals.

We have revealed circles (levels) of sacredness (family, patronymic, conditional clan, village, regional, tribal and territorial), showing how the mythological opposition between sacred and profane is relative within each local area, existing implicitly within the limits of a wider area of sacredness.

We have briefly characterised how extensive study has been of the different types of religious landscape, and the present state of the art.

Keywords: approaches and methods of study, levels of sacredness, ritual, sacred space, shrine, structure and semantics of space, traditional, Udmurt

Since the beginning of the $1990^{\text {s }}$ the Udmurt Research Institute has organised research on the cult places and shrines of the Udmurt, the Besserman and other peoples who have lived between the Kama and the Vyatka from the Middle Ages onwards. This entailed the investigation of such topics as cultural landscape and sacred space. The output of this research is four monographs and some dozens of articles on the topic (Shutova 2001, 2011, 2012, 2013a; Cult Monuments 2004; Shutova et al. 2009; Popova 2011). Let us highlight the main results of our research.

\section{The concept of the 'sacred'}

In scientific literature the terms 'sacred', 'sacral' (in Russian sakral'nyy, svyashchennyy, from Lat. sacrum, Ger. sakral) are seen as a concept connected with the idea of God, and as being contrary to the terms 'profane', 'worldly', 'secular' (Bayburin 1993: 183). There are many definitions of the equivalent Russian sacral'nyy 'sacred'. The most complete and detailed meaning of this term was given by E. Levkievskaya: "Sacred is one of the central concepts in archaic worldview and in Christian theology: it is a quality intrinsic to God and the main divine forces (God's 
mother, angels, archangels, saints), and to the sphere in which they live and manifest themselves. In a wider traditional context, it is a quality intrinsic to the cult and worship sites, which are full of religious meanings and charged with peculiar force, characterised by blessing and pureness" (Levkiyevskaya 2009: 534).

In Udmurt, for a long time the word seems to have been vös'am (lit: 'used through prayer', 'filed with prayer', 'blessed'). This quality is achieved through special ceremonies, rituals, incantations. Another word, a kind of duplication, dun chylkyt, meaning 'very pure', first appears in T. Borisov's dictionary (Borisov 1991': 89). It comes from the Udmurt adjective dun 'transparent, clean, valuable' and the noun 'price, value, assessment' (URS 2008: 189-190; Karpova 2013: 171) and chylkyt ('clean, pure'). According to our opinion, the first term dun is used both literally and figuratively. The word chylkyt characterises cleanness in the physical meaning. In the Finnish-Udmurt Dictionary and in the Udmurt-Finnish Dictionary some other words meaning sacred are introduced for the first time: dun-s'ölyktem, vös'lyko, vös'o-buro (Maksimov et al. 2008: 115; Maksimov 2013: 536). M. Atamanov used the word dun-chylkyt to express the Orthodox concept 'saint (Godly)'; 'pure, immaculate' (Vös'as'kon"yos 2000: 146).

In addition, the Permic peoples used the archaic notion vozh, vozho, vezha from the Proto-Permian word verza 'sacred, sacral, blessed' (KESK 1970: 49-50). In the Udmurt traditional calendar, terms with the stem vozho expressed transitional periods in the lunar and solar years. Thus, we have for example invozho ('the days of the summer solstice'; in 'sky, celestial'; vozho 'sacred', 'transitional') and vozhodyr/uyvozho 'days of the winter solstice' (vozho 'sacred', 'transitional'; dyr 'time, period'; uy 'night' or uypal 'north, northern part') (Pervukhin 1888: 58-60; Vladykina, Glukhova 2011: 33-39). The root vozh is also to be found in the name of the family/ clan deity of the Slobodskoy Udmurt (Kirov Oblast') Vozhshud (in other areas Vorshud), who symbolised sacred (ancient/genuine) happiness (luck/fate/sharing) (for more details, cf.: Shutova 2014: 
276-282). The term vezha, as meaning sacred/sacral appears in Proto-Permic liturgical texts. In Komi, this word is used in its literal meaning 'sacred, sacral, blessed' and belong to the Christian semantic field: vezha va 'holy water', vezha dyr 'Christmas', vezha lun 'church holiday', as well as vezhay 'godfather', vezhan' 'godmother', vezhapi 'godson', vezhanyv 'goddaugher' (KESK 1920: 49-50; Limerov 2002: 157-158).

Permic words with the root vozh, vozho, vezha, have meanings related to a precise quality existing in nature, time and space both in material objects and in non-material phenomena but always connected with the cult of dead ancestors. These terms relate to the connection between group or person and another reality, which in the framework of the traditional worldview is divided into two spheres: the lower underground/underwater realm, and the higher, heavenly, realm. This is the origin of the double hypostasis of the Udmurt word vozho and Komi word vezha and the ambivalence of the sacred transitional time vozhodyr/vezhadyr. On the one hand, this is the best time to attract luck and success, to enter into contact with the other, the divine sphere: ceremonies organised in this period were received with more favour and reached their addressee more quickly. On the other hand, this is a transitional time, a dangerous period that requires behaviour rules, prohibitions, and taboos related to the natural environment to be respected. The concepts of vös'am, vös'lyko, vös'o-buro, refer to qualities of things, substances, phenomena that are the result of religious ceremonies. The terms dun-chylkyt and dun-s'olyktem reflect the abstract Christian understanding of sacredness, purity, value and virginity; the double form of these concepts strengthens their meaning. Moreover, while the word dun-s’olyktem must be used to express the Christian understanding of innocence or purity, dun-chylkyt can be used in a wider context. In many Udmurt areas, people also widely used the Russian loanwords suyatoy and suyashchennyy. 


\section{The main approaches and principles of the research}

In reconstructing the Udmurts' traditional sacral space, we used the systematic and the structural-semiotic (semiotic, from Gr. semeion 'sign', 'feature' - the science of signs and sign systems) methods. The first looks at space as a complicated natural, historical and cultural, religious and mythological complex, while the second looks at the semantics of cult places, objects and rituals.

Our research, dedicated to the specific features of the sacred space, relies on three fundamental approaches. The first approach presupposes that the sacred space has some peculiar qualities: it encompasses the presence of the divine or of an irrational (mystical) component. The famous scholar of religion Mircea Eliade, who introduced the category of hierophany (Gr. hieros 'sacred' and fanos 'light, torch', meaning the manifestation of sacredness) to scientific discourse, said: "Each sacred space implies some hierophany, some intrusion of the sacred, with the result that some territory separates from the surrounding cosmic space, deploying qualitatively distinct properties" (Eliade 1959: 164; Eliade 1994: 25).

The second approach imagines sacred space as the result of a particular creative activity intended to symbolically domesticate and transform the surrounding natural, social, cultural and spiritual sphere. According to Siberian ethnographers I. Gemuev and A. Salagaev, "The domestication of natural resources by a group of people was accompanied by its spiritual domestication in forms typical for traditional society" (Gemuev, Salagaev 1986: 189).

The third approach sees the sacred space as the result of creative transformations (following historian of the arts A. Lidov). Researchers have proposed the term hierotopia (Gr. hieros 'sacred' and topos 'place, space', 'concept', i.e. the process of creating sacred space) for a particular kind of artistic creation and a particular domain of historical research in which scholars reveal and analyse examples of this art: "...the centre of the universe, in the representations of 
the bearers of ancient and medieval traditional religion, was a nonmaterial and at the same time a real, an existing space, around which was organised the world of the objects, sounds, smells and other effects" (Lidov 2006: 14; 2012: 12-13).

In recent years the hierotopia approach has been widely implemented and used to analyse the Christian sacred space (the Old Testament, New Testament, Byzantine period) (Hierotopia 2006), the Muslim sacred places in Siberia (Seleznev 2013: 111-119), the city of Tyumen' (Semenova 2013: 280-283), the space of new religious movements (Seleznev 2014: 282-292) and other cases. According to A. G. Seleznev, this approach "opens additional perspectives in viewing the sacred space by taking into account, as an important factor, the formation of ethnic and cultural identity" (Seleznev 2013: 118).

\section{The main means of organising sacred space in the Udmurt tradition}

Acting creatively in order to organise a people-friendly space required the use of two main approaches. The first was the formation of a system of cult monuments of different kinds, their deployment in the surrounding landscape and the installation of their inner structure. This entailed the analysis of indicators such as the types and the diversity of cult places, their social meaning, their sacred status (higher, lower) depending on their position in the system of the traditional world order, which deity the shrine or cult spaces was dedicated to and its topography and interior organisation.

The second approach was the organising of two groups of regular ritual ceremonies. The first group encompassed ceremonies of votive and sacrificial offerings at the sanctuaries - family, patronymic, clan, village, community, tribe and territorial; the second group was family and calendar rites. 
In order to study how to design a sacred space to be part of the ritual process one must take into account the following indicators:

1. the form and the date of the ritual;

2. the features of the site and the roles of the participants, their ages and gender composition;

3. ritual paraphernalia (trees, branches from trees, headgear, towels with embroidered ends, a special costume the ritual leader, costumes for participants);

4. the interpersonal skills or particular talents of the priest or organiser of the ceremony;

5. a particular procedure for blessing the food;

6. particular actions including musical accompaniment (zither or violin, the rhythm, the singing), walking in circle, meditation on sacred characters, exclamations, bows, the setting of a fire (a fireplace, sometimes a candle), the ritual offering of a meal and a system of hospitality, the visions that might be the motivation for organising a ceremony;

7. the mystic nature of the outcome of the ceremony, i.e. when the rituals and ceremonies have consequences (a positive or negative effect). People felt the favourable influence of the ceremony;

8. the presence of a divine (irrational) component during the ritual itself.

We must observe that after the performance of a ceremony at the sanctuary, the reconstructed sacred space and time continued in the settlement, for example the blessed food coming from the sanctuary was offered to all those who were not able to attend the ceremony. There was a precise hosting system within each kin group. In several regions, the hosting took place even between large local groups, outlining the living areas of ethno-territorial groups of Udmurt. At the turn of the $20^{\text {th }}$ century annual purification ceremonies were performed by all Udmurt groups, with the aim of reconstructing a new sacred space and time in order to assure future prosperity. 
This happened at the beginning of the new year according to the traditional calendar, during the holiday that was held to welcome spring and start the spring fieldwork (the name depends on the area: Bydzh'ym nunal 'the Great Day', Akashka 'Akashka', etc.) (for more details, cf.: Lintrop 2002; Minniyakhmetova 2003: 83-152; Shutova 2013b). This feast presents clear agrarian symbols as its aim was to activate the forces of nature and to ensure the fertility of land, livestock and people. These rituals had various productive, purifying and apotropaic functions and contributed to the purification and sacralisation of village cultural space. The feast was characterised by an address to the dead ancestors, to family and clan deities, as well as to territorial divine protectors, calling for their help. There were banquets, and people visited patrilineal kin around the village, moving either up-stream or clockwise in order to bring good luck. Young men rode on horses and performed purification and other rituals (Shutova 2015).

\section{The structure and semantics of the Udmurt traditional sacred space}

The Udmurt traditional sacred space is the most thoroughly studied in the region between the Kama and the Vyatka. The sacred space has been reconstructed in around 20 places, in each of which the peculiarities as well as common features in organisation of religious and mythological space have been highlighted. As a rule in the surroundings of each village community in the region, there was a complete system of cult places and sites with different levels of significance. Depending on the social importance and the role of the deities and spirits, there were four basic categories of sites of worship. The first category, known as the small kuala, the mudor kuala, or the great kuala, were situated within the limits of the village or close to them and were dedicated to the protectors of the family or clan. In Udmurt mythological awareness, the clan 
sanctuaries were symbols of the familiar, i.e. the domesticated, space. They were inhabited by kin deities and protectors such as Vorshud, Mudor, Invu, who guaranteed prosperity for members of the clan and were responsible for (internal) intergenerational relations as well as (external) relation of the kin group with its close natural environment.

Shrines on the second group were meant for ceremonies carried out for the masters of wild nature, and were connected with the cult of the main landscape elements: forests, higher places, trees, groves, springs, stones, lakes, rivers. The places of worship for the masters of wild nature (lud/keremet, n'ulesmurt) symbolised space that had not been domesticated by man, and represented the male sphere of activity - hunting, fishing, animal breeding, forest beekeeping, as well as cultivation on slash-and-burn land. The deities of this level, according to the elder Udmurts, were also inhabitants of the middle world and were in a kind of opposition to the divine protectors of family and clan. They were masters of the forests, meadows, bogs and grassland used by the people as pasture, and of hunting land.

Thus, in the Udmurt milieu, there were two main types of cult place (the great kuala and the sacred grove $l u d$ ), at which they worshipped two groups of deities (family and clan protectors on the one hand, masters of wild nature on the other). This shows that within the traditional worldview there were representations of the duality of the middle world, of its horizontal articulation according to the principle of domestication, i.e. either domesticated by people, or not. And there is also a clear awareness of the different levels of domestication of marginal, transitional zones between these oppositions in the world of the earth. As an important element of the mytho-ethnic model of the world, lud, alias wild nature, appears as a life-giving, an all-creating, all-absorbing principle. This world was a kind of peripheral space in relation to the central domesticated space. 
The third category of sacred place is represented by the collective tribal or territorial sanctuaries. We can identify three ways of creating them and, as a consequence, three different kinds of shrine within this type. The first way of designing these sanctuaries is connected with the ulterior development and complexification of the archaic cult of clan protectors (the shrines of Imma created by the Slobodskoy Udmurt). The second way is based on the deification of legendary ancestors who were the founders of the clans (Bulda shrines by southern Udmurt), which undoubtedly means the sanctuary and its deities are male. The third way is the result of an evolution of the ceremonies dedicated to the spirit master of a natural site (the sanctuary of Lek Oshmes in Igra district, Udmurtia, Lyz'i lake in Baltasi district, Tatarstan). Tribal and territorial cult monuments were places dedicated to the worship of powerful gods who became protectors of whole social groups, expressing an awareness of their unity. The distinction between tribal and territorial shrines founded by kin or neighbour religious communities is now progressively disappearing.

The fourth category is monuments intended for funerary, commemorative and propitiatory rituals. The cemetery was seen as a kind of settlement for dead ancestors. Because of how developed the ancestor cult was, these places became sacred places and objects of worship for the living. They regularly host commemorative banquets and there are precise rules for visiting. There are also different places to perform the commemorative ritual called yyrpyd s'oton (lit: 'offering of the head and legs (of an animal)'); other places, called bel'gy, are dedicated to those who have passed away abroad; there are other locations at which people dispose of what remains of the clothes and utensils of the dead, called kurkuyan (lit: 'throwing of the plank (on which the dead was washed)') and kuparkuyan (lit: 'throwing of the ladle (used to wash the dead)').

The design of each shrine (hierotopy) was carefully planned. Each pre-Christian high ranking sanctuary (kuala, lud, others) had an organised internal structure: a quadrilateral, or a circle with, 
inside, a quadrilateral (for example, the sacred grove of Esymbay lud in Novaya Uch'a, Kukmor district, Tatarstan); or a polygonal form or two juxtaposed polyhedra (for example, the sacred grove in Varkled-Bod'ya, in Agryz district, Tatarstan). In the design of the quadrilateral sanctuaries a curve in one line of the rectangular fence alludes to the place where in the early Christian basilicas and in Russian churches the eastern altar would stand (for example great kuala sanctuary, and Bulda in Varzi-Yatchi, Alnashi district, Udmurtia). There are other markers of sacred space, such as a fireplace with cauldron and paraphernalia, sacred tree or stump, sacred stone/remains of millstone, pit or hollow, pole or board, shelves, table and benches, as well as other interior objects. The space adjacent to the sacred site was usually fenced either artificially or naturally (trees, angle of slope, etc.). In several cases, depending on the level of sacredness of each section, there could be two or three enclosures. Cult sites of a lower rank, connected with commemorative rituals (kurkuyan, yyr-pyd s'oton, others), were not marked in a man-made way.

Depending on status, two main principles determined sanctuary location, related to local rivers, there was a kind of vertical and horizontal axis in regard of the settlement, which was seen as the centre of the universe, the most domesticated cultural space. Sanctuaries of higher rank, dedicated to more influential deities (family, clan and tribe protectors; masters of forests, meadows and lakes) usually occupied the more elevated places at a location. As a rule, the sacred places were situated upstream from the village, while the cult places connected with funerary and commemorative rites were seen as sacred sites of a lower status, and, traditionally, were located downstream from the village. Cemeteries were usually located at elevated locations outlined by the surrounding landscape. The other group of sacred places, the yyr-pyd s'oton, kurkuyan, koparkuyan, were situated in valleys, in ravines, dips and lower places close to rivers and springs. In the representations of the 
people of that time, lower (impure) places were connected with the world of the dead, and of underground and underwater beings.

The local forms and ways of designing the sacred landscape of Udmurt villages reveal a high level of their inhabitants' interconnection with their surrounding natural space. Sacred monuments are adjacent to some particular elements of the landscape. Whole sacred complexes are formed in places where these elements are concentrated (elevation, spring/river, trees/uncommon trees, stones, waterfall, old settlement, etc.), and they were actively used in the ritual practice of the local population. Here, the natural sites themselves functioned as sacral monuments. It was particularly important to take into account their position in regard to the domesticated space of the village (human settlement being a symbol of the middle level of the universe) and the river valley (the river as a symbol of the horizontal and vertical axes of the universe). A network of sacred loci existed not only in the village, but also in each private household.

In general, the traditional Udmurt system for designing spiritual space in a rural location implied the existence of a religious centre, a regional sanctuary, with the main sacred values in the older mother village, a network of smaller villages and, in each of them, a village sacred place as well as a series of clan or patronymic cult sites. Sacred places for the worship of wild nature (lud, n'ulesmurt, springs, lakes) and dead ancestors were located outside the limits of each village. Furthermore, there were also collective tribal or territorial sacred places, which defined the larger space of kin or territorial groups including from 5 to 70 villages. The traditional system of sacral space used a clearly determined structure, with a centre and a periphery, a rigid inner hierarchy of sacred places and a system of worship and rules for visiting within the region. 


\section{The levels of sacred space}

Relying on the deployment system and the diversity of sacred sites and cult centres we can talk about the existence of several levels of sacredness:

1) the family level is limited to the boundaries of the house/ household, the core of which is the sacred building (the small kuala with a fireplace, the fenced vös'as'kon inty space, or the pit, called vös'as'kon gop);

2) the patronymic sacred space, the centre of which is either in the Mudor kuala building (according to the western (transVyatka) Udmurt) or in the sacred grove Norel'lud or Byzho lud in Staraya Uch'a (according to the Kukmor Udmurt);

3) the territory of the wider kin group or clan, centred on the great kuala sanctuary of the Durga clan (according to the Slobodskoy Udmurt); or on the Esymbay lud, which serves several villages (according to the Kukmor Udmurt); or on the Ven'a clan (according to the western (trans-Vyatka) Udmurt);

4) the village space, including the limits of the settlement, with contiguous sacred places (the great kuala sanctuary, the lud vös'as'kon sacred grove, the location of the n'ulesmurt ceremony, the ground for agrarian ceremonies);

5) the sacred place of the community, including the limit of the rural area with 5-10 villages that share a regional sacred place (the mör vös' ceremony of the eastern Udmurt; lake Lyz'i of the Kukmor Udmurt);

6) the tribe or territorial space encompassing a wide collective group consisting in 10-70 settlements. For the territorial group of the southern Udmurt the sacred places dedicated to Bulda played an important role as spiritual centres that helped to consolidate the ethnic group, with the cult of Bulda becoming a significant ethnic characteristic. Tribal or territorial sacred 
places existed for the Slobodskoy Udmurts and the Vatka Udmurts from Uni (whose sacred place was Inma), the western Udmurt (sacred place Kuris'kon near Nyr"ya), the Glazov Udmurt (sacred place Gubervös'), the Kalmez Udmurt (sacred place Demen / Kalmez vös'). The collective sacred centres and the cult of powerful gods showed the on-going processes of consolidation and formation of wide ethno-territorial groups of Udmurt. We have found no data about the existence of an allUdmurt sacred place from the turn of the $20^{\text {th }}$ century. However, the author would not rule out the possibility of the existence of a big Permian religious centre outside Udmurt areas in the Urals region.

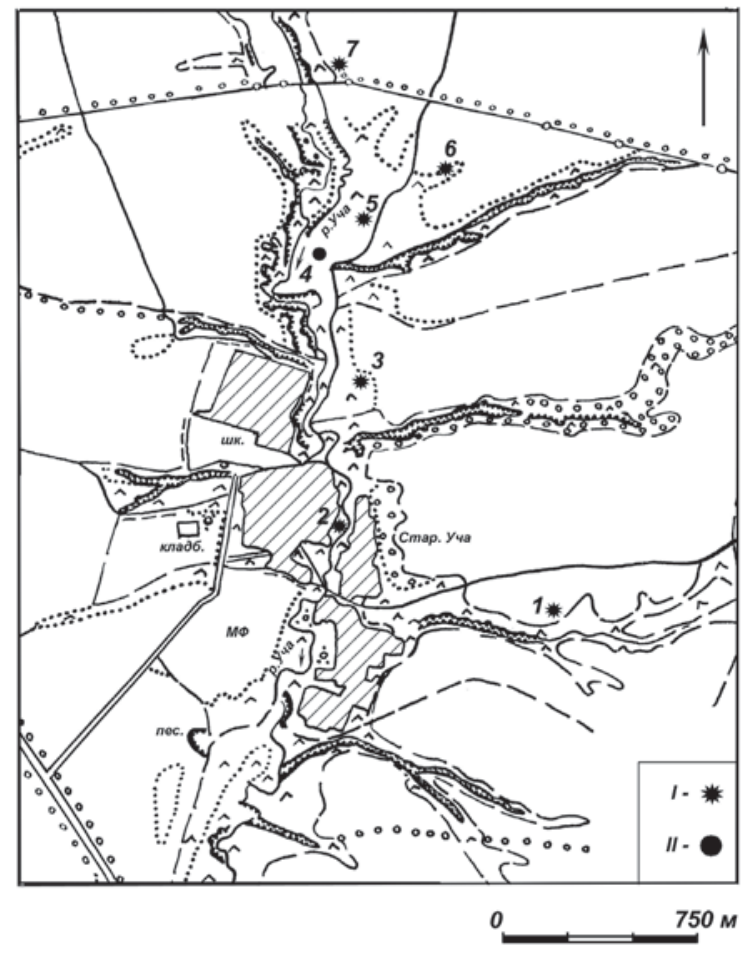

Figure 1. Layout plan of the cult places in the surroundings of Staraya Ucha village: 1) Meren kuris'kon shrine; 2) sanctuary Bydzh'ym kuala; 3) sacred grove of Norel lud; 4) old settlement of Chetker; 5) sacred grove of Byzho lud; 6) sacred grove of Gur'yan lud; 7) sacred grove of Esymbay lud. 
It is not always possible to categorise precisely sacred places according to the level of their social significance: several transitional forms of sacred place also functioned, and there were evolutions within the categories, for example evolution from a family to a patronymic place, then to a clan place. Therefore, we cannot always identify the level of a sacred space, which in any case can intertwine or overlap one another, vary, change.

We can however highlight that our materials show the relativity of the mythological (semantic) opposition between 'sacred' and 'profane' (Lat. profanes, Ger. Profane 'deprived of sacredness', 'secular', 'unholy'). In traditional society, the entire environment (settlements and natural surroundings) is, to a certain level, spiritually domesticated. The sacred and the profane are intertwined, the profane, implicitly is present at the limits of each greater area of sacredness.

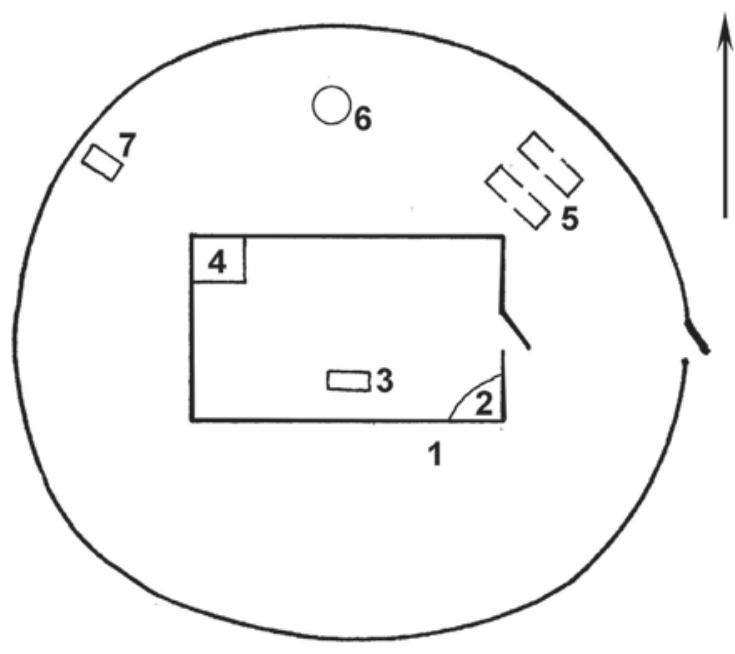

Figure 2. Schematic plan of the Esymbay lud shrine. It was prepared according to the sketch by B. Gavrilov (1891: 111-114): 1) sacred building kuala, 2) shelf mudor, 3) table, 4) wardrobe, 5) benches for sitting, 6) fireplace, 7) place for sacrificing of animals. 


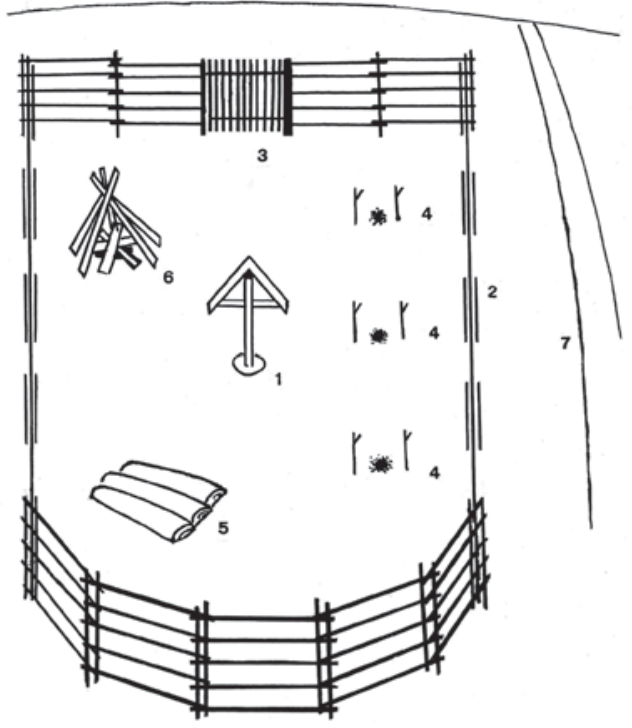

Figure 3. Bulda sanctuary in the village of Varzi-Yatchi. Fenced plot with a rounded south side, with a gate on the north side. In the center is a pillar with an icon of the Kazan Mother of God. Nearby there are three fireplaces for hanging cauldrons.

\section{Who takes care of organisation?}

As we see, at the turn of the $20^{\text {th }}$ century, rural Udmurt society dedicated much attention to the organisation and design of the sacred space. Two categories of persons had sacred knowledge and practiced cult activities. One was sacrificial priests and the wardens of sacred places, as well as their helpers, who led the ritual activities and kept order at the sacred places and buildings. In each village there were more than a dozen stewards taking care of the village's sacred places (sacrificial priests and assistants) depending on the number of sacred places (for more details see Shutova 2010: 130-137). The second category consists in people who had special knowledge and could foretell the future and influence nature, people and livestock. These were the tuno 'foreteller', 'wizard', 'prophet', the kuyas'kis' 'propitiator of evil spirits', the pel'l'as'kis' 'healer', the 
vedin/vegin 'witch', etc. People of the older generation were the most active keepers of religious tradition. Furthermore, all the ordinary participants in the ceremonies and rituals contributed to some extent to the formation of the sacred space at the family level as well as at other, higher, circles of sacredness.

\section{Types of sacred space}

As we have shown above, the pre-Christian sacred landscape of the Udmurt at the turn of the $20^{\text {th }}$ century has been thoroughly studied. There have been other investigations in the same field, for example the sacred space of the Besserman (Popova 2011); the research of the Mari sacred spaces in Udmurtia has been started (Kapitonov et al. 2014). A reconstruction of the Orthodox religious landscape has been attempted in the "Spasov okrug", ${ }^{2}$ in the former uyezd of Mamadysh, and Belaya Kholunitsa in the former Slobodskoy uyezd of the Vyatka governorate (today Kirov oblast) (Prikazchikova 2004; Shutova 2008). Compared with the traditional religious and mythological space, the Orthodox space seems to be more standardised and unified. Nevertheless, in each location there are peculiarities in the design of the space due to the diversity of temples and chapels, votive crosses, rules of receiving guests and of cross processions (for example, the icon of Edessa on the river Velikaya to the Venerable Simeon Verkhoturskiy, or the journey along the Vyatka with the icon of Nikola-Beryozovskiy).

Traditional Udmurt and Orthodox sacred landscapes have often undergone odd transformations, overlapping one another: they have intermingled and combined with one another because of increasing population density, progressive Christianisation of native ethnic groups, increasing complexification of the ethnic and confessional structure of the population, as well as because of ethno-cultural mutual influence. The intermingling of elements of traditional, Orthodox and Muslim rituals gave rise to significant adjustments 
in the features of the cultural landscape. The existence of different forms in the tradition of worship at pre-Christian, Orthodox and Muslim cult sites in an area of intense interethnic contact has led to the formation of a complex, multi-layered, and mosaic-like system of sacred landscapes.

\section{The present situation}

The design of sacred landscape is an ongoing process, even today. Orthodox and Muslim sacred landscapes are permanently reconstructed, as well as the landscapes of other religious confessions. Almost every family, depending on confessional belonging, performs particular consecration or blessing rituals such as prayer, sprinkling holy water, setting icons or other cult objects, crossing oneself, participation in Church services and processions, etc. The reproduction of traditions mainly occurs at family feasts, and religious holidays and events.

Work aimed at reconstructing traditional sacral space is being performed by the eastern Udmurt in Bashkortostan, in a dozen villages in Udmurtia and Tatarstan, for example Kuz'ebayevo (Alnashi district, Udmurtia), Varkled-Bod'ya (Agryz district, Tatarstan), Nizhniye Yurashi (Grakhovo district, Udmurtia), Porvay (Igra district, Udmurtia), Karamas-Pel'ga (Kiyasovo district, Udmurtia) and others. Another ongoing project in several administrative regions is the formation of an Udmurt ethnic sacred landscape, with the annual republic celebrations, called Gerber in Udmurtia, and Gyron bydton in Tatarstan; moreover, the territorial ceremonies Mör vös' and El'en vös'take place regularly in Bashkortostan and the Perm oblast'. Udmurt cultural NGOs (Demen, an Udmurt cultural association, and Udmurt Ken'esh, an all-Udmurt association) are trying to create a city sacred space in Izhevsk. Twice a year (on June $12^{\text {th }}$ for the Gerber celebration and August $2^{\text {nd }}$ for Saint Elijah) these groups organise Udmurt events in the Birch Grove, 
the city park in the capital. At the same time, the non-baptised Udmurt gather here to perform their ritual ceremonies, which are deeply religiously significant for the organisers and activists. There is a project aimed at building a traditional kuala within this grove. For the majority of participants, the events at the Birch Grove are attractive because of their ethnic contents, with these events considered Udmurt folk holidays.

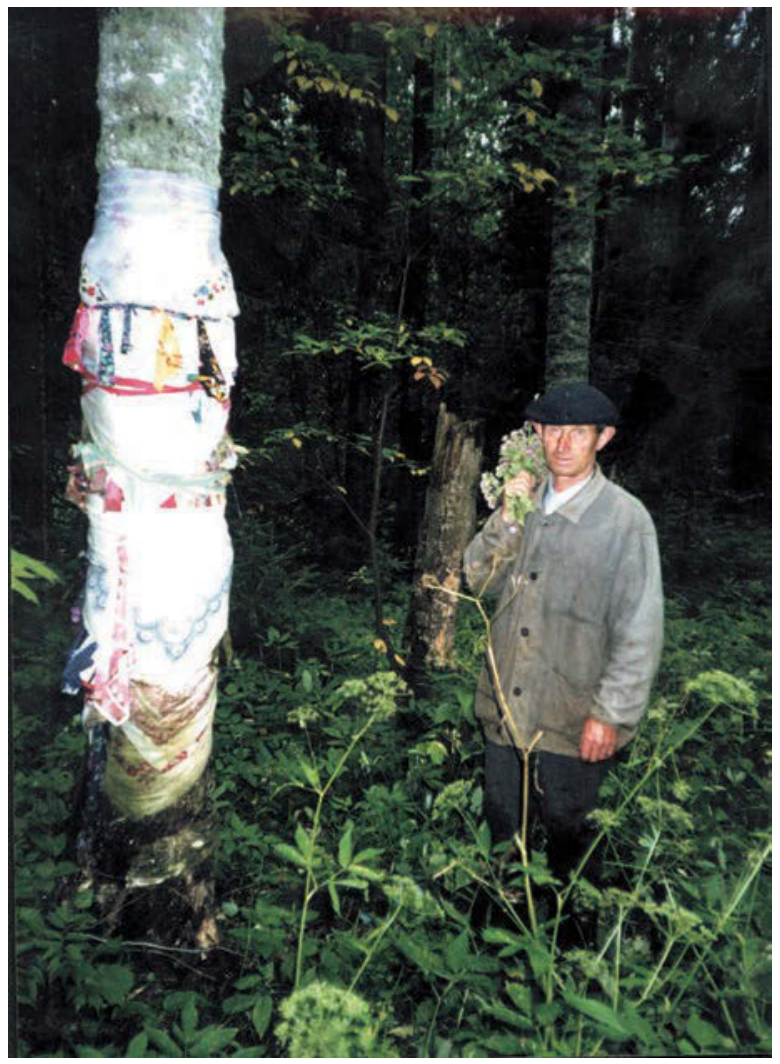

Photo 1. Sacred birch at the tribal/territorial shrine of Inma. Northern Udmurts. Informant S. Boltachev. N. Shutova, 1999. 


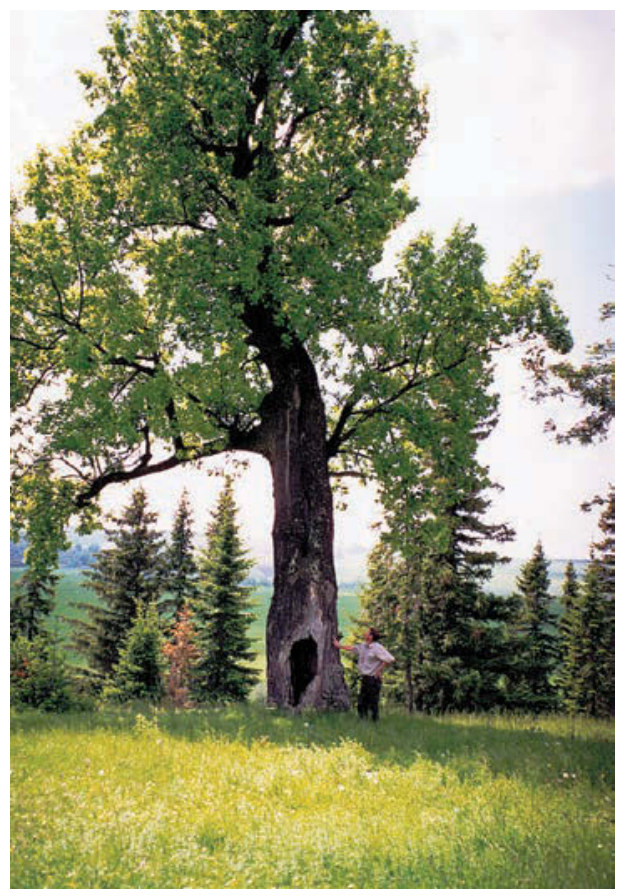

Photo 2. The sacred linden tree with a hollow in Lud grove. Kuz'ebayevo village. Informant V.Lavrent'ev. N. Shutova, 2003.

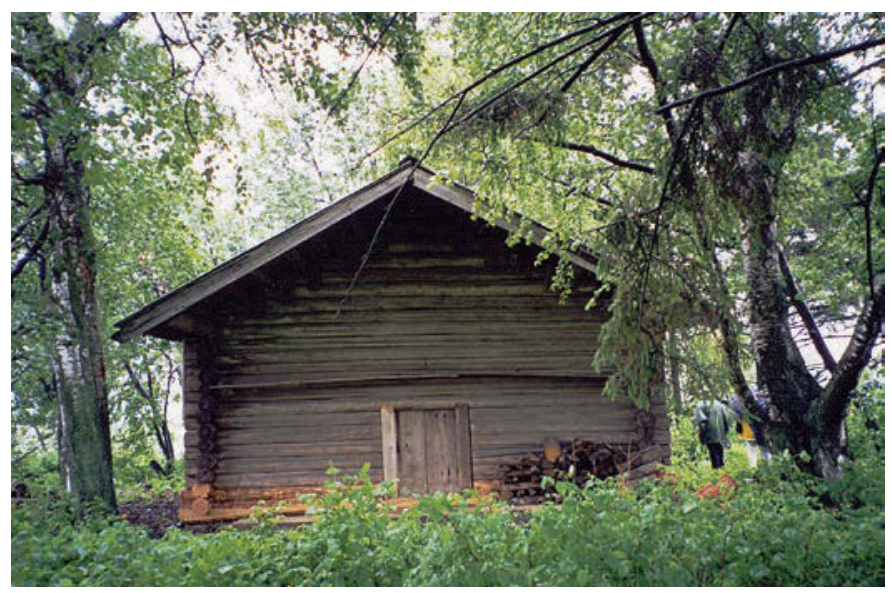

Photo 3. Bydzh'ym (Great) kuala sanctuary in the village of VarkledBod'ya. N. Shutova, 2003. 


\section{A Systematic Investigation of Sacred Space}

Photo 4. Sacred shelf mudor within Bydzh'ym (Great) kuala in the village of VarkledBod'ya. N. Shutova, 2003.
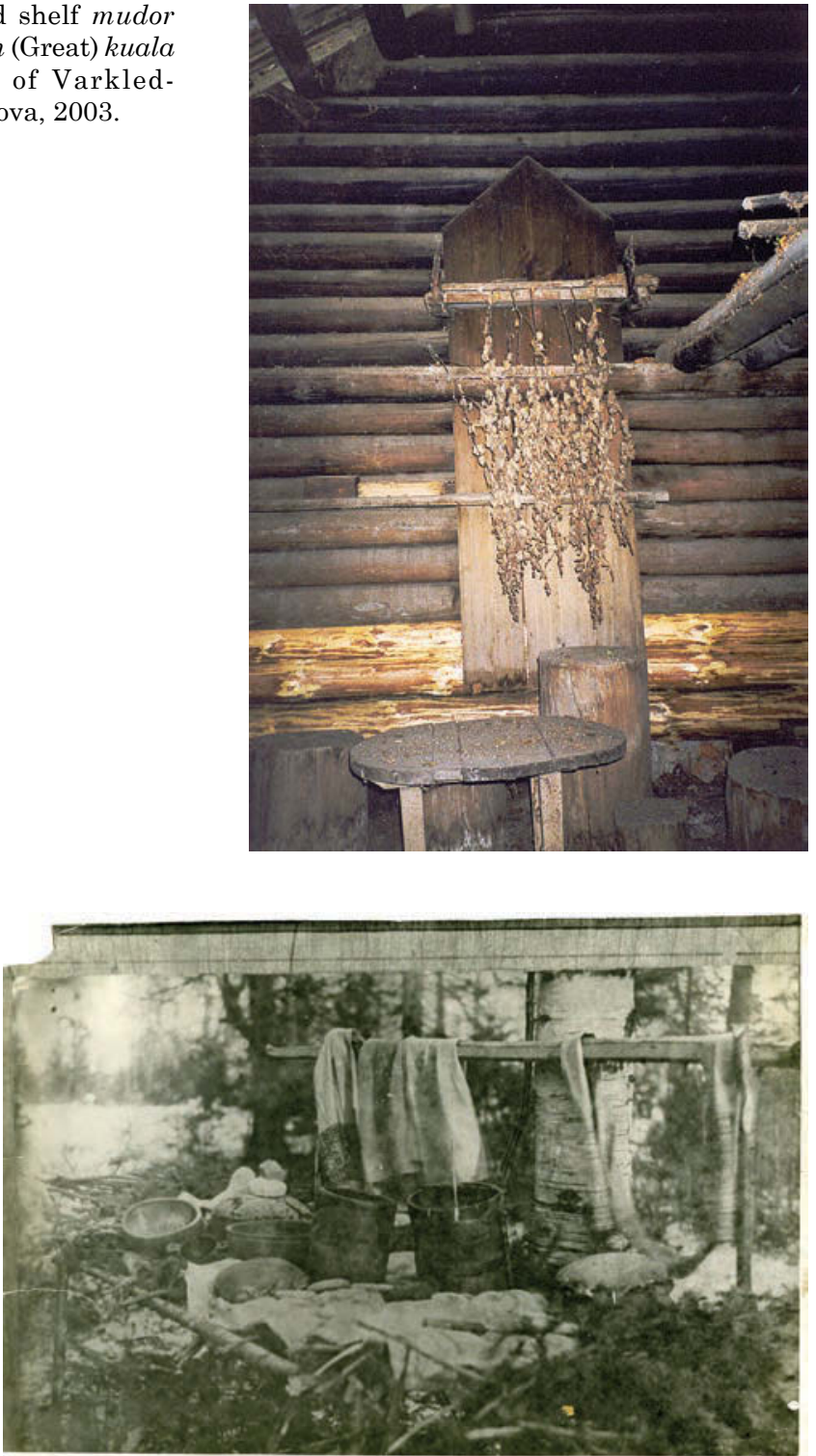

Photo 5. Bulda shrine in a birch grove. 1900. Vyatka Province. From the collectons of the National Museum of the Udmurt Republic (hereinafter as NMUR). No. HB-2420. 


\section{Nadezhda Shutova}

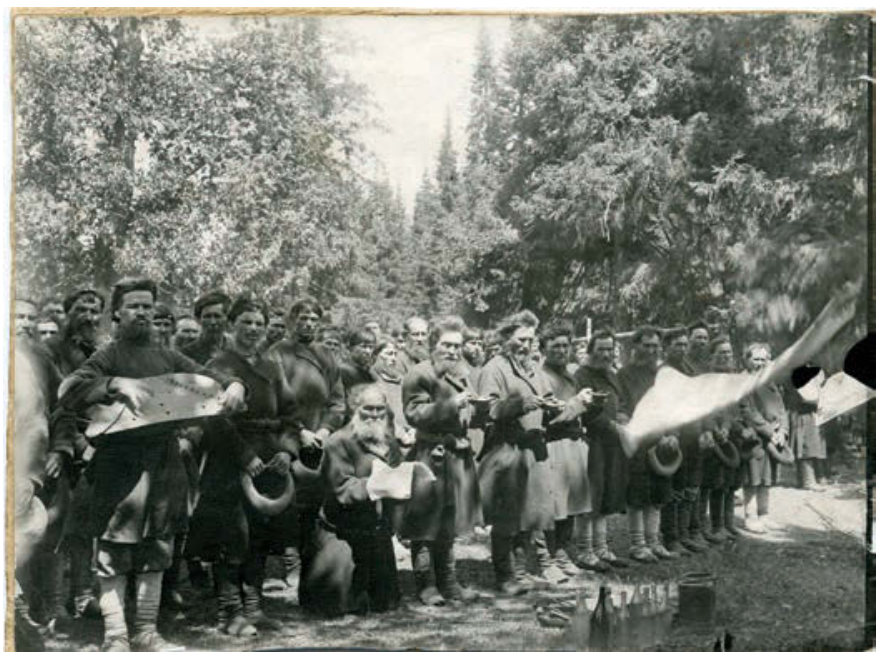

Photo 6. Bulda shrine in a birch grove. $1900^{\mathrm{s}}$. Vyatka Province.

From the collectons of NMUR. No. NV-2423/2.

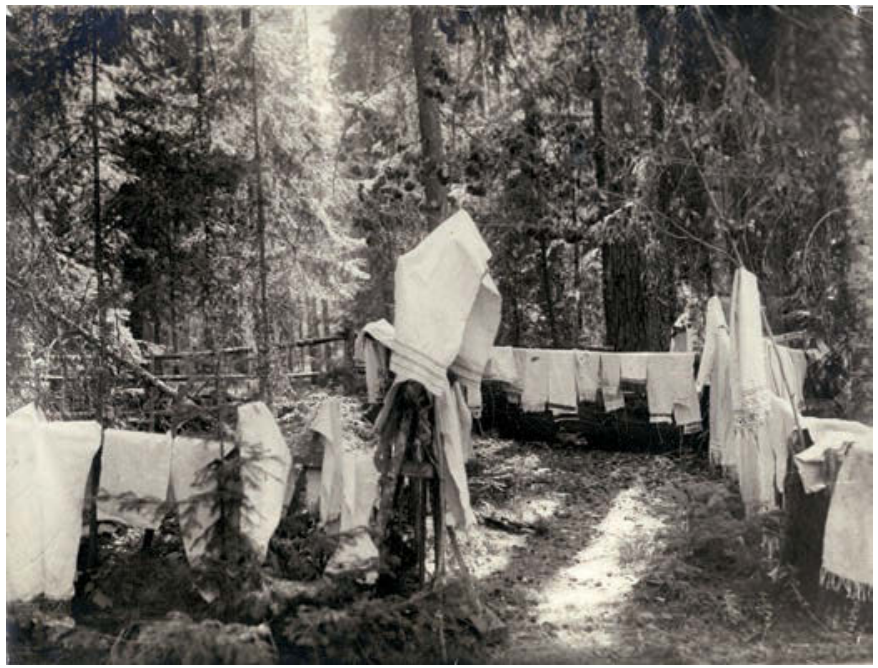

Photo 7. Holy grove before a prayer. The village of Nizhniye Yuri, Malaya Purga District, Votskaya Autonomous Oblast' (hereinafter as VAO). V. Belitser, 1930. From the collections of NMUR. No NV-2429. 


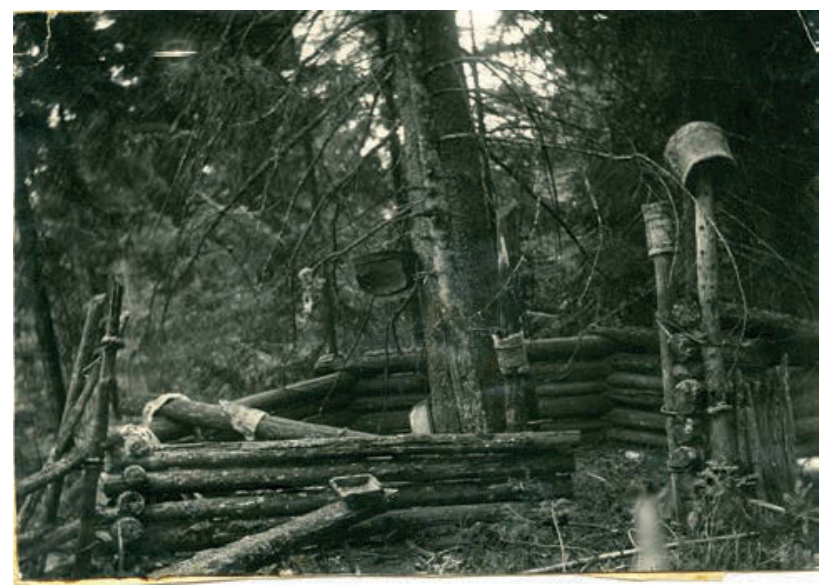

Photo 8. Place for sacrifices in the holy grove of Keremet. $1930^{\text {s. }}$ Kykva village, Yakshur-Bod'ya Volost', VAO. From the collections of NMUR. No NV-4794/2.

Photo 9. Sacred spruce at the Bydzh'ym (Great) kuala sanctuary in the village of Porvay. N. Shutova, 2008.

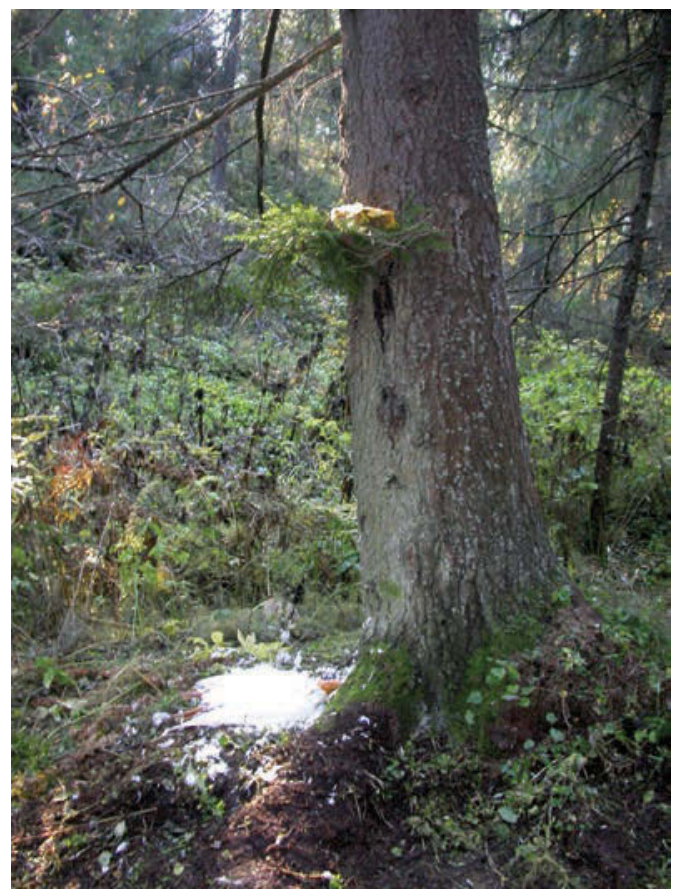




\section{Nadezhda Shutova}

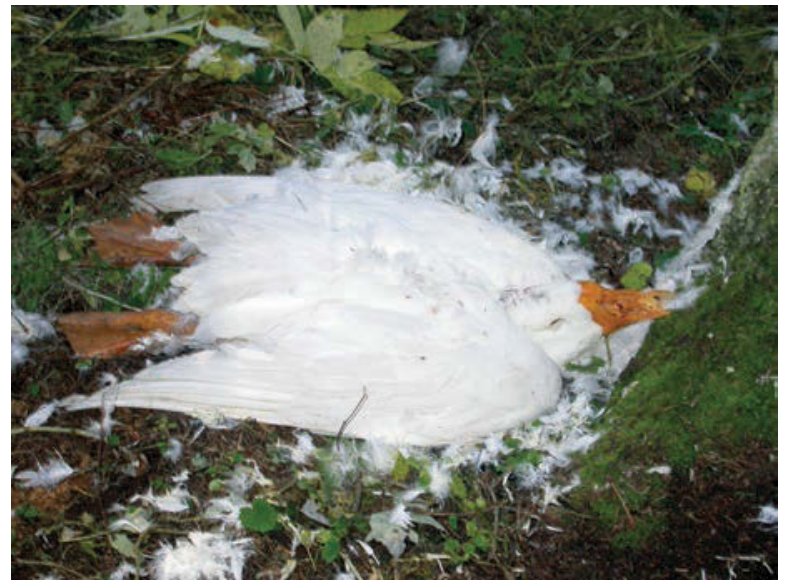

Photo 10. Goose sacrificed to the master of forests at the Bydzh'ym (Great) kuala sanctuary in the village of Porvay. N. Shutova, 2008.

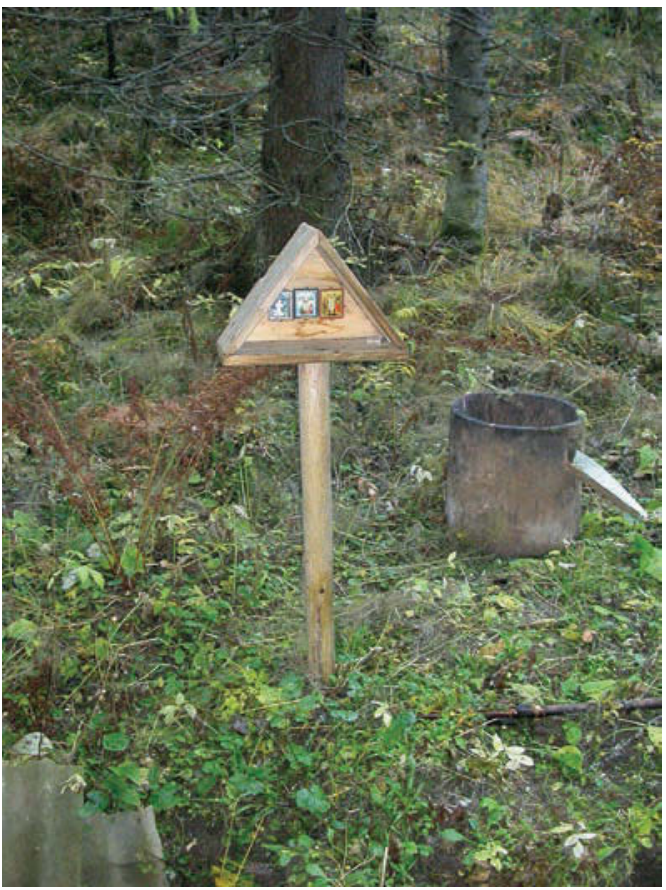

Photo 11. Christian attributes at the Bydzh'ym (Great) kuala sanctuary in the village of Porvay. N. Shutova, 2008. 


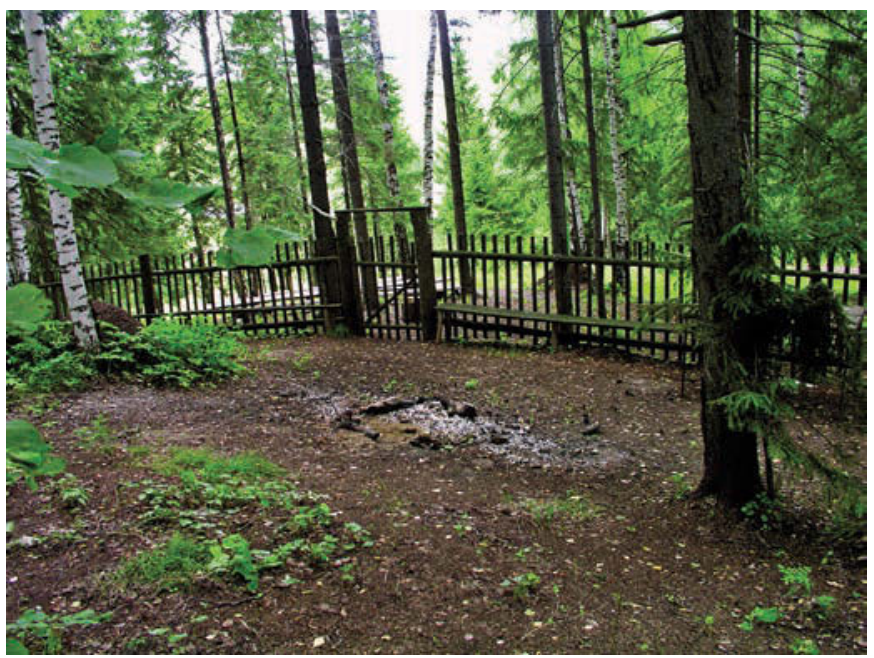

Photo 12. Bulda sanctuary at the village of Kuz'ebayevo. V. Kapitonov, 2005.

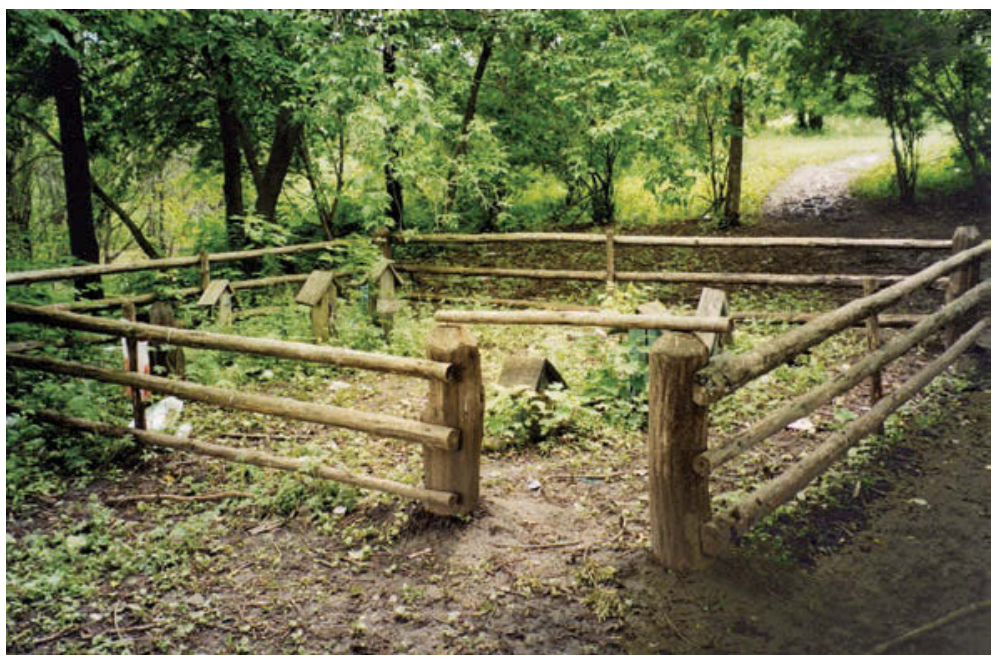

Photo 13. The village of Novyy Kan'isar. Cemetery for the commemoration of people passed away abroad. N. Shutova, 2003. 


\section{Nadezhda Shutova}

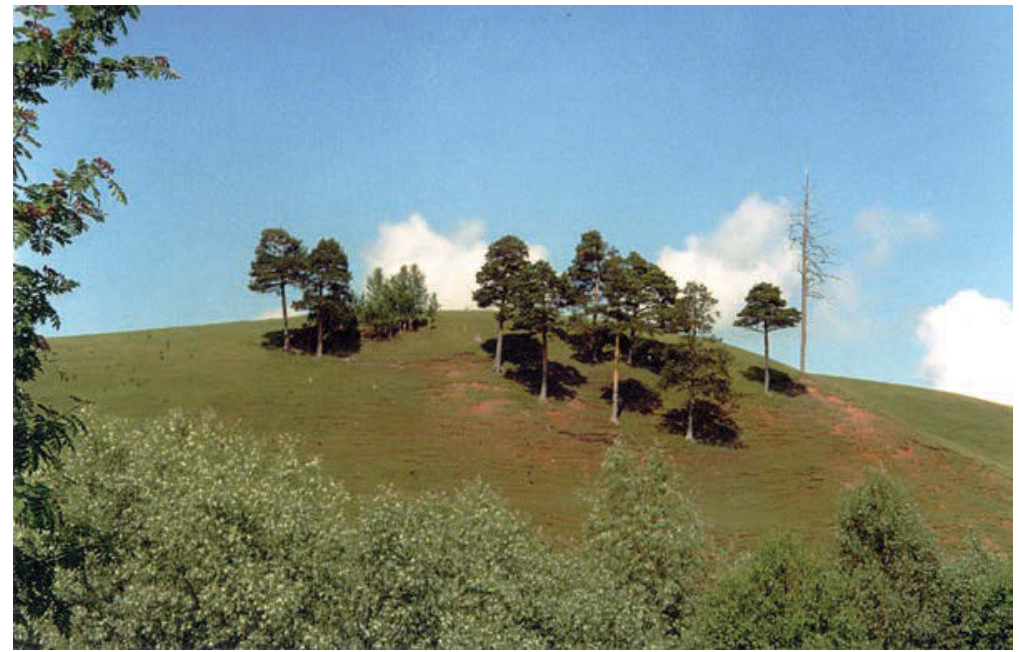

Photo 14. Holy grove of Norel' lud in the village of Staraya Ucha. N. Shutova, 2003.

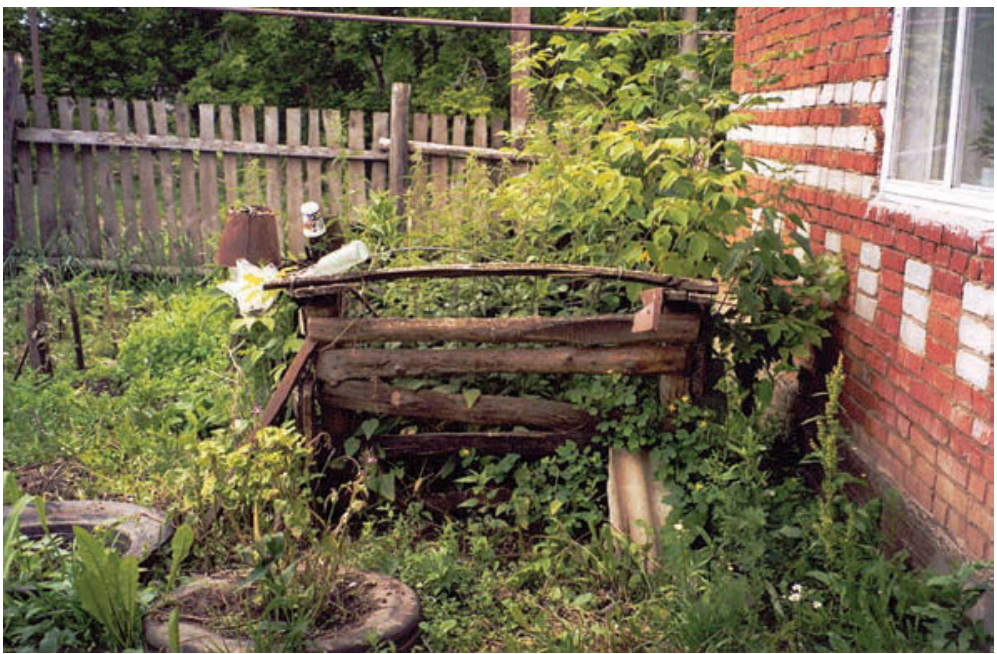

Photo 15. Mudor kuala sanctuary of Kukmor Udmurts. N. Shutova, 2003. 


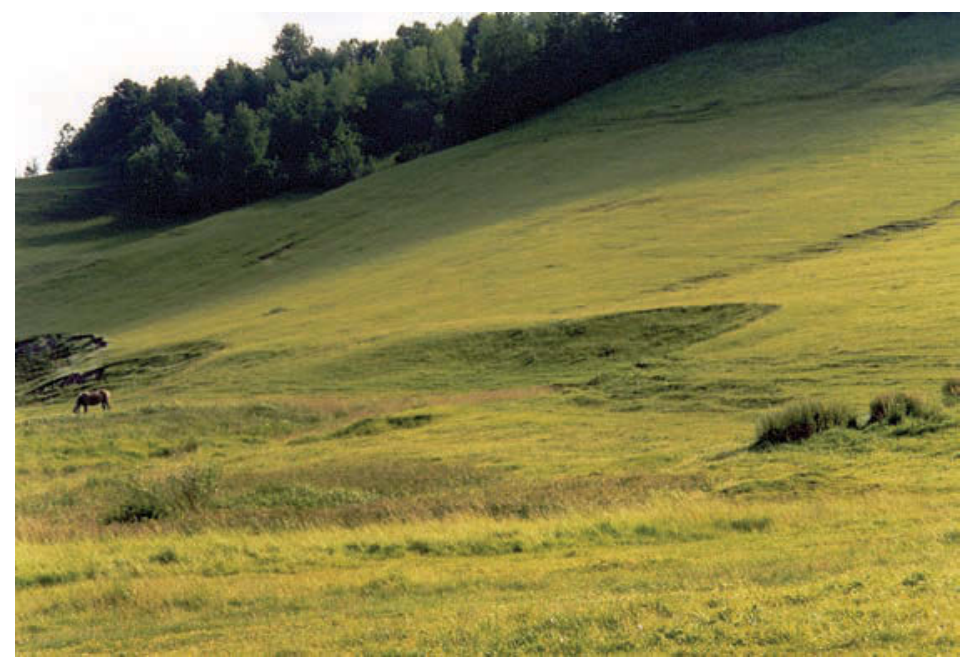

Photo 16. Cult depression of Vös'as'kon inty to pray for rain. The village of Nyr"ya. N. Shutova, 2003.

\section{Notes}

1 Actually Borisov's dictionary was first published in 1931, but because its author became a victim of Stalinist repressions, it was long forgotten (TN).

2 The Spasov okrug is a territory along the River Vyatka. The procession moves from Elabuga, carrying an icon of the Saviour (TN). 


\section{References}

Bayburin, A.1993. Sakral'noye [Sacred]. In: Religioznyye verovaniya. Svod etnograficheskikh ponyatiy i terminov [Religious Beliefs. Code of Ethnographic Concepts and Terms]. Moscow: Nauka publ.

Borisov, T. 1991. Udmurt kyll'ukam = Tolkovyy udmurtsko-russkii slovar' [Udmurt-Russian Explanatory Dictionary]. Approx. 15 thousand words. Izhevsk: UIIYaL UrO AN SSSR.

Eliade, M. 1994. Suyashchennoye i mirskoye [The Sacred and the Profane]. Translated and commeted by N. Garbovskiy. Moscow: MGU Publ.

Eliade, M. 1959. The Sacred and the Profane: The Nature of Religion, Translated by Willard R. Trask. New York: Harcout, Brace and Company.

Gemuev, I., Sagalaev, A. 1986. Religiya naroda mansi. Kul'tovyye mesta XIX - nachala XX veka [Religion of the Mansi People. Cult Places of the $19^{\text {th }}-$ Early $20^{\text {th }}$ Century]. Novosibirsk: Nauka.

Ierotopiya. Sozdaniye sakral'nykh prostranstv v Vizantii i Drevney Rusi 2006 [Hierotopiya. Creation of Sacral Spaces in Byzantium and Ancient Russia]. Edited by A. Lidov. Moscow: Progress-traditsiya.

Kapitonov, V., Popova, E., Shutova, N. 2014. Nauchnyy otchet kompleksnoy ekspeditsii po obsledovaniyu prirodnogo i istoriko-kul'turnogo ob"ekta "svyashchennye roshchi" mariytsev Udmurtskoy Respubliki [Scientific Report of the Complex Expedition on the Inspection of the Natural, Historical, and Cultural Object of Mari "Sacred Groves" in the Udmurt Republic]. Izhevsk.

Karpova, L. 2013. Leksika severnogo narechiya udmurtskogo yazyka: Srednechepetskiy dialect [Lexicon of the Northern Dialect of the Udmurt Language: Middle Cheptsa Dialect]. Izhevsk: Udmurtskiy institut istorii, yazyka i literatury Uralskogo otdeleniya Rossiyskoy akademii nauk.

KESK $1970=$ Lytkin, V., Gulyayev, E. 1970. Kratkiy etimologicheskiy slovar' komi yazyka [Brief Etymological Dictionary of the Komi Language]. Moscow: Nauka.

Kul'tovyye pamyatniki Kamsko-Vyatskogo regiona: Materialy i issledovaniya 2004 [Cult Monuments of the Kama-Vyatka Region: Materials and 
Research]. Edited by N. Shutova. Izhevsk: Udmurtskiy institut istorii, yazyka i literatury Uralskogo otdeleniya Rossiyskoy akademii nauk.

Levkiyevskaya, E. 2009. Sakral'noye [Sacral]. In: Slavyanskiye drevnosti: Etnolinguisticheskiy slovar'v 5-ti tomakh [Slavic Antiquities: Ethnolinguistic Dictionary in 5 Volumes]. Editor-in-chief N. Tolstoy. T. 4: (Pereprava cherez vodu) - S (Sito). Moscow: Mezhdunarodnyye Otnosheniya, pp. 534-538.

Lidov, A. 2006. Ierotopiya. Sozdaniye sakral'nykh prostranstv kak vid tvorchestva i predmet istoricheskogo issledovaniya [Iyerotopiya. Creation of Sacred Spaces as a Type of Creativity and Subject of a Historical Research]. In: Ierotopiya. Sozdaniye sakral'nykh prostranstv $v$ Vizantii $i$ Drevney Rusi [Iyerotopiya. Creation of Sacred Spaces in Byzantium and Ancient Russia]. Edited by A. Lidov. Moscow: Progress-traditsiya, pp. 9-31.

Lidov, A. 2012. Ierotopiya. Sozdaniye sakral'nykh prostranstv kak vid tvorchestva i predmet istoricheskogo issledovaniya [Iyerotopiya. Creation of Sacred Spaces as a Type of Creativity and Subject of a Historical Research]. In: Khortits'kii seminar: Sakral'na geografiya $i$ fenomen palomnitstva: vitchiznyanii $i$ svitovii kontekst [Khortitsa Seminar: Sacred Geography and the Phenomenon of Pilgrimage: Domestic and Global Context]. Edited by Y. Zavgorodnii. Zaporizhzhya: Dike Pole, pp. 12-37.

Limerov, P. 2002. Termin vezha $\mathrm{v}$ kontekste mifopoeticheskikh predstavleniy komi [The Term of Vezha in the Context of Mythopoetic Representations of the Komi]. Permistika [Permistica] 5. Izhevsk: Udmurtskiy universitet, pp. 157-164.

Lintrop, A. 2002. The Spring Prayer Feasts in the Udmurt Village of Varklet-Bodya in Tatarstan. Cosmos. The Journal of the Traditional Cosmology Society. Vol. 18, pp. 43-55.

Maksimov, S. 2013. Suomalais-udmurttilainen sanakirja = Finn-udmurt kyllyukam $=$ Финско-удмуртский словарь $=$ S. Maksimov, S. Saarinen, V. Danilov, E. Seliverstova. Apuneuvoja suomalais-ugrilaisten kielten opintoja varten XVI; Hilfsmittel für das Studium der finnisch-ugrischen Sprachen XVI. Suomalais-ugrilainen seura. Helsinki: SUS.

Maksimov, S., Danilov, V., Saarinen, S. 2008. Udmurttilais-suomalainen sanakirja $=$ Udmurt-finn kylsuz'yet $=$ Udmurtsko-finskiy slovar'. Publications of the Department of Finnish and General Lingustics of the University of Turku; Udmurt State University. Laboratory of Linguistic Mapping. Turku: Turku University. 
Minniyakhmetova, T. 2003. Traditsionnyye obryady zakamskikh udmurtov: Struktura. Semantika. Fol'klor [Traditional Rites of the Eastern Udmurt: Structure. Semantics. Folklore]. Tartu: Tartu University Press.

Pervukhin, N. 1888. Eskizy predaniy i byta inorodtsev Glazovskogo uyezda [Essays about the Legends and the Everyday Life of Non-Russians of the Glazov District]. Eskiz 1: Drevnyaya religiya votyakov po ego sledam v sovremennykh predaniyakh [Essay 1: The Ancient Religion of the Votyak in Its Traces in Modern Traditions.]. Vyatka: Gubernskaya tipografiya.

Popova, E. 2011. Kul'tovyye pamyatniki i sakral'nye ob"ekty besermyan [Cult Monuments and Sacral Objects of the Besserman]. Izhevsk: Udmurtskiy institut istorii, yazyka i literatury Uralskogo otdeleniya Rossiyskoy akademii nauk.

Prikazchikova, Y. 2004. Svyashchennye derev'ya i stolby-chasovni $v$ kul'turnom landshafte yuga Vyatskogo kraya [Sacred Trees and PillarChapels in the Cultural Landscape of the South Territories of the Vyatka Region]. In: Kul'tovyye pamyatniki Kamsko-Vyatskogo regiona: Materialy $i$ issledovaniya [Cult Monuments of the Kama-Vyatka Region: Materials and Research]. Izhevsk: Udmurtskiy institut istorii, yazyka i literatury Uralskogo otdeleniya Rossiyskoy akademii nauk, pp. 181-191.

Seleznev, A. 2013. Islamskiye kul'tovyye kompleksy astana v Sibiri kak ierotopiya: sakral'nyye prostranstva i religioznaya identichnost' [Islamic Cult Complexes Astana in Siberia as an Iyerotopiya: Sacral Spaces and Religious Identity]. In: Vestnik arkheologii, antropologii $i$ etnografii Evrazii [Archeology, Ethnography and Anthropology of Eurasia] 2, (21), pp. 111-119.

Seleznev, A. 2014. Sovremennyye ierotopii v Sibiri: tekhnologiya konstruirovaniya novykh kul'turno-religioznykh identichnostey [Modern Iyerotopiya in Siberia: Technology of Designing of New Cultural and Religious Identities]. In: Sibirskiy sbornik-4. Grani sotsial'nogo: Antropologicheskiye perspektivy issledovaniya sotsial'nykh otnosheniy i kul'tury [Siberian Collection 4. Sides of Social: Anthropological Perspectives on the Study of Social Relations and Culture]. Sankt-Petersburg: MAE RAN, pp. 282-292. https://www. synlab.ee/russian.

Semenova, V. 2013. Ierotopiya Tyumeni (sakral'noye prostranstvo goroda kontsa XVI - XVIII vv.) [Iyerotopiya of Tyumen (Sacral Space of the City in the Late $16^{\text {th }}-18^{\text {th }}$ Centuries)]. In: Integratsiya arkheologicheskikh 
$i$ etnograficheskikh issledovaniy II [Integration of Archaeological and Ethnographic Researches]. Vol. 2. Irkutsk, pp. 280-283.

Shutova, N. 2015. Ritual as a Means of Organizing the Traditional Udmurt Sacred Space (The Late $19^{\text {th }}-$ Early $20^{\text {th }}$ Century). In: The Ritual Year 10. Magic in Rituals and Rituals in Magic. Edited by T. Minniyakhmetova and K. Velkoborská. Innsbruck-Tartu: ELM Scholarly Press, pp. 213-219.

Shutova, N. 2010. Derevenskiye zhretsy v narodnoy religii udmurtov (konets XIX - pervaya polovina XX vv.) [Rural Priests in the Folk Religion of Udmurts (the Late of $19^{\text {th }}$ - the First Part of the $20^{\text {th }}$ Century)]. In: Ural'skiy istoricheskiy vestnik [Ural Historical Journal] 1 (26), pp. 130-137.

Shutova, N. 2001. Dokhristianskiye kul'tovyye pamyatniki v udmurtskoy religioznoy traditsiy: Opyt kompleksnogo issledovaniya [PreChristian Cult Monuments in the Udmurt Religious Tradition: An Interdisciplinary Study]. Izhevsk: Udmurtskiy institut istorii, yazyka i literatury Uralskogo otdeleniya Rossiyskoy akademii nauk.

Shutova, N. 2008. Obshchyeye i osobennoye v formirovanii istorikokul'turnogo landshafta otdel'nykh mikrorayonov v Kamsko-Vyatskom regione [General and Special in Creation of a Historical and Cultural Landscape in Some Micro-Districts of the Kama-Vyatka Region]. In: Vyatskiy rodnik: Sbornik materyalov Devyatoy nauchno-prakticheskoy konferentsiy [Vyatka Spring] 9, pp. 46-56.

Shutova, N. 2011. Problema izucheniya sakral'nogo landshafta v KamskoVyatskom regione [Problem of Study on the Sacral Landscape of the KamaVyatka Region]. In: Geokul'turnoye prostranstvo Evropeyskogo Severa: genezis, struktura, semantika = Geocultural Space of European North: Genesis, Structure, Semantics. Arkhangel'sk: S(A)FU, pp. 119-130.

Shutova, N. 2012. Kul'turnyy landshaft Kamsko-Vyatskogo regiona: osnovnyye itogi, printsipy i metody izucheniya [Cultural Landscape of the Kama-Vyatka Region: Main Results, Principles and Methods of Study]. In: Ezhegodnik finno-ugorskikh issledovaniy [Yearbook of Finno-Ugric Studies] 1. Izhevsk: Udmurtskiy universitet, pp. 88-101.

Shutova, N. 2013a. Traditsionnoye sakral'noye prostranstvo udmurtskoy okrugi v kontse XIX - nachale XX veka [Traditional Sacral Space of the Udmurt Districts at the Late $19^{\text {th }}$ - the Early $20^{\text {th }}$ Century]. In: Integratsiya arkheologicheskikh $i$ etnograficheskikh issledovaniy $\mathrm{v} 2-k h$ tomakh [Integration of Archaeological and Ethnographic Researches]. Vol. 2. Irkutsk: IrGTU, pp. 301-305. 
Shutova, N. 2013b. Vesenniy prazdnik Akashka/Bydzh'ymnunal yuzhnykh udmurtov v kontse XIX - nachale XX v. [Spring Holiday Akashkal Bydzh'ymnunal of the Southern Udmurts in the Late $19^{\text {th }}-$ Early $20^{\text {th }}$ Century]. In: Arkheologiya, etnografiya $i$ antropologiya Evrazii [Archeology, Ethnography and Anthropology of Eurasia] 3(55), pp. 107-111.

Shutova, N. 2014. Ob etimologii i semantike termina vorshud/vozhshud [On the Etymology and Semantics of the Term vorshud/vozhshud]. In: Linguistica Uralica 4, pp. 276-282.

Shutova, N., Kapitonov, V., Kirillova L., Ostanina T. 2009. Istorikokul'turnyy landshaft Kamsko-Vyatskogo regiona [Historical and Cultural Landscape of the Kama-Vyatka Region]. Izhevsk: Udmurtskiy institut istorii, yazyka i literatury Uralskogo otdeleniya Rossiyskoy akademii nauk.

URS 2008 - Udmurtsko-russkiy slovar'= Udmurt-zuch kyll'ukam [UdmurtRussian Dictionary]. Edited by L. Kirillov. Izhevsk: Udmurtskiy institut istorii, yazyka iliteratury Uralskogo otdeleniya Rossiyskoy akademii nauk.

Vladykina, T., Glukhova, G. 2011. Ar-god-bergan: Obryady i prazdniki udmurtskogo kalendarya ("Udmurtskaya obryadovaya azbuka") [YearCircle: Rituals and Celebrations of the Udmurt Calendar ("Udmurt Ritual Alphabet")]. Izhevsk.

Vös'as'kon"yos. Kanon"yos. Kyrdzh'an"yos [Prayers. Canons. Hymns] 2000. Udmurt kyle beryktiz no pottyny das'az protodiakon M. Atamanov. Izhevsk: Udmurtskiy universitet.

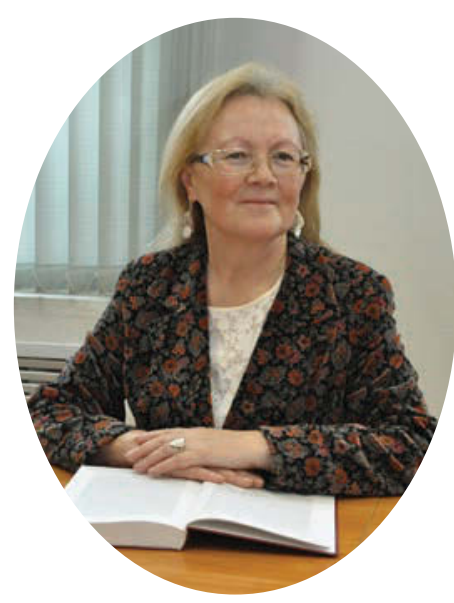

Nadezhda Shutova ( $\mathrm{PhD}$ hab) is a leading researcher at the Udmurt Institute for Research in History, Language and Literature (Udmurt Federal Research Centre of the Ural Branch of the Russian Academy of Sciences). She is an archaeologist and an ethnologist investigating traditional folk culture and ethnoterritorial groups from the point of view of ritual and religion. e-mail: nad_shutova@mail.ru 


\title{
Tradition and Diversity among Udmurt Sacrificial Priests ${ }^{1}$
}

\author{
Eva Toulouze \\ e-mail: evatoulouze@gmail.com \\ Liivo Niglas \\ e-mail: liivo.niglas@ut.ee
}

\begin{abstract}
In the Udmurt diaspora of Northern Bashkortostan the traditional Udmurt religion is very much alive and is part of the villagers' everyday lives. Rituals are regularly held both at the village level and in the wider community, composed of several villages, involving the whole population. Since 1990, a revitalisation process has taken place in almost all villages of the region, so that by the beginning of the $2020^{\text {s, }}$ the huge majority of villages have their own ceremonies and their own sacrificial priests, even where the tradition had been interrupted for decades. This article focuses on the key figure in Udmurt ritual, the sacrificial priest, called the vös'as', and attempts to sketch a pattern of function-performance and transmission, taking into account practice in groups of villages. It also reflects on its historical perspective in a Finno-Ugric context in which the practice of ethnic religions is often seen and/or used as a marker of ethnicity.
\end{abstract}

Keywords: ethnicity, ritual, sacrificial priest, transmission, Udmurt religion 
The Udmurt are a people who speak a Finno-Ugric language in the Volga region. Since 1920 most Udmurt have lived in an administrative region called Udmurtia, now a Republic within the Russian Federation. There are also Udmurt communities in neighbouring regions, some of them, the so called Eastern Udmurt, are the descendants of migrants who have settled in Muslim areas since the $17^{\text {th }}$, and mainly $18^{\text {th }}$, centuries (Minniyakhmetova 1995 : 332; Toulouze, Anisimov 2020). Before the arrival of the Russians, and for some time afterwards, the Udmurt practised an agrarian religion based on animism. Although the Udmurt who remained in their core territory had converted to Orthodoxy by 1765 , it is particularly interesting to follow the religious situations in areas where ethnic religions were able to persist without interference until the Soviet period. In Eastern Udmurt villages the traditional animistic religion is still very much alive at the beginning of the $21^{\text {st }}$ century.

As in most traditions, ritual occupies a highly significant place in Udmurt lives. The main output of any ceremonial action was (according to ethnographers ${ }^{2}$ ), and is still, the cooking of a porridge made of lamb broth, various grains and lamb meat (see Toulouze 2020a). In some cases the ceremony can be performed by the male head of the family, while in others - important calendar feasts and seasonal agricultural turning points - the ritual is to be led by a specialist. The authors' fieldwork assists in ascertaining what still exists, what has disappeared, what has changed and what is entirely new.

While previous research has mainly focused on reconstructionattempting to ascertain the details of the rituals before modernityour goal is to focus on the current practice of this peculiar form of worship, and to analyse how the population understands it. We intend to study a key figure in the perpetuation of the tradition, the sacrificial priest, for in the context of urbanisation and rural exodus transmission is a core question. In a wider context the question of the possible use of ethnic religion as an identity marker and the priest's possible role in this must also be considered. 
Very few of these practices have resisted the successive efforts of evangelisation and sovietisation in Udmurtia. As Ranus Sadikov, an Udmurt ethnographer who specialises in the Eastern Udmurt, emphasises, the disruption of the village community by collectivisation has seriously transformed collective life in the countryside, in Udmurtia as well as in the farther-flung Turkic regions (Sadikov 2012: 48). There are still places where tradition has shown itself more resilient. One of these is the Republic of Bashkortostan, where Udmurt peasant communities practice forms of worship as ethnographers described them in the $19^{\text {th }}$ century.

This is easily explained. In Udmurtia the communities had to face evangelisation and then collectivisation - the first imposing a new and enduring way of thinking about oneself in the world, the second revolutionising the way people related to each other in everyday life. In Bashkortostan the first disruptive phase did not take place. The effects of collectivisation were similar in Bashkortostan as elsewhere: the basis of community life changed, and antireligious ideology was spread through school, the army, and state institutions, while more or less active repression led to the fading of the traditional Udmurt mental world. However, the areas the Bashkortostan Udmurt inhabited were totally rural and remote, and they were able to retain much of their religion. We can also infer that the dominant ethnic layer in Bashkortostan was not Russian, but Turkic (Tatar and Bashkir) and that they were not so unanimously hostile to Udmurt ritual.

Contemporary scholars have emphasised the persistence of Udmurt rituals in this region: Tatiana Minniyakhmetova (1961) and Ranus Sadikov (1973), themselves natives of northern Bashkortostan, have defended doctoral dissertations and written many studies on them in their current forms, and have described rituals in continuity that have created a corpus, based both on fieldwork and on older literature, the main emphasis of which is on the beginning of the $20^{\text {th }}$ century, a period in which tradition was still strong and modernity had not yet penetrated. Nevertheless, external research 
on these questions is still practically non-existent. Although Finnish (Kirsti Mäkelä, Seppo Lallukka) and Hungarian researchers (Boglárka Mácsai, Zoltán Nagy) have conducted fieldwork in the region, their findings are still to be published. In the present article we reflect on what we have witnessed, while concentrating on the key role of the sacrificial priest.

\section{Is the Udmurt religion a religion?}

As a general introduction, a remark about the name of the Udmurt religion. If we look at what has been published in Udmurtia, among the publications is an important book titled Udmurt oskon ("Udmurt faith", Vladykin, Vinogradov 2010), with a choice of texts, comments and photos. The word 'oskon' comes from the Udmurt verb 'to believe' and is clearly a term generalised under the influence of Christianity. Another term used more in the context of the traditional religion is vös', a word used to refer to a sacrifice, and also to a sacrificial ceremony in general. It is also the name that has been chosen by the Izhevsk activists for their association. The word vös' also provides the basis for many other derivation terms, for example the term for the sacrificial priest, which is the main topic of this article.

The main question we shall now reflect about is the following: is it proper to call what the Udmurt call Udmurt oskon or Udmurt vös', a religion? We shall not develop this point, but we would like to pinpoint a terminological confusion that is difficult to unravel because of the lack of proper concepts in our toolbox.

The kind of practice we shall study is usually called 'paganism' in Russia. For us, the main problem with the term 'pagan' lies in the fact that it was originally used in opposition to 'Christian'; scholars now prefer to approach the phenomenon from a more neutral starting point. Moreover, the word 'pagan' contains other implicit features, probably because of the connection with antique beliefs. These features do not fit the fluid and situative object of 
our study, which is not characterised by a developed and fixed mythology, a sophisticated polytheism. However, the term has been integrated into the discourse as an objective scientific category.

We could use the term 'belief', which is used both in anthropology and folklore studies as opposed to religion as a formalised and dogmatic system. But 'belief' is also somewhat problematic, for it implies the conscious act of believing. In spite of what is suggested by Christianity's dominance, not every 'belief system' is based on belief. A 'credo' is rather a peculiarity of monotheistic world religions such as Judaism, Islam, and Christianity. Faith and belief are quite improper concepts in many other systems, where the propositional dimension is not articulated into a rigid system. These notions have been imposed on the natives by missionaries, who as professionals could only interpret the unfamiliar by using familiar categories: their thinking habits and their languages did not and do not provide them with appropriate tools to understand the realities they discovered. At the same time, these categories have been accepted and interiorised by the natives themselves (Asad 1993): in contact situations, speaking a language that was not theirs, they domesticated the conceptual tools introduced by the 'other'. They have become weapons: even if they did not fit theoretically, they could still be pragmatically and advantageously used. This is the case with the Udmurt, who have adopted the term udmurt vera (or, also in Udmurt 'udmurt oskon') which can be directly translated as 'Udmurt faith', in contrast to dzh'uch vera, 'Russian faith' (Orthodox Christianity) and biger vera, 'Tatar faith' (Islam).

We thus face the challenge of expressing something without the appropriate conceptual tools. We have been tempted by the concept of spirituality, as used by Hann (2007: 387), but even this term is critical and we shall not use it in this article, for the boundary between the spiritual and the profane is somewhat nebulous. Here, moreover, the practice consists in everyday common actions in the countryside - the slaughtering of animals, cooking, and eating, although they are encompassed in a framework that makes 
them sacred and gives them place, time, performers, words, and gestures. In conclusion, we are forced to compromise and use the unsatisfactory term 'religion'.

\section{The Udmurt religious world in Bashkortostan at the beginning of the $21^{\text {st }}$ century}

In the second decade of the $21^{\text {st }}$ century peasant life in the Udmurt communities of Northern Bashkortostan is still punctuated by religious gatherings. Continuity is clearly felt, as we observed in our fieldwork since June 2013 up to 2020, after which we were not able to do fieldwork due to the corona crisis. We attempted to penetrate the world of Udmurt rituals by attending and filming ceremonies, but also through the mediation of sacrificial priests. We stayed in the Tatyshly district, in Northern Bashkortostan, and worked in several of the area's villages as well as in some villages in other districts. Being acquainted with specialist literature, we could observe some changes, and in this context we observed that many features that once existed have been forgotten. Others have not faded, while some have been revived, and new forms have also been invented. We find thus merged into a single common practice elements with different historical status. A comparison with Udmurt religious practice in Udmurtia itself may provide further insights.

What we have discovered is a bustling and varied world of Eastern Udmurt religious life, where local traditions are dominant and almost all village have different ceremonies. There are some people, especially among local administration workers, who think that the Udmurt religious ceremonies should be standardised following the example of Christianity and Islam (FWM 2014³). In our opinion, the variety in ritual practices manifests the richness and the strength of the tradition, and we shall endeavour to show this in this article. 


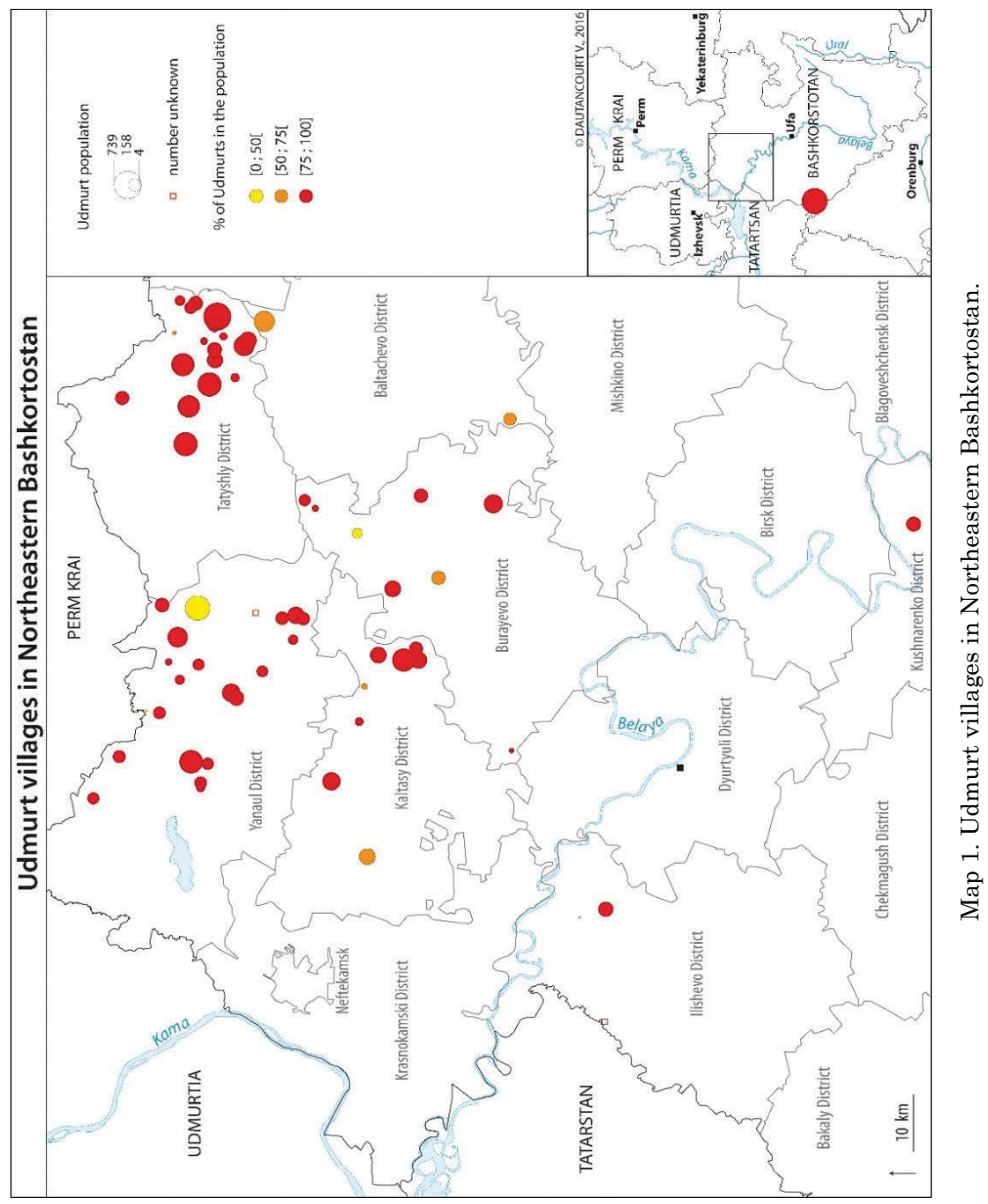


The traditional religious life of the Eastern Udmurt has been characterised by a complex annual ceremonial cycle. Some of these ceremonies have been forgotten. For example, the Easter ceremony, the Bydzh'ym nunal (Great Day) festival, ${ }^{4}$ has very limited importance in Bashkortostan. The tradition is alive only in particular villages, while in other locations it is reduced to scenic reconstructions (FWM ${ }^{5}$ 2018). These reconstructions are usually organised by the Udmurt ethnic organisation, the NKC (National and Cultural Centre, cf. Toulouze, Anisimov 2020), so that people do not forget ceremonies that are no longer widespread in daily life, but which still live in the memories of the elder generations. Another example is the spring three-village ceremony (FWM ${ }^{6}$ 2014). People remember which villages performed it and with whom, but the tradition is no longer alive in some places, while in other places it has undergone transformation. In general, grass-roots ceremonies have been less disrupted by political interference.(FWM $\left.{ }^{7} 2013\right)$

The tradition of the village ceremony (gurt vös') during the summer solstice period has generally continued without interruption. ${ }^{8}$ The mör vös', the following ceremony in the summer cycle, one or two weeks after the village event, is observed together by eight to ten villages, and has also been quite resilient. A similar joint ceremony, the tol mör vös', is also held in winter (FWM ${ }^{9}$ 2016) and is the only ceremony of the winter cycle that has been preserved, except one village ceremony, the gurten vös' celebrated in Starokalmiyarovo. In many places, the celebration of joint ceremonies, both in summer and winter, was interrupted for some years but was immediately revived when the Soviet Union collapsed. These very public ceremonies are attended by large gatherings, some of the attendants, as our fieldwork reveals, are 'expatriate' Udmurt, i.e. Udmurt who live and work outside the compact Udmurt area but who return for the occasion (FWM $2013^{10}$ and $2019^{11}$ ).

In some areas of Bashkortostan, for example Kaltasy district, where Udmurt village and joint ceremonies had been thoroughly documented at the end of the $19^{\text {th }}$ century (Toulouze 2020a), the 
interruption lasted for decades. When the revitalisation process started, there were no informants left who remembered the ceremonies and the prayers precisely (FWM $\left.{ }^{12} 2018\right)$.

Another ceremony had also totally disappeared: the 'country' ceremony, el'en vös', for which all the Udmurt of Bashkortostan and the Perm region used to gather, was attested to in older literature (Sadikov 2008: 46). It rotated between three villages, Varyash, Kirga, and Altayevo, the only places where its memory has not faded (Sadikov 2008: 194). As no data are available after the beginning of the $20^{\text {th }}$ century, we may assert that by the beginning of the Soviet period it was no longer being held. It has now been revived and has been performed since 2008 in the three villages that hosted it previously (Sadikov 2010: 34), becoming a very popular event, even attracting people from Izhevsk, the capital city of Udmurtia (FWM $2013^{13}$ and $2018^{14}$ ).

Having illustrated and sampled the overall framework with these examples from our fieldwork, we shall focus on one key issue. What is the current situation of the specialised bearers of this tradition, the sacrificial priests? ${ }^{15}$ Has their role changed, what is it, who are they, how have they become what they are, and how do they perpetuate themselves? Is this role somehow political? These are the concrete questions we shall attempt to answer.

\section{The central role of the sacrificial priest, the vös'as'/ kuris'kis'16}

In the continuation of a tradition, the existence of 'people who know' is crucial. In the Udmurt tradition, at the turn of the 20th century the ritual specialists, the vös'as', were responsible for larger ceremonies, while the family head (or elder kin member) could pray in everyday life and at family events (Khrushcheva 1995: 197). ${ }^{17}$

Not everybody could perform at public ceremonies. We know of various kinds of priest: 
- the leader of the ceremony, the vös'as', was responsible for the whole ceremony and recited the prayers;

- the tylas'was responsible for the fireplace and for throwing whatever was supposed to go there into the fire (pieces of bread, blood, bones, entrails);

- and the partchas'was responsible for the sacrificial animals and the actual sacrifice (Sadikov 2008: 191).

This task-sharing has now disappeared. ${ }^{18}$ We know that until the $1920^{\text {s }}$ the vös'as' was elected by the assembly of the family heads, i.e. the village council, called ken'esh, ${ }^{19}$ but this is no longer the case. However, in 1928 the ken'esh became an enemy for the Soviet authorities as the incarnation of the "kulak's power". ${ }^{20}$ Moreover, especially after the $1930^{\text {s, }}$, all religious specialists were grouped with Orthodox priests, accused of being exploiters of the people, and repressed. All the local leaders were accused of being kulaks and eliminated. While no statistics are available, it is likely that many vös'as'were victims of repression. However, they had a lower public profile than Orthodox priests because they were peasants like everyone else, and so many survived. Thus, after the war, the communities were not totally deprived of their priests.

The main problem lay elsewhere, however, in the younger people, who had been trained by Soviet education in the cult of modernity and material progress and who seldom followed the spiritual traditions of their elders. From this perspective the 1980s and $1990^{\mathrm{s}}$ were years of decline: the older men who had continued to lead ceremonies died without anybody to replace them. Without a priest, worship might disappear. Even if people wanted to continue, they were not able to do so: "[W]e may say that in the 20th century it is only thanks to the vös'as' that the tradition of collective ceremonies was preserved. If the priest had no successors, the holding of sacrifices was interrupted" (Sadikov, Danilko 2005: 230-231).

For this reason we focus on this figure, who is so crucial for the survival of the tradition. 


\section{The task of the vös'as'}

Today the sacrificial priest's tasks are varied. He is the master of ceremonies of a fairly complicated ritual that includes several simultaneous actions. He therefore has assistants. The tasks formerly undertaken by particular priests are now entrusted to these assistants. However, the priest must ensure that everybody acts according to the rules. We shall describe his tasks in the simplest ceremony, the village one. ${ }^{21}$ We have chosen to describe the ceremonial practice in the village of Malaya Bal'zyuga, ${ }^{22}$ because it is a tradition that has never been interrupted. Nazip Sadriev, known in the community as Nazip agay, ${ }^{23}$ a sacrificial priest for sixty years who has thoroughly trained his assistants and successor, continued to conduct it until the $2010^{\text {s }}$.

Before the event the priest organises the gathering of offerings bread, grain, sacrificial animals, and money, given by all the households of the village. These items are brought to the venue of the ceremony. Every ceremony starts with an opening ritual, the siz'is'kon, held on the morning of the main ceremony. Porridge is cooked without meat, and the priest prays to ask permission to make a sacrifice while holding some porridge in a bowl on a towel with some birch ${ }^{24}$ branches. Then all the people ${ }^{25}$ eat a spoonful of the ritual porridge. Only then may the preparations for the sacrificial ritual itself start.

During the first prayer two assistants present the sacrificial animal, a lamb. They 'purify' it before the sacrifice, sprinkling it with water using a birch branch. Later, they cut the lamb's throat, also using a sprig of birch, which is cut at the same time as the throat, while another assistant is ready with a spoon to gather the first blood and to throw it into the fire. He repeats this thrice. At the same time, the priest utters a prayer, holding bread baked by the former owners of the sacrificial animal. This bread must have a coin pressed inside it. During the prayer the other assistants kneel and bow when the priest says 'amin'. Afterwards the sacrificed animal must be skinned and cut into portions. 
The priest must then pour salt into the pot. The salt is the first element of the porridge, only then come the other ingredients. While in principle meat should be put into the pot onto the salt, and only then water added, in reality the water is already boiling when the meat is thrown in. At the same time, the grain given by the population must be prepared and the money counted. The meat takes a long time to be cooked. When it is ready, the priest looks for the ritual parts, puts them on a plate, ${ }^{26}$ and recites a prayer over the plate, holding it as before on a towel and branches. Meanwhile some of the assistants separate the meat from the bones, giving the audience some bones to clean before throwing them on the fire; the meat is then put back into the pots. At the same time, other assistants have placed the grain into the broth and look after the porridge: their task is physically hard as they must stir the porridge in the pots with huge wooden poles until it is ready. Finally, the porridge is distributed to the assembled people, and the priest recites the last prayer in gratitude for the money offerings. When the people have gone home, the fireplaces are 'closed' by sweeping them with the birch or fir branches, then all the utensils must be cleaned and packed away. The remains of the porridge are brought back to the village and the priest distributes it to those who were unable to attend.

This is a complex ritual with many concomitant activities, and it is the sacrificial priest who is responsible for the whole. ${ }^{27}$

\section{The transmission of knowledge and the choice of priest}

With the disruption of the rural community in the $1930^{\text {s }}$, it was clearly impossible to maintain this competence in the framework of the furiously anti-religious collective farm. The formerly elected vös'as'continued in secret and were solely responsible for the future.

Nazip Sadriev, born in $1930,{ }^{28}$ and today the region's most prestigious and famous vös'as', told us how he became a priest. He was 
in his twenties and had long been an assistant. One of the vös'as' ceased to pray and another died. The remaining vös'as' told him: "Now, son, you will pray." "The first time, my hands shook. They decided that it was too soon and postponed it. Next year I passed the test, ... although my hands still shook"(FWM 2013 ${ }^{29}$ ). He was thus co-opted by a functioning priest, although he had learnt the prayers beforehand by listening to them for a long time and incorporating his elder's experience.

The problem of transmission is a real concern for Nazip agay (Sadikov, Danilko 2005: 232). He is today considered the most important specialist to consult in the entire Udmurt diaspora and is often invited to lead ceremonies (Sadikov, Danilko 2005: 232). In the last decade, he has concentrated on teaching younger people to provide the communities with priests. As is to be expected, the results are mixed. With some, he believes, it has not worked. With others, it has worked poorly, and with others adequately. ${ }^{30}$ There are several preconditions that have to be respected when choosing a future vös'as'. Nazip agay has been strict about some of these requirements and more flexible about others. As in the past, the future vös'as' must be a married man (Lintrop 2002: 44), as must his assistants. They must all be full members of the community (bachelors are not considered 'whole' and cannot be trusted with such responsibility): "The scope of peasant society is to reproduce itself. You cannot be an active member if you have not done all you can to fulfil your aim", explains Sadikov. The second personal criterion is that the person must have an impeccable social profile. Priests are not supposed to drink, they should not smoke and they should be good workers, husbands and fathers.

Although people in the villages marry early, it is much more difficult to find men who do not drink and who are motivated for the task. According to our observations the rule of not smoking is not taken seriously today. Some well-respected and experienced vös'as' actually smoke during breaks in the ceremonies, but never inside the sacrificial space (FWM $2013^{31}, 2015^{32}$ and $2016^{33}$ ). 
The choice is still quite limited. Nazip agay therefore ignores some other criteria from earlier times in choosing a vös'as'.

For example, one important criterion that should be met, but is often overlooked, is that the priest should have a 'pedigree', i.e. he should come from a family of priests so that there is a sacrificial priest among his ancestors. Therefore, when the revitalisation process started, the local Udmurt leaders looked for people who were kin to former vös'as'. Only when no one could be found, or the person did not agree to take over the task of becoming the priest for the village, was the position proposed to people unconnected to families of priests. This is how Salim Shakirov from Novye Tatyshly and Anatoliy Nasipullin in Bol'shoy Kachak became sacrificial priests (see below). Another important criterion for eligibility of becoming a priest is age. According to ethnographic data only those older than forty can be elected a vös'as' (Sadikov 2008: 191). Nazip agay, who himself started his career as a vös'as'at the age of 24, has not insisted on

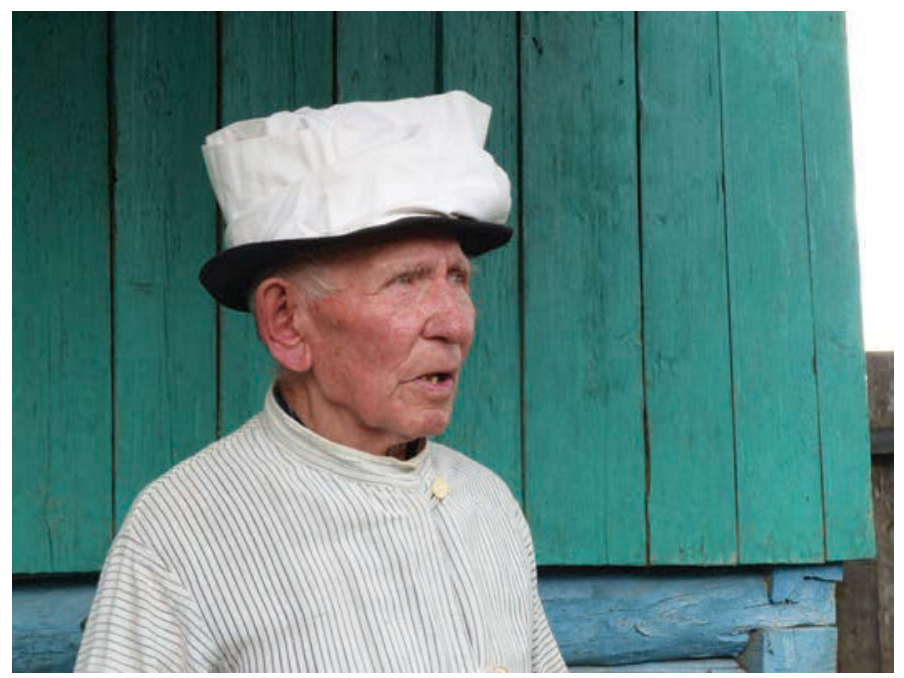

Photo 1. Nazip Sadriev, elder priest of Malaya Bal'zyuga. On the threshold of his home, showing us how the sacrificial priest used to dress, 8 June 2017. Photo Eva Toulouze. 
this age limit. Some years ago, he chose a young man in his late twenties to be his successor in his own village. That is how Fridman Kabipyanov became vös'as' of the village of Malaya Bal'zyuga.

Young men have also become sacrificial priests in other communities. In December 2013, we attended in Tatyshly district a second religious group's winter prayers. In that group, the collective ceremonies are organised by a special 'head of the ceremony' (vös' kuz'o), who in this case was not a sacrificial priest. Not only did he organise all practical aspects of the ceremony (finding sacrificial animals, transportation), but he also appointed the priests who prayed at the ceremonies. As some elder men were ill, he appointed two very young helpers who had been attending and assisting in ceremonies for years, Evgeniy Gayniyarov from Alga, in his late twenties (he was not married at the time) and Yashka, Yakov Fazlyev, from Verkhnebaltachevo, who was in his early thirties and used to look after the horses that carried paraphernalia to the ceremonies. (FWM 2013 ${ }^{34}$ ) We interpreted this as a manifestation of a discreet but effective staff policy.

\section{How are the candidates trained?}

Training 'methods' today very much follow the traditional pedagogical methods of native societies. They do not rely on verbal expression or theoretical knowledge, but on experience and observation (Ingold 2000; Vallikivi 2009). Nazip himself was trained in the natural way, by staying close to sacrificial priests, seeing them performing, and imitating them. He teaches in the same way: the apprentices are close to him and observe what he does. They are then expected to imitate their master.

One of the central aspects of the priest's work is prayer. Every priest has one prayer, whose core is repeated in every situation, while the introduction and/or the conclusion depend on the aim of the prayer and its place in the ritual. According to tradition the priest 
had to 'steal' a prayer, which meant that he had to learn it naturally, by hearing it without attempting to memorise it (Sadikov 2008: 192). But very few living priests have learnt their prayers in this way.

Most have learnt them from older people, not orally, but from written texts, or by cutting out clippings from newspapers or journals. ${ }^{35}$ For example, in 2014 the younger Bal'zyuga vös'as' Fridman gave us two prayers by copying them onto our memory stick from his computer. He had not yet learnt his prayer by heart and read it from a sheet of paper during the ritual (FWM 2014 $4^{36}$ ). Some priests do the same in other villages. Thus, the penetration of written culture can be observed, as it is accepted by leaders of ceremonial life such as Nazip agay.

Is the Udmurt prayer thus becoming a written genre? Nothing is less sure, although the written form is the main way that the tradition is transmitted today. It is true that most of the priests now read their prayers during the ceremonies. But it is interesting to follow, for example, Fridman's development as a priest: when we saw him first pray, he read the prayer from a text, but now he has read his prayer so often that he knows it by heart, and even allows himself to improvise. It is exactly what Anatoliy Galikhanov, the authoritative Altayevo sacrificial priest, told us about his experience: he too started by reading, but then when he had mastered the rules of the genre, he composed his prayers himself (FWM $2016^{37}$ ). In any case the output is oral and this will not change. The written text is only a tool on the way to professionalisation. It helps beginners to memorise long prayers that last for several minutes, but it does not change the nature of the praying process.

Prayers are inevitably witnesses of their times, although there is also a huge dimension of stability. People pray to obtain what they need, and these basic needs do not change fundamentally. The Udmurt ask for health for them and for their animals, for fertility for their land, for a good harvest, for good weather. But some needs may change and priests are concerned about whether they are authorised to change old texts. This was the content of 
a discussion that the Alga group's main vös'as', Evgeniy Adullin, had with Eva in 2015 (FWM 2015 ${ }^{38}$ ). An analysis of collected prayers shows that changes have always been introduced. At the beginning of the $20^{\text {th }}$ century, they prayed that their young people would please the Tsar in order to defend the country, ${ }^{39}$ or they asked God to give them the means to pay taxes to the tsar: "When we must pay tribute to the Great Tsar, give [us] yourself help!" 40 Of course, with the new conditions after the revolution this kind of demand no longer made sense. In the Soviet period, they prayed for the kolkhoz to become rich, ${ }^{41}$ for its livestock to be healthy, ${ }^{42}$ for its machine and combine operators to work with joy. ${ }^{43}$ Today, the couple of horses needed to transport grain to the thrashing floor $^{44}$, until recently mentioned in prayers, have been replaced by a couple of cars. ${ }^{45}$

Other new demands have emerged, reflecting the concerns of contemporary Udmurt society. Today there is a concern for Udmurt identity. In a socio-political context where specific non-Russian identities are under threat, and vernacular languages practically eliminated from school, the Udmurt have started identifying themselves in prayer: "all your unanimous Udmurt people"; "let in the world spread the glory of the Udmurt"; "let our children protect our Udmurtness". We feel here the concern that with newer generations attachment to Udmurt values could diminish. Other concerns are revealed by new prayers: "let our children listen to their mother and father, let them respect the elders". In former prayers there were no such concerns, but we understand that today's young Udmurt do not differ from other ordinary young people who are not so keen to follow tradition without thinking. The formidable influence of others is to be felt in the request: "Let the Udmurt people never lose its sweet modest customs". In other words, let it resist Russian influence. ${ }^{30}$ Other prayers ask for protection against drug addiction ${ }^{46}$ or for success in the youngsters' attempts to enter university, ${ }^{47}$ etc. 


\section{Perpetuation and transmission: Some portraits of $v o ̈ s ' a s '$}

The Udmurt sacrificial priests in Northern Bashkortostan are quite different from one another. Their differences illustrate the variety of the ceremonies and the richness of Eastern Udmurt rituals. We have met many of the priests, but we shall concentrate on only a few whom we have recorded in action and in interview. Although we have been working with Udmurt sacrificial priests in various districts of Northern Bashkortostan, most of the following cases come from Tatyshly district, which has been our main area of fieldwork, although we will move on to those who live in other districts.

\section{Tatyshly district}

Today the nineteen Udmurt villages in the compact territory of the Tatyshly district are traditionally divided into two village groups separated by a river, the Yuk. According to the villages where their main joint ceremonies take place, one could be called the Vil'gurt group and the other the Alga group. ${ }^{48}$ Both groups have their own rituals, which are almost parallel. The villages hold their ceremonies on the same day, with the joint ceremonies held on different days (the Vil'gurt group performs its mör vös' a week before the Alga group's event) to allow people to visit the other ceremony. The Alga group also performs a slightly more complicated cycle in June and December, because they have not only maintained but developed the principle of the three-village ceremony, with, an eight-village ceremony held one week before the mör vös'. Another difference is that in the Alga group the population brings offerings to the ceremony and gives them personally to the vös'as', who receives them with a personal prayer. In Vil'gurt the people put the offerings on a pole themselves. 
Thus, the comparison between both mör vös'allows us to identify clear differences in ritual performance (although this is not the aim of this paper). What we wish to emphasise here is the persistence of strongly differing local traditions. ${ }^{49}$ We shall only comment on some differences in the role of the vös'as'.

\section{Bal'zyuga}

Malaya Bal'zyuga is a small village of 240 inhabitants, homogeneously Udmurt (99\%), with two priests. One is Nazip Sadriev, who is now 91 and is retired. After sixty years as a priest he kept his wits and was willing to share his knowledge widely for a long time. Today, while his prestige is still high, he shows signs of old age and tiredness. He is an old man full of dignity, with intelligent, benevolent and penetrating eyes. He is the primary tradition bearer and is unhappy to see his disciples neglecting some of the rules he has attempted to teach them. He often does not hesitate to formulate opinions concerning them that we would not dare to repeat. Nazip agay ${ }^{50}$ is a real 'old-timer'. He does not recognise much value in other regional practices of prayer ceremonies. Over the river that flows north of Bal'zyga (400 $\mathrm{m}$ from the village), there are villages with slightly different ceremonial practices that resisted for the whole of the Soviet period, but for Nazip they are wrong. He would not disapprove of standardisation of ceremonies, but it would have to happen on his terms (FWM 201751).

This reminds us that in traditional society, people are mainly concerned with their own community and are not so much bothered with how others do things. We, the scholars, are interested in comparing different ways of conducting a prayer ceremony, but our informants have very limited knowledge of any other tradition. When we presented our film material to different sacrificial priests, we realised that many of them discovered with interest and curiosity what was happening in neighbouring villages. 
Photo 2. Fridman Kabipyanov, the young sacrificial priest of Malaya Bal'zyuga. Malaya Bal'zyuga, 11 June 2013. Photo Eva Toulouze.

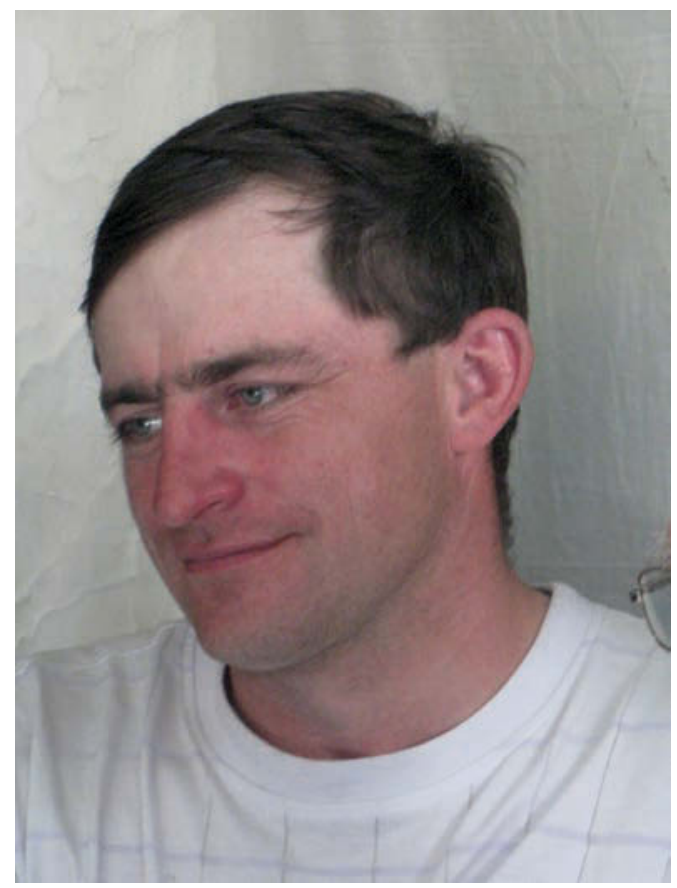

Nazip Sadriev has been the living authority in the region on practicing the Udmurt religion. He was even invited to the capital of Udmurtia, Izhevsk, to share his knowledge with his colleagues there. He claims he has trained all the active priests in the region, ${ }^{52}$ and approves more or less of them. His last choice, in his own village, has been to train a young man as his successor. This vös'as' is a modest, now 39-year-old man, Fridman, whose grandfather was a vös'as'. He is of course married, and has a seventeen-yearold son. Fridman Kabipyanov is a respected member of the rural community: he drinks very moderately and only occasionally, and he does not smoke; he studied music in Izhevsk and is a trained singer and musician who teaches in the music school of the neighbouring village, Novyye Tatyshly. As we mentioned earlier, initially he read his prayer from a text. 
For some in the village, it was a mistake to appoint such a young man, and it diminished the gravity of the ceremony, but most were happy to see a young man take this role. Now, after ten years of experience, he knows the prayer by heart and leads the ceremony with confidence. He works with a small team of experienced and skilled helpers, who help him to organise and conduct the ceremony. Fridman has started to pray in more conspicuous ceremonies and is able to give advice and pass on his expertise to those interested in Eastern Udmurt ceremonial practices. In 2016 he was invited, as a representative of the 'pagan' Finno-Ugrians, to conduct a prayer ceremony at the Finno-Ugric Congress in 2016, in Lahti, Finland.

\section{Vil'gurt}

In Udmurt Vil'gurt means 'new village' and it is the Udmurt name of a village called in Russian Novyye Tatyshly, 'New Tatyshly', as opposed to 'Upper Tatyshly', Verkhniye Tatyshly (the centre of the district). Vil'gurt is a large village of around six hundred inhabitants; its importance is due to it being the headquarters of the agricultural cooperative, the biggest local employer. For many decades the cooperative was led by a charismatic leader, Rinat Galyamshin, who, when he was the kolkhoz chairman, created the Udmurt national and cultural centre, which is the equivalent of the local national movement. Later he handed over the post of leader of the enterprise to his son and concentrated until 2015 on the revival of Udmurt identity in the region, taking advantage of his authority and connections. He had then to retire due to ailing health (FWM 201553) and passed away in 2020. Thus, Vil'gurt has benefited from the strength of its leader, thanks to whom many necessary facilities have been built in the village, including a new prayer house on the local ceremonial ground. ${ }^{54}$

When we started our fieldwork in Vil'gurt, the local press as well as the workers of the cultural centre and local teachers all 
acknowledged one vös'as' in the village, the retired agricultural worker Salim Shakirov. He made handmade artefacts for sale and had a prosperous household (FWM 2011 ${ }^{55}$ ). Salim was the 'official' priest to whom foreigners were sent, and who performed in ceremonies as ordered by the cooperative.

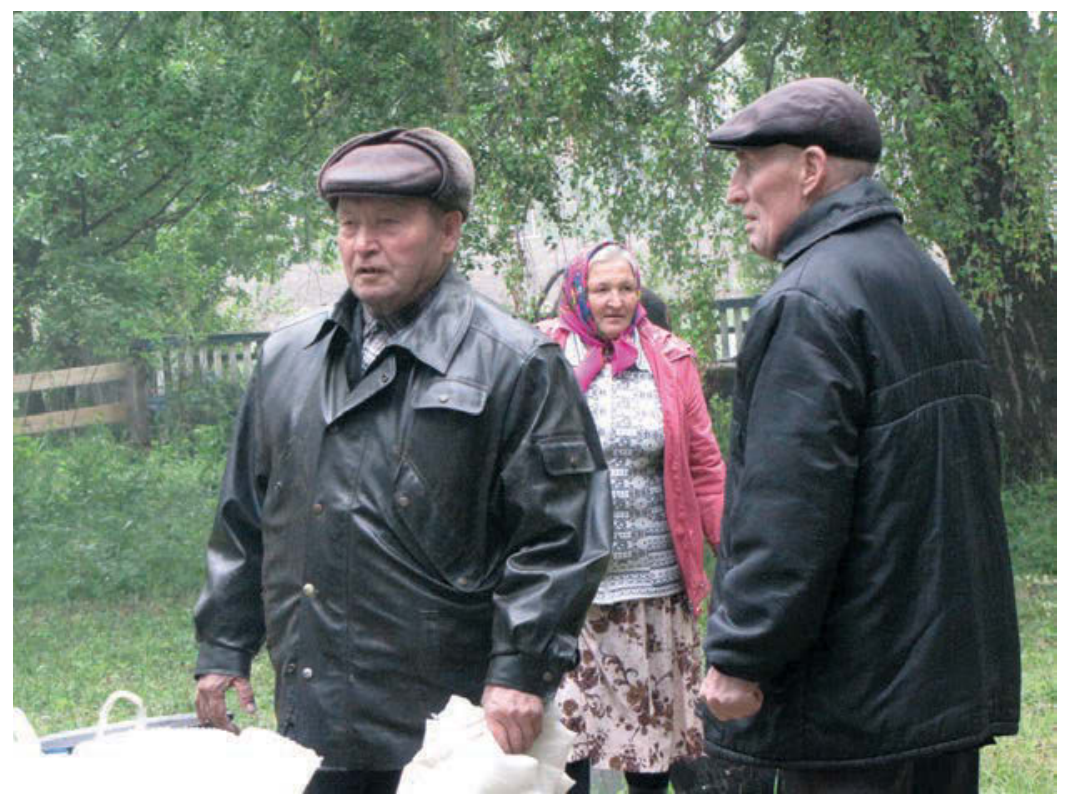

Photo 3. Salim Shakirov, Novyye Tatyshly's sacrificial priest. Mör vös', 7 June 2013. Photo Eva Toulouze.

He told us that nobody in his family had been a vös'as' and that he was chosen because he was a 'virtuous' member of the community. ${ }^{56}$ Nazip confirmed that he had chosen and trained him, and that he was not entirely satisfied with the result (FWM 2013 ${ }^{57}$ ). When asked about his succession, Salim answered without ambiguity that none of the youngsters was interested. 
We were a little surprised to discover when we arrived at the Vil'gurt mör vös' in June 2013 that Salim was not leading the ceremony, even though he was present. The leading priest, Rais Rafikov, was a simple cooperative retired worker from the village; he led the ceremony very confidently, without hesitation, keeping everything under control. He was the one who prayed the introductory siz'is'kon at the opening of the ceremony; in the two following prayers he was accompanied by three other priests (there were four priests, four lambs, and four loaves), among whom was Salim; and the closing prayer was performed by him and Salim. We discovered that the journalists present did not know him at all. He seems to avoid all publicity. However, he has authority, though not unshared, in religious matters. His personality fits the function: he is joyous and quick in his action, and inspires confidence. However, it was Salim who acted as a 'head of the ceremony' or vös' kuz'o, and organised the material part of the ceremony. In recent years, especially after Salim's death in 2019, Rais agay has acquired a strong reputation of his own.

Photo 4. Rais agay, June 2013. Photo Eva Toulouze.

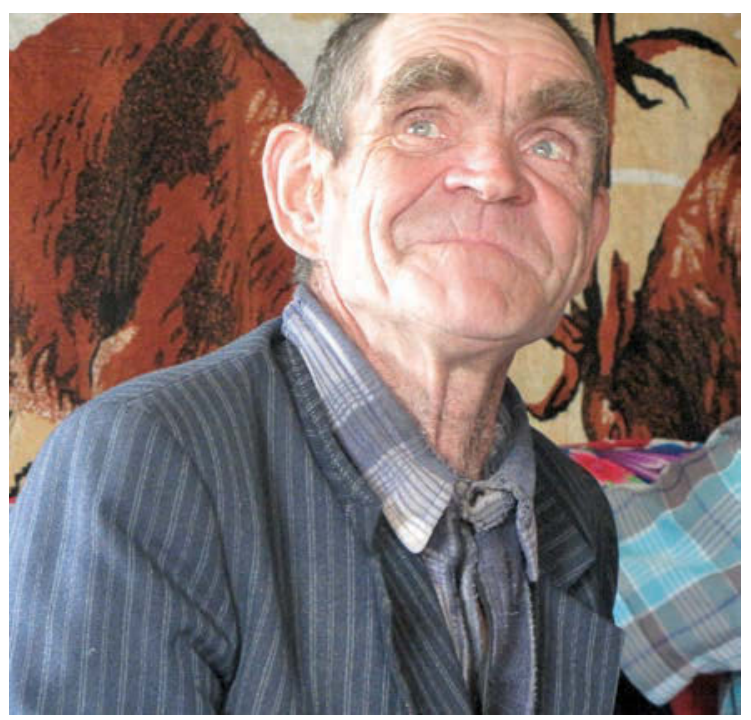


Nazip also told us that Rais had learnt his job well, and when he watched the video of the ceremony, he approved of many of the decisions he had taken. Nazip complained, however, that Rais had not thanked him for teaching him. The text of Rais's prayer also differed considerably from Nazip's own prayer. We decided to interview Rais, who lives alone with his wife, a Tatar, in a household that seemed more modest than Salim's (FWM 2013 ${ }^{58}$ ). We learnt that Rais's father was a vös'as' and that Rais himself had learnt his prayer properly by standing next to him, according to the old tradition of 'stealing' the prayers. Asked about transmission to younger generations, he answered that he was training his son.

During this interview, we could understand part of the tension between him and Nazip: while the latter considered himself the teacher who had given Rais the opportunity to learn the job, Rais placed more importance on what he had learnt from his father, and was attached to his own prayer. The old master is more dogmatic than his pupils, who, in performing ceremonies in slightly different ways, also follow local tradition.

We also met other sacrificial priests in the field, although we did not spend as much time with them as with those mentioned.

\section{The Alga group}

What is important to emphasise is that while the Alga group's people are perhaps less charismatic than Nazip Sadriev, and certainly less spectacular, they also kept ceremonies going during the Soviet period with quite a good transmission rate. In the $1970^{\text {s they had }}$ a strong vös'as', Islam Armanshin. We know about him because Hungarian scholars visiting this area recorded him, as well as Udmurt linguists (Vikár, Bereczki 1989). So we have a couple of recordings, in which we may appreciate what his younger grandson Vladik Khazimardanov, now sacrificial priest in Verkhnebaltachevo, meant when he said that his grandfather "sang" the prayers (FWM ${ }^{59}$ 2015). Indeed, he has a chanting intonation when 
praying. Vladik's elder brother Boris is also a sacrificial priest. He started much later, after 2016, and is the sacrificial priest at the village of Staryy Kyzyl-Yar.

The main vös'as' in the Alga group of villages is Evgeniy Adullin, who works as the main bookkeeper of the Rassvet cooperative, based in Nizhnebaltachevo, where he lives. So Evgeniy has a solid legacy on which to rely. He was given the title 'Great' sacrificial priest (badzh'ym vös'as') and is the main authority in the Alga group. He is the one who in 2013 ordered, on the behalf of the agricultural enterprise, about two dozen frocks for the sacrificial priests, remembering the traditional costume, today mainly disappeared. Evgeniy can also be called to perform outside ordinary ceremonies, for particular events. For example, in June 2013 he led a ceremony with a small staff of volunteers in the little village of Utar-Elga that celebrated the 'Day of the Village', offering a lamb in order to have a sacrifice.

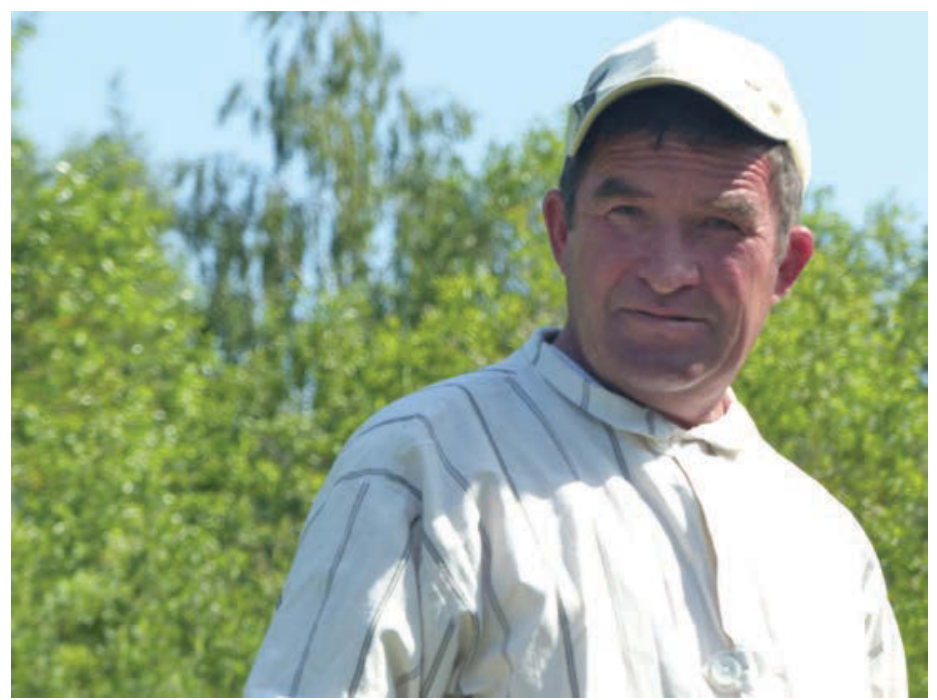

Photo 5. Evgeniy Adullin, Great vös'as' of the Alga group. Nizhnebaltachevo village ceremony, 3 June 2016. Photo Eva Toulouze. 


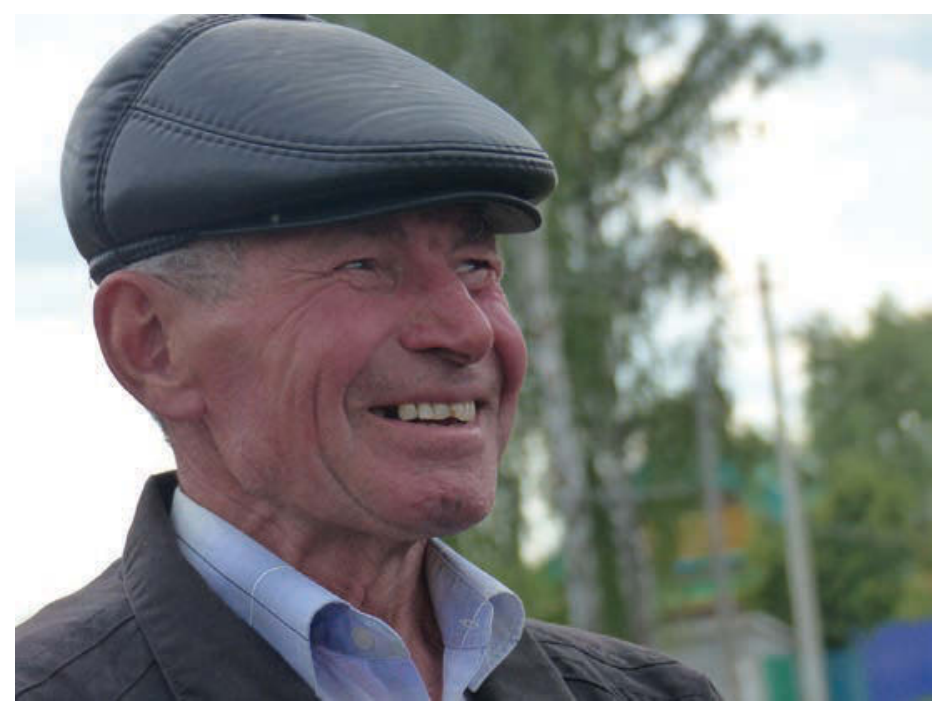

Photo 6. Farkhulla (Garifulla) Garifanov, main organiser of the Alga group. Nizhnebaltachevo, 5 June 2016. Photo Eva Toulouze.

What is still characteristic of the way the Alga group's ceremonies are led is that Evgeniy is very efficiently supported by the head of the ceremony, the vös' kuz'o, Farkhulla Garifanov. He is an older man who is not a priest, but seems to be a knowledgeable and practical guardian of tradition. He is a former village head and has clear authority. He materially organises all the ceremonies meaning that Evgeniy has only to perform his own role, which is to pray and to give all the signals connected with the ceremonial activities. Farkhulla prepares background elements such as having the grass cut, having the logs ready to make the fire, making sure the sacrificial animals are in the right place, etc. He is also in charge of 'promoting' sacrificial priests: if one of the appointed vös'as' is absent, he decides who will pray in his stead. There is always someone to fulfil the role of a vös' $k u z^{\prime}$, but in many cases it is the sacrificial priest, as in Bal'zyuga. So, vös'as' and vös'kuz'o 
exercise two distinct functions, although sometimes these are concentrated in the same person, but sometimes shared between two villagers as in the Alga group. Farkhulla is a passionate leader who sees that rules are respected. He orders children who attend ceremonies in shorts to go home and change into proper clothes, or sends away women who enter the sacred space (FWM 2016 ${ }^{60}$ ). He knows everybody in the Alga group of villages and is in the best position to identify possible future leaders.

\section{Aribash and Vyazovka}

In Tatyshly district there are many other sacrificial priests. An interesting case is that of the village of Aribash, which belongs to the Vil'gurt group. The sacrificial priest of the village is Aleksey Garaev, who has interesting memories of his youth that encouraged him to be active in the ceremonial life of the village. For instance, he remembers an interesting small detail vividly: when the porridge was ready,

Photo 7. Aleksey Garaev, the sacrificial priest of Aribash, at the village ceremony 5 June 2015. Photo Eva Toulouze.

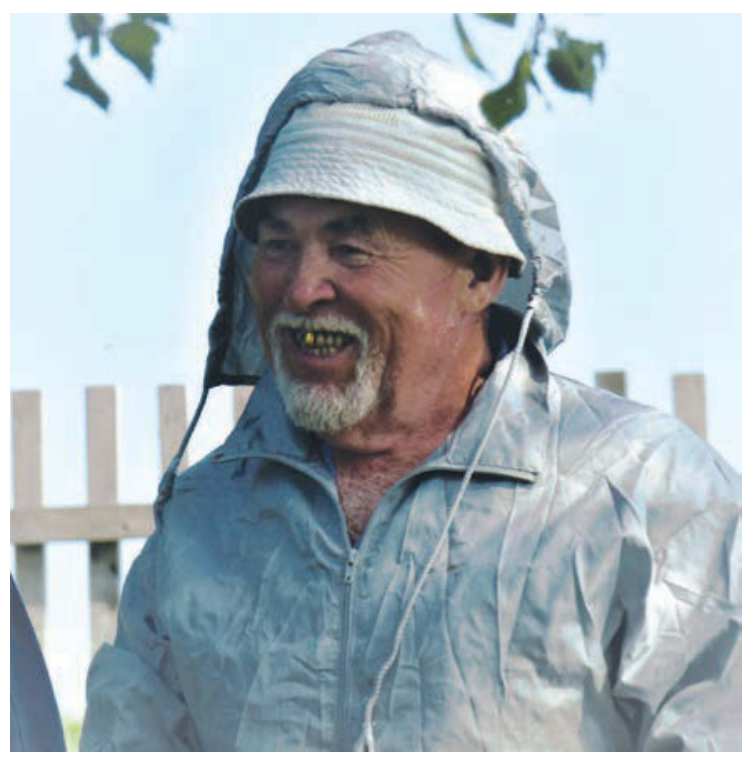


young men rode into the village calling everybody to the ceremony. This detail was reported at the end of the $19^{\text {th }}$ century by Finnish ethnographer Yrjö Wichmann in the village of Bol'shekachakovo (Sadikov, Mäkelä 2008).

What distinguishes him from other priests is that an important role in his ceremonial activities is played by his wife Liliya. She is from another village, where she was brought up by a quite traditional grandmother who taught her lots of things about her culture. Liliya is an intellectual who writes in the local Udmurt paper and is the author of many short prose texts (FWM 2014 ${ }^{61}$ ).

Liliya has been of the utmost importance for Aleksey because of her support and practical help. During the village ceremony, she helps him dress, a detail we have not noticed in any other ceremony (FWM ${ }^{62}$ 2015). The Aribash ceremony also presents another peculiarity in that the place's agency seems to dictate the ritual.

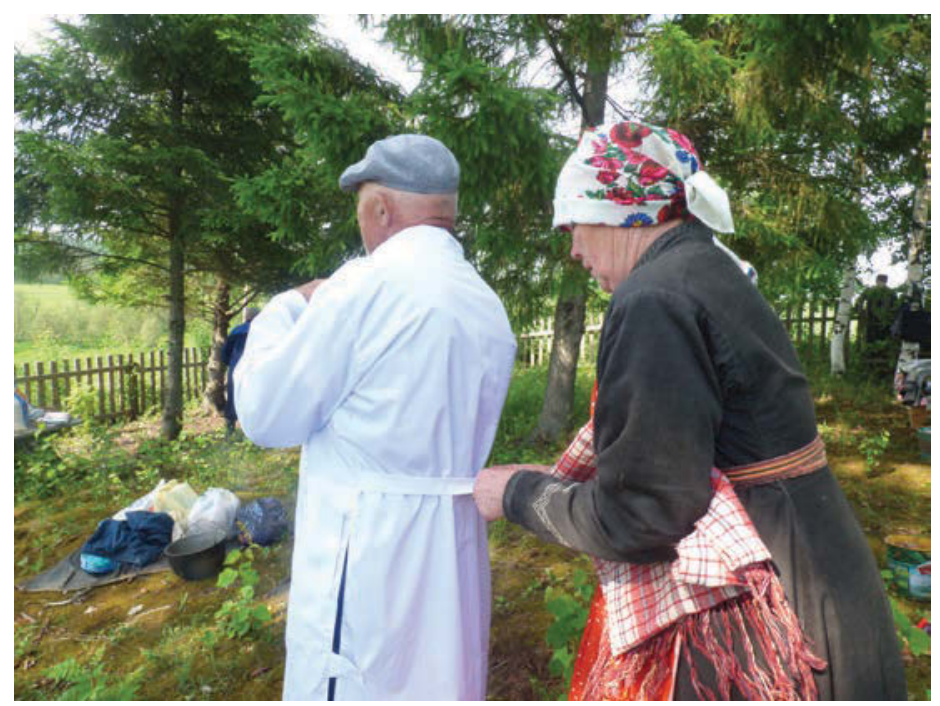

Photo 8. Aleksey Garaev, the sacrificial priest of Aribash and his wife Liliya at the village ceremony 5 June 2015. Photo Eva Toulouze. 
As the Aribash people have chosen to hold their village ceremony in a former $l u d$, many features of the $l u d^{63}$ cult have been taken on, for example the male character of the ceremony (only rams are sacrificed, only men attend) and the use of flat bread kuar n'an'. So we do not know whether this custom of helping her husband dress is also connected to the lud cult, although in the other ceremony of this cult that we attended in Votskaya Osh'ya this kind of act was not noticed.

In Tatyshly district there are other sacrificial priests who have their own peculiarities. For example, the priest in the village of Vyazovka, Filarit Shaymardanov, is the only one in the district to pray in the traditional garment that was formerly worn not only by the priests, but also by all the people, both men and women, who attended the ceremony $\left(\mathrm{FWM}^{64}\right.$ 2013). This whitish home-spun sarafan-type garment is called shortderem. Nazip Sadriev and Filaret are the last to have a shortderem, along with some elder women.

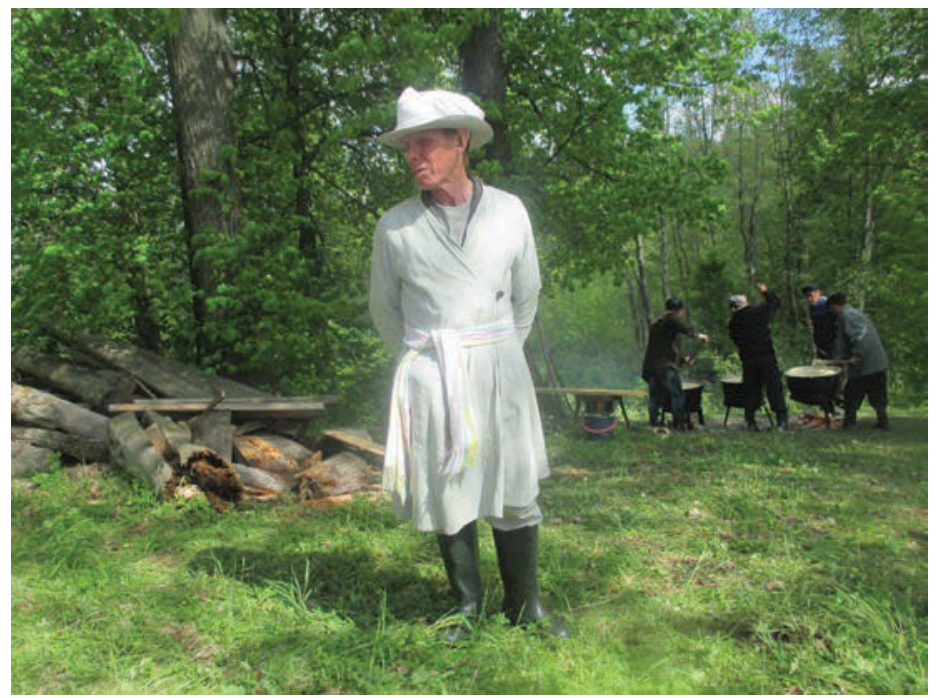

Photo 9. Filarit Shaymardanov, Vyazovka's sacrificial priest. Vyazovka village ceremony, 7 June 2017. Photo Eva Toulouze. 
This garment's fate is not to be transmitted to the next sacrificial priest, but to be used as a deceased priest's mortuary clothing. Therefore, most shortderems have disappeared. As the priests were supposed to be dressed in white they used, throughout the Soviet period, an ordinary white household or medical frock. Only at the beginning of the $21^{\text {st }}$ century did sacrificial priests feel the need for something more solemn, more aesthetic, than ordinary white frocks, and started to add different patterns.

Certainly, Tatyshly district is well-known as the centre of the Udmurt revitalisation process, although this does not mean that there is nothing elsewhere. Some of the most authoritative priests among the Eastern Udmurt are to be found in other districts. We shall now take three examples of priests from three different districts. They are all sacrificial priests who have impressed us with their exceptional personality and local peculiarities of ritual practice.

\section{Baltachevo district}

In Baltachevo district there are two Udmurt villages, both very active in their religious practice. Although we have met both sacrificial priests, we have not yet been able to attend Kizganbashevo's ceremonies yet. However, we were able to visit Asavka's priest and his ceremonies several times. Let us focus on him.

Vladimir Galiyev is among those whom we may call the 'younger' priests, although he is not exceptionally young, being born in 1971 . $\mathrm{He}$ is a freelance construction worker, who often has to work far from home in order to feed his family of six children. ${ }^{65}$ Of the priests we have met he is certainly the most concerned with the spiritual dimension of his task. He was appointed by the village elders when the previous priest decided to retire. Vladimir is permanently in touch with both of them. 


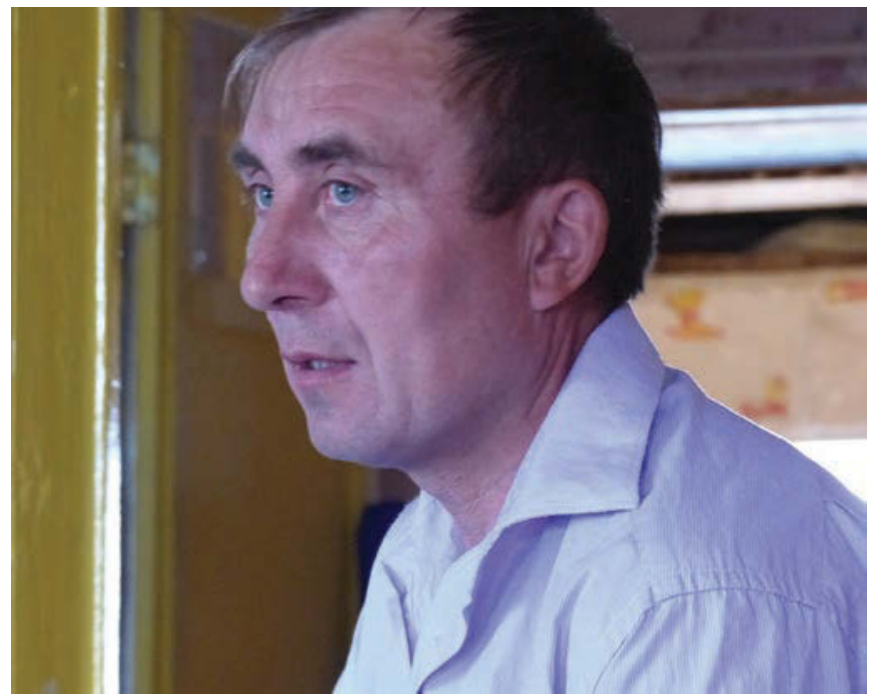

Photo 10. Vladimir Galiyev, Asavka's sacrificial priest. At his home, 8 June 2016. Photo Eva Toulouze.

Vladimir was surprised and disturbed when he discovered that the prayers were mainly dedicated to asking the gods for benefits, and that there was never an expression of human gratitude. He discussed this with the elders, who agreed to his wish to add some parts at the beginning of the prayer he reads thanking the supreme God Inmar for the Sun, the Moon, the trees, the birds, etc. ${ }^{66}$ So, in his discreet ways, Vladimir is also an innovator; in addition to which he is a bright, luminous personality (FWM ${ }^{67}$ 2016).

\section{Kaltasy district}

The Kaltasy district is particularly interesting, for it reveals the failure of research to follow the rituals through time. The village, today called Bol'shekachakovo, known in literature as Badzh'ym 
Kachak, was visited in 1884 and 1895 by two Finnish researchers, Aksel Heikel and, more important, Yrjö Wichmann, who spent one full month in the village, describing the contemporary religious life of the village, in which there were many deities and many more ceremonies (Toulouze 2020a).

Thus we know much of how the village lived in 1895, although except Wichmann literature tells us nothing. During the $20^{\text {th }}$ century no scholar visited this village, at least no scholar we know of. Of course, the subjects we are interested in here were not acceptable topics for research in the Soviet period. So we know what happened in the village thanks to the remembrances of the inhabitants, collected by Kirsi Mäkelä in 2008 (Mäkelä-Hafeez 2015). We thus know that by the $1960^{\text {s }}$ the traditional ceremonies had disappeared. The places of the cult of $l u d$ were destroyed and the trees cut during the Second World War, although some sacred places remained intact throughout the Soviet period. At the beginning of the $1990^{\text {s }}$ the ceremonies were revived and they now live their normal lives.

The present priest of the village, Anatoliy Nasipullin, is a retired schoolteacher (FWM ${ }^{68}$ 2018). Although he does not come from a family of priests, he is highly respected in the village. $\mathrm{He}$ is deeply interested in traditional Udmurt culture and sings with great pleasure songs he has collected in his village. The Kaltasy people present some differences in the keeping of tradition in comparison with the other Bashkortostan Udmurt: while in other places the ceremonies are done strictly by men, here women are as active as men. This can be disturbing for other priests, for example when they are praying together with Anatoliy's team at the el'en vös'. But Anatoliy finds it normal that women are active as his helpers, for the majority of the people who attend the ceremonies are women. He has not yet memorised his prayer and reads it from a handwritten text. 


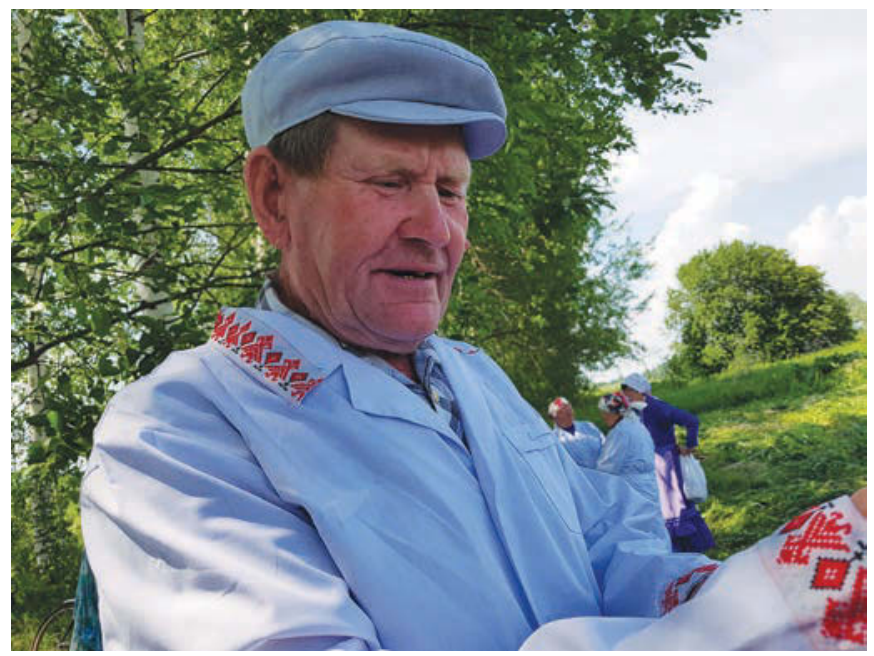

Photo 11. Anatoliy Nasipullin, Bol'shekachakovo sacrificial priest. At the promise of a sacrifice, siz'is'kon. Bol'shekachakovo, 20 June 2018. Photo Eva Toulouze.

\section{Burayevo district}

There are several Udmurt villages in Burayevo district. In one of them, Kissa (Kasiyarovo) the ceremonies were long discontinued because of the death of the priest in the $1980^{\text {s. The situation was }}$ particularly sad because the old priest had carefully prepared his succession, and chosen two younger men to whom he transmitted his knowledge. But they did not take over the task, and the ceremonies were restarted only 15 years later, under pressure from the local population ${ }^{69}$.

There is another village in the district which is also a centre of Udmurt religious activity in Bashkortostan. The peculiarity of Altayevo is that it was one of the three locations were the el'en vös' ceremony was organised. It was also the reason, allegedly, why it was revitalised. The population remembered that this ceremony 
took place. One of the most authoritative sacrificial priests among the Eastern Udmurt is Anatoliy Galikhanov. He lives in the village, but his brother, Kasim, is an architect and graphic artist who lives in Izhevsk. Kasim has been most active in the Udmurt capital in revitalising there the Udmurt religion, and had even prepared a project for an Udmurt sanctuary in the city - a project that was finally refused by the authorities (FWM ${ }^{70}$ 2019). The idea of revitalising el'en vös' was most probably a Galikhanov family initiative. Kasim could mobilise the Izhevsk association of Eastern Udmurt and has the support of his brother.

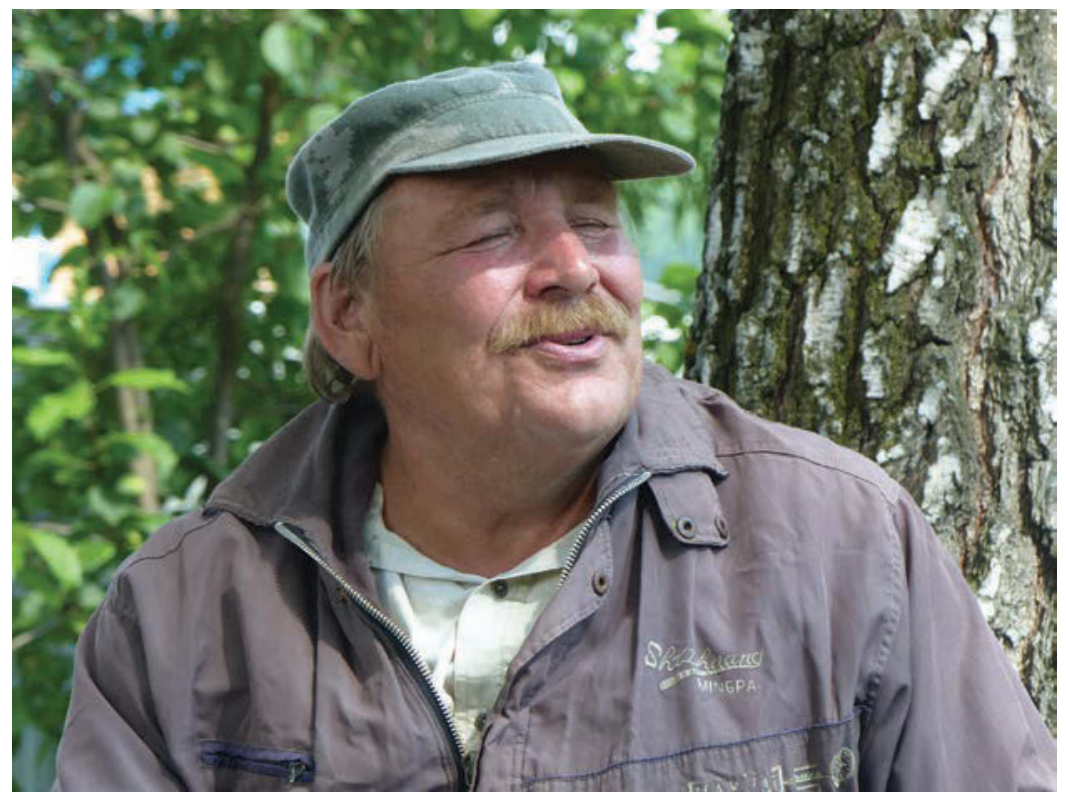

Photo 12. Anatoliy Galikhanov, Altayevo's sacrificial priest. Altayevo, meeting of the vös'ken'esh, a gathering of elder men who decide on ceremonial life, 6 June 2016. Photo Eva Toulouze. 
In Altayevo the main ceremonies were almost continuously preserved. Anatoliy mentions that they could have been interrupted for one or two years, but he is sure that the interval between two vös'was never three years, because after such a break they would have closed the ceremony. ${ }^{71}$ During the Soviet period, they had to ask for permission to hold the ceremony and, according to Anatoliy's words, the kolkhoz always gave the necessary ewe for sacrifice. They never had problems with Communist Party officials. Anatoliy was elected as a vös'as' in 2010 at an ordinary village meeting held in spring to discuss all kinds of practical problems. The previous vös'as' decided to give over the task to a younger man, and he was proposed. During his training by the former priests, Sharifgali agay and Salimyan Mardanov, he also addressed Nazip Sadriev, who was quite happy with him, and found him gracious enough to recognise his teaching and to thank him for it (FWM $\left.{ }^{72} 2013\right)$. At the beginning he also read his prayer from paper, but acknowledged that reading is not a proper way of praying. The prayer should come from inside because God does not understand words, words are for people, he says. But God understands the metaphors and the soul of the people. Anatoliy was given a prayer by his predecessor. He later developed it himself, and he has continued to produce prayers of his own.

The last aspect we wish to emphasise concerning Anatoliy Galikhanov is that he has a particular profile among all the vös'as'. He has a vocation to be a public person and has invested in the field of social media. He has his own page on the VKontakte social network, where he shares his texts and his ideas and gives recommendations, telling people what is allowed and what is forbidden according to traditional rules. Thus, he also has a certain influence in educating people, for what he posts is certainly followed and accepted as the word of an authority. 


\section{Eva Toulouze, Liivo Niglas}
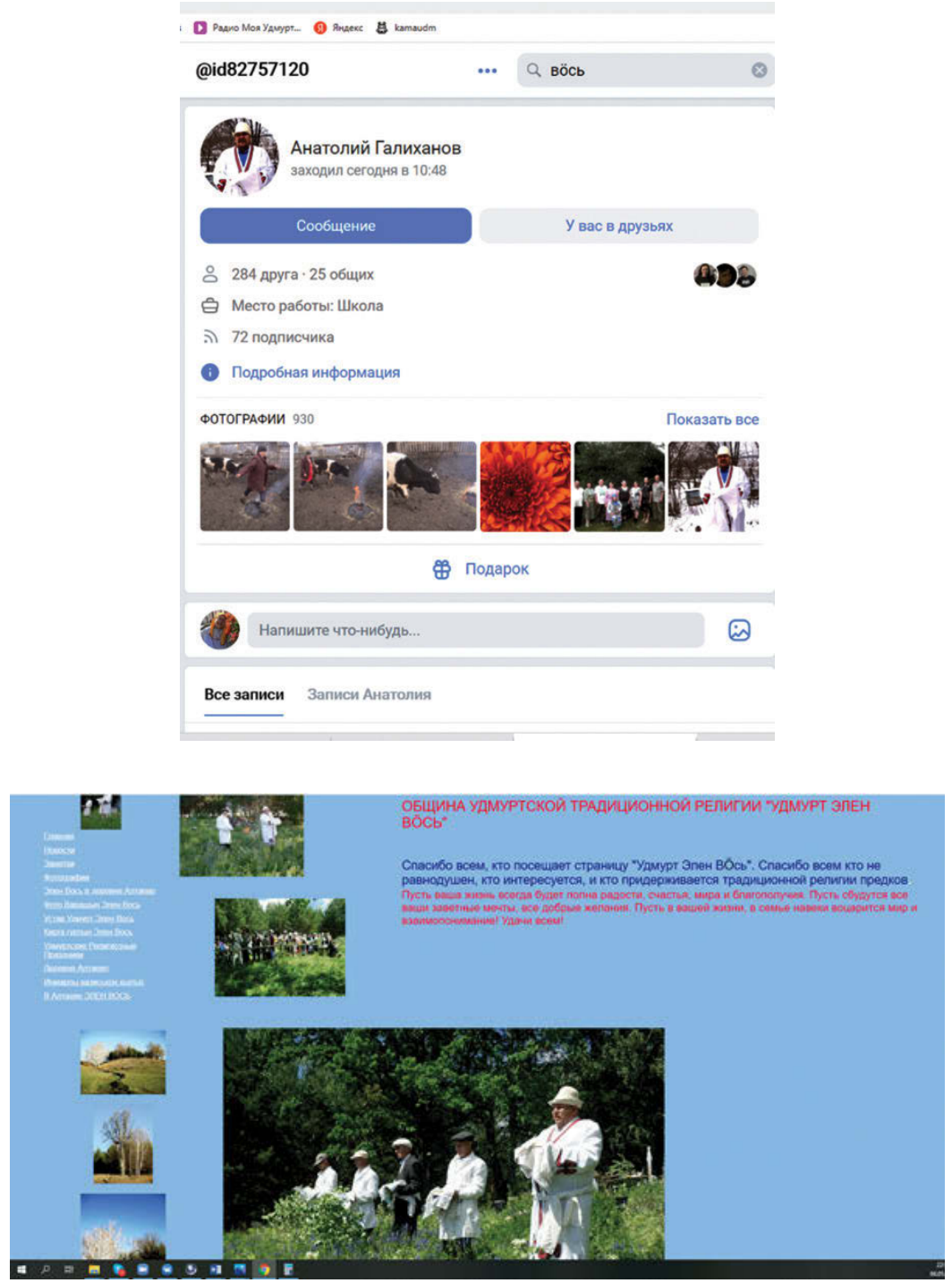

Screenshots 1 and 2. Anatoliy Galikhanov's social media pages, 2 May 2021. Photo Eva Toulouze. 


\section{The vös'as' as a political leader?}

If we examine the Eastern Udmurt situation within the regional context and extend our observations to other Finno-Ugric communities in the region, we can observe that traditional religions are often used as a powerful ethnic marker (Luehrmann 2011: 42; Leete, Shabaev 2010; Alybina 2014: 90-91). This is particularly true of the Mari in Mari El Republic. The Mari are the least Christianised of the Volga Finno-Ugric peoples: their religious identity proved most resistant to forced evangelisation, and after the collapse of the Soviet Union the ethnic Mari religion has been powerfully revived (in $200419.4 \%$ of the Mari considered themselves followers of the Mari religion in more or less syncretistic ways - Sharov 2007: 175). The public discourse around this is thoroughly connected with national identity (Alybina 2014: 91). This is not the case among the Udmurt. In Udmurtia there are only a few villages in which the ethnic religion has been preserved without explicit Christian interference (this does not exclude indirect influence from the general environment, while all over the country there are other manifestations of syncretism in the people's religious practices), and these are seen more as a curiosity than as a lighthouse for Udmurt ethnicity.

Although the Mari religion has been institutionalised in Mari $\mathrm{El},{ }^{73}$ with publications, new rituals, and a strong hierarchy including sacrificial priests (Alybina 2014: 92, 98-99), in Bashkortostan the political and identity dimension seems to be reduced to the more or less emotional feelings of particular vös'as', and it never appears in public discourse. Even at the Congress of the Udmurt National Cultural Centre, in November 2015, ${ }^{74}$ no mention was made of religious practice during the entire day the congress lasted, and few priests attended. Their absence shows the almost total disconnection of religious activity from the Udmurt national movement in this area. 
The Bashkortostan ceremonies are not accompanied by any public or personal ideological discourse. While analysis clearly shows that they are probably now the only place where communication in $\mathrm{Udmurt}$ is guaranteed (because of the rise in mixed marriages the minority language may no longer be dominant in the family), and thus might be a strong pillar of Udmurt identity, it does not seem to act as such, at least for now. When asked why these ceremonies are important, both sacrificial priests and the lay population simply emphasise the 'natural' link to what the ancestors did: things have to be done in certain way because it is how they have always been done. When asked what happens if one does not attend the ceremonies, answers are hesitant. People look for examples of misfortune affecting lazy adherents, and usually find them, but this is a reflection of their desire to please the interviewer. This question does not seem relevant: tradition is self-justified, without the need to give any foundation through rational argument.

This is a strength, but also a weakness that can in the dangerously near future threaten the very existence of this religious practice. It is a strength because it is an intrinsic part of life that is taken for granted. Even where it is the result of revival or of a recent construction, the aim is to put things right and re-establish order and balance where there was chaos. No additional ideological meanings are added in the process. This does not mean that the revivers do not intend to enhance ethnic awareness. Usually the impulse for revival comes from the centre: its primus motor is often the head of the local agricultural cooperative. For example, long-term director of Demen kolkhoz, Rinat Galyamshin, who later founded the Udmurt national and cultural centre in the district, initiated the building of prayer houses, the fencing of the sacred places (a new feature in the tradition) and even influenced the content of some village ceremonies. He had companions in different districts who acted likewise in order to revitalise religious practice: they usually asked a respected older man, somebody active in local politics, to 
fetch an older sacrificial priest or his sons and tell them to officiate again, even after breaks of years or decades. When people are told by influential personalities to organise ceremonies they are obedient, and traditions have thus been started everywhere. In some places, local activists have taken over and devoted themselves to these activities (for example the Garayev couple in Aribash). In others, the involvement has been more mechanical, but the response from the population is unanimously positive, and the new ceremonies have quickly taken root and are massively attended.

Considering the importance of collective prayer ceremonies for the Eastern Udmurt, as well as the dangers to their identity in today's world, it is surprising that this religious revival movement has not been tied to an explicit ethnic ideology. However, this might be changing. As demonstrated above, the emergence of the 'Udmurt topic' is clearly visible in the activities and prayers of Anatoliy Galikhanov, who is the priest of Altayevo village and the man behind the revival of el'en vös', although other sacrificial priests have so far been reluctant to stress an ethnic and political dimension in their ceremonial practices. Only the priests of the Alga group have started using some of the Galikhanov's formulas in their prayers, although they are, at the moment, the only ones.

The lack of an ideological background supporting and accompanying ceremonial activity can be a weakness: if the situation becomes critical, there will be no supporting mental framework to maintain it. The language situation, while still very comforting in terms of minority language use and preservation, is already wavering: young Udmurt couples leaving their home area to look for work in other more industrial regions find themselves in the midst of the Russian population and start speaking Russian to their children, even though Udmurt is their mother tongue. They are not supported by an ethnic ideology that will motivate them to raise their children bilingually or multilingually. We therefore have the impression that the situation is aptly comparable to the position of 
Animism in the face of Christianity or Islam: it is weak, because of the lack of a strong dogma that can withstand pervasive ideologies.

The reluctance to turn Udmurt religion into something more ideological and dogmatic is manifested in the failed attempts to standardise ceremonial practices in the manner of Christianity and Islam. In 2015, there was an attempt to create a coordinating instance of the sacrificial priests of the Eastern Udmurt by the Association of the Eastern Udmurt in Izhevsk. Ultimately, nothing came of the idea because there was permanent tension between the leadership of the association and the head of the Udmurt national movement in Bashkortostan.

At the same time, or even a little earlier, Udmurt civil servants working in Tatyshly district administration, emerged with the idea that a standardisation was long overdue. Taking as a model the world religions Islam and Christianity, these administration workers launched a plan according to which the Eastern Udmurt all had to pray using the same text. They did not go very far with their project, which clearly received no support from the people concerned that the administration was disconnected from the sacrificial priests and did not themselves attend ceremonies. They also received more than critical opinions from the scholars whom they addressed for advice (FWM $\left.{ }^{75} 2014\right)$. At that time the process was stopped.

The attempt to standardise ceremonial practises was resumed later, when the Udmurt leader had changed. The new head of the Udmurt movement in Bashkortostan, took over the initiative and called a meeting of the vös'as' in January 2019 (FWM ${ }^{76}$ 2019). The situation seemed to be ripe and a coordinating association was created. But so far it has not attempted to establish any standards for collective prayer ceremonies. The association of sacrificial priests remains, for the time being, just a coordination forum where priests can discuss their concerns and coordinate the dates of their ceremonies. 


\section{Conclusion}

This short overview is an attempt to decipher the present state of the spiritual world of the Bashkortostan Udmurt, who have been more successful than others in Russia in preserving their old values. Their keeping of their ritual traditions is not led, as our examples show, by a desire to reproduce precisely ancient practices that have disappeared. Even the most conservative of activists, such as Nazip Sadriev, acknowledge that things change and seek in their own practice to ensure the vitality of the whole system rather than to reproduce it mechanically. The differences among vös'as', even on the small scale we chose, reveal real tensions and problems as in all human communities, as well as different ways to be vös'as' and to set ceremonial practices. We can therefore argue that the system is vibrant and that its diversity is its strength, and the presence of younger men among those chosen suggests there is a future for these forms of worship.

In conclusion, we have examined here a core problem in the practice of religion: the role of the key figure in ritual, with his abilities and knowledge, and how this role is transmitted to younger generations. The vös'as' is an entirely ordinary member of the village community, who is respected and considered 'virtuous' and who takes upon himself the organisation of the community's ritual life. The transmission of this role is possible because being a vös'as' is something that can be learnt and does not require, at least today, peculiar features or extraordinary knowledge. It is facilitated by the position of the elders in charge of transmission, who have chosen to encourage young people to act as religious leaders. It seems a reasonable adaptation in the wider social context where youth is increasingly challenging old age for prestige in society. However, unlike in other nearby regions, their role as leaders is merely religious, and has no political implications, at least for now. 
The elders responsible for Udmurt religion in Bashkortostan have chosen the most reasonable path to allow their religion to be preserved. Nevertheless, the challenges are not in practice itself, but in its context. The Udmurt religion is thoroughly connected to rural life, while rural life itself is threatened by modern ways, by a set of values that relegate the rural to the bottom of the social socle. Today, even in the remote villages that are involved in these community rituals, the younger generation is computer and townoriented and shares networks and entertainments with youngsters all over the world. Will they remain in the village, or will they return to marry and become members of the community, allowing it to thrive? Moreover, the traditional structure of village life is being shattered. In some parts of the country this collapse took place two decades ago. Here the collective farms were successful at the end of the Soviet era, and have been replaced by cooperatives that reproduce the previous model quite closely. While these cooperatives have been able for some years to adapt to a market economy and have achieved good productivity, this well-being is seriously threatened. What will happen if the cooperative fails? It will be important to follow the viability of rural life if the chances of this unique religious practice surviving are to be assessed.

\section{The team}

EB - Evgeniy Badretdinov

ET - Eva Toulouze

LN - Liivo Niglas

LV - Laur Vallikivi

NA - Nikolai Anisimov

RS - Ranus Sadikov 


\section{Notes}

1 This research has been funded by the Estonian Research Council (PUT590, UT PHVKU19913 "Soome-ugrilased multietnilises ühiskonnas: kohtumine religioonide piiridel" (Finno-Ugrians in a multiethnic society: Meeting at the border of religions).

2 Among others, Pervukhin 1888, Holmberg 1914.

${ }^{3}$ Conversations with Salim Garifullin in Verkhniye Tatyshly, Tatyshly district, Bashkortostan with ET, LV LN and NA.

4 The Mari have the same kind of holiday, also called the 'Great Day' (kugu keche), corresponding to the Easter period. Its absence or lesser resilience in Bashkortostan may be connected to the absence of Christianity in the area (there was no church whatsoever in the Tatyshly district until 2018, when an orthodox church was built in its centre, Verkhniye Tatyshly). There are memories of the existence of badzh'ym nunal, but it has lost its significance. According to our main informant people used to gather and eat porridge in groups of three or four families; today, when something happens, the celebration is limited to one family, without outsiders, with the head of the family saying ritual words over the porridge.

5 Event in Banibash, Yanaul district Bashkortostan, recorded by ET.

${ }^{6}$ Recorded from Nazip Sadriev, in Malaya Bal'zyuga, Tatyshly district Bashkortostan, by ET, LN, and LV.

7 However, people still recall a time when party officials interrupted the ceremony and the contents of the sacrificial cauldrons were thrown on the ground. This did not affect the practice as the inhabitants of the village simply changed the location of the ceremony to more hidden places. Conversations with Nazip Sadriev, Flyura Nuriyeva, in Malaya Bal'zyuga, recorded by ET, LN, RS.

8 This is true of the spring cycle. In winter, it is the village ceremony that has disappeared, while the collective ones are still performed.

9 Recorded in Novyye Tatyshly, Tatyshly district, Bashkortostan, by ET, LN, NA, RS.

${ }^{10}$ Conversation with a woman living in Yekaterinburg, at the mör vös' 2013, Novyye Tatyshly, Tatyshly district, Bashkortostan, by ET.

${ }^{11}$ Conversation with an Udmurt dentist living in Krasnodar, Kaymashabash yshtiyak vös', Yanaul district, Bashkortostan, by ET. 
${ }^{12}$ Conversation with Anatoliy Nasipullin, Bol'shekachakovo, Kaltasy district, with ET and RS.

${ }^{13}$ El'en vös', Kirga, Kuyeda district, Perm krai, recorded by ET, LN.

${ }^{14}$ El'en vös', Staryy Varyash, Yanaul district, Bashkortostan, recorded by ET, EB.

${ }^{15}$ We use here the expression introduced by Aado Lintrop (Lintrop 2003).

${ }^{16}$ These two words are synonymous, with a use more or less local. The word kuris'kis' comes from the verb 'to ask' and its derivate, to pray. The kuris'kis' is the one who prays.

${ }^{17}$ This is still the case. Although it is not the focus of this article, let us mention an event that happened during our fieldwork: Tolya, the son of our host's neighbour was called up, and was to leave on $25^{\text {th }}$ June very early in the morning. The celebration started in the evening, and at about 4 am the father prayed for his son and a ritual porridge was distributed to those who attended (FWM 2013: recorded from Flyura Nuriyeva, in Malaya Bal'zyuga, Tatyshly district, Bashkortostan, by ET and LN).

${ }^{18}$ We heard the word partchas'only once, in the mouth of the older vös'as', Nazip, who used it to mean 'assistant'. Ranus Sadikov, who has spent years studying the Udmurt religion, reacted to this word, for it was the first time he had heard it in current speech.

19 This is what Khrushcheva asserts (1995: 197). Lintrop argues that, with reference to Udmurtia, in former times the tuno, or wizard, used to appoint the fore-prayers; now the vacant places are filled through a vote (Lintrop 1995: 271).

${ }^{20}$ The Udmurt word ken'esh was used in the $1920^{\text {s }}$ for the Russian 'Soviet' until it became taboo, and the institution was abolished. There is abundant literature on this issue, especially by Galina Nikitina $(1993,1998)$.

${ }^{21}$ Our description is based on our observation and video recording of the Malaya Bal'zyuga gurt vös' in 2014 (see Niglas 2019b). FWM 2014, recorded by LN, ET, LV.

${ }^{22}$ Although we have also attended other village ceremonies, for example in 2014 (Urazgil'dy: LN, ET, LV), 2015 (Aribash: ET, RS), 2016 (Nizhnebaltachevo ET, RS, NA), 2017 (Vyazovka: LN, RS, LV, NA, ET), 2018 (Starokalmiyarovo ET), and 2019 (Yuda EB and Verhnebaltachevo ET, LN, LV). Some of these ceremonies have been kept quite traditional, while others have either been revived in a more elementary shape (Urazgil'dy) or merged with another form of ceremony, for example the keremet vös'(Aribash). 
${ }^{23}$ Agay is an honorific title given to older men, meaning in Udmurt 'brother', 'uncle'.

${ }^{24}$ The branches used in the ceremonies differ according to the season: in spring and summer they are birch, in winter, fir. Whenever branches are used, the season determines which tree they are taken from.

${ }^{25}$ Usually, at this stage, only assistants - and anthropologists - are concerned.

${ }^{26}$ Some particular parts of the animal - the heart, the head, the liver, a right rib, and the right fore thigh - have previously been marked and will be used in the next prayer.

${ }^{27}$ We have published an ethnography describing the proceedings at an Udmurt ceremony in full (Toulouze, Niglas 2014).

${ }^{28}$ He worked with horses in the local agricultural cooperative, or kolkhoz, and never left his village, where he married and had five children (Sadikov, Danilko 2005: 229; Toulouze et al. 2015)

${ }^{29}$ Conversation with Nazip Sadriev: ET, LN, and RS.

${ }^{30}$ Actually, his assessment is based on what he considers to be the only right way to act. However, in parallel to his tradition there are other competing traditions: in the neighbouring area of Alga ceremonies vary in detail, Nazip agay considers them erroneous, while for the local priests they correspond to their local traditions. FWM 2013: ET, LN, and RS.

${ }^{31}$ Observations at the Alga mör vös', Tatyshly district, Bashkortostan, December 2013, by ET, LN.

${ }^{32}$ Observations at the Bagysh vös', Kyzyl Yar road, Tatyshly district, Bashkortostan, by ET, RS.

${ }^{33}$ Observations at the Nizhnee Baltachevo gurt vös', ET, NA, RS.

${ }^{34}$ Alga tol mör vös' December 2013: ET, LN.

${ }^{35}$ In the $1990^{\mathrm{s}}$ and $2000^{\mathrm{s}}$ prayers were published in the local press.

${ }^{36}$ Malaya Bal'zyuga gurt vös', by ET, LN, LV.

${ }^{37}$ Conversation with A. Galikhanov, Altayevo, Burayevo district, Bashkortostan, ET, NA, RS.

${ }^{38}$ Conversation at the Bagysh vös', Kyzyl Yar road, Tatyshly district, Bashkortostan, by ET, RS.

${ }^{39}$ Prayer recorded on June 251971 in Kalmiyar (Kueda district, Perm region) by Mikhail Atamanov from former priest Zidiyar Suyushev 
(b. 1916). NOA UdIIYaL UrO RAN. Manuscripts. Manuscripts. Inventory 2-N. Dossier 439. Sheet 33-34. Clearly, this text is from the informant's remembrances.

${ }^{40}$ Text collected in 1885 by Bernát Munkácsi, in Mozhga, from 'uncle' Apshivyr. Munkácsi 1887: 168; another prayer with the same request was collected by Munkácsi in 1916 in a prisoner's camp in Esztergom, from Muradshin Mardymsha and Dzhandusov Akmadysha from Urzagil'de. Munkácsi 1952: 111-114.

${ }^{41}$ Text collected in Asavka (Baltachevo district) by M. Garifullin in 1992, from Minnigali Ziyangarov (b. 1920) (Garifullin 1992: 456-459).

${ }^{42}$ Text collected in Bolshetuganeevo (Kaltasy district) in 2003 by Yantimir Minlyakhmetov (Sadikov 2011: 125-129).

${ }^{43}$ Text collected in 2006 by S. Baymetova, student of Bol'shekachakovo high school, from Sabyr Fayzrakhmanov (Sadikov 2011: 129-132).

${ }^{44}$ For example Prayer by Salim Shakirov 2009 (Shakirov 2009).

${ }^{45}$ The 2019 version of the Alga group prayers (Tatyshly district).

${ }^{46}$ Text collected in 1994 by journalist A. Grebina from priest Anatoliy Galikhanov (b. 1962), Altayevo (Burayevo district).

${ }^{47}$ Prayer by Anatoliy Galikhanov (b. 1962), Altayevo (Burayevo district), recorded during the el'en vös' in 2013 (see Niglas 2019a).

${ }^{48}$ We call them this for the purposes of this article, but these are not recognised names.

${ }^{49}$ The acknowledgement of these peculiarities has led us to a long-term project, which is to record all nineteen village ceremonies, so that we do not involuntarily become the means of standardising the ceremonies according to those we have already recorded and left as DVDs with the sacrificial priests.

${ }^{50} \mathrm{He}$ has already been presented in an article (Danilko, Sadikov 2005).

${ }^{51}$ Conversation with Nazip Sadriev, in Malaya Bal'zyuga by RS, ET, LV, NA.

${ }^{52}$ Nevertheless, this assertion is probably only partly justified. At least two of the priests we have interviewed did not mention Nazip agay as having played any part in their training: one learnt from his father, the other from his grandfather.

${ }^{53}$ Congress of the Bashkortostan Udmurt November 2015, by ET, LN, RS. 
${ }^{54} \mathrm{He}$ also built a mosque in the village, although there are only a few Muslims in the area, showing that he is quite able to exploit the political context.

${ }^{55}$ Meeting with Salim Shakirov, Novye Tatyshly, Tatyshly district, Bashkortostan, August 2011, ET, MM.

${ }^{56}$ We do not yet have enough insights into local society to appreciate the degree of tension that might be connected with being or not being virtuous.

${ }^{57}$ Conversation with Nasip Sadriev, Malaya Bal'zyga, Tatyshly district, Bashkortostan, ET, LN, RS.

${ }^{58}$ Conversation with Rais Rafikov, Novye Tatyshly, Tatyshly district, Bashkortostan, by ET, LN, RS.

${ }^{59}$ Conversation at the Bagysh vös', Kyzyl Yar road, Tatyshly district, Bashkortostan, by ET, RS.

${ }^{60}$ Observations at the Nizhnee Baltachevo gurt vös', ET, NA, RS.

${ }^{61}$ Meeting with Lilya Garaeva, Aribash, Tatyshly district, Bashkortostan, ET, LN, LV.

${ }^{62}$ Aribash gurt vös', Tatyshly district, Bashkortostan, ET, RS.

${ }^{63} \mathrm{Lud}$ is a sacred grove that is usually fenced. Lud or Keremet is an Udmurt deity, allegedly of Turkic origin. It was an all-male cult.

${ }^{64}$ Mör vös' in Novye Tatyshly. Conversation with Filarit, ET.

${ }^{65}$ We can also add that among his children, his daughter Viktoriya, after a period as a teenager when she was attracted by all that was Tatar or Russian, is now an inspired activist for Udmurt culture.

${ }^{66}$ We might here identify a Christian influence, which Vladimir is probably not fully aware of.

${ }^{67}$ Conversation with Vladimir Galiev, Asavka, Baltachevo district, by ET, NA, RS.

${ }^{68}$ Conversation with Anatoliy Nasipullin, Bol'shekachakovo, Kaltasy district, Bashkortostan, ET, RS. Later, the same year, several meetings at Bol'shekachakovo ceremonies and at el'en vös'with ET.

${ }^{69}$ Oral information by Ranus Sadikov.

${ }^{70}$ Conversation with Y. Yagupov, Izhevsk, Udmurtia, ET, NA, LV. 
${ }^{71}$ Meaning they would have performed a special ceremony to declare that the vös'would no longer be performed. FWM: Conversation in Altayevo, Burayevo district, Bashkortostan, ET, NA, RS.

72 Conversation with Nazip Sadriev, Malaya Bal'zyuga, Tatyshly district, Bashkortostan, ET, LN, RS.

${ }^{73}$ Officially, Mari Traditional Religion.

${ }^{74}$ Where the authors attended.

${ }^{75}$ Conversations with Salim Garifullin in Verkhniye Tatyshly, Tatyshly district, Bashkortostan with ET, LV, LN and NA.

${ }^{76}$ Novyye Tatyshly, Tatyshly district, Bashkortostan, ET.

\section{Sources}

Niglas, L. 2019a. Elen vös: Kaama-taguste udmurtide ühispalvus [Elen Vös: Joint Prayer Ceremony of the Eastern Udmurts] (46 min) (Ethnographic Film). Mp Doc.

Niglas, L. 2019b. Gurt vös: külapalvus [Gurt Vös: Village Prayer Ceremony]. (62 min) (Ethnographic Film). Mp Doc.

\section{References}

Alybina, T. 2014. Vernacular Beliefs and Official Traditional Religion: The position and meaning of the Mari worldview in the current context. Approaching religion 4 (1), pp. 99-100.

Asad, T. 1993. Genealogies of Religion: Discipline and Reasons of Power in Christianity and Islam. Baltimore: John Hopkins University Press.

Garifullin, M. 1992. Tanyp shur dure... Inmaren ken'esheny [On the Shores of the Tanyp... Consulting Inmar]. Ken'esh [Council]. No. 1, pp. 456-459.

Hann, C. 2007. The Anthropology of Christianity per se. Archives Européennes de sociologie, 48 (3), pp. 383-410.

Holmberg, U. 1914. Permalaisten uskonto [The Religion of the Permians]. Porvoo: Suomalaisen Kirjallisuuden seura. 
Ingold, T. 2000. The Perception of the Environment: Essays on Livelihood, Dwelling and Skill. Abingdon-on Thames: Routledge.

Khrushcheva, M. 1995. Folk beliefs in the Udmurt system of the calendar rituals. M. Kõiva, K. Vassiljeva (ed.) Folk Belief Today. Tartu: ETA, EKI, EKM, pp. 192-200.

Leete, A., Shabayev, Y. 2010. Notes about re-identification of ethnographic groups. Folklore: Electronic Journal of Folklore 46, pp. 169-176.

Lintrop, A. 1995. Pagan Sacrificing procedures of the Udmurts. M. Kõiva, K. Vassiljeva (ed.) Folk Belief Today. Tartu: ETA, EKI, EKM, pp. 270275 .

Lintrop, A. 2002. The Spring Prayer Feasts in the Udmurt Village of Varklet-Bodya in Tatarstan. Cosmos 18, pp. 43-55.

Lintrop, A. 2003. Udmurdi usund [The Udmurt Religion]. Tartu: ERM.

Luehrmann, S. 2011. Secularism Soviet Style: Teaching Atheism and Religion in a Volga Republic. Bloomington: Indiana University Press.

Mäkelä-Hafeez, K. 2015. Pyhien paikkojen merkitykset udmurtti kylässä Baškortostanin tasavallassa [The Meaning of the Sacred Places in an Udmurt Village in the Republic of Bashkortostan]. Pro gradututkielma. Helsingi yliopisto.

Minniyakhmetova, T. 1995. Eating of beestings as an original calendar rite of the Bashkirian Udmurts. M. Kõiva, K. Vassiljeva (ed.) Folk Belief Today. Tartu: ETA, EKI, EKM, pp. 331-334.

Munkácsi, B. 1887. Votják népköltészeti hagyományok [The Votyak Folklore Traditions]. Budapest: MTA.

Munkácsi, B. 1952. Volksbrauche und Volksdichtung der Wotjaken [The Votyak's Folk Customs and Folk Poetry]. Aus dem Nachlasse von Bernhard Munkácsi. Herausgegeben von D. R. Fuchs. Mémoires de la Société Finno-Ougrienne. Helsinki: SUS.

Nikitina, G. 1993. Sel'skaya obshchina-buskel'v poreformenniy period (1860-1900 gg.) [The Rural Community Buskel' in the Period of the Reforms]. Izhevsk. Izhevsk: UdIIYaL UrO RAN.

Nikitina, G. 1998. Udmurtskaya obshchina v sovetskiy period [The Udmurt Community in the Soviet Period]. Izhevsk. Izhevsk: UdIIYaL UrO RAN. 
Pervukhin, N. 1888. Eskizy predaniy i byta inorodtsev Glazovskogo uyezda [Essays about the Legends and the Everyday Life of Non-Russians of the Glazov District]. Eskiz 1: Drevnyaya religiya votyakov po ego sledam v sovremennykh predaniyakh [Essay 1: The Ancient Religion of the Votyak in Its Traces in Modern Traditions.]. Vyatka: Gubernskaya tipografiya.

Sadikov, R. 2008. Traditsionnye religioznye verovaniya $i$ obryadnost' zakamskikh udmurtov (istoriya i sovremenniye tendentsii razvitiya) [Traditional Religious Beliefs and Rituals of the Eastern Udmurt: History and Contemporary Development Trends]. Ufa: TsEI.

Sadikov, R. 2010. Elen vös' - "molenie stranoy". Zhivaya drevnost' na prostorakh Bashkirii [The Elen Vös', the 'Ceremony for the Country'. Living Antiquity on the Horizons of Bashkiria]. Vordskem kyl [Mother Tongue] 7, pp. 34-35.

Sadikov, R. 2011. Molitvy-kuris'kon zakamskikh udmurtov (modernizatsiya kul'tury - transformatsiya teksta) [The Kuris'kon, the Prayers of the Eastern Udmurt. The Culture's Modernisation, the Text's Transformation]. Traditsionnaya kul'tura narodov Uralo-Povolzh'ya $v$ uslovakh modernizatsii obshchestva. Ufa: Institut etnograficheskikh issledovaniy im. R. G. Kuzeeva UNC RAN, pp. 125-129.

Sadikov, R. 2012. Religioznye verovaniya i obryadnost' zakamskikh udmurtov (sokhranienie i preemstvennost' traditsii) [Religious Beliefs and Rituals of the Eastern Udmurt - Preservation and Continuity of Tradition]. Ufa: Nauchnyy centr RAN.

Sadikov, R., Danilko, E. 2005. Udmurtskiy zhrec - khranitel' traditsii (vzglyad vizual'nogo antropologa) [The Udmurt Sacrificial Priest, a Keeper of Tradition, Seen by a Visual anthropologist]. G. Nikitina (ed.) Diaspory Uralo-Povolzh'ya [The Diasporas of the Volga and Urals Region]. Izhevsk: UdIIYaL UrO RAN, pp. 230-233.

Sadikov, R., Mäkelä, K. 2008. Yrjö Wichmannin muistiinpanot Kamantakaisten udmurttien uskonnollisista käsityksistä ja tavoista [Yrjö Wichmann's Notes about the Religious Undestandings and Customs of the Eastern Udmurt]. Suomalais-Ugrilaisen Seuran Aikakauskirja. No. 92, pp. 241-263.

Shakirov, S. 2009. Vös'len radlykez no Mör vös' [The Organisation of a Ceremony and the Mör vös'. In: Oshmes [Source], 16 April. No. 15. 
Sharov, V. 2007. Mariytsy v Respublike Marii El. Depopulizatsiya ili nesovershenstvo perepisi? [The Mari in the Republic of Mari El. Depopulation or Imperfection of the Census?]. V. Stepanov, V. Tishkov (eds.) Etnokul'turnyy oblik Rossii. Perepis 2002 g. [Russia's Ethnocultural Profile. The 2002 Census]. Moscow: Nauka, pp. 163-176.

Toulouze, E., Niglas, L. 2014. Udmurt animistic ceremonies in Bashkortostan: fieldwork ethnography, Journal of Ethnology and Folkloristics 8 (1), pp. 111-120. http://www.jef.ee/index.php/journal/article/ view/176/_1.

Toulouze, E. et al. 2015 = Toulouze, E., Vallikivi, L., Niglas, L., Anisimov, N. 2017. Udmurdi ohvripapp Nazip Sadrijev [The Udmurt Sacrificial Priest Nazip Sadriev]. T.-K. Raudalainen (ed.) Soome-ugri sõlmed 2016 [Finno-Ugric Knots]. Tallinn: Fenno-Ugria, pp. 119-125.

Toulouze, E. 2020. The Power of Porridge: Udmurt Ritual Food. Traditsionnaya kul'tura [Traditional Culture]. Vol. 21, No. 3, pp. 157-170.

Toulouze, E. 2020a. Bol'shekachakovo: ritual'naya zhizn' vchera i segodnya, i chto my znaem o ney [Bol'shekachakovo: Ritual Life Yesterday and Now, and What We Know about It]. L. Bekhterova, I. Pozdeev, T. Stepanova (eds.) Gosudarstvennost' Udmurtiy: istoriko-kul'turnye praktiki i strategii sovremennogo razvitiya [Udmurtia's Statehood: Historical and Cultural Practice and Strategies of Contemporary Development]. Izhevsk: UIIYaL FITs UrO RAN, pp. 37-59.

Toulouze, E., Anisimov, N. 2020. An Ethno-Cultural Portrait of a Diaspora in Central Russia: the Formation and Culture of the Eastern Udmurt. Folklore: Electronic Journal of Folklore, 79, pp. 31-58. DOI: 10.7592/ FEJF2020.79.toulouze_anisimov.

Vallikivi, L. 2009. Christianisation of words and selves: Nenets reindeer herders joining the state through conversion. In: M. Pelkmans (ed.) Conversion After Socialism: Disruptions, Modernities and the Technologies of Faith. Oxford, New York: Berghahn, pp. 59-83.

Vikár, L., Bereczki, G. 1989. Votyak folksongs. Budapest: Akadémiai kiadó.

Vladykin, V., Vinogradov, S. 2010. Udmurt oskon [The Udmurt Religion]. Izhevsk: Udmurtia. 


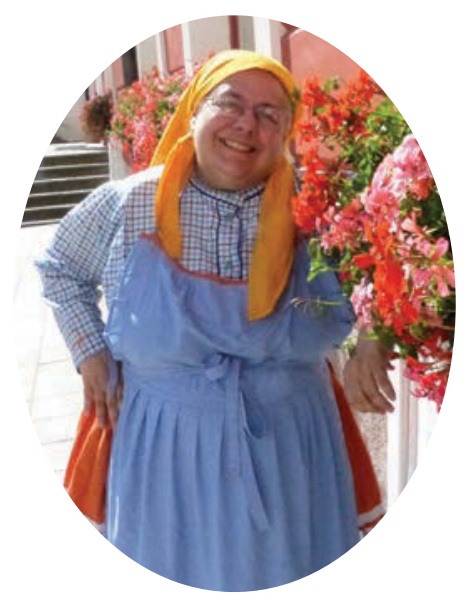

Eva Toulouze ( $\mathrm{PhD}$ hab) is a professor of Finno-Ugric languages at the Institute of Eastern Languages and Cultures (INALCO, Paris), and a researcher at the Department of Ethnology, University of Tartu, Estonia. Her main fields of interest are the cultures of Russia's FinnoUgric peoples, the emergence of a written culture in Finno-Ugric areas, Forest Nenets culture and Udmurt religious practice.

e-mail: evatoulouze@gmail.com

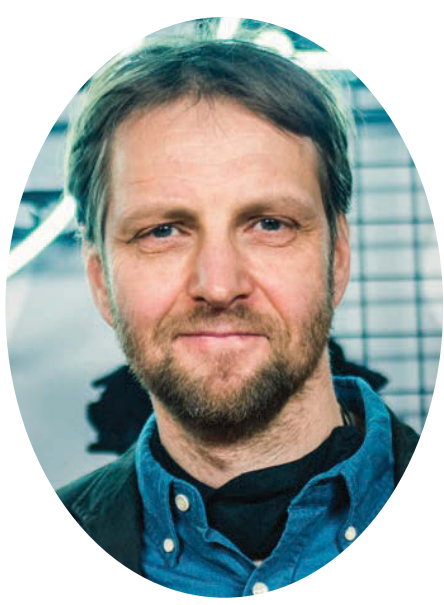

Liivo Niglas $(\mathrm{PhD})$ is a researcher in the Ethnology department at University of Tartu, and as a visual anthropologist author of many anthropological films. He has worked in several regions of the world (France, Estonia, the USA, Mozambique), but mainly in Russia, both in Siberia and in Bashkortostan.

e-mail: liivo.niglas@ut.ee 


\title{
"Seeing off a Recruit": The Ritual and Its Songs in the Udmurt Traditional Culture
}

\section{Valeriia Fedorova}

e-mail: loptem.gon@ya.ru

\begin{abstract}
The rite of Seeing Off a Recruit is one of the most relevant Udmurt family rite traditions that is still performed. Conscription is of particular importance in the life of the Udmurt family and recruit. This article aims to study the songs performed in the rite, and more precisely, their functions of performance at different stages such as the symbolic patterns and items that build a connection between the rite songs and the rite itself. The ethnographic data collected is based on the tradition of the village of Chutozhmon, Malaya Purga District in the Udmurt Republic of the Russian Federation.

Through analysis of the data, I construct a detailed description and scenario for the rite of Seeing Off a Recruit. The model for the rite is similar in all Udmurt traditions, although the song component is rather different depending on the village. The original songs and tunes used in the village of Chutozhmon are well preserved and create a complete picture of the rite, thus it has been possible to thoroughly research it.
\end{abstract}

Keywords: folk song, rite, ritual, Russia, seeing off, symbols, Udmurt tradition 


\section{Introduction}

The rite of Seeing off a Recruit is one of the most relevant functioning family rites in the Udmurt tradition to this day and retains local differences even in this age of globalisation. It preserves its ritual features, follows its original scenario and has no analogue; in many local traditions, the ritual tunes and songs that accompany the significant actions of the ritual are still known.

This tradition is an extensive topic for research as the rite can be studied from ethnographic, religious, historical, linguistic, anthropological, poetic, ethnomusicological, and other perspectives, although there has not been much research yet.

Seeing off a Recruit as a rite began only in the $18^{\text {th }}$ century, after Peter the Great issued a decree introducing compulsory military service on February $20^{\text {th }} 1705$. Thus, it is a relatively 'young' rite in comparison with others. The need for the rite was natural: initially recruits were conscripted into the tsarist army for life, later reduced to 25 years, although in both cases they might never return home. Today, the duration of service is shorter at five years during the Soviet, then afterwards three years, and now only one or two years for every young man. However, it is still necessary to conduct the rite because the Udmurt believe that the young men are going to an unknown, alien world, and the ritual will help them serve well and return home healthy. This is also a kind of initiation rite for the young men with becoming a soldier treated as a step towards adulthood. Once the rite is completed the recruit is no longer seen as a boy - serving in the army is serious and hard work, and after returning home the soldier becomes a respected adult.

The rite of Seeing off a Recruit in the Udmurt language varies from district to district, from village to village. It is called saldate kel'an 'seeing off to soldiery', saldatpi kel'an 'seeing off of a soldier', 
armiye kel'an 'seeing off to the army'. The ritual songs also have different names, in parallel: saldat kel'an gur 'the tune of seeing off the soldier', saldate kel'an gur 'the tune of seeing off to the soldiery', saldatpi kel'an gur 'the tune of seeing off the soldier boy', armiye kel'an gur 'the tune of seeing off to the army', saldat gur 'the tune of the soldier', saldatpi gur 'the tune of the soldier boy', l'ekrut gur or l'ekurt gur 'the tune of the recruit'. The word gur means 'tune', but here it can also be translated as 'song' because, for example, the 'archaic' songs are sung to the same tune but can have different names relating to the situations they are for. Only a certain song can be used at a certain stage of the rite. The informants (tradition-bearers) distinguish the purpose of the songs by their tunes because some lyrics can be universal for all rites.

This article is based on data collected in the Udmurt village of Chutozhmon in Malaya Purga District on expeditions to that village and the village of Baykuzino in the same district between 2015 and 2018. Chutozhmon is a small village the population of which was never more than 300 people. It was founded in the second half of the $18^{\text {th }}$ century, approximately in 1750-1780. The first settlers were from Malaya Purga, which is now the district centre (Atamanov 2005: 169-170). Today, fewer than 50 people live in Chutozhmon and it is possible to say that the folk tradition of the village has already disappeared because the inhabitants are all elderly. They have no opportunity to perform the rite, but they can talk about the past and sing the traditional songs. Fourteen different songs were recorded in the village (not counting duplicate recordings).

Every Udmurt rite has a special tune and set of songs, although some songs are common to all rites. Moreover, tunes for the same rite are different in almost every village, while the lyrics can coincide. So, in one village, people have different kinds of tune wedding tunes (always two in the Udmurt tradition), tunes for 
meeting guests, tunes for particular calendar holidays, or tunes for seeing off a recruit - even though the lyrics can be the same. Despite the differences in the rite of Seeing off a Recruit in different Udmurt traditions, the main content remains the same: the recruit bids farewell to family, friends, beloved, fellow villagers, house, and the village itself. Elena Boykova and Tatiana Vladykina (1992: 15) concludmutied that according to ethnographic data, the earliest form of the rite consisted of two main stages: moving "from house to house" and departure.

Since soldiers might not return home, some rituals are supposed to help them return safely as well as to influence positively their future. Pinning a red ribbon to a ceiling beam or to the gate was a special way of leaving the house, a ritual farewell to everything that surrounded the recruit (including inanimate objects like the house, other buildings, natural objects, etc.). The recruit must leave something as a reminder of himself as a substitute during his period of absence. Usually this is the red ribbon, or it could be a piece of red fabric, that thus becomes an icon. The beam is believed to possess magical properties, and to protect the soldier from trouble because of the connection through the red ribbon. His family and girls from the village also make symbolic gifts of towels and handkerchiefs. There are also different symbolic items in the rite, for example ribbons (especially red), coins, a knife, and white towels.

The rituals in the rite were always aimed at the recruit's safe return. The Udmurt attempted to follow his fate with some omens. For example, Tatiana Vladykina writes that, in some Udmurt traditions, the recruit was associated with a young spruce. To know whether he was to return home or not, the young boy chopped off a shoot at the top of a tree, or skinned part of the trunk at the top so that the tree would have the appearance or silhouette of a person. If the tree did not dry out, he would return (2004: 56-57). 


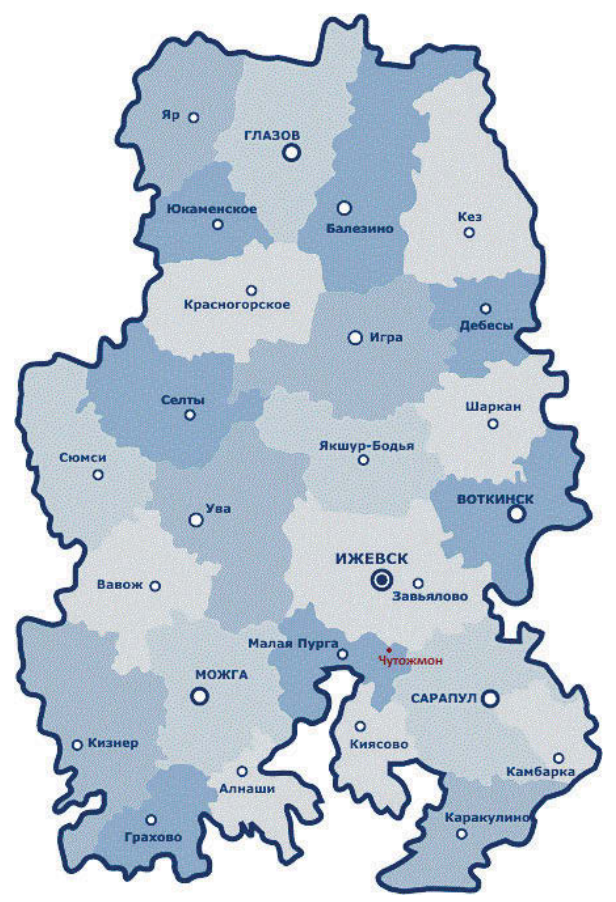

Map 1. Map of The Udmurt Republic with the village of Chutozhmon marked in red. Source: http://www.udmgossovet.ru/interaction/local/regions/.

\section{Previous research}

Researchers' interest in ritual songs appeared at the end of the $19^{\text {th }}$ century. They used the philological approach in the systematisation of songs until the 1990s and turned to musicology 
only at the end of the $20^{\text {th }}$ century. Modern ethnomusicologists classify Udmurt folk songs according to their functional confinement and distinguish ritual songs (timed to the folk calendar and family or tribal holidays) and non-ritual songs (ditties, lyric songs, etc.).

Udmurt rite songs are extensively represented by now, and thus there is a good basis for research. The Udmurt Research Institute ${ }^{1}$ published a series of ritual songs called Udmurt Folklore. Each book in the series is dedicated to specific local traditions, for instance, southern or northern Udmurtia, as well as regions outside the Republic, where Udmurts live and preserve Udmurt traditions (for example Bashkortostan, Tatarstan, Perm Krai, Kirov Oblast, etc.). In these series, the researchers present accurate musical decoding, detailed information about informants, descriptions of the region or locality, and the specifics of the local traditions.

The first mentions of Seeing off a Recruit can be found in books of older ethnographers and writers such as Nikolai Pervukhin (1888), Petr Bogaevskiy (1888), and Grigoriy Vereshchagin (1889), where they describe the rite held in Sarapul and Glazov counties (uezd) in Vyatka Governorate.

Active study of the rite of Seeing off a Recruit began at the end of the $20^{\text {th }}$ century, with research by Russian and Udmurt scholars such as Elena Boykova, Elena Vershinina, Tatiana Vladykina (Perevozchikova), Petr Pozdeev, Irina Pchelovodova, Lyudmila Khristolyubova, Al'bert Shakhovskoy, who produced mainly descriptive work that acts as a good database of information about the rite.

Petr Pozdeev (1967: 32-33) concluded that related songs are similar to those that were sung when seeing off a bride during the wedding. These songs were seen as appropriate for this rite too because the roles of both recruit and bride are similar in that way that they are going to an 'alien world' and are not expected back in their home or land. Vershinina and Vladykina (2014) agree with this but more research on this topic is needed. 
The structure of the texts of the songs is composed of stable motifs: receiving the call-up, certifying fitness for service, parting with relatives and the native home, opposition between peaceful everyday lives and the soldiers' lot. In content, all the songs are commentaries on ritual acts (Vladykina et al. 2018: 144). In 1888, Bogaevskiy emphasised in his essay that all songs are functionally important in the rite structure because continuity means that a particular song is performed at a certain time and place.

\section{Methods}

This research intended to reconstruct, on the basis of the collected information, the scenario of the rite. The songs were collected in the villages of Chutozhmon and Baykuzino, and in the capital of Udmurtia, Izhevsk, where tradition-bearers (so-called informants) from Chutozhmon lived. I relied on data from the Internet as well as lyrics in songbooks and available musical decodings of the rite songs from across the spectrum of Udmurt culture. The data (the songs and narration of the informants) regarding the rite were recorded between 2014 and 2018. The scenario of the rite was reconstructed relying mostly on materials from the village of Chutozhmon.

\section{Detailed Description of the Rite of Seeing off a Recruit}

By using rare sources from the $19^{\text {th }}$ century, it is possible to give a full description of the Udmurt rite of Seeing off a Recruit, and from this to conclude that it coincides with the same rite held in the recent past in the village of Chutozhmon, Malaya Purga district of the Udmurt Republic. 
The rite began on the day the recruit received his call-up papers and became aware of the date of his admission into the army. On the same day, the whole village received the news. The closest relatives of the recruit and the families of his friends were honour-bound to invite him to their house and agreed among themselves on the order of invitation. Because there might also be other recruits in the village, all of them were supposed to move together from house to house for refreshments and to perform certain rituals in every house. These visits took place before the recruits' departure, usually on a single day. Each recruit was dressed in casual clothes, with a jacket that was part of the holiday outfit, and a hat. On the right side of the jacket, on the chest there was a big pin onto which girls tied long colored ribbons while the recruit went around the village (if there was not enough space, they hooked on another pin). A pin was also attached to the cap at the back, to which girls tied more long colored ribbons. The recruit and the company of his friends rode through the village streets on the best cart with horse(s). The arch of the cart was decorated with bells, ribbons, and towels. Later, when there were no longer horses in the village, the recruit and his friends went from house to house on foot singing songs in all the houses. There was usually a single tune that was sung with different lyrics starting first at the gates of the houses. Knocking on the gate or without knocking (if they were invited by the hosts), the recruit and his company sang soldate kel'an gur, 'seeing off to soldiery'. 


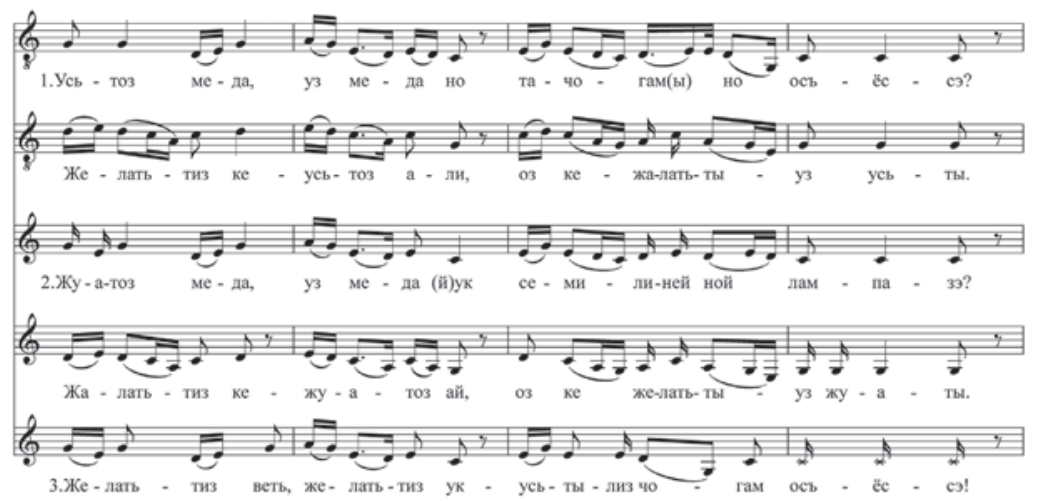

Figure 1. The text of Seeing off a Recruit. Saldatez yumshaton ('The Soldier Festivities') 2 .

Saldatez yumshaton

Us'toz(y) meda, $u z(y)$ meda (y) Will they open their locked uk ta tshogam(y) no ös"yosse? doors or not?

Zhelat'tiz ke - us'toz al'i, öz ke If they wish - they will open, zhelat'ty - uz us'ty.

Dzhuatoz(y) meda, uz(y) meda

(y)uk s'emil'in'eynoy lampaze?

Zhelat'tiz ke - dzhuatoz ay, öz ke zhelat'ty - uz dzhuaty.

Dzhuatiz al'i, dzhuatiz al'i s'emil'en'eynoy lampaze.

Zhelat'tiz vet', zhelat'tiz ukus'tyliz tshogam ös"yosse.
The Soldier Festivities if not - they will not open.

Will they light the seven-line (kerosene) lamp or not?

If they wish - they will light, if not - they will not light. They lit, they lit the seven-line (kerosene) lamp.

They wished, they wished they opened the locked doors.

When the doors were open, guests came in and sang the same tune but with other lyrics explaining the purpose of their visit: 


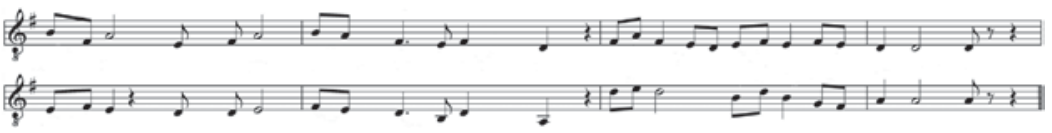

Figure 2. The tune of Seeing off a Recruit. Saldatez yumshaton ('The Soldier Festivities'). ${ }^{3}$

Saldatez yumshaton

Dzh'ech ivor no kylis'kiz no, mi The good news was heard, and pyrono karis'kim.

Dzh'ech ivor no kylis'kiz no, mi pyrono karis'kim.

Mi pyrem no, oy, pönna (y)uk vozh"yostes no en vaye.

Mi pyrem no, oy, pönna (y)uk vozh"yostes no en vaye.
The Soldier Festivities we decided to visit you.

The good news was heard, and we decided to visit you.

Do not become angry that we came in.

Do not become angry that we came in.

Guests were invited to sit at the table, eat and drink some wine. For the ritual of hammering a ribbon, the hosts gave the recruit a red ribbon, a coin, a knife, and put forth a chair. The recruit got up on the chair to hammer the ribbon onto the beam.

The beam is an important part of the house not only because it supports the ceiling of a wooden house in the middle, but also because it has semantic meaning as the division of the house into two parts, private and external. People could go to the private zone only with the permission of the hosts. The recruit and everybody else stood against the front door in the private zone of the house.

The leader singer started to sing a recruit tune with other lyrics for the ritual of hammering a ribbon (for more details, see below):

Gord armiye bas'tizy no gord chuk shukkyny kosizy.
I was taken to the Red Army and they forced me to hammer a red ribbon. 
Ta shukkem no, oy, chuk"yosme Keep these hammered ribbons achim bertoz' voz'ele. until my return.

Mone addzh'emdy potyliz ke, If you want to see me, look at ta chuk shoram uchkele. my ribbon.

Mone addzh'emdy öz ke poty, If you do not want to see me, yshkaltysa kushtele. pull it off and throw it away.

Tapala ke berytskono, ta purt If I am to come back here, let metshak med merchchoz. this knife stick into the floor. Sopala ke, oy, byrono, ta purt If I am to die there, let this urdesly n'i met us'oz. knife just fall sideways. Bertoz al'i, ta purt metshak merchchas'kiz. He will come back, he will come back, this knife has stuck into the floor.

Tapala bertemen ivor kylis'kiz If you want to hear news ke, mul'y bas'tysa das'ale. about my return, buy sunflower seeds.

Sopala byremen ivor kylis'kiz If you want to hear the about my ke, s'us'tyl dzhuatsa vös'as'ke. death, light a candle and pray.

\section{Text of Seeing off a Recruit. Chuk shukkon gur (Song for Hammering a Ribbon) ${ }^{4}$}

During the song, the recruit stuck the red ribbon into the beam with the edge of a knife, then hammered a coin onto the red ribbon with the handle of a knife (in other Udmurt traditions a hammer or axe was used instead of a knife). After that, guessing his future, the recruit threw the knife onto the floor while singing: "Tapala ke berytskono, ta purt metshak med merchchoz..." ('If I am to come here back, let this knife stick into the floor...'). Everyone looked at how the knife fell. If it stood upright, it meant that the young man 
would return home safely after service, if the knife fell sideways, it was considered a bad omen, according to the lyrics.

After this ritual of hammering a ribbon, the recruit descended from the chair and thanked the hosts. Girls in every house gave him different gifts, such as embroidered handkerchiefs, here they tied colored ribbons to the pins on his jacket and hat, and the hosts gave him white towels (previously, only the godmother gave a towel, while the parents gave neither scarves nor towels).

Moving to the next house, the young people thanked the hosts with the same tune as Seeing Off a Recruit set to other lyrics ${ }^{5}$ :

Saldatez yumshaton

Taule no, taule no, s'udem(y)ly no s'ektam $(y) l y$.

Taule no, taule no, s'udem(y)ly no s'ektam $(y) l y$.

Mil'am(y) s'iyem-yuem intyyamy

Inmar kuin'men med s'otoz.

Mil'am(y) s'iyem-yuem intyyamy

Inmar kuin'men med s'otoz.
The Soldier Festivities

Thank you, thank you for food and drink.

Thank you, thank you for food and drink.

God must give you three times more for your hospitality.

God must give you three times more for your hospitality.

Everything was repeated in the next houses. In the meantime, in the streets or sitting on the bench in front of houses, they also sang. They could sing Russian Soviet songs, army songs or songs about parting. In Chitozhmon, the informants remember that they were singing songs like "Kak rodnaya men'a mat'provozhala”, "Oy, krasivy nad Volgoy zakaty", and "Dobryy vecher, devushki”. These songs have an author and composer, so people probably heard them on the radio.

Here some examples of these Russian songs ${ }^{6}$ : 


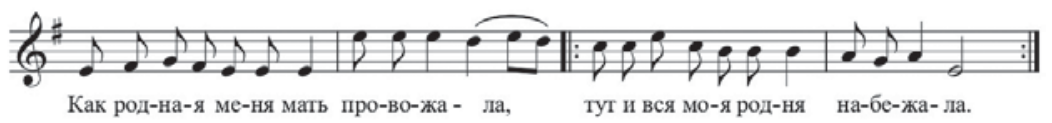

Figure 3. Provody ('Seeing off'). Original lyrics by Dem'yan Bednyy.

Full text from: http://a-pesni.org/grvojna/kr/provody.php.

Provody $^{7}$

Kak rodnaya men'a mat'

provozhala,

Tut i vs'a moya rodn'a nabezhala.

Tut i vs'a moya rodn'a nabezhala.

Oy, kuda zh ty, paren'ok, oy, kuda ty?

Ne khodil by ty Van'ok vo soldaty,

Ne khodil by ty Van'ok vo soldaty.

V Krasnoy Armii shtyki, chay, nayduts'a,

Bez men'a bol'sheviki

oboyduts'a.

Bez men'a bol'sheviki

oboyduts'a.
Seeing off

As my mother was seeing me off,

And all my relatives came running.

And all my relatives came running.

Oh, where are you going, boy, oh, where are you going?

You wouldn't go to soldiery, Vanyok.

You wouldn't go to soldiery, Vanyok.

There are enough bayonets in the Red Army, The Bolsheviks will manage without me.

The Bolsheviks will manage without me. 
Ponevole ty id'osh al's okhotoy, Van'a, Van'a, propad'osh n’iza chto ty.

Van'a, Van'a, propadyosh n’i za chto ty.

Mat'stradaya po tebe

posedela,

Evon v pol'e i v izbe skol'ko d'ela.

Evon v pol'e i v izbe skol'ko d'ela.

A d'ela t'eper'poshl'i l'ubomilo,

Skol'ko srazu k nam z'eml'i prival'ilo.

Skol'ko srazu k nam z'eml'i prival'ilo.

Ut'esn'en'iy prezhn'ikh n'et iv pomin'e.

Luchshe b ty zhen'ils'a, svet, na Arin'e.

Luchshe b ty zhen'ils'a, svet, na Arin'e.

$S$ molodoy by zhil zhenoy, n'e l'en'ils'a.

Tut ya mat'eri rodnoy poklon'ils'a,
You go involuntarily or with pleasure,

Vanya, Vanya, you'll die for nothing.

Vanya, Vanya, you'll die for nothing.

Mother turned gray suffering for you,

Look how much work in the field and the hut.

Look how much work in the field and the hut.

And now the things went nicely,

How much land immediately fell upon us.

How much land immediately fell upon us.

There is no trace of former oppression,

It would be better if you married Anna, dear.

It would be better if you married Anna, dear.

You would live with a young wife, you would not be lazy, Then I bowed to my mother. 
Tut ya mat'eri rodnoy

Then I bowed to my mother poklon'ils'a,

Poklon'ils'a vsey rodn'e u poroga, N'e skul'it'e vy po mn'e, rad'i Boga.

N'e skul'it'e vy po mn'e, rad'i

Boga.

Bud' takiye vs'e kak vy, rotoz'ei,

Chto b ostalos' ot Moskvy, ot Rassei?

Chto b ostalos' ot Moskvy, ot Rassei?

Vs'o poshlo b na staryy lad, na n'edolgo,

Vz'al'i b vs'o u nas nazad, z'eml'u, vol'u.

Vz'al'i b vs'o u nas nazad, z'eml'u, vol'u.

S'el by barin na z'eml'e zlym Mal'utoy, My b zavyl'i v kabal'e samoy l'utoy.
I bowed to all relatives at the doorstep,

Don't whine at me, for God's sake.

Don't whine at me, for God's sake.

If all were like you loafers,

What would be left of Moscow, of Russia?

What would be left of Moscow, of Russia?

Everything would go in the old way, in shortage, They would take everything back from us - the field, the will.

They would take everything back from us - the field, the will

A gentleman would sit on land as evil Malyuta, We would howl in the fiercest bondage. 
My b zavyl'i v kabal'e samoy l'utoy.

A idu ya n'e na pl'as, na pirushku,

Pokidayuchi na vas mat' starushku.

Pokidayuchi na vas mat' starushku.

S Krasnoy Armiyey poydu ya pokhodom,

Smertnyy boy ya povedu $s$ barskim sbrodom.

Smertnyy boy ya povedu $s$ barskim sbrodom.

Chto s popom, chto $s$ kulakom - vs'a bes'eda:

V br'ukho tolstoye shtykom miroyeda!

$V$ br'ukho tolstoye shtykom miroyeda!

N'e sdayoshs'a! Pomiray, shut s toboyu!

Bud'et nam mil'eye ray, vz'atyy s boyu.

Bud'et nam mil'eye ray, vz'atyy s boyu.
We would howl in the fiercest bondage.

And I'm not going to a dance, to a feast, Leaving you my old mother.

Leaving you my old mother.

I'll go on a campaign with the Red Army, I will lead a mortal battle with a lordly rabble. I will lead a mortal battle with a lordly rabble.

What's with the priest, what's with the kulak - the whole conversation:

A bayonet to the fat belly of the world-eater!

A bayonet to the fat belly of the world-eater!

Don't give up! Die, the jester with you!

Paradise taken from battle will be sweeter to us. Paradise taken from battle will be sweeter to us. 
N'e krovavyy, p'yanyy ray miroyedskiy

Rus' rodnaya, vol'nyy kray, kray Sovetskiy!

Rus' rodnaya, vol'nyy kray, kray Sovetskiy!
Not a bloody, drunken paradise of the world-eaters, But Russia native, free land, Soviet land!

But Russia native, free land, Soviet land!

Another example:

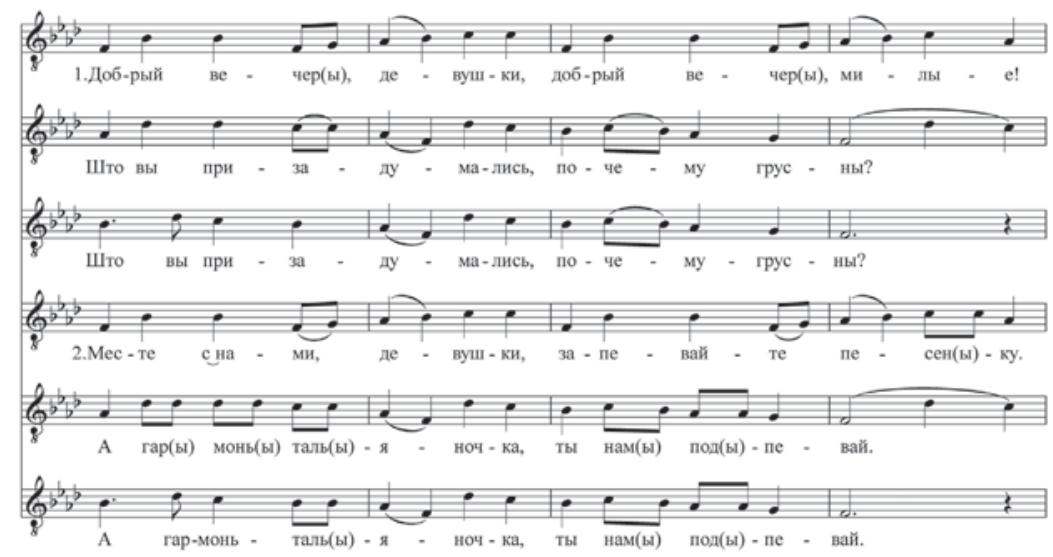

Figure 4. Dobryy vecher, devushki ('Good evening, girls'). Original lyrics and music by Pavel Dmitriev-Kabanov. ${ }^{8}$

Dobryy vecher, devushki

Dobryy vecher(y), devushki, dobryy vecher(y), milye. Shto vy prizadumal'is', pochemu grusny?

Shto vy prizadumal'is', pochemu grusny?
Good evening, girls

Good evening, girls, good evening, dears.

What are you thinking about, why are you sad?

What are you thinking about, why are you sad? 
[V]m'est'e s nami, devushki, Girls, sing a song together zapevayt'e pes'en $(y) k u$. with us, A, gar(y)mon'(y)-tal'(y)yanochka, ty $\operatorname{nam}(y) \operatorname{pod}(y)$ pevay.

And Talianka accordion, you A, gar $(y) \operatorname{mon}^{\prime}(y)-\operatorname{tal}^{\prime}(y) y a n o c h k a$, ty $\operatorname{nam}(y) \operatorname{pod}(y)$ pevay. sing along to us.

And Talianka accordion, you sing along to us.

Yed'em(y) s nami, devushki [v] Girls, come with us to the armiyu sovetskuyu, Soviet army

Nashey slav(y)noy Rod'in'eTo serve our glorious mat'eri sluzhit'. Motherland.

Nashey slav(y)noy Rod'in'emat'eri sluzhit'.

To serve our glorious Motherland.

Ne grust'it'e, devushki, n'e grust'it'e, milyye.

Do not be sad, girls, do not be sad, dears.

My op'at' ver(y)n'oms'a $k$ vam, bud'em(y) pomn'it'vas.

We will return to you again,

My op'at' ver(y)n'oms'a $k$ vam, bud'em(y) pomn'it'vas. we will remember you. We will return to you again, we will remember you.

In addition to this there was also some kind of entertainment. People danced, singing ditties to different dance tunes playing on harmony. In the village of Chutozhmon, people danced the quadrille for four people or improvisations in a circle one by one. On this day, the recruit was asked to dance despite his skills. If the recruit was a harmonist or a singer, on this day he will not be left without attention to his talents.

On the evening before departure, the recruit hammered a ribbon into the beam of his family house and all the songs that people had sung in other houses, they sang here again. The house of the recruit was attended by relatives and his friends. Villagers could also come to his house to see him off. Nobody came empty-handed: 
women brought some food, girls gave him embroidered handkerchiefs or pouches, boys could give him paper, pencils for writing letters, tobacco, and sometimes gave money (giving money is a later tradition). Everyone gave something to the recruit with an expression of various good wishes and a request not to forget them. $\mathrm{He}$ thanked everyone and asked them to forgive him if he had said or done anything wrong, and not to remember him badly as they were parting forever (Khristolyubova 1984: 90-111).

Here are some wishes expressed to recruits:

- Inmar dzh'ech s'ures met s'otoz! - God bless your way!

- Kydzh'y ke tatche shuldyr kel'as'kom, odzh'y ik pumitany med kyldoz! - As joyfully we saw you off, so joyfully let us meet you! - Dzh'ech ke vetlid, dzh'ech med bertod! - Safe service and safe return home!

In the house of the recruit, people sang other rite songs to different melodies, which seem to be more modern compared to the recruit tune:

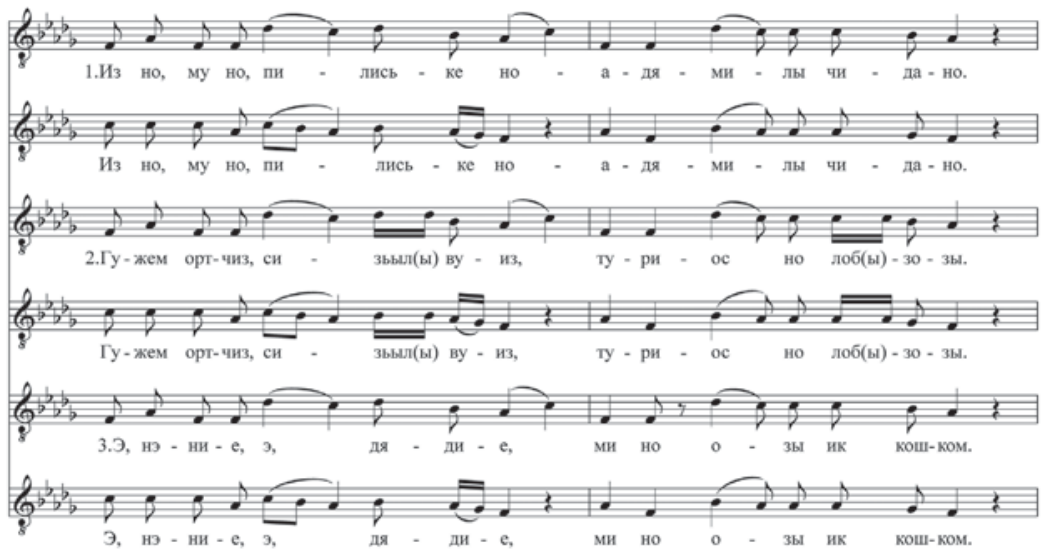

Figure 5. Soldate kel'an gur ('The Song of Seeing off a Recruit'). ${ }^{9}$ 
Soldate kel'an gur

Iz no, mu no pil'is'ke noad'amily chidano.

Iz no, mu no pil'is'ke noad'amily chidano.

S’ödo-s'ödo, oy, pil'em"yos vas'ko, vas'ko Kam kuz'a. S’ödo-s'ödo, oy, pil'em”yos vas'ko, vas'ko Kam kuz'a.

Guzhem ortchiz, siz'yl vuiz, turios no lobdzh'ozy.

Guzhem ortchiz, siz'yl vuiz, turios no lobdzh'ozy.

$E$, nenie, e, d'adiye, mi no oz'y ik koshkom.

$E$, nenie, e, d'adiye, mi no oz'y ik koshkom.

Asme addzh'yton, oy, ponna, fotoosme mon(y) ledzh'o.

Asme addh'zyton, oy, ponna, fotoosme mon(y) ledzh'o.

As'me todyton(y), oy, ponna, I will send you my letters to gozhtet"yosme mon(y) ledzh'o. let you know about me. As'me todyton(y), oy, ponna, I will send you my letters to gozhtet"yosme mon(y) ledzh'o. let you know about me.
The Song of Seeing off

Stone and ground break up the human must endure.

Stone and ground break up the human must endure.

Black black clouds go down above the Kama river. Black black clouds go down above the Kama river.

Summer is over, autumn came, and cranes flew away. Summer is over, autumn came, and cranes flew away.

Oh, my mom, oh, my dad, we will leave in the same way. Oh, my mom, oh, my dad, we will leave in the same way.

I will send my picture to let you see me.

I will send my picture to let you see me. a Recruit 
On the morning of his departure, the recruit got up early, his father harnessed the horses, and his mother prepared his things. Before leaving the house, the recruit visited every building in the family yard. After going around, he took a piece of wood from the beam and took it to the army, so that he always had a piece of his house with him. "In some villages, he drove his ring with a ribbon into the beam as a keepsake. He came out of the house backing away, and his mother threw some fabric under his feet" (Bogaevskiy 1888: 49). According to belief, leaving the house in this way contributed to his speedy and safe return.

"Before leaving the house, he walked around the stove three times and touched the beam, with the words "Atay korka, vuzh korka, med voz'maloz mone" (Father's house, let this old house wait for me). The recruit's mother took his hat and touched the stove with the hat and tossed it over the stove several times to the elder son or someone else. This and the previous actions reveal faith in the protective magic of beam and stove" (Gazieva 2014: 11).

One of the most common traditions of leaving home is when two guys took the recruit in their arms as if "on a chair" (the recruit grabbed friends by their necks). But the recruit could leave the house by himself as in the example of Bogaevskiy (1888). Necessarily he touched the stove and the beam to get some strength and protection from them.

While everybody was going out of the house, they sang: 
Valeriia Fedorova

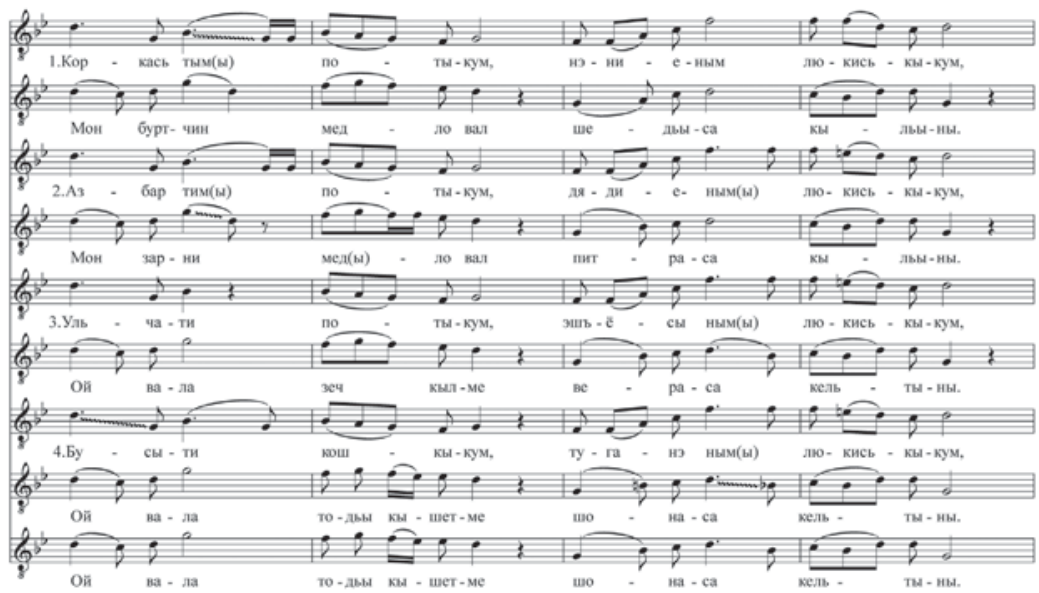

Figure 6. Soldate kel'an gur ('The Song of Seeing off to the Soldiery'). ${ }^{10}$

Soldate kel'an gur

Korkas'tym(y) potykum, neniyenym l'ukis'kykum, Mon burtchin medlo val shegysa kyl'yny.

$\operatorname{Azbartim}(y)$ potykum, d'ad'iyenym(y) l'ukis'kykum, Mon zarn’i med(y)lo val pitrasa kyl'yny.

Ul'chati potykum, esh"yosymy(y) l'ukis'kykum, Öy vala dzh'ech kylme verasa kel'tyny.
The Song of Seeing off to Soldiery

Going out of my house, parting with my mother, I would like to be a silk thread to catch and stay.

Passing through my yard, parting with my father, I would like to be a gold coin to roll off and stay.

Passing along the street, parting with my friends, I did not understand how to say any good word. 
Busyti koshkykum, tuganenym(y) l'ukis'kykum, Öy vala töd'y kyshetme shonasa kel'tyny.
Passing through the field, parting with my beloved, I did not understand how to wave my white handkerchief.

They could also stay a little in the yard and sing another song. All the way to the village gate they walked singing songs:

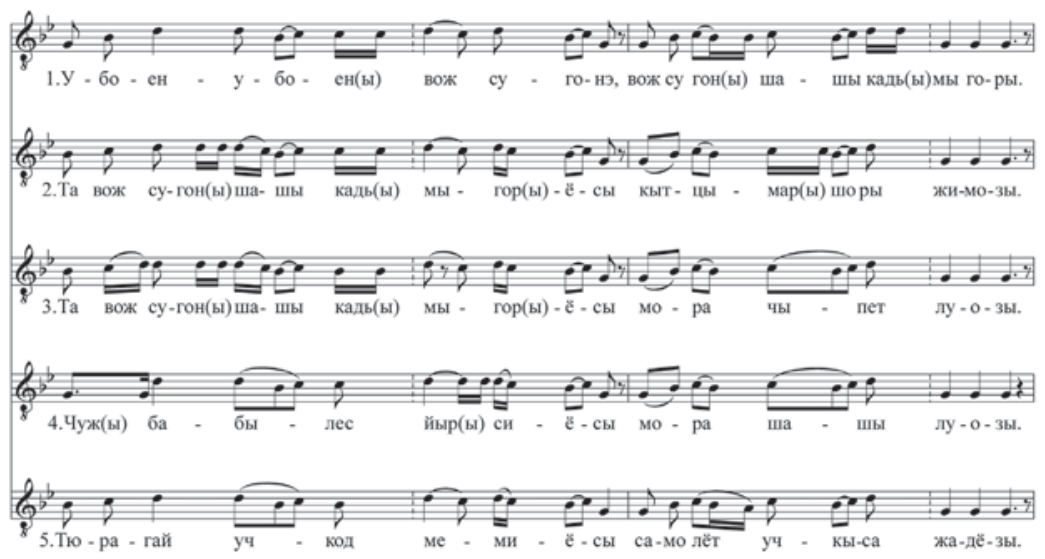

Figure 7. Soldat gur ('Song of the Soldier'). ${ }^{11}$

Soldat gur

Uboyen-uboyen (y) vozh

$\operatorname{sugon}(y)$, shashy kad'(y)

mygor (y).

Ta vozh sugon(y), shashy

kad'(y) mygor(y)yosly, kytstsymar(y) shory dzhimozy?
Song of the Soldier

Bed by bed my green onion, my body is like the leaves of the green onion.

This body is mine, like the leaves of a green onion, where will it go? 
Ta vozh sugon(y), shashy kad'(y) mygor(y)yosy mora tshypet luozy.

Tshuzh babyl'es yyr(y)s'iosy mora shashy luozy.

T'uragay uchkon memiyosy samol'ot uchkysa zhad'ozy.

Gery kuton(y) kikiyosy vin(y)tovka nullysa zhad'ozy. Gery kuton(y) kikiyosy vintovka nullysa zhad'ozy. Borozda l'ogon(y) bybiosy kudzh' s'ures l'ogasa zhad'ozy.

Borozda l'ogon(y) bybiosy kudzh' s'ures l'ogasa zhad'ozy.

En(y) bördy, nenie, en bör $(y) d$, d'ad'ie, ber kyl'em $(y)$ nyl(y)depide dzh'ech vor(y)dy. En(y) bördy, nenie, en bör(y) $d$, d'ad'ie, ber kyl'em(y) nyl(y) de-pide dzh'ech vor(y)dy.
This body of mine, like the leaves of a green onion, will become an obstacle to the sea. My blonde curly hair will become algae.

My parents looking at the nightingale will get tired of expecting a plane.

My hands holding soho will get tired of carrying a rifle. My hands holding soho will get tired of carrying a rifle. My legs stomping the furrow will get tired of treading the long road.

My legs stomping the furrow will get tired of treading the long road.

Don't cry, mum, don't cry, dad, bring up the remaining children well.

Don't cry, mum, don't cry, dad, bring up the remaining children well.

The whole family, relatives, friends, fellow villagers, and his beloved saw off the recruit. The recruit took only one towel and one handkerchief, and left the rest of the ribbons, scarves, and towels to his parents and sister(s) (if he had any). His parents hung these gifts on the wall until he returned.

Horses were already waiting there at the end of the village where the village gate was (two spruces). Later, the horses were waiting 
in front of the recruit's house. The recruit stood in the cart facing the village and waving the handkerchief until he was out of sight.

The last song before leaving was the recruit tune with which the ritual started, ending in different lyrics.

Upon his return, the soldier came to every house where he had hammered red ribbons, and removed them from the beam with his teeth, standing on a chair or raised in the arms of friends as on the eve of his departure.

\section{About the Songs of the Udmurt Rite of Seeing off a Recruit}

There are 14 songs in total which were recorded and which relate to Chutozhmon heritage, and more specifically are intended to be performed as part of the rite of Seeing off a Recruit.

Some reflections about the most archaic layer of the songs in the rite. First of all, it is necessary to define the differences between the different layers of the songs in the village of Chutozhmon. As for the 'archaic' layer, six songs are sung to the same melody, i.e. one archaic tune with different lyrics designed for different contexts. It is very common, in the Udmurt tradition, that every particular rite has its tune - one special melody for one rite but with different lyrics (often used for different purposes). In addition, one of the most indicative features is that every line of the song ends with three unison notes, as in the next figure:

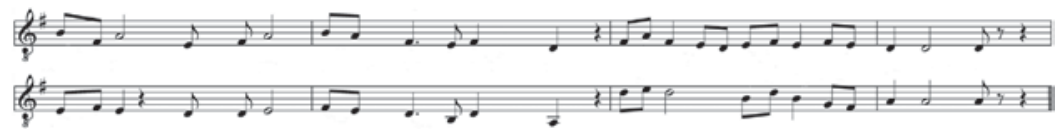

Figure 8. The Tune of Seeing Off a Recruit. 
The 'archaic' songs are those sung to the same melody, to the same tune, and one song which is sung to another tune but which has the abovementioned feature of the ending of the line with three unison notes.

The 'old' layer consists of five songs in Udmurt that are sung to other melodies and melodiously developed on a wide range. These songs could be old lyrical songs suitable for farewell, but it may be assumed that they were composed before the $20^{\text {th }}$ century and had authors. Or they could be the songs performed at wedding as 'seeing off the bride' songs.

The third, 'modern', layer is the three songs that are in Russian from the Soviet period “Kak rodnaya men'a mat' provozhala”, " $O y$, krasivy nad Volgoy zakaty", and "Dobryy vecher, devushki". The authors of these songs are known, although these songs are called folk songs because they became popular and widely used in ceremonies of seeing off recruits in almost all folk traditions in Russia.

The 'archaic' songs are interesting in that that they have very strict melodic structures. As far as the songs are performed by several people, it is very common in the Udmurt tradition that there will be at least three voices: the main voice performs the lower melodic variations, the supporting voice performs higher melodic variations, and the head register which performs the main voice variations an octave higher. This practice can be associated with Russian polyphonic singing and Turkic head voice singing. Small variations in every voice are allowed.

Usually, the variations are in the range of thirds when it comes to polyphonic singing, and it is also very common that a quarter note can be divided into two eighth notes. The melodic structure in both lines is the same and consists of the same major pentatonic scale sounds (except the last bar where the G is added):

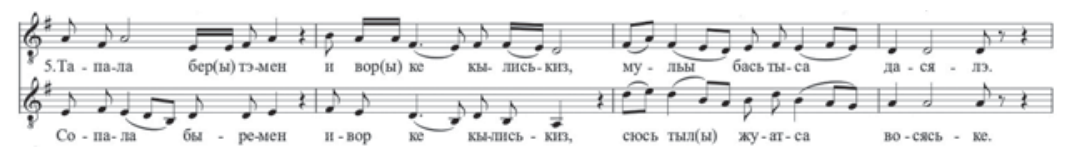

Figure 9. The Tune of Seeing off a Recruit 
There is no meter designation because folk songs 'prefer freedom' in the duration. The notes designate approximate duration relative to each other. The rests were marked according to the singer's pauses in performance, not to make the notation metrically correct.

The rhyme and the meter are less important in rite songs, but there is a visible rhyme between some stanzas, a rhyme that is not constant and visible only in some stanzas. Furthermore, the stanzas may be sung in a variable order. In this case, probably, it would be better to call them not stanzas but couplets. But to call them couplets, we would need refrains between them that we do not have, so it follows that we cannot call them couplets either.

The songs depend on their musical structure and musical accents more. In Udmurt, stress is fixed on the last syllable of a word (it can be different but only with some grammatical forms). If we read the lyrics without their musical accents, they do not sound like poems because the number of syllables, the stress in the words and rhyme do not function the same way as in poems. The stanzas will sound like ordinary sentences in narration, and after you sing them once, it becomes difficult to get rid of musical accents when reading them without the melody again. Therefore, normal word stresses can change due to musical accents.

Here is an example of musical accents that do not match the last-syllable stress of the words bas'tizy, kosizy, shukkem, chuk'yosme, voz'ele:

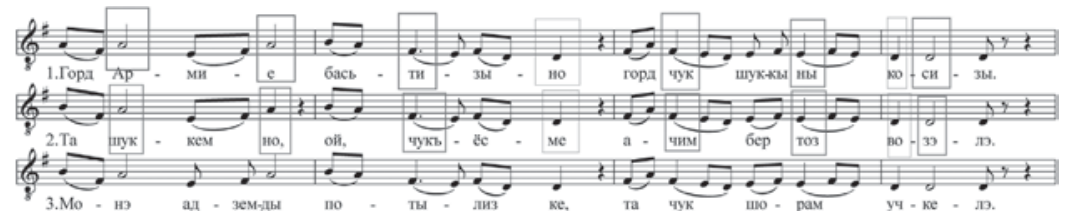

Figure 10. The Tune of Seeing off a Recruit

Although the first notes are on the strong beat, the singer's accents are to be made on the long notes, which are supposed to be on the weak beats. So, this is one more peculiarity in folk songs. 
The grief of recruitment and forced separation from the family are the main motifs of Udmurt recruit songs. In the musicological work of the researcher Rimma Churakova "The Udmurt Wedding Songs", we find important conclusions for us: a peculiar feature of the wedding is that during a conspiracy or at the time of the bride's farewell to the parental house, the songs of 'seeing off a bride' sound. Besides them, any song about a passing youth, about separation, and others can be performed (Churakova 1986: 16). Based on the diapason of melodies, the researcher assumes that the bride's songs "entered the wedding ritual with a later layering" (Churakova 1986: 26). Rimma Churakova, after Petr Pozdeyev, also notes the mutual transitions in the texts of the 'seeing off' rites: "similar plots can be heard in recruiting, guest, and non-ritual lyric songs" (Pchelovodova 2006: 14).

Tatiana Perevozchikova identifies several types of bride lamentation, including: "lamentation songs (characteristic of the southern Udmurt song tradition) with a strong lyrical beginning, which later turned into the category of lyric songs and could be performed outside of any rite; and non-ritual lyrical songs dedicated to the 'seeing off the bride' stage of the wedding" (Perevozchikova 1986: 23). Since 'seeing off the bride' songs also entered the tradition of 'seeing off a recruit', the tendency to perceive lyrical songs as rite songs, which were originally not dedicated to the rite, is clear. Furthermore, it is possible that lamentations were recitative and only later became melodically related to both rites.

The Hungarian researcher Vikár László (1989) has recorded many songs from the Udmurts (Votyaks) who live on the periphery of the ethnic group. He considers these songs archaic since they are based on only three notes. They are different from the songs of the neighboring peoples, and Vikár believes that this suggests that the trichord is primordial and most archaic for the Udmurt. It is this song layer, as the Hungarian scientist noted, that is the basis of the Udmurt song tradition. In our case, this may indicate 
that before triordic singing there could be recitative lamentation in rites that does not imply a developed melodic system. However, in the tradition of the southern Udmurt, including the village of Chutozhmon, there is significant Turkic influence meaning that the tunes are based on major pentatonic scales with singers showing fine ornamental technique.

\section{Symbolism in One Seeing off a Recruit Song}

As we said before, the lyrics of the Seeing off a Recruit tune were polyfunctional for all other rites and festivities, so songs asking for permission to enter, with people giving their purpose for coming and thanking the host for hospitality, could theoretically also be used in the seeing off the bride part of the wedding. However, the lyrics of that talk about hammering a red ribbon onto the beam are used only for Seeing off a Recruit.

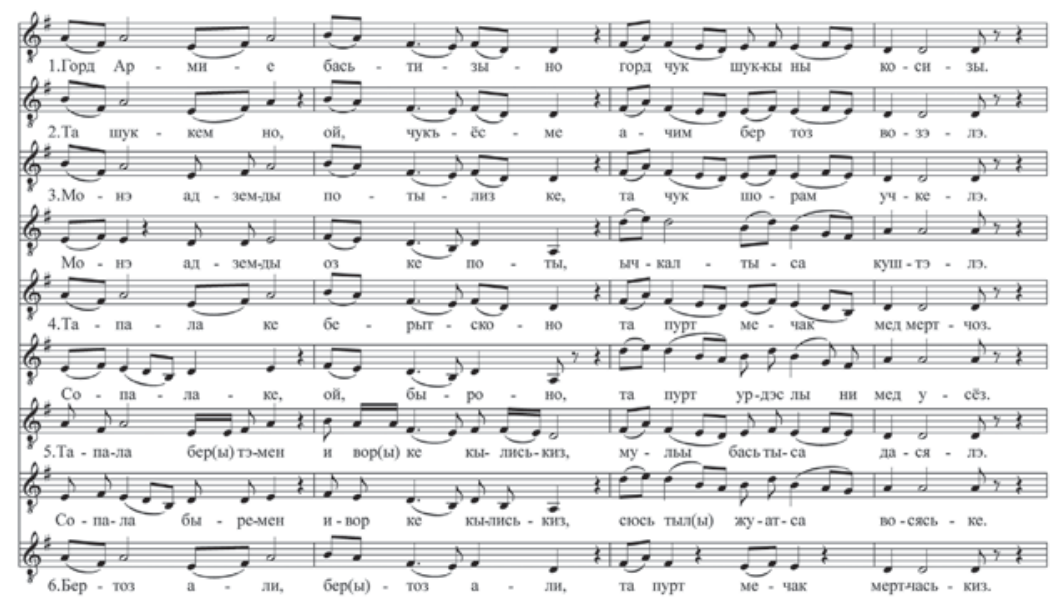

Figure 11. Chuk shukkon gur ('The Song for Hammering a Ribbon'). ${ }^{12}$ 
Chuk shukkon gur

Gord armiye bas'tizy no gord chuk shukkyny kosizy.

Ta shukkem no, oy, chuk"yosme achim bertoz' voz'ele.

Mone addzh'emdy potyliz ke, ta chuk shoram uchkele.

Mone addzh'emdy öz ke poty, yshkaltysa kushtele.

Tapala ke berytskono, ta purt metshak med merchchoz.

Sopala ke, oy, byrono, ta purt urdesly n’i met us'oz.

Bertoz al'i, ta purt metshak merchchas'kiz.

Tapala bertemen ivor kylis'kiz ke, mul'y bas'tysa das'ale.

Sopala byremen ivor kylis'kiz ke, s'us'tyl dzhuatsa vös'as'ke.
The Song for Hammering

a Ribbon

I was taken to the Red Army and they asked me to hammer a red ribbon.

Keep these hammered ribbons until my return.

If you should want to see me, look at my ribbon.

If you do not want to see me, pull it off and throw it away. If I am to come back here, let this knife stick into the floor. If I am to die there, let this knife just fall sideways. He will come back, he will come back, this knife stuck into the floor.

If you will hear the news about my return, buy sunflower seeds.

If you will hear the news about my death, light a candle and pray.

The ribbon is an invariable attribute of the rite of sending a recruit to the army. Often recruits hammered a red flap of material, shreds of multi-colored fabric or red ribbons to the beam with a coin, and later banknotes, too. Money plays the role of tribute to the beam, one of the most sacred parts of the house. Judging by the 
information in sources from the $19^{\text {th }}$ century, a more archaic version of the talisman was the recruit's ring (Bogaevskiy 1888: 49).

Furthermore, I must mention again that this song is performed on an 'archaic' original Seeing off a Recruit tune and can be read as a description of the whole rite: it contains in its lyrics an image of the whole rite from beginning to end and is a kind of commentary on the actions. The structure of the text is composed of the stable motifs of receiving the call-up, certification of suitability for service, parting with a native home and relatives, and a contrast between peaceful everyday life and the soldier's lot.

There has been a modification in the lyrics that might come from the need to adapt to a particular period, for example 'Gord armiya', the Red Army, which was formed only in 1918. However, the rest of the lyrics leave absolutely no doubt that the song is much older than the Red Army because of some significant things mentioned in the song.

In the main recruit tune, the quintessence is the motif of hammering the red ribbon onto the beam. The red ribbon is a symbolic replacement of a young man during his absence. Moreover, it can be considered an icon. Therefore, close attention is paid to the attributes used during the ritual of hammering the ribbon. We have already mentioned that after the recruit has hammered the ribbon to the beam, he has to throw a knife or a hammer in front of himself or over his shoulders, and he must be lucky to throw it so that it does not fall sideways. The knife must stick into the floor or the hammer 'stand on its head'. The recruit throws the knife to the words:

Tapala bertemen ivor kylis'kiz ke, mul'y bas'tysa das'ale.

If I am to come here back, let this knife stick into the floor.

Sopala byremen ivor kylis'kiz ke, s'us'tyl dzhuatsa vös'as'ke.

If I am to die there, let this knife just fall sideways. 
In addition to hammering the red ribbon to the beam in his family house, the recruit will do the same thing at the houses of relatives and villagers, whom he visits with his friends. According to belief, the more ribbons a recruit hammers onto house beams, the more successful his military service will be. In the modern tradition, the ribbon is regarded as a kind of memorial gift to the family home and relatives (s'inpel'/s'inpel'et), the apotropic function of which is directly related to the beam and its protective properties: the ribbon is a gift for the beam, the beam protects the one who hammered in the ribbon (Vladykina et al. 2018: 144-147).

The symbolic function of the red ribbon (gord chuk) is deciphered in the tradition as the ribbon becoming the symbolic material substitution of the soul of the recruit who is leaving for the army: "Ta shukkem no, oy, chuk'yosme achim bertoz'voz'ele" ('Keep these hammered, oh, my ribbons until my return'). Tatiana Vladykina et al. (2018) give an example of part of a Seeing off a Recruit song that is likely to be a continuation of lyrics of the song from Chutozhmon:

Etot vbityy, oy, moy chuk

khran'it'e do moyego

vozurashchen'iya,

Esl'i vernus', oy, sam zubami vyrvu, esl'i sam vernus', zubami vyrvu.

Esl'i pyl', oy, s'ad'et, smetayt'e, oy, krylyshkom.

Esl'i pyl', oy, s'ad'et, smetayt'e, oy, krylyshkom.

Esl'i men'a n'e zakhot'it'e uvid'et', vyrvit'e i bros't'e,
Keep this ribbon, oh, my

ribbon until my return,

If I return, oh, I will pull it out with my teeth, if I return, I will pull it out with my teeth.

If the dust, oh, sits down (on the ribbon), sweep it off, oh, with a wing,

If the dust, oh, sits down (on the ribbon), sweep it off, oh, with a wing,

If you want to see me, pull out and throw (the ribbon), 
Vyrvit'e i bros't'e da v reku Volgu.

Esl'i v Volgu-reku brosit'e, pust'ko mn'e on priplyv'ot, Esl'i v Volgu-reku brosit'e, pust' ko mn'e on priplyv'ot.
Pull out and throw (the ribbon) into the Volga River. If you throw it into the Volga River, let it sail to me, If you throw it into the Volga River, let it sail to me.

The mood for return is revealed in the song itself since the recruit promises to pull out the ribbons upon his return, which he must do in every house with his teeth. According to informants, this is to show that an adult, a strong man, had returned instead of young inexperienced boy. In this way the recruit also shows his respect for the villagers, although this action is not connected with any part of the rite.

Here is one more interesting thing to pay attention to in the next lines:

Tapala bertemen ivor kylis'kiz ke, mul'y bas'tysa das'ale.

If you will hear the news about my return, buy sunflower seeds.

Sopala byremen ivor kylis'kiz ke, s'us'tyl dzhuatsa vös'as'ke.

If you will hear the news about my death, light a candle and pray.

Informants explain that sunflower seeds ( $\left.m u l^{\prime} y\right)$ are a favorite for recruits as they cannot find them in the army. However, the semantics of this word is not entirely clear even to old-timers. Looking deeper into semantics in the Slavic Antiquities ethnolinguistic dictionary there is the following explanation: "seed, seeds - a symbol of future life, fertility and abundance. S. unites the beginning and end of life: the 'dead' S. thrown into the earth turn into a new plant, tree, grass, bread, etc.” (Ethnolinguistic Dictionary: 616). Thus, 
the image of the seed here was not random because its meaning is endowed with a mythological idea of a new life and fertility. We can conclude that upon return the soldiers form a kind of family, on the one hand, and attain the status of a man, on the other.

Regarding the beam, there is no wonder the Udmurts preferred to build houses of spruce or pine. These trees with long, even trunks fit well in the log house, joining tightly together with the large number of resins contained in them preventing rapid decay. Such houses also retained heat well. The ribbon hammered into the beam is semantically adequate to identify a recruit with a tree. In some villages, recruits hammered a shred or ribbon and a coin into a birch, pine, or spruce in the sacred places of the village, which could symbolise both the gift to the tree and the person's involvement in his native world (the same definition as that of the gift to the beam). The pine tree symbolises a young man, and that tree, into which the recruit hammers the ribbon, is considered to guard the soldier when he goes to a 'foreign' land. A tree becomes a substitute for the soul of the recruit who has left home; this option, apparently, is more archaic than the action with the beam.

"During the 'seeing off' rite, the recruit, climbing up the spruce, cut down several of the upper branches, exposing the trunk. The upper branches remained, giving the tree a human appearance, which corresponds to its name later [see below]. Sometimes the top of the tree was directly cut down, but this had to be done so that it continued to grow. It was believed that if the tree after that dries up, then this person will not return home, if it does not dry up, he will return from service" (Vladykina et al. 2018: 144-147).

These trees then receive special names, for example yyro kyzspruce with head, chyrtyo kyz - spruce with neck, or kartuzo kyzspruce with a hat. 
The fact that the recruit throws a knife to the floor could also be connected with the three-part vision of the world: the higher - the world of God, the middle - the world of humans, the lower - the world of evil. It can be assumed that the beam is part of the higher world, and the floor is the lower world. The recruit throws the knife to know if he will die or not, i.e. if the lower world wants to take him or not. The knife, in turn, has the meaning of male principle and protection. Since it was a male instrument and was close to the recruit from childhood, it was also a symbol of the recruit.

\section{Conclusion}

The main purpose of this article was to initiate research about musical aspects of Seeing off a Recruit on the basis of the material collected in the village of Chutozhmon.

I started by presenting a detailed desciption of the ritual including, or mentioning, the songs that mark the structure of the ritual. The roles and motifs of most of songs are quite clear, while the song about hammering the red ribbon onto the beam are dealt with separately at the end of the article. The ritual contains a certain set of motifs that illustrate emotional expression and state of mind. Having received the call-up, the recruit does not resist his fate, but obeys it: leaving for the army is perceived by him as the norm. The same attitude applies to the micro-plot with the knife. According to researchers, submission to one's fate "is not connected in any way with ethnic weakness or silence, but is determined at the level of worldview within which any life situation was perceived as predestination from above, therefore the question of confrontation was impossible in principle" (Pchelovodova 2009).

As Elena Boykova and Tatiana Vladykina concluded, according to ethnographic data the earliest form of the rite consisted of two main stages: moving from house to house, and departure (Boykova, Vladykina 1992: 15). The two-part nature of the ritual has been 
preserved in the same ritual among the Besserman. While some ritual episodes have been lost, the key actions are:

1. A home feast on the eve of departure to the army, preserving the initial ritual episode of tying a belt and towels;

2. The action, performed on the day of departure, containing the central climax episode of the rite of 'leaving the house' (Shakhovskoy 1993: 5).

The available material makes it possible to give the rite a more detailed structure:

a) reception of conscription papers from the military by a young man;

b) sharing the news with the neighborhood and starting to prepare for the rite;

c) the rite activities: moving from house to house, hammering a red ribbon in every house, tying ribbons, a belt and towels to the recruit, etc.;

d) farewell meeting at the house of the recruit's family;

e) seeing off the recruit to the army.

The Udmurt songs of both 'archaic' and 'old' layers have the function of commentary on the rite, telling of things that happen in the rite and conveying the feelings and emotions of the recruit and his family. This fact makes the process of reconstruction more logical and easier to understand.

Table 1. Functions of the Songs of the Rite of Seeing off a Recruit (songs from the village of Chutozhmon).

\begin{tabular}{|l|l|}
\hline \multicolumn{2}{|c|}{ The 'archaic' layer } \\
\hline \multicolumn{1}{|c|}{ Song } & \multicolumn{1}{|c|}{ Function } \\
\hline “Us'toz(y) meda, uz(y) meda (y) & asking for permission to enter \\
uk ta tshogam $(y)$ no ös"yosse" & the house \\
\hline $\begin{array}{l}\text { "Dzh'ech ivor no kylis'kiz no, } \\
\text { mi pyrono karis'kim" }\end{array}$ & $\begin{array}{l}\text { explanation of the purpose } \\
\text { of the visit }\end{array}$ \\
\hline
\end{tabular}




\begin{tabular}{|c|c|}
\hline $\begin{array}{l}\text { "Taule no, taule no, s'udem }(y) l y \\
\text { no s'ektam }(y) l y \text { " }\end{array}$ & $\begin{array}{l}\text { thank for hospitality and good } \\
\text { wishes for the hosts }\end{array}$ \\
\hline $\begin{array}{l}\text { "Gord Armiye bas'tizy no gord } \\
\text { chuk shukkyny kosizy" }\end{array}$ & $\begin{array}{l}\text { hammering the ribbon; expla- } \\
\text { nation of the situation of the } \\
\text { rite and explanation of actions } \\
\text { the recruit performs }\end{array}$ \\
\hline $\begin{array}{l}\text { "E, kyl'oz uk, kyl'oz ik uk ta } \\
\text { Chutozhmon kalyked" }\end{array}$ & $\begin{array}{l}\text { farewell to the village and all } \\
\text { people }\end{array}$ \\
\hline $\begin{array}{l}\text { "Uboyen-uboyen }(y) \text { vozh } \\
\text { sugone, vozh sugon }(y) \text { shashy } \\
\text { kad'(y) mygory" }\end{array}$ & $\begin{array}{l}\text { expression of recruit's feelings } \\
\text { and experiences }\end{array}$ \\
\hline \multicolumn{2}{|c|}{$\begin{array}{ll}\text { The 'old' layer } \\
\end{array}$} \\
\hline "Chastushkaos" & $\begin{array}{l}\text { dance tune and song; atten- } \\
\text { tion to talents of the recruit }\end{array}$ \\
\hline $\begin{array}{l}\text { "Iz no, mu no pil'is'ke no- } \\
\text { ad'amily chidano" }\end{array}$ & $\begin{array}{l}\text { narration about the hard life } \\
\text { of ordinary people and about } \\
\text { the future of youth }\end{array}$ \\
\hline $\begin{array}{l}\text { "Korkas'tym(y) potykum, } \\
\text { neniyenym l'ukis'kykum” }\end{array}$ & $\begin{array}{l}\text { the narration about the re- } \\
\text { cruit's leaving home and his } \\
\text { desires }\end{array}$ \\
\hline $\begin{array}{l}\text { "Kytky, d'ad'i, par val"yoste, } \\
\text { us'ty, memi, kapkade" }\end{array}$ & $\begin{array}{l}\text { narration about people whom } \\
\text { the recruit leaves; thinking } \\
\text { about the meaning of life }\end{array}$ \\
\hline $\begin{array}{l}\text { "Serego no serego ta } \\
\text { Chutozhmon busyyed }(y) \text { " }\end{array}$ & $\begin{array}{l}\text { narration about the village } \\
\text { and people the recruit leaves }\end{array}$ \\
\hline \multicolumn{2}{|c|}{ The 'modern' layer } \\
\hline $\begin{array}{l}\text { "Kak rodnaya men'a mat' } \\
\text { provozhala" }\end{array}$ & $\begin{array}{l}\text { entertaining song about the } \\
\text { day of farewell }\end{array}$ \\
\hline $\begin{array}{l}\text { "Dobryy vecher }(y), \text { devushki, } \\
\text { dobryy vecher }(y), \text { milyye" }\end{array}$ & $\begin{array}{l}\text { dialogue of recruits with girls } \\
\text { about the soldiery's honour }\end{array}$ \\
\hline $\begin{array}{l}\text { "Oy, krasivy nad Volgoy } \\
\text { zakaty" }\end{array}$ & $\begin{array}{l}\text { dialogue with beloved and } \\
\text { true love }\end{array}$ \\
\hline
\end{tabular}


The division of these songs into three layers of 'archaic', 'old', and 'modern' helped analyse the functions of the songs in the rite and how they could be brought to the rite. There are six songs in the 'archaic' category, five of which are sung to the same tune and one to another recruit rite tune that could be brought from another village tradition. Among the 'old' songs there are four Udmurt songs as well as an example of the ditties that can be sung to different melodies. And as for the 'modern' layer, there are three Russian songs from the Soviet period.

The modern world surrounding us and its conditions have a strong influence on people, regardless of where they live - in village or city. Nevertheless, even in a small village, knowledge and experience transmitted by the ancestors still exists. Expedition materials recorded expand our knowledge of the existence of the traditions, which allows us to introduce them in the context of world culture.

The material studied can make it possible to recreate a complete picture of the rite and to conduct it for future recruits.
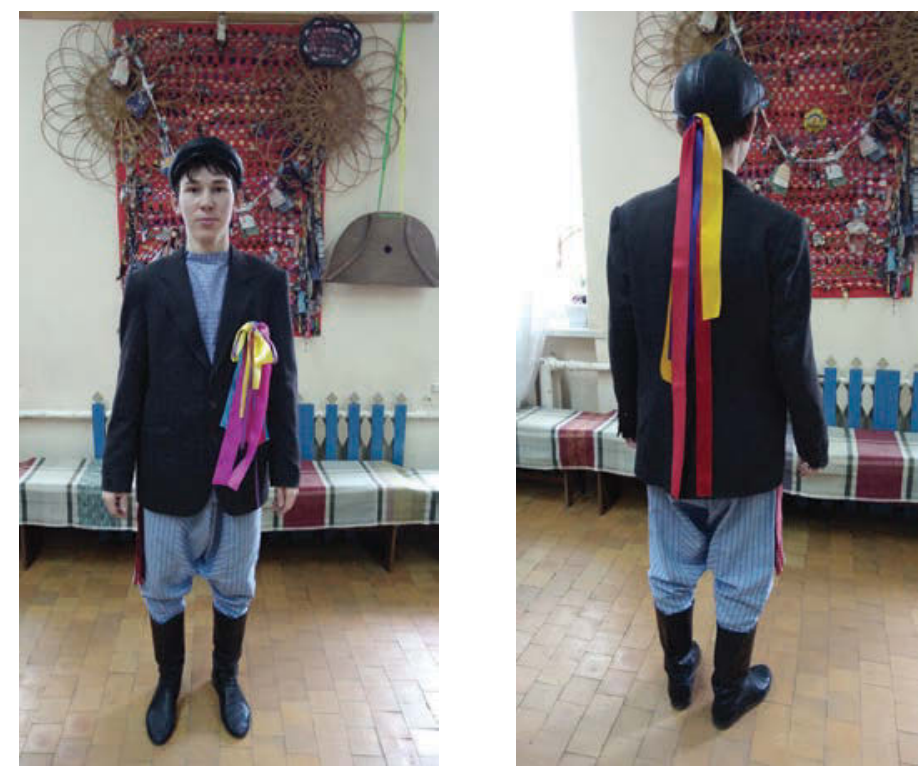

Photos 1 \& 2. Recruit. Izhevsk, 2019. Photos by Margarita Khamatova. 


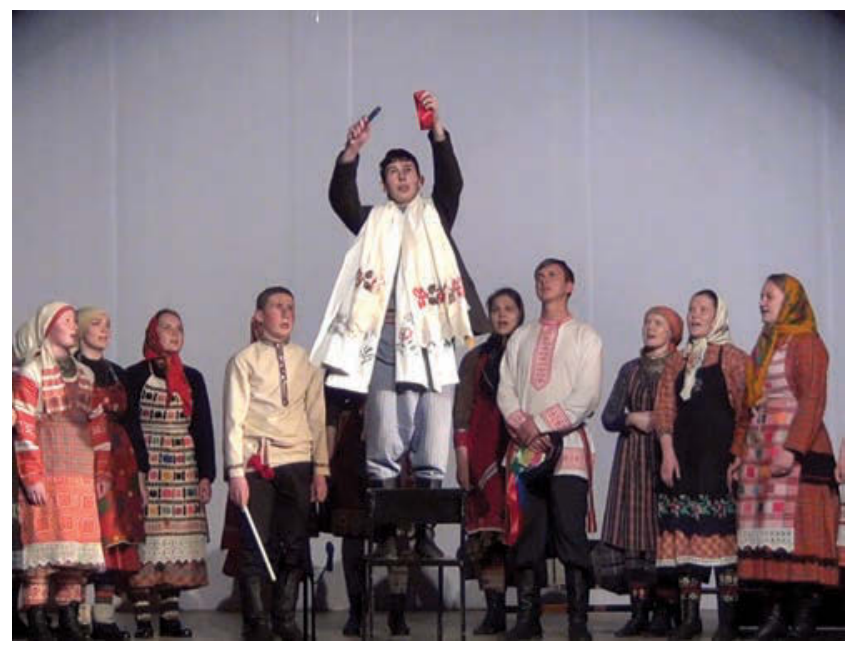

Photo 3. Seeing off a Recruit ritual Mise-en-scène by the students of the Republican Musical colledge, Izhevsk.

Source: https://youtu.be/KBtPX7joR1c.

\section{Notes}

1 Udmurt Institute of History, Language and Literature of the Ural Branch of the Russian Academy of Sciences.

2 FWM 2015. Recorded from Lyubov' Andreevna Lebedeva, born 1941, in Chuzhtomon, by Valeriia Fedorova, in Baykuzino.

3 FWM 2018. Recorded from Lyubov' Andreevna Lebedeva, born 1941, in Chuzhtomon, by Valeriia Fedorova, in Baykuzino.

4 FWM 2015. Recorded from Lyubov' Andreevna Lebedeva, born 1941, in Chuzhtomon, by Valeriia Fedorova, in Baykuzino.

5 FWM 2018. Recorded from Lyubov' Andreevna Lebedeva, born 1941, in Chuzhtomon, by Valeriia Fedorova, in Baykuzino.

6 FWM 2018. Recorded from Lyubov' Andreevna Lebedeva, born 1941, in Chuzhtomon, by Valeriia Fedorova, in Baykuzino.

7 The Russian songs within this ritual are performed by Udmurts. We have chosen to adopt Udmurt transliteration principles, taking into account the phonetic peculiarities of Udmurt pronounciation. (Editors) 


\section{Valeriia Fedorova}

8 FWM 2008. Recorded from Nina Ivanovna Petrova, born 1934, in Chuzhtomon, by Irina Pchelovodova, in Baykuzino.

9 FWM 2015. Recorded from Nina Ivanovna Petrova, born 1934, in Chuzhtomon, by Valeriia Fedorova, in Baykuzino.

${ }^{10}$ FWM 2015. Recorded from Lyubov' Andreevna Lebedeva, born 1941, in Chuzhtomon, by Valeriia Fedorova, in Baykuzino.

${ }^{11}$ FWM 2015. Recorded from Lyubov' Andreevna Lebedeva, born 1941, in Chuzhtomon, by Valeriia Fedorova, in Baykuzino.

${ }^{12}$ FWM 2015. Recorded from Lyubov' Andreevna Lebedeva, born 1941, in Chuzhtomon, by Valeriia Fedorova, in Baykuzino.

\section{List of the informants}

The songs and detailed description of the rite of Seeing off a Recruit were recorded in expeditionary semi-structured interviews in the villages of Chutozhmon and Baikuzino, and the city of Izhevsk (the places of residence of interviewees at the time of the interviews in the years 2015-2018) from the following informants (tradition bearers):

Bykova, Galina Stepanovna, born in 1942 in Chutozhmon;

Fedorova, Alevtina Petrovna, born in 1969 in Chutozhmon;

Fedorova, Petr Nikandrovich, born in 1935 in Chutozhmon;

Lebedeva, Lyubov' Andreevna, born in 1941 in Chutozhmon;

Petrova, Nina Ivanovna, born in 1934 in Chutozhmon.

\section{References}

Atamanov, M. 2005. Ot Dondykara do Ursygurta. Iz istorii udmurtskikh regionov. Monografiya [From Dondykar to Ursygurt. From the History of Udmurt Regions]. Izhevsk: Udmurtia.

Bogaevskiy, P. 1888. Ocherki byta Sarapul'skikh votyakov [Essays about the Everyday Life of the Sarapul Votyak]. Sbornik materialov po etnografii pri Dashkovskom muzee [Collection of Materials about Ethnography at the Dashkovski Museum]. Vol. 3. Moscow: [b.i.].

Boykova, E., Vladykina,T.1992.Udmurtskiy fol'klor.Pesniyuzhnykh udmurtov: Materialy i issledovaniya [Udmurt Folklore. Songs of the Southern Udmurt: 
Materials and Research]. Vol. 1. Izhevsk: Udmurtskiy institut istorii, yazyka i literatury Uralskogo otdeleniya Rossiyskoy akademii nauk.

Cerban, M. 2017. Types of Relation Between Subordinated Clauses in Wake for Susan by Coman Mccarthy. Iulian Boldea (ed.) Literature, Discourses and the Power of Multicultural Dialogue. Tîrgu Mureș : Arhipelag XXI Press, pp. 89-94.

Gazieva, T. 2014. Pesennyy fol'klor udmurtov [The Singing Folklore of the Udmurt]. https://schoolfiles.net/1056715 (accessed 12.05.2021).

Halliday, M. A. K., Hasan, R. 1976. Coherence in English. London: Longman.

Hasan, R. 1984. Coherence and Cohesive Harmony. In: Flood, J. (ed.) Understanding Reading Comprehension. Delaware: International Reading Association, pp. 181-219.

Hatten, R. n.a. Embodying Sound: The Role of Semiotics. Lecture 2. https:// semioticon.com/sio/courses/musical-gesture/role-of-semiotics/.

Khristolyubova, L. 1984. Semeynyye obryady udmurtov (traditsii i protsessy obnovleniya) [The Family Rituals of the Udmurt (Transition and Innovation Processes)]. Izhevsk: Udmurtia.

Lázár, K. 2006. Finnugor nyelvü népek zenéje [The Music of the FinnoUgric Peoples]. Budapest.

Mahlberg, M. 2006. Lexical Cohesion. Corpus Linguistic Theory and Its Application in English Language Teaching. International Journal of Corpus Linguistics 11 (3), pp. 363-383.

Morris, J., Hirst, G. 1991. Lexical Cohesion Computed by Thesaural Relations as an Indicator of the Structure of Text. Computational Linguistics. Vol. 17, No. 1.

Pchelovodova, I. 2006. Udmurtskiye liricheskiye pesni: istoki i formirovaniye traditsii [The Udmurt Lyrical Songs: The Sources and the Formation of Tradition]. Rukopis' dissertatsii na soiskanie uchenoy stepeni kandidata filologicheskikh nauk. PhD Dissertation. Manuscript, 10.01.2009. Izhevsk.

Pchelovodova, I. 2009. Osobennosti kompozitsii udmurtskikh liricheskikh pesen [Peculiarities of the Composition of the Udmurt Lyrical Songs]. Vestnik Vyatskogo gosudarstvennogo gumanitarnogo universiteta [Messenger of the Vyatka State University in Humanities] 1, pp. 108-114.

Perevozchikova, T. 1986. Svoyeobraziye zhanra prichitaniy v udmurtskom fol'klore [Peculiarities of the Lament Genre in the Udmurt Folklore]. 
Problemy tvorcheskikh svyazey udmurtskoy literatury i fol'klora [Problems of the Creative Connections between Udmurt Literature and Folklore]. Izhevsk: Nauchno-issledovatel'skiy institut pri Sovete Ministrov Udmurtskoy ASSR, pp. 18-49.

Shakhovskoy, A. 1993. Pesni besermyanskogo obryada provodov v armiyu: Uchebnoye posobiye [Songs of the Besserman Ritual "Seeing of a Recruit"]. Moscow: Rossiyskiy institut iskusstvoznaniya.

Tolstoy, N. 2004. Slavyanskiye drevnosti: Etnolinguisticheskiy slovar' [Slavic Antiquities: Ethnolinguistic Dictionary]. N. Tolstoy (Editor-inchief). Vol. 3. Moscow: Mezhdunarodnyye otnosheniya.

Tolstoy, N. 2009. Slavyanskie drevnosti: Etnolinguisticheskiy slovar' [Slavic Antiquities: Ethnolinguistic dictionary]. N. Tolstoy (editor-in-chief). Vol. 4. Moscow: Mezhdunarodnye otnosheniya.

Vershinina, E., Vladykina, T. 2014. Udmurtskiy fol'klor. Pesni yuzhnykh udmurtov [Udmurt Folklore. Songs of the Southern Udmurt]. Vol. 3. Izhevsk: Udmurtskiy institut istorii, yazyka i literatury Uralskogo otdeleniya Rossiyskoy akademii nauk.

Vladykina, T., Glukhova, G., Panina, T. 2018. Chuk v traditsionnoy kul'ture udmurtov [The Ribbon "Chuk" in the Traditional Culture of the Udmurt]. Traditsionnaya kul'tura. Vol. 19 (1), pp. 139-151.

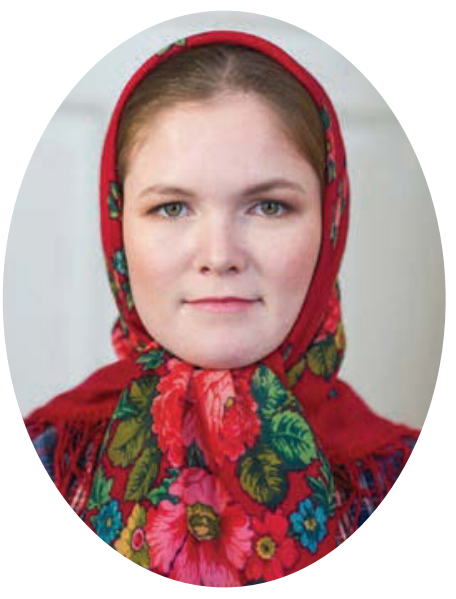

Valeriia Fedorova is a doctoral student at the Multilingualism Doctoral School, University of Pannonia (Veszprém, Hungary), and doctoral student of Music Sciences at the Ankara Music and Fine Arts University (Ankara, Turkey). Her main interest in research is Udmurt folk tradition from the sociolinguistic and semiotic point of view.

e-mail: loptem.gon@ya.ru 


\title{
The Ritual Importance of the Chuk, a Symbolic Bundle of Thread
}

\author{
Tatiana Vladykina \\ e-mail: tgvladykina@mail.ru
}

Galina Glukhova

e-mail: galant@udm.ru

\section{Tatiana Panina}

e-mail: tipanina@mail.ru

\begin{abstract}
The article aims to analyse one of the specific objects of Udmurt traditional culture, chuk (in southern dialects) / tug (in northern dialects), i.e. red thread/yarn; a bunch or bundle of different coloured threads, fringes, ribbons, shreds; towels, bedspreads, and kerchiefs. The multifunctional nature of the object is revealed in everyday and ritual contexts; it can be of different forms and convey various meanings. Depending on the situation, chuk is regarded as a label, a protective charm, a sacrifice gift, or a tangible symbol of a substitute for the human soul.

In everyday situations chuk is used in apotropaic magic and folk medicine. For example, red thread/yarn is worn around the ring finger to cure a sty, or it can be worn on an infant's right wrist to protect him or her against the evil eye. A bunch of wool or linen threads is attached to knitted and woven things when their pattern is copied. The custom of marking young animals with brightly coloured strips of material, usually red, has survived to this day.
\end{abstract}


Chuk is an essential attribute in the Udmurt calendar rites of the spring and summer cycles, wedding ceremonies and recruit rites. In calendar rituals chuk is recognised as a kind of sacrificial offering or gift. Praising flourishing nature alongside youth and early adulthood, the rites of welcoming spring and summer (Vöy, Shrovetide; Akashkal Byddzh'ynnal, Easter; Gershyd, Whitsunday) are regularly marked by the offering of different types of cloth (towels, kerchiefs, head towels for young married women) to mark passage through different stage of life. At different stages of the wedding ceremony (including pre- and postwedding) the semantics of chuk depends on how it correlates with the participants of the ceremony: in regard to the bride chuk is definitely recognised as a gift, in regard to the groom's relatives and friends as a way to personify a humorous image of strangers. In recruits' rites chuk is hammered into the main ceiling beam of the recruit's house and serves as a material symbol of, or substitute for, the human soul of the recruit, combining the functions of a label, a protective charm and a sacrifice.

Keywords: chuk: thread/shred/cloth/fabric, chuk in calendar rituals, chuk in everyday situations and in rituals, chuk in family rites, gift, label, protective charm, recruit's chuk, sacrifice, traditional culture, Udmurts

\section{Introduction}

Traditional cultures contain things that have special symbolic status. In different life situations, these symbols convey definite information, readable by representatives of the society. One of the interesting attributive symbols in the Udmurt traditional culture is chuk (southern dialect), tug (northern dialect), red thread/yarn; a brush or bunch of multicoloured threads or bands; also towels, blankets and handkerchiefs.

The polyfunctionality of the subject is present in every day and ritual contexts and has multiple forms and meanings. Depending on the situation it performs the function of a label, an amulet or a substitute for the soul. 


\section{Chuk in apotropaic magic and medicine}

Udmurt women used to sew a brush from threads, with the addition (or not) of beads and nacred buttons to the woven end of the married woman's head towel (chalma) (see photos 1, 2 and 3), as well as to home-woven carpets, knitted or woven socks and mittens, and the traditional male belt (see photo 4) if the pattern was copied from the chalma (see photo 1). Here chuk was, it was believed, a form of gratitude and a symbolic-offering, able to protect from the evil eye. According to Udmurt belief, when you transmit something you have made yourself to another person, you may forever lose the skill of making it (kis'ör, lit: 'leave for (alien's) hands'), or lose your happiness, your welfare, or your good luck (del'et), therefore chuk functioned as an amulet (Khristolyubova 1995: 187). It was possible the judge the skill of the craftswoman by the number of brushes on pattern items and by how many copies of her items had been made.

Chuk could also be used in local exchange in place of money, for example for vegetables from somebody's kitchen garden. Chuk made from multicoloured cloths or bands was pinned to the inside of clothes if lent for a while to relatives or strangers ${ }^{1}$.

Young livestock (sheep, goats, cows) were marked with bright shreds before they were taken to the fields. Here the chuk was used to both identify the animals and to provide protection against the evil eye. Protective features were attributed to bright colours, especially red, which had a high symbolic status. That's why even today one can frequently see animal collars with multicoloured shreds; the younger the animal is, the brighter the label is. ${ }^{2}$ Red thread/yarn worn on the right wrist was also used to protect babies from the evil eye (s'inus'em) (Gerd 1993: 55).

Red shreds or red thread is often mentioned in folk medicine (Panina 2014: 167-168), for example if there were pains in the body, chuk was worn on the wrist "in the form of a ring of red threads" (Vereshchagin 2000: 27). Red shred was knotted around on the 
wrist as a cure for measles, while a red thread was worn on the ring finger to cure a sty.

\section{Chuk in calendar rituals}

Chuk became a kind of sacred offering/gift as part of ritual and festive culture. Thus, the southern Udmurts celebrate Maslenitsa (Vöydyr/Masl'encha, Shrovetide): when young men visited homes, hostesses tied to the distaff shreds of fabric, ribbons and towels, and when young married women visited they tied head towels (chalma). In the tradition of the Udmurts beyond the Vyatka river (the territory of the modern Republic of Tatarstan) thus were gifts/presents collected for young married ladies. Young women went from home to home with her distaff top part of and in each home sang a kubo chuk kuran (lit: distaff petition) (Munkacsi 1952: 34-35):

Kubo chuk kule mil'emly, aygay! Distaff sacrifice / chuk we need, aigai!

Kubo chukt'osty evol ke, aygay: If you don't have a distaff sacrifice-chuk, aigai:

Chon'ari votosty d'araloz, aygay! Your spider web will do, aigai!

Chon'ari votosty evol ke, aygay: If you don't have a spider web, aigai:

Kün'küz'a sinysty d'araloz, aygay! Your three threads will do, aigai!

Kün'küz'a sinysty evol ke, aygay: If you don't have three threads, aigai:

Kon'don uks'ody yaraloz, aygay! Even pocket change will do, aigai! Kon'don uks'ody evol ke, aygay: If you don't have pocket change:

Cheryk basmady yaraloz, aygay! a quarter arshin [4 vershoks] of chintz will do, aigai! 
Cheryk basmady evol ke, aygay: If you don't have a quarter arshin, aigai!

Ok s'umyk arakty d'araloz, aygay! One shot of vodka will do, aigai!

Ok s'umyk arakty evol ke, aygay: If you don't have a shot of vodka, aigai:

Ok s'umyk sur"yosty yaraloz, One small glass of beer will do! aygay!

Ok s'umyk sur'yostyevolke, aygay: If you don't have small glass of beer, aigai

Yshtan kal"yosty yaraloz, aygay! A belt will do, aigai!

Oydole potom so korka, aygay, Let's visit another house, aigai,

Kuasam no n'an'de s'iyny, aygay! We're going to eat a pasties, aigai! Kuasam n'an'n'osty n'an'kayik, Your pasties is [delicious] like aygay, bread, aigai, Ach`ides vylem lul kaiyik aygay! And you are so warm-hearted, aigai!

(Munkácsi 1952: 34-35)

Chuk was a significant element in the northern Udmurt kren' yuon ritual (lit: feast of horseradish), held on the next day after Maslenitsa (Vladykina, Glukhova 2016: 100). A group of women, walking from house to house, was guided by the "woman's foreman", an old man in a birchbark cylinder or conical cap with chuk sewn on (Pervukhin 1888: 110) and with a staff in his hand, to which his wife tied a fabric shred, tobacco pouch or kerchief (see photo 5). This man received gifts also called chuk in every home (see photo 6).

The chuk kurany / chacha bichany (lit: collect chuk, i.e. cloths and baby toys) custom, when girls collected cloths, was specific among the northern Udmurts on Great Thursday (Vel'ikochetverik/ Tshukmuncho uy), and involved various beliefs and rituals based on apotropaic and cleansing types of magic. According to mythological 
ideas, at night between Wednesday and Thursday during the Passion week sinister forces (werewolves, wizards, ancestors) have the opportunity to harm people and livestock. From the early morning female teenagers gathered in small groups, wrapped their wrists with red thread and walked from house to house asking for multicoloured woollen threads or shreds. At every home, the hostess tied 'gifts' to the threads the function of which was to keep the girl's family from feeling tired during summer haymaking. Shreds were used to tailor clothes for dolls or make a zavertka shred doll. Toys were provided with apotropaic functions that would protect their owners from illnesses and misfortune (Vladykina, Glukhova 2011: 139; also see Popova 2009: 13).

As an obligatory ritual attribute, chuk is present during the Easter celebration (Bydzh'ym nunal / Akashka - lit: Great Day/ festival of spring greeting), which in the $19^{\text {th }}$ century was celebrated for a whole week in the village of Nizhnyaya Ucha, Mamadysh Uyezd in the Kazan governorate (now the Republic of Tatarstan). On the second day of the Akashka-d'uon ritual (spring greeting feast) in the afternoon there were games and outdoor festivities valen d'umshan, during which young men rode on horses from house to house accompanied by women playing the Udmurt zyther krez'. A few old men accompanied them. On the doorstep of each house they received eggs, pancakes (tabans) and egg flatbreads, praying to God: "May [the Lord] protect this home from bad luck, evil, and fire". After the prayer, the host plied the guests with food and drink. Initially it was eaten by the old men who had recited the prayer, then by the young men. During the visits, eggs and towels were gathered as chuk from newly married. After the visit, young men and young women rode to the fields and rode around their plots. Then races began, with the gathered towels awarded as prizes for the winners (Munkacsi 1887: 170). Back in the first half of the $20^{\text {th }}$ century in Staraya Sal'ya village, Kiyasovo district, horse races (puchy-vortton, lit: 'bud races') were held on the third day of the Easter holiday (Bydzh'ym nunal). In the morning, chil- 
dren visited young married women and collected chuk in the form of towels (kuz'kyshet), kerchiefs (kyshet) and head towels (chalma) to present to the winners (Vladykina, Glukhova 2011: 164-166).

According to modern field documents the farewell ceremony of Akashka (Akashka kel'an), the first spring holiday in the village Nizhniye Yurashi, Grakhovo district, is marked by young women marching outside the village. They 'see off' the holiday by singing the ritual song, each girl holding a staff with shreds of cloth knotted around it which she obtained when visiting the houses and gathering eggs, cereals, milk and butter to prepare a common meal. Once the holiday is over the pole was either dug into the ground or thrown away (Pchelovodova 2015: 111).

\section{Chuk in rituals of gender and age socialisation of youth}

The abovementioned examples of gifts in the form of chuk given as part of calendar rituals are related to gender and to age-related socialisation of village community members. Chuk is presented to young men and girls before their marriage, often by young married women, constituting for the former a gift, for the latter a sacrifice.

Chuk as an offering or gift is also part of the autumn pukis' kuno / kubo voz'mas' (lit: sitting visitor / 'guarding the distaff') youth ritual in the central regions of Udmurtia (Sharkan and Yakshur-Bod'ya districts). After finishing work in the field a young woman was invited by her god-parents for a get-together. On the appointed day they took her, with one or two of her close friends, 'to guard the distaff'. Usually the 'guest' used to knitted and did other handwork for a month. Afterwards a gift ritual was organised, which turned into a kind of 'inspection' of the prospective bride. The god-parents' relatives visited their place, as well as the woman's parents. At that time, the god-parents prepared a new decorated distaff. The guests, telling jokes and casting spells, tied 
and/or put presents onto the distaff (see photo 7). The first were the godparents, then the young woman's parents and then the rest of the guests. After the gift ceremony, the distaff was carefully and tightly wrapped in a piece of cloth and turned into a 'doll'. During the feast, everyone tried to cheat the woman and her friends in order to steal the chuk, the distaff with the gifts attached. If they succeeded, the woman had to buy them off with homemade wine. If the 'guards' were considered guilty of stealing the chuk, they were asked to sing and dance. At the end of the celebration, the woman was blessed. At home, the presents were unwrapped and handed to the mother. These gifts later became part of the bride's dowry. In general, this type of get-together was apparently a preparation for the wedding ritual. This is also shown by the woman being covered with a kerchief with fringes, a shawl or a simple kerchief before being taken to her godparents for get-togethers. The symbolism of this custom ties in with the marriage offering ritual and the affianced bride being taken to the groom's house ${ }^{3}$.

In the central regions of Udmurtia (the Igra, Debesy and Sharkan regions) there is still a post-wedding tradition of offering work tools to the young married woman, for example a rake (mazhes) or a scythe (kuso). Before haymaking starts, the bride's mother visited her relatives with the rake in hand and the relatives would attach mazhes tug / mazhes chuk. Decorated tools were taken to the bride and symbolically used on the first day of haymaking.

An interesting example of chuk is used at the Udmurt wedding feast (s'uan). Afterwards, the bride relatives give chuk in the form of clothes to the groom's friends (s'uanchi) who put them on over on top of their own clothes, with men wearing women's dresses and wrapping themselves in kerchiefs, while women dress in men's shirts, trousers and hats. Girls present chuk to young unmarried men, fastening bow-like bands to their head-dresses. Two or three weeks later the chuk is returned to the owners with a gift wrapped 
into the clothes (candy, gingerbread, pastry) (Khristolyubova 1995: 187).

Chuk also fulfilled the role of gift for deceased parents in the commemorative ritual of yyr-pyd s'oton (the giving away of the head and legs (of an animal)). A basket containing bones, small coins and fabric pieces such as dress-like or shirt-like pieces of fabric were taken to the roots of a particular tree (Vladykin 1994: 172).

\section{Chuk/Tug in the recruit ritual}

Chuk/Tug is used as part of the 'seeing off' ceremony that is performed before a young man joins the army. As part of the ceremony, chuk was fixed by hammering in a coin into the central beam ${ }^{4}$. A more archaic version, according to 19th century sources, used a striped ring driven into the beam. The recruit would then chip off a piece of wood from the beam and sew it into his bag as an amulet (Bogaevskiy 1888: 49). In the modern tradition chuk can consist of various items, depending on local tradition. According to the southern Udmurt, the recruit nails satin ribbons and paper banknotes to the beam ${ }^{5}$, and if he has a girlfriend her handkerchief is added. Chuk is nailed or hammered to the beam of the recruit's father's house during the family farewell party. The same ritual of attaching chuk to the main ceiling bean is also performed on the eve of departure at the homes of relatives. Attaching chuk is accompanied by the singing of a recruit tune (l'ekrut gur / saldat gur), which differs in each local tradition. The structure of the texts is punctuated by the motifs of receiving the call-up, being declared fit for service, saying farewell to family and home, and the juxtaposing of peaceful everyday life with the soldier's lot (Zav'yalovo, Malaya Purga, Kiyasovo districts) (Vershinina, Vladykina 2014: 363). In content they are a kind of comment on the ritual: 
Mlemyzmemeymarlyvor(y)dylem What did our mother gave birth

- mumykorez, oy, duryny,

Ml'emyz memey marly vor(y)dem

- mumykorez duryny.

Mumykorez duryny no gorodys'gorode, oy, vetlyny, Mumykorez duryny no kuz' s'uresez l'ogany.

Vayele no, oy, s'otele burchchin gyne, oy, chuk"yostes, Vayele no, oy, s'otele burchchin gyne chuk"yostes.

Burchchin chukty, oy, övöl ke, derem sep no yaraloz, Burchchin chuk"yosty övöl ke, derem sep no yaraloz.

Vayele no, oy, s'otele zarn'i gyne, oy, moloddes, Vayele no, oy, s'otele zarn'i gyne moloddes.

Zarn’iyez ke, oy, övöl uk, chag kes'on purt no yaraloz, Zarn’iyez ke, oy, övöl ke, prostoyez no yaraloz. to us for - oh to forge a beam, Our mother gave birth to us to forge a beam.

To forge a beam from town to town, oh, to move, To forge a beam and to tramp along a long road.

Oh, bring me, oh give me only, oh, silk chuks.

Oh, bring me, oh give me only, oh, silk chuks.

If you don't have a silk chuk, a shred from a shirt will do, If you don't have a silk chuk, a shred from a shirt will do.

Oh give me your golden hammer,

Oh give me your hammer that is golden.

If you don't have a golden one, a knife-scythe will do, If you don't have a golden one, a knife-scythe will do. 
Vayele no, oy, s'otele kuasam bero, oy, pukondes, Vayele no, oy, s'otele kuasam bero pukondes.

Kuasam beroyez ke(y) övöl, prostoyez no, oy, yaraloz, Kuasam beroyez ke(y) övöl, prostoyez no yaraloz.

Ta chuk"yosme mon shukkis"ko til'edly, oy, s'inpel'ly, Ta chuk"yosme mon shukkis'ko til'edly s'inpel'ly.

Tuzon ke no, oy, puks'yloz, tylyyen shukkysa, oy, voz'ele, Tuzon ke no, oy, puks'yloz, tylyyen shukkysa voz'ele.

Ta chuk"yosy tshuzhektiz ke, "Van'a byrem", oy, shuele, Ta chuk"yosy tshuzhektiz ke, "Van'a byrem" shuele.
Oh, bring me, oh, give me your chair oh, with a folding back, Oh, bring me, oh, give me your chair oh, with a folding back.

If you don't have a chair with a folding back, a plain one will do, If you don't have a chair with a folding back, a plain one will do.

This chuk ribbon I'm nailing for you to remember, This chuk ribbon I'm nailing for you to remember.

If it gets dusty, oh, sweep it off with a wing, If it gets dusty, oh, sweep it off with a wing.

If this chuk gets yellow, say "Vanya has died" If this chuk gets yellow, say "Vanya has died".

Gozhnya, Malaya Purga district (Vershinina, Vladykina 2014: 247-248)

According to the beliefs, the more shreds or ribbons a recruit leaves, the more successful his service will be. In the modern tradition, chuk is supposed to be a memento or gift to your native home and to your relatives (s'inpel'/s'inpel'et). Its apotropaic function is 
directly related to the beam and its protective features: "Tug - so mumykorly kuz'ym, mumykor med ut'oz n'i shusa shukko" (Tug is a present to the beam, they are nailed for the beam to protect (the soldier)) (FWM 20176). Before leaving home, the recruit once more touches the beam saying: "Bertonez med adzh'o, dzh'ech s'ures s'ot, ut' mone" (May I see my return, give me a good journey, protect me) (FWM 2017, cf. note 6), "Voz'ma mone, mumykor!” (Wait for me, beam!") (Khristolyubova 1984: 105). The chuk/tug is kept until the soldier returns from the army. Having returned, he visits the houses where he had nailed the chuk ribbons and gives present to the hosts, removing the chuk himself.

In recruit songs, the main function of $c h u k$ as an amulet is to become a substitute for the soul of the young man leaving for the army:

Ta shukkylem, oh, chu"yosme This, oh, my nailed chuk, achim berttoz'voz'ele, please keep it until I get back, Achim ke no, oy, bertyli, If I come back I will rip it off pin'ynym ishkaltysa bas'tylo(y), with my teeth, Achim ke no, oy, bertyli, If I come back I will rip it off pin'ynym ishkaltysa bas'tylo(y). with my teeth.

Tuzon ke no, oy, puks'yliz, tylyyen tshushsa, oy, voz'ele, Tuzon ke no, oy, puks'yliz, tylyyen tshushsa, oy, voz'ele.

Adzh'dzh'emdy ke, oy, potyliz ishkaltysa kushtele, Ishkaltysa kushtele no Volga shure kushtele.
If it gets dusty, oh, sweep it off with a wing,

If it gets dusty, oh, sweep it off with a wing,

If you want to see me, pull it out and throw down, Pull it out and throw it into the Volga. 
Volga shure kushtidy ke, so mon dory med lyktoz, Volga shure kushtidy ke, so mon dory med lyktoz.
If you throw it into the Volga, may it float to me, If you throw it to the Volga, may it float to me.

Staraya Burozhik"ya, Malaya Purga district region (Vershinina, Vladykina 2014: 44)

Ta shukkylem no, oy, chuk"yosme asme voz'many,oy, This nailed chuk I nail to wait shukkis'ko,

Ta shukkylem no, oy, This nailed chuk I nail to wait chuk"yosme asme voz'many,oy, for me to come back. shukkis'ko.

Achim ke no, oy, bertyli, pin'ynym ishkaltysa, oy, bas'tylo, Achim ke no, oy, bertyli, pin'ynym ishkaltysa, oy, bas'tylo.

Tuzon ke no, oy, puks'yliz, dzh'az'eg tylyyen, oy, shukkele, Tuzon ke no, oy, puks'yliz, dzh'az'eg tylyyen, oy, shukkele.

Tshuzhektyny, oy, kutskiz ke, "pimy mözme", oy, shuody,
When I come back, I shall pull it down with my teeth, When I come back, I shall pull it down with my teeth,
If it gets dusty, oh, sweep it off with a goose's wing, If it gets dusty, oh, sweep it off with a goose's wing,

If this chuk goes yellow, you will say "our son is homesick" 
Tshuzhektyny, oy, kutskiz ke, If this chuk goes yellow, say "pimy mözme", oy, shuody, "our son is homesick"
Algancha-Igra, Malaya
Purga district (Vershinina, Vladykina 2014: 250)

The nailing process was accompanied by a fortune telling for the recruit. After the amulet was fastened to the beam, the recruit was to throw a knife or a hammer back over his shoulder in such a manner that it didn't fall flat: a knife was to supposed to stick into the floor, and the hammer to stand on its head (yyr yylaz sultyny kule):

Tuzh s'ekyt uk, tuzh s'ekyt uk pukon vyle tubylon, Eshsho s'ekyt, oy, vylem uk mumy korez durylon.

Vaye(y) al'i, s'otele azves' nydo purttestes, Vaye(y) al'i, s'otele(y) uk zarn'i nydo molottes.

Oy s'ekyt uk, tuzh s'ekyt uk mumy korez duryny, Oy s'ekyt uk, tuzh s'ekyt uk mumy korez duryny.

Berto meda, ug n’i meda: purte yyr yylaz med us'oz,
Oh it's so difficult to climb onto the chair, It's much harder to forge the beam, it turned out,

Oh give me a knife with a silver handle, Oh give me a hammer with a golden handle.

Oh it's so difficult to forge the beam,

Oh it's so difficult to forge the beam.

Shall I come back or not: may my knife stick into the floor (lit: 'fall on its head'), 
Berto meda, ug n’i meda: purte Shall I come back or not: may yyr yylaz med us'oz, my knife stick into the floor.

Bertonez ke öy adzh'dzh'y n'i, If I'm not destined to return purte medaz byshkalsky, home, may my knife not stick into the floor.

Bertonez ke(y) ug adzh'dzh'y If I'm not destined to return n'i, purte yyr yylaz medaz us'. home, may my knife not stick into the floor.

Berto (y) al'i, berto(y) al'i anay- I will come back, I will come atay yurt"yosam, back to my parent's home, Berto (y) al'i, berto(y) al'i anay- I will come back, I will come atay yurt"yosam. back to my parent's home (my knife stuck into the floor).

Kechevo, Malaya Purga district (Vershinina, Vladykina 2014:283)

The chuk nailed into the beam in its semantics equals the recruit's actions with a tree. In certain villages, recruits nailed a piece of cloth or a coin into a birch or a fir tree at the sacred places of the village. Thus, the coins might symbolise both a gift to a tree (Shutova 2001: 56; Shutova 2004: 159), and the person's involvement in his native surrounding world, part of it being a tree, which would guard the soldier while he was in a foreign land. The tree, like a chuk on a house beam, became a substitute for a person who had left his native land, although the tree version was apparently more archaic. This appears in Udmurt micro toponyms, among which are the names of trees, such as yyro kyz, lit: 'fir with a head'; chyrtyyo kyz, lit: 'Fir with a neck; kartuzo kyz, lit: 'fir with a peak cap'. "During the seeing off, the recruit climbed a fir and cut off a few of the upper branches, stripping the truck. The upper branches were 
left and the tree began to look like a human. This was to be done in such a manner that the tree continued to grow. It was believed that if after this ritual the tree withered, this young man would not return, and if the tree did not wither he would return from service" (Vladykina, Kirillova 2017: 238; see also Vladykina 2003: 56-57). ${ }^{7}$

Another version of chuk in a recruit's ritual was gifts from friends and relatives: towels, a tobacco pouch, handkerchiefs, ribbons. Towels were hung around his neck, ribbons and bunches of ribbons were fixed to the clothes or to his hat ${ }^{8}$. The recruit waved with towels during farewell party when well-wishers led him through the village to the outskirts and waved with towels until he was out of sight.

\section{Conclusions}

Analysis of the everyday and ritual uses of various forms of woven item (ribbons, shreds, towels, women's head towels) or items used in textile craft (thread or a brush made from thread) has allowed us to show chuk as a multifunctional attributive symbol in the traditional culture of the Udmurt. Its manifold use is apparently due to overlapping of homonyms. The Udmurt word chuk meaning 'thread/yarn', 'brush / bunch of multicolour threads', 'fringe', 'bands', 'shreds', 'towels, blankets, kerchiefs' was borrowed from the Tatar chuk/tyuk 'brush', 'cluster'. Chuk meaning 'sacrifice', from bulgar chuk "tzh" (Tarakanov 1981: 49) by its function. As a result of this intermingling, depending on the situation, chuk is a mark or amulet, sacrifice or gift, symbol and sign of a soul substitute.

\section{Informant}

Anna Egorovna Lekomtseva, born in 1930, Udmurt, native of the Lonki-

Vortsy of Igra district, has lived in Sep village of Igra district since 1951, education 7 classes. 
Photo 1. Chuk on the embroidered head towel chalma (mid-twentieth century, Varzi-Yatchi, Alnashi district, Udmurtia). Photo by Tatiana Panina, 2018 (materials from the fund of the Architectural and Ethnographic open-air museum "Ludorvay").

Photo 2. Chuk on the embroidered head towel chalma (early twentieth century, Mozhga, Mozhga district, Udmurtia). Photo by Galina Glukhova, 2017 (materials from the folklore archive of the Institute of Udmurt Philology, Finno-Ugric Studies and Journalism, Udmurt university).
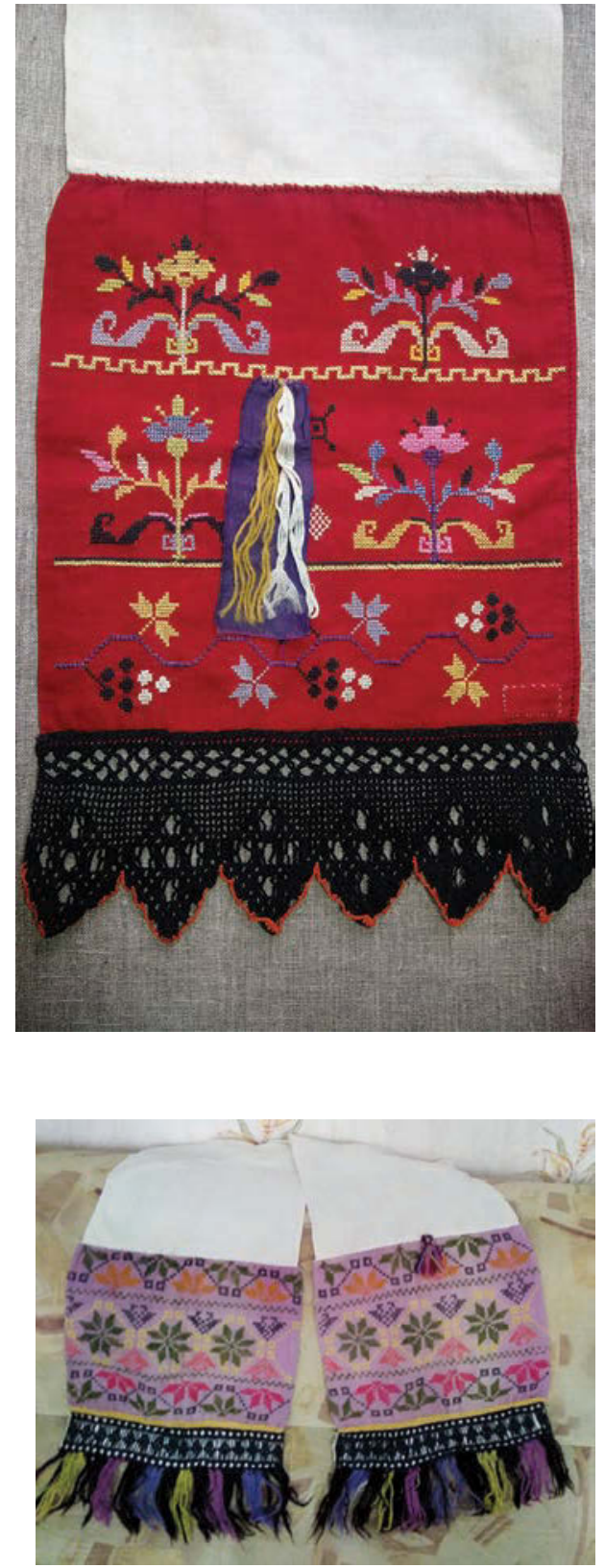


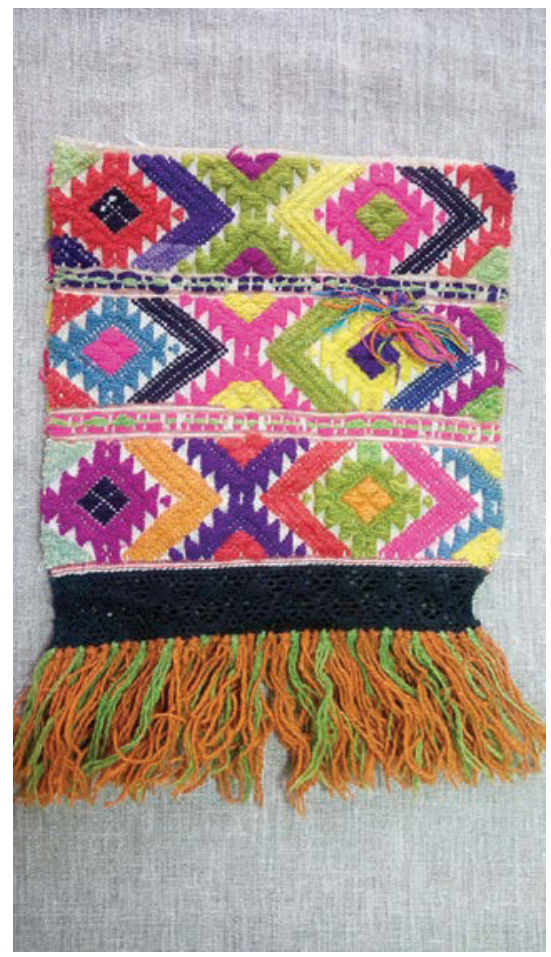

Photo 3. Chuk on the woven head towel chalma (end of the nineteenth century, Novaya Mon'ya of Sarapul Uyezd, Vyatka Governorate). Photo by Tatiana Panina, 2018 (materials from the fund of the Architectural and Ethnographic open-air museum "Ludorvay").

Photo 4 (below). Chuk on traditional dresses (from left to right: linen dress - mid-twentieth century, village of Bal'zashur, Mozhga district, Udmurtia; woolen dress - midtwentieth century, Buro-Zhik'ya, Malaya Purga district, Udmurtia; linen dress - mid-twentieth century, village of Bob'ya-Ucha, Malaya Purga district, Udmurtia). Photo by Tatiana Panina, 2018 (materials from the fund of the Architectural and Ethnographic open-air museum "Ludorvay")

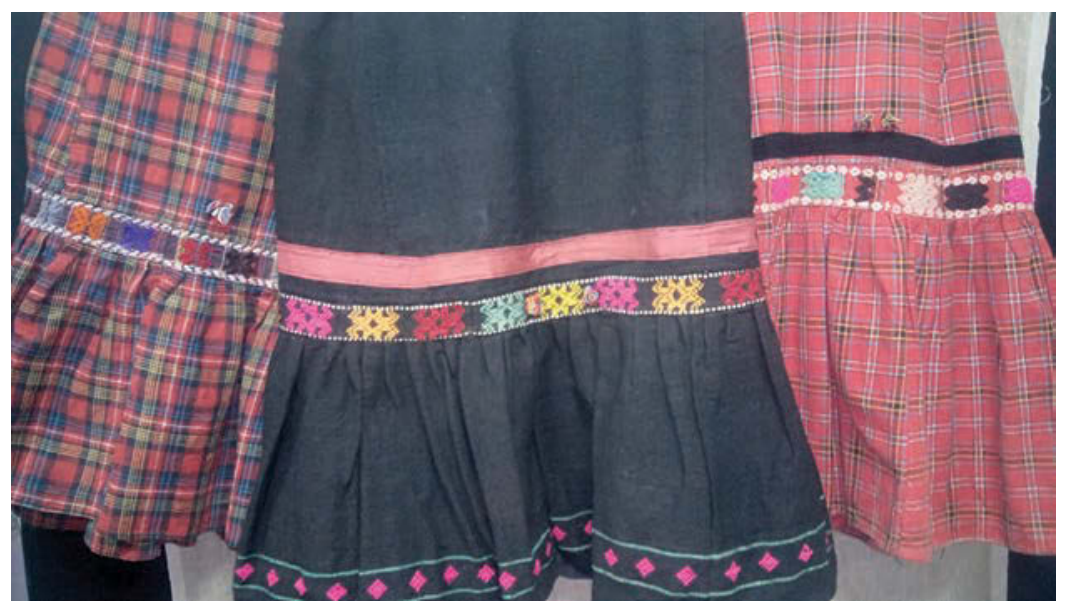



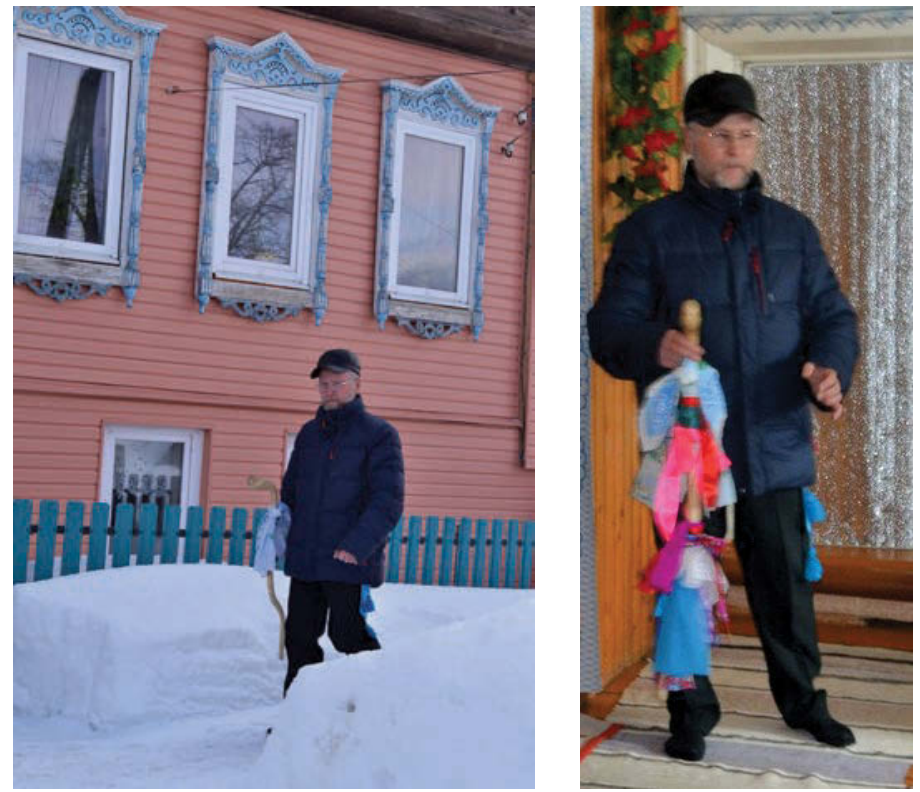

Photos $5 \& 6$. Chuk on the staff in the reconstructed ritual kren'yuon before and after visiting houses (village of Kel'dysh, Sharkan district, Udmurtia). Photo by Galina Glukhova, 2017 (materials from folklore archive of the Institute of Udmurt Philology, Finno-Ugric Studies and Journalism, Udmurt university).

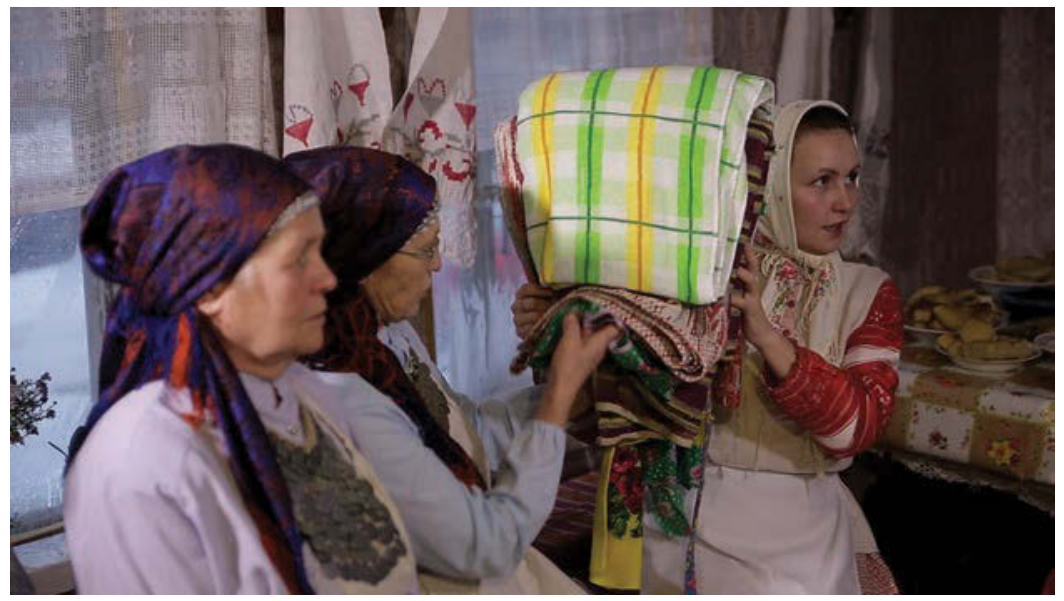

Photo 7. Chuk on the distaff in the reconstructed ritual kubo voz'man (village of Dyrdashur, Sharkan district, Udmurtia). Photo by N. Sharychev, consulted by Galina Glukhova, 2017 (Republican House of Folk Art - House of Youth). 


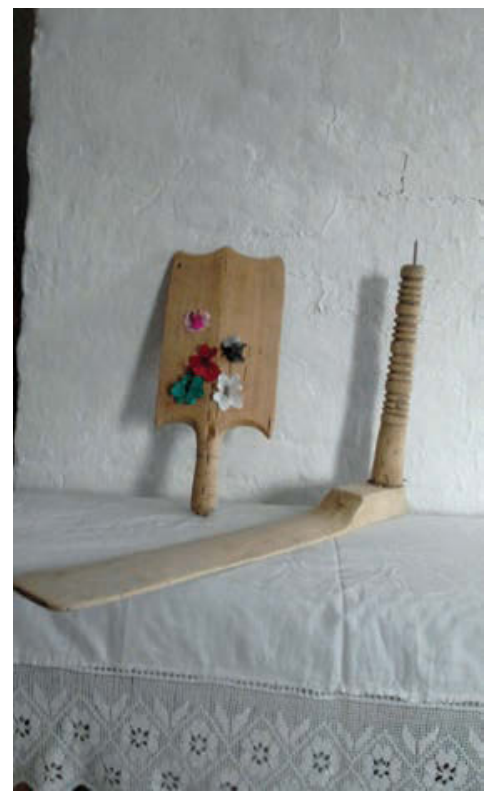

Photo 8. Chuk / chacha on the distaff bride's dowry (village of Dyrdashur, Sharkan district, Udmurtia). Photo by Galina Glukhova, 2017 (materials from the folklore archive of the Institute of Udmurt Philology, Finno-Ugric Studies and Journalism, Udmurt University).

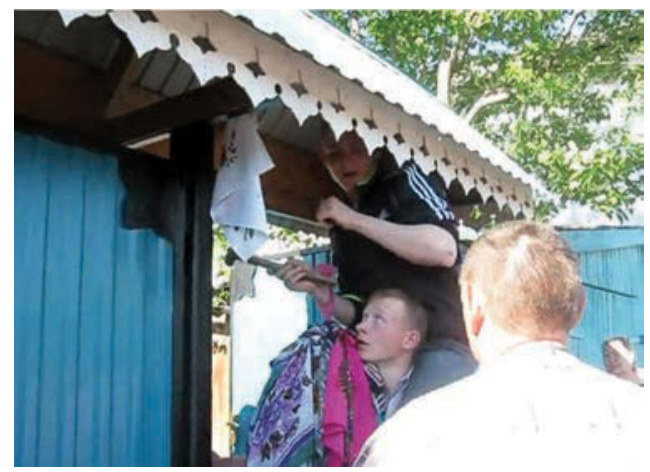

Photo 9. Recruit's chuk (village of Kapustino, Malaya Purga district, Udmurtia). Photo by Galina Glukhova, 2017 (materials from the folklore archive of the Institute of Udmurt Philology, Finno-Ugric Studies and Journalism, Udmurt University). 


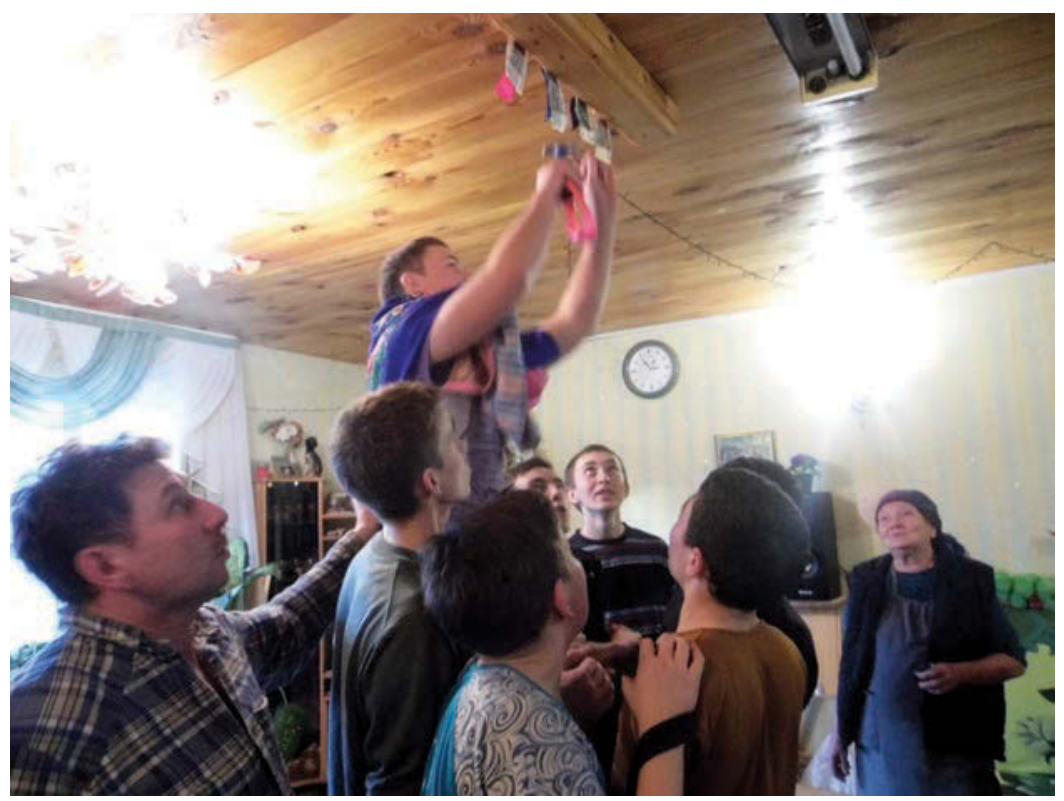

Photo 10. Recruit's chuk (village of Varkled-Bod'ya, Agryz district, Tatarstan). Photo by Galina Glukhova, 2017 (materials from the folklore archive of the Institute of Udmurt Philology, Finno-Ugric Studies and Journalism, Udmurt University).

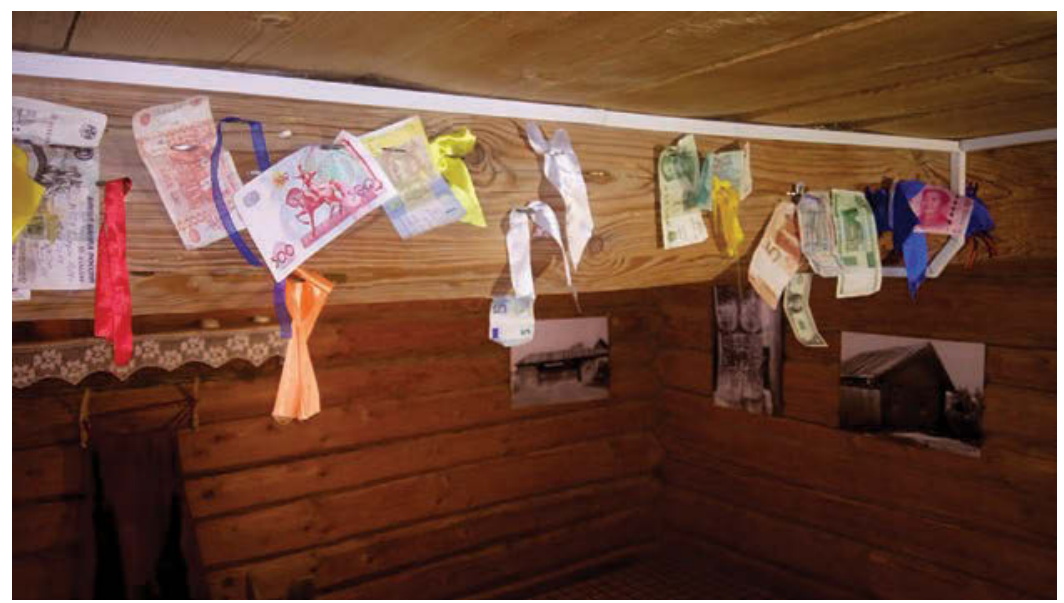

Photo 11. Chuk nailed to the central beam of a traditional house in the Architectural and Ethnographic open-air museum "Ludorvay". Photo by Tatiana Panina, 2018. 


\section{Notes}

1 We thank L. Fedorova, native of Kuz'ebayevo village, Alnashi region, Udmurt Republic, associate professor at the Udmurt State University.

${ }^{2}$ It's an interesting fact that the Udmurt language preserved the expression gord chuk dumom no s'iyom (lit: we'll tie the chuk up and eat it) in the meaning of 'draw blood', 'stab', 'slaughter an animal'. The circumlocution was used in order to conceal a situation since it was assumed that livestock, like the surrounding world, understand human speech (Vladykina 2008).

3 The distaff could be presented to the bride during the wedding feast or after the wedding as a dowry. In this case chuk could be of various forms (see photo 8).

${ }^{4}$ If there was no beam in the modern house construction, chuk/tug is nailed to the upper part of the door or gate (photo 9) frame, or to a wood bar nailed to the ceiling to imitate the beam (photo 10).

5 This tradition has found an unexpected expression in a new custom, performed by visitors to the Ludorvay Architectural and Ethnographic open-air museum, who nail chuk to the central beam of a traditional house (see photo 12). We express our gratitude to the director of the museum Tatiana Shklyaeva for giving us an opportunity to work with the museum's collection.

${ }^{6}$ Collected from A. E. Lekomtseva, born in 1930 in Lonki-Vortsy, Igra district, Udmurtia, and living in Sep, same district, by T. I. Panina.

7 Customs to break a birch or a fir tree in a recruit's seeing off rites among Russians from Vologda region (Yarygina 2001: 151), recruit's karsikko in the Karelian tradition (Konkka 2013: 96-103).

8 See the tradition of gift and treatment of presents among Russians from the upper river Kama, in particular, a way to belt oneself with towels and fixing of bands, kerchiefs and towels on a pole (Chernykh 2001: 148-149).

\section{References}

Bogaevskiy, P. 1888. Ocherk byta Sarapul'skikh votyakov [Essay about the Everyday Life of the Sarapul Votyak]. Sb. materialov po etnografii, izdavaemyy pri Dashkovskom etnograficheskom muzee. Vyp. 3. [Collection 
of the Materials of Ethnography Published at Dashkov's Ethnographic Museum. Edition 3]. Moskva: Tip. E. G. Potapova, pp. 14-64.

Chernykh, A. 2011. Povedencheskiye normy v rekrutskoy obryadnosti [Behaviour Norms in the Recruits' Rites]. Muzhskoy sbornik. Vyp. 1. Muzhchina $v$ traditsionnoy kul'ture: Sotsial'nyye $i$ professional'nyye statusy i roli. Sila i vlast'. Muzhskaya atributika i formy povedeniya. Muzhskoy fol'klor. Sost. I. A. Morozov, otv. red. S. P. Bushkevich [Male Collection. Edition 1. Man in traditional culture: Social and professional statuses and roles. Strength and power. Male attributes and behaviour forms. Male folklore. Composed by I. A. Morozov, executive editor S. P. Bushkevich]. Moskva: Labirint, pp. 142-149.

Khristolyubova, L. 1984. Semeynyye obryady udmurtov (traditsii i protsessy obnovleniya) [Family Rites of the Udmurt (Traditions and Processes of Renewal)]. Izhevsk: Udmurtia.

Khristolyubova, L. 1995. Kalyk syam"esty chaklasa: Udmurtskiye narodnyye obychai [Following Folk Customs. Udmurt Folk customs]. Izhevsk: Udmurtia.

Konkka, A. 2013. Karsikko [Cross-Tree]. Petrozavodsk: Izd-vo PetrGU.

Munkácsi, B. 1887. Votják népköltészeti hagyományok [Votyak Folklore Traditions]. Budapest: MTA.

Munkácsi, B. 1952. Volksbräuche und Volksdichtung der Wotjaken [The Folk Customs and the Folk Poetry of the Votyak]. Aus dem Nachlasse von Bernhard Munkácsi. Herausgegeben von D. R. Fuchs. MSFOu, 102. Helsinki: SUS.

Panina, T. 2014. Slovo i ritual v narodnoy meditsine udmurtov [Word and Ritual in the Udmurt's Folk Medicine]. Izhevsk: Udmurtskiy institut istorii, yazyka i literatury Uralskogo otdeleniya Rossiyskoy akademii nauk.

Pchelovodova, I. 2015. Traditsionnyye kalendarnyye obryady udmurtov v usloviyakh sovremennoy derevni (na primere Grakhovskogo rayona Udmurtskoy Respubliki [Traditional Calendar Rites of the Udmurt in the Modern Village (Based on the Example of Grakhovo Region of the Udmurt Republic)]. Vestnik Udmurtskogo universiteta. Seriya Istoriya $i$ filologiya [News Messenger of the UdSU. Series History and Philology]. Vol. 25 (6), pp. 109-113.

Pervukhin, N. 1888. Eskizy predaniy i byta inorodtsev Glazovskogo uyezda [Essays about the Legends and the Everyday Life of Non-Russians of the Glazov District]. Eskiz 2: Idolozhertvennyy ritual drevnikh 
votyakov po ego sledam $\mathrm{v}$ rasskazakh starikov i v sovremennykh obryadakh [Essay 2: The Idol-Sacrificial Ritual of the Ancient Votyak in Its Traces in the Stories of Elder People and in Modern Rituals]. Vyatka: Gubernskaya tipografiya.

Popova, E. 2009. Antropomorfnyye figury v sovremennoy znakharskoy praktike besermyan [Antropomorphic Characters in a Modern Witchcraft Practice of the Besserman]. Traditsionnaya kul'tura [Traditional Culture] 1, pp. 11-19.

Shutova, N. 2001. Dokhristianskiye kul'tovyye pamyatniki v udmurtskoy religioznoy traditsii [Pre-Christian Cult Monuments in Udmurt Religious Tradition]. Izhevsk: Udmurtskiy institut istorii, yazyka i literatury Uralskogo otdeleniya Rossiyskoy akademii nauk.

Shutova, N. 2004. Svyatilishcha v okrestnostyakh d. Malyy Dasos: $\mathrm{K}$ voprosu o tipologii i semantike besermyanskikh kul'tovykh mest [Sanctuaries in the Outskirts of the Village Malyy Dasos: About the Typology and Semantics of the Besserman Cult Places]. Kul'tovyye pamyatniki Kamsko-Vyatskogo regiona: Materialy i issledovaniya: Sb.st. Otv. red, avt. predisl. N. I. Shutova [Cult Monuments of the Kama-Vyatka Region: Materials and Research: Collection / Exec. ed. N. I. Shutova]. Izhevsk: Udmurtskiy institut istorii, yazyka i literatury Uralskogo otdeleniya Rossiyskoy akademii nauk, pp. 154-166.

Tarakanov, I. 1981. Inoyazychnaya leksika $v$ sovremennom udmurtskom yazyke: Uchebn. posobiye [Foreign Language Lexicon in the Modern Udmurt Language: Study Guide]. Izhevsk: UdGU.

Vereshtchagin, G. 2000. Sobranie sochineniy: V $6 t$. [Collection of Works: In 6 Volumes]. T. 3: Etnograficheskie ocherki. Kn. 2. [Ethnographic Articles. Book 2]. Izhevsk: Udmurtskiy institut istorii, yazyka i literatury Uralskogo otdeleniya Rossiyskoy akademii nauk.

Vershinina, E., Vladykina, T. 2014. Pesni yuzhnykh udmurtov. Vyp. III [Songs of the Southern Udmurt. Edition III]. Izhevsk: Udmurtskiy institut istorii, yazyka i literatury Uralskogo otdeleniya Rossiyskoy akademii nauk.

Vladykina, T., Glukhova, G. 2011a. Dni nedeli v sisteme predstavleniy udmurtov o vremeni [The Days of the Week in the Time Apprehension System among the Udmurt]. Ezhegodnik finno-ugorskikh issledovaniy. Vyp. 3 [Annual of Finno-Ugrian Research. Edition 3]. Izhevsk, pp. 38-54.

Vladykina, T., Glukhova, G. 2011b. Ar-god-bergan: Obryady i prazdniki udmurtskogo kalendarya [Year-Circle: Rituals and Celebrations of the Udmurt Calendar]. Izhevsk: Udmurtskiy universitet. 
Vladykina, T., Kirillova, L. 2017. "Imennyye derev'ya" (nimtulo pispu) v mikrotoponimii udmurtov ["Name Trees" (Nimtulo Pispu) in the Microtoponimy of the Udmurt]. Nauchnyy dialog [Scientific Dialogue] 11, pp. 232-246.

Vladykina, T. 2003. Fol'klornyy tekst v mifologicheskom kontekste [The Folklore Text in a Mythological Context]. Udmurtskaya mifologiya [Udmurt Mythology]. Izhevsk: Udmurtskiy institut istorii, yazyka i literatury Uralskogo otdeleniya Rossiyskoy akademii naukб, pp. 54-66.

Vladykina, T. 2008. Mifologiya vizual'nogo i akusticheskogo v kommunikativnom povedenii udmurtov [Mythology of the Visual and the Acoustic in Communicative Behaviour of the Udmurt]. Vestnik Udmurtskogo universiteta. Seriya Istoriya i filologiya. Vyp. 1 [News Messenger of the UdSU. Series History and Philology. Edition 1]. Izhevsk.

Yarygina, E. 2011. Kologrivskiy rekrutskiy obryad [Kologrivsky Recruit Rite]. Muzhskoy sbornik. Vyp. 1. Muzhchina v traditsionnoy kul'ture: Sotsital'nye i professional'nye statusy i roli. Sila i vlast'. Muzhskaya atributika $i$ formy povedeniya [Male Collection. Edition 1. Man in Traditional Culture: Social and Professional Statuses and Roles. Strength and Power. Male Attributes and Behaviour Forms. Male Folklore]. Sost. I. Morozov, otv. red. S. Bushkevich [Composed by I. Morozov, Executive Editor S. Bushkevich]. Moskva: Labirint, pp. 150-151.

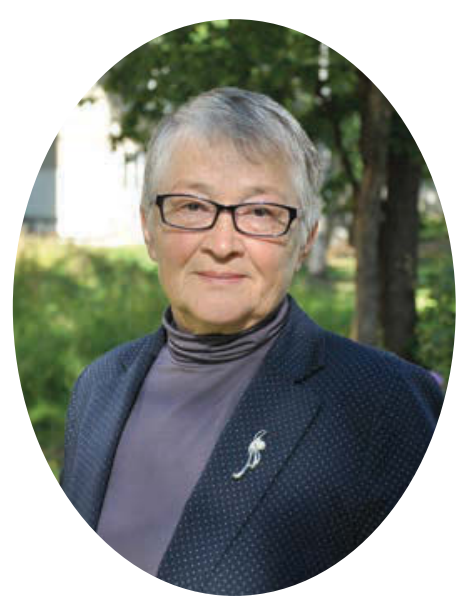

Tatiana Vladykina is ( $\mathrm{PhD}$ hab) a professor and leading researcher at the Udmurt Institute for Research in History, Language and Literature (Udmurt Federal Research Centre of the Ural Branch of the Russian Academy of Sciences). She has covered the range of topics in Udmurt folkloristics, especially mythology, specialising both in genre and in the treatment of the most important topics across genres.

e-mail: tgvladykina@mail.ru 


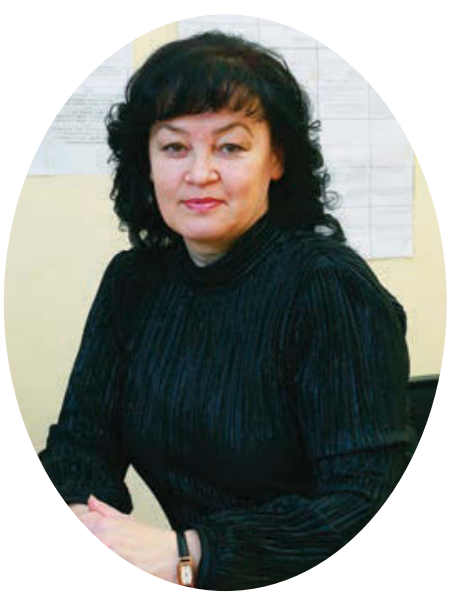

Galina Glukhova ( $\mathrm{PhD}$ ) is an associate professor and director of the Institute of Udmurt Philology, Finno-Ugric Studies and Journalism of Udmurt State University and teaches Udmurt literature and folklore. Her main field of interest is related to research on Udmurt and FinnoUgric folklore, Udmurt traditional culture, and the interaction of Udmurt folklore and literature.

e-mail: galant@udm.ru

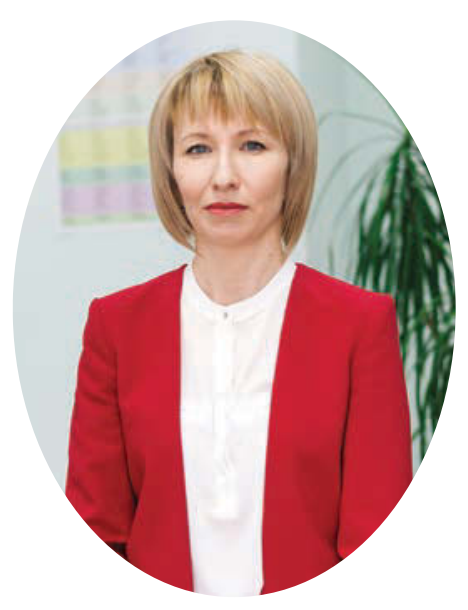

Tatiana Panina (PhD) is a researcher at the Department of Philological Studies, at the Udmurt Institute for Research in History, Language and Literature (Udmurt Federal Research Centre of the Ural Branch of the Russian Academy of Sciences). She is interested in traditional Udmurt culture, more precisely in folk medicine, incantation tradition and more recently dreams. Panina teaches English at the Izhevsk State Medical Academy. e-mail: tipanina@mail.ru 


\title{
A Contemporary Commemoration of the Dead: Yyr-pyd s'oton in Southern Udmurtia
}

\section{Denis Kornilov}

e-mail: denkornilove@gmail.com

\begin{abstract}
The subject of the article is a description of one of the major commemorative rituals of the Udmurt, the yyr-pyd s'oton, 'giving away of the head and legs (of an animal)' supplemented by pictures. This particular traditional commemoration with innovative elements was conducted in the village of Bagrash-Bigra in Malaya Purga district, Udmurt Republic in September, 2021 in honour of those who died during the Great Patriotic War ${ }^{1}$.
\end{abstract}

Keywords: ancestor commemoration, photographic evidence, tradition and innovation, Udmurt, yyr-pyd s'oton ritual

The yyr-pyd s'oton 'giving away of the head and legs (of an animal)' ritual is one of the major rituals in the system of the ancestor cult that regulates - according to belief - relationships with dead ancestors in time and space. It is also known in various local traditions by other names: val s'uan 'the steed's wedding', myddorin / ber s'uan 'the wedding inside out / the last wedding', ly potton 
'taking out / bringing out of the bones (of the sacrificial animal)' (Atamanov, Vladykin 1985; Vladykin, Churakova 1986; Vladykin 1994: 169-179; Minniyakhmetova 2000: 57-59; Shutova 2001; Vladykina 2004; Sadikov 2004: 123; Anisimov 2017: 168-271; Vladykina et al. 2021; and Anisimov 2021 in this issue).

Unlike other annual calendar-connected memorials such as kis'ton 'libation', the ritual is aimed at a one-time commemoration of dead parents:

...everyone in their life was obliged to go through this rite at least once. A cow was sacrificed for the mother, a horse for the father. It was believed that with the parents' commemoration (three, five, seven years after the death and later, but not earlier than a year after the funeral) 77 generations were being commemorated (77 vyzhy kulem"yos). These ancestors might be supportive towards the living if they are commemorated, or, on the other hand, could cause damage and do harm if disrespected. The time of the ritual was supposed to correspond strictly with the calendar. Usually it was held in deep autumn, at the time of butchering; according to an unspoken instruction the date was supposed to be before the winter solstice, i.e. before December $25^{\text {th }}$. We find local reminders of this rite in the form of cooking ritual dishes from the head and legs of the butchered animal during winter holidays not later than Maslenitsa (Vladykina, Glukhova 2011: 74).

The commemoration was included in a number of family rituals when a particular family organised a sacrifice and invited their patrilineal relatives, the böl'ak. It was thought that the late parents protected the livestock making the sacrifice of a large animal obligatory. The basic stages of the ritual were the butchering of the animal and the cooking of sacrificial body parts, i.e. the head and the legs which, it was believed, were the 'skeleton' of the animal 
and were endued with the ability to transfer its soul so that it could set off and pass from this world to the other. All the family, as well as the invited kin, took part in the banquet. After being separated from the flesh the large bones and skull were collected in a basket and the family put them together with kumyshka (moonshine), bits of ritual dishes, coins, basma sep (fabric shreds) cut by scissors but not woven together, tiny dresses and a shirt. The feast was accompanied by a special song that addressed the dead to receive the sacrifice, with the sacrifice characterised as "fast running", "gold/ silver hooved", as having "golden horns" or "an udder with six nipples" (Vladykin, Churakova 1986: 129-133). The basket was taken out of the yard on a sledge by a 'married couple', a pantomime of a male-female duo. The procession consisted of a few people basically of old age and children going to a special place marked by a tree, most frequently a fir tree. The large bones and the skull were hung on branches, small bones and the content of the basket was piled up at the roots. On returning to the village, the procession says of those who were commemorated: auntie (name) or uncle (name) said that they lived well and wished to everybody health, wealth and happiness.

Time induces changes in the practice of rituals. Tradition doesn't necessarily become dogma, it can change depending on life conditions. We had the opportunity to confirm this using the example of the yyr-pyd s'oton commemorative ritual in Bagrash-Bigra village in the Udmurt Republic ${ }^{2}$.

Malaya Purga district is one of the southern districts of Udmurtia. Here some traditions are still alive or are being revitalised. Specifically in this village the position of elder of the clans and of the elected elder of the village has been re-established, a position currently held by former history teacher Anatoliy Yakovlevich Matveev. A unique building was built by the citizens, according to the veme custom, to become the village museum, the Daur shykys culture centre (Photo 24). Many members of the village community can speak about the history of the village through the history of 
their families. Thus, Vladimir Fedoseevich Botnikov, former engineer, remembers that his clan includes almost 200 people. He was able to remember the details of many family calendar rituals, organize them and tell young people about them (Photo 20).

According to Vladimir Matveev the idea of holding a commemorative ritual in honour of the Great Patriotic War ${ }^{3}$ dead was raised a long time ago: "Many of them even didn't have time to form families. Who could remember them but us? It's our duty. Some of them have families: wives and children. But many of them are not alive anymore". This idea was never more suitable than at the $75^{\text {th }}$ anniversary of victory: "An odd number of years should pass for a yyr-pyd s'oton ritual, both seven and five are the numbers that fit. So we decided this year to commemorate all our dead". They visited all families whose relatives went to the Army and didn't return, announcing a gathering of donations and putting out a special box at the village shop (Photo 3). The wish to perform this ritual in spring coincided with coronavirus prohibitions. But the promise was made and it made many citizens of the village restless. Failure to keep this promise, according to the tradition, caused undesirable consequences such as illness, livestock deaths and misfortune in many undertakings. This is why in more or less favourable circumstances the decision was made to conduct the ritual together with the spring-summer vös' ritual in honour of the end of sowing and to promote a good harvest (which was also not held because of quarantine measures). The combining if the rituals doesn't seem to fit the framework of tradition, but what was thought and said had to be fulfilled. A date and place were agreed: September $12^{\text {th }}$ in the gully called Bign'uk, where formerly rituals were performed (Photo 1). The organisers tried to take into account the distance from the villages of Bagrash-Bigra and Orlovo (Udm. Orloy) so that elder people would be able to attend the ceremony. Although the day chosen was at the weekend, there were fewer participants than expected, which can be explained as being the result of the general quarantine situation. 
The location used to host the cheka vös' commemorative ritual, in which all ancestors were commemorated. Everyone from the village attended this ritual. But yyr-pyd s'oton is a commemoration of a particular family, commemorating the parents, the father or the mother, the husband or the wife. One day before the ritual, the heads of the kin groups, böl'ak kuz'oos, chose a sacrificial priest, called the kuris' (literally the one who begs/prays). Two assistants were appointed from the family of Bagrash and Akan to kill the sacrificial animal, the sugymlyk vandis' (literally stabbing a sacrifice - sugymlyk (Tat.) is a sacred animal fed for butchering, Tarakanov 1993: 114), because, according to the tradition, the sacrificial priest could not participate in this process. Cooks were also appointed.

With the donations from the population, both a ram (for the vös'ceremony) and a young bull (for the yyr-pyd s'oton ritual) were bought from the villagers. The ram was slaughtered at the ritual place, the bull in the village. Meat from the ram and the head of the calf were cooked in separate cauldrons (Photos 2,4). The sacrificial food for the vös'ceremony was sanctified separately (Photos 15-17).

An interesting detail about the surroundings of the ceremonies was the 'table' and the specially painted huge cable adapted for this ritual. It was brought to the location on a cart drawn by a tractor, as with the rest of the paraphernalia. The table was covered with an old white sheet, which was used at home only in sacred situations (Photo 5). The participants of the ritual put on the table the food offered as a donation (Photos 6, 7). Earlier, during the vös' ceremonies, there were no tables. Dishes with sacrificial food were placed at a specially prepared location under a tree.

It is no less important to pay attention to the garment of sacrificial priest Vladimir Botnikov. To sanctify the dishes and perform the ritual he put on a special frock (Udm. dukes) and headgear, and girt himself with a ritual waist belt (Udm. kuskertton / puto), while special rules had to be taken into account to place the ends of the 


\section{Denis Kornilov}

belt on the side (Photos 8-10). It's noticeable that all ritual clothes are new, and the fabric of the frock has not been bought but woven.

The scenario of the ritual included particular mise-en scènes which were important for this particular situation. After a preliminary sanctifying of the ritual food, representatives of the local authorities took the floor. A. Matveev spoke about the figures of those who went to the War and those who fell, about the hard labour of those on the home front (Photo 12). Alongside chuk in the form of ordinary rags and strips, old women fastened brown and black St George's ribbons to the tree. To make it easier to tie chuk to the tree screws were placed in the trunk (Photos 13, 14).

The ritual was completed by traditional eating and drinking (Photos 22, 23). The promise was kept. This ceremony was embedded in the participants' memory not as an ordinary event, but as a duty fulfilled, an offering for the souls of fallen fellow-villagers. According to Vladimir Botnikov, "this prayer could happen only once".

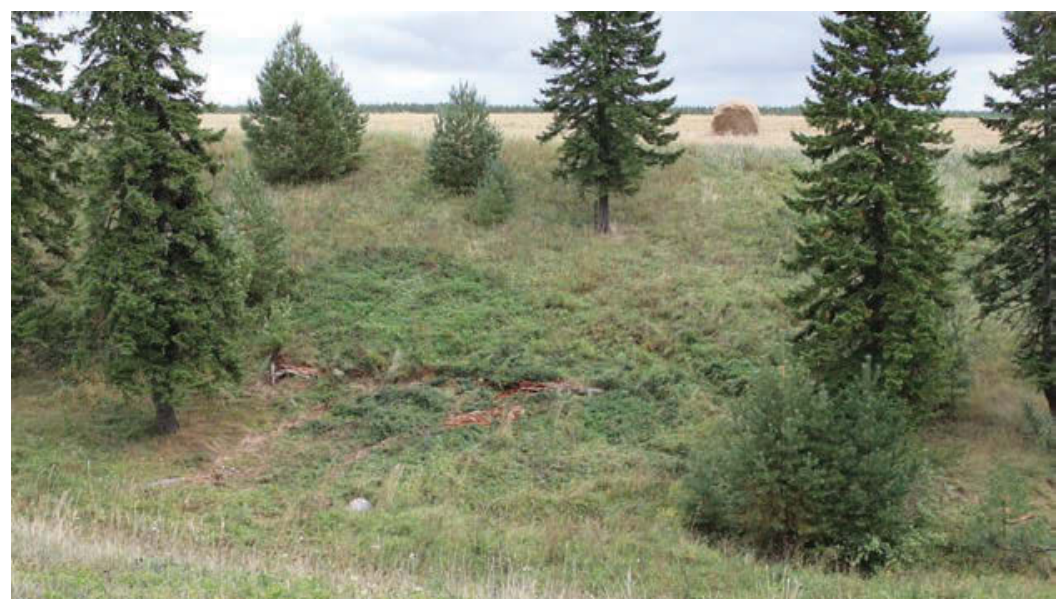

Photo 1. Bign'uk gully, the former ritual location. 


\section{A Contemporary Commemoration of the Dead}

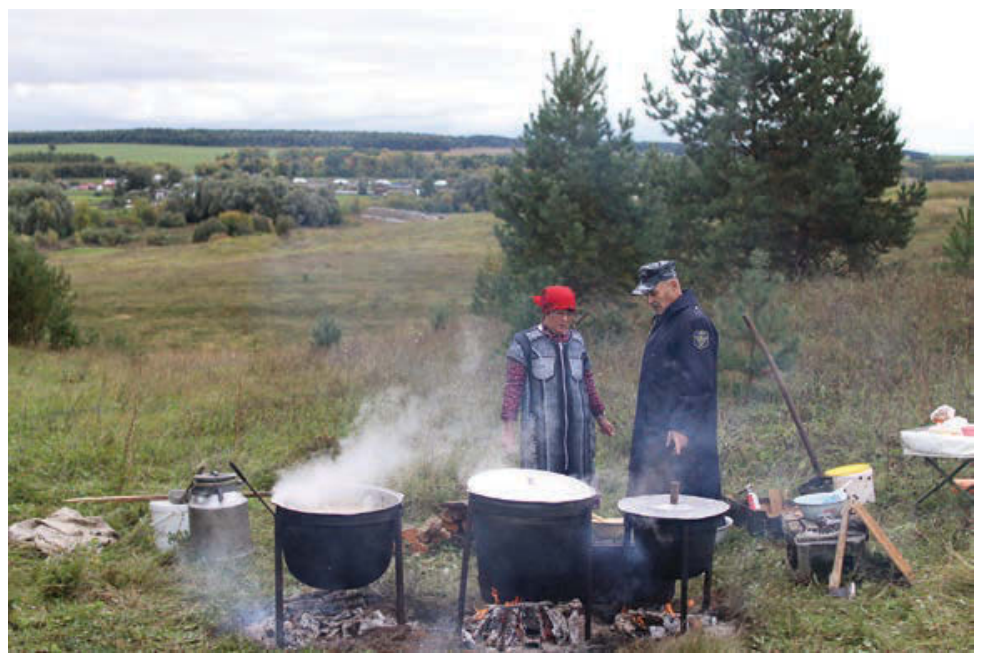

Photo 2. Preparation of the sacrificial food: porridge, and meat from the sacrificial animal's head.

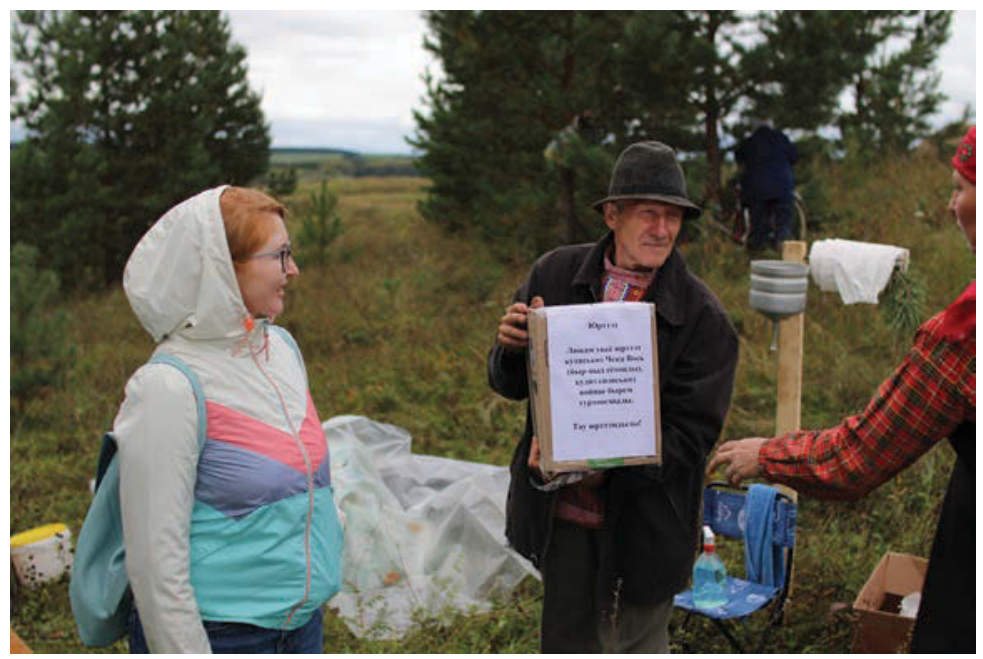

Photo 3. The donation box with a message reading: "Help. The collected funds will be used for the Cheka vös' ritual, which will be devoted to those who didn't return from the War. Thanks for your help!" 


\section{Denis Kornilov}

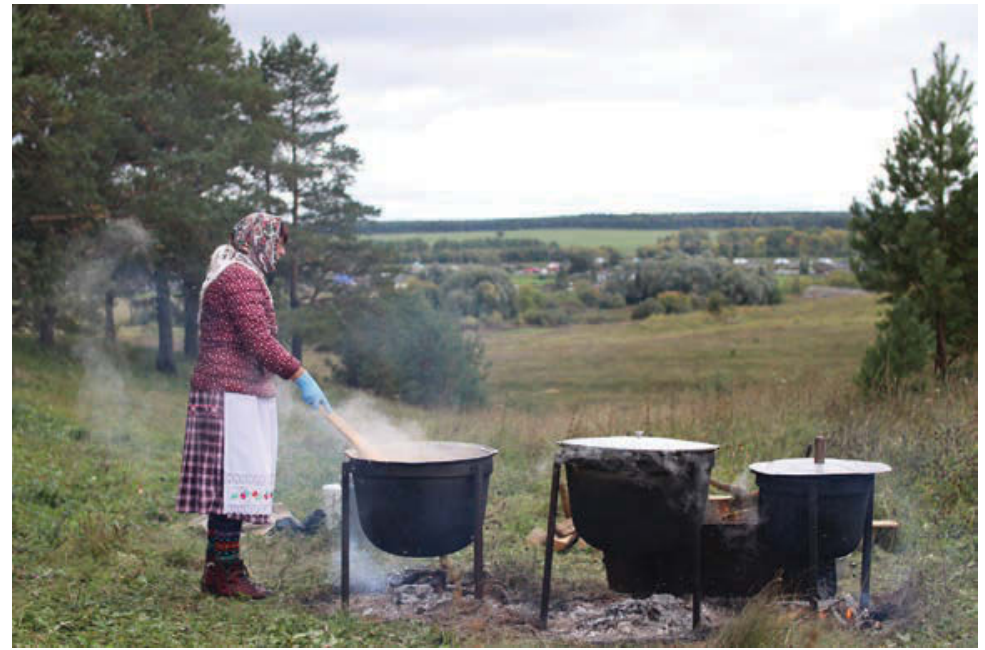

Photo 4. Preparation of the sacrificial food for the vös' and yyr-pyd s'oton ceremonies in separate cauldrons.

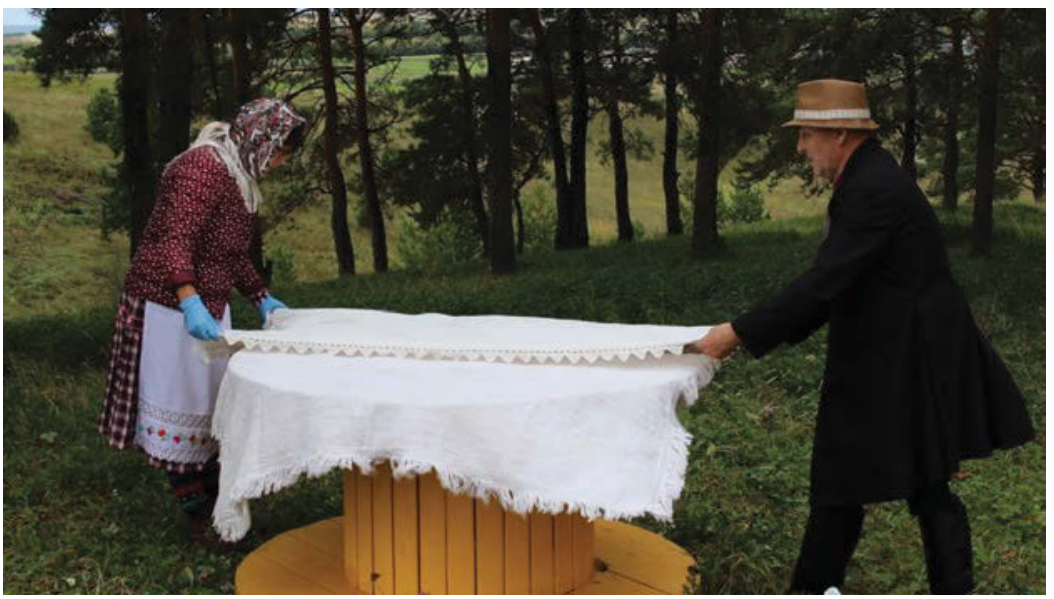

Photo 5. The table for offerings from participants in the ritual. 


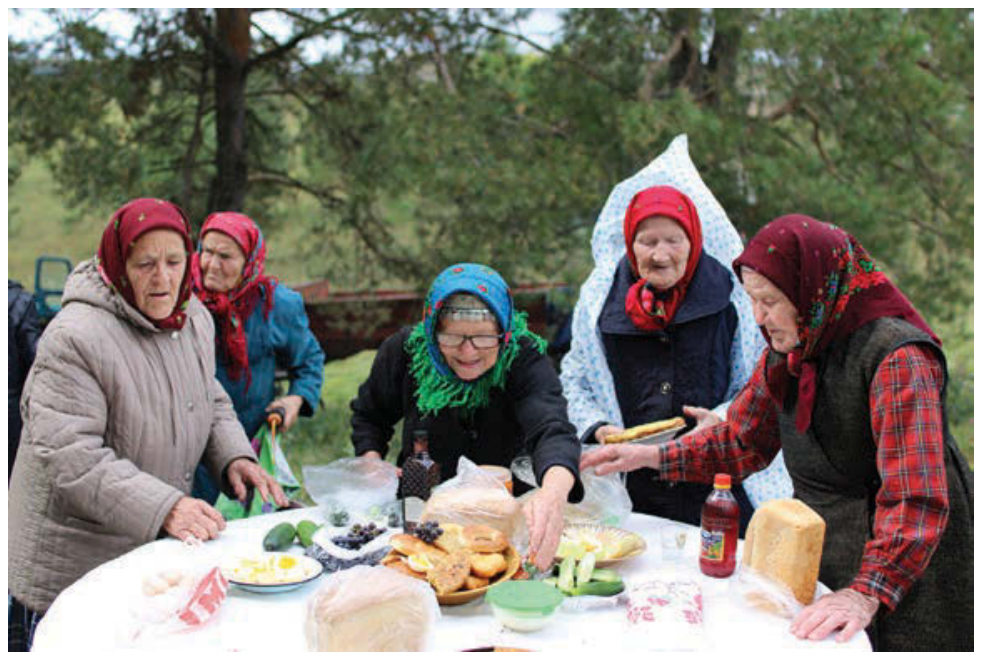

Photo 6. Offerings from the villagers of Bagrash-Bigra and Orlovo.

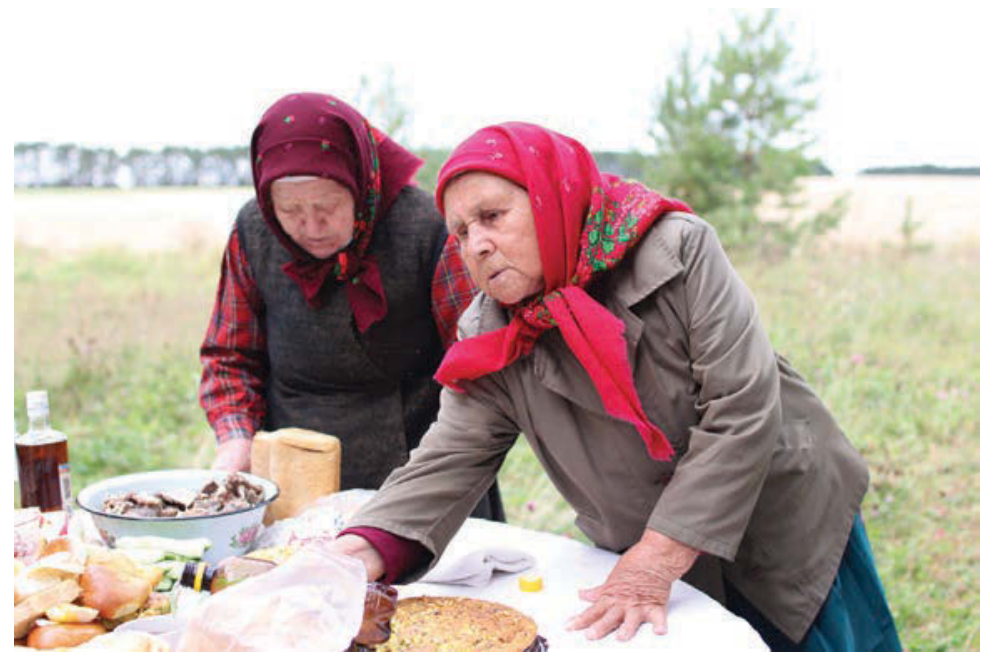

Photo 7. A participant in the ritual pours her moonshine (kumyshka) into the common vessel. 


\section{Denis Kornilov}

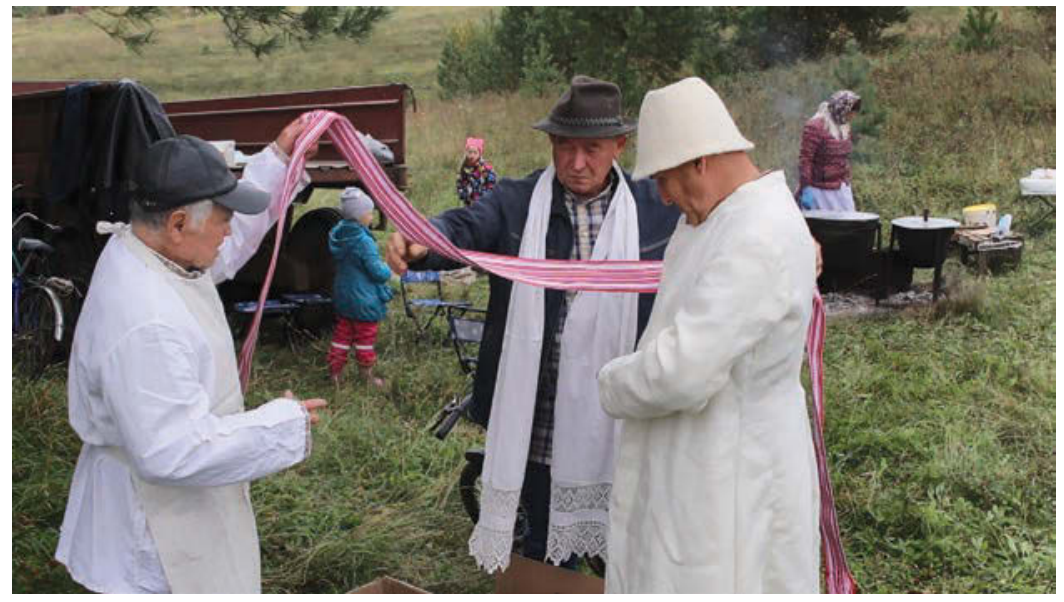

Photo 8. The assistants help the sacrificial priest put on ritual clothes.

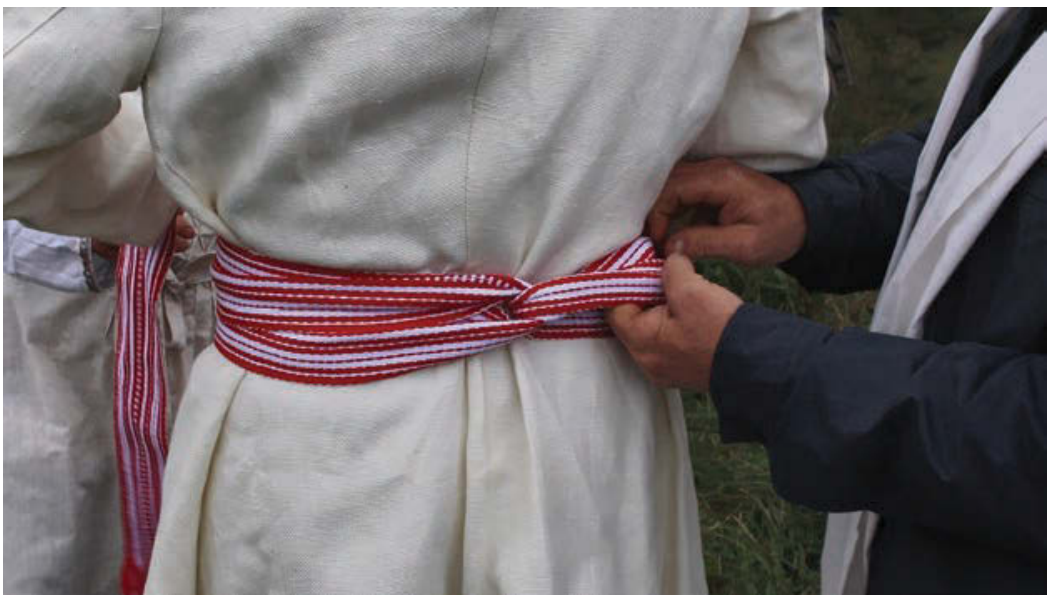

Photo 9. Prayer belt (rear view). 
A Contemporary Commemoration of the Dead

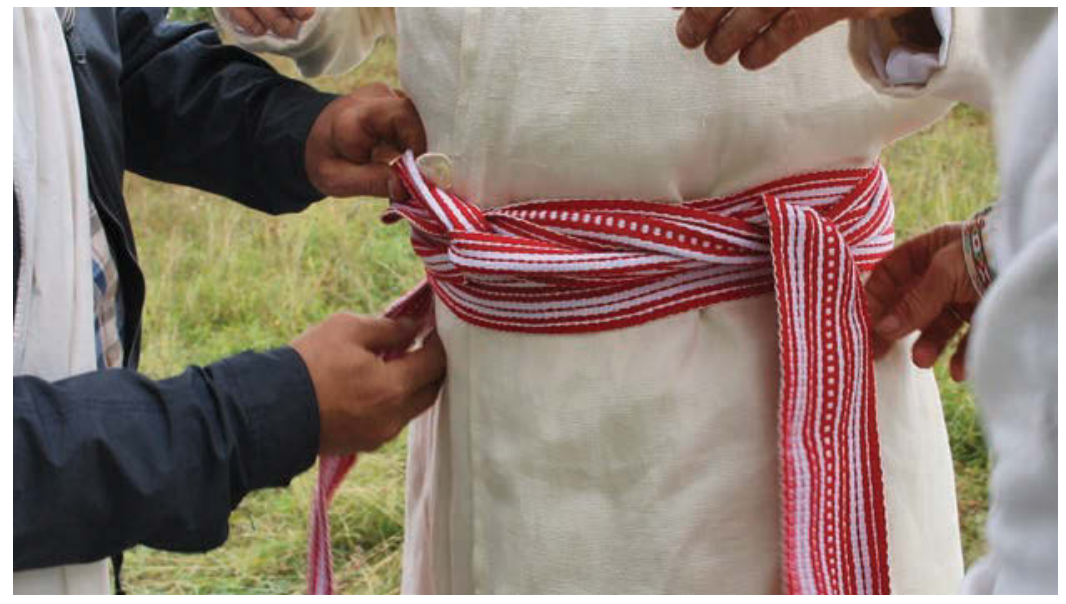

Photo 10. Prayer belt (front view).

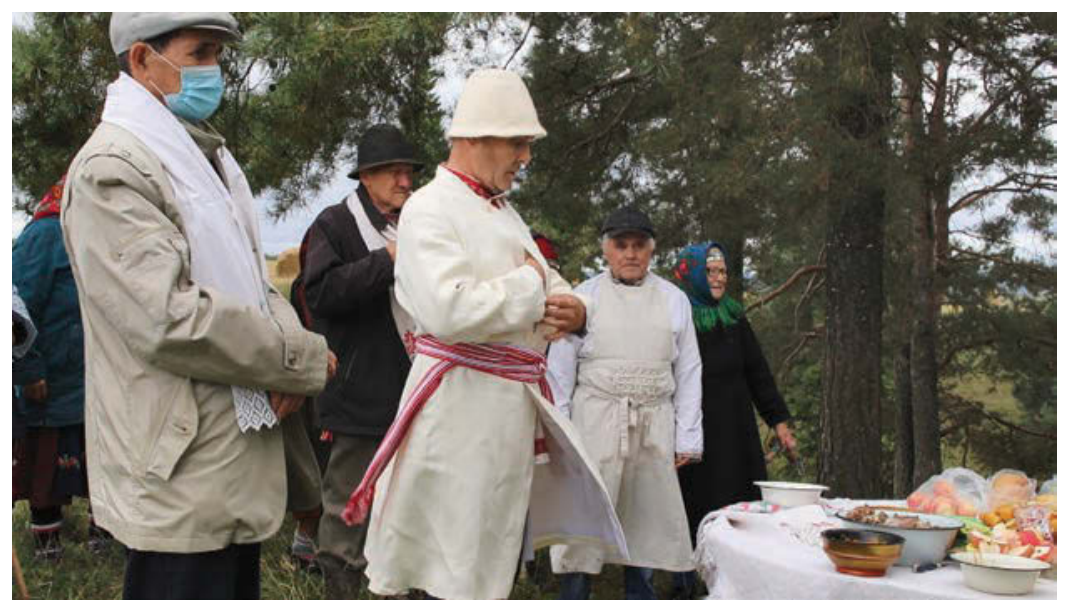

Photo 11. The first stage of the prayer (kuris'kon). 


\section{Denis Kornilov}

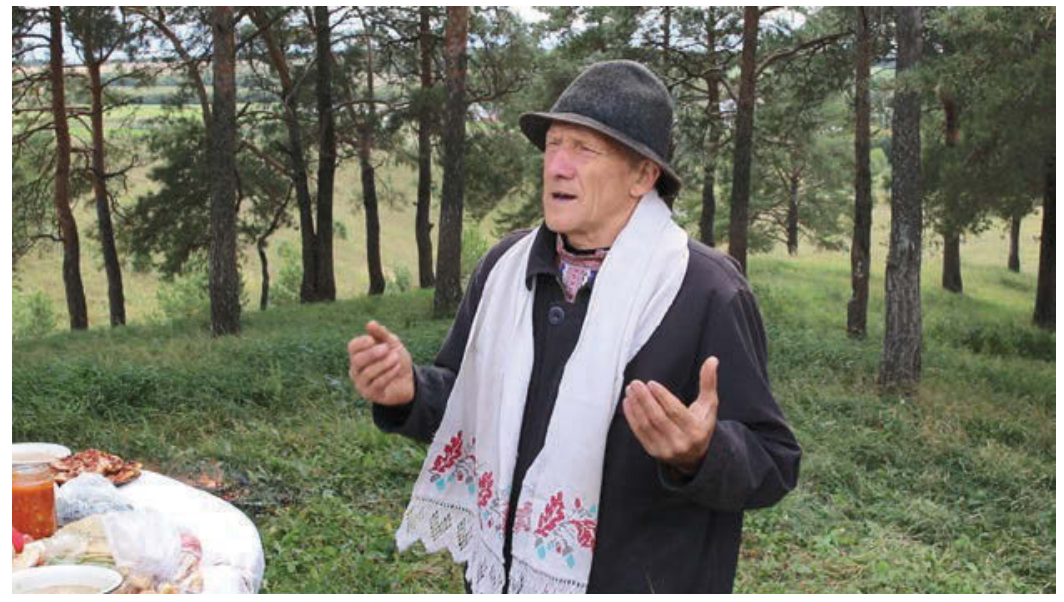

Photo 12. Village elder Anatoliy Yakovlevich Matveev speaks about the War.

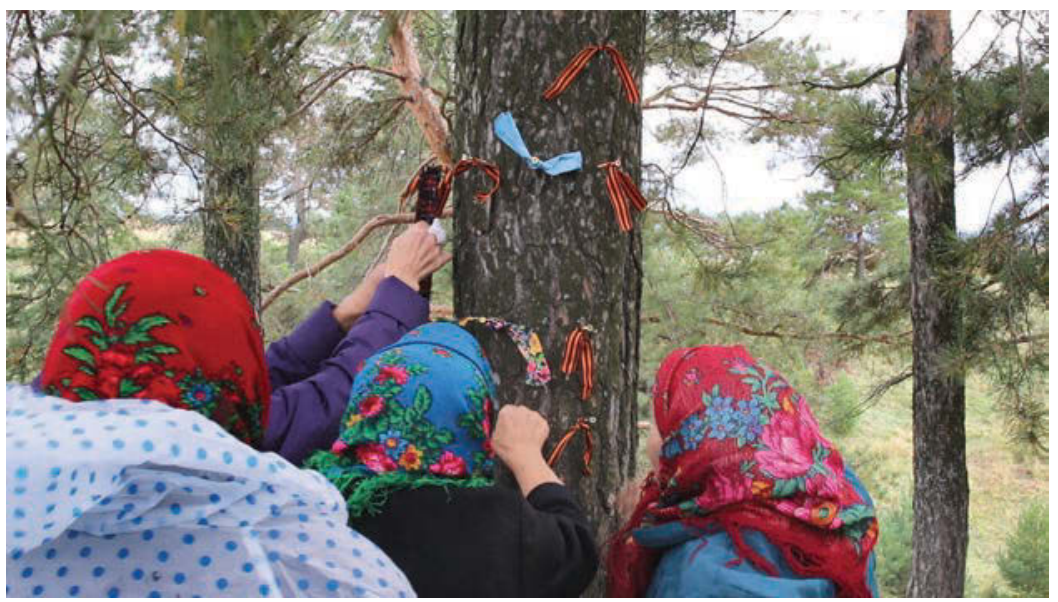

Photo 13. Offerings in the form of chuk strips. 
A Contemporary Commemoration of the Dead

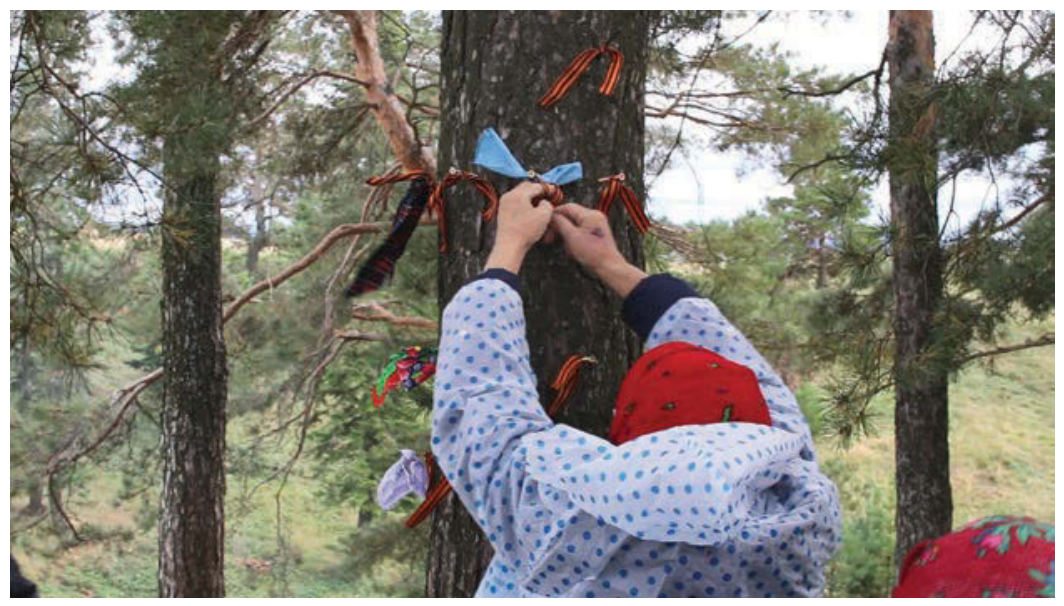

Photo 14. Sacrifice/gift chuk strips.

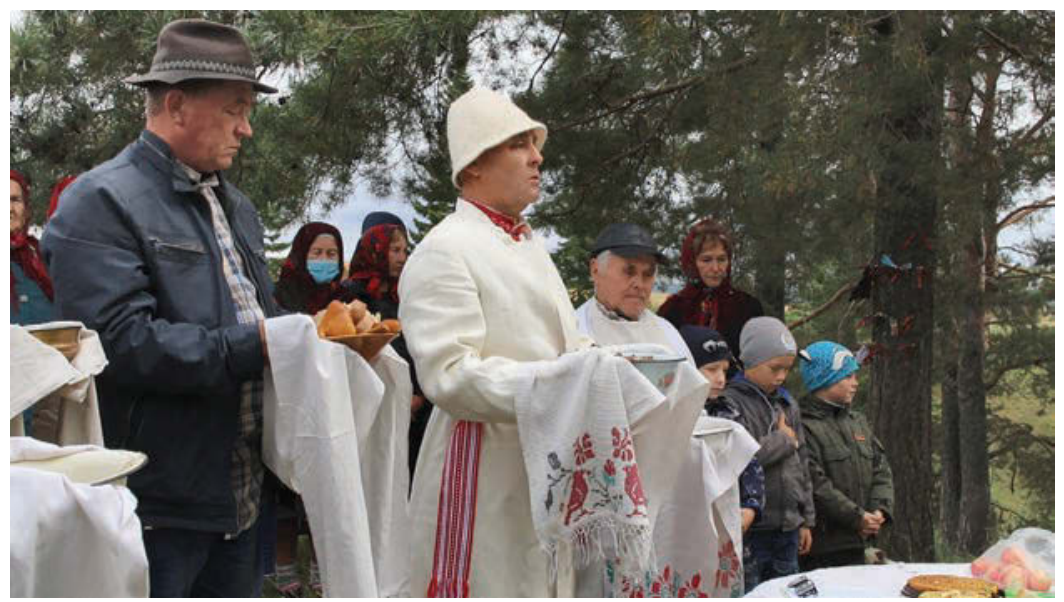

Photo 15. Sanctifying the food for the vös'ceremony. 


\section{Denis Kornilov}

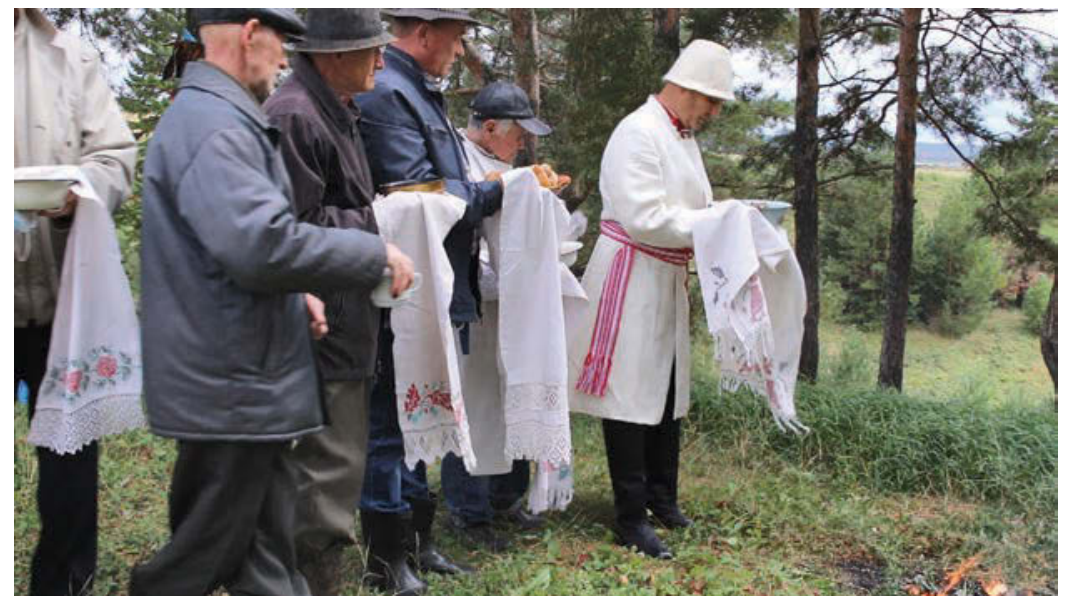

Photo 16. Sanctifying the food for the vös' ceremony.

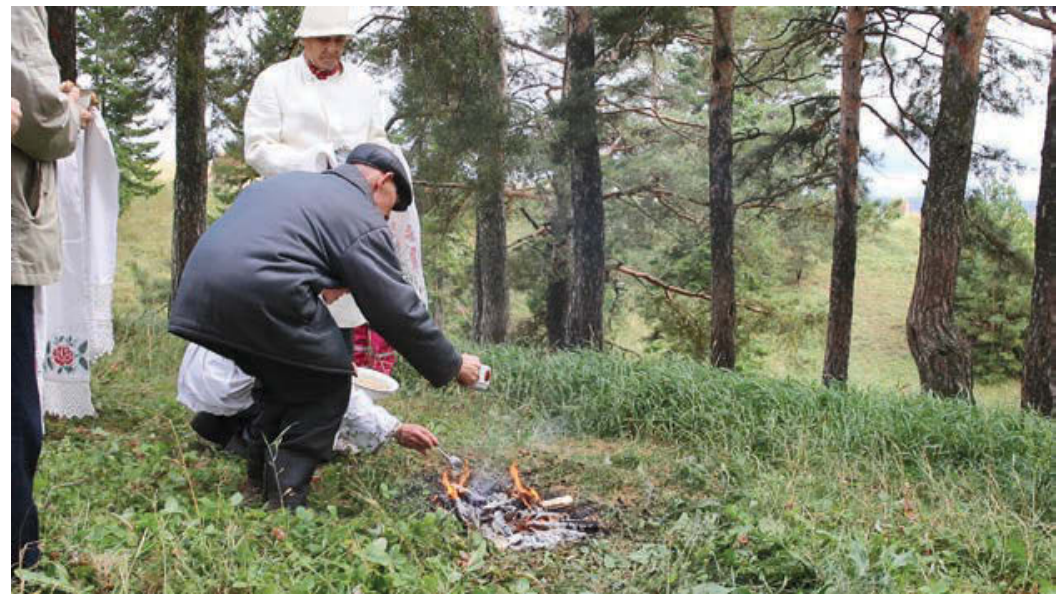

Photo 17. Sacrificing the ritual food and drink for the vös'ceremony. 
A Contemporary Commemoration of the Dead

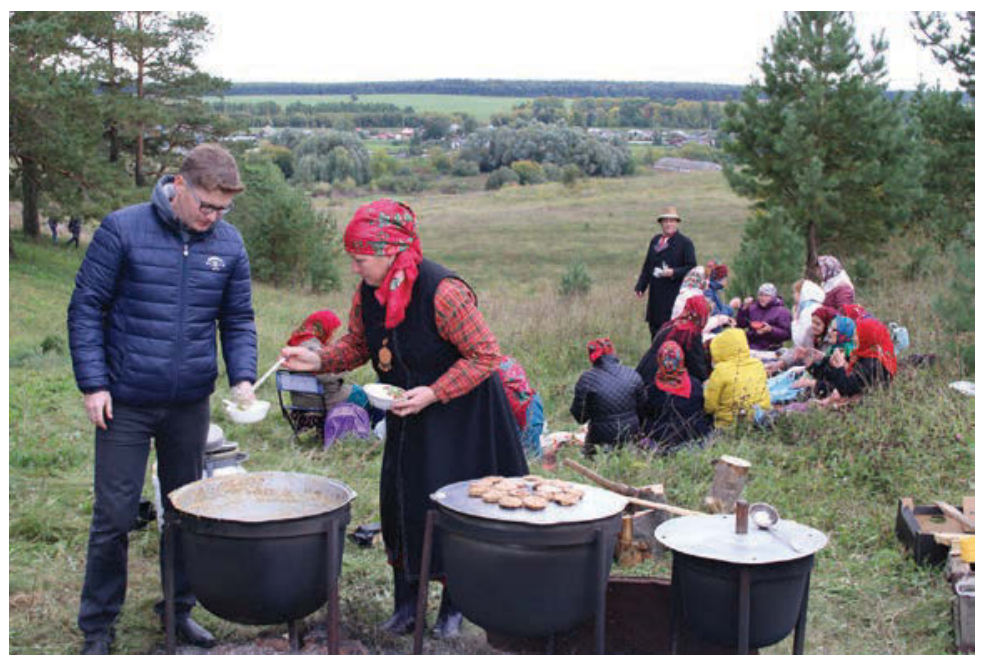

Photo 18. Ritual banquet.

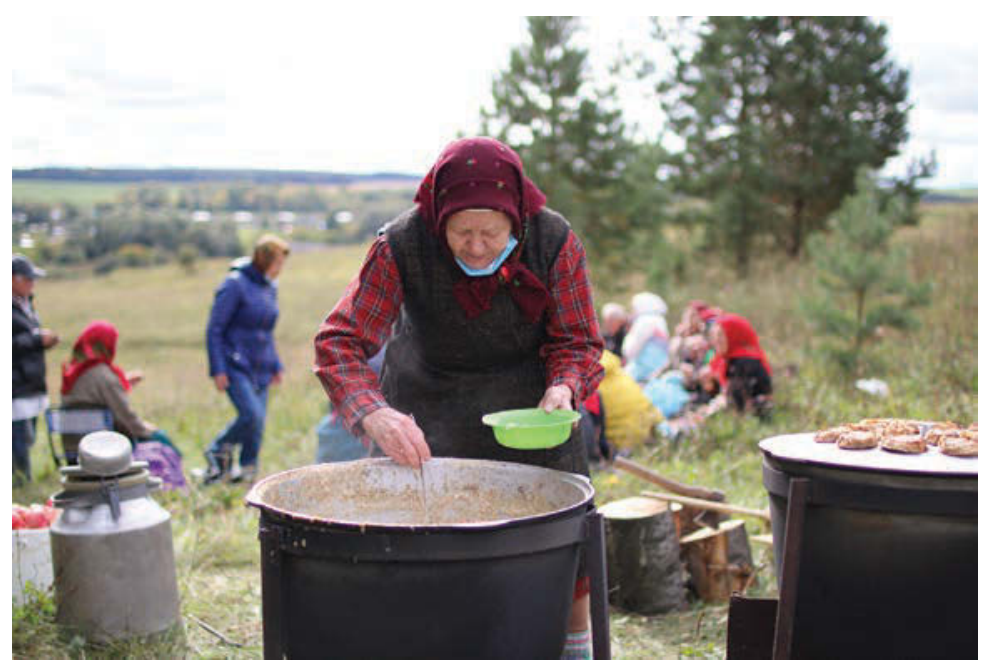

Photo 19. Ritual banquet. 


\section{Denis Kornilov}

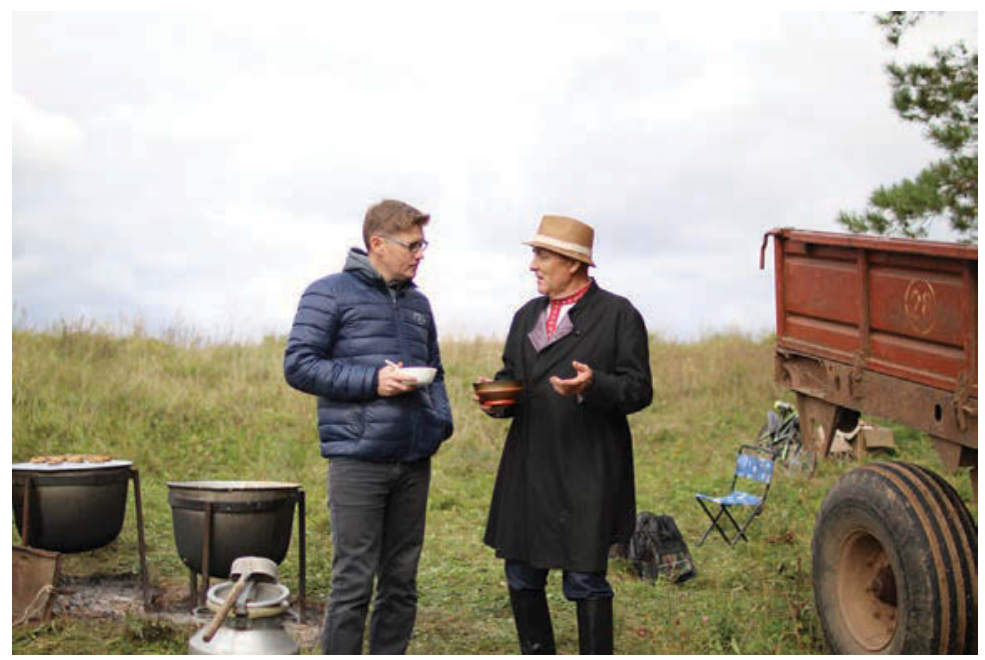

Photo 20. Vladimir Fedoseevich Botnikov speaks about the peculiarities of the ritual.

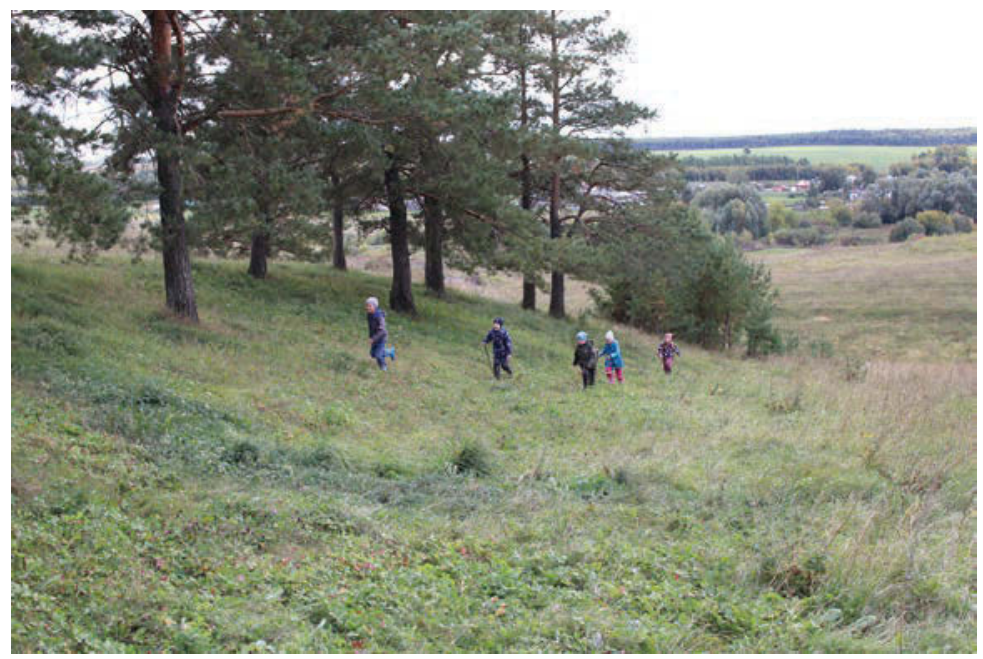

Photo 21. Children running to the ritual location. 


\section{A Contemporary Commemoration of the Dead}

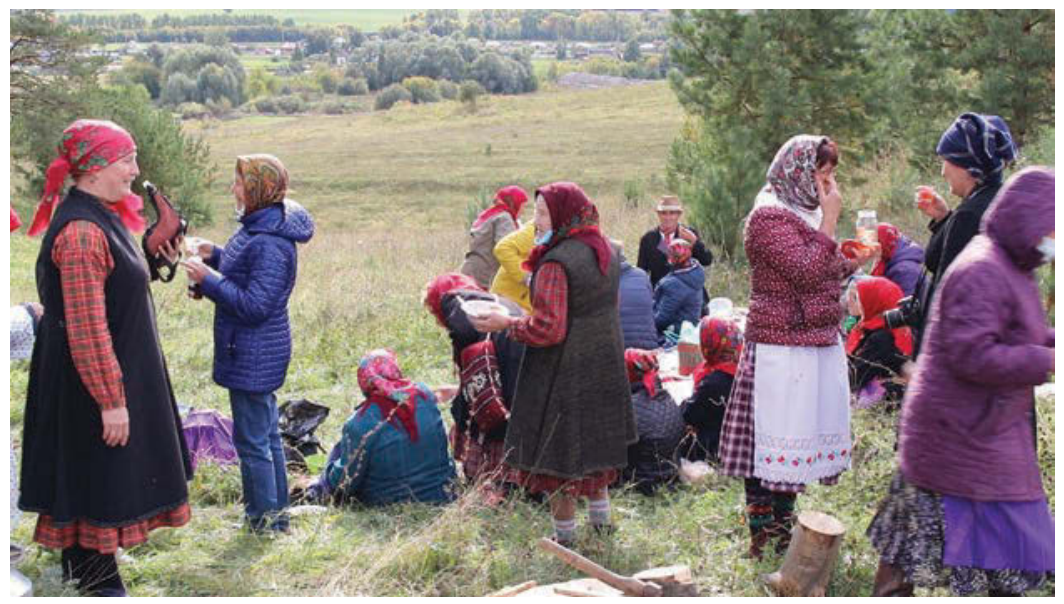

Photo 22. Common eating-and-drinking of the ritual participants.

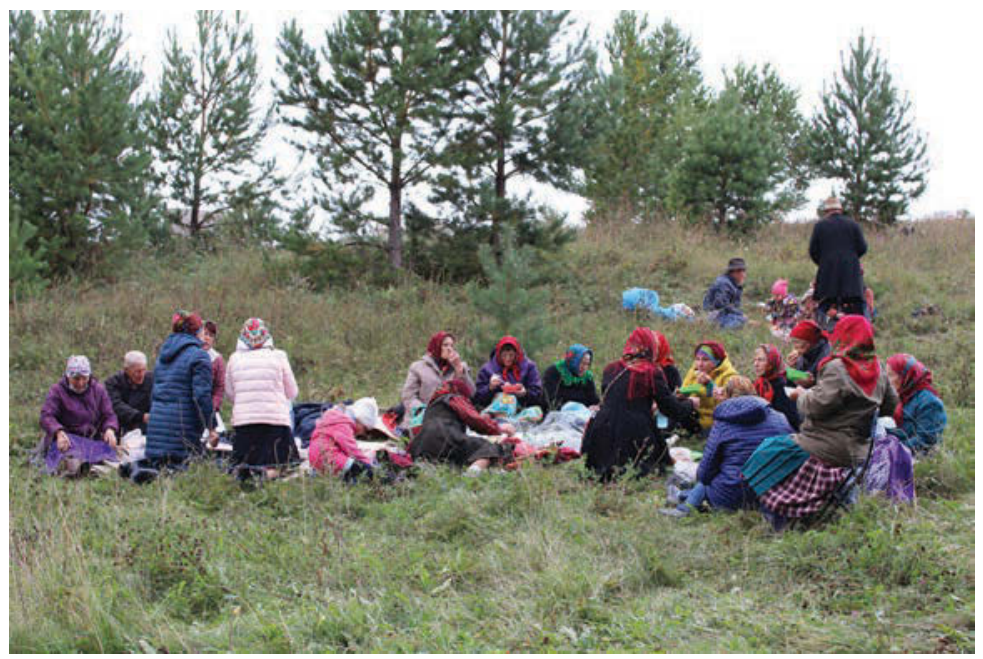

Photo 23. Common eating and drinking of the ritual participants. 


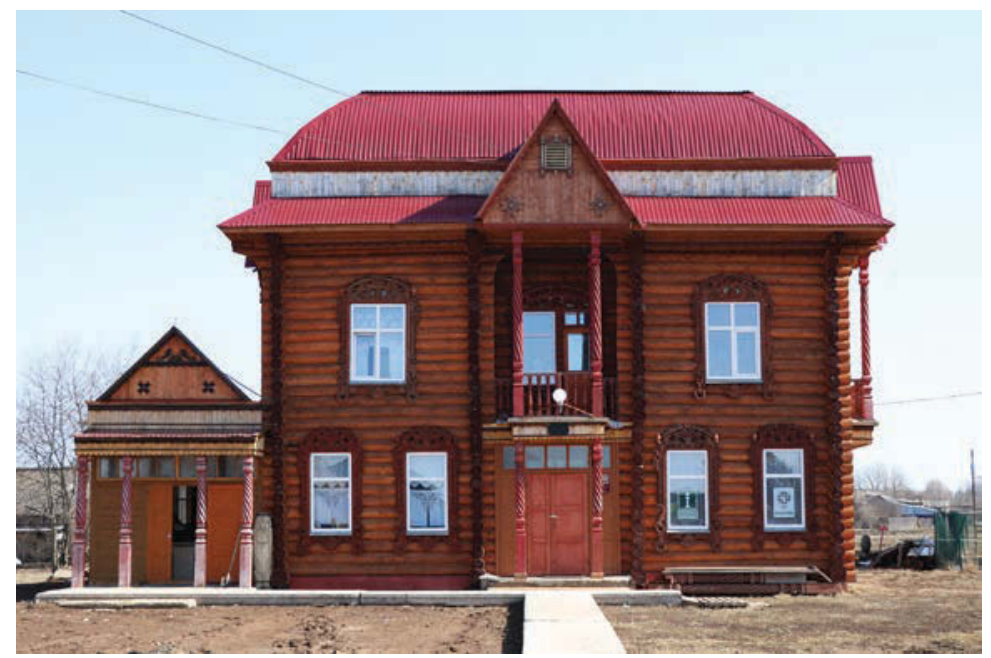

Photo 24. Daur shykys cultural centre in Bagrash-Bigra.

\section{Notes}

1 The Russian name for the Second World War.

2 Videos of the ritual and testimonies of its participants were recorded on September $12^{\text {th }}, 2020$ during a combined UIIYaL FITs UrO RAN (Denis Kornilov) and Republic House of Folk Arts (Veronika Fedorova) expedition.

3 This is the name used in Russia for World War II whose dates are not the same than for the West, for Russia it is encompassed between 1941 and 1945. 


\section{References}

Anisimov, N. 2017. "Dialog mirov" v matritse kommunikativnogo povedeniya udmurtov: dis. ... doktora filosof. po fol'kloristike ["Dialog of the Worlds" in the Matrix of the Communicative Behaviour of the Udmurts: Dis. ... Doctor of Philosophy in Folkloristics]. Tartu: University of Tartu Press.

Anisimov, N. 2021. Simvolika odezhdy umershego v traditsionnoy kul'ture udmurtov [Symbolics of the Clothes of the Dead in the Traditional Culture of the Udmurts]. Predmetnyye realii udmurtskoy etnokul'tury: Kollektivnaya monografiya [Objects as Elements of the Udmurt Ethnic Culture: Collective Monography]. Pod obshch. red. Vladykinoy T. G. [Ed. T. G. Vladykina]. Izhevsk: UdmFITs UrO RAN, pp. 58-69.

Atamanov, M., Vladykin, V. 1985. Pogrebal'nyy ritual yuzhnykh udmurtov (kon. XIX - nach. XX vv.) [Funeral Ritual of the Southern Udmurts (End of XIX Century - Beginning of XX Century)]. Materialy srednevekovykh pamyatnikov Udmurtii [Materials of the Middle Age Monuments of Udmurtia]. Ustinov: SRI, pp. 131-183.

Minniyakhmetova, T. 2000. Kalendarnyye obryady zakamskikh udmurtov: Monografiya [Calendar Rituals of the Udmurts beyond the Kama River: Monograph]. Izhevsk: Udmurtskiy institut istorii, yazyka i literatury Uralskogo otdeleniya Rossiyskoy akademii nauk.

Sadikov, R. 2004. Svyatilishcha zakamskikh udmurtov: Obshchaya kharakteristika i tipologiya [Sanctuaries of the Udmurts from beyond the Kama River: General Characteristics and Typology]. Kul'tovyye pamyatniki Kamsko-Vyatskogo regiona: Materialy i issledovaniya: Sb. st. [Cult Monuments of the Kama-Vyatka Region: Materials and Researches: Coll. of Articles]. Otv. red., avt. predisl. N. I. Shutova. [Ed. and the Preface's Author N. I. Shutova]. Izhevsk: Udmurtskiy institut istorii, yazyka i literatury Uralskogo otdeleniya Rossiyskoy akademii nauk, pp. 119-124.

Shutova, N. 2001. Dokhristianskiye kul'tovyye pamyatniki v udmurtskoy religioznoy traditsii: Opyt kompleksnogo issledovaniya [Pre-Christian Cult Monuments in the Udmurt Religious Tradition: Experience of the Integrated Study]. Izhevsk: Udmurtskiy institut istorii, yazyka i literatury Uralskogo otdeleniya Rossiyskoy akademii nauk.

Tarakanov, I. 1993. Udmurtsko-tyurkskiye yazykovyye vzaimosvyazi (Teoriya i slovar'). [Udmurt-Turkic Language Interactions (Theory and Dictionary)]. Izhevsk: Publishing house of the UdGU. 
Vladykin, V. 1994. Religiozno-mifologicheskaya kartina mira udmurtov. [The Udmurts' Religious-Mythological Worldview]. Izhevsk: Udmurtia.

Vladykin, V., Churakova, R. 1986. Obryad "yyr-pyd s'oton” v pominal'nom rituale udmurtov [The Ritual "yyr-pyd s'oton" in the Commemorative Ritual of the Udmurts]. Muzyka v svadebnom obryade finno-ugrov $i$ sosednikh narodov [Music in the Wedding Ritual of Finno-Ugrians and Neighbouring Peoples]. Tallinn: Eesti Raamat, pp. 108-133.

Vladykina, T. 2004. Znayushchiy (tuno) v udmurtskoy traditsionnoy kul'ture [The One Who Knows (Tuno) in the Udmurt Traditional Culture]. Udmurtskaya mifologiya [Udmurt Mythology]. Izhevsk: Udmurtskiy institut istorii, yazyka i literatury Uralskogo otdeleniya Rossiyskoy akademii nauk, pp. 97-102.

Vladykina, T., Glukhova, G. 2011. Ar-god-bergan: Obryady i prazdniki udmurtskogo kalendar'ya [Year-Circle: Rituals and Celebrations of the Udmurt Calendar]. Izhevsk: Udmurtskiy universitet.

Vladykina et al. 2021 = Vladykina, T., Glukhova, G., Panina, T. 2021. Chuk v traditsionnoy kul'ture udmurtov [Chuk in the Traditional Culture of the Udmurt]. Predmetnyye realii udmurtskoy etnokul'tury: Kollektivnaya monografiya [Objects as Elements of the Udmurt Ethnic Culture: Collective Monography]. Pod obshch. red. Vladykinoy T. G. [General ed. T. G. Vladykina]. Izhevsk: UIIYaL UrO RAN, pp. 36-49.

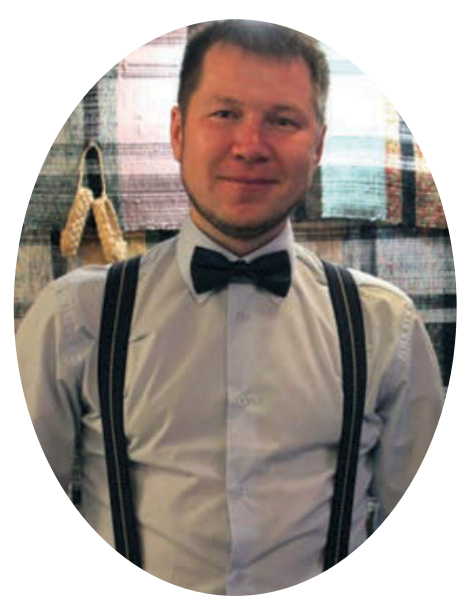

Denis Kornilov is a junior researcher at the Department of Philological Studies at the Udmurt Institute for Research in History, Language and Literature (Udmurt Federal Research Centre of the Ural Branch of the Russian Academy of Sciences). He is the author of anthropological films and investigates possible ways of using high-tech in studying the traditional culture of the Udmurt. e-mail: denkornilove@gmail.com 


\title{
Sound in Udmurt Rituals
}

\section{Irina Nurieva}

e-mail: nurieva-59@mail.ru

\begin{abstract}
This article is dedicated to the Udmurt's understanding of the world of sounds, their norms of behaviour towards sound in the acoustic community. The Udmurt sound worldview has been formed under the influence of the surrounding landscape. The peculiar sound of the Forest, that the Udmurt see and hear in their particular way, causes a particular sound reaction and musical approach. According to tradition, the voice of a singing person must fit into the natural soundscape in order to respect acoustic balance.

Within the hunting and fishing cults, singing has received the particular function of a magic incantation. The texts of incantatory songs in hunting and in honey producing, are characterised by incantation formulas as well as by different kinds of sound imitations.

The collective community ritual singing is one of the most important elements that organise the Udmurt's soundscape. The acoustic code is integrated in a whole system of ritual practices; it sanctifies the surrounding cultural and natural landscape. The spring-summer half of the year is characterised by a particularly strong intensity of sounds, as in the most significant calendar holiday, the beginning of the agricultural year, Akashka / Byddzh'ym nunal.

The rituals of welcoming have their own aesthetics of sound behaviour. According to the Udmurt community's mentality, the voice of the singing person is not supposed to stand out of the general sound field. Everywhere, the skilful singer occupies a peculiar position on the Udmurt society: they are valued and respected. At the same time, the belief according to which those who are able to sing well are deeply unhappy
\end{abstract}




\section{Irina Nurieva}

in life is very widespread. Taking into account that human voice and singing, in the representations of the Udmurt, possessed a huge force and influence on the surrounding world, we may infer that the singer (the skilful singer!) in the ancient society, who mastered this complicated art, had particular authority. It is even possible that at some moments, he/she fulfilled the function of a mediator between the worlds. And similarly to the shaman, the good singer, usto kyrdzh'as' could not refuse to practice his/her art, this art given him/her by fate.

Thus, the Udmurt's sound worldview is encompassed into an ontological worldview, which sets the rules of behaviour. It requires a proper sound behaviour inside the natural space as well as in the socio-cultural one, and determines the Udmurt's behaviour not only in their natural environment but also in the urban space.

Keywords: ethnic psychology, natural soundscape, sound behaviour, sound ontology, sound and singing's magic, Udmurt

The natural environment is full of different kinds of sounds, noises, voices, which in the traditional awareness are identified and loaded with cultural concepts. In particular, natural sounds may appear as special signs or signals from the world beyond. In the $19^{\text {th }}$ century, the researchers observed that Udmurts immediately reacted to "ordinary phenomena of nature": "An owl shrieks, a dog barks, a pine moans under a strong wind, and the Votyak is already expecting an accident - and how he expects: all the village is alerted, people run from house to house, and share condolences and speculations" (Koshurnikov 1880: 39-40). The numerous beliefs of the Udmurt about natural sounds were reflected in omens:

"if an owl will cry in the yard, in that house there will be a death or some grief";

"if a raven cries on the roof, it announces a fire or another misfortune" (Gavrilov 1891: 148);

"If in spring you hear first on an empty stomach the cry of the cuckoo, - all the year long you will be poor in bread" (Vereshchagin 1995: 115); 
"if the dog howls, lifting his muzzle, there will be a fire, if he just howls it announces a death" (Karpova 2005: 312);

"if during the night you hear the sound of something being thrown in the house, in this house somebody is going to die" (Vereshchagin 2001: 33).

In the traditional culture, there was a whole system of normative behaviour rules, whose aim was to keep in the sound community a balance between the natural and human environments. When, for example, in Spring, one heard the cuckoo for the first time, it was recommended just to roll (Vladykina 1997: 247). In order to transform the grief or the loss in the family foretold by the "howling" of the samovar, one had to hit the samovar a little with one's belt and say: "don't bring grief to us, only to yourself" (Gavrilov 1891: 148). Following a raven who fled over with a shout over our heads towards the North, one should also say: "say good things, bird" (ibid.). The other world could even call a person by his or her name. It was considered as a bad omen to hear one's name in a dream. Therefore, if "somebody unexpectedly hears one's name, as if somebody called her/him, he/she must not answer thrice. Otherwise he will die" (Vereshchagin 2001: 115).

\section{The natural landscape of the Kama region and Udmurt psychology}

The sound ontology of the Udmurt is widely determined by the Forest landscape. The ancestors of the Finno-Ugrians occupied for millennia a huge territory in the Eastern European forest belt. In his famous paleo linguistic research, the Hungarian scholar Péter Hajdú presents some names of taiga trees common to the Ural and Finno-Ugric protolanguages: the fir, the Siberian cedar, the spruce, the larch and the elm (Hajdú 1985: 156). Among the main 


\section{Irina Nurieva}

trees forming whole forests, one must mention the fir - a tree that wields a particular status in the Udmurt religious and mythological picture. Today's taiga fauna comprehends about 50 species of wild animals, among whom many are game. This territory is covered by a dense network of rivers. For centuries, rivers were the main way of communication and the populations concentrated in their shores. For the ancestors of the Udmurt, hunting, fishing, and breeding forest bees were the main subsistence activities. The fur from different species (the marten, the beaver, the ermine, the bear, the fox, the squirrel, etc.), as well as the production of apiculture, were traditionally the main merchandise on which exchange and tax payment relied. 19th century scholars, who visited the Kama region, described brilliantly the local nature: "[...] For dozens of versts, the traveller will see the very same picture [about the road from Vyatka to Glazov - I. N.] - lowlands covered in forests, almost undulating until the horizon. He admires the same view from the hillforts on the right shore of the Cheptsa, nearer to Glazov. If we go deeper south, within this forest area, then turning East and later further south, from every small eminence the traveller will see, again, these very same lowlands, covered by huge, dark portions of forest. [...] The landscape becomes more precise when our traveller enters deeply into these dark woods. The area drops; groves on sand soil alternate with fir woods and coniferous forests that grow directly on the bog.... [...] In the most woody and boggy areas, [...] fifteen years ago in summer all communication between close villages was interrupted. The neighbours waited for winter, in order to be able to visit one another. The culprit were the bogs, so abundant in the forest" (Smirnov 1890: 80-82).

However, even in such harsh conditions, where wild forests and bogs separated rare population pockets, gradually the people was able to conquer from the forest land for cultivation. The archaeologists have found traces of agricultural activities from the Neolithic period. For a long time the rule was the slash-and-burn system. In the natural and climatic conditions of the area, according to Mar- 
garita Grishkina, this archaic system in combination with the use of steam happened to be "extraordinary alive and was practiced in Udmurtia [...] until the late 19 th and even the early $20^{\text {th }}$ century" (Grishkina 2004: 70). The Udmurt were seen as "diligent cultivators": "Agriculture is the main activity among the Votyaks, and we must say that in this field they are the best model of industriousness" (Vladykin 1994: 43). Throughout the centuries, the Kama area was characterised by a complex economy that combined old crafts and a developed agriculture, the first being dominant in the northern areas and the second in the southern ones.

The surrounding nature, undoubtedly, was one of the factors determining the ethnic psychology of the Udmurt. As Lev Gumilev noticed: "[...] the landscape obliges people to elaborate complicated adaptational skills - their ethnic behaviour stereotypes [...] the unique combination of landscapes, in which an ethnic group has grown, determines its behavioural originality - and widely form the point of view of culture" (Gumilev: http://www.kulichki. com/ gumilev/articles). Writer Petr Vail writes an interesting observation: "The connection between a person and the place where he/she lives is mysterious, but obvious. Or in other words: it exists beyond doubt, but it is mysterious. It is managed by the famous and ancient genius loci, the "genius of the place", which connects the intellectual, spirituals and emotional phenomena with their material surroundings" (P. Vail Genius loci: http://lib.ru/PROZA/ WAJLGENIS/genij.txt, accessed 21.05.2021). The link between the natural and geographical environment and the "psychical dispositions" of the Udmurt has been observed since the late $19^{\text {th }}$ century by the scholars and ethnographers. Ivan Smirnov, author of the monograph The Votyaks, highlights: "[...] two features are the undeniable result of the influence of the environing circumstances self-restraint in expressing impressions, which leads to practice silence and the infinite ability to endure - "submission to fate without end". The grim forests are silent, all around the Votyaks, they are silent and the Votyak is silent too, contaminated by his 
surroundings" (Smirnov 1890: 85). Grigoriy Vereshchagin observes the same peculiarity: "The main features in their character - an exceptional shyness, restraint and reticence in expressing their feelings [...] Whether he is joyful or sad, rich or poor, or has some enterprise, you won't know it, he is silent, does not boast either complain about his fate, and if you ask, he answers: "it is to be endured!" (Vereshchagin 1995: 22). This merging with nature, "the permanent emotional contact (dialogue) with nature [...] the disposition towards cooperation with nature, absorption of its 'answers"' (Shklyayev 1998: 20), may be observed until the end of the $20^{\text {th }}$ century.

\section{The soundscape of the forest}

The natural landscape significantly influenced the cultural soundscape. Millennia formed the peculiarities of its profile, sound ideal, of the traditional musical thinking, and this all left its trace on the genetic code of the cultural tradition.

The Udmurt hear and see the Forest in their own way, and its particular sound has caused a corresponding sonic reaction and musical mind-set. According to folk representations, in the forest dwell different spirits, among whom the main one is the Master of the Forest: n'ulesmurt, tshatshtshamurt, bydzh'ym n'un'a, n'ules n'un'a, tshatshtsha n'un'a, s'ikmurt, yagmurt, yagperi, 'Forest man, Great old man, Forest spirit'. The cult of the Master of the Forest today is more widespread among the Northern Udmurt, for in southern Udmurtia the Forest has already been cut down. The Forest man in the mythological awareness is loaded with a powerful force: "He is huge, wears a white cap with a hole on the top, which shows n'ulesmurt's bare pate. He moves inside a whirlwind with tremendous quickness. According the Udmurt beliefs, if a whirlwind hits you, you become paralysed" (Vereshchagin 1996: 89). He brings the wandering persons in deep places and drives them until 
he does not come back to the original place (Vereshchagin 1998: 178). Among the Glazov Udmurts, according to Vereshchagin, he is the god of the forests and the winds, and people bring him regular offerings (Vereshchagin 1998: 214).

The forest, along with land, water and fire, represent the sacred elements, and they have their name day: tel'/tshatshtsha imen'n'ik 'the name day of the forest'. On that day, it is severely prohibited to go into the forest, and even more to cut trees and take off bark. The acoustic code may be the only signal that inform about someone violating the taboo. In one northern Udmurt legend, on the Forest name day, tshatshtsha n'imal'n'ik, a man went to cut wood: "He did not know what day it was, he was already old. Well even if he would have known, he would probably have gone anyway. They called him communist [...] He went to the forest and started cutting trees. Suddenly, somewhere, the sound of an axe was heard [...] this sound comes closer and closer, it is now very near to him, but Bladi does not see anyone [...] Then a whistle started [...] somebody walks noisily and whistles" (Karpova 2005: 233-234). In another legend, also written down in Northern Udmurtia, the situation is analogous (by the river, a woman heard the axe, trees falling, and this ended after she said "oste". It was necessary to give the Forest Master an offering: to put on that place a bit of bread and cereals (Karpova 2005: 515). The informants observe that on that day it also prohibited to sing songs (FWM-2002), clearly in order not to disturb the spirit of the forest.

\section{The magic of singing in the forest rituals}

Within the hunting cults, singing in the forest had a particular role in magic spells. Udmurt traditional culture has retained deeply archaic samples of forest singing: these are hunting and forest beekeeping songs. The first to have collected forest beekeeping songs was Hungarian scholar and linguist Bernát Munkácsi at 
the end of the 19th century in the Malmyzh uyezd (in the villages of Yumgi-Omga and Silo-Pur). For musicologists, it is particularly precious that he made a remark about the text being sung, and not just uttered: "This song, called by the Votyaks mush öt'on gur ("tune for inviting the bees" - I. N.) is sung by the beekeeper, when he prepares a new hive for a future bee swarm; therefore all the words are addressed to the bees" (Munkácsi 1887: 319). Rimma Churakova has recorded a whole collection of forest beekeeping songs (with the tunes!) some years ago in Southern Udmurtia, and she has analysed them in an article (Churakova 2002: 124-174). It was possible yet to record hunting songs in the 1930ies, two of them with the tunes have been published in a collection of articles edited by Evgeniy Gippius and Zinaida Eval'd (Gippius, Eval'd 1989: 15-16, 46-47). The Udmurt folklorists have also managed to record another almost complete sample of hunting singing, s'or kuton gur 'tune for hunting a marten' at the beginning of the $20^{\text {th }}$ century in Central Udmurtia (district of Uva).

The common feature of these songs is faith in the magic strength of the uttered words: the forest beekeeping songs are called to act on the swarming bees, the hunting ones to set a spell on animals. The anonymous author of the essay The Votyaks of the Vyatka Governorate, published in the mid-19 ${ }^{\text {th }}$ century, had the luck to witness a song of hunting spelling during a squirrel hunt, and he writes about it with some irony: "Nowhere the Votyaks song as much as while hunting and especially while hunting the squirrel. They sing to it different panegyrics, in order to have it stop and aim at it better" (Votyaks 1956: 68). The clearly expressed magic function of those songs allowed the scholars to call them "songsspells", "songs-incantation" (Gerd 1997: 130; Churakova 2002: 132).

The texts of the forest songs are in general an improvised description of the process, a developed topic about the future or the present hunt or activities of the bees. 
S’or kuton gur

Oz'y no shuom no

Atased tshuk sultoz

no,

"Kokorik!" kariz ke,

Tel'an potto mon

Dzh'ichied, kioned dory.

Dzh'ichied, kioned

Voz'ma meda ta viyn,

Voz'ma ta kapkanam?

Pumel'ad shed'id ke,

Shumpotis'kod, dyr, uk.

Oy, dzh`ichie, kione,

Shukom val no,

Oz'y shuod uk no.

Mush ut'on gur

Oy, doniosy, doniosy, doniosy, Shunyt shundyya papady.

Doniosy, doniosy, doniosy,

Shunyt shundyya

pozyr"yas'kysa potody, Shunyt shundyya paldyny.

Oy, doniosy, doniosy, doniosy, Dzhuzhyt kyze puks'ody.

Oy, doniosy, doniosy, doniosy, Mi til'edyz oktomy badzh'ym kudyosy,

Oktomy puzho kudyosy.
Hunting song (Selty district)

So, so, we'll say, yes,

Your rooster wakes up in the morning

When "Kokorik!" he sings,

I go out hunting

Hunting the fox, hunting the wolf,

The fox, the wolf,

Are they waiting for me now,

Are they waiting in these traps?

How do you fit in the trap,

We shall so rejoice so,

"Oh, my fox, my wolf"

We say it was, yes

So we tell, it happened.

(Gippius, Eval'd 1989: 47)

Song for forest beekeeping

(Kizner district)

Oh, my dear, dear, dear

Birds of the warm sun,

my dear, dear, dear

with a warm sun, fly in circles

With a warm sun, in order to

swarm.

Oh, my dear, dear, dear

Sit on a high fir

Oh, my dear, dear, dear

We shall gather you in our

great baskets,

We shall gather you by swarms. 
Oy, doniosy, doniosy, doniosy, Oh, my dear, dear, dear, Mi til'edyz korkady

pyrtomy,

Tshoge oshysa voz'omy

dzhytoz'.

Oy, doniosy, doniosy, doniosy, Sobere umortoyady pyrtomy.

Oy, doniosy, doniosy, doniosy, Chil'as' turyn dzhuzhaloz, Chil'as' turyn vyle turly s'as'ka dzhuzhaloz.

Oy, doniosy, doniosy, doniosy, Turly s'as'ka pölys'duno yemysh bich'alody.

We shall bring you back to the house,

We'll hang you on a peg until the evening.

Oh, my dear, dear, dear, Then we will put you in your hive. Oh, my dear, dear, dear, Fresh grass will be lifted, In the fresh grass different flowers will grow. Oh, my dear, dear, dear, Among different flowers precious fruits you will gather. (Churakova 2002: 133-134)

In these forest songs, it is interesting to observe the metaphorical replacement of the address. For example, the bees are called $e$, doniyosy 'eh, my dears', dun papa 'pure bird', biz papaos 'buzzing birds', zarn `i mugor”yos 'golden bodies'. In songs, as remaks Rimma Churakova, we find another replacement - s'olyktem lul"yos 'sinfree souls', which highlights the high status of this "bird" in the Udmurts' mythological worldview. According to beliefs, along with ordinary bees there are earth bees and heavenly bees. The latter, in mush, have great power: they play after the swarms of ordinary bees have gone out, flying close to the earth. They have their prince, under the rule of which there are countless swarms. When they fly, they overshadow the sun (Vereshchagin 1996: 128).

A characteristic of the magic forest texts is the presence of incantational formulas as refrain dun-dun, dun-dun; doniye-doniye, with different kinds of imitations: the buzzing of the bees, the barking of the dogs, the crowing of the rooster, which, according to Evgeniy Gippius, are "conditional verbal symbols" (Gippius, Eval'd 1989: 16). In different texts, we find a severe imperative: “[...] bees, 
fly here, ringing zhingyr-zhingyr" (Gippius, Eval'd 1989: 16), "Oh, quickly, yes, oh quicky // bees-birds you are. // Through the forest, yes, there, oh yes, through the branches // come here quickly, bees-birds. // Through the forest, yes, there, oh yes, through the branches // come here to me, my bees" (Churakova 2002: 150-151). However, and it is an interesting detail, this imperative of the poetic text (fly, come), which characterises the incantation genres in the folklore tradition, does not find an adequate equivalent in the musical part. In the sample of forest beekeeping tune published by Gippius (recorded in 1937), for example, the tune consists in two melodic phrases, each one of them relied on two related sounds. Indeed, it is not possible to call it a tune in the full sense of the word, it is more a recitativo uttered in a narrow sonic field. The "chamber", "intimate", "conversational" character of the tune is subordinate to the text, which comments the deeds of the beekeeper, who is calling the bees.

Example. Mushöt'ongur. Tune for calling the bees (Uva district)

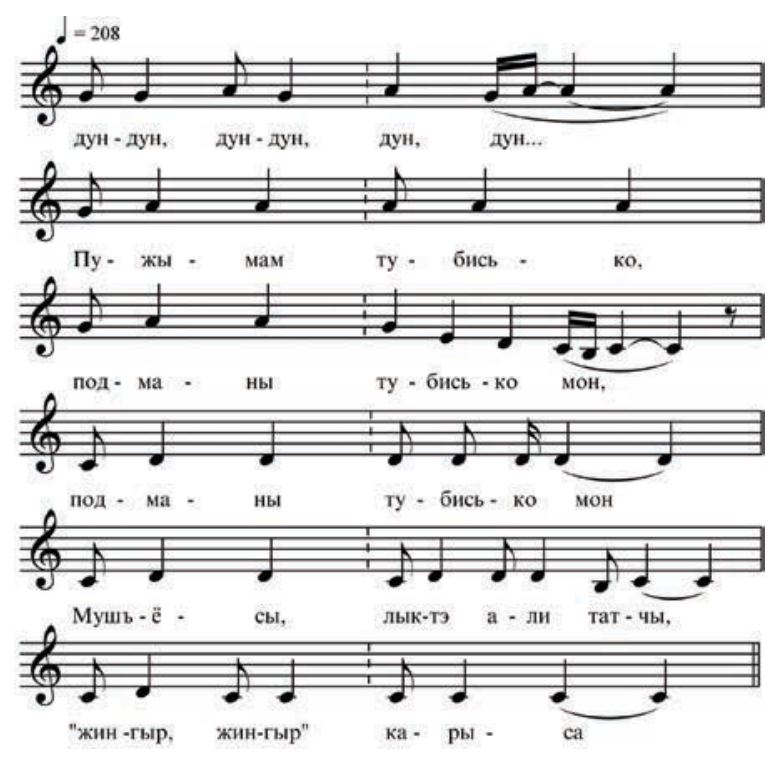


Dun-dun, dun-dun, dun, dun...

I climb on a pine,

I climb on a pine,

I climb on a pine.

Bees, fly here,

Ringing zhingyr, zhingyr.

(Gippius, Eval'd 1989: 15)

Rimma Churakova observes that the forest beekeeping songs in her collection are sung softly, not loud. For example, an informant told her how she remembered her mother, when she climbed a fir to catch a swarm, "quietly sung, explaining her actions and intentions" (Churakova 2002: 133). She also described another very curious performance situation, in which the informant, Aleksandra Serebryakova (Vavozh), who loved her bees and often talked to them, addressed them when they swarmed: "said to them crying: "Where are you flying away? At least you, do not leave me, do not go away!" (Churakova 2002: 138-139). The only description of a performance in another tone is given by Petr Pozdeev: "Matryona Yakovlevna sang in a low voice, straight and strong, so that [...] it was impossible to listen to it quietly, you were taken by shivers" (Churakova 2002: 139).

Echoes of these beliefs are encompassed in folk tales, which describe the effect of these songs on animals: "A Votyak went to gather alms and on the road, he sang a sung. A rabbit heard his song. He liked it a lot. He ran to the man, jumped on the sledge, and started to repeat what he said. Afterwards they met a wolf, who behaved in the same way. Finally, they went further and they met a bear, who also remembered his song, and he also climbed on the sledge and started to sing" (Pervukhin 1889: 27). In this collection by Nikolai Pervukhin, we discover another version of this tale, in which the protagonist is "a woman", who conquered with her voice these same forest animals. Significantly, in the folk tale, the power of the voice on the animals is connected with the crying, 
the chanting. The hero not only sang, "she was skilled in crying and lamenting: "She saw that grief had come to her, and she started to cry and to lament, and a rabbit heard this song of hers, [...] she went on crying and singing more dejectedly then previously, [...] and more desperately she cried, and she lamented even better than before" (Pervukhin 1889: 26).

Contemporary field materials show that the forest remains one of the Udmurt' favourite places for singing. Meanwhile, the singer's voice must blend into the surrounding soundscape: "In the forest I do not sing loud, I do not want with my singing to frighten birds, to disturb the babbling of the brook" (FWM-2013). We must examine in the same line the ban on whistling and of making any loud shout among the Uva (central) Udmurt-Kalmez: "Shaytan"yos pyrozy, perios, nechistoy silaos kylozy no l'ukas'kozy" ('Devils will come, spirits, evil spirits will hear and gather').

In the informants' tales we find the following pattern: they sing in solitude, gathering mushrooms or raspberries, softly, sometimes well-known sad songs, but more often improvising, without words, they sing when grief is in their hearts, therefore often along with the singing, they shed tears: "When I go to the pasture, I walk alone on the meadow. I sing all the day long. I sing and cry. I sing sad songs [...] if I do not know exactly the words, I sing to myself (Udm. as ponnam), I walk anyhow, and sing" (FWM-2000). There is here a clear analogy with the Baltic-Finnic tradition. For example, Valentin Vinogradov describes the phenomenon of lament in the forest in the Veps culture: "Singing in the forest implied the women lamenting their grief. They started with "hurtful" chastushkas, which oriented the singer towards an emotional state. The refrains were performed loudly, and they alternated with a soft, soundless lament" (Vinogradov 2011: 101). The soundless improvised song in the forest with a clear magical purpose (to provide protection from predators for both the singer and her animals) in the Northwest Russia was the object of Mikhail Lobanov's research. Thus, in Novgorod oblast', the women, while they gathered berries, "sang 


\section{Irina Nurieva}

something softly without words. This kind of singing was not formalised at all, the gatherers could start with the tune of whatever long song, or chastushkas or tune with voice accompaniment, then the contours of the song blurred and gave way to a spontaneous improvisation. In general, what to sing - whether something unknown, or repeating part from a song without words - was not regulated. The main thing was how it was performed, as talking to oneself. This kind of singing had a name: it was called, in Russian, nynykat' or tynynykat" (Lobanov 1997: 92). In places with mixed population (Tver Carelians and Russian), the author has also recorded improvisational singing in the Forest. He makes an important observation about forest nicknames: "In performing the nynykan'ya and the improvised tunes, introversion dominates. The singer is fully wrapped up in his/her inner world. By vocalising whatever comes instantly to sound, without repeating any known tune, he/she at that moment is fully independent of the collective factor" (Lobanov1997: 92).

\section{The sound rhythms of the agricultural year}

The collective principle is achieved in ritual community singing, which is an integral part of the everyday life of the traditional agricultural Udmurt society. The "singing element" is ruled by rigorous laws of organisation in time and space. The rhythm of the surrounding nature, of the cosmos itself, acts on the rhythm of the "singing time", sensitively capturing the ups and downs of the year cycle. For ethnomusicologists, the Udmurt understanding of the yearly cyclic times as formed of two independent halves, reflected in acoustic behaviour. The 19th century scholars observed "The civil year is divided, for the Votyaks, into two halves: the first starts approximately in March, the second, in September" (Vereshchagin 1996: 74). The months in each of these halves function in central symmetry: "They (the Udmurt - I. N.) consider Summer and Win- 
ter as two different years [...] The Votyak qualifies Christmas as "green time" as he qualifies February telling that in Summer, at the same time, rye is reap" (Gavrilov 1880: 159). Just as symmetrically are the most dangerous periods, when the borders between the visible and the invisible worlds are particularly fluid: these are the times of the Winter and Summer solstices (Vozhodyr 'sacred time' and Invozho Dyr 'heavenly sacred time'). The winter sacred time of Christmas Vozhodyr allowed to hear sound signals from the other world, which in that period were very sensitive. For example sounds heard at road crossings at midnight announced the future: threshing sounds foresaw good harvest, richness; the sound of woodcutting forebode bad harvest or death, a joyful song from far away, a wedding or good harvest, a sad song, illness and bad harvest (Pervukhin 1888: 127). A bell heard by a girl announced a wedding, by a boy - going to the army. The sounds of an axe or of quarrelling were seen as announcing a death or illness. Sounds heard around barns, granaries or empty houses, foretold either an abundant life (noise of pouring cereals) either starving (sounds of sweeping broomstick) (Popova 2004: 176).

The "sound" behaviour during Summer and Winter solstices was severely regulated. The acoustic code of the sacred time ruled out loud ritual singing, so that it would not disturb invisible spirits, the water, the earth, the nature, while they were gathering new forces. The Northern Udmurt, at winter vozho time, in order not to disturb the inhabitants of the other world, were afraid to walk over a bridge with songs (Pervukhin 1888: 59). In the summer period, invozho, all the actions of the Udmurt farmers were turned towards the protection of the harvest. Any noise made by a person when cereals were blooming could call for a misfortune: "In this period, which lasted circa 10 days or even one month, many activities were banned: digging, cutting wood, building, mowing, knocking, singing, playing instruments [...] The time at the middle of the day was particularly strictly taboo. People were also not allowed to dress in colourful or bright clothes, because the fields risked then to be 


\section{Irina Nurieva}

as colourful" (Vladykin 1994: 188). A lot of prohibitions concerned people's behaviour close to water: it was prohibited to bathe in the river (especially before lunch), to fish, to rinse laundry, to push the herd into the river, to enter the river with sharp objects, to make noise, to whistle and shout, in order not to disturb the spirit of the water. Otherwise, the cereals would be beaten by hail (Gavrilov 1891: 144; Churakova 1995: 83).

\section{The magic of ritual singing}

The community's collective singing of ritual songs is one of the main elements organising the sonic space. The acoustic code is inserted in a whole system of ritual practice, which consecrates the surrounding cultural and natural soundscape. Singing during rituals has never been seen as entertainment. Also in song texts we find emphasised the necessity to perform together special songs in a ritual situation:

Akashka (Gershyd) gur

Mi pyrem ponna vozh"yostes en potte, Mil'emyz buddzh'ymdor kyrdzh'any kossa lez’iz.

Akashka gur

Armis' no lyktem odig pol Akashka nunalmy, Vay kyrdzh'asa-verasa, oy, yyvome.
Tune of the ritual Akashka (Gershyd) (Kizner district)

Do not be angry that we came, The elder of the clan has sent us to sing in each house.

(Churakova 1999: 38)

Tune of the ritual Akashka (Alnashi district)

Once a year comes our day of Akashka,

Let us, oh, rejoince with songs and tales.

(Boykova, Vladykina 1992: 36) 
Akashka (Gershyd) gur Tune of the ritual Akashka

(Gershyd) (Kizner district)

Akashka s'amen kyrdzh'alomy, We sing as in Akashka, Vayele, verale verano kyl"yostes. Tell the words to be put in the song.

(Churakova 1999: 38)

Akashka gur

Mi ke gyne kyrdzh'amy, tuzh cheber kyrdzh'alom, Turly tylobudoyoslen gurenyz. Turly gyne tyloburdolen, oy no, gurenyz, Anayen no ataylen s'amenyz.
Tune of the ritual Akashka (Alnashi district)

If only we sing, we sing very nicely, With the tune of different birds. Only with the tune of a different bird, According to the custom of mother and father. (Boykova, Vladykina 1992: 40)

At the same time, it was prohibited to sing these ritual songs outside the proper ritual time, which also was reflected in the ritual poetics of the Southern Udmurt.

Akashka gur

Kyrdzh'ale, kyrdzh'as' esh"yosy, tunne kyrdzh'an nynalmy,

Tunneles' ke kyl'iz uk, nosh arly kyl'oz uk, Kyrdzh'amdy potoz no, kyrdzh'an dyr uz lu n’i.
Tune of the ritual Akashka (Kizner district)

Sing, my friends - singers, to day is our day for songs,

If today we do not sing, we shall have to wait a whole year, You will want to sing, - but the time for songs will not be.

(Churakova 1999: 37) 


\section{Irina Nurieva}

In the singing calendar of the Besserman, unlike in the Southern Udmurt tradition, there is the feast of Saint Elijah, which divided the summer and autumn seasons. This liminal status of this feast is marked at the auditive code level: "In summer, as soon as the haystacks are set, we may not sing [summer songs - I. N.] anymore. The custom has been set by the elder, and the younger respected it” (Popova 2004: 134).

In some Southern Udmurt local traditions, there is a precise period for learning the ritual songs: "One of the possibilities of transmitting the tradition from generation to generation was the teaching from the elder women to the young girls one week before the given feast and one week after it" (Vladykina 1997: 86). In the Kizner tradition, the learning of the tune Akashka took place one week before the holiday, on Palm Sunday, when it was "allowed to teach the singing of this song, it was necessary to transmit the knowledge and the skill to be able to perform the tunes corresponding to the day" (Churakova 1999: 7).

The spring-summer half of the year is characterised by a higher intensity of sound, and it is opened by the most significant holiday for the Udmurt, the calendar festivity starting the agricultural works, Akashka / Vel'iktem / Badzh'ym nunal. This ritual, as well as the slow spring round dances on the meadow, was an imitation of the wedding ritual in Summer, only near to the winter cultures, and it had a particular timbre, which fulfilled the important mission to have a magical effect on the surrounding micro and macro world. Singing in the open space is reflected in the poetic texts of the Udmurt ritual songs: kyrdzh'am kuaraye kyr"ya koshke... 'my voice pours itself on the horizon as a song'; kyrdzh'ay, dyr, badzh'ym, ay, kuarayen, shukkis'kiz Kumor gurt kuz'a... 'I sang, probably, with a ringing voice (lit: a big voice), the song was heard along the village Kumor' (Nurieva 2004: 68, 101). The (sacred) ringing of the procession in the nuptial songs of the Southern Udmurt may be compared with the metaphor of the mythologic Great Sacred River Töd'y Kam or with the sound of the chipchirgan: 
Yarashon gur

töd'y kamlen tulkymez met

shukkis'koz yardure -

mil'am zhingres kuaramy met kyl'is'kos kyd'oke.

S’uan gur

met shukkis'kos kuaramy kam s'örys'en s'öroz';

takem shuldyr s'uanmy daur"yosyn met kyl'oz.
Song of the processions of the bride's side (Malaya Purga district)

Let the waves of the White River beat the shore, Let our ringing voices let be heard far away. (Kel'makov 1990: 170)

Wedding tune (Malaya Purga district)

Let our voices be heard from one shore of the Sacred river to the other, Let [the remembrance] of such a joyful wedding remain for centuries.

(Kel'makov 1990: 166)

S'uan gur

Shuldyrte ay, shuldyrte, oy, muso no esh"yosy;

Ledzh'e al'i, ledzh'ele chipchirgan golostes.

Chipchirgan golos"yosmes ogadzh'et'i ledzh'om.
Wedding tune (Zav'yalovo district)

Rejoice, yes, rejoice, my dears and my friends.

Sing, sing with the voice of a chipchirgan.

With voices like a chipchirgan let us sing together.

(Kel'makov 1990: 61)

The ethnolinguistic analysis of the Udmurt folk terms, connected with the concept of singing kyrdzh'any, gurlany, shows that they rely on a series of synonymous words around the concept of singing: call, shout, name, sound, sing, loudly cry, make noise, praise 


\section{Irina Nurieva}

(Vladykina 1997: 46-47; Nurieva 1999: 81-82). The definitely loud singing, "unusual" for everyday life, may be assessed not only as a call, an address to the forces of nature, but also an alien speaking, or, according to the saying of Boris Asaf'ev, "an intentional concealment of the timbre of human voice" (in Zemtsovskiy 1976: 898). This "concealment of the voice" is a particular way of behaving, which always become the contrary to everyday life (look for example, at the behaviour of masquerades, of the members of nuptial processions etc.).

The timbre of the ritual songs in the Udmurt tradition is one of the most important musical and stylistic ways of distinguish it, both vertically (ritual and later genres) as well as horizontally (local peculiarities). In the Kukmor singing tradition, for example, the performances of the elder generation have preserved a ritual singing way that reminds an instrumental timbre. Thus, Ariadna Golubkova, the first to draw attention to this feature, highlighted a "nasal" ("oboelike") colouring of the sound (Golubkova, Pozdeev 1987: 9). True, in her arsenal there were only solo recordings of ritual songs. The collective ritual singing, as I see it, is connected with another instrument, the bagpipe. The sound is formed pressuring the vocal cords, which give the impression of a "tight", but sharp sound, through the nose. The local stylistic peculiarities of the Udmurt song melody, with its ongoing development throughout the strophe, the narrow diapason consisting of three sounds, the melismatic repetition of the main tones, are also similar to bagpipes playing. As Igor' Matsievskiy noticed, 'the bagpipes' tunes with the continuity of play, the monotony, the characteristic phrases, based on the alternation of elongated tones and quick transitions typical of the instrument's nature in the framework of a rigidly limited ambitus, have strongly influenced all the European music" (Matsievskiy 2007: 103). Is the similarity of the ritual singing and the timbre of the bagpipes accidental? We know today that the bagpipe was widespread mostly in the Besserman tradition (Steinfeldt 1894: 243-244). However, as the historians suppose, part 
of the Ar Udmurts whose descendants are the Kukmor Udmurts (Napol'skikh 1997: 51-52) may have participated in the ethnogenesis of the Besserman. Moreover, there are traces of presence of the Besserman in this territory also in toponymics. Another mode of performance, noticed by the Eastern Udmurt among the singers of the eldest generation, is the peculiar vibrato on the last sounds of the melostrophe, which evokes the timbre of the kuray.

\section{The aesthetics of sound and the sound behaviour}

The Udmurt traditional society has shaped its particular sound behaviour, and it is expressed in the rituals of welcoming etiquette. The community ritual singing is a symbol of co-unity, co-friendship, compassion. This unity is expressed in a most characteristic detail. When singing around the table, in the welcoming rituals, one of the singers, finishing one strophe, stands up and with two hands he presses the hand of a guest staying in front of him (or of the host, if the guest addressed him). It is indeed difficult to name another field of activity by the Udmurts, where would dominate such atmosphere of mutual understanding and unity:

S'uan s'am

oydo kyrdzh'alom-gurlalom, ay gay,

kel'shoz medam kuyyosmy(y), ay gay?

$\operatorname{Maly}(y)$ uz kel'shy (y)

kuyyosmy (y), ay gay,

Van'myz no $(y)$ as'me

kamanda(y), ay gay.
Nuptial tune

(Kukmor district of Tatarstan)

Come on, let us sing, let us

chant, ay gay,

Shall our tunes fit together,

ay gay?

Why noy merge

with our tunes, ay gay.

If all of us we are

one kin, ay gay.

(Nurieva 1995: 146) 


\section{Irina Nurieva}

According to the mentality of the Udmurt community, when singing a ritual song, the voice of the singer must not stand out of the general sound field. To those who attempt to stand out, in general others comment: Katy en kyrdzh'ale, en kes'as'ke, en cherek"yale ('Do not sing loud, do not shout, do not yell'). This is well shown in the memoirs of a gifted singer from the Eastern Udmurt tradition: "While visiting, the young were even not allowed to sing, but I so wanted to sing. Shertzan (the name of her husband) went out on the porch to smoke, and immediately I started to sing. My husband's mother quietly stood up and went out. As soon as my husband entered from the porch, his mother told me: "Daughter in law, come out from the table, Shertzan is calling you". I already knew that he was going to admonish me, his mother, I suppose has brought him up so. "Why, he said, when you sing, your voice comes out louder than the elders' voice. If you want to sing, sing, but not louder than the elder. When you'll have two or three children, I shall not restrain you". So ignorant they were, they could have said she sings well, she knows how to sing" (Kamaltdinova 2007: 39).

Along with the general understandings about sound aesthetics, in some local groups there are particular, different traditions of values in singing. The Eastern Udmurt, for example, who experienced the strongest influence from the Turkic musical milieu, not only are able to sing the most complicated melodic ornamentation, but have loaned from the Tatars the aesthetic category of $m o^{\circ}$. In Tatar culture, one of the meanings of $m o^{\circ}$ "is not directly translatable in the description of the "performance phenomenon", and covers a whole complex of artistic, emotional and purely musical aspects: mastery, intimacy, ability to create with the performance a particular atmosphere, interpretation freedom, ability to add to the tune rich ornamentation, as well as often including the feeling of sadness, melancholy" (Sayfullina, Sageeva 2009: 81). The concept mynly kyrdzh'as', which exists by the Eastern Udmurt, can be translated as "skilful singer", who has a good musical ear, 
a flexible voice, a good knowledge of lyrics, the ability to transmit through singing an emotional message. The skilful singer pays the role of the leading singer, he or she drags others in his/her wake. If among the singer there are several "skilful singers", they take turns to sing. In the villages, this kind of performer is generally most respected: "Before, they adorned the songs, and they adorn them also today. Just compare, how I sing and how Faniya, she is sings in your style, sound and rhythm, but for us, "a skilful singer" (mynly kyrdzh'as'). Singing with ornaments, not everybody is able to. The "skilful singer" will not be able to do it without efforts. My granny also sang skilfully (mynly), but in her old age she was no more able to sing so well" (Kamaltdinova 2007: 46).

\section{Usto kyrdzh'as' - shudtem lue... (the gifted singer is not a happy person...)}

In the Udmurt traditional culture, there is an ambiguous attitude towards the singing art: on the one hand, the village community deeply appreciates and respects those who know traditional songs, and are able to sing, although the status of the performer-singer in the traditional Udmurt society is significantly different from the status of the performer-instrumentalist. Unlike the latter, even a skilful singer does not stand out in a particular category of persons, and he is not seen as an equal to the master of instrumental play, who received a gift from above. Everybody is expected to be able to sing, and this appears clearly in the ritual situations: to sing out of tune, to stamp out of rhythm, is made fun of and condemned. This kind of singers are called pal'l'an kyrdzh'as' 'a singer at the left'. On the other hand, a very widespread belief says that those who are able to sing well are unhappy in life. There are whole song texts about the unhappy fate of the "skilful singer" the usto / dzh'ech kyrdzh'as': 
Yuon s'am

anay mil'emly no(y) en

kyrdzh'a(y) shuiz,

shuttem no(y) loud no(y) ton (y)

shuiz.

anayles'veramze no pel'am öy

pon,

shuttem nyl"yosyz no(y) mon(y) lui.

Yuon s'am

n'ules(e)ki myni no pu

korany $(y)$,

koram $(y)$ puos no(yy) tyzhy

$\operatorname{tot}(y) \operatorname{mo}(y)$.

pichis'en $(y)$ kyr $(y) z$ 'any no

us(y)to lui,

shuttemmy lueme no(yy)

$\operatorname{tuzh}(y) \operatorname{tot}(y) \operatorname{mo}(y)$.

\section{Guzhem yuon gur}

N'upyr vydem dhz'eg"yosly en s'in'mas'ke esh"yosy, N'upyr vydem dzh'eg"yosyz tis'tem lue, shuo val. Kyrdzhas'-veras' nyl'l'osly en s'in'mas'ke, esh"yosy, Kyrdzhas'-veras' nyl'l'osyz shudtem lue, shuo val.
Welcoming tune

(Kukmor district, Tatarstan)

Mother told us

do not sing,

You will be unhappy,

she said.

I put my mother's words

aside,

Among her children I became unhappy.

(Nurieva 1995: 124)

Welcoming tune

(Kukmor district, Tatarstan)

I walked in the forest to cut

trees

The trees I cut are easy to

recognise.

From childhood I was

a master in singing,

It is well known that I will be unhappy.

(Nurieva 1999: 89)

Tune of the summer feast

(Kizner district)

Do not rejoice at the collapsed

rye, my friends

Collapsed rye may be without grains, they say.

Do not envy singing girls, my friends,

Singing girls happen to be

unhappy, they say.

(Churakova 1999: 68) 
Kuzebay Gerd is the first to have pointed out this characteristic ("the song is connected to the representation of an unhappy person"), and he explained it with the difficulty of being a singer: "to master the singing creativity, means to master a difficult art"; you may achieve perfection only through ordeals in your life (Gerd 2004: 150).

\section{Udmurt zout}

T'il'as'(i) sapegez(y) no(y) aigi kuchchasa no

ektyny(y) usto no mon lui. $\operatorname{turly}(y e)$ nuzh(y)noyez(y) no(y) mon ik adzh'ysa no

kyrd'any (y) usto no mon lui.

Ot'i no tat'i no aigi ve'lysa(y) be'lyny usto mon lui( $(y)$.

anaytem-ataytem ayig

budysa $(y)$

kyrdzh'any usto no mon lui(y).
Udmurt tune

(Mari-Turek district, Mari El)

Wearing bright boots,

I became

a skilful dancer.

Different sufferings,

Seeing, yes

I became a skilful singer.

Walking much here and there, I became a skilful walker.

Having remained without

a mother and a father,

I became a skilful singer.

(Nurieva 1999: 89)

This strange phenomenon is today difficult to explain unequivocally. The singer, the skilful singer, had also particular empowerment. It is not excluded that at some moment he/she had the status of a mediator between the worlds. And that, similar to a shaman, the usto kyrdzh'as' could not give up his art, predetermined by fate.

\section{Conclusion}

Thus, the sound worldview of the Udmurt, which has been forming for millennia, harmoniously integrated in the ontology and consisting in a permanent dialogue within the acoustic community, 


\section{Irina Nurieva}

demanded a strict sound behaviour within the natural world, as well as in the social and cultural space. Until today, this picture determines the behaviour of the Udmurt not only in their traditional milieu, but also in towns and cities.

\section{Sources}

Irina Nurieva's field data 2000 (FWM-2000).

Folklore expeditions of the Udmurt Institute and History, Language and Literature (FE UIIYaL). Record in the village of Baydalino, Yar district from T. Pashkina, born in 1938.

PMA-2002. FE UIIYaL. Enrollment in the village of Yushur, Krasnogorsk district from E. Alekseeva, born in 1928.

PMA-2013. FE UIIYaL. Recording in the village of Chutyr Igra district from T. Korepanova, born in 1964.

\section{References}

Boykova, E., Vladykina, T. 1992. Pesni yuzhnykh udmurtov [Songs of the Southern Udmurts]. I. Izhevsk: Udmurtskiy institut istorii, yazyka i literatury Uralskogo otdeleniya Rossiyskoy akademii nauk.

Churakova, R. 1995. Zvukovoy mir udmurtskogo narodnogo kalendarya [Sound World of the Udmurt Folk Calendar]. In: Golos i ritual [Voice and Ritual]. Moscow: GII.

Churakova, R. 1999. Pesni yuzhnykh udmurtov [Songs of the Southern Udmurts]. Izhevsk: Udmurtskiy institut istorii, yazyka i literatury Uralskogo otdeleniya Rossiyskoy akademii nauk.

Churakova, R. 2002. Bortnich'i pesni v udmurtskoy fol'klornoy traditsii [Forest Beekeeping Songs in the Udmurt Folk Tradition]. In: Etnomuzykovedeniye Povolzh'ya i Urala $v$ areal'nykh issledovaniyakh [Ethnomusicology of the Volga Region and the Urals in Areal Studies]. Izhevsk: Udmurtskiy institut istorii, yazyka i literatury Uralskogo otdeleniya Rossiyskoy akademii nauk.

Gavrilov, B. 1891. Pover'ya, obryady i obychai votyakov Mamadyshskogo uyezda, Urias'-Uchinskogo prikhoda [Beliefs, Rites and Customs of the Votyaks of Mamadysh District, Urias'-Ucha Parish]. II. In: 
Trudy chetvertogo arkheologicheskogo s"yezda v Rossii [Proceedings of the $4^{\text {th }}$ Congress of Archaeologists of Russia]. Kazan: Tipografiya Imperatorskogo universiteta, pp. 80-156.

Gavrilov, B. 1880. Proizvedeniya narodnoy slovesnosti, obryady i pover'ya votyakov Kazanskoy $i$ Vyatskoy guberniy [Productions on Folk Literature, Rituals and Beliefs of the Votyak of Kazan and Vyatka Provinces]. Kazan: Tipografiya A. A. Kokovinoy.

Gerd, K. 2004. Votyak v svoikh pesnyakh [The Votyak in His Songs]. In: K. Gerd Sobraniye sochineniy: $v 6 t$. Stikhotvoreniya, poemy, perevody, stat'i, nauchnyye raboty, pis'ma [Poems, Translations, Articles, Scientific Works, Letters]. Vol. 4. Izhevsk: Udmurtia.

Gerd, K. 1997. Udmurt v svoikh pesnyakh [The Udmurt in His Songs]. In: K. Gerd O ney ya pesn' poyu.... Stikhi i poemy, stat'i i nauchnye raboty, pis'ma [I sing a Song about Her ...: Poems, Articles and Scientific Works, Letters]. Izhevsk: Udmurtia.

Gippius, E., Eval'd Z.1989. K izucheniyu poeticheskogo i muzykal'nogo stilya udmurtskoy narodnoy pesni [To the Study of the Poetic and Musical Style of the Udmurt Folk Song]. Udmurtskiye narodnyye pesni [Udmurt Folk Songs]. Izhevsk: Udmurtskiy institut istorii, yazyka i literatury Uralskogo otdeleniya Rossiyskoy akademii nauk.

Golubkova, A., Pozdeev, P. 1987. Sokrovishche narodnoye: Ocherk ob udmurtskoy narodnoy pesne [Folk Treasure: Essay on the Udmurt Folk song]. Izhevsk: Udmurtia.

Gumilev, L. Ritmy Evrazii [Rhythms of Eurasia]. http://www.kulichki. $\mathrm{com} / \sim$ gumilev/ articles/Article05.htm/.

Hajdú, P. 1985. Ural'skiye yazyki i narody [Ural Languages and Peoples]. K. Maytinskaya (ed.). Moscow: Progress.

Istoriya Udmurtii: Konets XV - nachalo XX veka, 2004 [History of Udmurtia: Late $15^{\text {th }}-$ Early $20^{\text {th }}$ Century]. K. Kulikov (ed.). Izhevsk: Udmurtskiy institut istorii, yazyka i literatury Uralskogo otdeleniya Rossiyskoy akademii nauk.

Kamaltdinova, A. 2007. Dopesennoye i pesennoye intonirovaniye $v$ muzykal'nom fol'klore zakamskikh udmurtov (metodika notirovki zvukozapisey): vyp. kvalifikatsionnaya rabota [Presong and Song Intonation in Musical Folklore of the Eastern Udmurt (Method of Notation of Sound Recordings)]. Izhevsk: Institut iskusstv i dizaina UdGU. Manuscript.

Karpova, L. 2007. Srednechepetskiy dialekt udmurtskogo yazyka: Obraztsy rechi [The Central Cheptsa Dialect of the Udmurt Language: Speech Samples]. Izhevsk: Udmurtskiy institut istorii, yazyka i literatury Uralskogo otdeleniya Rossiyskoy akademii nauk. 
Kel'makov, V. 1990. Obraztsy udmurtskoy rechi 2: sredinnyye govory [Samples of the Udmurt Speech 2: Central Subdialects]. Izhevsk: Udmurtskiy institut istorii, yazyka i literatury Uralskogo otdeleniya Rossiyskoy akademii nauk.

Koshurnikov, V. 1880. Byt votyakov Sarapul'skogo uyezda, Vyatskoy gubernii: Etnograficheskiy ocherk [Life of the Votyak of the Sarapul District, Vyatka Province: Ethnographic Sketch]. Kazan: Tipografiya Imperatorskogo Universiteta.

Lobanov,M. 1997.Lesnyyeklichi:Vokal'nyye melodii-signalyna Severo-Zapade Rossii [Forest Calls: Vocal Melodies-Signals in the North-West of Russia]. Sankt-Petersburg: Izdatel'stvo Sankt-Peterburgskogo universiteta.

Matsievskiy,I.2007. Narodnayainstrumental'naya muzykakakfenomenkul'tury [Folk Instrumental Music as a Cultural Phenomenon]. Almaty: Daik-Press.

Munkácsi, B. 1887. Votják népköltészeti hagyományok [Votyak Folklore Traditions]. Budapest: Magyar Tudományos Akadémia.

Napol'skikh, V. 1997. "Bisermini" ["Bisermins"] in O Besermyanakh [About the Besserman]. G. K. Shklyayev (ed.). Izhevsk: Udmurtskiy institut istorii, yazyka i literatury Uralskogo otdeleniya Rossiyskoy akademii nauk.

Nurieva, I. 1999. Muzyka v obryadovoy kul'ture zavyatskikh udmurtov: Problemy kul'turnogo konteksta i traditsionnogo myshleniya [Music in the Ceremonial Culture of the Trans-Vyatka Udmurt: Problems of Cultural Context and Traditional Way of Thinking]. Izhevsk: Udmurtskiy institut istorii, yazyka i literatury Uralskogo otdeleniya Rossiyskoy akademii nauk.

Nurieva, I. 2004. Pesni zavyatskikh udmurtov [ Songs of the Trans-Vyatka Udmurt] II. Izhevsk: Udmurtskiy institut istorii, yazyka i literatury Uralskogo otdeleniya Rossiyskoy akademii nauk.

Pervukhin, N. 1888 (1). Eskizy predaniy i byta inorodtsev Glazovskogo uyezda [Essays about the Legends and the Everyday Life of NonRussians of the Glazov District]. Eskiz 1: Drevnyaya religiya votyakov po ego sledam $\mathrm{v}$ sovremennykh predaniyakh [Essay 1: The Ancient Religion of the Votyak in Its Traces in Modern Traditions.]. Vyatka: Gubernskaya tipografiya.

Pervukhin, N. 1888 (2). Eskizy predaniy $i$ byta inorodtsev Glazovskogo uyezda [Essays about the Legends and the Everyday Life of Non-Russians of the Glazov District]. Eskiz 2: Idolozhertvennyy ritual drevnikh votyakov po ego sledam v rasskazakh starikov i v sovremennykh obryadakh [Essay 2: The Idol-Sacrificial Ritual of the Ancient Votyak in Its Traces in the Stories of Elder People and in Modern Rituals]. Vyatka: Gubernskaya tipografiya. 
Pervukhin, N. 1889. Eskizy predaniy i byta inorodtsev Glazovskogo uyezda [Essays about the Legends and the Everyday Life of Non-Russians of the Glazov District]. Eskiz 4: Sledy yazycheskoy drevnostiv obraztsakh ustnoy narodnoy poezii votyakov [Essay 4: Traces of Pagan Antiquity in Images of the Oral Folk Poetry of the Votyak]. Vyatka: Gubernskaya tipografiya.

Popova, E. 2009. Kalendarnyye obryady besermyan [Calendar Rituals of the Besserman]. Izhevsk: Udmurtskiy institut istorii, yazyka i literatury Uralskogo otdeleniya Rossiyskoy akademii nauk.

Sayfullina, G., Sageeva, G. 2009. Kategorii tatarskoy traditsionnoy muzykal'noy kul'tury: annotirovannyy slovar' [The Categories of Tatar Traditional Musical Culture: An Annotated Dictionary]. Kazan: Tatarskoye knizhnoye izdatel'stvo.

Smirnov, I. 1890. Votyaki: Istoriko-etnograficheskiy ocherk [The Votyaks. Historical and Ethnographic Essay]. Izvestiya Obshchestva arkheologii, istorii i etnografii pri Imperatorskom Kazanskom universitete. Vol. 8, issue 2. Kazan: Tipografiya Imperatorskogo universiteta.

Shklyayev, G. 1998. Etnicheskaya psikhologiya udmurtov po literaturnym dannym [The Udmurt"s Ethnic Psychology According to Literature]. In: Ob etnicheskoy psikhologii udmurtov [On the Ethnic Psychology of the Udmurts]. Izhevsk: Udmurtskiy institut istorii, yazyka i literatury Uralskogo otdeleniya Rossiyskoy akademii nauk.

Steinfeldt, N. 1894. Besermyane. Opyt etnograficheskogo issledovaniya [The Besserman. Experience of Ethnographic Research]. In: Kalendarya pamyatnaya knizhka Vyatskoy gubernii na $1895 \mathrm{~g}$. [Calendar and memorial book of the Vyatka province for 1895]. Vyatka: Gubernskaya tipografiya, pp. 220-259.

Wail, Petr 2013. Genius of the Place. http://lib.ru/PROZA/WAJLGENIS/genij.txt.

Vereshchagin, G. 1995. Votyaki Sosnovskogo kraya [The Votyak of the Sosnovka Region]. In: Sobraniye sochinyeniy: V6 6 . [Collected Works in 6 Vols]. Vol. 1. Izhevsk: Udmurtskiy institut istorii, yazyka i literatury Uralskogo otdeleniya Rossiyskoy akademii nauk.

Vereshchagin, G. 1998. Kamay. Iz byta votyakov. In: Sobraniye sochinyeniy: Etnograficheskiye ocherki [Collected Essays: Ethnographic essays]. Vol. 3. Izhevsk: Udmurtskiy institut istorii, yazyka i literatury Uralskogo otdeleniya Rossiyskoy akademii nauk.

Vereshchagin, G. 2001. Sobranie sochineniy: V $6 t$. [Collected Works: In 6 Vol.]. Vol. 4: Fol'klor. Book 1: Udmurtskiy fol'klor: Predaniya. Legendy. Pobyval'shchiny. Skazki. Basni. Poslovitsy. Pogovorki. Zagadki [Folklore. Book 1: Udmurt folklore: Traditions. Legends. Stories. Fairy tales. Fables. Proverbs. Riddles]. Izhevsk: Udmurtskiy institut istorii, yazyka i literatury Uralskogo otdeleniya Rossiyskoy akademii nauk. 
Vereshchagin, G. 1996. Votyaki Sarapulskogo uyezda Vyatskoy gubernii. Sobraniye sochinyeniy: $v 6 t$. [The Votyak of the Sarapul District, Vyatka Governorate. Collected Works in 6 Volumes]. II. Izhevsk: Udmurtskiy institut istorii, yazyka i literatury Uralskogo otdeleniya Rossiyskoy akademii nauk.

Vereshchagin, G. 1998. Staryye obychai i verovaniya votyakov Glazovskogo uyezda [Old Customs and Beliefs of the Votyak of the Glazov District]. In: Sobraniye sochinyeniy: $v 6 t$. [Collected Works in 6 Volumes]. Vol. 3. Izhevsk: Udmurtskiy institut istorii, yazyka i literatury Uralskogo otdeleniya Rossiyskoy akademii nauk.

Vinogradov, V. 2011. Golosa lesa v sisteme mifologicheskikh predstavleniy narodov Evropeyskogo Severa [Voices of the Forest in the System of Mythological Representations of the Peoples of the European North]. II. In: Ot kongressa $k$ kongressu: materialy Vtorogo Vserossiyskogo kongressa fol'kloristov [From Congress to Congress: Materials of the Second All-Russian Congress of Folklorists]. Moscow: GRTSRF.

Vladykin, V. 1994. Religiozno-mifologicheskaya kartina mira udmurtov [Udmurts' Religious and Mythological Worldview]. Izhevsk: Udmurtia.

Vladykina, T. 1997. Udmurtskiy fol'klor: problemy zhanrovoy evolyutsii $i$ sistematiki: Monografiya [Udmurt Folklore: Problems of Genre Evolution and Taxonomy. Monography]. Izhevsk: UIIYaL UrO RAN.

Votyaki Vyatskoy gubernii 1856. [The Votyaks of the Vyatka Governorate]. In: Vyatskiye gubernskiye vedomosti [Vyatka News] II, No. 10.

Zemtsovskiy, I. 1976. Narodnaya muzyka [Folk Music]. Vol. III. In: Muzykal'naya entsiklopediya [Musical Encyclopedia]. Moscow: Sovetskaya enciklopediya.

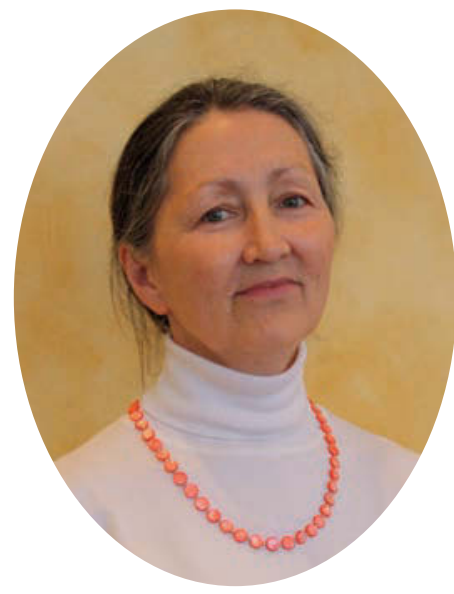

Irina Nurieva, ( $\mathrm{PhD}$ hab) is working as ethnomusicologist at the Udmurt Institute for Research in History, Language and Literature (Udmurt Federal Research Centre of the Ural Branch of the Russian Academy of Sciences). She has worked on Udmurt musical folklore, and has published a series of works about Udmurt folk music.

e-mail: nurieva-59@mail.ru 


\title{
An Udmurt Flute
}

\section{Irina Pchelovodova}

e-mail: orimush@mail.ru

\begin{abstract}
The article gives a complete description of the $u z^{\prime} y g u m y$, the Udmurt traditional flute. Published articles by Russian researchers and new field material recorded during expeditions between 2004 and 2009 are used as the main sources. For the first time the process of manufacture of the instrument is observed, the territory of its existence is outlined, preferable sizes of the instrument are given, the way of playing and repertoire of executed folk tunes are described.
\end{abstract}

Keywords: end-blown flute, manufacture, methods of playing the instrument, repertoire, Udmurt, traditional musical instruments

Today, there are separate articles devoted to this or that musical instrument, although the culture of Udmurt traditional instruments is still generally poorly investigated in Russian ethno-organology.

The investigation of Udmurt musical instruments began in the middle of the $20^{\text {th }}$ century with the greatest attention paid to chordophones. The oldest Udmurt musical instrument the krez' (zyther) is especially distinguished among them (Buch 1882; Belyaev 1989; Gippius, Eval'd 1989; Golubkova 1978, 1989, 1992; Karpov 1989; Kungurov 1992). The sound is produced by strings stretched between two fixed holders. A musical collection of folk 
tunes performed on the kubyz (violin) was published in 2004 (Nurieva 2004, 2005; Pchelovodova, Demeter 2011; Pchelovodova 2012). There is much less information about Udmurt aerophones. Significant information about them appeared after field expeditions between 2004 and 2009 (Pchelovodova 2010). This article is devoted to a complete description of the Udmurt traditional flute, the $u z^{\prime}$ 'yumy, based on materials from published and field sources.

The instrument was named after the umbellate uz'ygumy/gumy plant (Angelica) from which it is made and it is an archaic musical instrument of the Udmurt (photo 1). This is an end-blown labial fricative flute $50-80 \mathrm{~cm}$ in length with a whistle hole but no finger holes. The uz'ygymy produces only natural sounds that depend on the material and the size of the instrument. A musician can modify the sound pitch of the instrument by closing the lower hole with a forefinger, tightening the lips and changing the blowing force. There are some similar musical instruments in the traditional cultures of the Finno-Ugric people (the Komi have the otika pöl'an, the Mari the shiyaltysh, the Karelians and Finns the siirtotulppaiset huilut, and the Hungarians the tilinkó) (Chistalev 1984; Gerasimov 1996; Leisiö 1983; Vargyas 2005), the Turkic people (the Tatars and the Bashkirs have the kuray, the Chuvash the shahlich) (Makarov 2006; Chuvashi 1970), the Slavonic people (the Russians have the travyanaya dudka / kalyuka) (Kiryushina 1989), the peoples of Siberia (the Tuvinians have the murgu, the Altais the shoor) (Suzukey 2007), the Scandinavian people (the Norwegians have the spaltefløyta) (Sevåg 1973), the South American Indians (Izikowitz 1935) and many others. Probably one of the reasons for the popularity of the instrument is the simplicity of its manufacture. All these instruments are made from the stalk of umbellate plants such as Angelica, Reed, Rhubarb, etc. 


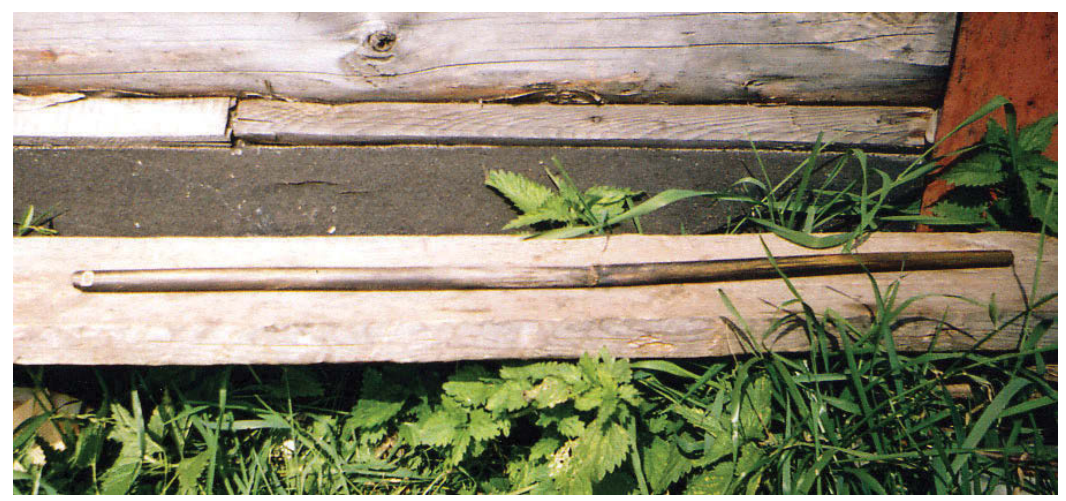

Photo 1. Uz'ygumy. Novyy Untem, Kez district, Udmurt Republic. Photo by Irina Pchelovodova, 2004.

\section{The data from written sources}

The first data on the uz'ygumy appeared in an article by Soviet researchers Evgeniy Gippius and Zinaida Eval'd titled "On the Study of the Poetic and Musical Style of Udmurt Folk Songs" (Gippius, Eval'd 1989). In the article authors describe the uz'ygumy and the chipchirgan (a natural trumpet), which hadn't been mentioned previously. Music samples of traditional folk tunes written at Evgeniy Gippius's request in 1936 were published only in 1989. Two folk tunes (wedding and recruiting) were presented there.

In 1989 the editors added the article "Information about Udmurt Folk Musical Instruments" by musicologist Viktor Belyaev (Belyaev 1989), which the editors thought had been written at Evgeniy Gippius's request. The value of the work consists in the attempt to classify Udmurt musical instruments. Viktor Belyaev divides them into percussion instruments, stringed instruments and wind instruments, which are sub-divided into families of trumpets (chipchirgan), flutes (uz'ygumy) and clarinets (byz (bagpipes)). Some 
more music samples were published in the Udmurt Folk Songs collection by Irina Travina (Travina 1964). However, the author does not give the characteristics of instruments.

Between the 1970s and 1990s new works were published containing descriptions of construction, methods of playing and the technical possibilities of the Udmurt flute (Vertkov, Blagodatov, Yazovitskaya 1975; Golubkova 1978, 1989, 1992; Karpov 1989; Kungurov 1992). All publications reported that the uz'ygumy had disappeared from tradition. Only the works of modern ethnologist Elena Popova, devoted to Udmurt and Besserman ${ }^{1}$ children's game culture, contain information on the $u z^{\prime} y$ gumy shulan, a whistle made from angelica $15-50 \mathrm{~cm}$ in length (Popova 2005).

\section{The field ethnographical materials}

The expedition materials of the Udmurt Institute of History, Language and Literature at the Udmurt Federal Research Centre of the Ural Branch of the Russian Academy of Science (below UIIYaL FITs UrO RAN) from 2004-2009 have shown that the tradition of playing the $u z^{\prime}$ 'yymy isn't lost but survives in practice. Modern field ethnographic materials have expanded knowledge about the Udmurts end-blown flute. These data have allowed us to specify an area where the instrument is spreading and to reveal some varieties of Udmurt flute.

We recorded the playing of an $u z^{\prime} y g u m y$ for the first time in the north of the Udmurt Republic in 2004-2005 and then again in $2007^{3}$. The instrument was $49 \mathrm{~cm}$ in length with a whistle hole and no finger holes. As material for the instrument the player Evgeniy Khudyakov (1939-2009) used a rubber hose (photo 2). He considered that the traditional material (umbellate plant stalk) was too short-lived and impractical. Therefore he used modern materials such as a rubber hose, plastic and aluminium tubes. 
But Khudyakov had tried to keep the traditional form of the instrument. Thus he made the top part of the instrument from a wide tube and for the bottom part used a narrower tube. When making the uz'ygumy from a plant stalk Khudyakov used human measurements to find the length of the instrument, depending on length of the arm 78-82 cm, with the width of the instrument corresponding to the width of the thumb.

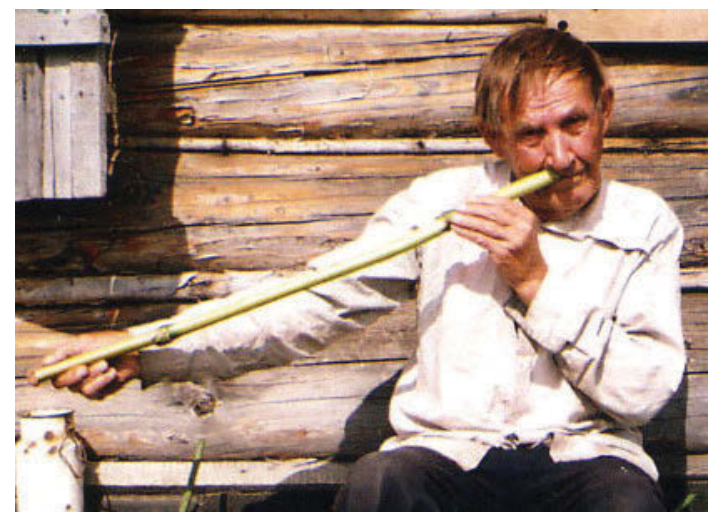

Photo 2. Uz'ygumy player Evgeniy Andreevich Khudyakov. Novyy Untem, Kez district, Udmurt Republic. Photo by Irina Pchelovodova, 2004.

The other players (Aleksey Semyonov, 1938 and Nikolay Chupin, 1925) had shorter instruments, $40-60 \mathrm{~cm}$ in length. In rare cases the $u z^{\prime}$ ygumy had finger holes, but no more than two and cut roughly.

In 2008 data, the uz'ygumy was fixed in the south of Udmurt Republic for the first time ${ }^{4}$. The construction of the instrument was similar to the previous examples mentioned. The flute was cut from 
between crosspieces of a plant and was 40-42 cm in length with no finger holes. The performer, Anatoliy Bykov (b. 1938), preferred instruments made from a fresh, not dried, plant stem because the sound is more sonorous (photo 3 ).

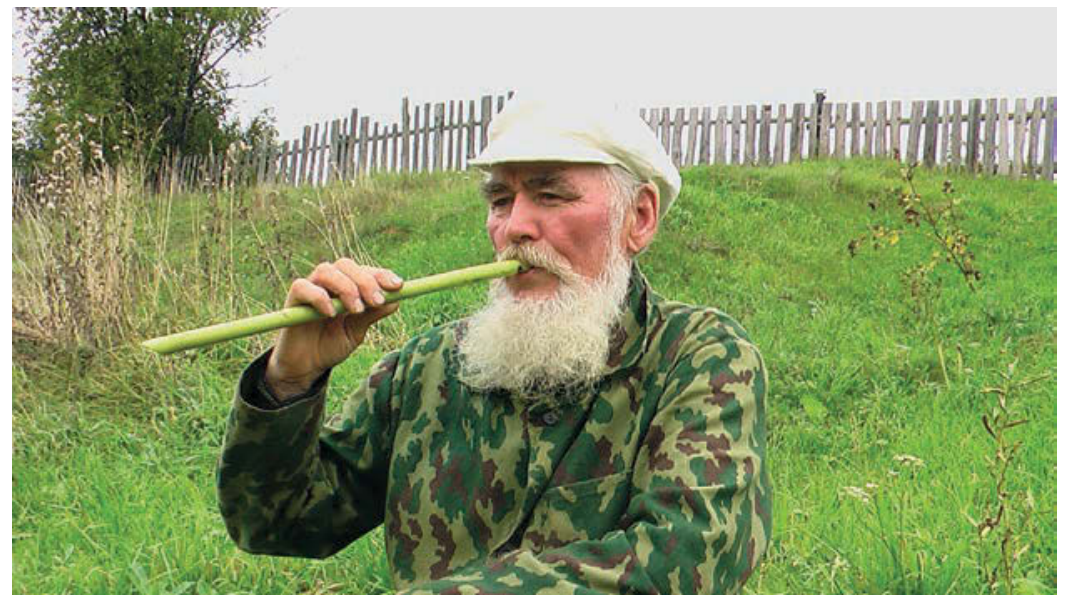

Photo 3. Uz'ygumy player. Anatoliy Dmitrevich Bykov. Chutozhmon, Malaya Purga district, Udmurt Republic. Photo Irina Pchelovodova, 2009.

The Siberian Udmurt living in the Tomsk region of Russia also had similar a instrument, also known as a $u z^{\prime} y g u m y^{5}$. Vasilisa Perevozchikova (b. 1929) said that the instrument had been made from chushni (Anthriscus sylvestrus). At the upper end of the instrument there was a whistle plug while the other end was closed by the plant's natural crosspiece. Probably, there were also finger holes.

All performers have their own methods of playing the instrument. When playing the uz'ygumy musicians put it to their mouths in such manner that the whistle hole is in the bottom part of the tube, or more rarely above. Air is blown into the hollow tube of 
the instrument and the bottom part is closed. In the south of the Udmurt Republic one performer, Anatoliy Bykov, demonstrated different ways of playing the flute. Thus he created melodies through the mobility of his lips and by changing the instrument position.

As has been said before one of the reasons for the popularity of the instrument was the simplicity of its making. As a rule the Udmurt flute was mainly used by shepherds. In addition, playing the uz'ygumy accompanies young people's outdoor festivals, returning to village after haymaking, and when searching for honey. During the Great Patriotic War the uz'ygumy was the only musical instrument in villages.

It was possible to play uz'ygumy solo or in an ensemble. Performers held competitions with the best performers estimated on skill of playing. Only male shepherds and young guys could play the instrument. In traditional culture grazing was men's work and so women didn't play the uz'ygumy.

Each musician has his own repertoire, for example Evgeniy Khudyakov performed only dance (ekton gur) and chastushka tunes. Sometimes he played in ensembles with an harmonica if the key of the instruments concurred. Masterly uz'ygumychi (player) Ivan Shabalin (1902-19??) from Selty district in the Central part of Udmurt Republic played different melodies such as dance tunes (ekton gur), work tunes (pur kel'an gur, tunes performed during timber rafting), ceremonial tunes (kuno gur, 'guest tune'), borrowed melodies (dzh'uch gur, 'Russian tune') and also his own melodies. It is possible to play song melodies on the instrument as well as improvisations.

At a preliminary stage of our research we can say that Udmurt end-blown flute is a culture phenomenon that occurs in all Udmurt groups. We can distinguish two types of uz'ygumy according to construction (design). The first type is the open end-blown flute with a whistle hole and without finger holes (or with no more than two). The length of the instrument depends on the length of the 
musician's arm. However the length of the instrument could be shorter depending on the desire of the performer to tune to a specific range. The second type is the closed end-blown flute with a whistle plug and probably with finger holes too.

In conclusion, let us observe that today the uz'ygumy is not present in living tradition. We must acknowledge the fact that transmission of playing has been interrupted. Nevertheless, the uz'ygumy, its making and playing, have continued in the repertoires of some folklore ensembles in Udmurtia, such as Aykay, the Udmurt state theatre of folk songs and dances; the folklore and ethnographic ensemble Chipchirgan; and the folklore ensemble Soroka ('magpie') from the Republic's musical college. One of the present masters and makers is Evgeniy Bikuzin.

\section{Notes}

1 The Besserman people are ethnically a group of Udmurt with a strong Turkic influence.

${ }^{2}$ Folklore and ethnographic expedition of the Udmurt Institute of History, Language and Literature in 2004: Kez district of Udmurt Republic. Participants: T. Vladykina, A. Mutina, I. Pchelovodova, A. Nikulin, E. Lozhkina, T. Vladykina. In $2005 \mathrm{Kez}$ district of Udmurt Republic. Participants: I. Pchelovodova, A. Nikulin.

${ }^{3}$ Folklore and ethnographic expedition of the Udmurt Institute of History, Language and Literature in 2007: Glazov district of the Udmurt Republic. Participants: I. Pchelovodova.

${ }^{4}$ Folklore and ethnographical expedition of the Udmurt Institute of History, Language and Literature in 2008: Malaya Purga district of Udmurt Republic. Participants: I. Pchelovodova.

5 Folklore and ethnographical expedition of the Udmurt Institute of History, Language and Literature in 2006: Chainsk district of Tomsk region. Participants: I. Pchelovodova in the delegation from Udmurt Republic. 


\section{References}

Belyaev, V. 1989. Spravka ob udmurtskikh narodnikh muzykal'nykh instrumentakh [Information about the Udmurt National Musical Instruments]. E. Gippius, Z. Eval'd. Udmurtskiye narodnyye pesni: Teksty i issledovaniya. Izhevsk: Udmurtskiy institut istorii, yazyka i literatury Uralskogo otdeleniya Rossiyskoy akademii nauk (Pamyatniki kul'tury. Fol'klornoe nasledie), pp. 34-38.

Buch, M. 1882. Die Wotjäken, eine ethnologische Studie [The Votyak. An Ethnologic Study]. Helsingfors: Finnische Litteratur Gesellschaft.

Chistalev, P. 1984. Komi narodnyye muzykal'nyye instrumenty [The National Musical Instruments of the Komi]. Syktyvkar: Komi knizhnoye izdatel'stvo.

Chuvashi. Etnograficheskoye issledovaniye [Chuvash. Ethnographic Research] 1970. Vol. 2. Cheboksary: Chuvashskoye kn. izd-vo.

Gerasimov, O. 1996. Traditsionnyye muzykal'nyye instrumenty mari [The Traditional Musical Instruments of the Mari]. Yoshkar-Ola: Mariyskiy izd.-poligr. kombinat.

Gippius, E., Eval'd, Z. 1989. Udmurtskie narodnye pesni: Teksty $i$ issledovaniya [The Udmurts National Songs: Texts and Researches]. Izhevsk: Udmurtskiy institut istorii, yazyka i literatury Uralskogo otdeleniya Rossiyskoy akademii nauk (Pamyatniki kul'tury. Fol'klornoye naslediye).

Golubkova, A. 1978. Muzykal'naya kul'tura Sovetskoy Udmurtii (1917-1967) [The Musical Culture of the Soviet Udmurtia]. Izhevsk: Udmurtia.

Golubkova, A. 1989. K voprosu o rannikh etapakh formirovaniya muzykal'noy kul'tury udmurtov [About the Early Stages of Formation of Musical Culture of the Udmurt]. Istoki iskusstva Udmurtii. Izhevsk: Udmurtskiy institut istorii, yazyka i literatury Uralskogo otdeleniya Rossiyskoy akademii nauk, pp. 3-11.

Golubkova, A. 1992, Rol' muzykal'nyh instrumentov i instrumental'noy muzyki v dukhovnoy kul'ture udmurtov [The Role of Musical Instruments and Instrumental Music in the Spiritual Culture of the 
Udmurts]. Vestnik UdGU [Bulletin of Udmurt University]. No 6. Izhevsk, pp. 63-69.

Izikowitz, K. 1935. Musical and other sound instruments of the South American Indians: a comparative ethnographical study. Goteborg: Elanders.

Karpov, A. 1989. Drevniye muzykal'nyye instrumenty (Ketnograficheskomu izycheniyu) [The Ancient Musical Instruments (To Ethnographic Studying)]. Istoki iskusstva Udmurtii. Izhevsk: Udmurtskiy institut istorii, yazyka i literatury Uralskogo otdeleniya Rossiyskoy akademii nauk, pp. 12-22.

Kiryushina, T. 1989. Traditsionnaya russkaya instrumental'naya kul'tura [The Traditional Instrumental Culture of the Russian]. Moscow: GMPI im. Gnesinyh.

Kungurov, S. 1992. Udmurtskiye traditsionnyye muzykal'nyye instrumenty [The Udmurt Traditional Musical Instruments]. Izhevsk: RDNT-Dom molodyozhi.

Leisi, T. 1983. Suomen ja Karjalan vanhakantaiset torvi-ja pillisoittimet: nimistö, rakenteet ja historia [The Primitive Trumpet and Pipe Instruments in Finland and Karelia: Organonymes, Constructions and History]. Kaustinen: Kansanmusiikki-instituutti.

Makarov, G. 2006. Traditsionnyye dukhovnyye muzykal'nyye instrumenty tatar Volgo-Kam'ya (Problemy genezisa $i$ istoricheskoy rekonstruktsii) [The Traditional Wind Musical Instruments of the Tatar of the Volga and Kama Region (Problems of Genesis and Historical Reconstruction)]. Kazan: IIALI AN RT.

Nurieva, I. 2004. Pesni zavyatskikh udmurtov [Songs of the Trans-Vyatka Udmurts]. Vol. 2. Izhevsk: Udmurtskiy institut istorii, yazyka i literatury Uralskogo otdeleniya Rossiyskoy akademii nauk (Udmurtskiy fol'klor).

Nurieva, I. 2005. Kubyz/kubyzchi v mezhnatsional'nom kontekste kul'tur [The Kubyz and the Kubyzchi in the International Context of Cultures]. Muzykant v kul'ture: kontseptsii i deyatel'nost'. Sankt-Petersburg: RIII, pp. $46-50$.

Pchelovodova, I., Demeter, M. 2011. Kubyz: sposoby i priyomy igry traditsionnykh ispolniteley [The Kubyz: Ways and Methods of the Play of Traditional Performers]. Otechestvennaya etnomuzykologiya: 
istoriya nauki, metody issledovaniya, perspektivy razvitiya [Russian Ethnomusicology: History of the Discipline, Research Methods, Development Perspectives]. Sankt-Petersburg: Universitetskiy Obrazovatel'nyy okrug Sankt-Peterburga i Leningradskoy oblasti. T. 2, pp. 310-321.

Pchelovodova, I. 2012. Khordofony v traditsionnoy kul'ture udmurtov [The Chordophones in the Traditional Culture of the Udmurt]. Traditsionnaya kul'tura [The Traditional Culture]. No 4, pp. 44-49.

Pchelovodova, I. 2010. Aerofony v sisteme traditsionnoy instrumental'noy kul'tury udmurtov [The Aerophones in the System of Traditional Instrumental Culture of the Udmurt]. Ezhegodnik finno-ugorskikh issledovaniy [Yearbook of Finno-Ugric Studies]. Vol. 1, pp. 95-108.

Popova, E. 2005. Igrushki iz rasteniy v detskoy igrovoy kul'ture udmurtov i besermyan [The Toys from Plants in Children's Game Culture of the Udmurt and Besserman]. Traditsionnaya kul'tura [The Traditional Culture]. No 3, pp. 85-93.

Sevåg, R. 1973. Det Gjallor og det loet. Frå skremmeog lokkereiskapar til folkelege blåseinstrument. Oslo: Norsk Kulturarv.

Suzukey, V. 2007. Muzykal'naya kul'tura Tuvy v XX stoletii [The Musical Culture of the Tuva in the $20^{\text {th }}$ Century]. Moscow: Kompozitor.

Travina, I. 1964. Udmurtskiye narodnyye pesni [The Udmurt Folk Songs]. Izhevsk: Udmurtia.

Vargyas, L. 2005. Folk Music of the Hungarians. Budapest: Akadémiai Kiadó.

Vertkov, K., Blagodatov, G., Yazovitskaya, E. 1975. Atlas muzykal'nykh instrumentov narodov SSSR [Atlas of Musical Instruments of the People of the USSR]. Izd-vo 2-e, dop. i pererab. Moscow: Muzyka, pp. 73-75. 


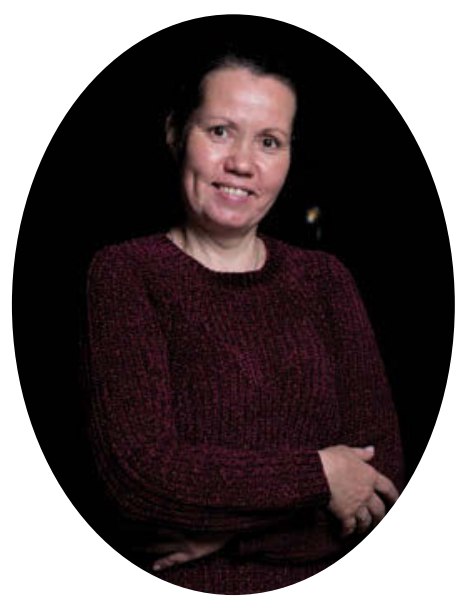

Irina Pchelovodova $(\mathrm{PhD})$ is an ethnomusicologist and a research associate at the Udmurt Institute for Research in History, Language and Literature (Udmurt Federal Research Centre of the Ural Branch of the Russian Academy of Sciences). She is interested in Udmurt folk music, folk song and folk instruments. She teaches at the University and at the Music college; she is the leader of the folklore and ethnographic musical group Chipchirgan.

e-mail: orimush@mail.ru 


\title{
An Udmurt Exceptional Performer, Dzhakapay
}

\author{
Irina Pchelovodova \\ e-mail: orimush@mail.ru
}

Nikolai Anisimov

e-mail: nikolai.anisimov@folklore.ee; kyldysin@yandex.ru

\begin{abstract}
This article concentrates on the phenomenon of the individual in the ethnic culture of the Udmurt, bearing in mind that this has never been attempted before. This is a proper framework to analyse Ol'ga Solov'yova's (1932-2018) personality, who was famous among the people as Dzhaky / Dzhakapay / Dzhaky apay (lit: Aunt Jay). A whole range of reasons justifies scientific interest in her: her huge repertoire of songs and rituals, her ability to improvise freely within her local tradition, her unique musical and auditory skills.

The analysis of Dzhakapay's character allows us to connect the songs of her repertoire and her fate. Many non-ritual songs are in fact autobiographical narratives, dedicated to reflexions on an unhappy fate, on being an orphan. A considerable number of songs in her repertoire belong to the category of so-called personal songs (in Russian: imennyye pesni, 'name songs'), which represent a kind of personal memoire in musical form. Another unique feature of this performer's art is her knowledge of songs from neighbouring villages in their original language (Russian, Mari, Tatar) and their translation into Udmurt.

Her knowledge of the local traditional rituals made her very important to the local community, in which she was deeply respected. Until the last day of her life, she followed the ontological positions, the rules
\end{abstract}


of behaviour, the canons of ritual and singing performance elaborated by tradition, and attempted to instil them into the people surrounding her. This awakened her genuine interest in the social and scientific milieu. And today, when she is no longer among us, her name is attached to many very different projects.

Keywords: biography, individual, performer's character, singing repertoire, Udmurt, tradition

\section{Dzhakapayez bure vayysa no s'ulmys' tau karysa Remembering Dzhakapay and thanking her from the heart}

In every people's culture, there are individuals who distinguish themselves because of their creative potential and their charisma. Often they have deeply individual signatures in performance and are able to accumulate and transmit the cultural heritage of their people. Therefore, "it is important to approach folk culture through the world of its makers, persons, individuals, creators" (Romodin 2009: 9). As Romodin justly observes, only by going back to the human, subjective principle (unlike the formal and theoretic investigation of folklore units) can we see the living, intrinsic and fundamental component of ethnic culture (ibid.). Moreover, "the interest towards the human being as a subject of cultural tradition can be seen as one of the expressive trends emerging in today's humanities" (Lichnost'... 2014: 5).

Recent investigations have revealed that in tradition there are different types of folk musician (balanced, expressively unbalanced, mixed (transitionary) (Romodin 2009)), different manifestations of individuality in folk musical culture (Zhulanova 2014), as well as different modes in narrative tradition (Alpatov 2014). There have also been very convincing investigations into other cultures (for example Juha Pentikäinen 1971; Pino 2000). We must acknowledge that in Udmurt ethnomusicology and folkloristics, there has yet been no special research dedicated to the creative individual in 
traditional culture. We can mention only research by Svetlana Starodubtseva "Oh, My Poor Grieving Heart" (songs from Natalia Vlasova's repertoire)” (Starodubtseva 1999). This article attempts partly to fill this gap.

Thus, our attention concentrates on the main features of one of the brightest and most charismatic personalities in Udmurt traditional culture, Ol'ga Nikolaevna Solov'yova (1932-2018), called Dzhakapay. This choice is justified by the fact that, firstly, Dzhakapay demonstrated a colossal knowledge of folklore and ethnographic material from her tradition. In addition, both of the article's authors are well acquainted with her and for some years visited her regularly. This allowed them to observe her in everyday life, to participate in ritual action, and to interview her repeatedly, recording in writing her comments across the years.

\section{Childhood, family}

Dzhakapay was born in 1932 in Karamas-Pel'ga (Udm. Ud'd'ad'i), Kiyasovo district in Udmurtia, where she is best known under the name Dzhaky / Dzhakapay / Dzhaky apay (lit: Aunt Jay). She received this ornithomorphic name at birth, according to an old Udmurt tradition in which children received bird, animal and plant names because of frequent child mortality and long-term child illness. According to Dzhakapay, several children in her family died one after another, after which her parents gave her the name of the jay, Dzhaky.

In 1942, when she was ten, she and her three-year-old brother were orphaned when her father was killed at the front and her mother died suddenly. The children managed to avoid the orphanage and lived instead with their grandfather at his home.

These were difficult years for them and they were obliged to go about the village asking the villagers for food; they never had good clothes at this time. Sometimes the local kolkhoz helped and gave 
Irina Pchelovodova, Nikolai Anisimov

them half a $p u d^{1}$ of flour from the mutual aid fund. The assistance given by the villagers themselves was irreplaceable and Dzhakapay frequently thanked them in her songs.

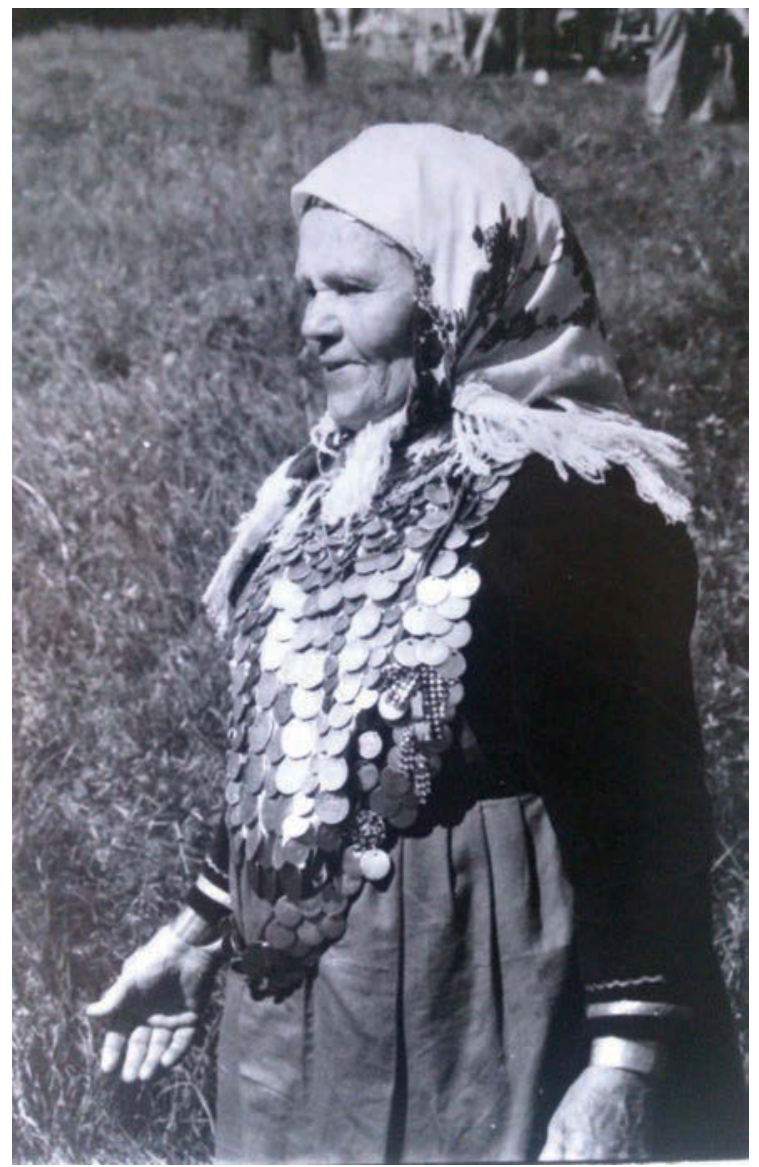

Photo 1. Dzhakapay - Ol'ga Solov'yova.

Photo from the Solov'yov family archive. 
As she remembered, on one of the hungry war days she decided to kill herself. However, an extraordinary event happened, and became a turning point in her fate:

Once I woke up early in the morning and I went out into the yard... My brother is small, my grandfather old. Then grandfather also died. We have no food, no clothes. The weather is windy. The neighbouring birch bends in different directions. To this day, I see this birch as my guardian angel. "Should I already die? What should I do?" I break down and weep. Then the birch seemed to answer me: "Do not die! Look at me: I bend down to the earth, and then I stand up, I straighten myself". At the same moment, without my noticing it, my brother came to me and said with tears in his eyes: "Sister, do not die! I shall never more weep or ask for food". These words remained in my heart for all my life.

Photo 2. Dzhakapay with her brother Semyon, 1954. Photo from the Solov'yov family archive.

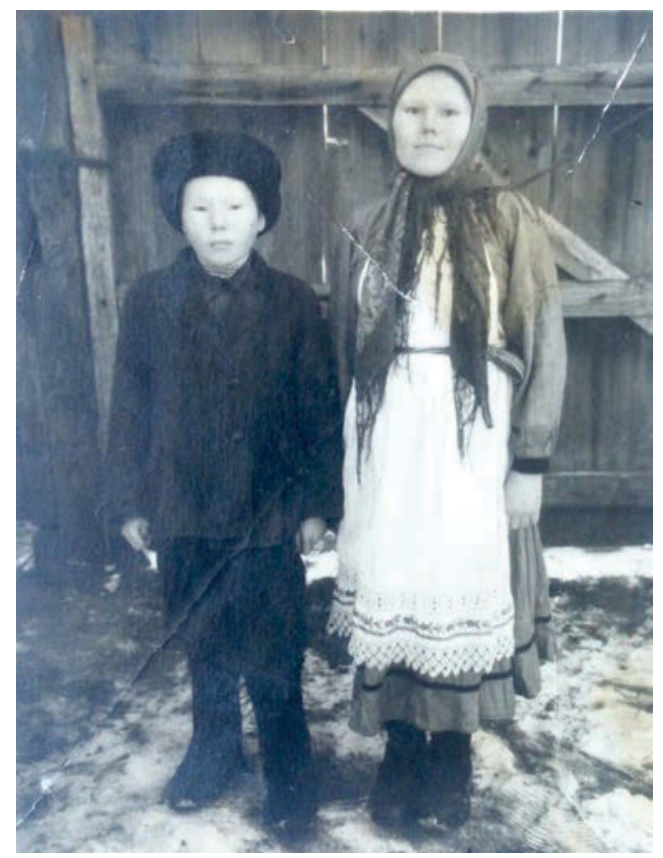


Because of the difficult circumstances of her life, Dzhakapay could not receive a full formal education, completing only four classes. But she promised herself that she would educate her brother Semyon Nikolaevich Utekhin. Semyon did indeed finish high school and went to university, to the Izhevk Agricultural Institute (now the Izhevsk State Agricultural Academy).

Dzhakapay married a man from the same village, a widower with six children. She did not have any children herself but raised her husband's children as her own. In addition, she took under her wing two of her brother-in-law's children who had become orphans.

She started her working life at the local kolkhoz, named Harvest (in Russian: urozhay, later renamed Lenin). She worked as a postman at the Karamas-Pel'ga liaison office receiving recognition for her work and her achievements: she was awarded the People's Friendship order and the medals For Labour Valour and Veteran of Labour. In 2005, she was awarded the title Kiyasovo District Citizen of Honour and in 2008 was given the Recognition award for her contribution to the development of folk art, bestowed by the government of the Udmurt Republic.

\section{Singing art and folk wisdom}

In Dzhakapay's hard fate, performing songs became her salvation. Through songs, she sang and shared her experiences, her concerns, her sorrows and her joys. This phenomenon reflects the Udmurt traditional psychology. Expressing emotions and thoughts through music is for the Udmurt a communicative channel that brings powerful cathartic and psychotherapeutic effects. In the psychology of the Udmurt, this is explained, according to ethnomusicologist Irina Nurieva, as a stereotypical Udmurt feature: "According to the rules of communication, the Udmurt, introverts by nature, are not allowed to express their emotions openly and loudly, to weep one's eyes out, to laugh loudly, to gesticulate widely" (Nurieva 2014: 206). Performing 
songs allows the Udmurt to express, to let out their inner state. These words are confirmed by what Dzhakapay herself says about singing:

I had not much experience of evening gatherings and funmaking. Partly I heard how my friends come back with songs from evening gatherings. But I composed songs in solitude, and I sang in my head. I even had no clothes to be in company. That's why I was very ashamed.... If I had not sung all this in my songs, I suppose I would not be alive with all the sorrows and hardness of life.

Many songs reflected her fate. In particular, she described the difficult period of her life in an autobiographical text using the tune from an Udmurt folksong. This song is close to the Udmurt lyric songs, reflecting on a sorrowful and unhappy fate. One of the main motifs expressing this state of mind is that of the orphan, who from a young age must go about among the people to earn herself a piece of bread to survive:

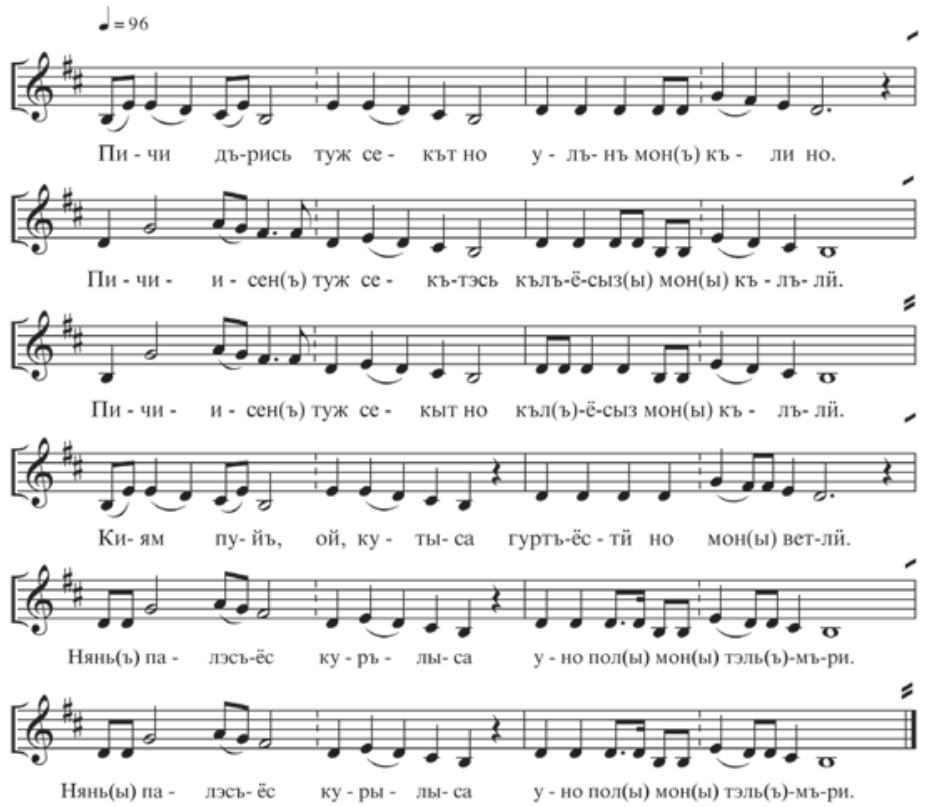


Pichi dyris' tuzh s'ekyt no Fromchildhooditisvery hard, and Ulyny mon(y) kyl'i no. I had to live, and.

Pichiis'en(y) tuzh s'ekytes' From childhood, very hard Kyl"yosyz(y) mon(y) kylyli. $\quad$ Words, yes, I heard.

Pichiis'en(y) tuzh s'ekyt no From childhood, very hard Kyl(y)yosyz mon $(y)$ kylyli. $\quad$ Words, yes, I heard.

Kiyam puyy, oy, kutysa, Taking in my hand, oh, a bag, Gurt"yosti no mon vetli. I went, yes, around the villages. N'an'(y) pales"yos kurylysa, Asking for crusts of bread, Uno pol(y) mon(y) tel'(y)myri. Many times I begged. N'an'(y) pales"yos kurylysa, Asking for crusts of bread, Uno pol(y) mon(y) tel'(y)myri. Many times I begged.

Bör(y)dis'ko no tshushis'kis'ko I weep and I dry my tears Töd'y vekchi kyshetam. With my thin white scarf. Mal(y)pas'kis'ko no paymis'ko I think and I wonder Yyrylen chidamezly. About the patience of my head Malpas'kis'ko no paymis'ko, I think and I wonder Yyrylen chidamezly. About the patience of my head ${ }^{2}$. (Kyrdzh'as'... 1995)

Frequently Dzhakapay used her songs to thank the people of her village because they did not allow her to quit the village, her father's house and her kin: 


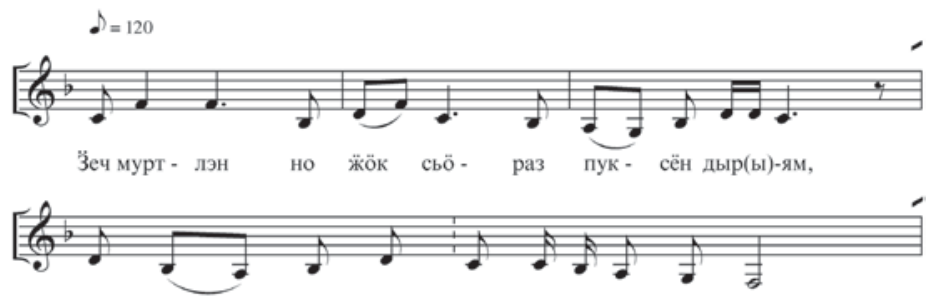

гурт ка - лы - ке- лы та - у ка - рись - ко.

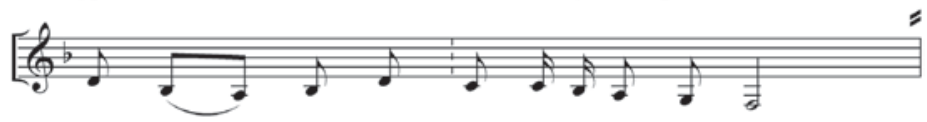

Гурт ка- лы - ке- лы та-у ка - рись - ко.

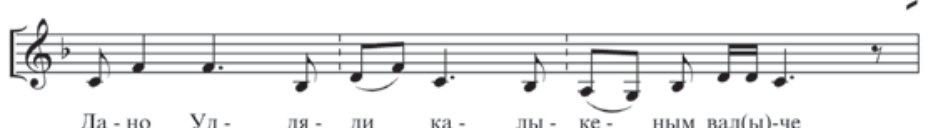

Да-но Уд- дя- ди ка- лы- ке- ным вал(ы)-че

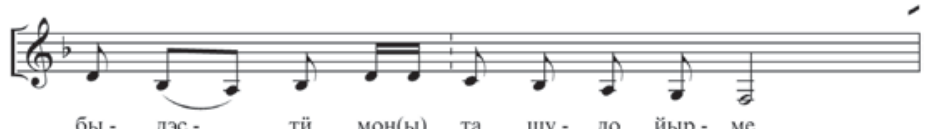

бы - дэс - тй мон(ы) та шу - до йыр - ме.

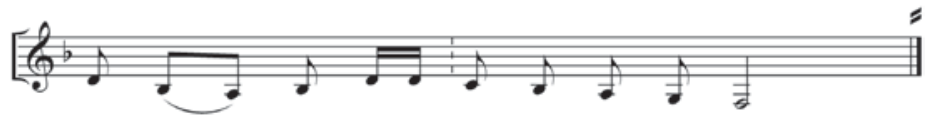

Бы - дэс- тй мон(ы) та шу - до йыр - ме.
[...]
$[\ldots]$

Dzh'ech murtlen no dzhök s'öraz When I sit down at good people's puks'on dyr(y)yam, tables,

Gurt kalykely tau karis'ko. I I thank the people of my village.

Gurt kalykely tau karis'ko. I I thank the people of my village.

Dano Ud'd'ad'i kalykenym With venerable people of val(y)che Karamas-Pel'ga, Bydestimon(y)tashudoyyr(y)me. I have raised my happy head. Bydestimon $(y)$ tashudoyyr(y)me. I have raised my happy head.

(Kyrdzh'as'... 1995) 
Dzhakapay knew and performed a huge corpus of so-called name songs, i.e. personal songs. The main distinguishing feature here is the presence in the title of the performer's name. For example, Pisl'eg Luker'yapaylen gurez, 'Aunt Pisleg (lit: Tit) Luker'ya's Tune', and Girgalen gurez, 'Girga's Tune', etc. (For more details, see Pchelovodova 2013.) For Dzhakapay, these tunes were a kind of memory of each person, encompassed in the form of musical song. She knew the story of each of these songs perfectly and could speak in detail about the former performers. Often, when singing, she interrupted the song with a surge of emotion and tears, reliving the situations the song talked about and remembering the original performer.

Some of these name songs were published as performed both solo by Dzhakapay, and with a folklore ensemble, in the collection Songs of the Southern Udmurt, which is dedicated to the singing folklore of Kiyasovo district of the Udmurt Republic (Pchelovodova, Anisimov 2020):

- Kaylo Petyr agaylen gurez-Uncle Kaylo Petyr's Tune/Song,

- Sof'yapaylen kyrdzh'an gurez - Aunt Sofia's Tune/Song (this tune was sung by a woman called Sofia when she said farewell to the people of her village on her way to the frontline during the Second World War),

- Terentey Pakapaylen Ud'd'ad'i gurtles' mözmon gurez Aunt Terentey Paka's Tune/Song. Aunt Terentey Paki was homesick for her village Karamas-Pel'ga (Ol'ga Solov'yova heard this tune from a woman called Paki, who had married into the Lyali family (Alnashi district), when once she came back to meet her kin, performing this song to express her yearning for her native village),

- Dulam Palagey apaylen gurez - Aunt Dulam Palagey's Tune/Song, 
- Pad'ey apaylen gurez - Aunt Pad'ea's Tune/Song,

- Kuz'Ondrey agaylen gurez-Uncle Kuz' Ondrey's Tune/Song (Solov'yova first heard this song from a villager from Staraya Sal'ya at the funeral of his sixteen-year-old daughter who had drowned in the river).

Other songs close to these are those called 'village tunes', characterised by geographical names. Thus, from Dzhakapay's repertoire, we have recorded Ud'd'ad'i gur, Karamas-Pel'ga's Tune; L'al'iis' vayem gur, A Tune Brought Back from Lyali; Sal'l'a gur, Staraya Sal'ya's Tune; and Böd'yalas'vayem gur, A Tune Brought Back from Varkled-Bod'ya. According to Dzhakapay, she had heard these tunes, or they had been heard by the Ud'd'ad'i people, in these villages. For example, she had never heard the Karamas-Pel'ga tune in other villages.

Another interesting text is one of the songs from Varkled-Bod'ya. Here, in addition to the loaning, we observe a kind of 'authorisation' process. The text evokes the names of people connected to the tune and from whom the singer heard the songs:

$O y$, ta gur(y)yos kin'(y)len ke no Oh, whose tunes are these, if shuylidy, you ask, yes,

Okt'abyris' Tymyr(y)shalen, oy, These tunes belong to Tymyrshi gur"yosyz. from Oktyabr'.

Okt'abyris' Tymyr(y)shalen, oy, These tunes belong to Tymyrshi gur"yosyz. from Oktyabr'.

Okt'abyris' Tymyr(y)shalen(y) This tune does not belong to gurez övöl ta, Tymyrshi from Oktyabr', 
D'em(y)yan gyne kudomylen, oy, These tunes belong only to gur"yosyz.

Dem'yan, the in-law.

D'em(y)yangynekudomylen, oy, These tunes belong only to gur"yosyz.

Dem'yan, the in-law.

D'em'yan gyne kudolen gurez It does not belong only to övöl ta,

Dem'yan, the in-law,

Choko gyne Vas'agaylen, oy, These are only Choko's and gur"yosyz. uncle Vasi's tunes.

Choko gyne Vas'agaylen, oy, These are only Choko's and gur"yosyz. uncle Vasi's tunes.

(Pchelovodova, Anisimov 2020:

Among the people of Karamas-Pel'ga there is today a tune considered to belong to Dzhakapay, called Dzhakapay's Tune, Dzhakapaylen gurez.

In conversation, when she was asked "Do you compose your songs yourself?" Dzhakapay almost always answered: "No. I live from what exists. Before me the people composed so many beautiful and warm songs." Knowing her great talent, the authors of this article understand that on the one hand, this is a manifestation of an Udmurt woman's modesty, while on the other hand it reflects the understanding of her intimate involvement with the tradition in which she lived. She had no difficulties remembering a song after only one hearing, which confirms her exceptional musical and auditory abilities. Several times we witnessed, how Dzhakapay could easily and organically include in a song any text about emotions, the moment in which we were living, her inner state, memories of her own life, etc. Improvisation for her was not something complicated - on the contrary, as she said: "All I want to say, I express it all through singing. I do not like to talk much." We have a good example of this with the song she performed on a TV show called Kyrdzh'as' 
lul-s'ulem (The Singing Soul), recorded by GTRK Udmurtia ${ }^{3}$. In this song, Dzhakapay used poetic motifs with different content, close to her life situation. We must also emphasise that singing, in the Udmurt culture, foretells a sad fate. Researchers have justly observed the ambiguous Udmurt attitude towards the art of singing: the people who know songs and have nice, strong voices are deeply respected in village society, but these performers are also understood to be unhappy people (Nurieva 1999: 87-88). This is despite the fact that Dzhakapay herself asserted it was singing and song that helped her survive the most difficult situations in her life:

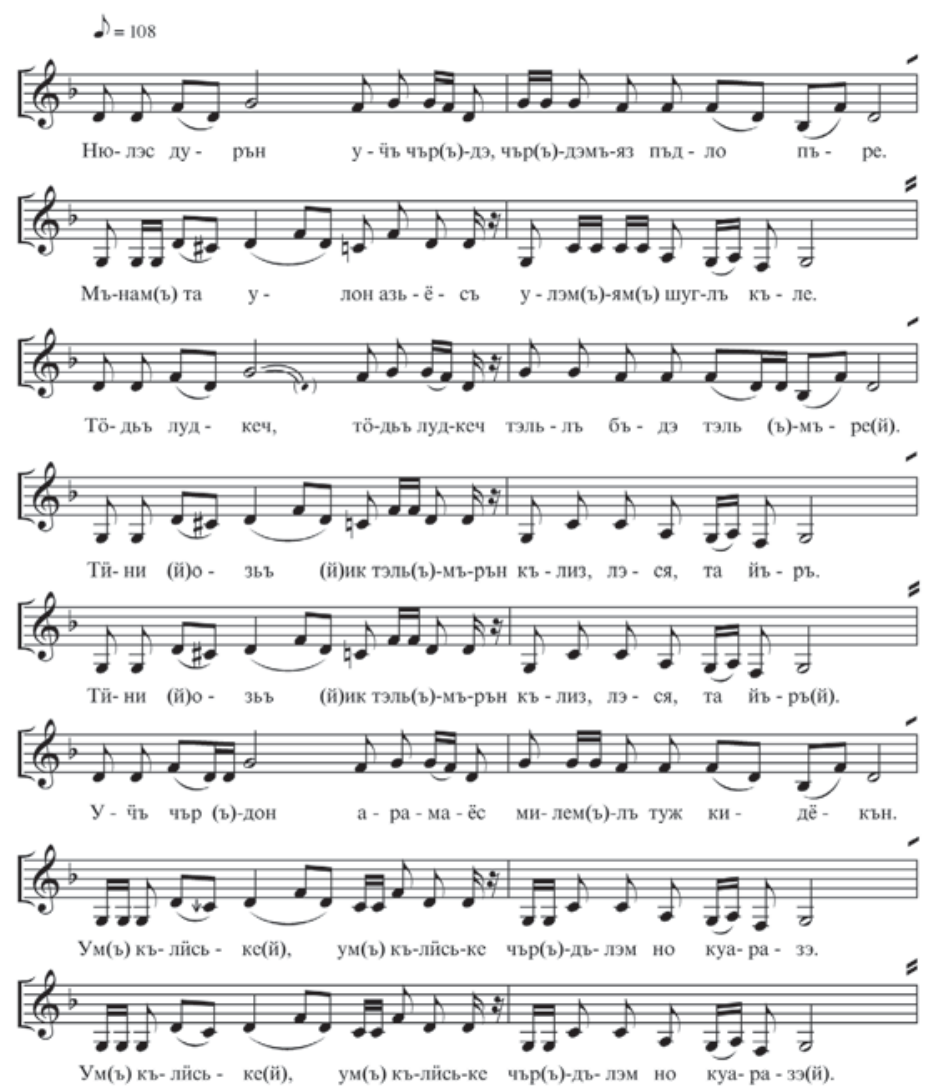


N'ules duryn utshy chyr $(y)$ de, By the forest a nightingale sings, Chyr(y)dem"yaz As far as he sang, he flew deep pydlo pyre.

Mynam(y) ta ulon az'yosy

$\operatorname{Ulem}(y) \operatorname{yam}(y)$

shugly kyle. into the forest.

This is my fate

Throughout my life, it becomes hard and harder.

Töd'y ludkech, töd'y ludkech

Tel'ly byde tel'(y)myre $(y)$.

Tin'i (y)oz'y (y)ik tel'(y)myryn Kyl'iz, les'a, ta yyry.

Tin'i (y)oz'y (y)ik tel'(y)myryn Kyl'iz, les'a, ta yyry (y).

Utshy chyr (y)don

aramayos

Mil'em(y)ly tuzh kid'okyn.

Um(y) kylis'ke(y), um(y) kylis'ke

Chyr(y)dylem no kuaraze.

Um(y) kylis'ke(y), um(y) kylis'ke Chyr(y)dylem no kuaraze(y).

Anay-atay $(y)$ tem nyl $(y)$ piyed Uy no nunal(y) tel'y (y)myre(y).

Kylis’övöl, kylis'övöl(y)

Tel'(y)myrem no kuaraze.

Kylis'övöl(y), kylis'övöl

Tel'(y)myrem no kuaraze(y).

Pichi(y)is'en

usto lui

$\operatorname{Kyr}(y) d z h$ 'any no verany $(y)$.

Kemalas'en todmo luiz,

Tatshe shudtem lueme(y).
White rabbit, white rabbit All the forest is grieving. And thus grieving Seemingly remains my fate. And thus grieving Seemingly remains my fate.

The groves where the nightingale sings, Are very far from us

We do not hear, we do not hear, His voice nor his singing.

We do not hear, we do not hear, His voice nor his singing.

The children without parents Grieve day and night.

Nobody hears, nobody hears Their voice and their grieving. Nobody hears, nobody hears Their voice and their grieving.

From my childhood I became skilled In singing and storytelling. It has long been known That I lament, unhappy, 
Kemalas'en(y) todmo luiz, Tatshe shudtem lueme(y).

Usto shuo, usto shuo, $\operatorname{Kyr}(y) d z h$ 'any no verany $(y)$. Usto luod, usto luod, Kaygu pyr(y)ti potid ke. Usto luod, usto luod $(y)$, Kaygu pyr(y)ti potid ke.
It has long been known That I lament, unhappy.

She is skilled, they say, skilled, they say In singing and storytelling. You will be skilled, you will be skilled, If you go through sorrow. You will be skilled, you will be skilled, If you go through sorrow. (Kyrdzh'as'... 1995)

Among her fellow villagers, Dzhakapay was renowned for her deep knowledge, and performances, of a large number of songs, not only Udmurt but also belonging to neighbouring peoples. Kiyasovo district is characterised by its multi-ethnic population. Here in addition to Udmurts there are Russians, Tatars and Maris. Working as a mail carrier gave her the opportunity to get acquainted with the languages of these people, and later with their singing traditions. Her further interethnic communication and interrelations offered her a wide life experience, and an interethnic heritage. She performed the songs in their original form, in Russian, Tatar and Mari, as well as in Udmurt translation. She has become a unique repository of these songs from the Udmurt's regional neighbours. Thus, for example, she had in her personal repertoire songs from the neighbouring Russian village Starozaychikovo (Kiyasovo district, now disappeared). In 2015 Dzhakapay accompanied Anna Mishina (then a doctoral student at Tartu University, Estonia) on her expedition to the Mari village of Unur-Kiyasovo, in the Kiyasovo district (6 km from Karamas-Pel'ga). Here a significant event occurred: the local Mari were in pain, or did not wish to remember 
their tunes, but when Dzhakapay herself started singing them she 'provoked' them to perform their own songs ${ }^{4}$.

Her way of actively learning the repertoires of others was also manifest during her journeys to other regions and countries for festivals. She brought back other communities' songs and performed them in her own community, in their original language as well as, sometimes, in Udmurt translation. How surprised were Hungarian, Finn, and Estonian scholars and students to hear her singing their own songs in their own languages.

Dzhakapay not only sang traditional songs, but also had in her repertoire contemporary Udmurt variety songs, thus considerably widening her musical treasure. After performing traditional songs at holiday and cultural events, she could easily change to variety songs. She was proudly in awe of the work of amateur composer Nikolai Utkin, from her village, whose songs she sang with pleasure. The opposite also happened with songs from her personal repertoire entering the variety stage. For example, Tatiana Ishmatova and Aleksandr Katkov proposed a new version of the song Zarn’i shundy dzhuzhaloz, 'The Golden Sun Rises', of Mari origin. In a duet with Alyona Timerkhanova, Nikolai Anisimov included in his stage repertoire the dancing tune from Karamas-Pel'ga Ud'd'ad'i takmak"yos, 'Karamas-Pel'ga Chastushki'. The AR-GOD project (Estonia) produced a CD that includes some songs recorded by Dzhakapay5 from different periods: Utchyyed chirdoz, 'The Nightingale Chirps'; Ekton gur, 'Dancing Tune' (Karamas-Pel'ga); Kuno gur, 'Guest Welcoming Tune'.

From our perspective, Dzhakapay is one of the rare Udmurt who has retained the archaic way of performing ritual tunes, as she observed herself: "As I sing, nobody sings now". This reality reflects the particular attitude of the performer towards Udmurt musical heritage, i.e. understanding the sacred significance of the old ritual tunes and the importance of maintaining the archaic mode of performance. Here we see the important role of a single individual as keeper and performer of cultural heritage. 
In Udmurt singing tradition there is a particular timbre, quality of voice, for the calendar tunes. The first to have considered this problem is Irina Nurieva, relying on the singing tradition of the Western (Transvyatka) Udmurts (Nurieva 1999: 83-84). About Dzhakapay's way of performing, we note her powerful transmission of sound, the singing of long musical sentences in one breath. The sound nevertheless is not loud, but is very assertive: one feels the tension in the vocal chords. Dzhakapay has retained the typical archaic intonation of the unclear third. There is another feature in Dzhakapay's interpretation that we must comment on: the monotony of her performance, a kind of detachment, which allows for a meditative state of mind. Sadly, today this form of singing within the traditional culture has been lost and is only reconstructed by student ensembles in the Republic Musical College and the Udmurt State University.

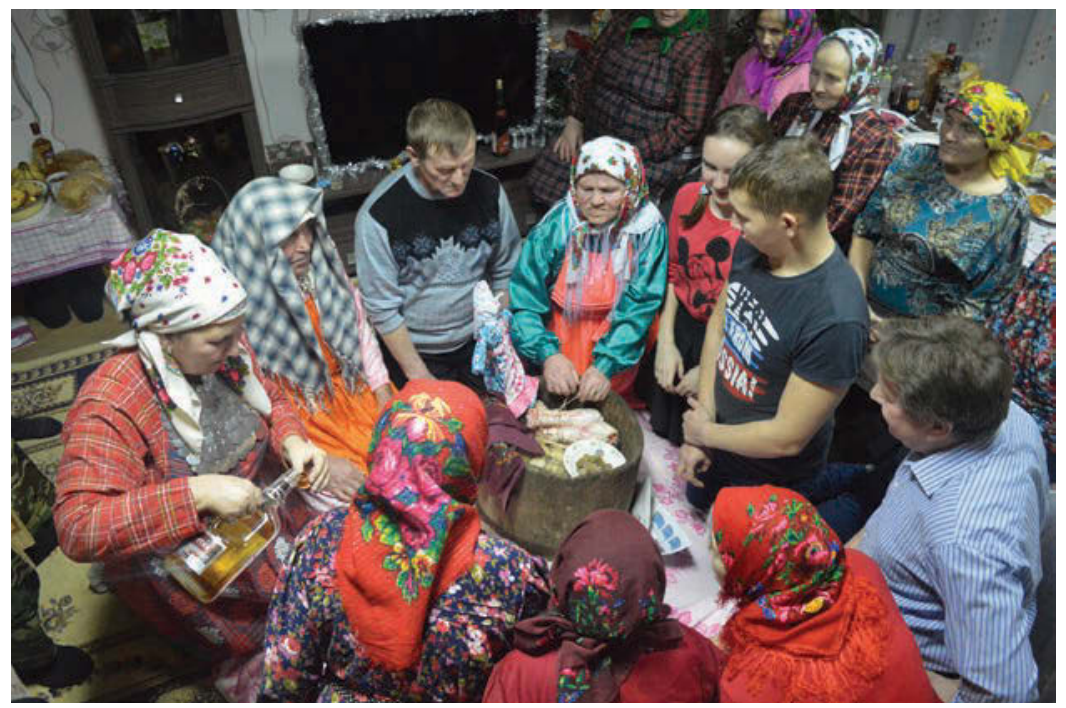

Photo 3. The yyr-pyd s'oton commemorative ritual (the giving of the head and legs (of the sacrificial animal)). Photo by Nikolai Anisimov, 2017. 
Irina Pchelovodova, Nikolai Anisimov

As an example, let us present the Tune of the Great Day, performed in 1993 by Dzhakapay, Bydzh'ynnal gur:

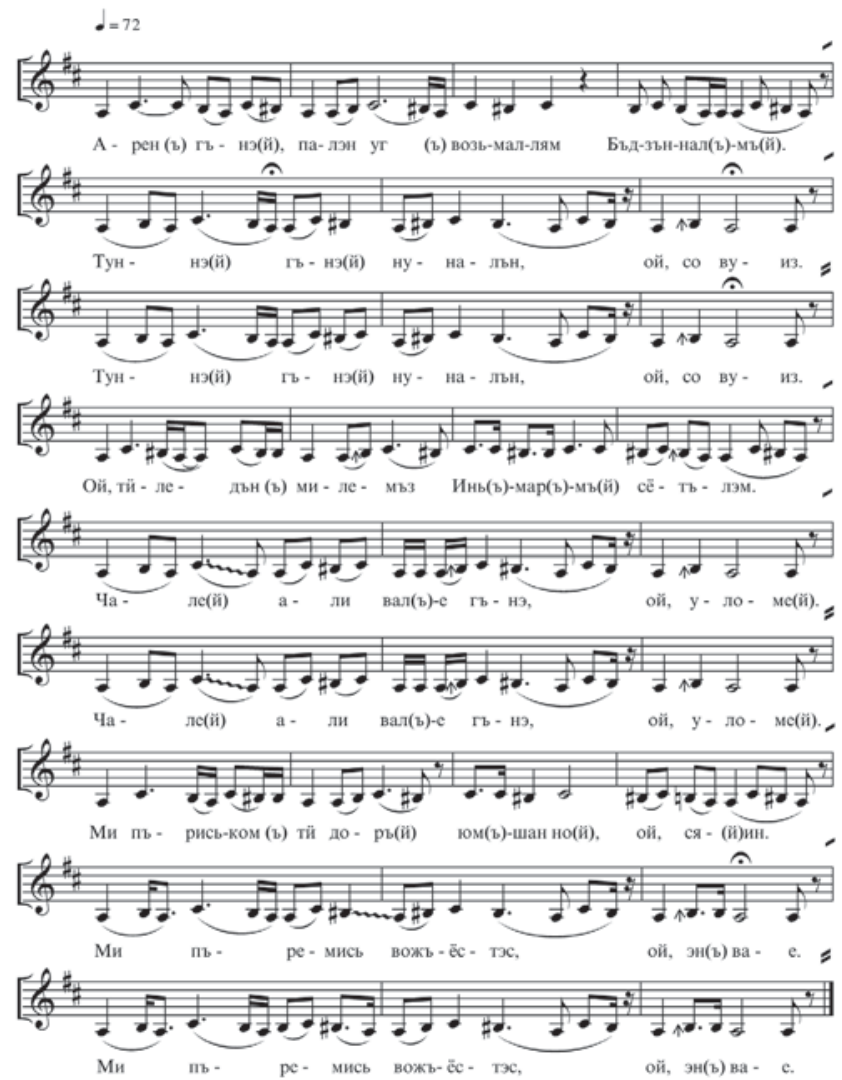

Aren $(y)$ gyne $(y)$, palen $u g(y) \quad$ Onlyinautumn ${ }^{6}$, half[ayear]Imean Voz'mal'l'am Bydydzh'ynnal(y) We have waited for our Great Day. $m y(y)$.

Tunne(y) gyne(y) nunalyn, oy, Only on today's day, oh, hehas come. so vuiz.

Tunne(y) gyne(y) nunalyn, oy, Onlyon today's day, oh, hehascome. so vuiz. 
Oy, til'edyn(y) mil'emyz

In'(y)mar(y)my(y) s'otylem.

Chal'e $(y)$ al'i val(y)che gyne, oy, Come on, let us live only together. ulome $(y)$.

Chal'e $(y)$ al'i vall(y)che gyne, oy, Come on, let us live only together. ulome $(y)$.

Mi pyris'kom(y) ti dory $(y)$ yum $(y) \operatorname{shan~no(y),~oy,~s'a(y)in.~}$ Mi pyremis'vozh"yostes, oy, en $(y)$ vaye.

Mi pyremis'vozh"yostes, oy, en $(y)$ vaye.

Achid(y) gyne kashamer, vinayed(y) kal'am(y)per. Tynes'tyd(y) bon ud(y) yuy(y), kin'(y)les'yuod? Tynes'tyd(y) bon ud(y) yuy(y), kin'(y)les'yuod?
Oh, to us and to you our In'mar ${ }^{7}$ has given,

When celebrating, we enter your place, Because we entered, oh, do not bear a grudge.

Because we entered, oh, do not bear a grudge.

Only you with nice cashmere, your aniseed alcohol, If you do not drink it at home, where shall you drink it? If you do not drink it at home, where shall you drink it? (Mardzh'an 1993)

Dzhakapay was not only a precious performer, she was also a keeper of folk wisdom. It is no coincidence that in her village she was jokingly called 'the computer'. This is certainly due to the personal interest she had in her native culture. Until the final day of her life, she respected and implemented traditional ontology, behaviour rules, canons of ritual and song performance, etc. - an approach that has been lost by the younger generations in the village. This explains her importance to the local community and the authority she had in it. People went to her for advice and help in the organisation of ritual ceremonies, as well as with different 
personal questions. For example, in 2017, when a family performed the commemorative yyr-pyd s'oton ritual, 'the giving of the head and legs' (of a sacrificial animal), Dzhakapay became angry with those who conversed while the participants in the ritual sang, calling the culprits to join the singing as it befitted the ritual situation. Rimma Lopatina, who organised this ritual, continuously consulted her on the actions of ritual scenarios, the implementation of rules, the uttering of formulas, the preparation of paraphernalia, etc.

Dzhakapay transmitted her knowledge and skills over long years through her participation in the Invozho local folklore ensemble at the Karamas-Pel'ga culture house. The ensemble's repertoire contains a good amount of songs generously shared by Dzhakapay on the basis of her memory and personal experience. She sang as a soloist as well as a member of the group. As a member of the group, she participated in many festivals, competitions and events at different levels, visiting many regions of Russia as well as some foreign countries. According to the ensemble's leader, Nadezhda Pakhomova, she was a kind of scientific adviser in their creative work, especially when they were preparing ritual stage reconstructions and singing ritual songs. ${ }^{8}$

In her last years, Dzhakapay was troubled by people 'chattering' a lot and singing less. She saw that life had become more sorrowful every year because tradition was disappearing and people had begun to live in isolation, lacking collective solidarity.

Another reason for the trouble she felt was the amount of knowledge that she did not want to take to her grave with her. Therefore, she started writing her memoirs in some notebooks. However, illness overtook her, which was reflected in the illegible handwriting, and some sentences remain unfinished. Now, these writings are kept by her kin. She dedicated a letter to one of the authors of this article, Nikolai Anisimov, in which she gives him her blessing and shares with him the text of one of her songs, asking him to perform it according to his wishes: 
Ulmo s'as'ka vakyte

Ton lykto, shuid, doram.

Mon voz'may, kuaz'ed sakte,

Ton öd vu, öd vu doram.

Puki sad pölyn ognam,

Kytyn ke argan shude.

Nyl kuara shuldyr

kyrdzh'a,

Tugane soly yurtte.

Puki sad pölyn ognam,

Utshy gurez

kylzysa.

Lyktemde voz'may, Az'am s'as'ka kuz'ym das'asa.

Mone pöyad shuysa, S'ulemam dzhozhan kendzhiz. Sadys' potid myn'asa, Verano kyly vuniz.

Pripev:

L’ömpu s'as’ka, l'ömpu s'as'ka,

Maly-o ton töldzh'is'kod?

Tulys kuaz'ez, yaratonez

Pös' s'ulemme kel'tis'kod.
When the apple trees bloom You said you shall come to me. I waited, dawn came [already], You did not come, you did not come to me.

I sat in the garden alone,

Somewhere the accordion plays.

The maidenly voice sings

beautifully,

My beloved helps her.

I sat in the garden alone,

Listening to the nightingale

singing.

I awaited your coming,

Preparing in front of me a gift of flowers.

Because you deceived me,

Grief inflamed my heart.

You left the garden smiling,

I forgot the words I had ready for you.

Refrain:

Wild cherry bloom, wild cherry bloom, Why did you fly away?

Spring time, love,

You leave them in my hot heart.

(From Nikolai Anisimov's

personal archive) 


\section{A precious informant}

Dzhakapay was a priceless informant for many Russian and foreign scholars and students, and this is reflected in their scientific publications. For instance, Valentina Makarova, who graduated from the Faculty of Udmurt Philology (today the Institute of Udmurt Philology, Finno-Ugristics and Journalism at the Udmurt State University) defended her graduation thesis titled "Muz"yem kol'osa, s'ulem piyala... Dzhakapaylen cheberlyko kylos portretez" ("The Earth is a Ring, the Heart is Glass: A Portrait of Aunt Jay's Creativity), in which she presents Dzhakapay's role as a unique creative personality in Udmurt culture (Makarova 2007). She summarised her conclusions thus: in Dzhakapay's repertoire, there are mainly songs that are reflections on life and people, and fewer songs about love, as they are directly connected with the singer's fate. Identifying poetic motifs in her songs (about lost youth, unhappy fate, separation), Makarova observes that one of the main themes is Solov'yova's gratefulness towards her fellow villagers for helping her at difficult moments. She makes interesting comments about a very widespread motif in Dzhakapay's songs, that of the birch. It is Dzhakapay's favourite tree, one, as we mentioned above, that played an important role in her life.

In 2010 Dzhakapay participated in Ekaterina Samodelko (Danilova)'s graduation concert for the students of the Folk Choir (today Music and Stage Arts) at the Institute of Arts and Design at the Udmurt State University.

For those students who became professional performers, Dzhakapay was an unofficial teacher in the skill of singing folk songs. In 2011, she was invited as a guest of honour, in the capacity of member of the Invozho folklore ensemble, to Maria Korepanova's first concert, which took place on the stage of the Udmurt Republic State National Theatre. 


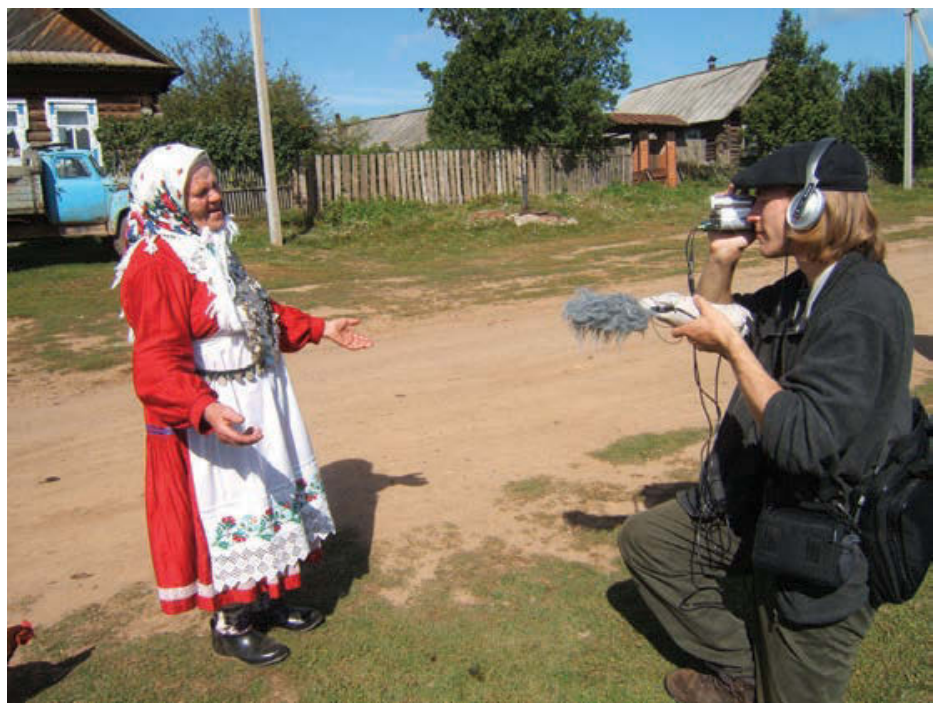

Photo 4. Dzhakapay performs for Estonian scholars 2005. Photo Eva Toulouze.

The Udmurt folklorist, doctor and professor Tatiana Vladykna dedicated her monograph Udmurt Folklore: Problems of Genre Evolution and Systematics ("Udmurtskiy fol'klor: problemy zhanrovoy evolyutsii i sistematiki" (Vladykina 1997) to Solv'yova and those who know the Udmurt folk traditions: "Dzhaky apayly no tros-tros muket”yosyzly, kin ut'iz no ut'e na udmurt kalykmyles'viz'nodze no kinen shud us'iz mynym pumis'kyny, - yybyrtysa”('To Aunt Dzhaky and many, many others who preserved and go on preserving our Udmurt people's folk wisdom and whom I had the chance to meet - with my deep respect.') (Vladykina 1997: 3).

In recent years the authors of this article also turned to her performing skills and deep knowledge. Thus, Dzhakapay was of great assistance when they gathered material for the Songs of the Southern Udmurt collection, dedicated to the non-ritual musical folklore of Kiyasovo district Udmurts (Pchelovodova, Anisimov 2020). 
Thirty-two of the songs are recorded in her interpretation, either solo or with an ensemble:

- $\quad$ state radio and television channel Udmurtia (Documentary films: Mardzh'an ('Pearl') 1993; Kyrdzh'as' lul-s'ulem ('Singing Soul') 1995; Ut'is' ('The Keeper') 2014;

- state radio and television channel Sankt-Petersburg (Letters from the Province, cycle of television programmes);

- in 2005 local TV in Riga filmed the Baltic Festival, in which the Karamas-Pel'ga folk ensemble took part;

- First Channel (participation in the Minute of Glory television show with the Invozho folk ensemble, 2010).

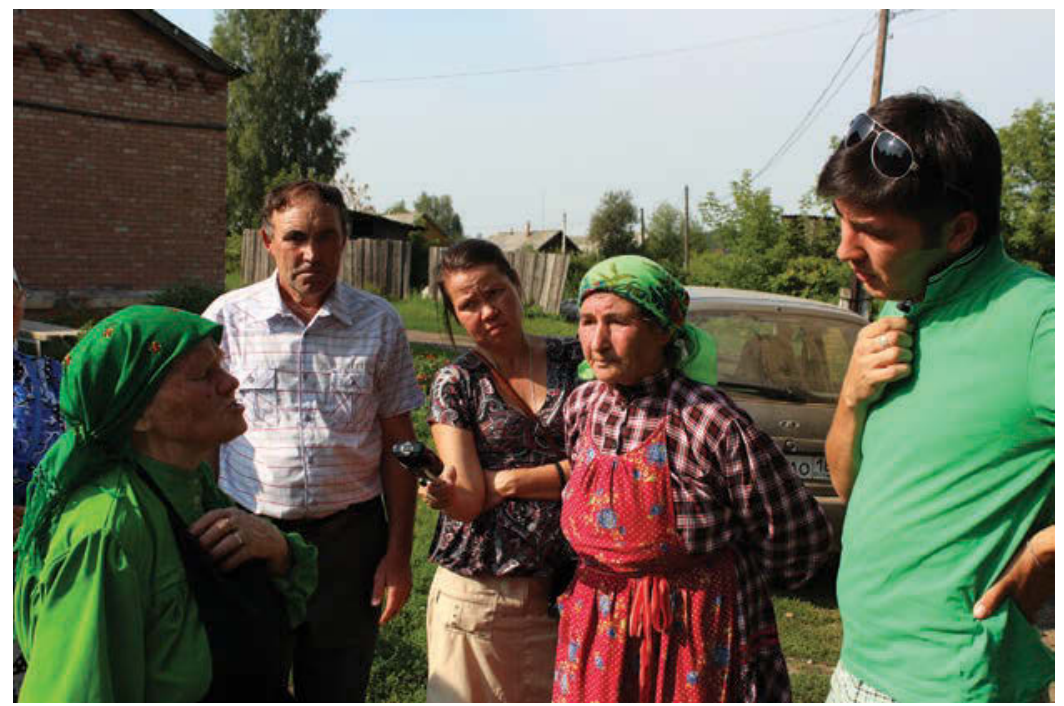

Photo 5. The authors of the article meet Dzhakapay, 2013. Photo Denis Kornilov. 
Photo 6. Dzhakapay in 2016. Photo Nikolai Anisimov.

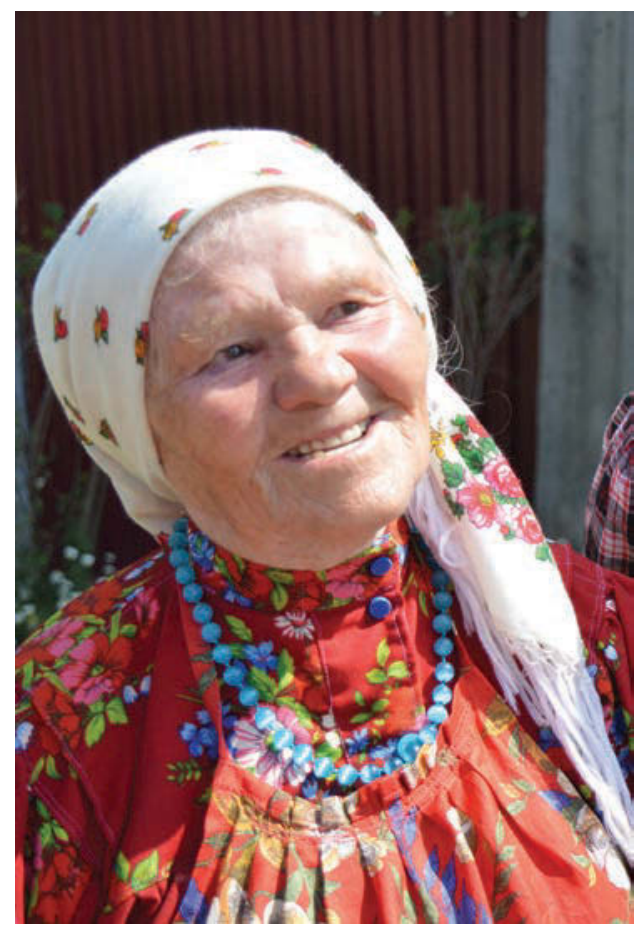

\section{In place of a conclusion}

Dzhakapay's demise on June 26th 2018 represented a great loss to the Udmurt culture. Much of her knowledge remained unrecorded, and what is recorded has not yet found a researcher so that it can enrich Udmurt science and culture. However, we may now assert with confidence that even the first research into the creative expression of an individual using Dzhakapay as an example and following her interaction with the canons of culture, illuminates how mechanisms of the collective and the individual function in the folklore tradition. Most precious are Dzhakapay's comments 
about cultural processes, as collective knowledge is often spread through the personal discourse of the singer or storyteller.

We plan several projects connected with Dzhakapay's unique personality:

- The young Udmurt cameraman Denis Kornilov, junior researcher at the Udmurt Research Institute, is preparing a film about her;

- Singer Dr. Maria Korepanova is preparing an album of songs sung by Dzhakapay both in her personal interpretation and in cooperation with other musicians;

- The authors of the article plan a separate book dedicated to her singing creation;

- In Karamas-Pel'ga, her son-in-law is reconstructing her native home so that it can function as a house museum in memory of Dzhakapay.

\section{Notes}

1 Around $8 \mathrm{~kg}$.

${ }^{2}$ Here and throughout, the Russian translations of the Udmurt texts are by the authors of the article. The English translations are made by the article's translator.

3 State radio and television channel.

4 Oral information from Anna Mishina, 2019.

5 The AR-GOD project (Estonia) includes Udmurt and Estonian musicians Maria Korepanova, Nikolai Anisimov and Toivo Sõmer. The group was created in 2014. The characteristic of their performance is a combination of traditional Udmurt and Besserman songs accompanied by ethnic musical instruments. 
6 According to Udmurt scholars, the word ar, which in modern Udmurt means "year" (as calendar year), comes from the Permian *ar "autumn" and in its very first meaning is to be found, for example, in calendar and ritual songs (Vladykina, Glukhova 2011: 1415). "In the coincidence of the concepts of autumn and year, the Udmurt folklorists perceive the great importance of the autumn and winter period, probably in connection with the archaic calculation of time, when the new year started in Autumn" (Anisimov 2017: 102).

7 In'mar - theonym of the supreme God living in heaven.

8 Oral information by N. Pakhomova, 2019.

\section{Sources}

Kto my. Armiye kel'an [Farewell to the Recruit]. https://youtu.be/nICe_ P8DhoI (accessed 26 November 2019).

Kyrdzh'akum bördis'ko, bördykum kyrdzh'as'ko [When I Sing I Weep, when I Weep I Sing]. O. Solov'yova; recorded by L. Tikhonova. Udmurt dun'n'e. 9. November 2012, pp. 6, 11. https://elibrary.unatlib.ru/dspace/ dsview.html (accessed 25 November 2019).

Letters from the province. https://youtu.be/EhYDW8KQpk4 (accessed 26 November 2019).

The holiday Akashka. Karamas-Pel'ga, Kiyasovo district, Udmurt Republic. https://youtu.be/ AhuPuJH0Vc4 (accessed 26 November 2019).

Udmurtia, I love you. https://youtu.be/AjXcPlnyxds (accessed 26 November 2019).

\section{References}

Alpatov, S. 2014. Skazochnik-balagur: lichnost' i tvorcheskiy tip [Joker Storyteller: Personality and Creative Type]. Lichnost'v traditsionnoy kul'ture [Personality in traditional culture]. Moscow: State Institute of Art Studies, pp. 41-59. 
Anisimov, N. 2017. "Dialog mirov" v matritse kommunikativnogo povedeniya udmurtov ["Dialogue of the Worlds" in the Matrix of Communicative Behavior of the Udmurts]. Tartu: University of Tartu Press.

Lichnost'v traditsionnoy kul'ture [Personality in Traditional Culture] 2014. Moscow: State Institute of Art Studies.

Makarova, V. 2007. Zemlya-koleso, serdtse-steklo... Tvorcheskiy portret teti Soyki: dipl. rabota [The Earth is a Wheel, the Heart is Glass ... Creative Portrait of Aunt Jay]. Izhevsk: BA work, manuscript.

Nurieva, I. 1999. Muzyka v obryadovoy kul'ture zavyatskikh udmurtov [Music in the Ritual Culture of Trans-Vyatka Udmurts]. Izhevsk: Udmurtskiy institut istorii, yazyka i literatury Uralskogo otdeleniya Rossiyskoy akademii nauk.

Nurieva, I. 2014. Udmurtskaya muzykal'no-pesennaya traditsiya: spetsifika zhanroobrazovaniya i funktsionirovaniya: diss. na soisk. uchenoy. st. doktora iskusstvovedeniya [Udmurt Musical Song Tradition: Specifics of Genre Formation and Functioning]. Izhevsk: UdGU, PHD dissertation.

Pchelovodova, I., Anisimov, N. 2020. Pesni yuzhnykh udmurtov. Vyp. 4. [Songs of Southern Udmurts. Vol. 4]. Izhevsk-Tartu: UdmFITs UrO RAN; Estonian Literary Museum.

Pchelovodova I. 2013. Udmurtskaya pesennaya lirika: ot motiva $k$ syuzhetu [Udmurt Song Lyrics: From Motive to Plot]. Izhevsk: Udmurtskiy institut istorii, yazyka i literatury Uralskogo otdeleniya Rossiyskoy akademii nauk.

Pentikäinen, J. 1971. Marina Takalon uskonto: Uskontoantropologinen tutkimus. [Marina Takalo's Religiosity: A Research in Anthropology of Religion]. Suomalaisen Kirjallisuuden Seuran toimituksia 299. Helsinki: Suomalaisen Kirjallisuuden Seura.

Pino, V. 2000. Elukutseline tegevus - setu rahvalaulik (Darja Pisumaa, alias Hilana Taarka Vasila Taarka) [Professional Activity - Setu Folk Singer (Darja Pisumaa, aka Hilana Taarka Vasila Taarka)]. Siirmann, Niina (ed.). Minevikumälestusi II. Põlvamaa kodulookogumik [Memories of the Past II. Põlva County Local History Collection]. Põlva: Põlva, pp. 79-86. 
Romodin, A. 2009. Chelovek tvoryashchiy. Muzykant v traditsionnoy kul'ture [Creative Man. Musician in Traditional Culture]. St. Petersburg: GNII "Institute of Art History".

Starodubtseva, S. 1999. Oh, rospechal'noye moyo serdechko (pesni iz repertuara Natal'i Vlasovoy) [Oh, My Sad Heart (Songs from the Repertoire of Natalia Vlasova)]. Vol. 1. Izhevsk: Udmurtskiy institut istorii, yazyka i literatury Uralskogo otdeleniya Rossiyskoy akademii nauk.

Vladykina, T., Glukhova, G. 2011. Ar-god-bergan: Obryady i prazdniki udmurtskogo kalendar'ya [Year-Circle: Rituals and Celebrations of the Udmurt Calendar]. Izhevsk: Udmurtskiy universitet.

Zhulanova, N. 2014. Lichnost' v traditsionnoy muzykal'noy kul'ture: ot sotsiokul'turnykh roley k unikal'nym individual'nostyam [Personality in Traditional Musical Culture: From Sociocultural Roles to Unique Personalities]. In: Lichnost' $v$ traditsionnoy kul'ture [Personality in traditional culture]. Moscow: State Institute of Art Studies, pp. 14-40.

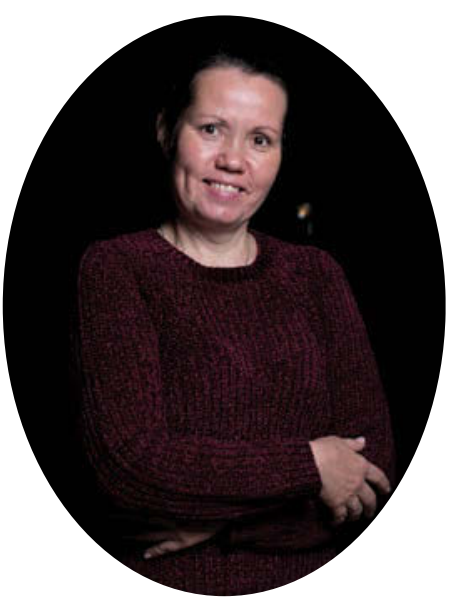

Irina Pchelovodova $(\mathrm{PhD})$ is an ethnomusicologist and a research associate at the Udmurt Institute for Research in History, Language and Literature (Udmurt Federal Research Centre of the Ural Branch of the Russian Academy of Sciences). She is interested in Udmurt folk music, folk song and folk instruments. She teaches at the University and at the Music college; she is the leader of the folklore and ethnographic musical group Chipchirgan.

e-mail: orimush@mail.ru 


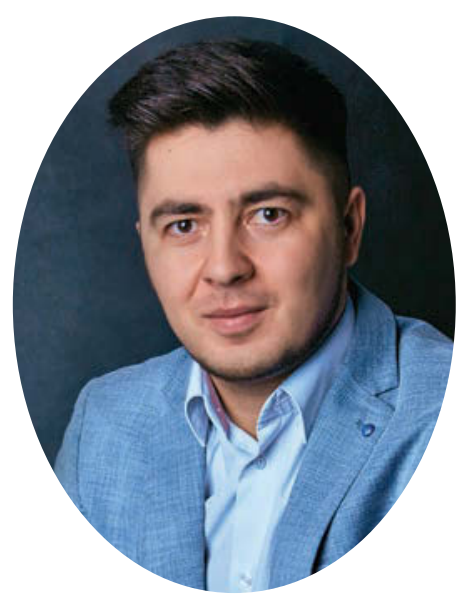

Nikolai Anisimov ( $\mathrm{PhD}$ ) is a researcher at the Department of Folkloristics at the Estonian Literary Museum, Estonia, and at the Department of Philological Studies at the Udmurt Institute for Research in History, Language and Literature (Udmurt Federal Research Centre of the Ural Branch of the Russian Academy of Sciences). His main field of interest is Udmurt traditional and contemporary culture, and more precisely, the Udmurt living ancestors' cult, and their singing tradition.

e-mail: nikolai.anisimov@folklore.ee 


\title{
Presence of Witchcraft in the Contemporary Udmurt Village
}

\author{
Nikolai Anisimov \\ e-mail: nikolai.anisimov@folklore.ee; kyldysin@yandex.ru
}

\begin{abstract}
Based on the author's fieldwork materials (2007-2021) as well as on sources from scientific literature, this article examines how wizards and witches are seen in today's Udmurt village. It analyses the characters of these magic specialists within the framework of folk understanding. It explains their role, their activities and their status in the village community, it presents magical methods of combat and selfdefence, as well as some trends of late years. The latest field materials show the present narratives about people who master magic strength and secret knowledge, updating the research. This new material highlights the innovative character of the research. The results allow us to say that alongside traditional understandings, there are relatively new cultural phenomena appearing at practically all the levels of the village perception of wizards and witches. The changes in the present world and the 'fashion' for magic knowledge give the village community a new focus on tradition. For example, people think that electricity cables, as well as mobile phone networks and satellite antennas, have started to disturb the flights of wizards and witches, and elements from other cultures have been added to magic apotropaic repertoire, etc. Thus, this article follows what is happening presently in Udmurt village communities with regard to the cultural mythical phenomena surrounding the worldview of magical specialists. The results of this study may be a useful basis for further research, and it will be important to observe the further evolution in the village reception of these phenomena.
\end{abstract}

Keywords: Udmurts, witchcraft, witches, wizards, worldview 
The topic of witchcraft is in all cultures of the world both an actively cultivated issue and a very intimate one, and it is also the case in Udmurt culture. We can say that the belief in magic, especially in people who are loaded with supernatural force, is still very much alive in particular Udmurt villages. In this article, I rely on materials from my fieldwork (further: FWM) between 2007 and 2021, mainly among the southern and eastern Udmurt; moreover I also rely on my personal experience, as I am a bearer of the researched culture. I rely heavily on interviews with people who are mastering what we call 'sacred knowledge' (healers, wizards, witches, etc.). I must highlight that because of the intimate nature of the topic as well as for ethical reasons, some informers expressed the wish to remain anonymous. I compare the results of my fieldwork with data on this issue from existing publications (for example, Emel'yanov 1921; Vladykina 1992; Minniyakhmetova 1996; Zaytseva 2003; Vladykina 2004; Vladykina 1997; Panina 2014). I concentrate here on contemporary narratives about witchcraft and the characters of wizards and witches, as well as relations between the village community and these magic specialists.

\section{The characters of wizards and witches}

According to folklore narratives, wizards and witches show almost no external differences to other people, but they have the gift of metamorphosis and are loaded with supernatural forces. According to my informants, wizards and witches master some secret knowledge, which is clearly reflected in the vernacular words that describe them in the local communities: todis'/todis'-valas'/todemez van' 'knower'/'knower-understander'/'one who has knowledge'. Udmurt folklorists Tatiana Vladykina and Galina Glukhova distinguish four levels of knowledge and magical skill in traditional Udmurt culture, from the weaker to the stronger. In this hierarchy wizards occupy the first, lowest, step (for more details, see Vladykina 2004: 
102; Vladykina, Glukhova 2011: 132), althoug this does not in any way diminish their status in the local community.

The Udmurt consider that the most skilled specialists in magic are the Mari and the Gypsies, i.e. ethnic Others. The Udmurt avoid having close contact with these people as they are afraid of becoming victims of their magical attacks $\left(\mathrm{FWM}^{1}\right)$. However, there are materials showing that the Udmurt's ethnic neighbours are, in turn, afraid of them, for example Russians, Tatars, Bashkirs. Thus, eastern Udmurts think that Tatar and Bashkirs are afraid of them because they think the Udmurt have mastered special magical strength and know how to curse:

Udmurtez kuzhmo shusa malpalo. Ad'amiyez söryny bugato shuysa. Udmurtlen danakges shuysa malpalo, todemzy. Kyz'y shuod, inkuaz'en matynges-a. Udmurt kargashiz ke no, kargashemez us'oz. Soin tin’i kyshkaloges in’i soos.

[The Tatar and Bashkir] think the Udmurts are strong [in magic]. That they are able to damage people. They think the Udmurts have more [magical] knowledge. How do you say, [the Udmurt] are close to nature, are they? When an Udmurt curses you, the curse functions. Therefore, they are afraid $\left(\mathrm{FWM}^{2}\right)$.

As an Udmurt, I experienced a similar situation in Izhevsk in 2011 when I was in a taxi talking with a friend in Udmurt. This produced a negative reaction in the driver, an ethnic Russian. He said rudely that we must not speak in a language he does not understand, and that all Udmurts are wizards who know only how to curse people. These examples reflect the imagined connection between native peoples and magic, in this case witchcraft (Panina 2014: 90). Ol'ga Belova observes about this aspect of culture: "The assessment of 'others' as enemies, dangerous beings, goes back to archaic beliefs that all that comes from outside and does not belong to the closer 
community circle are representatives of the other world and are gifted with supernatural properties" (Belova 2009: 581).

According to my informants, one can recognise wizards and witches either by their behaviour or by some external features:

- Witches do not allow anybody to look in the eyes, they react to visual contact by immediately turning their glance aside $\left(\mathrm{FWM}^{3}\right)$;

- In the eyes of the wizard or of the witch, everything is reflected from the head down ( $\mathrm{FWM}^{4}$; Vladykina, Glukhova 2011: 27);

- In his/her eyes and mouth, one can see a blazing fire $\left(\mathrm{FWM}^{5}\right)$;

- Witches and wizards have no shadow (FWM ${ }^{6}$; Vladykina, Glukhova 2011: 27);

- If you call them witch or wizard, they are very offended and angry $\left(\mathrm{FWM}^{7}\right)$; “...witches do not like gossip and they punish harshly those who spread rumours about them” (Minniyakhmetova 1996: 259);

- Under the influence of alcohol, they rave and show defiant behaviour - vedin'zy uzate/ulate - "the witchcraft force provokes" $\left(\mathrm{FWM}^{8}\right)$;

- They insist that a person tastes a dish or drink, in order to harm them through this food ( $\left.\mathrm{FWM}^{9}\right)$;

- A wizard will not eat a hunk of bread with the crust turned towards him (Vladykina 1997: 241), etc.

According to Udmurt beliefs, one can recognise a wizard thanks to some actions connected with the other world, the world of evil spirits. For example, when a witch or a wizard has entered the house, one must protect oneself in the following ways: put near to the door a broom with the handle downwards; overturn a container; put a piece of clothing on backwards; offer a hunk of bread with the crust turned towards the wizard, etc. It is also possible to use apotropic objects, for example, stick in the doorjamb a needle without an eye, or a knife or pair of scissors; pour salt, ashes or 
hot embers on the threshold where the witch or wizard trod; keep a bit of bread handy, attach a horseshoe to the threshold (FWM ${ }^{10}$; Vladykina 1992: 127-129; Vladykina 1997: 241). Wizards and witches cannot manage with a world 'upside down', constructed by people with the help of amulets, so they reveal themselves. In Udmurt there are special terms connected with the discovery of these characters - vedin'en/veginen kuton 'catching someone in witchcraft', vedin'ez/veginez pytsan 'to shut out a witch or wizard', vedin'ez/veginez tupaton 'to correct a witch or wizard'. I have in my material a fair amount of this kind of narrative. Here are some of them:

Ogpol vannapalan dyr"yaky, pysytem ven'ös d'yr d'yle ponysa, potis'tem kariz. Ug pot n’i, puke no puke. Khusnidiyan kenakez... Ug pot n’i. Murt pyriz no, biziz no, potiz no koshkiz. Ug poto n'i, pe, soos. Oz'y todyn lue vedonlykze. Pysytem ven' ke uan', ponis'kod no uchkis'kod, poto na taos, ug n'i-a. [...] So Arkadiyen Van'aos serekdzh'yalo inde Khusnidiyan kenakez pukytis'kom shuysa.

Once, when we were at the top of the street, [a man] having affixed over the door a needle without an eye, he made the witch unable to get out [of the house]. So she does not leave, she just sits and sits. Aunt Khusnidiyan ... And she does not leave. Another person entered, and [the witch] ran and went into the street. They did not go out. This way it is possible to reveal their witchcraft. If there is a needle without an eye, you put it and you observe, whether they go out or not. [...] They laughed, these Arkadiy and Vanya, they managed to oblige aunt Khusnidiyan to do it (FWM $\left.{ }^{11}\right)$.

Val dagayez no pono kad' no... olo, ös kusype. [...] Val daga, pe, poni no, todemez, pe, vylem kad'. Pyre, pe, val no, adzh'dzh'iz, pe, val dagame no, öz, pe, pyry n’i. 
They also put a horseshoe, it seems... Or at the threshold, at the door. [...] A horseshoe, they say [the master of the house] he put it, yes, [the man who came in] has knowledge, it seems. He entered, they say, and then he saw my horseshoe and did not come in $\left(\mathrm{FWM}^{12}\right)$.

In most of the stories, the person asks that her/his secret be kept. However, according to some witnesses, the discovered wizards or witches might take revenge on the person who uncovered them by causing their premature death $\left(\mathrm{FWM}^{13}\right)$. According to other data the witch or wizard cannot leave the place of their magical imprisonment until they have spilled their own blood (FWM $\left.{ }^{14}\right)$. It is also notable that someone could be suspected of witchcraft by avoiding magical obstacles set by wizards or witches, or if by chance this person is in the wrong place at the wrong time. Such people are immediately marked as connected to the magical sphere. For example, one informant told me that because of something that happened to her, she was identified as a witch. One night she came back after a birthday party in the village and met a couple at a crossing. After a short conversation, they parted. When she came home, she understood that this meeting had taken place at midnight. The next day she learned from a friend that the couple had visited a healer, who had asked them to go out at midnight at the crossing in order to be free of an enchanted bundle, after which they would meet the witch who was sending them their misfortune. This woman was so disturbed that that she went to see them, apologised, and explained that she was no witch. Later it became clear that they had not exited their home at midnight, but at a quarter to midnight. The informant concluded that if they had gone out exactly at midnight, they would have met the witch, and she would not have happened to be in such a suspicious position $\left(\mathrm{FWM}^{15}\right)$.

In many narratives, we note the ability of the wizards and witches to metamorphose. They can adopt whatever form they 
wish, anthropomorphic, zoomorphic, ornithomorphic and even transform into natural phenomena. Some informants suppose that what shifts shape is the soul of the wizard or witch, while others think that both the soul and the body metamorphose. Let us briefly observe both cases.

Anthropomorphism. According to the tradition of the southern Udmurt wizards and witches can transform themselves into any person and thus act upon their victims. Let us get acquainted with an example reported by a woman. In her story, one morning, before dawn, a witch in the form of her mother-in-law (who at that time was already at work) wanted to go near to her child, thinking of doing something to him. My informant, with her husband and the child, were still in bed. Suddenly, the child started to cry and would not stop, while in the yard the dog howled. The woman saw her 'mother-in-law' come from behind of the oven and move towards her. When the woman addressed her, the witch went back to the oven, and thus twice. The third time, the witch under the guise of the mother-in-law was already quite close to the child, so the woman started shouting. Then the witch fled back into the oven and disappeared. In the house, everybode woke up. Then the great grandmother, who was still alive, did something and the child calmed down. The great grandmother explained that witches were able to transform into acquaintances and thus harm people; they ask Inmar ${ }^{16}$ for permission to take a soul through the howling of dogs $(F W M)^{17}$. People also believe that a wizard or witch is able to send a curse through an acquaintance, without that person suspecting anything $\left(\mathrm{FWM}^{18}\right)$. Tatiana Minniyakhmetova presents some curious data about the eastern Udmurt: "if a witch goes to 'work' in the form of another person, and she meets someone, this person, undoing his/her buttons or unknotting her clothes, may bring her back to her original form. As a result, she must give the name of the person to whom she was going, or whom she had already managed 
to curse, and after this the person who caught her is able to free the victim from the curse (Minniyakhmetova 1996: 259).

Zoomomrphism. According to Udmurt belief, wizards and witches can turn into different animals. The most frequent are cats (both male and female), pigs, dogs, ewes, rams, goats and bucks. Here are some narratives about this kind of metamorphosis collected during my fieldwork:

Mil'am atay taka vyle puks'ysa vetlem. Ta takaez pyrtono shuysa Askar agayen puks'il'l'am no... Puks'em no vylaz, takayez mynon s'ainyz evölly, pe, potiz.

Our father rode a ram. He decided to bring him [to the yard]. He and uncle Aksar they sat [on the animal] and... [Father] was riding him, but after a little while, the ram disappeared $\left(\right.$ FWM $\left.^{19}\right)$.

Bazare mynis'yos kölyny pyril'l'am, olo, Vuzh Mön'yala, olo, Dzhik"yala. Kytynze ug tos'ky n'i. [...] Pyril'l'am kyshnomurten kyknazy no. Ey! nylynyz pyril'l'am kölny. Tare uyshor, pe, vuiz in'i no tare nylyz, pe, börde: "mynam s'iyeme pote", pe, shue. Bon, pe, shue maray, "yzh karis'kysa myn ay otsy, soos dory”. Kin'e ke no vera. [...] Mynem, vetlem. "Mynam soye s'iyeme ug luy", pe, shue. Sere nosh kuke soku vetlem. [...] Sere ogezles'-ogez kylysa, vs'o romno kin'e so kosem, vs'o romno so ad'ami kulem.

Those who went to the market arrived, perhaps it was at Old Mon'ya, perhaps at Old Burozhik. I do not remember where. [...] They entered the house, together, with a woman. Oh! They came to spend the night with their daughter. Then it was midnight and the daughter, they say, weeps: "I want to eat!" she says. So, she says, "Turn into a lamb, and go there, 
to them". And they mention someone. [...] She went. "I can't manage to eat him/her", she says. Then she went again somewhere. [...] Then she heard from someone [that the rumour went] that whoever she punished, this person died $\left(\mathrm{FWM}^{20}\right)$.

Id'ot sobaka, raz, raz, id'ot. Esl'i po sl'edu poyd'osh, on vstayot $i$ ukhodit chelovekom. [...] Potom id'ot koshka i pod nogi l'ez'et. Inogda tak sil'no meshayet po put'i, i nastupaesh' na khvost il'i cho. I tut chelovecheskim golosom govorit: "Zachem men'a b'yosh?'21

A dog walks, he walks. If you follow his footprints, he stands up and goes away as a person. ... Then a cat walks and it crawls under your legs. Sometimes he disturbs you so much that you tread on its tails or something. And then it speaks with a human voice: "Why do you beat me?" $\left(\mathrm{FWM}^{22}\right)$.

Pichapay nosh vera val. Püny, pe, lykte shydsa bertyky. Vü duryn shydo val az'lo. Püny, pe, lykte, taz'y ik tankaosyz “shyl'k-shyl'k-shyl'k", pe, kare tan'taz'y tan'i. Biz'is'kod es' in'i tan'taz'y tin'i. Pichapay gulbechti, pe, pyri, korkaz'ti no, pe, öy tuby n’i kyshkasa.

My aunt told me the following story. A dog, they say, goes, when they went home after the [evening] games. Before, they played by the water. The dog goes, they say, and the monist (breast adornment made from coins) jingles "shyl'k, shyl'k, shyl'k". You run so. My aunt entered through the cellar, she did not pass through the porch, she was so frightened $\left(\mathrm{FWM}^{23}\right)$.

Let me note that in spite of their animal form, wizards or witches retain their human properties: they do not loose their ability to speak with a humain voice, and they reveal their identity through 
attributes of the human world (for example jewellery). Udmurt folklorist Tatiana Panina observes that a magic specialist turned cat keeps his/her human teeth (Panina 2014: 36). And people think that the older the witch or wizard is, the bigger animal he/she chooses to transform into, for an older person is no longer able to be as quick and tough as a cat $\left(\mathrm{FWM}^{24}\right)$.

Ornithomorphism. The largest number of stories are connected with the transformation of wizards and witches into birds, either domesticated or not: geese, hens, sparrows, tits, swallows, and pigeons:

Mon kinen povaryn uzhay, vit' chasyn dzhyt tubis'ko, pe, kyshnomurt. Lymy, pe, us'e n'i, o-o-o. Tare kyti ke övöl az'am, pe, sach gyne dzh'adzh'eg us'iz. Tare, pe, uchkis'ko n'i, bon mar ta tatshe, kytshe-mar dzh'adzh'eg'yos na. Raz, da kyshnomurt, pe, kyldiz, o-o-o. "Nokinly no en vera, mon tynyd van'ze s'oto" shuiz no pedzh'dzh'iz, pe.

A woman [told me], with those with whom I worked as a cook: "I went [from work] at five in the evening. It was snowing, it was. Suddenly before my eyes a goose fell. Now I looked, which geese? Suddenly a woman was [in front of me], so she was." "Do not tell anyone, I will give you whatever you want", she said and fled away $\left(\mathrm{FWM}^{25}\right)$.

It is not seen as a good omen if a bird flies into the house or the sauna:

Informant 1: Mi se Savin Ol'apay shukom, o-o-o. Uramamy..., kuliz in'i so kyshnomurt... Se mi vedin shukom, y-y-y. [...] Guzhem kuaz', ognam, y-y-y, korkan. Korkamy vuzh al'i, main ay, guren. Kyk etazh"em korka. I, so sokemeti pyryny kule uk. Mon al'i ke no paymis'ko. [...] So mur"yoti us'ysa dzh'ol'gyri... Mon pervyy sytshe kual'ekti. [...] Kak dzh'ol'gyri us’iz. So 
s'öd-s'öd sues' luemyn, y-y-y. Kyk gyne pichiyes' uknoosmy. I, srazu uknoye tash gyne shukkis'kiz. So ves'su paz'gis'kiz, $y-y-y$. [...] Kokas'ke, kokas'ke, kokas'ke, potyny vyre. A mon todis'ko anaylen veramys'tyz, so oz'y pyrem umoyly övöl dzh'ol'gyri pyrem mur'yoti. Mon sobere main ke no kymay so dzh'ol'gyriyez. I byz'sa memey dory, so kytyn ke no azbaryn. [...] Vay ay, pe, Oriyez kes'kom, tshuzhapez. [...]

Informant 2: Ya, mon s'ures vyle sulti no dzhyny mugorze otchy kari, dzhynyze tapalaz kari. [...]

Informant 1: Tshukaz'eyaz-a mar-a opet' achim ik tupay, $y-y$-y. Tabere so Savin Ol'apay... So dotovo chork-chork vetle val. Olomar uknoye uchkyny shed'ti no, kin ke no oti vyleti vas'ke no "kin bon meda sytshe vis'is' kyshnomurt vas'ke?" shuis'ko. Ves' kongyr-kongyr gyne, y-y-y. [...] Tare mateges vuiz no, Oste! bon so Savin Ol'apay uk. Tare mon paymi. [...] Ukno pas' guzhem, y-y-y. I so mil'am kapkaz'amy vuiz no, $y-y-y$, “t'fu!" s'aldzh'is'kiz mar ke byddzh'a, "vir yuis'yos!" shuiz no koshkiz.

Informant 1: We call her aunt Savin Ol'a, so it is. In our street... this woman already died... We call her a witch, so it is. [...] In summer, [I am] alone, am I not, at home. Our home is an old house, with, what is it, an oven. A two-storey house. And look, he managed to fly so far. I am surprised even now. [...] A sparrow falling through the chimney... At the beginning, I was so frightened... When the sparrow fell. He was covered in soot, he was entirely black, so it was. We have only two small windows. And immediately it collided with the glass. Even the soot spread around, so it was. [...] It hits, hits, hits, trying to fly away. But I know that, according to my mother, such an intrusion is not a good omen - when a sparrow flies in through the chimney. Then I somehow 
covered this sparrow. And I ran to my mother-in-law, she is in the yard somewhere. [...] Come on, she said, let us call aunt Irina.

Informant 2: There, I was standing on the road, and [breaking up the sparrow] I threw half of the carcass on one side and the other on the other side [of the road]. [...]

Informant 1: The next day, again I was [at home] again, so it was. And now this aunt Savin Ol'a... [Before] she walked very straight. [I] looked out of the window, somebody is coming down the street and "strange, who is this sick woman who is walking?", I say [to myself]. [She walks] hunched over, so she did. [...] Now she comes closer and, oh my God! It is aunt Savin Ol'a! Now I was surprised. [...] In summer, the windows are open, so it is. She came to our gate, she did, and she spat loudly "t'fu!" and she said "Blood-drinkers!" and went away $\left(\mathrm{FWM}^{26}\right)$.

The unauthorised intrusion of elements from the natural world into the human sphere is everywhere a dangerous phenomenon with undesirable consequences ${ }^{27}$, and in this case, it is accompanied by the dire activities of wizards or witches.

Natural phenomena. According to Udmurt legends, wizards and witches may transform into a whirlwind, a sudden and strong blast, flying fireballs, a fire snake, etc.:

Poyekhal'i domoy, mama s papoy i ya. Mama s'ela vpered'i, na loshadke... Zimoy zhe, na sankakh. Vot, tol'ko vyshl'i on'i i loshad' uzhe nachala furkat'. S vorota vyshl'i on'i, i loshad' nachala furkat'. Ekh! Babushka zhe govorila: "Davayt'e nochevat'. Nochuyt'e, n'e ezdit'e uzh, utrom poed'et'e”. N'et, ot'ets n'e slushal. Vpered'i okazyvayets'a u nikh, cherez rechku, 
tam Kalmiyar-Baltachevo pereyt'i nado. Do rechki, uzhe vpered'i u nikh igrayet mal'en'kiy ogon'. Vot tak krut'its'a, id'ot. On'i edut i ogon' krut'its'a vpered'i. A loshad'vs'o-taki furkayet $i$ furkayet. E-e-e, babushka skazala: "N'e ezd'it'e noch'yu." N'e slushal'i. Obratno razvernul'is' iv Kalmiyarovo vernulis'. [...] Vot, [mestnyy koldun] Shaybak n'e pust'il. ${ }^{28}$

We went home, mother, father and I. Mother sat ahead, on a horse... It was winter, in sledges. So, we had just departed and the horse started to snort. Oh! Our granny said: "Come on, spend the night here. Sleep here, don't go, you'll go in the morning". But no, father did not pay attention. Ahead of them, over the river, we must cross Kalmiyar-Baltachevo. Before the river, ahead of us, there is a small fire playing. It turns and moves. We go on and the fire turns in front of us. And the horse continues to snort and snort. Eh... granny said: "Do not travel at night." We didn't listen. We turned around and went back to Kalmiyarovo.... That's it, [the local] wizard Shaybak did not allow us to leave (FWM $\left.{ }^{29}\right)$.

Kyar, anay kunoke mynem no Nurtda kenaken bertil'l'am, o-o-a. Soye bon marym shuizy es' in'i... Kyar pyrim no, pe, vydi. Soin, pe, bertim. Berti no, tan'taz'y seregti "shart!", pe, shuiz no, tyl, pe pyriz. Lyktiz no Nurtda, pe, vyzhiye sultiz. Sobere anay soye vedon shuiz in'i.

There, mother went visiting and came back with aunt Nurtda, so it happened. About her they told the same story ... We entered and, there [mother] was lying. With her, we went back home. [Mother] came back home and behind the corner "shart!", we heard and a fire just flew off. Nurtda came to me, and stood by me. After that Mother called her a witch $\left(\mathrm{FWM}^{30}\right)$. 
In the Udmurt folk worldview, whirlwinds can be the avatars of strong wizards or witches and confrontation with them does not bode well. Therefore, when meeting a whirlwind or a strong blast people utter a protecting verbal formula: tire-purte kiyam! 'My knife, my axe into my hand!' or tire-purte bordam! - 'My knife, my axe to me!' (Anisimov 2017: 179). According to some narratives, a witch or wizard to whom a person turned with complaints unexpectedly declared that this person had run into a curse that the witch or wizard had blown onto the wind $\left(\mathrm{FWM}^{31}\right)$.

One may recognise a wizard or a witch because of their unnatural behaviour under their new form. For example, if a goose flies at night or fearlessly follows a person, if a cat walks on its hind legs, a pig tries to enter the house, a lamb turns around a person, a hen cries like a rooster and so on. The village community interprets these as attempts made by a magical enemy, therefore, in order to discover the metamorphosis, they submit the animal to physical violence (beating, chopping, cutting of limbs, scalding, burning, etc.). Further, they wait kytys' no kytshe ivor kylis'koz, i.e. 'wherefrom and which news comes [as gossip]' (FWM $\left.{ }^{32}\right)$. People expect that after physical injuries the wizard or witch will fall ill and so for some time will not appear to others, thus revealing his/ her magical art. Some stories about this topic:

Bertis'ko, pe, marymyn, az'yn, uramyn, pe, kochysh kyk pyd dzh'ylaz, pe, sultiz i kyk pyd dzh'ylaz, pe, lykte shore. Shullasa, kyrdzh'asa, pe, bertis'ko. Syre kyshkasa, pe, kes'as'kis'ko. I syreaz voobshche zhugil'l'am so kochyshez. I so lusa potem peres' odig ad'ami mil'am gurtis', pr'amo seregyn so. Pisey lusa, pe, potem oz'y. Kutsa, pe, zhugil'l'am soye. Sobere so peres'vyrdzh'ylyn bygatytek kulon kyale vuem.

On the way home, and, ahead, in the street, a cat stood up on her hind legs and walks after me. Whistling, singing, I am going home. Then, out of fright, I shout. And later, 
they beat this cat. It turned out to be an old woman from our village, right on the corner (she lived). She turned into a cat, and she went out in that guise. She was caught and beaten. After that, she was not able to move anymore and lied until she died $\left(\mathrm{FWM}^{33}\right)$.

Naprimer, ton shydysa, pe, bertis'kod, o-o-a, uin, ognad. Az'tid pars', pe, vetle, o-o-a. Ton soye shukkis'kod no katyges karysa main ke soin, so shukaz'eyaz il'i maiz ke pydyz chute il’i kiyyz mar ke lüe. Oz'y todmany lüe. I, dzh'a demen küz'a kutid ke, zhugid ke, so "mon ta, mon", pe, shue sobere so murt.

I suppose after [evening] games, you go back home thus, alone in the night. In front of you, a pig walks just so. You beat it with something hard, and the next morning she (the witch) limps or there is something with her arm. In this way, one may know. And, if you catch them when they gather, if you beat her, "it's me, me", speaks this person $\left(\mathrm{FWM}^{34}\right)$.

Piseyen, pe, nerad lui. [...] Tubi, pe, no, olo, ukvaten, olo, san'egen shuiz. So piseyez, pe, kuti. S’inmaz, pe, byshkaltis'kem. Syre meshoke, pe, poni. [...] Syre so s'in'tem pukiz. Mon ik tupatysa oz'y luiz shuiz Natal'l'a.

She was fed up with the cat. [...] She went up [to the attic], with an oven fork, or with a pitchfork, she said. This cat, she caught it. She stabbed its eyes. Then she threw it in a sack. [...] Then he [the wizard], remained blind. After my (lit: correction, 'lesson', 'punishment'), [he] remained [blind], said Natalya $\left(\right.$ FWM $\left.^{35}\right)$.

In folk culture, this kind of violence against wizards and witches who have achieved metamorphosis is meant as a defence of the 
community against the evil intentions of the magical aggressor, as well as being a punishment.

\section{The role, the activity and status of marginal characters in village society}

All informants mention that behind the wizard or witch's unfriendly acts, there is a supernatural force that pushes them. If they cannot free themselves from the negative force within, and do not feed on the living energy of other people, they will become ill and might harm their loved ones. People also say that some wizards and witches, in order not to harm people (Udm. ad'amiyez s'iyyny 'to eat, devour a person'), nourish themselves with the living energy of a plant (most often a tree), which consequently starts to wither and dry. If the wizard or the witch does not find an object towards which to turn his/her curse, they can send it to a stone, a pillar, to the wind (Minniyakhmetova 1996: 261) or to other places (a gully, the forest) (Vladykina, Glukhova 2011: 30; Anisimov 2016: 46-50). The following text is about giving the negative energy of a wizard to the wind, and how this then met my informant:

Informant 1: Töl shory zhimem shuo es' in'i, so, dyr, in'i so. Töle lez'o es' in 'i “fu-u” shusa.

Informant 2: "Uf-f”' shusa pottysa lez'o no, o-o-a. Kinly, dyr, mynsa us'e. So cherla. [...] Töl shory zhimem shuysa mone Menziyan chuzhapay emn'az. Tabayez dzh'yrdatiz, mone shobyrtis'ky shuiz, o-o-a. "Taz'y töl shory zhimem. Emez-yumez ta med lo"-vu kis'tiz. So paryn marym karis'kod. "Töl shorys' zhimem. Emez-yumez ta med luoz, med koshkoz!"-shuiz.

Informant 1: They say I met the wind, and it is true, I suppose. They let it into the wind, breathing out "fuuuu". 
Informant 2: By breathing out "uuuuf" they let it go, and get free of it, so it is. On its way it sticks probably to someone. This person gets ill. [...] Aunt Menziyan healed me saying that I met the wind. She heated a pan, asked me to cover myself, so it is. [With the words] "She met thus the wind. Let this be to her a medicine, a healing" and she spat some water. With the steam it is done [you will be healed]. "You got ill from the wind. Let this be your medicine, your healing, let it leave you" said [the aunt] (FWM $\left.{ }^{36}\right)$.

As Tatiana Vladykina and Galina Glukhova noted, “...the influence on the forest is seen as a good deed: the wizard claims he spared the people and diverted the possible misfortune" (Vladykina, Glukhova 2011: 30). But there are also contradictory data, according to which another person, who meets this tree or cuts it, can receive the illness or even die:

Faydyr agay tin'i typu pogyrtem no, cherlasa bertem no, kulem. Busy shoris'... Busy shoryn typu kyl'l'e vylem. Soye pogyrtem no püly shusa, bertem no kulem.

Uncle Faydyr cut an oak, turned, fell and died. [The oak, which grew] in the middle of the field... In the field the oak grew. He cut it for wood, went home and died (FWM $\left.{ }^{37}\right)$.

This example shows that a persen skilled in witchcraft on the one hand gets rid of the negative forces within, and on the other hand transmits them on another living being. A person who is not aware, in contact with this being in which magic force is concentrated, receives psychophysical damage.

The interviewers commented that wizards and witches are particularly active during festive periods, and most of all at funerals and commemorations of the dead (for more details, see, for example Anisimov 2017: 130-133, 195-196, 207-208). Through 
magic manipulations, they curse people using food, drinks, received clothes, hair, fingernails, etc. Therefore, if the community sees a suspicious person, people become immediately vigilant and follow his/her actions: "So tin’i lykte ke, sak karis'kono n’i. Kytyn gyne mar gyne medaz uzha shuysa", "Now, if she comes, you must be vigilant so that she does not do anything harmful" $\left(\mathrm{FWM}^{38}\right)$. If there is somebody from outside the community, people are cautious of such a hostile person. I have faced this situation myself several times during my fieldwork (2009-2021) in different Udmurt groups. When somebody suspected of being a wizard or witch arrived, I was warned not to step close, not to take anything from him/her and not to taste his/her drinks.

According to other representations, witches often quarrel and do not get along with each other. According to one women, this happens when their vedin' $k y l$, their 'witchcraft word', does not fit, provoking personal conflict (Anisimov 2021).

In the village community, where everybody knows everybody else, such a marginal person is perceived with caution and even disdain. However, according to other data, such attitudes are not unanimous:

Vedin'en yake keretysa ulono, yake tuzh tupasa.

With a wizard or a witch you must live either quarrelling, or in total harmony $\left(\mathrm{FWM}^{39}\right)$

So achiz ik vedna no, achiz ik vednamze pel'l'a val.

He caused the ailment himself and he healed it himself $\left(\mathrm{FWM}^{40}\right)$.

Thus, these marginal people are feared and avoided, although people do also turn to them for various reasons. According to Elena Zaytseva's data: "people addressed the wizard asking him to heal 
them in rare cases, when the healer could not help, particularly when the etiology of the disease revealed a curse by a powerful wizard" (Zaytseva 2003: 171). Tatiana Panina also refers to this ambiguity in the way magic specialist are treated, observing that it is particularly visible in the southern districts of Udmurtia, in comparison with the North and the Centre (Panina 2014: 84). People still consider that a curse or an illness received from a Mari wizard or healer can only be cured by a magic specialist from the same ethnic group. Moreover such a curse is considered the strongest and most difficult to cure $\left(\mathrm{FWM}^{41}\right)$. This is confirmed by healers practicing incantational healing (Anisimov 2021).

However, we can also find diametrically opposed cases. For example in Gurez'-Pudga (Vavozh district, Udmurtia) an elder healer declared that she had previously helped people, but that she has been so much disparaged and called a witch, that now everybody in the district is afraid of her and treats her like a leper $\left(\mathrm{FWM}^{42}\right)$. In Starokalmiyarovo (Tatyshly district, Bashkortostan) local people said that when quarrels and turmoil occur between the children or grandchildren of a healer and others, the healer's family threatens the other children, saying that their granny will send them illness and misfortune. According to these informants, some healers indeed curse people in order to have this person address them for healing, and thus obtain financial profit. Elena Zaytseva confirms such understandings by the Udmurt: "If she is able to cure, then she is also able to curse" (Zaytseva 2003: 171).

\section{Methods of protection from wizards and witches}

Data from recent years show that people are aware not only of traditional methods of protecting themselves against wizards and witches, but also of entirely new ones. Among the traditional methods we can mention the following: keeping an onion or piece 
of garlic handy, or a pin or breadcrumbs; pouring salt on the head (both of an adult or a child), or having salt in one's pockets; wearing on one's wrist a red thread; biting one's thumb; holding thumb and ring finger together, etc. According to folk understanding, the most efficient method of depriving a wizard or witch of their magic force is to get them to eat their own excrement, added to some dish or drink (Vladykina 1997: 241; Anisimov 2017: 69). "Therefore, they hide their own feaces; they always attempt to hide it" (Vladykina 1997: 241). If this happens, the enemy becomes weak-minded and loses his/her magic force.

Peres' kyshnomurt, pe, vednas'ke val no shusa odig kyshnomurt veraz. Sere, pe, mi soye marym, kiz'enyz l'uktam, pe, no, viz'tem kad', pe, luiz. Nomyrze no, pe, ug vala n’i.

An old woman, they say, was a witch, as one woman said. Later, they say, we did that, we gave her her [own] urine to drink, and she became like a lunatic. She does not understand anything anymore (Anisimov 2021).

According to Tatiana Vladykina, human feaces is connected with the mask of death, which is a necessary object to address representatives of the world beyond, creating a "world upside down" and thus protecting people from the inhabitants of the other world (for more details see Vladykina 1997: 310-312), with which folk understanding connects wizards and witches.

In the tradition of Christian Udmurts there are different objects and verbal texts carrying Christian symbols (holy water, objects containing prayer, crosses, icons, etc.). Some of these methods that offer protection from the influence of witchcraft when receiving guests and offering them drinks are still practiced today (Anisimov 2019: 221-223).

In order to get help against wizards and witches, people turn to healers (Udm pel'l'as'kis'lit: 'one who blows' / pel'l'as' lit: 'one who 
blows' / pel'tis' lit: 'one who blows' / tunochi 'diviner'/tuno-pel'l'o 'diviner', 'healer'/emn'es'kis' 'physician'/todis' 'one who knows' I todysh"yas'kis' 'one who deals with knowledge, with witchcraft'), who endeavour to remove the curse and protect them from future influence (Anisimov 2021).

Among newer methods to protect oneself from magic, we can mention objects from foreign cultures. We can thus find in Udmurt villages objects with apotropaic functions from Asia, Africa, India, China, Turkey and other countries of the world. These case are not mass examples, and neither are they widespread, but they happen. In most of these cases the owners of these objects do not know the exact symbolism connected to them, but they believe in their force and protective abilities.

\section{Representations and trends in recent years}

In recent years I have met tales in which informants openly acknowledge that they belong to a family in which there are wizards or witches:

Mi ved' Tash vyzhyis', Tash vyzhyez vedin' shuo val uk.

Indeed we are from the clan Tash, which was said to be a clan of wizards $\left(\mathrm{FWM}^{43}\right)$.

I must add that the informants say this without any mystery or caution whatsoever. As one of them declares, sometimes in conversation she mentions this kinship, so that possible enemies will be afraid of her. It is interesting that formerly some things were never openly said; on the contrary, people were afraid of being recognised. Udmurt ethnologist Tatiana Minniyakhmetova confirms that: “... among people it was not customary to talk openly about people possessing 'an impure force' ... people able to make miracles did 
not acknowledge it, and pretended ignorance of its very existence, but when they were reminded, they might agree with the opinion of others" (Minniyakhmetova 1996: 259). In some cases, Udmurts warn or inform others that they possess a strong magical object with the help of which they can affect others, for example, threads obtained from a pillow on which somebody died $\left(\mathrm{FWM}^{44}\right)$.

Everywhere we hear stories about the impossibility of wizards and witches flying, because there are power transmission lines everywhere today. According to the informants, they are made of metals and as we know, metal is a protection from 'impure forces'. Moreover, wires, like a spider's web, extend across a space, disturbing free movement during flights.

Oz'y shuiz in'i chuzhatay, el'ektrichestvo, dyr, mar, dyr, syshe provod"yos... el'ektroprovoda sil'no, pe, vl'iyayut sycheosly. Sekyt, pe, lue sycheosly.

Grandfather said that electricity, probably, those wires... electric wires have a huge effect on such people. It is hard, they say, to become like them $\left(\mathrm{FWM}^{45}\right)$.

There were also data according to which transmissions from mobile networks and satellite antennas are an obstacle for wizard and witch flights:

Yöz”yosles' gyne övöl, antennaos no tros uk al'i, olokytshe no tarelkaos puktylemyn. So meshat'te, yyre s'ote. [...] Vyle tubkod ke, tatyn shuom sytshe tarelka, otyn sytshe. Sooslen shorazy kytshe ke no marayzy van'... Soles' vyle tubizy ke, mozhet'lobdzh'yny bygatozy, no vr'ad l'i kyd'oke pegdzh'ozy, lobdzh'ozy. 
There are not only wires, but now also many aerials, different kinds of dish. This disturbs, it hurts their heads. [...] When you move up, and here is one dish, there another, there another yet... and in the middle there is this thing... If they manage to move higher, perhaps they are able to fly, but they will probably not be able to flee very far, to fly away $\left(\mathrm{FWM}^{46}\right)$.

Being an active Church-goer, and proclaiming dedication to Orthodoxy can also be, as my field materials reveal, a reason to suspect someone of witchcraft. According to some informants, if a person has never, or rarely, attended church, and then suddenly starts to do so, this means that this person wants to pray him or herself out of the sin of being a witch or wizard. One informant acknowledged that her neighbour actively goes to church, but she still behaves in a definitely non-Christian way: she is envious, she curses, she gossips, she sends curses. Once, the woman who told the story went to her house and saw some strange action - her neighbour was standing in front of a small open window reading something from a book. When she noticed that she had been spotted, she started cursing and she was not happy that her neighbour had come and wished her gone. This gave her grounds to give this neighbour the status of witch.

It is quite interesting to observe that some of the informants tend to think that the majority of wizards or witches are young because the young are keen on practicing different kinds of magic. According to them, the reason for this is to be found in the number of TV shows and social media groups, in the availability of books about magic and objects, etc. These informants declare that they have a bad perception of this preoccupation, and think that young people will be made to pay through different forms of misfortune. 


\section{Conclusion}

As this research shows, belief in the existence of extraordinary people is alive among the Udmurt today. The wizard or the witch, who show evidence of having relations with both worlds (this world and the world beyond), experience a contradictory attitude from the community, despite which they have a special status as people who possess supernatural force and sacred knowledge. The available folklore stories and our interviews show that along with traditional representations and knowledge, there are also new understandings. I would highlight that one of the relatively recent representations is that young people have started to deal actively with magic practice, and that among the apotropaic objects one can find objects from abroad (for example the Turkish nazar bondzhuk amulet). Many tales about wizards and witches, as well as magic practices and supernatural forces, create a picture of the modern understanding of the Udmurt village and actualise folk knowledge present in tradition. This research does not pretend to give a full picture, and I plan in the future to publish a series of articles dedicated to the question of magical specialists in Udmurt culture. The next step can be also a comparative study. Especially in the Estonian and Livonian as well as in Finnish and Swedish traditions there is a well-known image of a witch whose soul can fly, or he/she turn into different animals and birds (Loorits 1928; Loorits 1926; Kõiva, Boganeva 2020; Finnish data: Jauhiainen 1998; Swedish: Klintberg 2010).

\section{Acknowledgements}

This research has been achieved with the financial support of Estonian research grant No. PUT590 "Tänapäevane soome-ugri animism: funktsioonid ja sotsiaalne kontekst (2015-2018)", French research grant IUF "Étude interdisciplinaire d'une minorité 
animiste en Russie d'Europe, les Oudmourtes orientaux: rituels, coutumes, engagement communautaire aujourd'hui (2018-2022)", Estonian Literary Museum research grant EKM 8-2/20/3 and the Centre of Excellence in Estonian Studies (TK 145) through the European Regional Development Fund.

\section{List of the informants}

Aleksandrov, Pavel Andreevich, born 1994 in Nikolashkino, Bavly district, Tatarstan

Anisimova, Elena Fyodorovna, born 1968 in Verkhnyaya Malaya Sal'ya, Kiyasovo district, Udmurtia and living in Dubrovskiy, same district

Garaeva, Liliya Zidiyarovna, born 1953 in Bigineevo, Tatyshly district, Bashkortostan and living in Aribash, same district

Garifullina, Al'fira Vasil'yevna, born 1982 in Vyazovka, Tatyshly dstrict, Bashkortostan

Gil'manova, Nina Ganniyanovna, born 1956 in Karabashevo, Il'ishevo district, Bashkortostan and living in Yagul, Zav'yalovo district, Udmurtia

Zaytseva, Yana Leonidovna, born 1973 in Bagrash-Bigra, Malaya Purga district, Udmurtia

Kamaltdinova, Rakhima Nurislamovna, born 1948 in Novyye Tatyshly, Tatyshly district, Bashkortostan and living in Vyazovka, same district

Karabaeva, Maria Ivanovna, born 1961 in Bob’ya-Ucha, Malaya Purga district, Udmurtia and living Malaya Purga, same district

Kornilova, Alevtina Leonidovna, born 1961 in Bob’ya-Ucha, Malaya Purga district, Udmurtia

Kulikova, Zinaida Frantsovna, born 1954 in Nizhnyaya Malaya Sal'ya, Kiyasovo district, Udmurtia, and living in Staraya Sal'ya, same district

Lukina, Nadezhda Nikolaevna, born 1970 in Puro-Mozhga Malaya Purga district, Udmurtia and living in Kuregovo, same district 
Mentdiyarova, Flyura Menkairovna, born 1951 in Urazgil'dy, Tatyshly district, Bashkortostan

Nikolaeva, Anastasia Fyodorovna, born 1941 in Novaya Mon'ya, Malaya Purga district Udmurtia, and living in Bagrash-Bigra, same district

Nikonova, Maria Pavlovna, born 1926 in Nizhnyaya Malaya Sal'ya, Kiyasovo district, Udmurtia and living in Dubrovskiy, same district

Nurieva, Flyura Aynukovna, born 1960 in Bigineevo, Tatyshly district, Bashkortostan and living in Malaya Bal'zuga, same district

Nurtdinov, Sal'akhutdin Minsharaevich, born 1952 in Urazgil'dy, Tatyshly district, Bashkortostan

Nurtdinova, Madina Shaykhundinovna, born 1955 in Nizhnebaltachevo, Tatyshly district, Bashkortostan, and living in Urazgil'dy, same district

Pavlova, Galina Nikolaevna, born 1957 in Dubrovskiy, Kiyasovo district, Udmurtia and living in Staraya Sal'ya, same district

Petukhova, Raisa Ivanovna, born 1956 in Staraya Sal'ya, Kiyasovo district, Udmurtia

Riyanova, Zoia Menkairovna, born 1964 in Urazgil'dy, Tatyshly district, Bashkortostan

Sovinova, Luker'ya Kuz'movna, born 1934 in Karamas-Pel'ga, Kiyasovo district, Udmurtia

Sufiyarov, Radik Ivanovich, born 1961 in Malaya Bal'zuga, Tatyshly district, Bashkortostan

Timerkhanova, Anifa Timershinovna, born 1960 in Vyazovka, Tatyshly district Bashkortostan

Usol'tseva, Ksenia Yakovlevna, born 1931 in Dubrovskiy, Kiyasovo district, Udmurtia

Filimonova, Irina Olegovna, born 1986 in Minderovo, Malaya Purga district, Udmurtia

Chibysheva, Irina Yakovlevna, born 1946 in Bagrash-Bigra, Malaya Purga district, Udmurtia

Chibysheva, Flyura Akhmetkhanovna, born 1962 in Andreevka, Yanaul district, Bashkortostan and living in Izhevsk, Udmurtia 
Shaysultanova, Yulia Vladimirovna, born 1964 in Starokalmiyarovo, Tatyshly district, Bashkortostan and living in Malaya Bal'zyuga, same district

Shirshina, Evdokiya Ivanovna, born 1931 in Novyye Kaksi Mozhga district, Udmurtia and living in Staryye Kaksi, same district

\section{Notes}

1 Recorded from M. P. Nikonova, born 1926 in Nizhnyaya Malaya Sal'ya, Kiyasovo district Udmurtia, now living in Dubrovskiy, same district, by N. Anisimov, 2013; from R. I. Petukhova, born 1956 in Staraya Sal'ya, Kiyasovo district, Udmurtia, by N. Anisimov, 2015; from I. O. Filimonova, born 1986 in Minderovo, Malay Purga district, Udmurtia, by N. Anisimov 2015.

2 Recorded from L. G. Pukrokova, born 1960 in Starokalmiyarovo, Tatyshly district, Bashkortostan and living in Asavka, Baltachevo district, Bashkortostan, by N. Anisimov, R. Sadikov, E. Toulouze 2016.

3 Recorded from I. O. Filimonova, born 1986 in Minderovo, Malaya Purga district, Udmurtia, by N. Anisimov, 2015; recorded from N. N. Lukina, born 1970 in Puro-Mozhga, Malaya Purga district, Udmurtia and living in Kuregovo, same district, by N. Anisimov, 2017.

${ }^{4}$ Recorded from M. I. Karabaeva, born 1961 in Bob'ya-Ucha, Malaya Purga district, living in Malaya Purga, same district, by N. Anisimov, 2015.

5 Recorded from S. M. Nurtdinov, born 1952 in Urazgil'dy, Tatyshly district, Bashkortostan, by N. Anisimov, A. Baydullina, 2017.

6 Recorded from E. I. Shirshina, born 1931 in Novyye Kaksi, Mozhga district, Udmurtia and living in Staryye Kaksi, same district, by N. Anisimov, 2014.

7 Recorded from E. F. Anisimova, born in 1968 in Verkhnyaya Malaya Sal'ya, Kiyasovo district, Udmurtia and living in Dubrovskiy, same district, by N. Anisimov, 2013.

${ }^{8}$ Recorded from K. Ya. Usol'tseva, born 1931, Dubrovskiy, Kiyasovo district, Udmurtia by N. Anisimov, 2014; recorded from L. K. Sovinova, born 1934, Karamas-Pel'ga, Kiyasovo district, Udmurtia by N. Anisimov, E. Toulouze, 2017. 


\section{Nikolai Anisimov}

9 Recorded from M. P. Nikonova, born in 1926 in Nizhnyaya Malaya Sal'ya, Kiyasovo district, Udmurtia and living in Dubrovskiy, same district, by N. Anisimov, 2013; from R. I. Petukhova, born in 1956 in Staraya Sal'ya, Kiyasovo district, Udmurtia, by N. Anisimov, 2015; from I. O. Filimonova, born 1986 in Minderovo, Malaya Purga district, Udmurtia, by N. Anisimov, 2015; from L. Z. Garaeva, born 1953 in Bigineevo, Tatyshly district, Bashkortostan and living in Aribash, same district, by N. Anisimov, 2016.

${ }^{10}$ Recorded from R. I. Petukhova, born in 1956 in Staraya Sal'ya, Kiyasovo district, Udmurtia, by N. Anisimov 2015; from I. O. Filimonova, born 1986 in Minderovo, Malaya Purga district, Udmurtia, by N. Anisimov 2015; recorded from N. N. Lukina, born 1970 in Puro-Mozhga, Malaya Purga district, Udmurtia and living in Kuregovo, Malaya Purga district, Udmurtia by N. Anisimov 2017; from L. K. Sovinova, born 1934 in Karamas-Pel'ga, Kiyasovo district, Udmurtia by N. Anisimov, E. Toulouze. 2017; recorded from A. L. Kornilova, born 1961 in Bob'yaUcha, Malaya Purga district, Udmurtia, by N. Anisimov, 2018.

${ }^{11}$ Recorded from F. A. Nurieva, born 1960 in Bigineevo, Tatyshly district, Bashkortostan and living in Malaya Bal'z'uga, same district, by N. Anisimov, 2017.

${ }^{12}$ Recorded from L. K. Sovinova, born 1934 in Karamas-Pel'ga, Kiyasovo district, Udmurtia by N. Anisimov, E. Toulouze, 2017.

${ }^{13}$ Recorded from R. I. Petukhova, born 1956 in Staraya Sal'ya, Kiyasovo district, Udmurtia, by N. Anisimov, 2015.

${ }^{14}$ Recorded from Z. F. Kulikova, born 1954 in Nizhnaya Malaya Sal'ya, Kiyasovo district, Udmurtia, and living in Staraya Sal'ya, same district by N. Anisimov, 2018.

15 This informant expressed the wish to remain anonymous. Recorded by N. Anisimov, 2018.

${ }^{16}$ Inmar - the suprime heavenly God.

${ }^{17}$ This informant expressed the wish to remain anonymous. Recorded by N. Anisimov, 2009.

${ }^{18}$ Recorded from N. N. Lukina, born 1970 in Puro-Mozhga, Malaya Purga district, Udmurtia and living in Kuregovo, same district, by N. Anisimov, 2017.

${ }^{19}$ Recorded from F. A. Nurieva, born 1960 in Bigineevo, Tatyshly district, Bashkortostan and living in Malaya Bal'zuga, same district, by N. Anisimov, 2016. 
${ }^{20}$ Recorded from A. F. Nikolaeva, born 1941 in Novaya Mon'ya, Malaya Purga district, Udmurtia, and living in Bagrash-Bigra, same district, by N. Anisimov, 2016.

${ }^{21}$ This story was told in Russian. This explains the difference in transliteration.

${ }^{22}$ Recorded from S. M. Nurtdinov, born 1952 in Urazgil'dy, Tatyshly district, Bashkortostan, by N. Anisimov, A. Baydullina, L. Vallikivi, 2017.

${ }^{23}$ Recorded from F. M. Mentdiyarova, born 1951, in Urazgil'dy, Tatyshly district, Bashkortostan, by N. Anisimov, A. Baydullina, 2017.

${ }^{24}$ Recorded from R. I. Sufiyarov, born 1961 in Malaya Bal'zuga, Tatyshly district, Bashkortostan, by N. Anisimov, 2016.

${ }^{25}$ Recorded from M. I. Karabaeva, born 1961 in Bob’ya-Ucha, Malaya Purga district, Udmurtia and living in Malaya Purga, same district, by N. Anisimov, 2014.

${ }^{26}$ Recorded from Ya. L. Zaytseva (Informant 1), born 1973, and I. Ya. Chibysheva (Informant 2), born 1946, both in Bagrash-Bigra, Malaya Purga district, Udmurtia, by N. Anisimov, 2016.

${ }^{27}$ For example it is assumed that if a village is visited by a cuckoo, a squirrel or a fox, there will be soon a fire.

${ }^{28}$ Here too, the story was told in Russian.

${ }^{29}$ Recorded from M. Sh. N., born 1955 in Nizhnyeye Baltachevo, Tatyshly district, Bashkortostan, and living in Urazgil'dy, same district, by N. Anisimov, A. Baydullina, L. Vallikivi, 2017.

${ }^{30}$ Recorded from Z. M. Riyanova, born 1964 in Urazgil'dy, Tatyshly district, Bashkortostan, by N. Anisimov, A. Baydullina, 2017.

${ }^{31}$ Recorded from A. T. Timerkhanova, born 1960 in Vyazovka, Tatyshly district, Bashkortostan, by N. Anisimov, 2015.

${ }^{32}$ Recorded from M. P. Nikonova, born 1926 in Nizhnyaya Malaya Sal'ya, Kiyasovo district, Udmurtia and living in Dubrovskiy, same district, by N. Anisimov, 2015.

${ }^{33}$ Recorded from F. A. Chibysheva, born 1962 in Andreevka, Yanaul district, Bashkortostan and living in Izhevsk, Udmurtia, by N. Anisimov, 2014.

${ }^{34}$ Recorded from Yu. V. Shaysultanova, born 1964 in Starokalmiyarovo, Tatyshly district, Bashkortostan and living in Malaya Bal'zuga, same district, by N. Anisimov, 2016. 
${ }^{35}$ Recorded from L. K. Sovinova, born 1934, Karamas-Pel'ga, Kiyasovo district, Udmurtia by N. Anisimov, E. Toulouze, 2017.

${ }^{36}$ Recorded from A. V. Garifullina (Informant 1), born 1982; R. N. Kamaltdinova (Informant 2), born 1948, both in Novyye Tatyshly, Tatyshly district, Bashkortostan and living in Vyazovka, same district, by N. Anisimov, L. Vallikivi, E. Toulouze, 2017.

${ }^{37}$ Recorded from R. N. Kamaltdinova (Informant 2), born 1948 in Novyye Tatyshly, Tatyshly district, Bashkortostan and living in Vyazovka, same district, by N. Anisimov, L. Vallikivi, E. Toulouze, 2017.

${ }^{38}$ My informant wished to remain anonymous. Recorded by N. Anisimov, 2016.

${ }^{39}$ Recorded from G. N. Pavlova, born in Dubrovskiy, Kiyasovo district, Udmurtia and living in Staraya Sal'ya, by N. Anisimov, 2010.

${ }^{40}$ Recorded from A. T. Timerkhanova, born 1960 in Vyazovka, Tatyshly district, Bashkortostan, by N. Anisimov, 2015.

${ }^{41}$ Recorded from R. I. Petukhova, born 1956 in Staraya Sal'ya, Kiyasovo district, Udmurtia, by N. Anisimov, 2015.

${ }^{42}$ Here and further on, my informants wished to remain anonymous: recorded in Gurez'-Pudga, Vavozh district, Udmurtia, by N. Anisimov, 2014; Starokalmiyarovo, Tatyshly district, Bashkortostan, by N. Anisimov, L. Vallikivi, R. Sadikov, E. Toulouze 2017.

${ }^{43}$ Recorded from G. N. Pavlova, born 1957 in Dubrovskiy, Kiyasovo district, Udmurtia and living in Staraya Sal'ya, same district, by N. Anisimov, 2017.

${ }^{44}$ Recorded from P. A. Aleksandrov, born 1994 in Nikolashkino, Bavly district, Tatarstan, by N. Anisimov, 2016.

${ }^{45}$ Recorded from N. G. Gil'manova born 1956 in Karabashevo, Ilishevo district, Baxhkortostan and living in Yagul, Zav'yalovo district, Udmurtia, by N. Anisimov, 2014.

${ }^{46}$ Recorded from N. N. Lukina, born 1970 in Puro-Mozhga Malay Purga district, Udmurtia and living in Kuregovo, same district, by N. Anisimov, 2017.

\section{References}

Anisimov, N. 2016. Alama/urod in(')ty "plokhoye mesto" v etnokul'turnom landshafte udmurtov: kommunikativnyy aspekt [Alama/urod in(') ty - "bad place" in the ethnocultural landscape of the Udmurt: the communicative aspect]. In: Ezhegodnik finno-ugorskikh issledovaniy 
[Yearbook of the Finno-Ugric Studies]. Vol. 10. $3^{\text {rd }}$ ed. Izhevsk: Udmurtskiy universitet, pp. 43-50.

Anisimov, N. 2017. "Dialog mirov"v matritse kommunikativnogo povedenija udmurtov ["Dialogue of the worlds" in the matrix of communicative behaviour of the Udmurt]. Tartu: Tartu University Press.

Anisimov, N. 2019. Alkogol' v kul'ture udmurtov: otkrytyy tekst i skrytyy kontekst [Alcohol in the Culture of the Udmurts: Open Text and Hidden Context]. In: E. Popova (ed.) Napitki v kul'ture narodov UraloPovolzh'ya: kollektivnaya monografiya [Drinks in the Culture of the Peoples of the Ural-Volga Region: A Collective Monograph]. Izhevsk: Udmurtskiy institut istorii, yazyka i literatury Uralskogo otdeleniya Rossiyskoy akademii nauk, pp. 205-226.

Anisimov, N. 2021. Specialists of magic in the udmurt culture: Some portraits. Journal of Ethnology and Folkloristics [In Press].

Belova, O. 2009. Svoy - chuzhoy [The Own - the Other]. In: Slavyanskiye drevnosti: Etnolingvistichesky slovar' [Slavic Antiquities: Ethnolinguistic Dictionary]. Vol. 4. Moscow: Mezhdunarodnyye otnosheniya, pp. 581-582.

Boganeva, E., Kõiva, M. 2020. Beliefs about flying serpents in Belorusian, Estonian and Russian Estonian tradition. In: M. Maeva, Y. Erolova, P. Stoyanova, M. Hristova, V. Ivanova (ed.) Between the Worlds: Magic, Miracles and Mysticism (1-23). Sofia: Paradigma.

Jauhiainen, M. 1998. The Type and Motif Index of Finnish Belief Legends and Memorates. Folklore Fellow Communications 267. Helsinki: Academia Scientiarum Fennica.

Klintberg, B. 2011. The Types of the Swedish Folk Legend. Folklore Fellow Communications 300. Helsinki: Academia Scientiarum Fennica.

Loorits, O. 1928. Liivi rahva usund III [Livonian Folk Belief III]. Tartu: Tartu University Press.

Loorits, O. 1926. Livische Märchen und Sagenvarianten [Versions of Livonian Tales and Legends]. Folklore Fellow Communications 66. Hamina: SKS.

Panina, T. 2014. Slovo i ritual v narodnoy meditsine udmurtov: Monografiya [Word and Ritual in the Udmurt's Folk Medicine: Monograph]. Izhevsk: Udmurtskiy institut istorii, yazyka i literatury Uralskogo otdeleniya Rossiyskoy akademii nauk.

Vladykina, T. 1992. Udmurtskiye pover'ya v sisteme etnosotsial'noy reglamentatsii [Udmurt beliefs in the system of ethnosocial regulation]. In: G. Shklyayev (ed.) Traditsionnoye povedeniye i obshcheniye 
udmurtov: Sbornik statey [Traditional Behavior and Communication of Udmurt: Collection of Articles]. Izhevsk: Udmurtskiy institut istorii, yazyka i literatury Uralskogo otdeleniya Rossiyskoy akademii nauk, pp. $126-170$.

Vladykina, T. 1997. Udmurtskiy fol'klor: problemy zhanrovoy evolyutsii i sistematiki: Monografiya [Udmurt Folklore: Problems of Genre Evolution and Taxonomy. Monograph]. Izhevsk: Udmurtskiy institut istorii, yazyka i literatury Uralskogo otdeleniya Rossiyskoy akademii nauk.

Vladykina, T. 2004. Znayushchiy (tuno) v udmurtskoy traditsionnoy kul'ture [The One Who Knows (tuno) in the Udmurt Traditional Culture]. In: T. Vladykina (ed.) Udmurtskaya mifologya [Udmurt Mythology]. Izhevsk: Udmurtskiy institut istorii, yazyka i literatury Uralskogo otdeleniya Rossiyskoy akademii nauk, pp. 97-102.

Vladykina, T., Glukhova, G. 2011. Ar-god-bergan: Obryady i prazdniki udmurtskogo kalendarya [Year-Circle: Rituals and Celebrations of the Udmurt Calendar]. Izhevsk: Udmurtskiy universitet.

Zaytseva, E. 2003. Kategorii vrachevateley u udmurtov [Categories of Healers among the Udmurts]. In: Etnos - Kul'tura - Chelovek: Sb. mater. mezhdunar. nauch. konf., posv. 60-letiyu V. E. Vladykina [Ethnos - Culture - Man: Collection of Papers, Dedicated to the $60^{\text {th }}$ Anniversary of V. Vladykin]. Izhevsk: ANK, pp. 168-173.

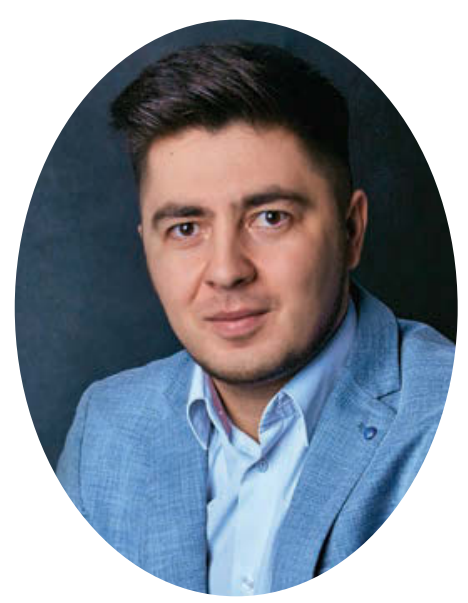

Nikolai Anisimov ( $\mathrm{PhD}$ ) is a researcher at the Department of Folkloristics at the Estonian Literary Museum, Estonia, and at the Department of Philological Studies at the Udmurt Institute for Research in History, Language and Literature (Udmurt Federal Research Centre of the Ural Branch of the Russian Academy of Sciences). His main field of interest is Udmurt traditional and contemporary culture, and more precisely, the Udmurt living ancestors' cult, and their singing tradition.

e-mail: nikolai.anisimov@folklore.ee 


\section{Book Reviews}





\section{The Udmurt Ritual Year and Its Roots}

\section{Mare Kõiva}

Estonian Literary Museum

Tatiana Vladykina, Galina Glukhova. Ar-god-bergan: Obryady i prazdniki udmurtskogo kalendarya. Izhevsk: UIIYaL UrO RAN, 2011, 319 p.

Year-Circle: Rituals and Celebrations of the Udmurt Calendar, by two renowned

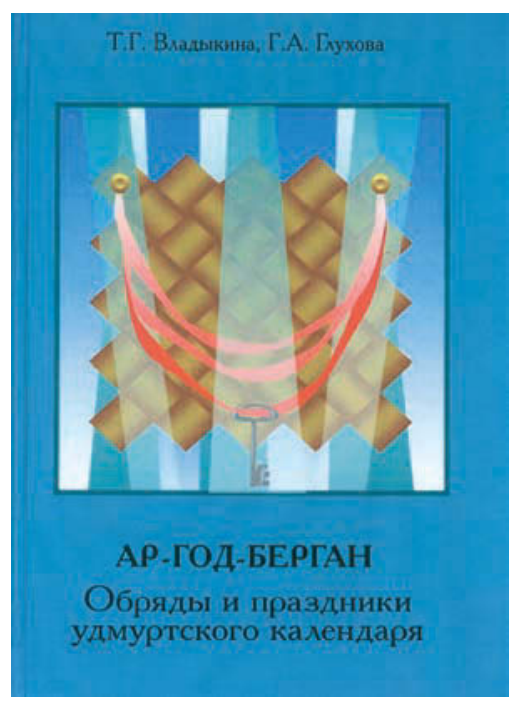
calendar specialists, Udmurt scholars, provides for the first time a complete overview of the system of ritual year customs with introductory articles, a glossary and sample texts. As befits an academic publication, indexes, a comprehensive list of sources and a bibliography are included. 
The literature even lists the BA and MA theses produced by students from various higher education institutions, as well as the publications by the Udmurt Research Centre for Udmurt History, Language and Literature. As for the references used in the book, there seems to be a comprehensive list of published studies on the Udmurt folklore and the Udmurt calendar.

Let us take a closer look at the content of this remarkable book. The authors present theoretical questions such as the possible beginning of year, suggesting it might be autumn because the terms autumn and year are similar; or spring because of its great importance as the beginning of the Udmurt calendar cycle. However, the main focus is on the beginning of the events and the celebrations of the ritual year.

The first part, an encyclopaedia-style glossary, introduces the nature of Udmurt holidays and related traditions. The glossary presents the Udmurt term, then its meaning, dialect forms and description. The sayings, formulae and Udmurt short incantations are listed, along with translations into Russian where needed. The holidays are followed by both a concise description of the main custom and cross-references to other related celebrations, which are included for a complete overview (St. George's Day - Akashka, Guzhdor).

As is typical for calendar customs, there are influences from the Christian calendar (especially in northern Udmurtia) alongside traditions from the neighbouring Turkic peoples (in southern Udmurtia), and holidays originating thousands of years ago. Holidays are spread over the four seasons and the twelve months, with a particularly high concentration from October to March; Easter and June stand out as well. The critical and festive month of October, the transition period at the end of the year, and the beginning of a new one, as well as the period around Easter, the autumn and winter season are therefore important. 
As the authors have also been involved in mythology studies for a long time, it is inevitable that links with mythology are highlighted in the introductory article as well as in the glossary. These include connections with the earth and sky, with water bodies and the forest, with gods, deities and the guardian spirits of the forces of nature. The reader can follow the categories of time and space and mythical concepts (the pillar of heaven, the stairway to heaven, among others). Attention has also been paid to the places of worship where rituals were held.

Vladykina and Glukhova emphasise the influence of nature on human activity, including the calendar system. They highlight gender roles in relation to holidays: men as the performers of animal sacrifices and as priests, women as ritual food preparers and participants. However, the system also includes women's holidays and the important role of women in the spring festivals, which are linked to fertility. Young people's celebrations are introduced, with a special focus on the celebrations of maidenhood, when young people from several villages gathered to have fun. The book does not overlook the celebrations at which children play an important role as performers of the games and as participants in the ritual. The role of older women as initiators and organisers of rituals is notable.

Ar-god-bergan is a rural calendar and therefore festive events, ritual foods and activities associated with the beginning and end of work in the fields are essential. The relationship between the living and the dead is and was an important element of community life.

The second part of the book, which presents sample texts in Udmurt on the core activities and terms found in the dictionary using sources from the $19^{\text {th }}$ century to the present day, is equally indispensable for researchers and people interested in culture. Translations into Russian have been added to each text and this greatly expands the range of users, offering an insight into universal phenomena, local feasts and unique celebrations and concepts. 
Mare Kõiva

Vladykina's and Glukhova's monograph covers community identity and economics, intertwining religious and secular, masking and mumming, entertainment and ritual foods, drawing attention to the cosmological roots of the ritual year. This multifaceted book surely needs a follow-up dictionary of mythology, book on Udmurt natural culture, or a book focusing on the key events in human life. 


\section{How the Udmurt Understand the World, and Man in It}

\section{Eva Toulouze}

INALCO, Paris, France

\section{Nikolai Anisimov}

Estonian Literary Museum

Tatiana Vladykina. 2018. The Udmurt Folklore 'Worldtext': Forms, Symbols, Rituals. Izhevsk.

Tatiana Vladykina is today certainly the most famous folklorist in Udmurtia. She is a Doctor of folkloristics, a leading researcher in the Udmurt research institute, ${ }^{1}$ and a professor at the

\section{Ygmypmckuū}

фonbknopHbiū mupomekcm: obpaz, cumbon, pumyan Udmurt State University. She has written more than 300 publications about Udmurt folklore and traditional culture and has been editor of many books about 
folklore research. Her recent monograph The Udmurt Folklore 'Worldtext': Forms, Symbols, Rituals' (2018) sums up the results of a research process that has lasted decades. In this work, she systematises Udmurt representations of the world by analysing texts of different genres and screening calendar and kin rituals. Here lies the originality of this research. Only a scholar who has been familiar with Udmurt folklore for a very long time, and who has had the time and ability to syntethise her observations could write such a book. As Vladykina mentions, her sources are "different phenomena of language, of folklore, of religious cults, of decorative arts" (p. 35). The corpus of her sources covers a wide chronological spectrum, from the 19th to the beginning of the $21^{\text {st }}$ century, published sources, archive materials, oral information from colleagues, and the author's own field research. The aim of this study is to analyse the Udmurt's traditional representations of the structure of the world, the understanding of space and time within calendar and kin rituals, and the place of man in the metaphorically constructed models of nature and society, all on the basis of lexical poetic metaphors and symbols, linguistic and cultural patterns, discursive clichés, terminological vocabulary, behavioural stereotypes, etc.

If in her previous investigations Vladykina operated within a framework of precise genres, relying on the genre etic category to allow comparison between different cultures, here she concentrates on the semantics of different topics, which she explores transversally. In the title of the monograph she uses the rare term worldtext, probably an invention, which reveals her wide semiotic understanding of what can be called text, a text that transmits the perception by the ethnic community and its understanding of the world. For the first time, Udmurt mythological representations are examined through the prism of the Udmurt mentality, which "along its historical and cultural evolution is submitted to change, acquiring new features and inevitably losing some" (p. 260). 
The analysed historical and ethnographic material is presented in diachronic and synchronic cross-sections. The author includes within her interests historic data as well as contemporary material, revealing both evolution and stability. In some cases, she shows the changes undergone by some items, for example the new features acquired by the deity n'ulesmurt (forest man, forest spirit) (p. 101). In other cases, she highlights the stability of expressions, such as those used to describe eternity ("Shundy bertem, tolez' bertem, kiz'ili bertem" 'the sun comes back, the moon comes back, the stars come back') (pp. 47-50), which have been recorded since the end of the 19 th century to date.

The book is dedicated to the author's parents, both teachers, which undoubtedly influenced the insertion of the young Tatiana into her village community. Three chapters are structured according to the logic of the Udmurt folklore worldtext, more generally according to the Udmurt understanding of the world. Let us add that the content of all the three chapters is convincingly expressed in Vladimir Nagovitsyn's illustrations at the opening of each.

In the first chapter, the author studies phenomena we are tempted to call supernatural, if this term, as always, was not so unsatisfactory. The cosmos is natural and so are gods and spirits as well as their representatives. Yet we are still tempted, because of the prefix 'super', which defines those phenomena through the point of view of man. The objects, subjects, phenomena of the other world are far away, high; they form the foundation and the conditions of the world inhabited by man; they surround it on all sides. Here, the author analyses mythological representations and topics relating to the creation of the world/light, the peculiarities and the hierarchy of heaven's luminaries, the roles of fauna representatives and natural items in the organisation of man's relations with gods and ancestors, with his environment. There is a very curious analysis of the importance of such characters, for example the bee and the goose/swan in Udmurt traditional culture. As far as the 
significance of the bee is concerned, the author remarks that the bee and its particular role is present in almost all genres of Udmurt folk poetry. Vladykina also emphasises the highly symbolic and practical function of the goose in Udmurt mythical and ritual culture. She concludes that the goose in Udmurt culture is an envoy to the gods, informing them about a sacrifice or accompanying a sacrifice as a 'saviour' of the earth; the goose's character is perceived at the same level as the main celestial bodies, the Sun and the Moon. Not by chance is the Milk Way called in Udmurt the Way of the Wild Geese (Luddzh'az'eg-Lobon-s'ures /Luddzh'az'eg/ Kyrzh'az'eg-s'ures).

The second chapter examines the social organisation's mythological understanding within the perception of time and space. Relying on ritual ceremonies and on different folklore genres, we follow synchronic and diachronic cross-sections of the folk calendar, the landmarks of ethnic culture in time and space. The author had already developed these themes in one of her previous works (Vladykina and Glukhova 2011). The time and space worldview are analysed through such natural items as the source/spring and the tree, the ritual and ordinary activities of village society, the socialisation of girls, as well as commemorative rituals. Describing the evolution of the Udmurt folk calendar, the author mentions that the modern calendar reflects ethno-genetic processes in the VolgaUrals region that has taken many centuries and is an example of the mutual influence of cultures. For example, Vladykina clearly shows the local incorporation of the Orthodox Russian calendar in the Udmurt commemorative ritual system. The result of such processes is the organisation of communicative initiatives with the world beyond, which take place partly or entirely under the influence of the people's perceptions of time and space.

The last, third chapter has a very significant title, which is in clear opposition to Western anthropocentric approaches and "puts man in his place': "In This World, We Are Guests". Guest is a modest but honoured place that implies duties and responsibilities. 
This chapter is dedicated to the behavioural stereotypes of the Udmurt in connection with the representations of life and fate and the place of man within the overall picture of creation. The author studies here sacral knowledge, which represents much more than ordinary knowledge, and which is connected with all kinds of human perception, including sensory. Here we must emphasise the importance and the interest of all the observations connected with language, with the use of language by the Udmurt, with the typical Finno-Ugric illocutivity. This dimension, we argue, opens fruitful perspectives that we may sum up with the expression 'word magic', to be understood in the widest meaning. Here there is a particularly interesting section, the one where the spiritual culture is studied on the basis of ethnic stereotypes, i.e. stereotypes of ethnic worldview, of ethnic awareness. It is the first time anecdotes circulating among the Udmurt have been used for analysis, and the finding is that they are deeply connected with ritual culture. Through contemporary Udmurt folklore, Vladykina draws a conclusion about the perception of the world by modern people: "separated from the ritual Purgatory of pre-Christian beliefs, not consciously, i.e.: spiritually led towards the Christian self-surpassing Purgatory, the Udmurt soul, originally non-aggressive, remains alone with the aggression of the world, and often turns this aggression towards itself" (p. 259).

This monograph generalises the author's previous work in this field. Her published studies introduce to scientific communication substantial and often new material and highlight deep layers of Udmurt folklore, religious traditions and ethnic psychology. The huge number of examples from different times just enriches the research, allowing the author to make her points fully and convincingly. We must emphasise the importance of contemporary testimonies as analysed sources, which enlightens the material and allows us to reflect on a living tradition. Another precious input of this book is the number of terms in Udmurt with their local variations. We would like to emphasise the deep philological 
sensitivity revealed by the author. Throughout the research we notice with interest the richness of her remarks on Udmurt words. She highlights both diachronically and synchronically the countless nuances and connotations of ordinary Udmurt words when they appear in the names of phenomena or rituals in order to expose their deepest nature. She makes a very justified remark, illustrated by many examples throughout the book: even culture bearers are not always able to interpret many concepts, so how much more difficult it is for scholars with mother tongues other than Udmurt (p. 235)! Clearly, she has great talent in illustrating the richness of the Udmurt language.

For some of the examples, she gives the local origin. We welcome this choice, and would even have liked it to be more systematic. It allows the author to specify the geography of the used data, and, while it is clearly not among the author's priorities - she comments from the point of view of the whole ethnic group - this aspect is particularly interesting to the authors of this recension (and, possibly, not only us!).

The author uses traditional methods of scientifically analysing her material. She insists on participant observation, and particularly participant observation as a culture bearer herself, even if at the beginning she was not fully aware of the choice and its implications (p. 5). But by the time she writes this study, she fully understands its peculiarity and the privilege going with this position.

In the afterword, the author concludes that "traditional Udmurt culture selected the local and the dialectal sets needed for its identification, maintaining their archaic depth; only the period of globalisation has led them towards more abstract festival and stage forms" (p. 260).

Finally, Vladykina sets a task for the younger generation of researchers: to focus on an area that is almost unexplored in Udmurt traditional culture - the language of folklore. She 
reiterates the fact that scholars have started to build up the most necessary corpus of the Udmurt language and encourages them not to forget to include the challenges set by the language of the rich oral tradition. The conscious inclusion of the language of folklore could give the corpus additional richness and depth.

This book is an interesting reading for a wide circle of readers: folklorists, ethnologists, anthropologists, scholars of culture and those who are interested in folk culture, as well as simply people who are interested in the Udmurt and want to understand their worldview. Thus, this book is will be demanded by a wider readership than only scholars fascinated by Udmurt culture. The authors of the recension have expressed their satisfaction that this investigation has been published and are happy to wish the author the necessary inspiration, along with health and energy, to continue her exploration of the nature of folklore awareness.

\section{Note}

1 Udmurt Federal research centre of the Ural Branch of the Russian Academy of Science.

\section{References}

Vladykina, T., Glukhova, G. 2011. Ar-god-bergan: Obryady i prazdniki udmurtskogo kalendarya [Year-Circle: Rituals and Celebrations of the Udmurt Calendar]. Izhevsk: Udmurtskiy gosudarstvennyy universitet.

Vladykina, T. 2018. Udmurtskiy fol'klornyy mirotekst: obraz, simbol, ritual [The Udmurt Folklore 'Worldtext': Forms, Symbols, Rituals]. Izhevsk: UFITs UrO RAN UIIYaL. 

About

\section{Tatiana Vladykina}





\title{
Tatiana Vladykina's Contribution to Udmurt Folkloristics ${ }^{1}$
}

\author{
Aleksey Arzamazov \\ FRC Kazan Scientific Center, Russian Academy of Sciences
}

Galina Glukhova

Federal State Educational Higher Education Institution

Udmurt State University, Izhevsk

Tatiana Panina

Udmurt Federal Research Centre of the Ural Branch of the Russian Academy of Sciences

We dedicate this article to Tatiana Grigoryevna Vladykina. Let us list her titles: Doctor of Philology, Professor, leading researcher at the Udmurt Research Institute ${ }^{2}$, author of more than three hundred publications (monographs, popular-science publications, didactic writings, scientific articles), honoured scientist of the Udmurt Republic. It is impossible to overstate Tatiana Vladykina's contribution to the development of Udmurt folkloristics in particular, and Russian folkloristics in general. We do not exaggerate when we say that she is the leading folklorist not only in the Udmurt Republic, but also in the whole Urals-Volga region. Her dedication to research, her selfless work, her uninterrupted self-improvement and endeavours to find new fields and results, her fidelity to her people, these are some of the fundamental personal qualities that have determined her biography and scientific career. 
Tatiana Vladykina, née Perevozchikova, was born on September $8^{\text {th }} 1953$ in Staryye Keny, Zav'yalovo district, Udmurt Autonomous Soviet Socialist Republic. Her parents worked all their lives in village schools. Her father, Grigoriy Karpovich, was the director of Yakshur secondary school; he was the first person in the Republic to organise work on local history and founded the school's museum. Her mother, Sophia Grigoryevna, was a teacher of mathematics and supported her husband devotedly. Tatiana Grigoryevna always remembered her parents warmly and lovingly. For her, they were indisputable authorities and their understanding of life formed her character, her strength of purpose and her decency.

When she finished school in 1970, Vladykina entered the philology faculty of the Udmurt Pedagogical Institute and, once her course was successfully completed, she became a doctoral student at the University of Tartu (Estonia). She was interested in studying Udmurt riddles. For her PhD (Russian candidate) dissertation, she had to explore thoroughly the archives of the Udmurt Research Institute, as well as to collect material herself during field expeditions. She acknowledges that she discovered her genuine taste for research in her years as a doctoral student, and that this determined her scientific fate. In 1980, she defended her $\mathrm{PhD}$ on Udmurt folk riddles in Moscow and in 1999 presented her doctoral thesis Udmurt Folklore: Syncretism and the Functional Specifics of the Genre (Moscow). In 2005, the Supreme Attestation Commission awarded Tatiana Vladykina the academic title of Professor of Folkloristics.

At the end of her doctoral studies in 1978, she was appointed senior researcher at the Udmurt Research Institute ${ }^{3}$, with the rest of her fate, researching Udmurt folklore for more than forty years, remaining connected with the Institute. In the first years, the young researcher systematically collected folklore materials according to a wide and complex programme: with her colleagues and students, she investigated many districts in Udmurtia and 
worked in territories inhabited by the Udmurt in the bordering regions and republics. Thanks to her collecting work, the folklore funds of the Institute were enriched with hundreds of songs, legends, riddles, beliefs, narratives about calendar and family rituals and other folklore genres. From her first years as a professional, Tatiana Vladykina reflected on systematising the funds of the Institute's archives. Her work collecting fieldwork materials and systematising published and archive sources were the origin of one of the first volumes of the Udmurt folklore series, which included Proverbs: Riddles (Izhevsk 1982), Folk Aphorisms and Folk Sayings (Izhevsk 1987), Songs of the Southern Udmurt, Vol 1 (Izhevsk 1992), Songs of the Southern Udmurt Vol 3 (Izhevsk 2014) (these last two volumes in cooperation with musicologist E. B. Vershinina-Boykova). She also published important articles with rich text appendices: "The Genre Peculiarities of Chants in Udmurt Folklore" (Izhevsk 1986), "Omens and Beliefs about the Weather" (Izhevsk 1989), "Udmurt Beliefs in the System of Ethnic Social Regulation” (Izhevsk 1992).

Not only did Tatiana Vladykina do a great deal of work collecting and systematising funds of folklore and ethnographic knowledge, she also contributed to conserving manuscripts, audio, photo and video materials of the archive by implementing modern digital technology. In 2006, under her leadership, the Electronic Database of the Traditional Culture of the Peoples of Udmurtia project was launched, supported by the Russian Scientific Foundation for the Humanities within the wider project Image of Russia in the Contemporary World. In order to realise this project, some questions had to be solved, such as the elaboration of a working model of the hypertext database, the structure of the information base, a system of classification, all taking into account the perspectives of information conservation and the principle of rational access.

In the formation and development of her personality, we may not underestimate the importance of the leadership of one structural 
subdivision of the Institute. Between 1985 and 2000, Vladykina was the head of the Sector, later Department, of Folklore and Literature. It was a very tense period for the Institute as well as for Russian research as a whole. But this was also the period when the main directions in researching Udmurt folklore were determined, as well as the attention to precise issues and simultaneously to the general context of traditional culture. Tatiana Vladykina was connected with the legendary scholarly school of Yuri Lotman. Her years in Tartu and the discovery of older and newer ways of tackling philological issues became the starting point in the choice of a creative and scientific direction and the elaboration of a personal research strategy. She conversed much with Paul Ariste, Estonian academician, who was also an example of a genuine researcherphilologist, perceiving the world through words. Having started her $\mathrm{CV}$ with riddles and proverbs, Vladykina was able to implement rapidly her systematising potential, which led Udmurt folkloristics and humanities to a newer qualitative level. The characteristics of Vladykina's school and laboratory are systematism, complexity and creative comprehension of the heritage of her predecessors (N. Kralina, P. Pozdeev, D. Yashin, etc). One of the priority orientations of the sector became the study of Udmurt folklore as an integrated system, characterising the traditional Udmurt worldview, as well as the study of folklore genres, from the point of view of their functionality, narrowly local diversity, and overall text corpus. In order to achieve these goals, trained people were necessary, and so it was vital to keep those who already worked in the sector. Vladykina's friendliness, good interrelations within her team, as well as her defence of her co-workers came to the fore. She achieved her goals with her colleagues by organising conferences, monographs and collections of scientific articles.

Within such an approach to the study of folklore, we must emphasise the role for Udmurt folkloristics of Vladykina's monograph Udmurt Folklore: Problems of Genre Evolution and Systematics 
(Izhevsk 1998). Following the experience of her predecessors, and taking into account the demands and achievements of today's research, Vladykina created an overview of the verbal sphere of Udmurt spiritual culture, through the prism of the genres of Udmurt folklore, their genesis and evolution. After analysis of the material it became possible to avoid the generic classification coming from literary studies, and identify three genres fundamental to folklore: magic folklore, educational and didactic folklore, and recreational and ludic folklore. Characterising each genre, Vladykina shows how these three parameters and functions determine the nature and structure of each genre as a whole.

The Department of Literature and Folklore, under the authority, and with the direct participation, of Vladykina, organised the participation of ethnomusicologists. They used the methods of areal and functional research to study the ritual musical and singing tradition as well as folk lyrical songs. Since 1992, the Udmurt Folklore series has published song collections with musical notation and translation into two languages (since 2017 sometimes with the addition of English). Each volume is dedicated to a particular local tradition. Among eight volumes, two, mentioned already, have been prepared and published by Vladykina with musicologist E. Vershinina-Boykova as co-author; for almost every issues Vladykina has been the scientific editor. The high level of the whole series was very much determined by the first collection: on the one hand, it combined the highly professional work of the musicologist, and on the other hand of folklorist and philologist Vladykina, "who has long experience with words and who perceives them very finely" (Irina Nurieva).

As a head of department, Vladykina gave her colleagues the important task of publishing classic material from the late $19^{\text {th }}$ and early $20^{\text {th }}$ centuries. To accomplish this they founded the Monuments of Culture: Folklore Heritage series. Within the framework of this series, two books were publish with musical notations and 
song texts: E. Gippius, E. Eval'd, The Udmurt Folk Song, Izhevsk 1989; and The Udmurt Folk Song in the Work of D. S. Valsil'yevBugaev (eds. T. Vladykina, M. Khodyreva), Izhevsk 1992. In these books, the researcher is present no only as editor but also making translations and scientific comments to the musical texts, looking at them from a contemporary point of view.

This idea was pursued by researchers in literature. Between 1995 and 2011, V. Vanyushev organised the publication of six volumes in eleven books of the Complete Works of Grigoriy Vereshchagin, an Udmurt scholar, writer and folklorist who worked at the turn of the $20^{\text {th }}$ century. As a member of the editing committee of this fundamental publication, Vladykina contributed to the scientific comments on precise terms and concepts in the thematic indexes of the first three volumes. The fourth volume, two books including G. Vereshchagin's research and material on Udmurt and Russian folklore, was fully prepared by Vladykina with the cooperation of her folklorist colleagues.

We must observe that Tatiana Vladykina has been the scientific and responsible editor of practically all the folklore publications in the sector since the $1980^{\text {s. }}$.

Along with scientific publications, Vladykina has prepared a popular bilingual series called the Golden Krez', with six books that contain different folklore genres, systematised according to theme.

In the last decade, in her scientific work, Vladykina has focused particularly on Udmurt ritual practice. Following modern scientific trends, she pays close attention to worldview and mythological aspects of folklore texts such as metaphor, the paraphernalia and the actions that have peculiar qualities in the ritual context. One of her last books (co-authored by Galina Glukhova), Year-Circle: Rituals and Celebrations of the Udmurt Calendar, is the first in the Udmurt Ritual Primer series. The work has been achieved according to the principles of N. I. Tolstoy's ethnolinguistic school: 
each folklore term and it cultural definition are studied within a multidimensional worldview context.

Another important aspect of Vladykina's creative activity is pedagogical work. Between 1985 and 1987, she taught Udmurt language, literature and folklore at the Udmurt studio at the A. Lunacharski Russian Theatre Institute. She belongs to the category of people who permanently endeavour to enrich their knowledge, skills and qualities: she is always interested by new approaches in research, and new methods and tools in education. When she was in the Theatre Institute, she observed with great pleasure how they taught students stage speaking, and she went on to teach this subject based on Udmurt. She understood that this experience must be taken advantage of in other circumstances. She achieved her dream when she was invited to join the Faculty of Udmurt Philology at the Udmurt University. Here she delivered special cycles of lectures dedicated to folklore and the traditional culture of the Udmurt, as well as giving the course in rhetoric, teaching this subject with pleasure.

Vladylina has cooperated actively with the Udmurt University since the early 1980s as a permanent guest lecturer. She has been regularly appointed chairperson of the State exams and attestation commission. In 2003, she was invited to be head of the Chair of Russian Language and Literature in Interethnic Communication at the Faculty of Udmurt Philology. In the seven years that she was head of this chair she was able with her colleagues to implement new ideas and methods in the teaching activities of the University. She conceived and elaborated innovative folklore programmes for the older students and doctoral students. In her pedagogical activities, there is a special place for special cycles of lectures and textbooks for students, such as The Basis of Mythology, Mythopoetics, Folklore in the Culture of the Peoples of the World, Hermeneutics of the Folklore Text, Folkloristics Today: Methods, Orientations and Schools, and Local History. Among her numerous productions let 
us highlight Ingur (heavenly tune), a chrestomathy - textbook - for schoolchildren, students and a wide circle of readers. She included in the textbook folklore texts from the $19^{\text {th }}-21^{\text {st }}$ centuries, reflecting the state of the folklore text in its dynamics. Thanks to this chrestomathy the reader can widen his or her representations of the spiritual culture of the Udmurt, and can take into account the systematised experience of the mythic and folklore understanding of the world.

Tatiana Vladykina is a sensitive, gifted and demanding teacher. She delivers her lectures passionately and with characteristic thoroughness, to undergraduate as well as postgraduate students, as well as to colleagues and schoolteachers. She holds her audience form the very beginning to the last seconds of her lectures. These lectures in part do not resemble ordinary academic lectures, they are more similar to a lecture dialogue, as is requested by modem education norms. Dozens of students under her leadership wrote their graduation theses on the serious problems in Udmurt folkloristics. She has thus created a scientific school of Udmurt folklore study in the context of the traditional cultures of the peoples of the Urals-Volga region as well as kin Finno-Ugric peoples. Under her leadership there have been doctoral studies in folkloristics since 1995. After graduating students attempt to have her as a scientific supervisor, for she is a gifted teacher, a genuine professional in her sphere. She was very demanding towards her doctoral students and was proud of them: more than ten students defended their PhDs under her supervision. The transmitted knowledge and spirit helped them find the right way in the modern world. She was the chairperson of the Council for Doctoral Defences in the discipline 10.01.09. Folkloristics (Izhevsk 2002-2008) and was a member of the dissertation council at Ulyanovsk State Pedagogical University. Today, she is member of the dissertation council of the Udmurt State University, in the disciplines 10.02.02 Languages of the Peoples of Russia (Finno-Ugric and Samoyed languages) and 10.20.19 Language Theory. 
In 2000, a summer school was organised as an acknowledgment of Vladykina and Udmurt folkloristics in general, the International Summer School of Young Folklorists, in conjunction with the Open Society of the Soros Foundation, Russia. This project developed in Udmurtia and continued the tradition of international and allRussian schools for young scholars, a particular phenomenon in Russian research. In 2005 and 2009, Vladykina organised another two schools, which also became events in our region.

We cannot praise Vladykina highly enough for her achievements in popularising scientific knowledge of traditional culture. Her professional consultations are of great assistance to specialists who prepare television and radio programmes, folklore festivals, exhibitions, competitions, forums, seminars. Her precious comments, her ability to find the pearl in the work of the folk ensembles, these features characterise her activity, which stimulates and inspires the people working in culture to look for new ideas. She is a tremendous educator, one always wants to improve, to reach further when with her.

Vladykina is a foreign member of honour of the Finno-Ugric society (Helsinki, Finland); she started as a regional representative at the scientific Traditional Culture almanac (Moscow), and then became a member of its editorial committee; she is also a member of the editorial committees of the Scientific Education in the Humanities Messenger (Moscow), the Udmurt University History and Philology Messenger, and the Finno-Ugric Research Yearbook (Izhevsk).

Tatiana Vladykina sees her husband, Vladimir Vladykin, as almost her main teacher. He played a huge role in her development as one of the key characters in the humanities, in the spiritual scientific and education life of the Udmurt Republic. They complement each other in scientific and everyday spheres.

Together, instead of their old family house, they built a new house of modern design. Combining their folkloristic and ethnographic knowledge, they reproduced in this house a whole complex: 
a kinship sanctuary (kuala), a two-store granary (kenos), buildings that are no longer used but are interesting as part of a historical past. Today, it is a big household that requires permanent attention and care, intense work that goes unnoticed by observers.

The couple shows unquenchable vital energy and their home is permanently full of guests. People from the village who come as neighbours; foreign guests, colleagues, friends, kin, all of whom they host with joy. Regular visitors are doctoral students, who come for consultations, advice on life questions, and also just to honour their teachers. Tatiana Grigor'evna always offers Udmurt dishes that she prepares herself, and they are received as 'Vladykins' specials' with real enthusiasm.

The credo of Tatiana Vladykina's life is to live simply, without cheating or slyness, ready to help in any situation. She is a charming woman, a thoughtful researcher, a gifted teacher, a versatile personality. Few people know that she has written the text of the Udmurt Republic's anthem. Every time one meets her, one rejoices in her welcome and her kindness, admires her capacity for work, her innovative scientific ideas and her discoveries in the fields of folklore and traditional culture in general.

\section{Notes}

1 This text has been published in Russian in the Yearbook of Finno-Ugric Studies, 2018, 12 (3), pp. 191-197.

2 Udmurt Institute of History, Language and Literature, Udmurt Federal Research Centre of the Ural Branch of the Russian Academy of Sciences.

${ }^{3}$ Udmurt Research Institute of History, Language and Literature, Council of Ministries of the Udmurt ASSR. 


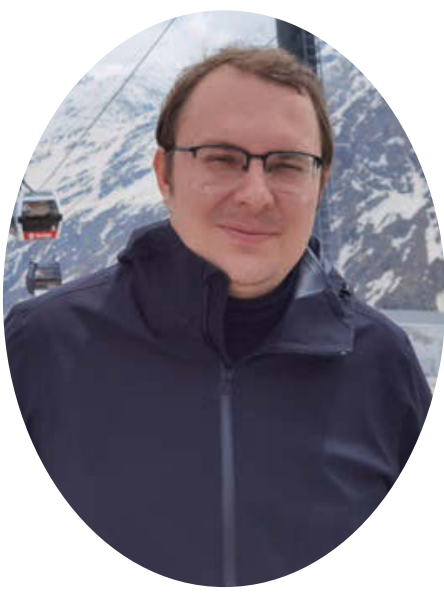

Aleksey Arzamazov ( $\mathrm{PhD}$ hab) is a professor, leader of the laboratory of multifactorial analysis and cognitive philology at the FRC Kazan Scientific Center, Russian Academy of Sciences. He is a specialist in literature in general and Udmurt modern literature in particular.

e-mail: arzami@rambler.ru

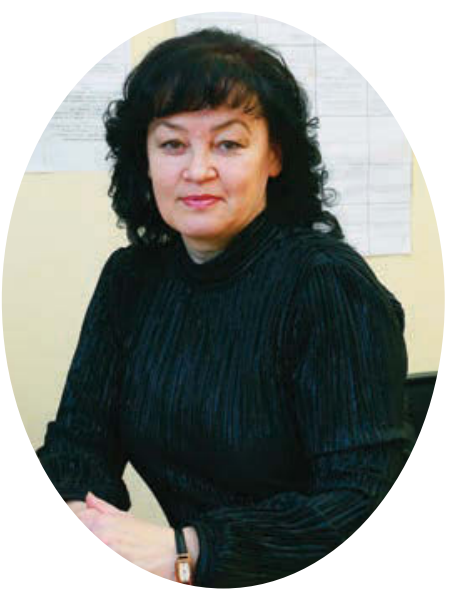

Galina Glukhova ( $\mathrm{PhD})$ is an associate professor and director of the Institute of Udmurt Philology, Finno-Ugric Studies and Journalism of Udmurt State University and teaches Udmurt literature and folklore. Her main field of interest is related to research on Udmurt and FinnoUgric folklore, Udmurt traditional culture, and the interaction of Udmurt folklore and literature. e-mail: galant@udm.ru 


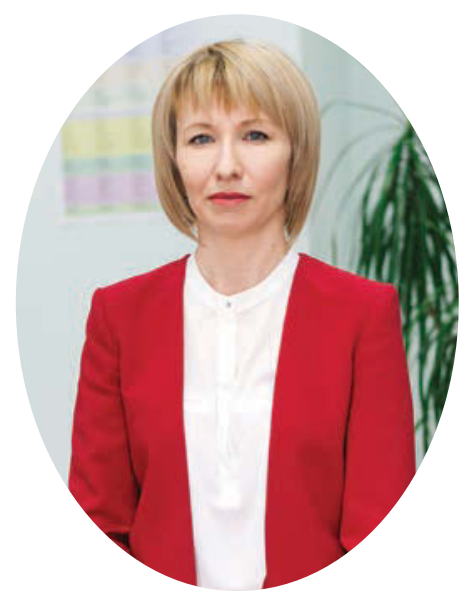

Tatiana Panina (PhD) is a researcher at the Department of Philological Studies, at the Udmurt Institute for Research in History, Language and Literature (Udmurt Federal Research Centre of the Ural Branch of the Russian Academy of Sciences). She is interested in traditional Udmurt culture, more precisely in folk medicine, incantation tradition and more recently dreams. Panina teaches English at the Izhevsk State Medical Academy. e-mail: tipanina@mail.ru 


\title{
Grateful Remembrances
}

\author{
Aleksey Arzamazov \\ FRC Kazan Scientific Center, Russian Academy of Sciences
}

I perfectly remember my first meeting with Tatiana Grigoryevna Vladykina. I had just arrived in Udmurtia and entered University. I studied Udmurt theatre and had joined a folklore group. Tatiana Grigoryevna had heard about me from my teacher, professor Vladykin, who had become my second father. She asked about my situation, how my studies were going, whether everything was all right. She has always been characterised by modesty and sensitivity, the ability to unobtrusively offer help and support.

My second flash of remembrance is of a trip to the ancient Udmurt village of Varkled-Bod'ya, situated in the Agryz district of Tatarstan. This two-day trip was in summer 2003, when I had just started the second year at university. As I come from a Russian metropolis I had not previously had the chance to get more closely in touch with the fascinating, but attractively dangerous world of the traditional belief and ritual. This trip was something of an initiation. After my first year living in Izhevsk, the Udmurt were still for me a terra incognita. Tatiana Grigoryevna opened the complex world of Udmurt spiritual culture for me, for well she understood that without a layer of knowledge it would be extremely 
difficult for me to work seriously with Udmurt material and to investigate the mytho-folklore vocabulary of the Udmurt. How many cultural and ethnographic discoveries were made in these days! Udmurt sacrificial priests loaded with the sounds and meanings of old prayers, silver coins at the bottom of the transparent river Varkled, the globeflowers, the Udmurt italmas flower opening to the clear sky, the 'heavenly gates' turned towards the clouds, ritual porridge, the forest covered with animal skulls... Many of my questions Tatiana Grigoryevna did not answer. And this silence hid a very deep pedagogical wisdom. I had to independently experience, explore the unknown, read folklore texts, reach the spiritual heights of the Udmurt sacred words while still being a student.

Tatiana Grigoryevna helped me a lot at the communication level. For me, a young man from the city, it was not easy to accept the Udmurt system of life. The compulsory presence at early morning lectures, the head-count at the beginning of the lessons, parents meetings at the faculty. None of this fitted my understanding of what university tuition was supposed to be. Tatiana Grigoryevna smoothed the rough edges; she explained how to behave properly and spoke with the teachers, endeavouring to convince them about my 'peculiarities'. Shortly, she attempted to get me to feel at home in this new system of everyday life at the faculty of Udmurt philology.

When I was in the second year, she had a great lecture cycle about Udmurt folklore. And she delivered her lectures in Udmurt. I had just started to absorb the rich and complex language of the Udmurt. I remember how I had to concentrate not so much about the lecture, but about Vladykina's constructions, her efficient Udmurt idiomatic turns. Her sophisticated Udmurt speech has always been a model for me. This is how a professor of an Udmurt university should speak her mother tongue. 
It was exciting to me to find my place in the world of Udmurt philology. As I then thought, I apprehended many things on the wing, but I behaved too confidently for a student. In my fourth year, I suggested to Tatiana Grigoryevna that I could deliver a course with her as co-lecturer, so we developed a programme for a special course called the Hermeneutics of the folklore text. Students as well as teacher were amazed and shocked: a student who delivers lectures with a professor. This had never happened. Vladykina did not pay attention to these rumours. She always supported what was useful to general interaction.

And what a fantastic supervisor. With her, I walked a long distance towards my professional growing, from the student's shy and at the same time arrogant interventions in scientific conferences for young scholars, up to serious monographs, my doctoral dissertation, and the serious status of leading research fellow at the Russian academy of Science. Her doctoral students adore her. And she always defended her students' interests.

Tatiana Grigoryevna is a marvellous hostess. I have had many happy opportunities to attend the 'Yakshur mansion'. How they receive their guests. This is stratospheric Udmurt hospitality quiet, sincere, based on the deepest knowledge of folk etiquette and traditions. The Vladykins' - Vladimir Emel'yanovich and Tatiana Grigoryevna - home in Yakshur is an amazing world for the happy few. Only, there are many of these happy few. Who has not been there? Scholars of international reputation, famous politicians, social activists and simple people from different towns and countries looking for advice. And in the kuala a fire burns and the welcome porridge is boiling...

To write about a person who is very dear, and with whom one meets regularly and has done for many years is not an easy task. Is it right to share one's impressions and remembrances? For me, this is a rhetorical question. One thing is clear: Tatiana Grigoryevna is 
a person who has played a very important role in my life. Со понна соль Бадӟьлм Tay! (For this, a huge thank you!)

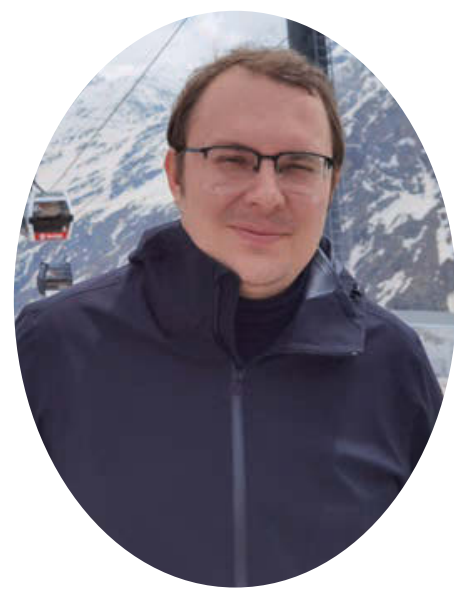

Aleksey Arzamazov (PhD hab) is a professor, leader of the laboratory of multifactorial analysis and cognitive philology at the FRC Kazan Scientific Center, Russian Academy of Sciences. He is a specialist in literature in general and Udmurt modern literature in particular.

e-mail: arzami@rambler.ru 


\section{My Teacher, My Master and My Friend for Life: Or the Person, the Scholar Who Determined My Fate}

\section{Galina Glukhova}

Federal State Educational Higher Education Institution Udmurt State University, Izhevsk

Although I have had in my life many interesting meetings and acquaintances, awareness grows with the years that the characters of those who particularly influenced me, who raised me, who helped me are engraved in my memory. Undoubtedly, my parents. Moreover, in the life of each of us, there have been teachers thanks to whom our life path has found its direction. Tatiana Grigoryevna Vladykina has played in my life such a function; she is a gifted scholar, a formidable teacher, a wise mentor, a real friend for life. Meeting her has determined my adult fate.

It was in 1993, in spring. I was an assistant at the chair of Udmurt literature and literature of the people of Russia at the Udmurt State University. After a regular lecture about Udmurt folklore, I went to the chair. As I remember now, the seminar issue was "small genres in folklore". Every time I taught this subject, 


\section{Galina Glukhova}

something in my head did not fit: why does the genre of paroemia belong to the "small genres"? Proverbs contain such depths of folk wisdom! I was as always troubled and this time I asked Tatiana Vladykina who, by a happy chance, happened to be at the chair. She answered my question: "If you want an answer to your question, come and do a $\mathrm{PhD}$ with me". And immediately she named the topic for my future $\mathrm{PhD}$ : "The poetics of the Udmurt lyrical songs". I was extremely surprised by this unexpected proposal.

This event determined my fate. In 1994, I became a doctoral student at the department of folklore and literature at the Udmurt Institute for History, Language and Literature at the Ural branch of the Russian Academy of Sciences; my supervisor was T. G. Vladykina, $\mathrm{PhD}$ in philological sciences, senior researcher and someone with a peculiar intuition.

She followed her students with a keen attention and, depending on their interests, proposed topics for their dissertations. When she identified in them a trend towards abstract thinking, she proposed a corresponding subject for scientific research. She was also convinced that the final choice should be the responsibility of the student, who must like the problematics, must be attracted by it. Her task was merely to adjust this choice, to orient it. Her scientific as well as human sensitivity, this is her characteristic, the style of her multifaceted nature. Therefore, when I entered doctoral studies, I was proposed another topic, "the symbolic of mummery in Udmurt's traditional culture", and I worked on it with immense pleasure (photo 1).

Tatiana Vladykina taught her doctoral students the culture of scientific creation, scientific ethics. She injected us, her doctoral students, with love of research, gave us the opportunity to taste science, get the feel of a scientific school; she helped us write scientific articles, taught us this art. I remember how genuinely she rejoiced at our first hard-won scientific articles in some collection. 
We attended with constant interest the methodologic seminars led by Tatiana Vladykina. She prepared all of our meetings thoroughly and responsibly. I always marvelled and marvel yet at her love of folklore. She always talks about complicated topics with passion and inspiration, making them understandable and accessible. Such is my teacher and mentor, concentrated, responsible, dedicated to her task.

Investigating oral creations, she taught us its poetics, the genres, and did not limit herself to text analysis. She paid particular attention to the collection and recording of materials. She considered that it was indispensable to master field folkloristics: it was compulsory to participate in fieldwork, to collect empirical material ourselves. She came with us in field practice, and demonstrated, from her own experience, how to work with our partners, how to obtain the result we yearned for, how to ask the proper questions (photo 2).

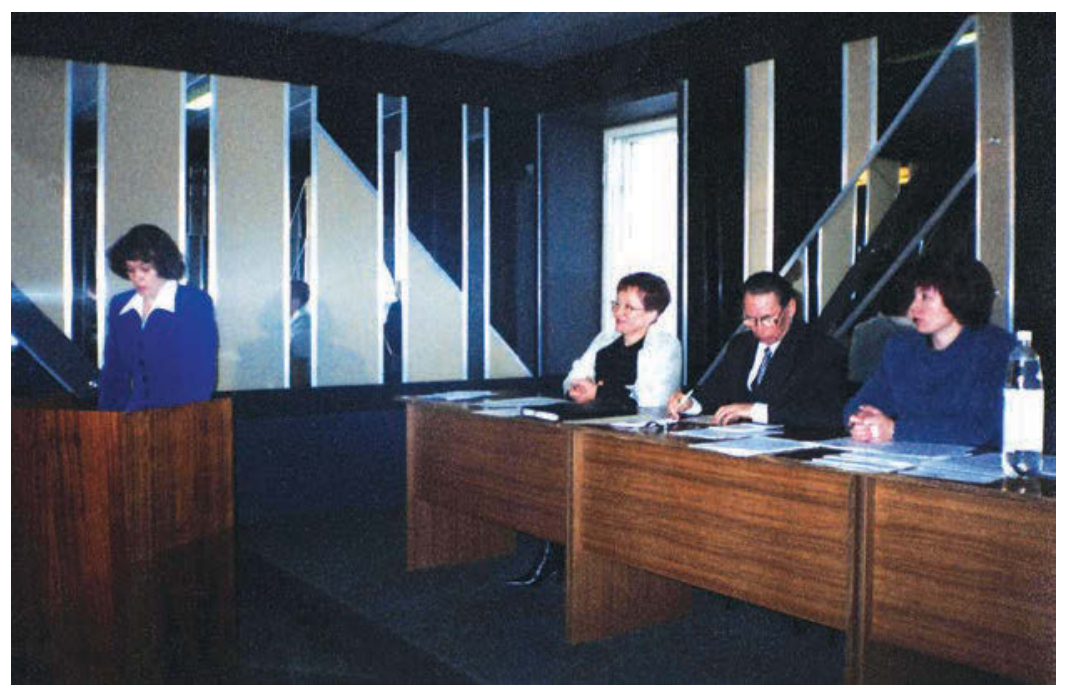

Photo 1. The defence of my PhD dissertation "The symbolic of mummering in the Udmurt's traditional culture". Izhevsk, UdIIYaL UrO RAN, December 2002. Photo G. Glukhova. 


\section{Galina Glukhova}
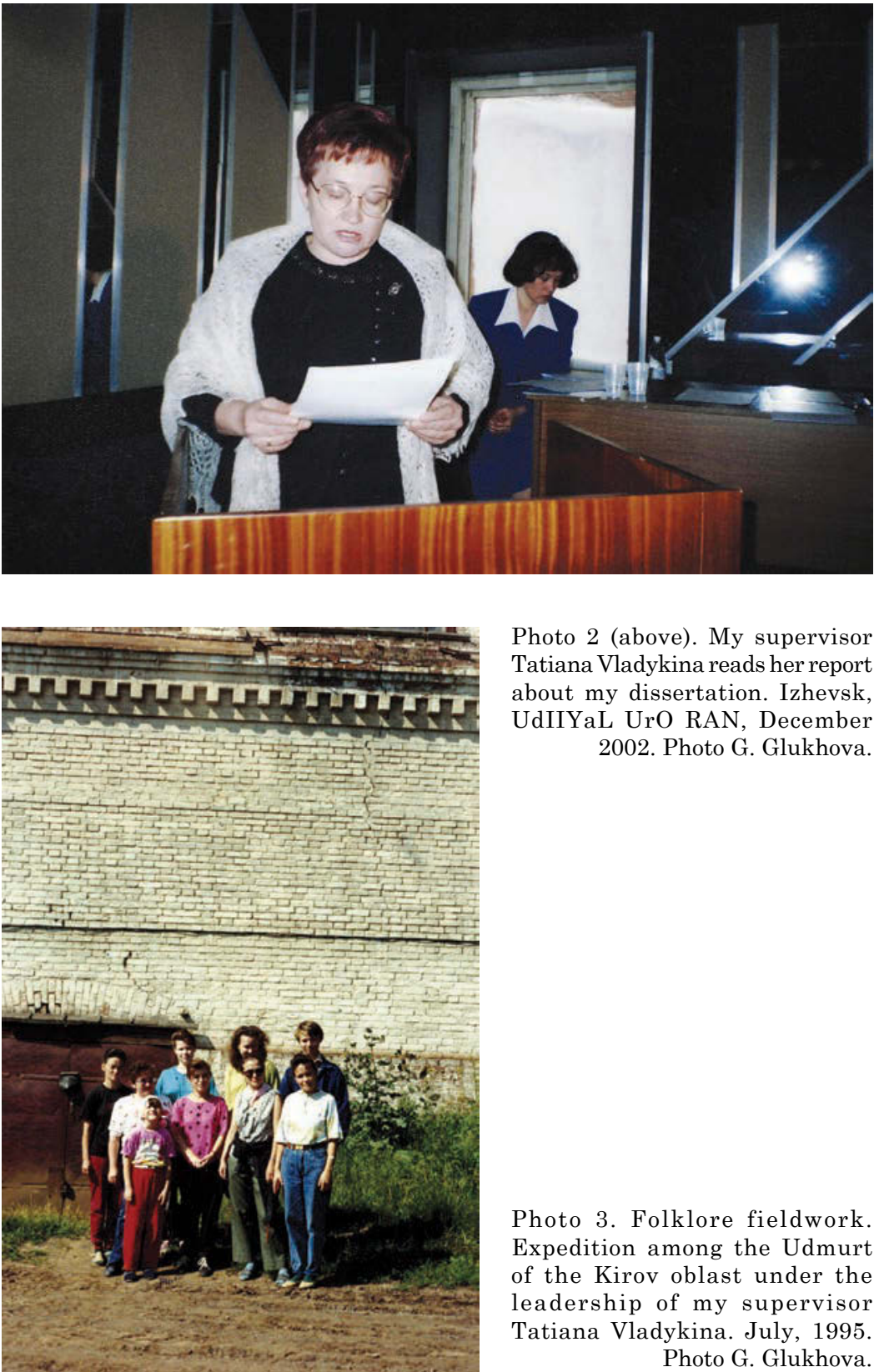

Photo 2 (above). My supervisor Tatiana Vladykina reads her report about my dissertation. Izhevsk, UdIIYaL UrO RAN, December 2002. Photo G. Glukhova.

Photo 3. Folklore fieldwork. Expedition among the Udmurt of the Kirov oblast under the leadership of my supervisor Tatiana Vladykina. July, 1995. Photo G. Glukhova. 


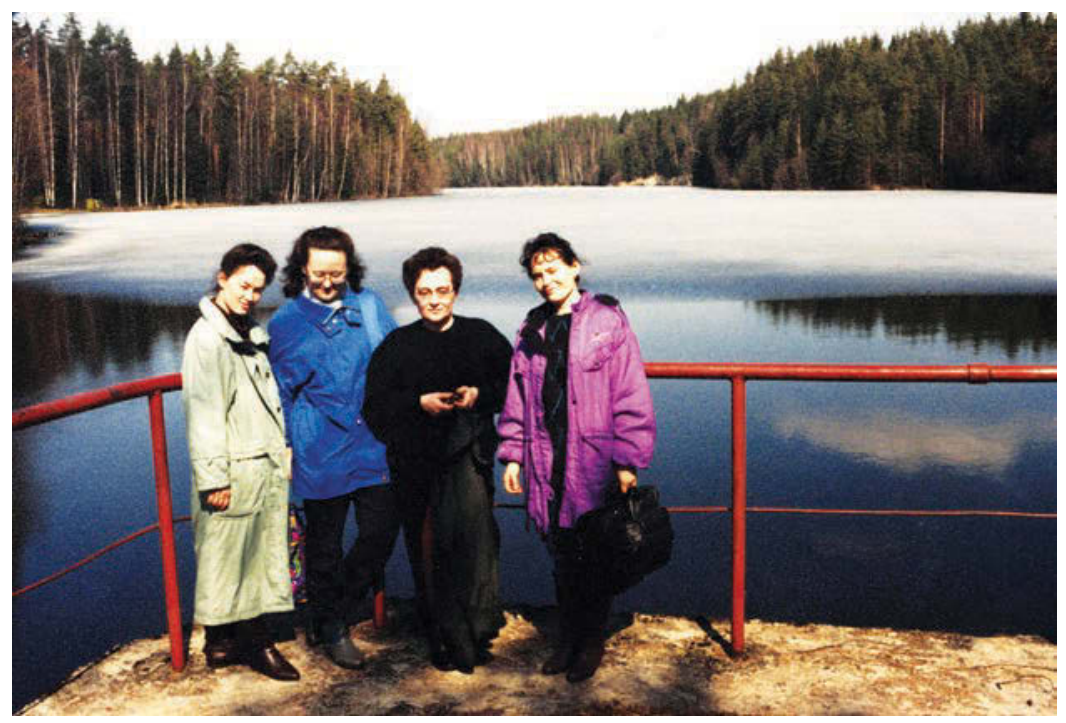

Photo 4. During our fellowship at the Estonian Literary Museum, Tartu (Estonia). April 1995. Photo G. Glukhova.

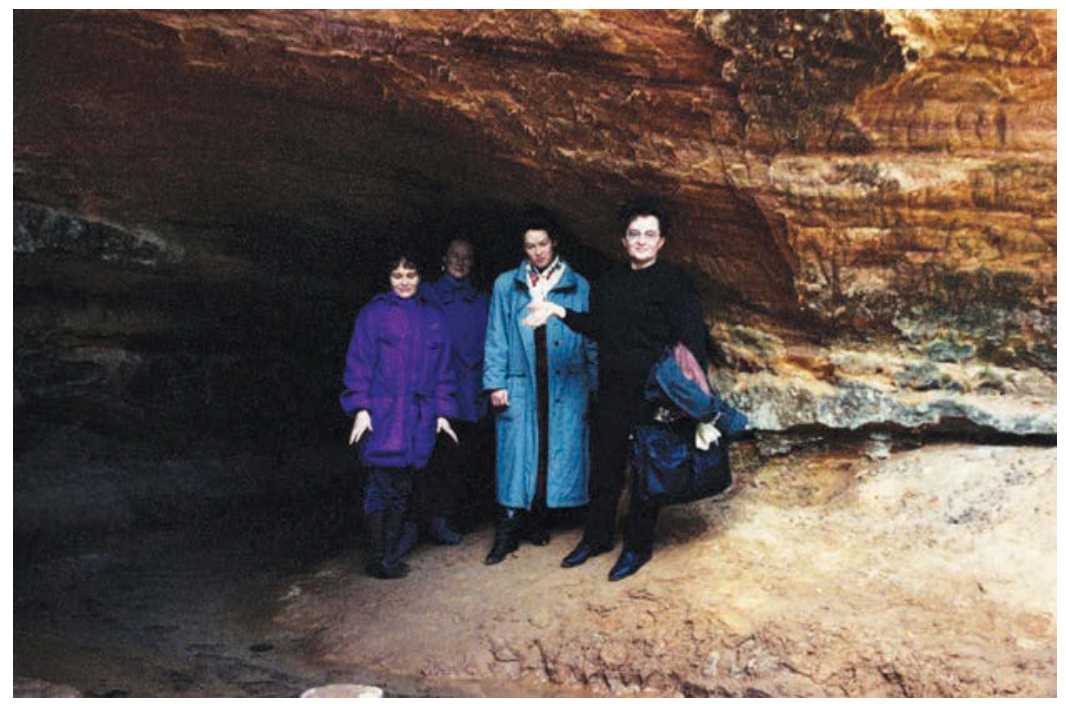

Photo 5. During our fellowship at the Estonian Literary Museum, Tartu (Estonia). April 1995. Photo G. Glukhova. 


\section{Galina Glukhova}

My first visit to Tartu (Estonia) was thanks to my supervisor. It was in 1995. Then for the first time, we discovered the scientific activity of the Estonian Literary Museum and had a glimpse into the world of research. We were stunned by the Museum's folklore archive. I think that the genuine enthusiasm, the indelible impression of what we saw there, also played an important role in what was to become my scientific path (photo 3).

Tatiana Vladykina is a highly moral personality, and she instructed her doctoral students in this spirit. She combined the talent of a great scholar and the experience of a gifted teacher and educator.

Now, we have already been acquainted with Tatiana Vladykina for more than a quarter of a century. Today she is for me more than merely a colleague, a mentor and a friend. She remains for me the Teacher, the one I want to resemble, to be as smart, as sympathetic, demanding, wise and decent.

Often I say to myself: "all I have as a teacher, and as a researcher, I have received from my University teachers, and most of all from my Teacher and Mentor Tatiana Vladykina”.

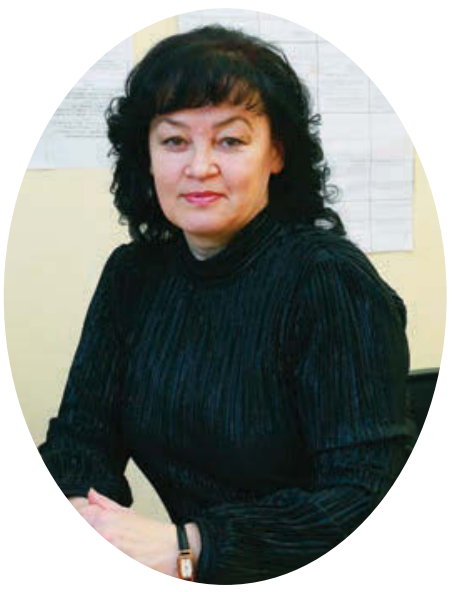

Galina Glukhova ( $\mathrm{PhD}$ ) is an associate professor and director of the Institute of Udmurt Philology, Finno-Ugric Studies and Journalism of Udmurt State University and teaches Udmurt literature and folklore. Her main field of interest is related to research on Udmurt and FinnoUgric folklore, Udmurt traditional culture, and the interaction of Udmurt folklore and literature. e-mail: galant@udm.ru 


\section{She Taught Me to See the World (Dedicated to Tatiana Grigoryevna Vladykina)}

\section{Tatiana Korobova (Okuneva)}

Izhevsk University

It was an ordinary day of study at the University when I first met Tatiana Grigoryevna. She was wearing black clothes and nice glasses. She looked very strict and serious. I do not exactly remember the lecture but I am still impressed by her work with an audience. She was completely absorbed in the theme, her eyes were shining and hands intensely gesturing. Students who were usually talkative and restless were sitting quietly and getting involved in the sacral world of folklore. It seemed that the professor could reach the innermost corners of our souls and reveal genetic layers of traditional consciousness. Culture, rituals, ceremonies, words began to form a certain order and make sense for us.

I could not imagine then that I would be one of those ten lucky people who got their post-graduate degrees in folkloristics under the supervision of Tatiana Grigoryevna. My post-graduate studies began in 2008, since when my way of thinking has changed significantly. Tatiana Grigoryevna taught me to analyse folk materials and read rituals as texts. Moreover, I realised that everything in 
folklore should be found between the lines, and that actions have double meanings. It was difficult and unclear initially, but my tutor was always near and ready to help. She gave me a lot of information and suggested different books and other reading material. We frequently participated in conferences and seminars.

After thirteen years of collaborative work I am proud to say that she has become not only my scientific mentor, but also my friend, my family. She combines such features of character as strictness, fairness, obligation, a sense of humour, responsiveness, kindness and grace in the same way that she combines the roles of elegant woman, perfect homemaker and successful professor.

It is always nice and warm in the house of Tatiana Grigoryevna and Vladimir Yemelyanovich. A special atmosphere of calm, peace and creation prevails there. Books, pictures, souvenirs from all over the world are interspersed with items of traditional Udmurt culture making the home of the professors a place of strength and enrichment. They feed their guests with a delicious dinner and warmly welcome, support, give advice and direction to every person who enters their house.

In my opinion, kindness is the most notable character trait of Tatiana Grigoryevna. She is always ready to help anyone. She finds the answers to all the questions. If she does not find one then she invents something of her own and solves the problem. Each of her graduate students can tell a story about how she helped them in a particular situation.

Tatiana Grigoryevna's love and empathy for animals deserve a mention as a separate topic. This particular trait defines her entire life. Animals always live in her house. Her favourites are cats and dogs. They are treated as family members. Moreover, she feels pity for every homeless animal. One day two years ago, she found a box with six abandoned puppies at a bus stop and could not pass by. Finding a home for puppies required a considerable effort from Tatiana Grigoryevna, but she managed it. Now all the dogs live happily with their new families. 
Undoubtedly, it is impossible to reflect the greatness of Tatiana Grigoryevna's personality in one sketch. You can talk to her and about her endlessly. As her student, I want to express my deep gratitude to her not only for her knowledge and guidance, but also for her inexhaustible interest in life, her endless search for new and unknown things. She taught me to see the world, to look straight and see miracles in everyday life.

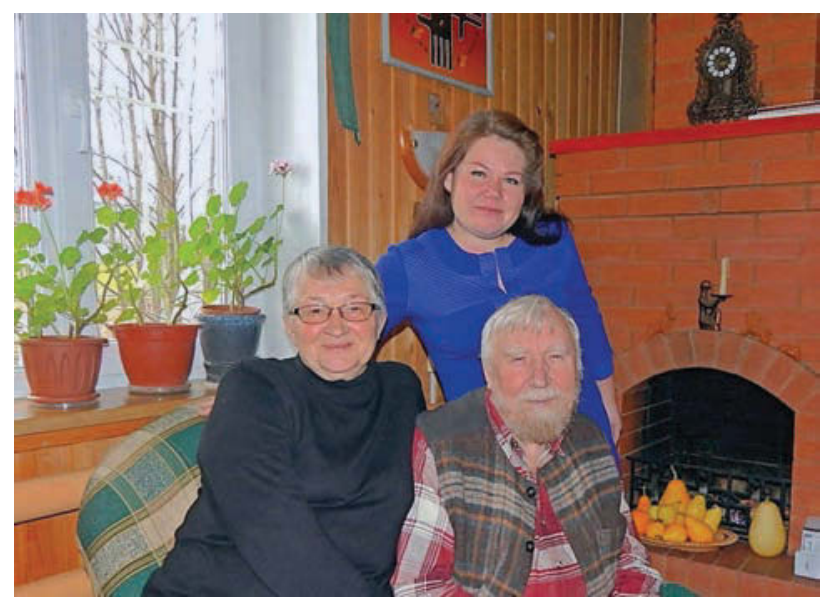

Visiting Vladimir Yemelyanovich and Tatiana Grigoryevna's home. October, 2015. Photo made by E. Okuneva.

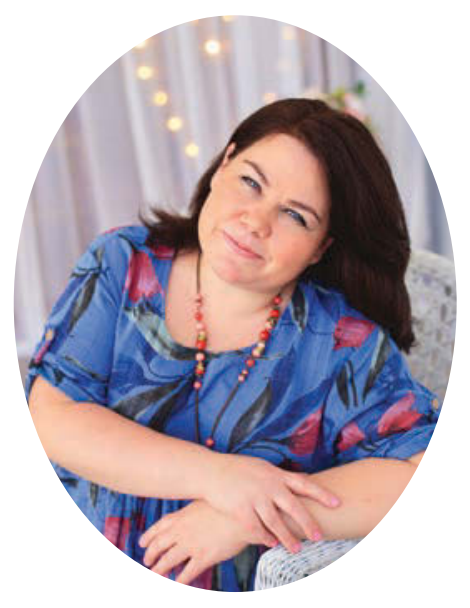

Tatiana Korobova (Okuneva) $(\mathrm{PhD})$ is a folklorist from Izhevsk University. Worked as a researcher at the Department of Philological Studies, at the Udmurt Institute for Research in History, Language and Literature (Ural Branch of the Russian Academy of Sciences). She is interested in Udmurt traditional culture and more precisely in the Udmurt traditional wedding. She currently teaches English at school. e-mail: oktan85@mail.ru 


\title{
About Tatiana Vladykina
}

\author{
Anna Mutina \\ State Museum of the History of Religion, St Petersburg
}

How can we measure the success of a scholar or a folklorist? By the quantity of publications in the index databases? By the shelves full of books and fieldwork notebooks? By the amount of terabytes of photographs and recordings of conversations and songs? By the number of under- and postgraduate students who defended their dissertations under her supervision? By the recognition of their colleagues? By official awards, titles and certificates of merit?

Undoubtedly, all this is part of Tatiana Vladykina's biography, and it represents its external aspect, the visible and bright tapestry of her life. But when I think about Tatiana Vladykina, about the scholar, the teacher, and the person close to me, I want to talk about something else. She taught us, her doctoral students, attentively and thoughtfully, what is the painstaking work of the scholar, how to edit a text, how to work on records. And I believe that these meetings, which did not at all take place during tedious seminars and lectures, but were vibrant and heated conversations, shaped our relationship with our chosen profession. The life of young scholars at the turn of the $21^{\text {st }}$ century could not be described as unclouded. We often faced a dilemma: should we write another part of our dissertation, or look for our daily bread? But Tatiana 
Vladykina was able to help us not only with our articles but also in our search for work, for additional income. And as with research, her help always was kindly, unobtrusive, and sensitive. And how exciting was our fieldwork, our common trips to conferences. When looking at the photos, we remember everything: the compulsory morning porridge ritual, the night escapes to the disco (and the subsequent gossip), and of course the journeys made together, side by side. What is the unique quality of Tatiana Vladykina's personality? I would think, it is her rare gift to be able to see and to understand the Other. It is felt by her village partners, whom she asked about traditions and rituals; by her colleagues when they discuss scientific texts, by the heads and leaders of folklore groups coming to her for consultations, by folk masters and artists. And, last but not least, by her students. The range of the topics treated in the dissertations defended under Tatiana Vladykina's supervision is formidable: Udmurt and Russian singing tradition, ritual folklore, historical legends, the children's world, and much, much, more. And always she endeavoured to bring out the individual features of the students, to show their merit and never to dictate what was right, or what to write.

Attempting to get to the point, she delves deep into the structure of Udmurt rituals and folklore genres, uncovers the secret meaning in the words of a song, but also gives the same level of attention to her partner, endeavouring to listen, to help, to engage. And each of her investigations is about how we, birds on the tree of life, sing our own song, which harmoniously fits in with the general choir, as we are all caught in one stream of traditional culture, walking on different paths yet in the same direction. And I am happy that on this road Tatiana Vladykina has been, for long years, my companion. 


\section{Anna Mutina}

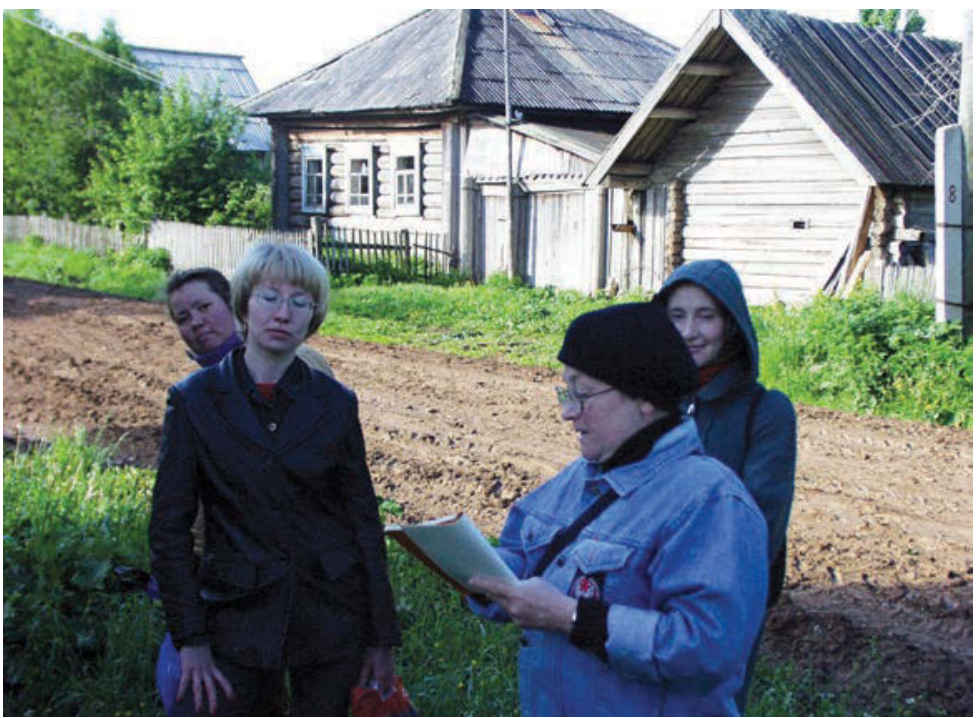

Photo 1. Fieldwork in the Kez district, Udmurtia. June 2004, Kuliga village. Tatiana Vladykina with her doctoral students: Tatiana Vladykina, Irina Pchelovodova, Elizaveta Lozhkina. Photograph: Anna Mutina

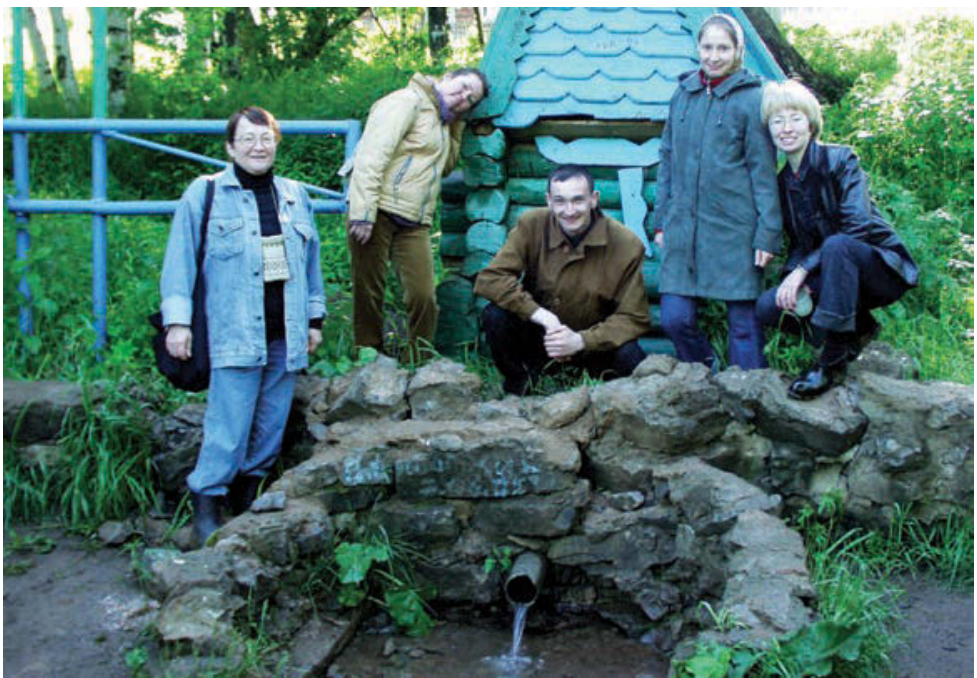

Photo 2. Fieldwork in the Kez district, Udmurtia. June 2004, Kuliga village. Tatiana Vladykina with her doctoral students at the source of the Kama (Tatiana Vladykina, Irina Pchelovodova, Elizaveta Lozhkina.). Photograph: Anna Mutina. 


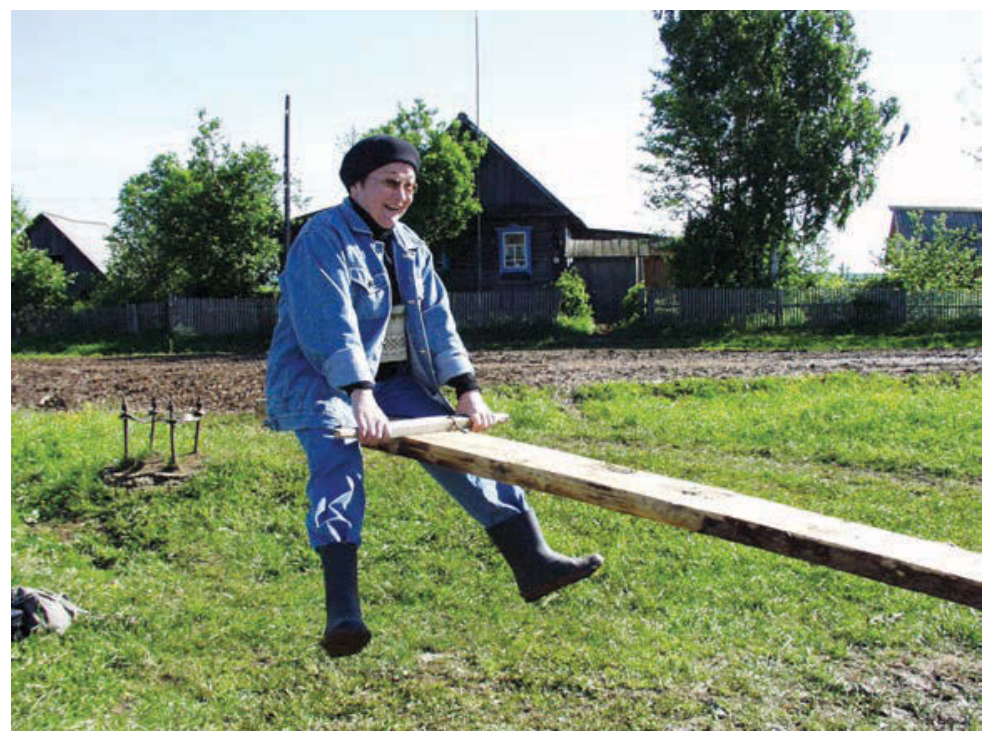

Photo 3. Fieldwork in the Kez district, Udmurtia. June 2004, Kuliga village. On the swing. Photograph: Anna Mutina.

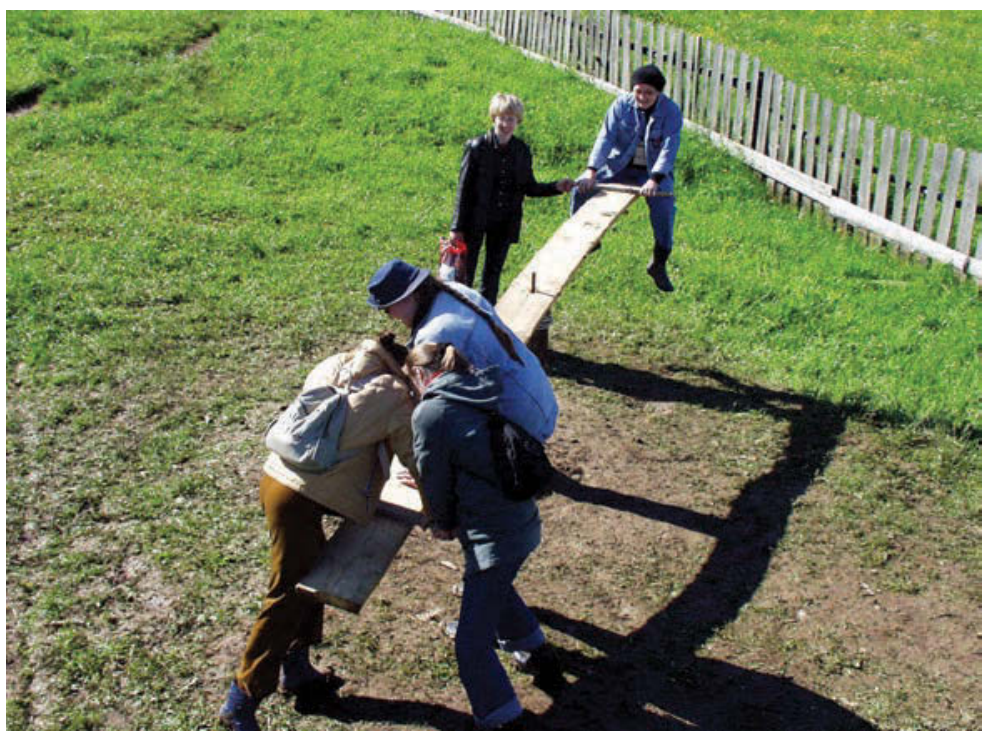

Photo 4. Fieldwork in the Kez district, Udmurtia. June 2004, Kuliga village. On the swing. Photograph: A. Nikulin. 


\section{Anna Mutina}

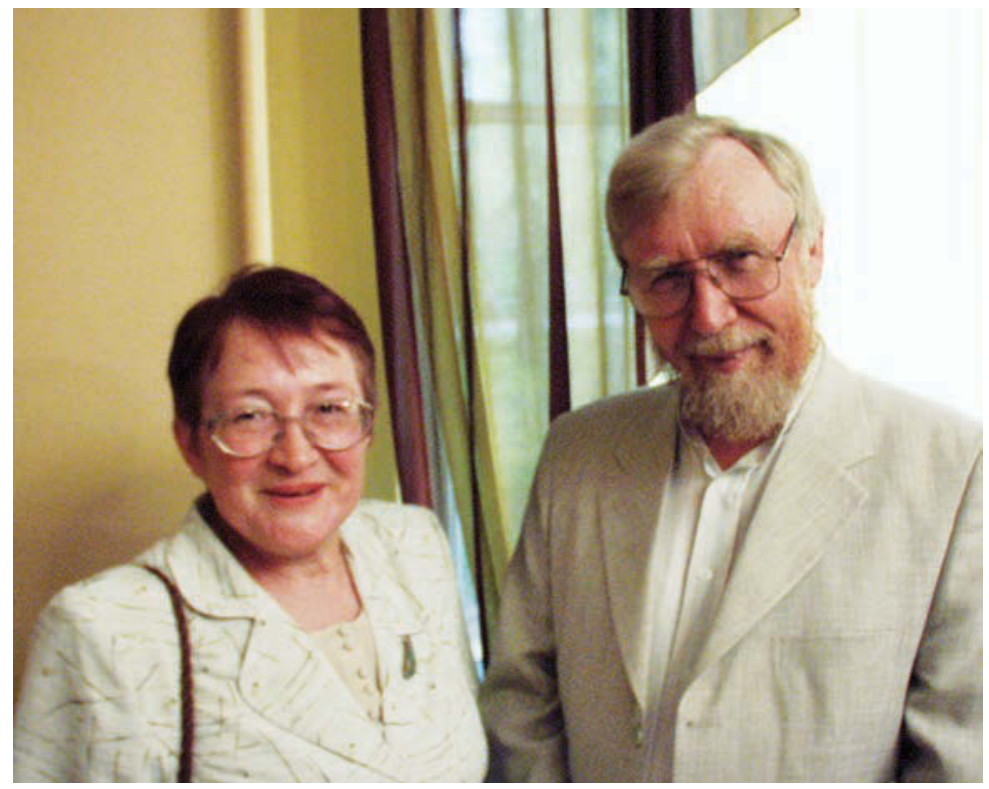

Photo 5. Beginning of the 2000. Photograph: Anna Mutina.

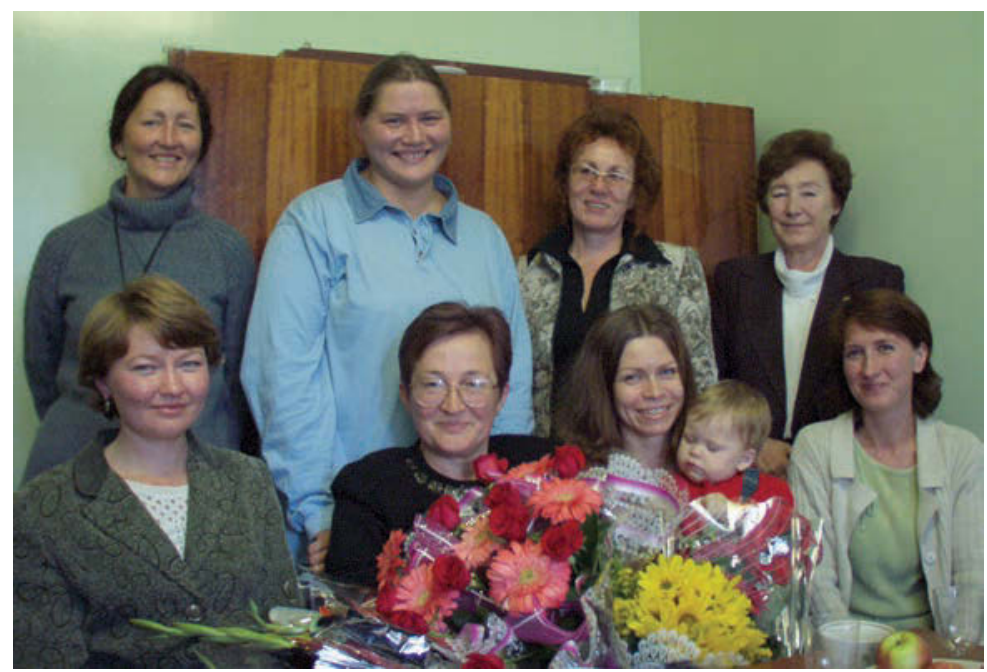

Photo 6. Beginning of the 2000. With colleagues. Below from left to right: Tatiana Zykina, Tatiana Vladykina, Yuliya Prikazchikova with her daughter, Alevtina Kamitova. Standing, from let to right: Irina Nuriyeva, Anna Mutina, Galina Nikitina, Margarita Ivanova. Photograph: Kuz'ma Kulikov. 
About Tatiana Vladykina

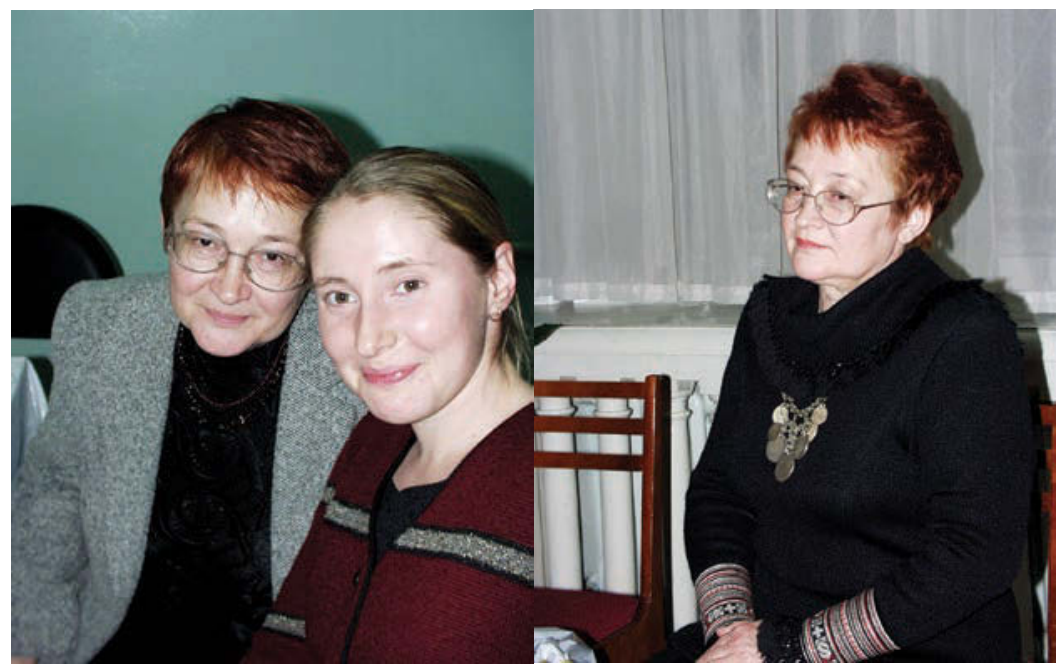

$7 \mathrm{a}$

$7 \mathrm{~b}$
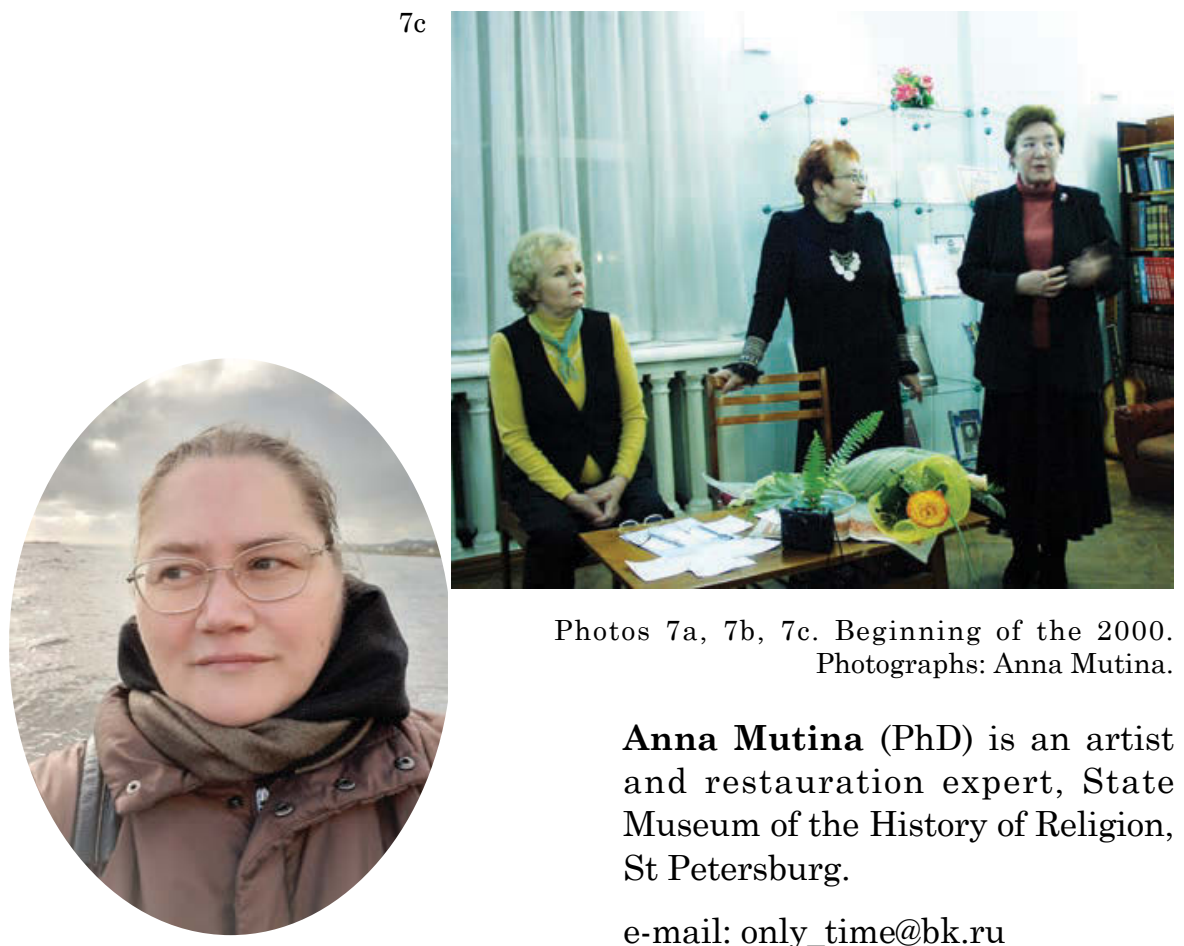

Photos 7a, 7b, 7c. Beginning of the 2000 . Photographs: Anna Mutina.

Anna Mutina $(\mathrm{PhD})$ is an artist and restauration expert, State Museum of the History of Religion, St Petersburg.

e-mail: only_time@bk.ru 


\section{To Tatiana}

\section{Mare Kõiva}

Centre of Excellence in Estonian Studies

Department of Folkloristics, Estonian Literary Museum, Estonia

I spent some time thinking about the warm and heartfelt relations that I have had with Tatiana Vladykina over the decades, regardless of the distance between Estonia and Udmurtia, and our rarely meeting face to face. In short, she is my kindred spirit, a person with similar thoughts walking the same spiritual road.

There is barely an age difference between us, but I have always considered her a wise and more experienced colleague. Perhaps one of the reasons for this was the first time we met. As a thirdyear student I took part in and helped organise Ingrid Rüütel's Finno-Ugric conference. The conference was held in Tallinn, and one of my tasks was to guide Finno-Ugric guests through the Old Town to meals. All my life, but especially during high school, I had travelled to Tallinn to visit the theatre. Hence, I knew where the theatres, the art museum and some cafes were, and I had explored the Old Town. Suddenly, I was in a situation where I was supposed to walk through the Old Town, leading a number of people who knew Tallinn even better than I did. I was enraptured by all of the presentations and evening recitals, bringing the archaic and unique sounds of the Uralic people to the concert hall in the form of 
live music. T. Perevozchikova delivered a talk on Udmurt dialogue incantations at this conference. I felt incredibly nervous, telling her that we have similar incantations of our own. My Russian was broken and ugly and I had no idea how to pronounce many words, never mind speak coherently. As every other person my age, I had learnt Russian from second grade, one or two hours a week for ten years, and had acquired my passive vocabulary from the best of Russian literature. This allowed me to read Russian fiction and Doctor Zhivago, but the urgency of speaking the language became apparent to me thanks to this conference.

Of course, I looked at Tatiana as an experienced scholar with great respect then, and do so today. I was always really glad when, over the years, she sent me books about Udmurtia. The Udmurt published much more than Estonian scholars did, this was and still is remarkable to me.

In 1987, there was a Finno-Ugric conference in Izhevsk (which at the time was called Ustinov for about six months, in memory of a late statesman). Following old conventions, many sections ranging from archaeology to several fields of linguistics, ethnology (ethnography), folkloristics, and literary science were represented, and this brought together participants from many institutes. I remember seeing the collections from the field work archive of the Udmurt Institute, and wondering how my colleagues managed to transliterate and write sheet music from tapes recorded during fieldwork, and still put out publications and write articles. Friendships lasting to this day were forged in the burning heat of Izhevsk.

Our relations developed during meetups at these conferences and joint projects, amidst folklore and as a part of its narrative. Tatiana and an Udmurt delegation came to Tartu in 1990 for a conference dedicated to Oskar Loorits. They represented their own school of thought and spirit. The Babel of scholars in Tartu, meetings and discussions in sections and during breaks, and the following work on publications deepened the friendly relations. In the following years, Tatiana sent some of her students for a visit 
funded by the Kindred Peoples' Programme, once as many as three young scholars, among them Galina Glukhova, whom I consider to be my good friend. Ethnomusicologists Marina Hodyreva and Irina Nuriyeva from the Kazan State Conservatory stayed in Tartu for a longer period thanks to scholarships.

Tatiana and I met again on a long winter's night in Finnish Karelia at a working meeting and conference on compiling the Mythologia Uralica. As wise as I am today, I can say that the arguments over mythology then affected every participant is evident from their published writings. The starting points were different from the beginning, and many scholars of Uralic languages admitted that neglecting religious life in research for too long and the shortcomings of newer collecting work would become our first stumbling block. The second one formed in discussions before our eyes. The Udmurt had their own school of thought and conventions of connecting newer research to earlier findings, as Tatiana's presentation also stated. Many experienced scholars present had started research on mythology in their own region. But still, I have rarely participated in project meetings where from early on practical plans have been overshadowed by the instantaneous formation of competing schools of thought and teams. Thirdly, the common thoughts we had formed in Karelia interfered with the participants' routine obligations and necessity to earn their living. In addition to the cooperation agreement, we should have signed a petition to different institutions to liberate the participants from other projects for a few years, while still securing their income. We went back to our everyday lives with big ideas.

For decades I have met with project participants from those times, discussed essential issues - mythology carries messages about the mindsets of the past, as well as the context of current cultural phenomena - and admired the fire burning slowly, but surely. We have kept track of what each of us has managed to achieve. Volumes in Russian, and in part in English, have been completed. Tatiana led and still heads the project to produce the 
Udmurt delegation's volume on local mythology. It remains to be hoped that together with her talented Udmurt co-workers she will soon present us with a publication on Udmurt mythology. Compared to the 1990s, much more knowledge has been acquired and many problems have found solutions.

On a more personal note, I remember how Tatiana and the Karelian scholars bolted to a pile of snow straight from the sauna, rolled around there and recommended this as a cure for rheumatism. I was cautious. I did not care much for the hot sauna, and the rest seemed like a Medieval test of courage. Bright-eyed, intelligent and happy, involved in research administration and therefore horrifyingly busy - this is how I have seen Tatiana work for decades, no matter in which European or Finno-Ugric country or at which academic forum we have run into each other.

I am sincerely grateful to her for organising the first international summer school for young Finno-Ugric scholars, this was the first of its kind in the whole of Russia, and attributed the specialisation much prestige. I was honoured to join the event as a lecturer, listen to talks by other lecturers and degree students, participate in fieldwork on the culture of the Besserman kindly led by Jelena Popova and others, and visit the holy mountain of Idnakar. Two of us Estonians went to the new missionary church and met the congregation and the pastor, as Udmurtia was changing in many ways. But this is another story.

This one, on the other hand, could not be complete without reminiscing about the endless songs at the event's final banquet. This is one of the soulful parts of Finno-Ugric events - the shared and unique songs we sing together. A small number of them were recorded, and I still listen to them when I'm in a bad mood.

Andres Kuperjanov, Galina Glukhova, I and a few of our colleagues were guests at the home of Tatiana and Vladimir Vladykin, and were amazed by the office they had built in an old granary, the sacred kuala, and the ethnographic atmosphere of the traditional auxiliary buildings in the garden of an otherwise modern house. 


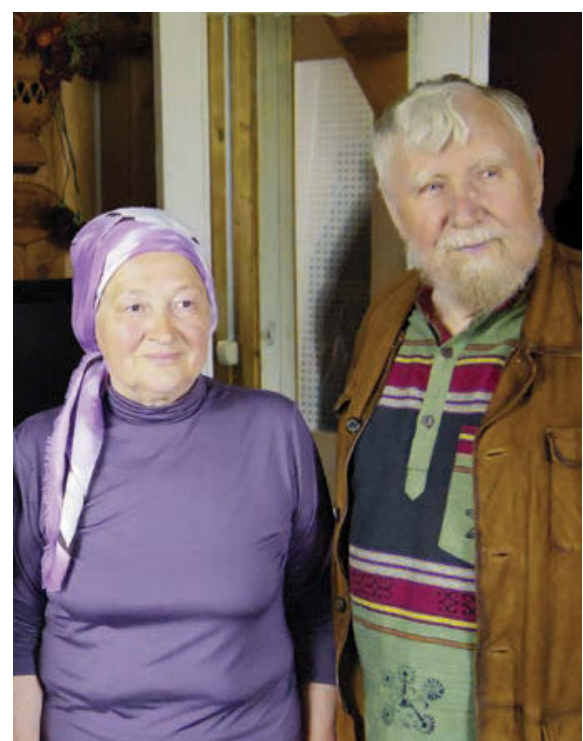

Summer time at home. Photo A. Kuperjanov 2017.

This was my first time meeting the great Vladykin, of whom I had heard a lot over the years, and whose works I had read. In my student days, I had eagerly listened to stories about a talented scholar, a red-bearded genius, as Yuri Scheykin, the then leading scholar of Siberian studies described him. Vladykin, the most easygoing of people, had turned his life around, given up his career in the capital, and gone to work at the end of the world, somewhere in the periphery. This was so brave! Even braver is the contribution that these two have left behind in Udmurtia and elsewhere in the world with their scholarly work and their students. I am so glad to have been able to share that road.

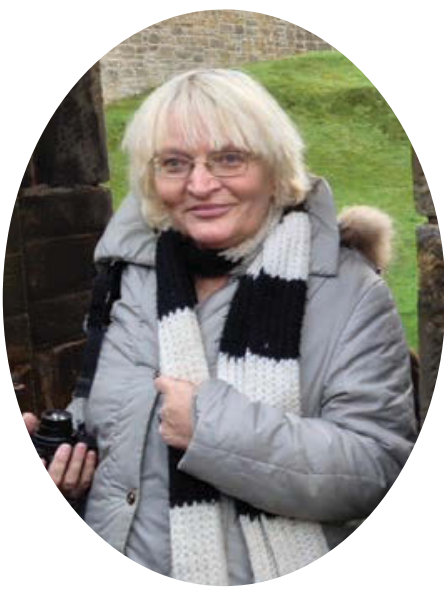

Mare Kõiva $(\mathrm{PhD})$ is Head of the Centre of Excellence in Estonian Studies, and Leading Research Fellow, Head of the Department of Folkloristics at the Estonian Literary Museum, Estonia. Her main research areas are charms and charmers, belief narratives, mythology, and human/non-human relationships.

e-mail: mare.koiva@folklore.ee 


\title{
A Mind That Understands Words...
}

\author{
Eva Toulouze
}

INALCO, Paris, France

University of Tartu, Tartu, Estonia

I once had the honour of becoming acquainted not with Tatiana Vladykina, but with Tatiana Perevozchikova ${ }^{1}$. It was so long ago... It was in 1985, in Syktyvkar, the capital of the Komi Republic. It was an exciting Finno-Ugric scholarly congress: for the first time, Western Finno-Ugrists were allowed to visit a Finno-Ugric region in Russia, and to meet many more Russian colleagues than the Congresses abroad could host. It was also a treat to many Eastern European scholars, who accessed for the first time Russia's FinnoUgric regions, which they had been working on for decades. It was the beginning of the opening up, the first swallow: some five years later, it became possible to access many other regions. The Tatiana Perevozchikova whom I met had just published one, or perhaps even more books, in the Golden krez'2 ${ }^{2}$ series, collections of Udmurt folklore with Russian translations, my first contact with Udmurt folk culture. I am sure that there remained much I could not access, as I did not know anything at the time about folk culture in general and Udmurt folk culture in particular. But I remember the day Tatiana offered me that book. 
Although our acquaintance goes far back in time, the same cannot be said of our friendship. We did not meet for decades. I started visiting Udmurtia in 1994. I decided, in the first decades of my discovery, not to seek out the Udmurt scholars and I am not sure I regret my choice. First of all, I was not interesting for them as I had no academic (or other) position. I was only an interested amateur. But I think I very much wanted to avoid the kind of experience my good friends and teachers had: Péter Domokos ${ }^{3}$ and Jean Luc Moreau ${ }^{4}$ were famous when they were able to visit Udmurtia for the first time, and they had whole rich programmes set up for them. I wanted time and leisure. I did not want anything official. Just to get acquainted with people, with ordinary people and get to know them by coming back and coming back again. I also suppose that I was not ready... Thus, my first contact with Udmurt colleagues was, as far as I remember, in 2001, the last year before the defence of my dissertation. Then, I already had a status. I was a teacher at Tartu University (although not in Finno-Ugristics) and I prepared a dissertation about Udmurt identity and literature. But the habits remained: I did not inform anyone of my visits, I was not expected with a red carpet, I could live at my friends' places and travel alone from village to village to meet different acquaintances I made throughout the years.

My closer relations with the Udmurt scholarly world are the fruit of the last years. Some of the Udmurt scholars I met through friends, but then the habit came of visiting them at the research Institute, which is now certainly one of the structuring places of my Udmurt world. But even then, our paths, Tatiana's and mine, did no cross. However, I heard about her as a brilliant and strict teacher, of whom, I am sorry to say, many were afraid. I understand now that those who were afraid of her direct speech were probably those who were not yet very close to her, and had not had the opportunity of benefiting from her harshness and to feel the benevolence behind it. And after all, hierarchy is very deeply 
rooted in Russia, and younger scholars could not avoid being in awe of such a coryphée. It requires maturity to start feeling comfortable and easy. All the more, because Tatiana Vladykina is one to say things as they are, without circumlocutions. Especially in the Udmurt world, where one is accustomed to extreme caution, such a direct approach can be frightening.

But our paths did cross at last, I suppose, when I was ready. It was at Russia folklorists' congress in Tula, in 2018. I was there with my good colleague Nikolai Anisimov, who is indirectly part of Tatiana Vladykina's school. She did not supervise his work, because of a technicality. Nikolai defended his doctoral dissertation at the University of Tartu, where he had a supervisor, and when he looked for additional support in Udmurtia, he turned to a teacher he knew pretty well, who had been his supervisor for his graduation. I suppose it would have been awkward to address such an authority. So, Galina Glukhova was his direct mentor, although she is undoubtedly a direct disciple of Vladykina. Therefore, if not a scientific mother, she is in the distant - and close - place of a grandmother.

We decided to attend her presentation, for she is always interesting, and indeed she was! She talked about a poem I was well acquainted with, and this gave me the opportunity of asking her a question. So started an interaction, which continues, if anything more and more deeply. We decided to find a place to continue our conversation, the three of us. I remember fragments: I commented about a presentation, in which a young scholar talked about Béla Bartók's folk songs and sang one of them, but with an operatic voice, which for me did not fit at all with the simplicity and purity of the song, and she agreed with me. We talked about the collection of articles we had thought of editing, about Udmurt contemporary culture and I asked her to write something about the power of words for the Udmurt. What do the Udmurt intend to say when they say something? I had understood that between the 'formal' 
meaning of the words and the reality in communication, there is a whole metaphorical world and I thought she was the best person to unravel this mystery. We talked about the importance of collecting dreams and of working on these texts.

The conversation was long. I discovered how fascinating exchanging ideas was with her, and I suppose she was intrigued and interested to face an external reflection on her culture. We decided that, as we were leaving Tula for Moscow the next day, we could travel together, and so we did. True enough, we had tickets in first class, and there were no more first class tickets left. Never mind, we were happy to give our places to Tatiana's neighbours and the three of us enjoyed our continued conversation. In Moscow, it was not over! We had some hours before our plane, and we spent them in a café, having lunch with Tatiana.

The foundations were set. Next time I was in Izhevsk, I was invited at the Vladykins' place in Yakshur. Others have mentioned this small Udmurt heart, with its inner sanctum, the kuala, and Tatiana's memorable porridge cooked on its open fire. The Vladykins are Christians, and they introduced in the otherwise very traditional kuala a high window in the form of a cross that allows light in. Otherwise, it respects the traditional rules, as does the rest of the household. Unfortunately, I had not the luck to meet her goat. She had told us many stories about her goat in Tula, and I remember how shocked a good friend was, who had admired all the beautiful flowers offered to Vladimir Emel'yanovich for his $80^{\text {th }}$ birthday, when she learned that they had been the delight of the goat's dinner. In this visit, I talked more to her husband, who was now more rarely to be met, and we talked both about the future of the study of traditional culture in Udmurtia and about the Nenets writer Yuri Vella, with whom I had long made fieldwork and whom Vladimir Vladykin also admired. Meanwhile, she had proposed that I go over to "thee" (informal 'you'), which is a huge step in Russia. But Vladykina has studied, as a post-graduate, in Tartu, and she 
knows that I am more comfortable with the absence of formality; this is the way we communicate to this day.

She has a deep and subtle feeling for linguistic accuracy and nuances. She accepted our invitation to edit our films about Udmurt ceremonies, which had been criticised for the Russian subtitles of the prayers, which did not transmit the poetic beauty of the original. She finally changed little, for subtitles do not allow for much flexibility, but by changing a word, or even just the place of a word, she was able to change the whole atmosphere transmitted, for which we are very grateful. For not only is she an Udmurt culture bearer, she is also very skilled and sensitive to Russian, a language she beautifully masters the scientific and literary register of.

For me, Tatiana has become the main person I consult about Udmurt words and meanings. Knowing several languages means also knowing that, however useful a bilingual dictionary is, it unavoidably simplifies and does not transmit the worldview richness expressed in words. Who better than she? If I want to understand the real meaning of what the Udmurt ask God for in their prayers, I cannot be content that shud, in Udmurt, is the word for happiness. What does happiness, for an Udmurt, mean? Moreover, I now understand Udmurt enough to identify, in the Udmurt texts of prayers, that the sacrificial priest asks God for his health, his happiness. As if God mastered all that is health and all that is happiness, and we ask him to share it. This detail is never translated, but I feel that it contains a whole worldview, and who better than Tatiana to open it to me? I wanted once to talk about a person I had met, to say that she was simple, simple as a major compliment like easy, unadorned, modest, pleasant. But the Udmurt word that exists for "simple" is also an equivalent of "ordinary", and this is very far from what I wanted to express. Tatiana opened for me the world of possibilities that the use of two adjectives allows, the one influencing the way the other is received. 
I like her straightforwardness, I feel comfortable with it. I like that she is always happy to help and to support. One of our younger colleagues, a very skilled and sensitive doctoral student, is not comfortable with writing. Tatiana is always happy to write with him and to help him to overcome this obstacle. I am so very grateful to her that we have become such good friends and colleagues in the last years and that she helps me to delve deeply into the Udmurt world and the Udmurt intellectual layers in order to be able to better understand a culture I am passionately interested in.

\section{Notes}

1 Tatiana Vladykina's maiden name.

${ }^{2}$ Udm. Zarni krez'.

3 Péter Domokos (1936-2014), Hungarian Finno-Ugrist and specialist in Udmurt literature and of Finno-Ugric literatures in general. In 1975 he published a substantial 550-page study of Udmurt literature, the first outside Udmurtia. Even then, until 1990 he could not discover Udmurtia directly.

4 Jean Luc Moreau (born 1937), French Finno-Ugrist, former professor of Finno-Ugric languages at INALCO, Paris. He learned Udmurt and in 1966 wrote an article in French about Udmurt literature, wherefore his name was well-known in Udmurtia.

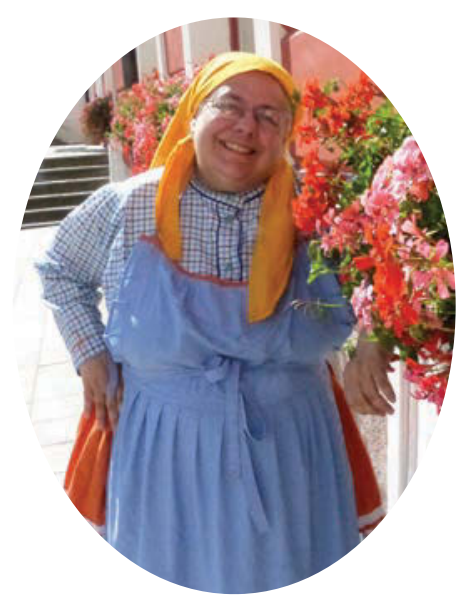

Eva Toulouze ( $\mathrm{PhD}$ hab) is a professor of Finno-Ugric languages at the Institute of Eastern Languages and Cultures (INALCO, Paris), and a researcher at the Department of Ethnology, University of Tartu, Estonia. Her main fields of interest are the cultures of Russia's FinnoUgric peoples, the emergence of a written culture in Finno-Ugric areas, Forest Nenets culture and Udmurt religious practice. e-mail: evatoulouze@gmail.com 


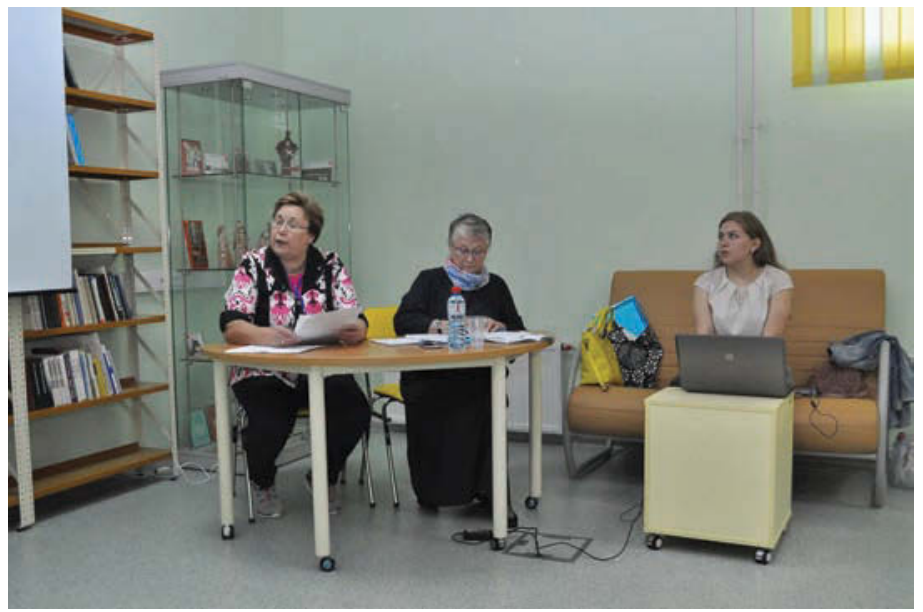

Photo 1. Tatiana Vladykina chairing a session. Congress of Russia's anthropologists in Izhevsk. 03.07.2019. Photograph Eva Toulouze.

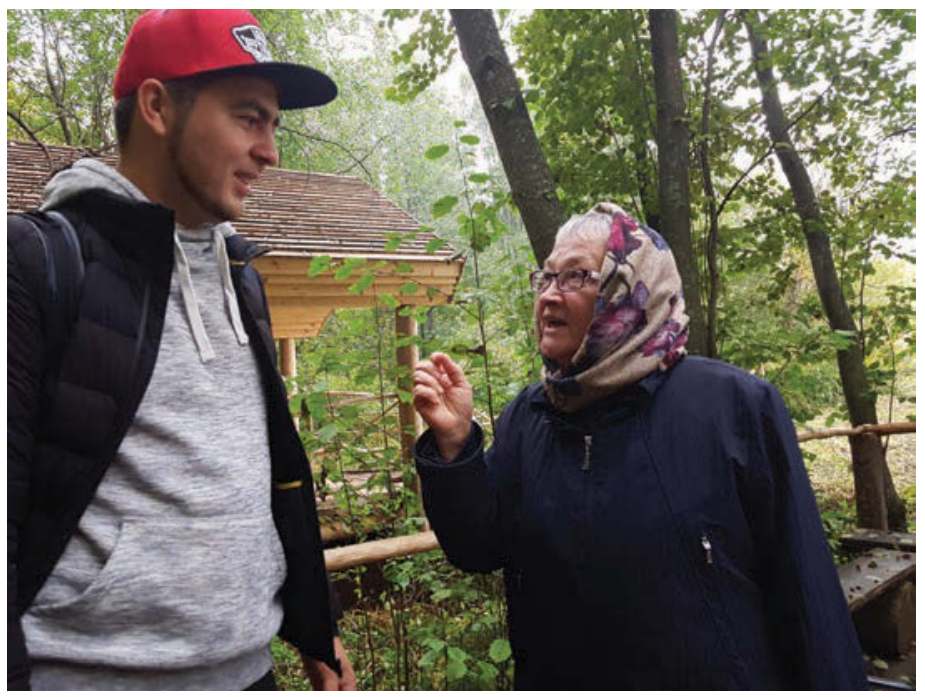

Photo 2. Tatiana Vladykina and Nikolai Anisimov, Ludorvay, Udmurtia, Field symposium, September 2018. Photograph Eva Toulouze. 


\section{Eva Toulouze}

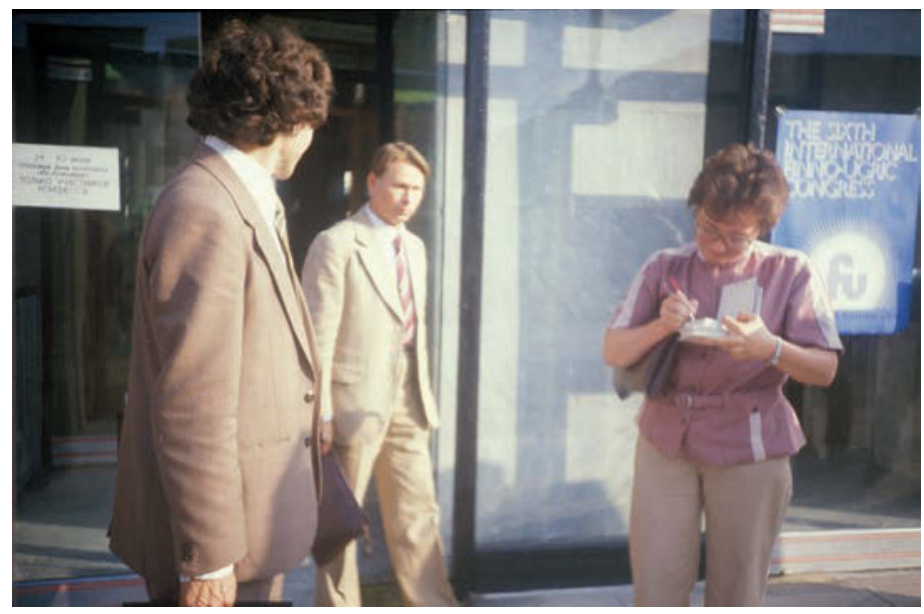

Photo 3. Tatiana Perevozchikova dedicates her book, on the picture Vasili Vanyshev and the Khanty writer Eremey Aypin. Syktyvkar, CIFU, August 1985. Photograph Eva Toulouze.

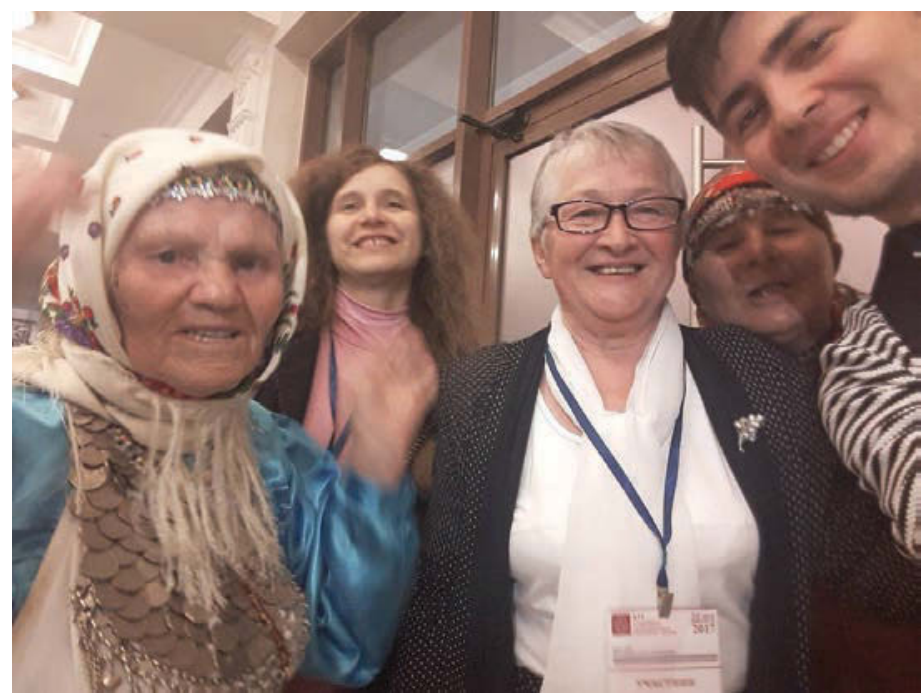

Photo 4. Tatiana Vladykina with the Udmurt folk singer Dzhakapay and Nikolai Anisimov at the Congress of Russia's anthropologists in Izhevsk. 02 07.2017. Photograph Eva Toulouze. 


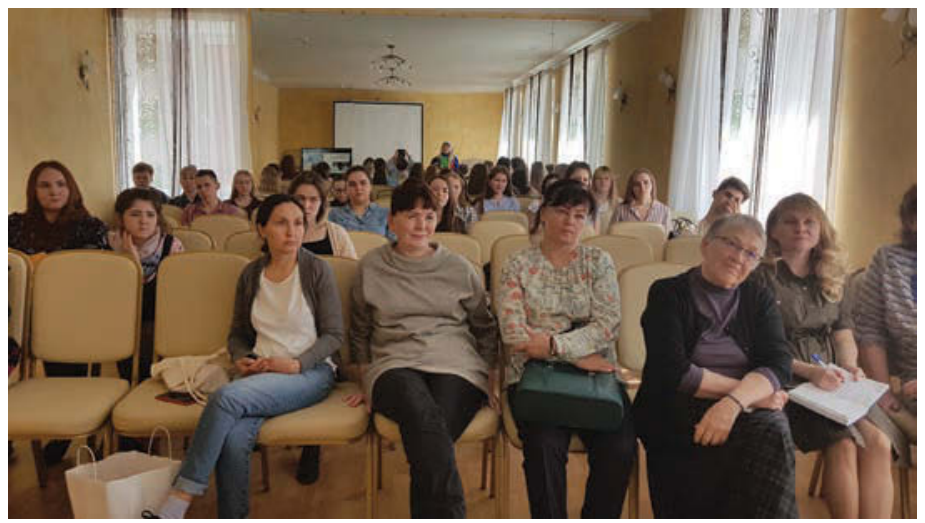

Photo 5. EvaToulouze's lecture at the Udmurt Institute: from left to right Elena Popova, the institute's librarian, Galina Glukhova, Tatiana Vladyina and Tatiana Russkikh. Photograph Eva Toulouze.

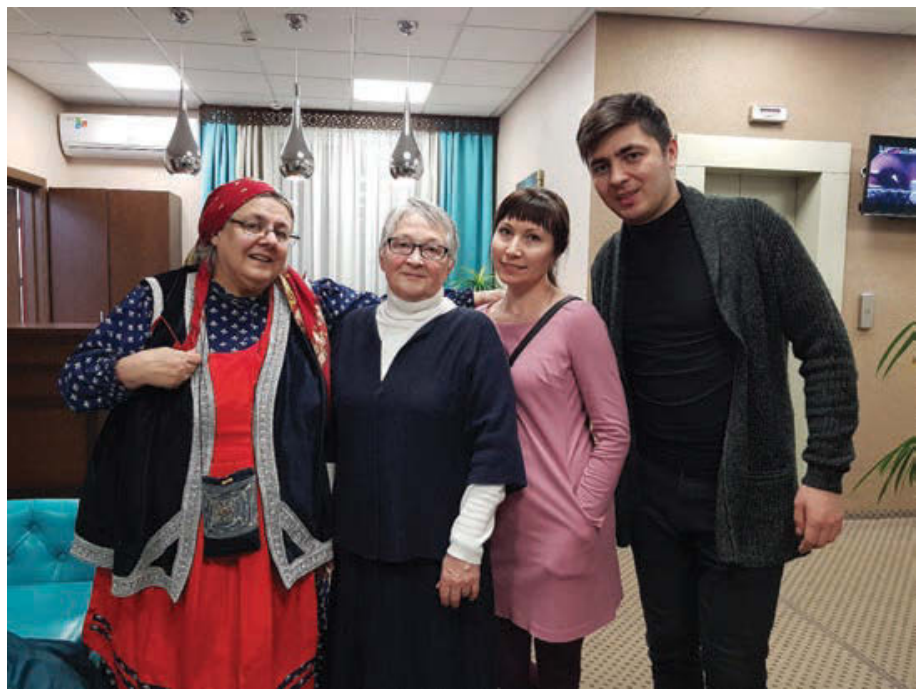

Photo 6. Tula Congress of Russia's folklorists: Tatiana Vladykina with a young Mari scholar, Eva Toulouze and Nikolai Anisimov, March 2018.

Photograph Eva Toulouze. 


\section{Eva Toulouze}

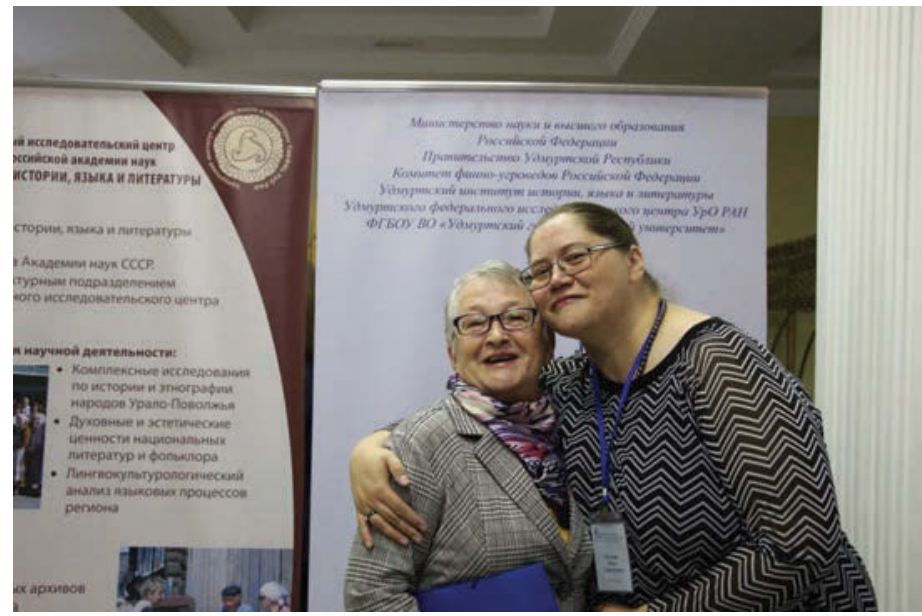

Photo 7. Tatiana Vladykina and Anna Mutina. Congress of Russia's anthropologists in Izhevsk, 29.07.2019. Photograph Eva Toulouze.

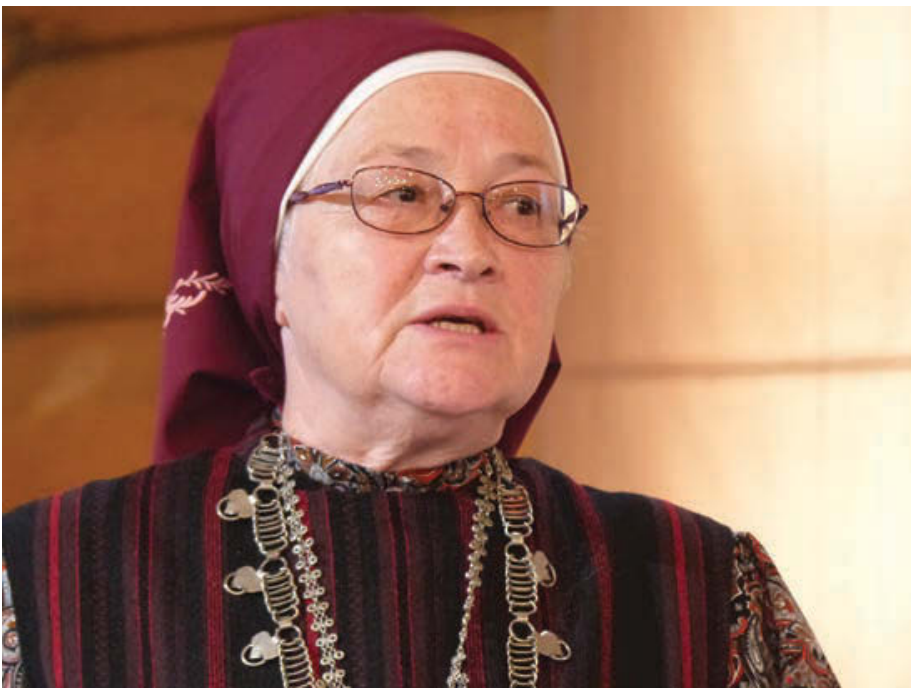

Photo 8. Tatiana Vladykina in a Field conference in Udmurtia, September 2016. Photograph Eva Toulouze. 


\section{SATOR 22 \\ Direct and Indirect Sources of the Articles}

The articles not mentioned here are entirely new writings.

\section{Rituals and Socialisation in the Udmurt Folk Calendar Tatiana Vladykina, Galina Glukhova, Tatiana Panina}

Fragments of this revised article have been published in Vladykina, Tatiana; Glukhova, Galina; Panina, Tatiana (2017). Udmurtskiy narodnyy kalendar' i sel'skiy sotsium [The Udmurt Folk Calendar and the Rural Society]. Nauchnyy dialog [Scientific Dialogue]. No 10, 149-169.

\section{Transition Periods in the Udmurt Folk Calendar and Their Spirits}

\section{Galina Glukhova}

In this article, the author has used materials from her $\mathrm{PhD}$ dissertation: Glukhova, Galina (2002). Simvolika ryazhen'ya v traditsionnoy kul'ture udmurtov: Diss. na soisk. uchenoy stepeni kand. filol. nauk (Rukopis') [The Symbolism of Mumming in the Udmurts' Traditional Culture. Manuscript]. Izhevsk.

\section{About vozho, the Spirit of Transition Time and Formation of Holiness among Udmurt and Komi \\ Aado Lintrop}

This article has been formerly published: Lintrop, Aado (2019). On the Udmurt Water Spirit and the Formation of the Concept 'Holy' among Permian Peoples. Folklore: Electronic Journal of Folklore, 26, 7-26. DOI: 10.7592/FEJF2004.26.lintrop. 
Direct and Indirect Sources of the Articles

\section{Water Bodies in Besserman Mythology and Rituals}

\section{Elena Popova}

Some excerpts and ideas have been published before in Russian in Popova, Elena (2012). Reki i rodniki v obryadakh i kul'tovoy praktike besermyan [The rivers and springs in the rituals and the cult practice of the Besserman]. Traditsionnaya kul'tura [Traditional Culture]. No 4, 15-22.

\section{The Udmurt Pantheon and the Udmurt Worldview Tatiana Vladykina}

This article has been published relying on the monograph: Vladykina, Tatiana (2018). Udmurtskiy fol'klornyy mirotekst: obraz, simvol, ritual [The Udmurt Folklore Worldtext: Metaphor, Symbol, Ritual] / UIIYaL UdmFITs UrO RAN. Izhevsk: Izdatel'stvo "MonPorazhen".

\section{Inmar, the Udmurt God, in Modern Udmurt Literature Aleksey Arzamazov}

This article has been formerly published in Russian: Arzamazov, Aleksey (2018). Mifologicheskiy personazh Inmar v sovremennoy udmurtskoy poezii [The Mythological Character Inmar in Today's Udmurt Poetry]. Filologicheskie nauki. Voprosy teorii i praktiki [Philological Sciences: Questions of Theory and Practice]. No 7-2 (85), 225-229.

\section{Forest Spirits in the Udmurt Worldview Tatiana Panina, Tatiana Vladykina}

Some fragments of this article have previously been published in: Vladykina, Tatiana (2009). Obrazy lesnykh dukhov v udmurtskoy mifologii i fol'klore: I. N'ulesmurt (lesnoy chelovek / leshiy) [The Forms of the Forest Spirits in the Udmurt Mythology and Folklore: I. N'ulesmurt (the Forest Man)]. Traditsionnaya kul'tura $v$ izmenyayushchemsya mire: Materialy VIII Mezhdunarodnoy shkoly molodogo fol'klorista "Traditsionnaya kul'tura $v$ izmenyayushchemsya mire" $i$ seminara "Permistika: yazyk $i$ stil' fol'klora" [Traditional Culture in a Changing World: Proceedings of the $8^{\text {th }}$ International School of Young Folklorists: "Traditional Culture in a Changing World" and of the Seminar Permistika]. Izhevsk: Udmurtskiy 
institut istorii, yazyka i literatury UrO RAN, 24-30; also in: Vladykina, Tatiana; Panina, Tatiana (2015). Obrazy lesnykh dukhov v udmurtskoy mifologii i fol'klore: II. Palesmurt ("Polovinnyy chelovek / chelovekoobraznoe sushchestvo - polovinka") [The Forms of the Forest Spirits in the Udmurt Mythology and Folklore: II.]. Palesmurt (The Half-Man or Man-Like Being)] Ezhegodnik finno-ugorskikh issledovaniy [Yearbook of Finno-Ugric Studies]. No 4, 59-67; and in: Panina, Tatiana (2017). Obrazy lesnykh dukhov v udmurtskoy mifologii i fol'klore: III. Obyda (lesnaya zhenshchina) [Forms of the Forest Spirits in Udmurt Mythology and Folklore: III. Obyda (the Forest Woman)]. Ezhegodnik finno-ugorskikh issledovaniy [Yearbook of Finno-Ugric Studies]. No 2, 53-66.

\section{A Systematic Investigation of Sacred Space in the Kama- Vyatka Region: Udmurt Materials}

\section{Nadezhda Shutova}

This article has been published in Russian: Shutova, Nadezhda (2017). Sakral'noe prostranstvo narodov Kamsko-Vyatskogo regiona: osnovnye itogi, podkhody i metody izucheniya [The Sacred Space of the KamaVyatka Peoples Region: Main Results, Approaches and Investigation Methods]. Ezhegodnik finno-ugorskikh issledovaniy [Yearbook of FinnoUgric Studies]. No 2, 133-149.

\section{Tradition and Diversity among Udmurt Sacrificial Priests Eva Toulouze, Liivo Niglas}

The text is a revised and widely extended version of Toulouze, Eva; Niglas, Liivo (2017). “The vös'as', the Udmurt sacrificial priest: an old task for young men”, Temenos: Nordic Journal of Comparative Religion, 53 (1), 9-39.

\section{"Seeing off a Recruit": The Ritual and Its Songs in the Udmurt Traditional Culture}

\section{Valeriia Fedorova}

This article is based on a revised part of a master dissertation: Fedorova, Valeriia (2020). Semiotics of the udmurt rite of "seeing off a recruit" in the musical paradigm. Based on the Songs of the Rite of "Seeing Off a Recruit" 
Direct and Indirect Sources of the Articles

of the Village of Chutozhmon, the Udmurt Republic. Thesis Supervisor Prof. Dr. Bodnár, Gábor. A Thesis Presented for the Degree of Master in Semiotics Faculty of Humanities Eötvös Loránd University Budapest, Hungary.

\section{The Ritual Importance of the Chuk, a Symbolic Bundle of Thread}

\section{Tatiana Vladykina, Galina Glukhova, Tatiana Panina}

This article has been published in Russian; Vladykina, Tatiana; Glukhova, Galina; Panina, Tatiana (2018). Chuk v traditsionnoy kul'ture udmurtov [Chuk in the Udmurt's Traditional Culture]. Traditsionnaya kul'tura [Traditional Culture]. T. 19, No 1. 139-151; Some elements of it may be found in Vladykina, Tatiana; Glukhova, Galina; Panina, Tatiana (2021). Chuk/tug v povsednevnom i ritual'nom kontekstakh [Chuk/tug in everyday and ritual contexts]. Predmetnye realii udmurtskoy etnokul'tury: kollektivnaya monografiya [The Material Realia in the Udmurt Ethnic Culture: Collective Monograph] / T.G. Vladykina [i dr.]; pod obshch. red. T.G. Vladykinoy. Izhevsk: UdmFITS UrO RAN, 36-49.

\section{A Contemporary Commemoration of the Dead: Yyr-pyd s'oton in Southern Udmurtia}

\section{Denis Kornilov}

This article has been published in Russian: Kornilov, Denis (2021). Pamyati pavshikh: traditsii i innovatsii v pominal'nom obryade yyr-pyd-s'oton [The Memory of the Fallen: Tradition and Innovation in the Commemorative Ritual yyr-pyd-s'oton]. Predmetnye realii udmurtskoy etnokul'tury: kollektivnya monografiya [The Material Realia in the Udmurt Ethnic Culture: Collective Monograph] / T.G. Vladykina [i dr.]; pod obshch. red. T. G. Vladykinoy. Izhevsk: UdmFITS UrO RAN, 69-80.

\section{Sound in Udmurt Rituals}

\section{Irina Nurieva}

This article is a revised and extended part of the author's doctoral dissertation: Nurieva, Irina (2014). Udmurtskaya muzykal'no-peresennaya traditsiya: spetsifika zhanroobrazovaniya i funktsionirovaniya: Diss. na 
soisk. uchen. st. doktora iskusstvovedeniya. [The Udmurt Musical and Singing Tradition: Peculiarities of the Formation of Genres and Their Functioning]. Izhevsk.

\section{An Udmurt Flute \\ Irina Pchelovodova}

Some fragments of this revised article have been published formerly: Pchelovodova, Irina (2010). Aerofony v sisteme traditsionnoy instrumental'noy kul'tury udmurtov [Aerophones in the System of the Udmurt's Traditional Instrumental Culture]. Ezhegodnik finno-ugorskikh issledovaniy [Yearbook of Finno-Ugric Studies]. V. 1. I Nauch. red. N. I. Leonov; sost.-red. A.E. Zagrebin, A.V. Ishmuratov, R.V. Kirillova; otv. red. D. I. Cherashnyaya. Izhevsk: Izd-vo "Udmurtskiy universitet”, 95-108; Pchelovodova, Irina (2009). Prodol'naya fleyta udmurtov [The longitudinal flute of the Udmurt]. PAX SONORIS: istoriya i sovremennost': Nauchnyy zhurnal [PAX SONORIS, history and present time. Scientific journal] V. III. / Gl. red. E. M. Shishkina. Astrakhan', 148-154.

\section{An Udmurt Exceptional Performer, Dzhakapay Irina Pchelovodova, Nikolai Anisimov}

This article has been published in Russian: Pchelovodova, Irina; Anisimov, Nikolai (2020). Ispolnitel' i traditsiya: fenomen lichnosti v sokhranenii i peredache kul'turnogo naslediya udmurtov [The performer and tradition: the personality phenomenon in maintaining and transmitting the Udmurt's cultural heritage]. Ezhegodnik finno-ugorskikh issledovaniy [Yearbook of Finno-Ugric studies], 14 (3), 418-433. DOI: 10.35634/22249443-2020-14-3-418-434.

\section{Presence of Witchcraft in the Contemporary Udmurt Village Nikolai Anisimov}

This article has been published in Russian: Anisimov, Nikolai (2019). Kolduny i ved'my v mirovospriyatii sovremennoy udmurtskoy derevni [Wizards and witches in the worldview of the Udmurt village today]. IV Vserossiyskiy kongress fol'kloristov: Tula, 1-5 marta 2018: sb. 
Direct and Indirect Sources of the Articles

nauch. st. $v 3$ t. T. 2: Mnogoobraziye fol'klornykh traditsiy: istoriya $i$ sovremennost' [The 4th Congress of Russia's Folklorists, Tula 1-5 March 2018. The Diversity of Folklore Traditions: History and Present Time]. Ed. A.B. Ipollitova. Moskva: Gosudarstvennyy Rossiiskiy Dom Narodnogo tvorchestva imeni V. D. Polenova, 244-256. DOI: 10.24411/9999-022A2019-10233.

\section{How the Udmurt Understand the World, and Man in It}

\section{Eva Toulouze, Nikolai Anisimov}

This recension has been formerly published in Toulouze, Eva Maria; Anisimov, Nikolai (2020). How the Udmurt Understand the World, and Man in It: Book Review. Journal of Ethnology and Folkloristics, 14 (2), 143-146. DOI: 10.2478/jef-2020-0010.

\section{Tatiana Vladykina's Contribution to Udmurt Folkloristics Aleksey Arzamazov, Galina Glukhova, Tatiana Panina}

This article has been published in Russian: Arzamazov, Aleksey; Glukhova, Galina; Panina, Tatiana (2018). Nauchnye miroteksty professora T. G. Vladykinoy [The Scientific Worldtext of Professor T. G. Vladykina]. Ezhegodnik finno-ugorskikh issledovaniy [Yearbook of Finno-Ugric Studies]. T. 12, vyp. 3, 191-197. 